
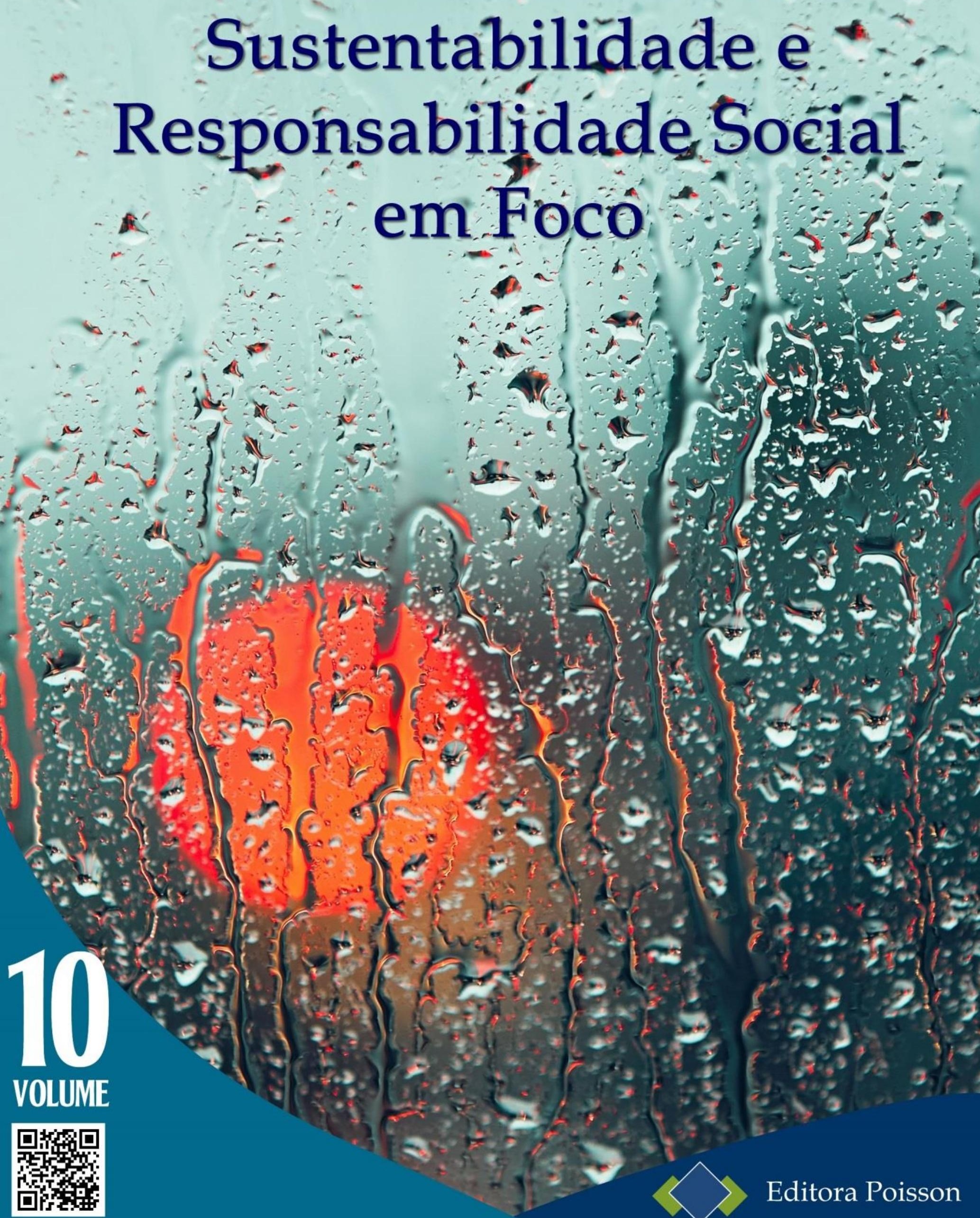
Editora Poisson

Sustentabilidade e Responsabilidade Social em Foco Volume 10

1a Edição

Belo Horizonte

Poisson

2018 
Editor Chefe: Dr. Darly Fernando Andrade

\section{Conselho Editorial}

Dr. Antônio Artur de Souza - Universidade Federal de Minas Gerais

Dra. Cacilda Nacur Lorentz - Universidade do Estado de Minas Gerais

Dr. José Eduardo Ferreira Lopes - Universidade Federal de Uberlândia

Dr. Otaviano Francisco Neves - Pontifícia Universidade Católica de Minas Gerais

Dr. Luiz Cláudio de Lima - Universidade FUMEC

Dr. Nelson Ferreira Filho - Faculdades Kennedy

Dados Internacionais de Catalogação na Publicação (CIP)
$\begin{aligned} & \text { S587s } \\ & \text { Sustentabilidade e Responsabilidade Social } \\ & \text { em Foco - Volume 10/ } \\ & \text { Organização Editora Poisson - Belo } \\ & \text { Horizonte - MG : Poisson, 2018 } \\ & \text { 257pp } \\ & \text { Formato: PDF } \\ & \text { ISBN: 978-85-93729-84-3 } \\ & \text { DOI: 10.5935/978-85-93729-84-3.2018B001 } \\ & \text { Modo de acesso: World Wide Web } \\ & \text { Inclui bibliografia } \\ & \text { 1. Gestão 2. Sustentabilidade. 3. } \\ & \text { Responsabilidade Social I. Título } \\ & \text { CDD-658 }\end{aligned}$
.

O conteúdo dos artigos e seus dados em sua forma, correção e confiabilidade são de responsabilidade exclusiva dos seus respectivos autores.

$\underline{\text { www.poisson.com.br }}$

contato@poisson.com.br 


\section{Sumárīo}

Capítulo 1: Avaliação Preliminar das Modificações no Plano Diretor Urbano e Ambiental do Município de Manaus/AM. Estudo de Caso: Reserva Florestal Adolpho Ducke.

Caroline Guarim Sena Geraldini, Danilo Soeiro de Sousa Menezes, Luiza Regina Ramiro de Carvalho, Reginelly Medeiros Gomes, Vanessa Letícia dos Santos

Capítulo 2: Análise da viabilidade técnica e econômica para o uso de biodigestores em organização militar criadora de eqüinos levando em consideração os créditos de carbono.....

Romero de Albuquerque Maranhão, Norberto Stori

Capítulo 3: "Quem não se comunica se trumbica!": Comunicação, Treinamento e Gestão Ambiental em Organização Militar do Estado de São Paulo.

Romero de Albuquerque Maranhão, Norberto Stori

Capítulo 4: Desenvolvimento sustentável e responsabilidade socioambiental nas forças armadas: Um estudo na marinha do Brasil

Romero de Albuquerque Maranhão, Norberto Stori

Capítulo 5: Gestão de resíduos de serviço de saúde: Um estudo de caso na construção do estaleiro e base naval da marinha em Itaguaí.

Romero de Albuquerque Maranhão, Norberto Stori

Capítulo 6: Violência doméstica e as implicações na saúde física e emocional de mulheres: inferências de enfermagem

Ana Cláudia Ribeiro Paiva, Vaneska Ribeiro Perfeito Santos, Sandra Mara dos Santos

Capítulo 7: Logística Reversa de Pneus Inservíveis: um Sinal de Consciência Socioambiental ou uma Estratégia Econômica?

Luís Carlos de Andrade Silva, Antônio Lisboa da Silva, Elvia Florencio Torres Ximenes,

Liliane Araújo Pinto, Tales Antão de Alencar Carvalho, Cléverson Vasconcelos da Nóbrega 


\section{Sumárīo}

Capítulo 8: Responsabilidade Social como estratégia de relacionamento com o colaborador: Um estudo à luz da percepção da gerência de recursos humanos.

Ana Valéria Vargas Pontes, Daiane Souza do Vale Carneiro, Ingrid de Oliveira, Marcelle Rosso Ferreira, Tatiane Dias da Cunha Vieira

Capítulo 9: A vila autódromo, seu histórico de luta e remoções.

Moyses Jaime Zeitune, Lincoln de Lima Faria, Guilherme Faria Souza Mussi de Andrade, Joás Lessa Martins

Capítulo 10: Logística sustentável: a utilização de biodiesel na operação de uma rede de restaurantes fast food

Agostinho Augusto Figueira, Beatriz Monica Schuchmann, Marcos Roberto Buri, Ranulfo Soares da Fonseca Junior, Rosa Maria Maia de Oliveira

Capítulo 11: Os desafios da gestão do terceiro setor: Um estudo de caso da Instituição Eunice Weaver (Educandário Carlos Chagas).

Aline Cristina de Oliveira Souza, Ana Valeria Vargas Pontes, Juliana Maioli Laval Bernardo, Luciana Novaes Vieira Ferreira

Capítulo 12: Ranking do saneamento do Médio Paraíba do Sul

Lucas Pereira de Almeida, Lunara de Andrade Silva, Ana Paula da Silva Souza Costa, Juliana Gonçalves Fernandes

Capítulo 13: A eficácia da logística reversa na cadeia de lâmpadas fluorescentes: Um estudo na região do Vale do Paraíba

Henrique Martins Galvão, Camila de Paula Conrado Rosa, Juliana Vieira Braz, Thais

Eugênio de Moraes, Paládia de Oliveira Romeiro da Silva

Capítulo 14: Determinantes da Divulgação Voluntária do Balanço Social no Brasil.

Dilciléria da Rosa de Oliveira Joyce Gonçalves Altaf 


\section{Sumárīo}

Capítulo 15: Análise comparativa dos indices de mérito de duas instalações fotovoltaicas: Casos UTFPR Neoville x Lar Junshin

Fabrício Fontoura dos Santos, Günther Kaltmaier Junior, Jair Urbanetz Junior Juliana D'Angela Mariano

Capítulo 16: Um modelo de simulação computacional para análise do custo-benefício da geração de biodiesel por uma empresa coletora de resíduos sólidos urbanos

Glauco Oliveira Rodrigues, Eugenio De Oliveira Simonetto, Wellington Furtado

Santos, Daniel Visentini De Barcelos, Adriano Pereira, Marcelo Cassanta Antunes

Capítulo 17: Gestão Estratégica de Empresas do Terceiro Setor: um Estudo de Caso

Rosilane Chimene, Ana Lúcia Magalhães , Éber José dos Santos, Bruno Andreoni

Capítulo 18: Os princípios do direito votados para a preservação ambiental

Ana Paula Lima Marques Fernandes, Amanda Araújo de Souza, Amauri Vítor dos Santos, Carlos Everaldo Silva da Costa, Fábio Augusto Lima Silva, Lidiane Maria dos Santos, Rodrigo Purcell

Capítulo 19: Resíduo Hospitalar: Um Estudo em um Município de Pequeno Porte do Sudeste Paraense....

Deuzenir Mendes Araújo, Wilcker Araújo Sampaio, Elizabete Campos Lima, Marcilene Feitosa Araújo

Capítulo 20: Proposta de certificação para Implantação de ferrovias verdes no Brasil.

Ana Carolina L. de Azevedo, Fabrício de O. Lavorato, Marcelo de Miranda Reis, Mayssa A. da Silva Sousa 


\section{Capítulo 1}

\section{AVALIAÇÃO PRELIMINAR DAS MODIFICAÇÕES NO PLANO DIRETOR URBANO E AMBIENTAL DO MUNICIPIO DE MANAUS/AM. ESTUDO DE CASO: RESERVA FLORESTAL ADOLPHO DUCKE}

\section{Caroline Guarim Sena Geraldini}

Danilo Soeiro de Sousa Menezes

Luiza Regina Ramiro de Carvalho

Reginelly Medeiros Gomes

Vanessa Letícia dos Santos

Resumo: O presente estudo tem como objetivo avaliar as mudanças realizadas no Plano Diretor Urbano e Ambiental do Município de Manaus, em relação a Reserva Florestal Adolpho Ducke. A qual situa-se a $25 \mathrm{~km}$ da cidade, é uma das mais importantes bases de pesquisa do Instituto Nacional de Pesquisas da Amazônia (INPA). Em virtude da expansão da cidade, a Reserva se tornou passível a sofrer um processo de fragmentação e possíveis desmatamentos, expansão urbana e ocupações. Com a mudança do Plano Diretor de Manaus, a reserva passa a ser considerada uma área de transição, o mesmo determina como deve ser o planejamento da cidade e como influenciará diretamente na sociedade. Por ser uma área de transição, cabe ao planejamento considerar as questões de como se procederão tais mudanças, tendo como base geral as normas de uso, ocupação do solo, licenciamento e fiscalização. Ademais, verifica-se no estudo os impactos ambientais e socioambientais que podem ser conseqüências de tal modificação e natural expansão urbana.

Palavras Chave: Plano Diretor, Reserva Adolpho Ducke, Expansão Urbana 


\section{INTRODUÇÃO}

O cenário atual do Brasil em relação à expansão urbana confere dados que possibilitam verificar o equilíbrio entre 0 crescimento populacional, a necessidade do desenvolvimento de planejamentos urbanos e ambientais e o trajeto projetado da economia atual e futura. Vista de uma maneira geral, a urbanização particularmente, no Brasil, com índice de urbanização de 31\% observado em 1940, passando para 75\% em 1990 e chegando a $81 \%$ em 2001, conforme dados do Instituto Brasileiro de Geografia e Estatística (IBGE, 2000).

De acordo com Chaffun (1997), o crescimento acelerado e desordenado das cidades, aliado a concentração da população e das atividades econômicas no espaço e os padrões tecnológicos da produção industrial, tem reforçado um quadro ambiental altamente degradado em consequência de um estilo de desenvolvimento que leva ao uso predatório dos recursos naturais (CHAFFUN, 1997, p. 28).

A realidade atual é complexa, pois as agressões ao meio ambiente são influenciadas por interesses econômicos cada vez mais ávidos e por novas fontes de lucros e de poder, encravados numa sociedade progressivamente imediatista e consumista. Tal modelo de sociedade extremamente capitalista e consumista leva a destruição dos ambientes naturais, trazendo, como conseqüência, prejuízos e riscos ao próprio homem.

O planejamento das cidades no Brasil é prerrogativa constitucional da gestão municipal que responde, inclusive, pela delimitação oficial da zona urbana, rural e demais territórios para onde são direcionados os instrumentos de planejamento ambiental. No âmbito do meio ambiente urbano, os principais instrumentos de planejamento ambiental são o Zoneamento EcológicoEconômico - ZEE, o Plano Diretor Municipal, o Plano de Bacia Hidrográfica, o Plano Ambiental Municipal, a Agenda 21 Local, e o Plano de Gestão Integrada da Orla. No entanto, todos os planos setoriais ligados à qualidade de vida no processo de urbanização, como saneamento básico, moradia, transporte e mobilidade, também constituem instrumentos de planejamento ambiental (MMA, 2012). O fundamental é que esses instrumentos sejam compostos por ações preventivas e normativas que permitam controlar os impactos territoriais negativos dos investimentos público-privados sobre os recursos naturais componentes das cidades. Com isso, almeja-se evitar a subutilização dos espaços já infraestruturados e a degradação urbana e imprimir uma maior eficiência das dinâmicas socioambientais de conservação do patrimônio ambiental urbano (MMA, 2012).

As conceituações de planejamento ambiental demonstram a necessidade da integração dos diferentes setores durante a elaboração de planos de desenvolvimento, ou seja, as ações devem ser elaboradas sob princípios holísticos e sustentáveis. Essa visão é defendida por Santos ao postular o seguinte:

[...] os princípios do planejamento ambiental se remetem, diretamente, aos conceitos de sustentabilidade e multidisciplinaridade, os quais, por sua vez, exigem uma abordagem holística de análise para posterior aplicação. Espera-se que temas biológicos, físicos e socioeconômicos sejam tratados de forma 19 integrada e possibilitem ações práticas direcionadas a solução dos problemas (SANTOS, 2004, p. 27).

Com esses pressupostos, o planejamento ambiental é um processo contínuo, que apresenta diversas etapas, como a coleta de dados, a organização e a análise sistematizada das informações através de procedimentos e métodos. Objetiva chegar a decisões ou escolhas acerca das melhores alternativas para 0 aproveitamento dos recursos disponíveis em função de suas potencialidades, e com a finalidade de se atingir metas específicas no futuro, levando à melhoria de determinada situação e a qualidade de vida das sociedades.

Um importante papel que se destina ao planejamento ambiental é ainda o de direcionar os instrumentos metodológicos, administrativos, legislativos e de gestão para o desenvolvimento de atividades num determinado espaço e tempo, incentivando a participação institucional e dos cidadãos, induzindo relações mais estreitas entre sociedade e autoridades locais e regionais.

O presente estudo de caso, através de levantamento de dados e pesquisas relacionadas a modificações nas situações de determinadas áreas, tem como objetivo avaliar as mudanças ocorridas no Plano Diretor Urbano e Ambiental do Município de Manaus, o qual foi sancionado e publicado no dia 16 de janeiro de 2014. Modificações estas 
realizadas especificamente no status da Reserva Florestal Adolpho Ducke (RFAD). Atualmente a Reserva é considerada Área de Transição, onde representa a faixa do território municipal que contorna os limites da Área Urbana, podendo abrigar atividades agrícolas, usos e atividades urbanas de baixa densidade, segundo o Art. 57 da Seção III do Plano Diretor Urbano e Ambiental do Município de Manaus.

Conforme as mudanças, o entorno da Reserva Ducke assumiria a classificação de Zona de Expansão Urbana (ZEU), passando a ser um fragmento urbano, sendo assim, a área está sujeita a diferentes formas de ocupação do solo, colocando em risco a existência da reserva, acarretando impactos ambientais e socioambientais. Segundo o Projeto de Lei 322/2013, da Câmara Municipal de Manaus, Art. 19 in verbis:

"Art. 19. Para fins de planejamento, gestão e aplicação das normas de Uso e Ocupação do Solo, a Área de Expansão Urbana, definida no Plano Diretor Urbano e Ambiental do Município de Manaus, divide-se em Zonas de Expansão Urbana - ZEU.

Parágrafo único. A Zona de Expansão Urbana é o compartimento territorial da Área de Expansão destinado ao planejamento e gestão da cidade, e apresenta aspectos físicos ou características de ocupação e de uso homogêneos com as mesmas diretrizes urbanísticas."

A Reserva Florestal Adolpho Ducke, é uma área de floresta amazônica primária de 100 $\mathrm{km}^{2}$, localizada próxima à cidade de Manaus e pertence ao Instituto Nacional de Pesquisas da Amazônia (INPA). Foi declarada como Reserva Biológica em 1963, nesta época a cidade de Manaus possuía uma população de aproximadamente 40.000 habitantes. Nas últimas quatro décadas (até 2005) a população saltou para cerca de 2.000 .000 de habitantes e a cidade expandiu sua área urbanizada, chegando aos limites da Reserva em duas de suas laterais. Aliado a isso, a devastação da floresta nas áreas próximas às outras duas extremidades, vem transformando a Reserva em um fragmento florestal isolado. Apesar dessas interferências nos seus arredores, os recursos naturais da Reserva Ducke continuam bem preservados, muito embora a área seja periodicamente invadida por caçadores de animais silvestres e outras pessoas interessadas na extração de produtos florestais

\section{INSTRUMENTOS DE POLÍTICAS URBANAS}

\subsection{O ESTATUTO DA CIDADE E O PLANO DIRETOR}

O Estatuto da Cidade de Manaus, Lei 10.257/2001, destaca o Plano Diretor como instrumento de planejamento municipal. No Capítulo II, Dos Instrumentos da Política Urbana, Seção I, Dos Instrumentos em Geral, in verbis:

"Art. 4ํ Para os fins desta Lei, serão utilizados, entre outros instrumentos:

I - planos nacionais, regionais e estaduais de ordenação do território e de desenvolvimento econômico e social;

II - planejamento das regiões metropolitanas, aglomerações urbanas e microrregiões;

III - planejamento municipal, em especial:

a) plano diretor;

b) disciplina do parcelamento, do uso e da ocupação do solo;

c) zoneamento ambiental;

d) plano plurianual;

e) diretrizes orçamentárias e orçamento anual;

f) gestão orçamentária participativa;

g) planos, programas e projetos setoriais;

h) planos de desenvolvimento econômico e social;"

O Plano diretor é um instrumento básico da política de desenvolvimento de cada município, tendo como finalidade atuar e orientar o poder político na privatização da construção dos espaços urbanos e rurais, visando melhorar condições de vida da população e como deve ser o Planejamento da cidade. Os participantes da criação do plano são, o prefeito municipal, a população e a câmara municipal, sendo assim, por iniciativa destes, o plano é feito e transformado em lei. O que se espera sempre de um plano como este, é que sejam propostos meios para garantir uma participação popular na gestão do município, rumos para um novo desenvolvimento local, economicamente viável, socialmente justo e ecologicamente equilibrado, soluções de melhorias públicas e que proponham diretrizes para proteger o meio ambiente, mananciais e principalmente as áreas verdes. 
Sendo assim, neste estudo de caso, foram analisadas as questões da mudança realizada na Reserva Adolpho Ducke para uma Área de Transição, tendo como ponto geral o código de normas de uso e ocupação do solo, código de obras e edificações, lei de licenciamento e fiscalização de atividade em estabelecimento e logradouros, lei do parcelamento do solo urbano e áreas habitacionais de interesse social.

Visto isso foram levadas em considerações as seguintes Leis que possibilitam a mudança da Reserva Floresta Adolpho Ducke para uma Área de Transição:

Lei $n^{-}$1.838/2014, que dispões sobre as normas de Uso e Ocupação do Solo no município de Manaus, vale ressaltar que a Lei foi promulgada na mesma data da publicação no Diário Oficial do novo Plano Diretor de Manaus, segue o Art. $1^{\circ}$ da Lei in verbis:

"Art. 1: As Normas de Uso e Ocupação do Solo no Município de Manaus passam a vigorar na forma estabelecida nesta Lei, tendo por pressuposto a utilização do potencial de adensamento das áreas territoriais mediante os seguintes critérios: I - a preservação das áreas de proteção e de fragilidades ambientais, incluídas as nascentes e as margens dos cursos d’água, as unidades de conservação, os fragmentos florestais e as áreas de fundo de vales;[...]"

A Lei 671/2002, regulamenta o Plano Diretor Urbano e Ambiental, estabelece diretrizes para o desenvolvimento da cidade de Manaus e dá outras providências relativas ao Planejamento e à gestão do território do município. Destaca-se que tal Lei é anterior as modificações realizadas no Plano Diretor, já considerando os limites onde se encontram a Reserva como Área de transição. O Art. 48, Da Área Urbana e Área de Transição, in verbis:

"Art. 48: - Área de transição é a faixa do território municipal que contorna os limites da Área Urbana, incluindo a Reserva Florestal Adolpho Ducke, podendo abrigar atividades agrícolas e usos e atividades urbanos de baixa densidade, onde são incentivadas atividades ecoturísticas.

Parágrafo único Quaisquer atividades desenvolvidas na área de transição deverão atender à legislação ambiental, visando à proteção dos recursos naturais, especialmente os recursos hídricos."
A Lei 672/2002, que institui as normas de Uso e Ocupação do Solo no município de Manaus e trata das unidades espaciais de transição, também anterior a publicação das mudanças no Plano Diretor, in verbis:

"Art. 24 - A Área de Transição é dividida nas seguintes Unidades Espaciais de Transição e setor urbano:

II - UET Ducke unidade residencial e agrícola, de integração do uso residencial de baixa densidade com a produção agrícola;[...]".

\subsection{PLANO DIRETOR}

Conforme o Plano Diretor Urbano e Ambiental do Município de Manaus, o qual caracteriza a área da Reserva Florestal Adolpho Ducke, nos seguintes eixos:

Título II - Das estratégias de desenvolvimento, Art. $2^{\circ}$ que constitui estratégias para 0 desenvolvimento do município de Manaus, no seu Parágrafo único, in verbis:

"São objetivos centrais das estratégias de desenvolvimento, dentro da área urbana, as Zonas Territoriais Urbanas de Manaus, a partir das características vocacionais a seguir descritas:

I - Zona Norte: constitui a grande área de transição e habitacional da Cidade, possuindo como limite a Reserva Florestal Adolpho Ducke;"

Título IV - Da Macroestruturação do município, Capítulo I - Do Macrozoneamento, Seção III - Da Área Urbana e da Área de Transição, Art.57, in verbis:

"Área de Transição é a faixa do território municipal que contorna os limites da Área Urbana, incluindo a Reserva Florestal Adolpho Ducke, podendo abrigar atividades agrícolas, usos e atividades urbanas de baixa densidade, onde são incentivadas atividades ecoturísticas.

Parágrafo único. Quaisquer atividades desenvolvidas na Área de Transição deverão atender à legislação ambiental, visando à proteção dos recursos naturais, especialmente os recursos hídricos."

Título V - Da Estruturação do Espaço Urbano, Capítulo I - Do Modelo Espacial, Art. 63, in verbis:

"Para efetivação da estruturação do espaço urbano é adotado Modelo Espacial, no qual: 
I - a Área Urbana é dividida em Zonas Urbanas, subdivididas em Setores Urbanos, Subsetores e Corredores Urbanos;

II - a Área de Transição é dividida em Zonas de Transição, respeitadas as unidades de conservação urbanas e os corredores ecológicos urbanos, assim delimitadas:

a) ZT Ducke: compreende área contribuinte da bacia do Rio Puraquequara, incluindo a Reserva Florestal Adolpho Ducke, com presença de ocupação por população de baixa renda, de estímulo à baixa densificação, relacionada à proteção dos recursos naturais, à valorização da paisagem e à promoção de programas e projetos de interesse social;"

A Lei № 1.839, 01/2014, dispõe sobre o perímetro urbano do município de Manaus e descreve os limites da Cidade, conforme as diretrizes do Plano Diretor Urbano e Ambiental de Manaus, no Art. 3ํㅡ, in verbis:

"A Zona Urbana limita-se ao Sul pela margem esquerda dos rios Negro e Amazonas, segue a Leste, a partir da margem esquerda do Rio Amazonas, pelo divisor de águas das bacias do rio Puraquequara e do igarapé do Aleixo, por este divisor até encontrar o novo limite oficial do Distrito Industrial II seguindo por este, na direção Norte, até reencontrar o divisor de águas do rio Puraquequara e por este até o limite Sul da Reserva Florestal Ducke, deste ponto segue no sentido OesteNorte pelo contorno da Reserva Ducke até o divisor de águas das bacias dos igarapés da Bolívia e do Mariano e seu prolongamento até encontrar a Oeste a margem esquerda do igarapé Tarumã-Açu e por esta seguindo até sua foz no Rio Negro."

\section{ESTUDO DE CASO}

\subsection{INFORMAÇÕES SOBRE A RESERVA FLORESTAL}

A Reserva Florestal Adolpho Ducke (RFAD), se encontra a $25 \mathrm{~km}$ da cidade de Manaus, Amazonas, Brasil. Possui 10.072 hectares $\left(100 \mathrm{~km}^{2}\right)$ e aproximadamente $10 \mathrm{~km}$ de cada lado, totalmente demarcada e é cercada na borda adjacente à área urbana. Atualmente, se encontra em excelente estado de conservação, mesmo tendo sofrido pequenos impactos antrópicos antes de sua demarcação em 1959, os mesmos foram minimizados e ordenados após a doação da área ao Instituto Nacional de Pesquisa na Amazônia.
A Reserva também serve como suporte há mais de 50 anos para todos os segmentos das pesquisas do INPA e de outras instituições nacionais e internacionais. Sua fauna e flora sendo compostas por, espécies de plantas (2136); espécies de anfíbios (50); espécies de peixes (71); espécies de répteis (80); espécies de aves (350); espécies de mamíferos (50) (PELD, 2015). Não sendo aberta a visitação pública e as visitas são permitidas apenas para propósitos de pesquisa e educação. O acesso só é permitido para pesquisadores e visitantes autorizados pelo setor de reservas do INPA (PELD, 2015).

Foi declarada Reserva Ecológica em 1972, havendo apenas um local de plantação de árvores de valor comercial em seu extremo noroeste. Como não faz parte do Sistema Nacional de Unidades de Conservação (SNUC), ela não se beneficia das vantagens desse sistema, como o direito legal à manutenção de uma zona tampão em seu entorno. Por outro lado, sua condição de reserva independente permite a realização de atividades de pesquisa que sofreriam grandes restrições na maioria das categorias do SNUC (PELD, 2015).

O clima da reserva é classificado como tropical úmido, com umidade relativa de 75$86 \%$ e precipitação anual de 1.750 a 2.500 $\mathrm{mm}$. A estação chuvosa ocorre de novembro a maio, sendo os meses de março e abril os de maior precipitação. A estação seca ocorre de junho a outubro, sendo setembro normalmente o mês mais seco. A temperatura média anual é de $26 \stackrel{\circ}{\circ} \mathrm{C}$ existindo pouca variação térmica durante $\mathrm{O}$ ano, com as temperaturas médias mensais diferindo entre si em menos que $3 \stackrel{\circ}{\circ}$. A maior variação de temperatura ocorre ao longo do dia, podendo chegar a $8 \stackrel{\circ}{\circ}$ (RESERVA DUCKE, 2008).

A topografia é um importante fator na formação de solos na região da Amazônia Central. Nos platôs os solos são argilosos e nas vertentes, a fração de argila vai gradativamente diminuindo até predominar a fração de areia nas áreas de baixios. $\mathrm{Na}$ Reserva Ducke, o terreno é formado basicamente por platôs com altitudes variando de 80 a $140 \mathrm{~m}$ de altitude. Os baixios são freqüentemente inundados na época das chuvas, sendo que grande parte deles apresentam igarapés, mesmo durante a estação seca (RESERVA DUCKE, 2008). 
No eixo Norte-Sul a reserva é cortada por um platô central, que é o divisor de águas entre duas bacias hidrográficas. No lado oeste estão os igarapés que deságuam no rio Negro e a leste drenam os igarapés que são afluentes do rio Amazonas. Quase todas nascentes desses corpos de água estão dentro da reserva, o que preserva a integridade desse sistema (RESERVA DUCKE, 2008).

Toda a região está coberta pela floresta tropical úmida de baixa altitude, com dossel bastante fechado e sub-bosque com pouca luminosidade, caracterizado pela abundância de palmeiras acaules como Astrocaryum spp. e Attalea spp. A flora é extremamente diversificada, com aproximadamente 1.000 espécies de árvores com altura entre 30 e 35 metros, com árvores emergentes alcançando 45 a 50 metros (RESERVA DUCKE, 2008).

A Reserva Ducke é localidade de dezenas de espécies e foi objeto de alguns dos guias de campo mais completos que existem para região neotropical, como o da flora (RIBEIRO ET AL., 1999), serpentes (MARTINS \& OLIVEIRA, 1998), miriápodos (ADIS, 2002), sapos (LIMA ET AL., 2006) e lagartos (VITT ET AL., 2008).

Figura 3.1.1 Imagem Landsat (2003) da região de Manaus.

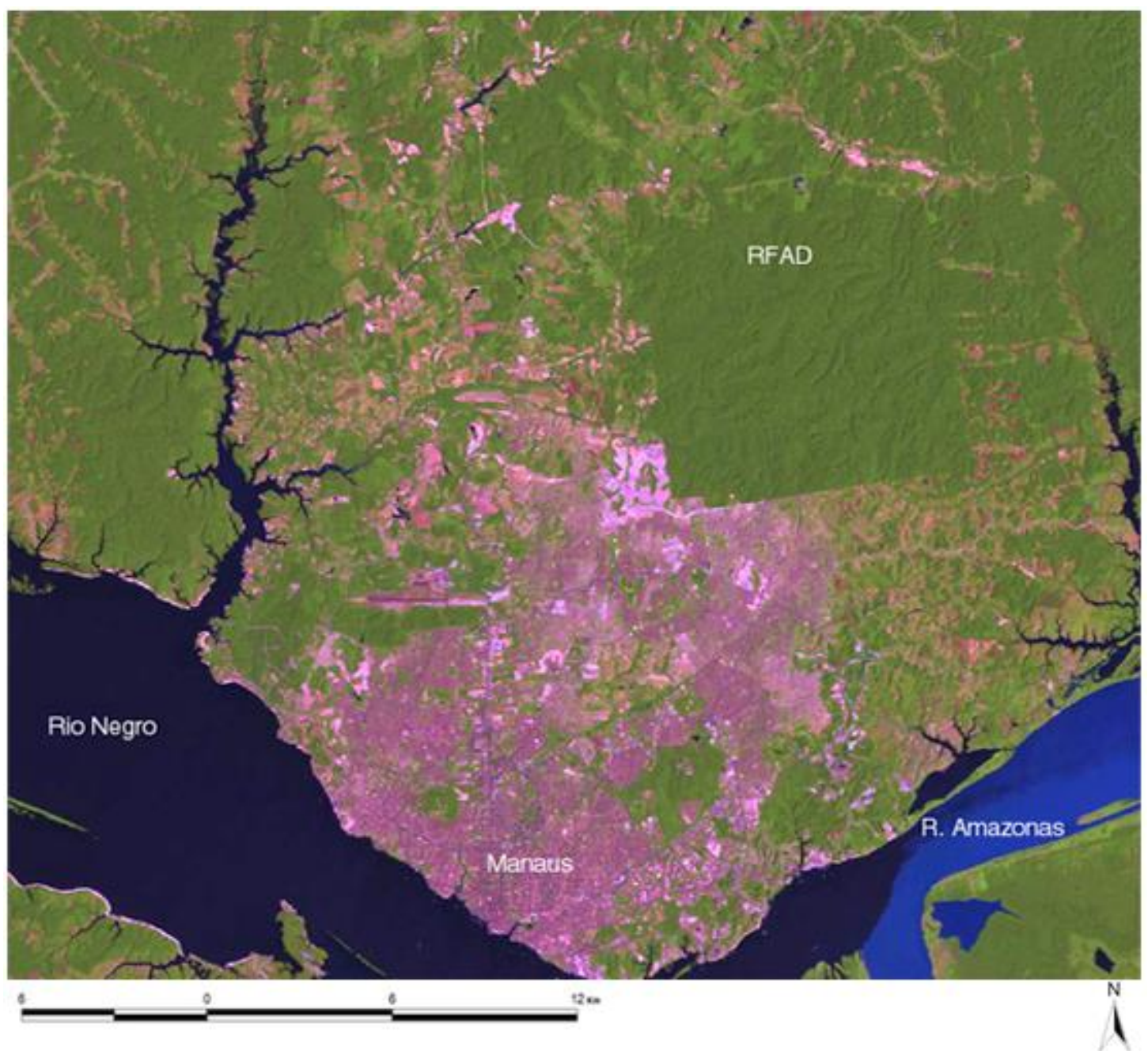

Fonte: Siglab/Inpa.

\subsection{QUESTIONAMENTOS}

Durante a década de 1960 as questões relacionadas com o meio ambiente passaram a ganhar maior ênfase não só apenas junto à sociedade leiga, mas, sobretudo, junto à comunidade científica. Essa nova perspectiva ganhou destaque mundial com a conferência das Nações Unidas sobre meio ambiente que procurou conciliar a necessidade de desenvolvimento econômico da sociedade 
com a promoção do desenvolvimento social e com o respeito ao meio ambiente, aonde veio consolidar essa tomada de consciência emergente.

A problemática ambiental apresenta enfoques diferentes por diversos estudiosos, dando destaque a vários fatores como o crescimento populacional, o crescimento econômico, a correção dos danos naturais, a desocupação humana de alguns ecossistemas, a redistribuição de poder e de recursos produtivos e a sustentabilidade ambiental e social. Elas têm em comum o mesmo conceito de ambiente, isto é, as relações dos homens com a natureza para a preservação dos recursos naturais.

Segundo Araújo (2004), a cidade de Manaus, capital do Amazonas, é um exemplo de zona urbana desenvolvida no meio da floresta e que atualmente tem pagado um preço ambiental muito alto por conta da expansão urbana que vem sofrendo nos últimos 20 anos, o modelo de desenvolvimento urbano excludente é a estruturação de arranjos urbanos marcados por um "mosaico" de paisagens reveladoras e geradoras da segregação sócio-espacial. Lado a lado erguem-se cidades modernizadas, cidades tradicionais, cidades operárias, cidades faveladas, cidades ilegais, perdendo-se, portanto, a concepção de cidade enquanto totalidade.

$\mathrm{Na}$ Tabela 1, percebe-se o crescimento demográfico do município de Manaus, onde a população aumenta significativamente conforme o passar dos anos.

Tabela 1. Censo demográfico do município de Manaus.

\begin{tabular}{|c|c|c|c|}
\hline Ano & Manaus & Amazonas & Brasil \\
\hline 1991 & 1.011 .501 & 2.103 .243 & 146.825 .475 \\
\hline 1996 & 1.154 .330 & 2.376 .965 & 156.032 .944 \\
\hline 2000 & 1.405 .835 & 2.812 .557 & 169.799 .170 \\
\hline 2007 & 1.646 .602 & 3.221 .939 & 183.987 .291 \\
\hline 2010 & 1.802 .014 & 3.483 .985 & 190.755 .799 \\
\hline
\end{tabular}

Fonte: IBGE: Censo Demográfico 1991, Contagem Populacional 1996, Censo Demográfico 2000, Contagem Populacional 2007 e Censo Demográfico 2010.

De 2014 para 2015, Manaus teve um aumento de 37.410 habitantes, representando $1,8 \%$ a mais que a última estimativa do órgão. Somado a população da Região Metropolitana da capital, que inclui cidades como Manacapuru, Irandura e Itacoatiara, o número chega a 2.523.901.

A cidade de Manaus registrou em 2015 um total de 2.057.711 habitantes, conforme estimativa do Instituto Brasileiro de Geografia e Estatística (IBGE). A capital manteve a posição de $7^{\circ}$ município mais populoso do país. Conforme a pesquisa, o Amazonas teve um acréscimo populacional de mais de 64,5 mil (GLOBO, 2015).

Portanto, as cidades vêm sofrendo com o processo de urbanização acelerado e desordenado gerando conflitos sócioambientais. A falta de planejamento urbanístico-ambiental, a poluição das industrias, a expansão urbana, a degradação ambiental nos faz pensar em um diagnóstico sombrio, em um grande desequilíbrio ambiental. $\mathrm{O}$ antigo Plano diretor da cidade de Manaus tinha preocupação com o entorno da reserva, fato que não se encontra no contexto atual.

Com base no exposto, observa-se que a Reserva tornou-se alvo de uma fragmentação, visto que é uma das mais importantes bases de pesquisa do Instituto Nacional de Pesquisas da Amazônia. O mesmo realizou um workshop com o tema da Reserva, com o objetivo de mobilizar e sensibilizar a sociedade, principalmente os moradores ao entorno da reserva, acadêmicos e pesquisadores para a importância da preservação de áreas verdes e discutir o impacto que trará a cidade caso venha transformar por completo o entorno da reserva.

Os pesquisadores afirmam que a região pode ser urbanizada rapidamente com o avanço do mercado imobiliário, por exemplo. Em discussão no INPA, no dia 4 de dezembro de 2013, Jaime Kuck, presidente do Conselho de Arquitetura e Urbanismo do Amazonas (CAU- 
AM), lamentou que: "Esse novo plano deixa claro que o entorno da reserva é uma área para onde a cidade pode crescer. No plano anterior dizia que aquela era uma área para onde a cidade não podia crescer.". Enquanto que o vereador Elias Emanuel, relator do Plano Diretor na Câmara Municipal de Manaus (CMM), afirma que a área está protegida, uma vez que, segundo ele "a proposta atual do documento não fez nenhuma mudança no regime de proteção da área de entorno da Reserva Adolpho Ducke. (...) E se em 11 anos não foi possível depredar e cortar a comunicação da fauna da reserva para o Puraquequara, como que na redação mantida no Plano Diretor teremos essa depredação? A gente só mudou a nomenclatura." (ELIAS EMANUEL, 2013).

Não concordando com o argumento de Elias Emanuel, o geógrafo Marcos Coelho, citou que "estabelecendo no mapa que a área se torna uma zona de expansão, induz o setor imobiliário a buscar tal eixo de crescimento, também trouxe o fato de que a economia não está como dez anos atrás, que atualmente tem ênfase no setor imobiliário". Concluindo que não há como comparar a realidade de dez anos com a atual (UOL, 2013).

Segundo a população do entorno existe uma preocupação com a mudança no status da Reserva e a qualidade de vida e ambiental do local. Como exemplo o aposentado José Teixeira de Castro tem 72 anos, dez deles vividos em um terreno de 250 metros quadrados nas vizinhanças da Reserva Ducke. "Sou idoso e escolhi um lugar saudável para morar o resto da via", afirma José. Acredita que o sossego no qual vive pode acabar. Com o Plano Diretor do Município transformando o entorno da reserva em Área de Transição, estudiosos defendem que a região estará sujeita a diferentes formas de ocupação do solo, colocando em risco, inclusive, a existência da reserva (UOL, 2013).

Para o aposentado José Teixeira, os moradores do entorno da reserva contribuem com a preservação da área. "Faça uma visita ao lado do prédio administrativo da reserva, do lado do bairro Nova Cidade, você vai encontrar toneladas de lixo. E visite o lado da reserva indo para o Puraquequara, onde têm moradores, você não vai encontrar lixo. Porque nós somos a cerca da reserva", disse Teixeira (UOL, 2013).

\subsection{POSSÍVEIS IMPACTOS AMBIENTAIS E SOCIOAMBIENTAIS}

Segundo Leite (2003), o meio ambiente ecologicamente equilibrado é um dos bens indispensáveis ao ser humano, por força de sua contribuição à sadia qualidade de vida e à dignidade social (LEITE, 2003, p. 284). Visto no âmbito do direito do indivíduo e de acordo com o Artigo 225 da Constituição brasileira, in verbis:

[...] todos têm direito ao meio ambiente ecologicamente equilibrado, bem de uso comum do povo e essencial à sadia qualidade de vida, impondo-se ao Poder Público e à coletividade o dever de defendêlo e preservá-lo para as presentes e futuras gerações [...] (BRASIL, 1998, p. 133).

Souza (2000) acrescenta que, a questão ambiental assume hoje uma magnitude impensada há décadas, visto que a pressão exercida pelo homem no meio ambiente tem aumentado significativamente desde a revolução industrial, assumindo uma situação de crise global. Souza diz que a "questão ambiental" diz respeito ao intenso processo de degradação generalizada do meio ambiente e dos recursos naturais, provocados pela intensificação do crescimento econômico e populacional no século XX (decorrente da industrialização, da explosão demográfica, da produção e do consumo em massa, da urbanização e da modernização agrícola, dentre outras causas). Com isso aumenta o nível de demanda ambiental e uma perda de biodiversidade e de recursos naturais nunca antes imaginados (SOUZA, 2000, p. 15).

No entanto, muitas dessas degradações trazem consigo riscos que ameaçam a vida humana, ao provocarem profundas alterações no meio ambiente, trazendo implicações significativas na perda da biodiversidade e nas alterações climáticas. E esta nova realidade que tem que ser reconhecida, onde novas medidas devem ser adotadas ( $O$ NOSSO FUTURO COMUM, 1987 apud CMMAD, 1991).

A Resolução do CONAMA 001/86 dispõe, sobre critérios básicos e diretrizes gerais para a avaliação de impacto ambiental, em seu Art. 1 que impacto ambiental é, in verbis:

“ [...] qualquer alteração das propriedades físicas, químicas e biológicas do meio ambiente, causada por qualquer forma de matéria ou energia resultante das atividades humanas que, direta ou indiretamente, afetam: 
I - a saúde, a segurança e o bem estar da população; II - as atividades sociais e econômicas; III - a biota; IV - as condições estéticas e sanitárias do meio ambiente; $\mathrm{V}$ - a qualidade dos recursos ambientais."

Assim, entende-se o impacto ambiental como qualquer alteração produzida pelos homens e suas atividades no meio ambiente, que excedam a capacidade de suporte desse mesmo ambiente. Para alguns pesquisadores o termo Impacto Ambiental está diretamente ligado aos danos causados ao meio ambiente pelo homem, como é o caso de Silva: O conceito de impacto ambiental refere-se exclusivamente aos efeitos da ação humana sobre o meio ambiente. Portanto, fenômenos naturais como tempestades, enchentes, incêndios florestais por causa natural, terremoto e outros, apesar de poderem provocar as alterações ressaltadas não se caracterizam como impacto ambiental (SILVA, 1999, p. 36).

De acordo com o Glossário de Ecologia (ACIESP, 1997), impacto ambiental é uma ação ou atividade, natural ou antrópica, que produz alterações bruscas em todo meio ambiente ou apenas em alguns de seus componentes, e que a alteração pode ser ecológica, social ou econômica. São processos que perturbam, descaracterizam, condições ou processos no ambiente natural; ou que causam modificações nos usos instalados, tradicionais, históricos, do solo e nos modos de vida ou na saúde de segmentos da população humana, ou que modifiquem de forma significativa opções ambientais (FEARO, 1979 apud FRANCO, 2001, p. 29).

O atual Plano Diretor de Manaus prevê a transformação do entorno da Reserva Florestal Adolpho Ducke em Zona de Transição. A área de transição é caracterizada pela presença de elementos rurais e urbanos. Com essas características, a região pode ser urbanizada rapidamente com o avanço, por exemplo, do mercado imobiliário, pelo comprovado aumento populacional. É uma área onde pode-se ter uso livre, podendo ser ocupada, ocorrer a construção de condomínios, conjuntos habitacionais, entre outros.

Referente a esses avanços urbanos, deve-se alertar a tais impactos, pois o mesmo causa insustentabilidade das cidades, afetando o equilíbrio ambiental não só dos espaços urbanos, mas também dos animais. Sendo assim, nessa concepção da cidade como bem ambiental, segue alguns exemplos de questões urbano-ambiental que afetam o equilíbrio, como:

- Alteração na fauna: Causando a fragmentação florestal, tirando a mobilidade animal de muitas espécies,perda da biodiversidade, manejo ambiental;

- $\quad \mathrm{Na}$ flora e espaços territoriais protegidos: Supressão de vegetação e intervenções em área de preservação permanente (APP) situadas em áreas urbanas, empreendimentos em expansão;

- No clima: Poluição causada por veículos automotores, comprometimento na qualidade do ar, mudanças climáticas; primária;

Perda de uma grande área de floresta

- Solo: Contaminação, poluição, aumento de resíduos sólidos;

- Meio Ambiente artificial: Assentamentos e loteamentos irregulares.

\subsection{POSSÍVEIS SUGESTÕES}

Considerando as modificações no Plano Diretor Urbano e Ambiental do Município de Manaus, o crescimento populacional, a expansão urbana e os consequentes impactos ambientais e socioambientais no entorno da Reserva Florestal Adolpho Ducke, recomenda-se o estabelecimento de uma zona de amortecimento, pois prevenir a degradação ambiental, preservar os ambientes naturais, e recuperar seus atributos ambientais tornaram-se necessidades vitais.

A Zona de Amortecimento (ZA, também chamada de "Zona Tampão") é uma área estabelecida ao redor de uma unidade de conservação com o objetivo de filtrar os impactos negativos das atividades que ocorrem fora dela, como: ruídos, poluição, espécies invasoras e avanço da ocupação humana, especialmente nas unidades próximas a áreas intensamente ocupadas.

Ela foi criada pelo artigo $2^{\circ}$, inciso XVIII da Lei do Sistema Nacional de Unidades de Conservação - SNUC (Lei no 9.985/2000), que a define como o "entorno de uma unidade de conservação, onde as atividades humanas estão sujeitas a normas e restrições específicas, com o propósito de minimizar os impactos negativos sobre a unidade". As 
zonas de amortecimento não fazem parte das Unidades de Conservação, mas localizadas no seu entorno, têm a função de proteger sua periferia, ao criar uma área de proteção que não só as defende das atividades humanas, como também previnem a fragmentação, principalmente, o efeito de borda.

A borda da área protegida é uma área sensível a uma gama de efeitos degradadores, o que a torna mais vulnerável a quaisquer alterações físicas (maior penetração do sol e do vento), químicas (luminosidade e umidade do solo) e biológicas (mudanças na interação entre as espécies). Uma ocorrência comum nas zonas limítrofes de áreas naturais, suas fronteiras acabam expostas e, por consequência, se tornam mais frágeis a condições que influenciam negativamente a estabilidade e o equilíbrio do ecossistema.

Não são apenas os fatores ecológicos que preocupam a vizinhança das unidades de conservação. Não mensurando as consequências de suas ações, atividades humanas desenvolvidas proximamente à área protegida podem afetar significativamente os atributos da unidade. Assim é que a simples criação de uma UC onde as restrições das atividades humanas fossem fixadas apenas dentro dos seus limites legais não seria suficiente para alcançar os objetivos da preservação.

Pela Resolução CONAMA no 428, de 17 de dezembro de 2010, atividades que possam afetar a zona de amortecimento só terão seu o licenciamento ambiental concedido após autorização do órgão gestor da unidade de conservação que ela circunda, que fará tal decisão mediante devidos estudos ambientais (EIA/RIMA). Se a Unidade foi estabelecida sem a definição de zona de amortecimento, empreendimentos com capacidade de impacto significativo ao ambiente deverão respeitar uma faixa estabelecida de $3 \mathrm{~km}$ de distância e serão obrigados a obter o licenciamento.

A faixa de proteção da ZA pode ser estabelecida no momento da criação da unidade ou em momento posterior pelo Instituto Chico Mendes de Conservação da Biodiversidade (ICMBio), na esfera federal, ou órgão ambiental responsável (nas demais esferas). Mais apropriado, tanto do ponto de vista ecológico quanto institucional, que a fixação da zona de amortecimento seja feita quando da elaboração dos estudos do plano de manejo da unidade.

Definida pelo art. $2^{\circ}$ da Lei do SNUC como a região do "entorno das unidades de conservação, onde as atividades humanas estão sujeitas a normas e restrições específicas, com o propósito de minimizar os impactos negativos sobre a unidade" as zonas de amortecimento se inserem no Sistema Nacional de Unidades de Conservação com o objetivo de contribuir para a manutenção da estabilidade e equilíbrio do ecossistema garantindo a integridade da área protegida.

Como a própria definição legal deixa transparecer, a finalidade da zona de amortecimento consiste na contenção dos efeitos externos que possam de alguma maneira influenciar negativamente na conservação da unidade. Desta maneira, mesmo não prevendo expressamente como seu objetivo a proteção aos reflexos ecológicos provocados pelo entorno, destinam-se as zonas de amortecimento a minimizar as conseqüências do efeito borda, de ocorrência comum nas zonas limítrofes, estabelecendo uma gradatividade na separação entre os ambientes da área protegida e de sua região envoltória, além de impedir que atuações antrópicas interfiram prejudicialmente na manutenção da diversidade biológica.

\section{CONSIDERAÇÕES FINAIS}

Em virtude do que foi mencionado, a Reserva Florestal Adolpho Ducke é considerada uma Área de Transição que é caracterizado pela presença de elementos rurais e urbanos, sendo considerada uma grande área de floresta primária preservada. Infelizmente com a expansão da cidade, a Reserva vem sofrendo um processo de fragmentação e possivelmente um isolamento, tendo como exemplo, desmatamentos, expansão urbana e ocupações irregulares. Apesar dessas intercessões ao redor da Reserva, seus recursos naturais continuam preservados.

Percebe-se que, a expansão da área urbana de Manaus é ocasionada pelo grande crescimento demográfico que a cidade vem enfrentando nas ultimas décadas. Assim como, podemos destacar que o mesmo ocorre nas grandes capitais brasileiras, a ausência de um planejamento urbano sistemático e a falta de controle relacionado ao crescimento da cidade ocasionando sérios 
problemas ambientais. Referente ao desmatamento, a cidade passa por uma situação de insustentabilidade, foi agravado por essa expansão e modernização dos espaços intra-urbanos decorrente dessa falta de planejamento, gerando praticas predatórias.

\section{REFERÊNCIAS}

[1]. AMBIENTAL E URBANO. As Zonas de Expansão Urbana. Disponível em: $<$ http://ambientalurbano.blogspot.com.br/2006/11/a s-zonas-de-expanso-urbana.html> Acesso em: 01/06/2016

[2]. CMM. Projeto de Lei № 322/2013. Disponível em: <http://www.cmm.am.gov.br/wpcontent/uploads/2013/08/PL_322_20131.pdf> Acesso em: 14/05/2016

[3]. CMM. Lei 1.838/2014. Disponível em: $<$ http://www.cmm.am.gov.br/wp-

content/uploads/2014/02/LEl_1838_DE_16_01_201

4.pdf> Acesso em: 14/05/2016

[4].

Flora da Reserva Ducke. Disponível

em:

http://webcache.googleusercontent.com/search?q = cache:Dly8eMs4hpAJ:rodriguesia.jbrj.gov.br/FAS CICULOS/Rodrig56_86/00b_introducao.pdf+\&cd=9 $\& h l=p t-B R \& c t=c l n k \& g l=b r$ Acesso enm: 11/04/2016

[5]. GLOBO.COM. População de Manaus cresce. Disponível em: <http://g1.globo.com/am/amazonas/noticia/2015/08 /populacao-de-manaus-cresce-e-chega-2057711estima-ibge.html> Acesso em: 10/05/2016

[6]. IBGE. Painel Populacional. Disponível em: $<$ http://cidades.ibge.gov.br/painel/populacao.php?lan $\mathrm{g}=\& \mathrm{codmun}=130260$ \&search=amazonasimanauslinfo gr\%E1ficos:-evolu\%E7\%E3o-populacional-epir\%E2mide-et\%E1ria> Acesso em: 28/05/2016

[7]. INPA. Reserva Florestal Adolpho Ducke. Disponível em: <http://peld.inpa.gov.br/sitios/ducke> Acesso em: 05/04/2016

[8]. INPA. Reserva Mapas. Disponível em: $<$ http://peld.inpa.gov.br/node/471> Acesso em: 05/04/2016

[9]. INPA. INPA discute. Disponível em: http://portal.inpa.gov.br/portal/index.php/ultimasnoticias/1002-inpa-discute-impactos-detransformar-entorno-da-reserva-ducke-em-zona-detransicao Acesso em: 11/04/2016

[10]. INPA. A Reserva Florestal Adolpho Ducke e o Plano Diretor de Manaus. Disponível em: $<$ http://peld.inpa.gov.br/node/471> Acesso em: 28/05/2016
Sendo assim, é preciso refletir sobre as premissas para a construção de políticas publicas sustentáveis, que faz parte de todo um conjunto, este o qual afeta a qualidade da vida humana, seu desenvolvimento socioeconômico e o desenvolvimento ambiental.

[11]. JUSBRASIL. Reserva Florestal. Disponível em: <http://www.jusbrasil.com.br/topicos/27233472/res erva-florestal-adolpho-ducke> Acesso em: 08/04/2016

[12]. LEIS MUNICIPAIS. Lei ordinária $\mathrm{n}^{\circ}$ 671/2002. Disponível em: <https://leismunicipais.com.br/a/am/m/manaus/leiordinaria/2002/68/671/lei-ordinaria-n-671-2002regulamenta-o-plano-diretor-urbano-e-ambientalestabelece-diretrizes-para-o-desenvolvimento-dacidade-de-manaus-e-da-outras-providenciasrelativas-ao-planejamento-e-a-gestao-do-territoriodo-municipio> Acesso em: 21/05/2016

[13]. MANAUS.GOV. Plano Diretor. Disponível em:

$<$ http://www2.manaus.am.gov.br//docs/portal/secre tarias/implurb/Legisla\%C3\%A7\%C3\%A3o/01Plano\%20Diretor/PLANO\%20DIRETOR\%202014.pd f> Acesso em: 09/04/2016

[14]. MANUAL DE PERÍCIAS. Estatuto da Cidade Lei № 10.257/2001. Disponível em: $<$ http://www.manualdepericias.com.br/perito-porarea/perito-engenheiro/ferramentas-do-peritoengenheiroarquiteto/estatuto-da-cidade-lei-no-10257-de-10-de-julho-de-2001/> Acesso em: 25/05/2016

[15]. MMA. CONAMA Resolução 001/86. Disponível em: <http://www.mma.gov.br/port/conama/res/res86/res 0186. html> Acesso em: 21/05/2016

[16]. MMA. Planejamento Ambiental e Urbano. Disponível em: <http://www.mma.gov.br/cidadessustentaveis/planejamento-ambientalurbano/itemlist/category/62-planejamentoambiental-urbano> Acesso em: 28/05/2016

[17]. MORAIS, L. M. F. A.; Expansão Urbana e Qualidade Ambiental, 2009. Disponível em: $<$ http://www.geociencias.ufpb.br/posgrad/dissertac oes/lenygia_maria.pdf> Acesso em: 01/06/2016

[18]. MP. Lei 672/2002. Disponível em: <http://www.mpam.mp.br/attachments/article/4856/ Lei672.pdf> Acesso em: 21/05/2015

[19]. Mudanças provocam impacto ambiental. Disponível em: <http://acritica.uol.com.br/noticias/MudancaManaus-provocar-impacto- 
ambiental_0_1042095801.html> Acesso em: $11 / 04 / 2016$

[20]. NOGUEIRA, A. C. F.; SANSON, F.; PESSOA, K.; A expansão urbana e demográfica da cidade de Manaus e seus impactos ambientais, 2007.

Disponível

em: <http://marte.sid.inpe.br/col/dpi.inpe.br/sbsr@80/20 06/11.14.17.45/doc/5427-5434.pdf> Acesso em: $10 / 05 / 2016$

$\begin{array}{lrr}\text { [21]. } & \text { Notícias Mudanças no } & \text { Plano } \\ \text { Diretor. } & \text { Disponível } & \text { em: } \\ \text { <http://www.acritica.com/channels/governo/news/p }\end{array}$ oder-publico-e-a-busca-pelo-meio-termo-paraobras-que-causam-impacto-ambiental>

Acesso em: 08/04/2016

[22]. OECO. Zona de Amortecimento. Disponível em: <http://www.oeco.org.br/dicionarioambiental/28754-o-que-e-uma-zona-deamortecimento/> Acesso em: 28/05/2016

[23]. SEMED. Cartilha do Plano Diretor. Disponível em: http://semed.manaus.am.gov.br/wpcontent/uploads/2010/12/cartilha-do-PlanaDiretor.pdf Acesso em: 15/04/16 


\section{Capítulo 2}

\section{ANÁLISE DA VIABILIDADE TÉCNICA E ECONÔMICA PARA O USO DE BIODIGESTORES EM ORGANIZACCÃO MILITAR CRIADORA DE EQÜINOS LEVANDO EM CONSIDERAÇÃO OS CREDITOS DE CARBONO}

\section{Romero de Albuquerque Maranhão}

\section{Norberto Stori}

Resumo: A geração de biogás produz inúmeras vantagens, principalmente em relação ao meio ambiente, transformando dejetos causadores de poluição em energia útil a ser aproveitada, através da biodigestão. Este trabalho consiste em uma análise técnica e econômica e preliminar da viabilidade de produção de energia térmica por meio de biogás, levando em consideração os créditos de carbono e sintetizado a partir de resíduos provenientes dos eqüinos criados por uma Organização Militar do Estado de São Paulo. Embora haja custos para implantação do sistema, o uso de biodigestores é: uma possível solução para o problema da destinação dos resíduos dos eqüinos; uma fonte de energia renovável; e uma fonte de recursos com a venda dos créditos de carbono, em função da não emissão de metano. 


\section{INTRODUÇÃO}

A criação de eqüinos, não diferente de outros manejos, causa impacto significativo ao meio ambiente e como tal requer adequada destinação dos resíduos gerados, sendo a implantação de biodigestores uma alternativa. Basicamente o biodigestor consiste, em uma câmara fechada onde a biomassa (volume de esterco produzido) é fermentada anaerobicamente (sem a presença do ar atmosférico), produzindo biogás e biofertilizante. Por si só, o biodigestor não produz o biogás, ele cria condições para que as bactérias metanogênicas produzam o gás metano, atuando sobre os materiais orgânicos na produção deste combustível (GASPAR, 2003).

A geração de biogás produz inúmeras vantagens, principalmente em relação ao meio ambiente, transformando dejetos causadores de poluição em energia útil a ser aproveitada, através da biodigestão. Resíduos animais, domiciliares ou industriais podem ser aproveitados, gerando economia e controle da poluição ambiental (MOURA \& PANNIR SELVAM, 2006).

Desta forma, a principal contribuição deste sistema é que os dejetos, produzidos são transformados em gás, além da possibilidade de utilizar os resíduos como fertilizantes. A produção de energia apresenta baixo custo, e o aproveitamento dos resíduos evita que estes sejam lançados no meio ambiente, poluindoo.

Assim, o presente trabalho consiste em uma análise técnica e econômica e preliminar da viabilidade de produção de energia térmica por meio de biogás, levando em consideração os créditos de carbono e sintetizado a partir de resíduos provenientes dos eqüinos criados por Organizações Militares, especificamente nesse estudo pelo Regimento de Cavalaria 9 de Julho da Policia Militar do Estado de São Paulo.

\section{EQÜINOS NO BRASIL}

O cavalo ocupa uma posição de destaque nos países desenvolvidos e em muitos daqueles em desenvolvimento. No Brasil, ao analisar o ciclo do açúcar no Brasil colonial, Gilberto Freire, destaca o papel do boi e do cavalo: o boi associado ao escravo e ao trabalho, e o cavalo ao senhor de engenho, destacando: "... essa caracterização do cavalo brasileiro como o animal, mais que qualquer outro, a serviço do domínio dos 'defensores da Ordem' sobre a massa" (FREYRE, 1937, p. 66).

Acredita-se que os primeiros cavalos voltados para utilização em solo brasileiro, chegaram em 1534, quando D. Ana Pimentel, esposa e procuradora de Martin Afonso de Souza (donatário da Capitânia de São Vicente), trouxe diversos animais domésticos das ilhas da Madeira e das Canárias. No ano seguinte, em 1535, Duarte Coelho (donatário da Capitânia de Pernambuco) iniciou a criação de animais domésticos no nordeste brasileiro incluindo, provavelmente, alguns cavalos (CEPEA, 2006).

De acordo com o CEPEA (2006), oficialmente, a chegada de cavalos no Brasil só foi registrada em 1549. Naquele ano, Tomé de Souza (primeiro governador-geral) mandou vir alguns animais, de Cabo Verde para a Bahia, na caravela Galga. Assim, nos primeiros anos da Colônia, a sua criação (junto com o gado bovino) foi iniciada formalmente e que seria fundamental para a formação do Brasil.

A criação de cavalos no Brasil colonial teve também importância estratégica. Durante o século XVII e parte do século XVIII o Brasil foi fornecedor de cavalos para as tropas portuguesas na África. Portugal tinha necessidade de cavalos para suas tropas, tanto para utilizar como armas de guerra quanto para intimidar os africanos (que demonstravam pavor ao cavalo) (CEPEA, 2006).

De acordo com dados do IBGE (2006), havia no Brasil, 5.787.250 eqüinos distribuídos por diversos Estados, conforme os dados da tabela 1. Sendo importante destacar que tais informações foram coletadas em correlação com a criação de bovinos junto aos criadores, estando fora da estatística os animais existentes em jockey clube ou Organizações Militares.

Em pesquisa realizada pelo CEPEA, em 2005, havia no Exército Brasileiro 1.570 cavalos, distribuídos por sete Estados, de acordo com a figura 1 e dados da tabela 2. Há predominância de eqüinos nas regiões sudeste, sul e centro-oeste. Além disso, registra que no mesmo ano havia nas Polícias Militares estaduais, um total 3.730 cavalos distribuídos pelo Brasil. (CEPEA, 2006). 


\section{1}

Tabela 1: Rebanho de eqüinos no Brasil, por Unidade da Federação, em 1990 e 2004.

\begin{tabular}{|c|c|c|}
\hline UF & Rebanho em 1990 & Rebanho em 2004 \\
\hline$A C$ & 10.518 & 32.752 \\
\hline $\mathrm{AL}$ & 58.408 & 52.686 \\
\hline AM & 11.199 & 11.907 \\
\hline AP & 3.757 & 3.706 \\
\hline BA & 659.330 & 614.073 \\
\hline CE & 231.894 & 139.102 \\
\hline DF & 8.350 & 6.000 \\
\hline ES & 84.823 & 72.956 \\
\hline $\mathrm{GO}$ & 452.330 & 442.818 \\
\hline MA & 286.923 & 175.027 \\
\hline$M G$ & 971.952 & 859.974 \\
\hline MS & 286.181 & 366.399 \\
\hline MT & 169.622 & 311.598 \\
\hline PA & 252.220 & 282.835 \\
\hline PB & 74.911 & 52.020 \\
\hline PE & 135.332 & 119.680 \\
\hline $\mathrm{PI}$ & 171.920 & 150.866 \\
\hline PR & 448.567 & 434.381 \\
\hline RJ & 107.300 & 105.827 \\
\hline $\mathrm{RN}$ & 39.103 & 40.338 \\
\hline $\mathrm{RO}$ & 52.263 & 146.683 \\
\hline $\mathrm{RR}$ & 36.316 & 27.800 \\
\hline $\mathrm{RS}$ & 593.555 & 484.512 \\
\hline SC & 164.418 & 128.343 \\
\hline SE & 82.646 & 68.640 \\
\hline SP & 611.563 & 500.177 \\
\hline TO & 152.430 & 156.150 \\
\hline Brasil & 6.157 .831 & 5.787 .250 \\
\hline
\end{tabular}

Fonte: IBGE (2006).

No Exército, os eqüinos são utilizados para diversas finalidades, tais como: a) ações de Garantia da Lei e da Ordem (GLO), nos Regimentos de Cavalaria (1은 $3^{\circ}$ e REsC); b) participação em cerimonial militar (desfiles, guarda de honra e escoltas de autoridades); c) patrulhamento em Organizações Militares e nos Campos de Instrução; d) instrução militar nas escolas de formações de oficiais e praças (AMAN - Academia Militar das Agulhas Negras; EsSA - Escola de Sargentos das
Armas; e, EsEqEx - Escola de Equitação do Exército); e) produção de imunobiológicos (soro antiofídico) em convênio do Ministério da Saúde com o IBEx - Instituto de Biologia do Exército; f) prática desportiva, integrando comissões de desportos nacionais; g) atividades de equoterapia; e h) programas de estudos e melhoramentos da eqüídeocultura nacional, na Coudelaria de Rincão (CEPEA, 2006). 
Figura 1: Distribuição de eqüinos no Exército Brasileiro.

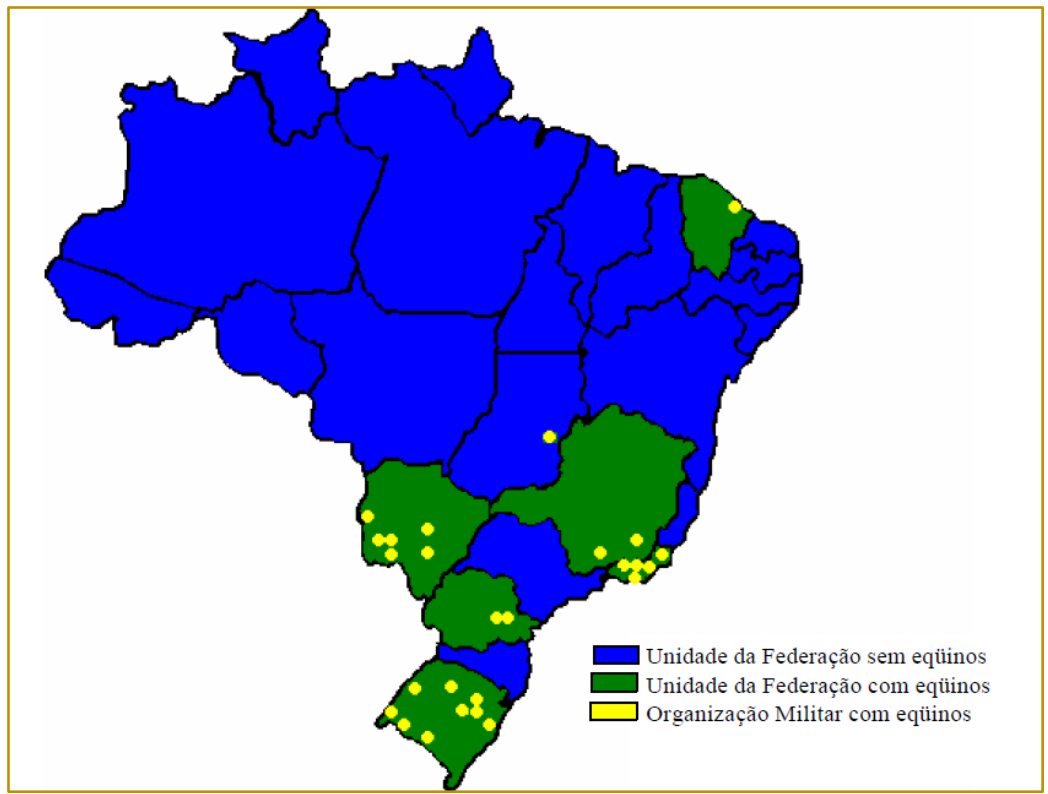

Fonte: CEPEA, 2006.

Tabela 2: Distribuição de eqüinos por Região Militar do Exército em 2005.

\begin{tabular}{|c|c|c|}
\hline \multirow{2}{*}{ Região Militar (RM) } & \multicolumn{2}{|c|}{ Efetivo } \\
\hline & Previsto & Real \\
\hline $1^{\text {a }} \mathrm{RM}$ (Rio de Janeiro) & 563 & 491 \\
\hline $3^{\text {a }}$ RM (Rio Grande do Sul) & 638 & 588 \\
\hline $4^{\mathrm{a}} \mathrm{RM}$ (Minas Gerais) & 70 & 67 \\
\hline $5^{\text {a }}$ RM (Paraná) & 2 & 2 \\
\hline $7^{\mathrm{a}} \mathrm{RM}$ (Ceará) & 15 & 14 \\
\hline 9a RM (Mato Grosso do Sul) & 96 & 98 \\
\hline $11^{\mathrm{a}} \mathrm{RM}$ (Distrito Federal) & 326 & 310 \\
\hline Total & 1.710 & 1.570 \\
\hline
\end{tabular}

Fonte: CEPEA, 2006.

\section{BIODIGESTOR E BIOGÁS}

Chama-se digestor a câmara onde se processa a digestão. Trata-se de um tanque fechado em concreto ou alvenaria onde a mistura (6 a $20 \%$ de sólidos e a restante água) a ser digerida é colocada (BATISTA, 1981).

O biodigestor é composto, basicamente, de uma câmara fechada chamada de digestor na qual biomassas (em geral detritos de vegetais e animais), são fermentadas anaerobicamente, isto é, sem a presença de ar. Como resultado desta fermentação ocorre à liberação de biogás e a produção de biofertilizante. Esse aparelho, não produz o biogás, apenas fornece as condições propícias para que as bactérias, as metanogênicas, degradem 0 material orgânico, com a conseqüente liberação do gás metano (COELHO et al, 2006).

Existem vários tipos de biodigestor, mas, em geral, todos são compostos, basicamente, de duas partes: um recipiente (tanque) para abrigar e permitir a digestão da biomassa, e o 
gasômetro (campânula), para armazenar o biogás.

Em relação ao abastecimento de biomassa, o biodigestor pode ser classificado como contínuo, isto é, abastecimento diário de biomassa, com descarga proporcional à entrada de biomassa, ou intermitente, quando utiliza sua capacidade máxima de armazenamento de biomassa, retendo-a até a completa biodigestão. Então, retiram-se os restos da digestão e faz-se nova recarga. $\mathrm{O}$ modelo de abastecimento intermitente é mais indicado quando da utilização de materiais orgânicos de decomposição lenta e com longo período de produção, como no caso de palha ou forragem misturada a dejetos animais.

De acordo com Coldebella et al. (2006), o biogás é composto por uma mistura de gases que tem sua concentração determinada pelas características do resíduo e as condições de funcionamento do processo de digestão. É constituído principalmente por metano $\left(\mathrm{CH}_{4}\right)$ e dióxido de carbono $\left(\mathrm{CO}_{2}\right)$, geralmente apresenta em torno de 65\% de metano, o restante é composto na maior parte por dióxido de carbono e alguns outros gases como nitrogênio, hidrogênio, monóxido de carbono entre outros, porém, em menores concentrações, conforme demonstrado na tabela 3.

Tabela 3: Composição do biogás.

\begin{tabular}{|c|c|c|}
\hline Gás & Símbolo & Concentração no biogás(\%) \\
\hline Metano & $\mathrm{CH}_{4}$ & $50-80$ \\
\hline Dióxido de carbono & $\mathrm{CO}_{2}$ & $20-40$ \\
\hline Hidrogênio & $\mathrm{H}_{2}$ & $1-3$ \\
\hline Nitrogênio & $\mathrm{N}_{2}$ & $0,5-3$ \\
\hline Gás Sulfídrico e outros & $\mathrm{H}_{2} \mathrm{~S}, \mathrm{CO}, \mathrm{NH}_{3}$ & $1-5$ \\
\hline & Fonte: La Farge, 1979.
\end{tabular}

Como pode ser observado na tabela 4 , os dejetos de eqüinos apresentam uma grande capacidade de produção de biogás, porém a produção de metano é variável e dependente da ração do animal.

Tabela 4: Produção de biogás por dejetos animais.

\begin{tabular}{|c|c|c|c|}
\hline Dejetos & $\begin{array}{c}\text { Sólidos } \\
(\mathrm{kg} / \text { /animal/dia })\end{array}$ & $\begin{array}{c}\text { Produção biogás } \\
\left(\mathrm{m}^{3} / \text { animal/dia }\right)\end{array}$ & $\begin{array}{c}\text { Gás metano } \\
\text { produzido }(\%)\end{array}$ \\
\hline Bovinos & $10-15$ & $0,292-0,980$ & 55 \\
\hline Suínos & $2,25-2,5$ & $0,799-0,933$ & 50 \\
\hline Eqüinos & 10 & $0,36-1,225$ & Variável \\
\hline Ovinos & $0,5-2,28$ & $0,25-0,32$ & 50 \\
\hline Aves & $0,12-0,18$ & $0,001-0,017$ & Variável \\
\hline \multicolumn{2}{|c|}{ Fonte: } \\
\hline
\end{tabular}

Costa (2006) ressalta que o poder calorífico do biogás depende fundamentalmente das proporções de metano e gás carbônico. Através da compilação dos trabalhos de Avellar (2001) apud Costa (2006) e de Coldebella et al. (2006), é possível estabelecer uma relação linear entre a concentração de metano e o poder calorífico do biogás, de acordo com o gráfico da figura 2.

O valor a ser utilizado como referência nesse estudo é o proposto por Nogueira \& Zürn (2005), pois diversos autores citam que a concentração de metano no biogás costuma variar entre 50 e 60\% (COSTA, 2006; 
COLDEBELLA et al, 2006; TEIXEIRA, 1985). Segundo Lucas Júnior (1987), o biogás produzido em biodigestores, pelo período de um ano, é em média, $57,7 \%$ de $\mathrm{CH}_{4}$ e 34,2 de $\mathrm{CO}_{2}$.

É importante destacar que o gás metano é um gás de efeito estufa com potencial de aquecimento global cerca de 21 vezes maior se comparado ao dióxido de carbono e é responsável por $20 \%$ do aquecimento global e, por isso, não deve ser lançado na atmosfera (CENBIO, 2008).

Figura 2: Relação linear entre a Concentração de Metano e o Poder Calorífico do Biogás.

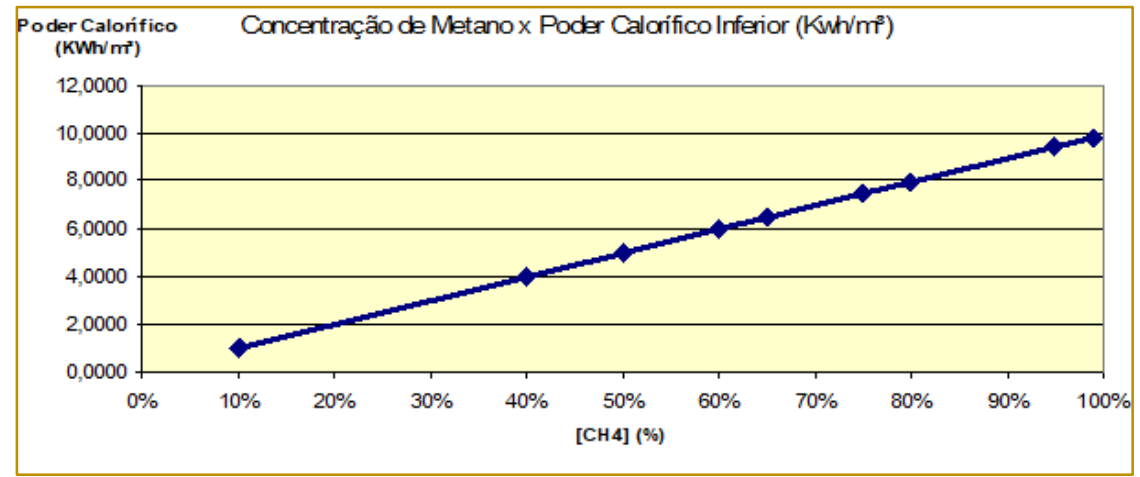

Fonte: Baseado em COSTA (2006) e COLDEBELLA et a./(2006).

Em função da porcentagem com que 0 metano participa na composição do biogás, o poder calorífico deste pode variar de 5.000 a $7.000 \mathrm{kcal}$ por metro cúbico. Esse poder calorífico pode chegar a $12.000 \mathrm{kcal}$ por metro cúbico uma vez eliminado todo o gás carbônico da mistura.
Segundo Sganzerla (1983) e Lucas Júnior et al. (2003), $1 \mathrm{~m}^{3}$ de biogás pode ser aplicado para gerar $1,428 \mathrm{kWh}$ de eletricidade, conforme dados constantes da tabela 5 .

Tabela 5: Correspondência entre o biogás e outras fontes de energia.

\begin{tabular}{|l|l|}
\hline \multirow{2}{*}{$1 \mathrm{~m}_{3}$ de biogás corresponde a } & $1,8 \mathrm{Kg}$ de I enha seca \\
\cline { 2 - 3 } & $910 \mathrm{ml}$ de ácool \\
\cline { 2 - 3 } & $610 \mathrm{ml}$ de gasolina \\
\cline { 2 - 3 } & $570 \mathrm{ml}$ de querosene \\
\cline { 2 - 3 } & $550 \mathrm{ml}$ de óleo diesel \\
\hline & $0,45 \mathrm{Kg}$ de GLP \\
\hline $1,428 \mathrm{kwh}$ de energia elétrica \\
\hline
\end{tabular}

Fonte: LUCAS JÚNIOR et al., 2003.

De acordo com Oliveira (2004), a geração de energia elétrica, com o uso de biogás como combustível, pode ser dividida nas seguintes tecnologias disponíveis no momento:

- Conjunto Gerador de Eletricidade: consiste em um motor de combustão interna ciclo Otto (álcool, gasolina ou diesel) adaptado para o uso do biogás como combustível, acoplado a um gerador de eletricidade, independente da rede de energia elétrica da concessionária local; e
- Conjunto Gerador Economizador de Eletricidade: consiste em um motor de combustão interna ciclo Otto (álcool, gasolina ou diesel) adaptado para o uso do biogás como combustível, acoplado a um motor assíncrono, 2 ou 4 pólos, que passa a gerar energia ao ser conectado à rede de energia elétrica da concessionária local.

No primeiro caso, o conjunto é independente de rede de energia elétrica local, gerando energia dentro da propriedade com o sistema de distribuição interno isolado. No segundo 
caso, gerador economizador de eletricidade, o equipamento gera energia somente se estiver conectado à rede de distribuição da concessionária de energia elétrica, deixando de funcionar se a mesma sofrer interrupção, ou manutenção nas redes elétricas externas. Neste caso a energia gerada é distribuída na propriedade e na rede externa até $O$ transformador mais próximo (OLIVEIRA, 2004).

\section{BIODIGESTOR EM ORGANIZAÇÃO MILITAR}

A primeira Organização Militar a utilizar biodigestores, no Brasil, é o 1ํ Regimento de Cavalaria de Guarda (RCG), do Exército em Brasília, oficialmente conhecido como Dragões da Independência. O projeto dos biodigestores foi desenvolvido por uma parceria entre o Ministério de Minas e Energia, o Exército e o Instituto de Tecnologia para o Desenvolvimento (LACTEC) - laboratório ligado à Universidade Federal do Paraná (UFPR) (AGÊNCIA BRASIL, 2007).
A central de produção de biogás do RCG é composta por dois biodigestores que recebem cerca de $500 \mathrm{~kg} / \mathrm{dia}$ de estrume, um misturador (figura 3) e um motor que gera a energia elétrica (EXÉRCITO BRASILEIRO, 2010). Numa primeira fase do projeto, a expectativa é de que a energia gerada ilumine o regimento durante a noite. "Tendo em vista a economia de luz, a gente mantinha o mínimo necessário; com isso eu posso manter todas as luzes acesas, aumentando a segurança do regimento", afirma o Comandante, coronel Souto Martins (AGÊNCIA BRASIL, 2007).

De acordo com o Comandante da Organização Militar, a economia na conta de energia pode chegar a até $20 \%$ dos $\mathrm{R} \$ 16$ mil que são gastos mensalmente na unidade. Numa segunda etapa do programa, a produção de gás pode abastecer o regimento também durante o dia, gerando uma economia de luz maior (AGÊNCIA BRASIL, 2007).

Figura 3: Misturador de estrume com água do 1ํ Regimento de Cavalaria de Guarda (RCG).

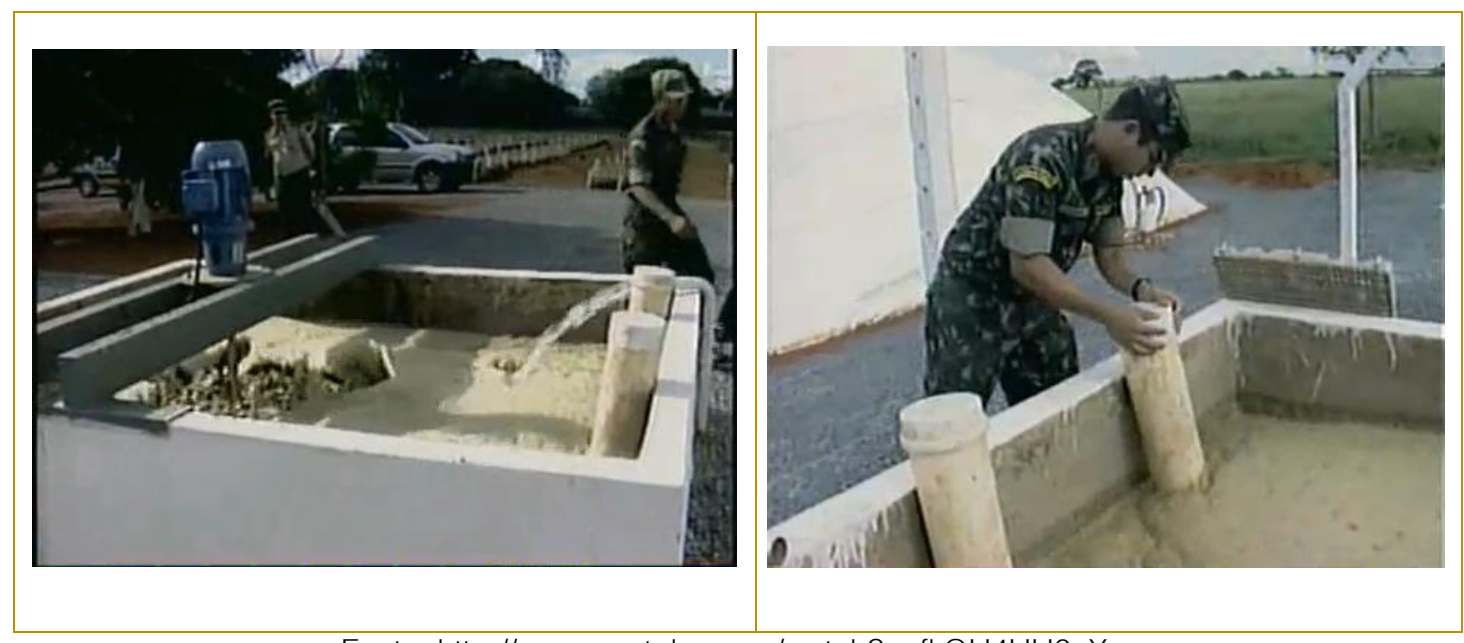

Fonte: http://www.youtube.com/watch?v=fkOU4UU6eXg.

O LACTEC tem a intenção de implementar o projeto também com a Polícia Militar do Estado do Paraná, para geração de energia, pois atualmente, as fezes dos animais são utilizadas para compostagem e fertilização do solo, mas esse é um processo bastante trabalhoso e de alto custo (PARANÁ ONLINE, 2007).

$\mathrm{Na}$ Inglaterra o estrume dos cavalos da unidade de cavalaria cerimonial do Exército britânico, cerca de 170 animais, terá a partir de 2011 um novo destino: a produção de energia para aquecer e iluminar a nova sede do regimento, no sul de Londres. A medida está alinhada com a meta do governo para reduzir as emissões de carbono (REVISTA EXAME, 2010).

\section{METODOLOGIA}

O Estudo foi desenvolvido no Regimento de Policia Montada 9 de Julho que é uma unidade da Polícia Militar do Estado de São Paulo, constitui em órgão especial de execução subordinado ao Comando de Policiamente de Choque atuando na 
preservação da órdem pública em operações especiais rurais e urbanas e controle de tumultos. Possui atualmente 3 destacamentos na Grande São Paulo, nas cidades de Mauá, São Bernardo do Campo e na Academia de Polícia Militar do Barro Branco.

O regimento da cavalaria possui 300 cavalos, com peso médio de 500 kg (CURY, 2010), que são confinados quando em estábulos (figura 4). Em decorrência de seu porte e de sua mobilidade, os eqüinos de Cavalaria são utilizados para vários fins, sendo insubstituíveis em situações específicas como no patrulhamento urbano e no controle de multidões. No entanto, para que exerçam sua função adequadamente, devem permanecer próximos ao homem (LEAL, 2007).

Figura 4: Regimento de Cavalaria 9 de Julho e os cavalos nos estábulos.

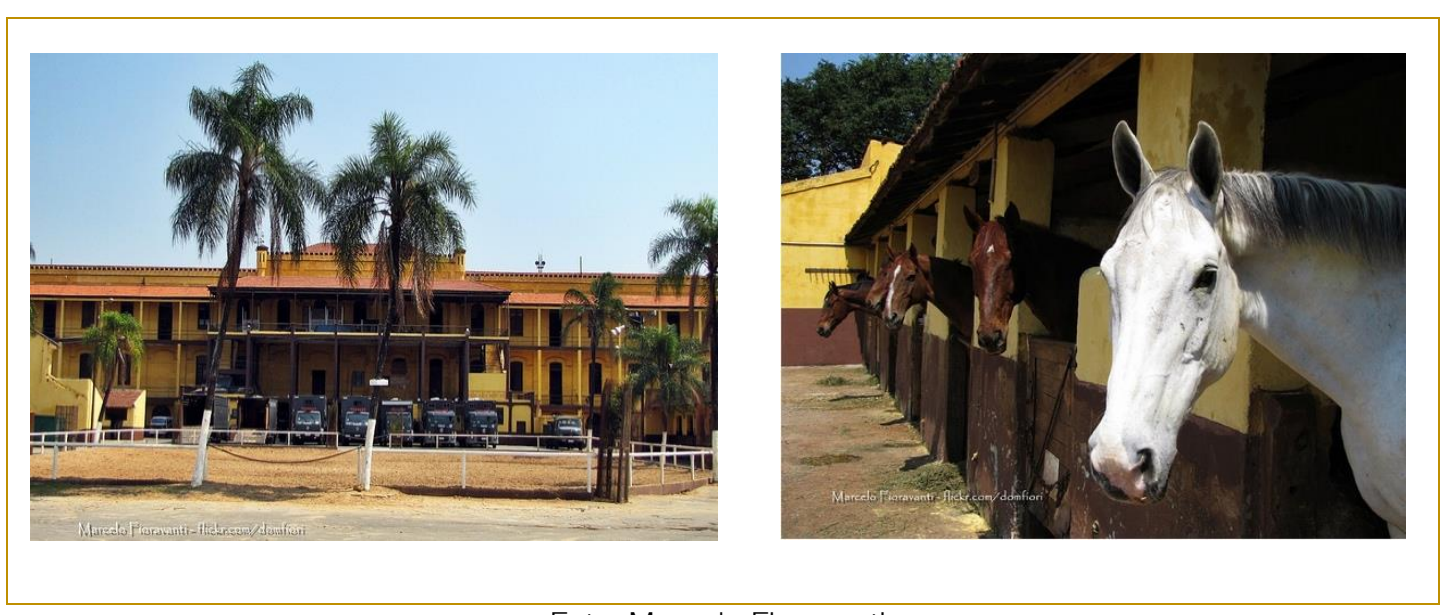

Foto: Marcelo Fioravanti.

\section{RESULTADOS E DISCUSSÃO \\ 6.1. VIABILIDADE TÉCNICA}

Os tipos de biodigestores mais usados são o indiano, o chinês e o canadense. O modelo indiano tem sua cúpula geralmente feita de ferro ou fibra. Nesse tipo de biodigestor o processo de fermentação acontece mais rápido, pois aproveita a temperatura do solo que é pouco variável, favorecendo a ação das bactérias. Ocupa ainda pouco espaço e a construção por ser subterrânea, dispensa o uso de reforços, tais como cintas de concreto.

Já modelo chinês foi desenvolvido voltado para as pequenas propriedades rurais. É um modelo de peça única, construído em alvenaria e enterrado no solo, para ocupar menos espaços. Este modelo tem o custo mais barato em relação aos outros, pois sua cúpula também é feita em alvenaria. Enquanto o modelo Canadense (figura 5) é um modelo tipo horizontal, apresentando uma caixa de carga em alvenaria e com a largura maior que a profundidade, possuindo, portanto, uma área maior de exposição ao sol, o que possibilita numa grande produção de biogás e evitando o entupimento. Durante a produção de gás, a cúpula do biodigestor infla porque é feita de material plástico maleável (PVC), podendo ser retirada. O maior empecilho deste equipamento é o alto custo da cúpula (CASTANHO e ARRUDA, 2008). 
Figura 5: Biodigestor modelo canadense.

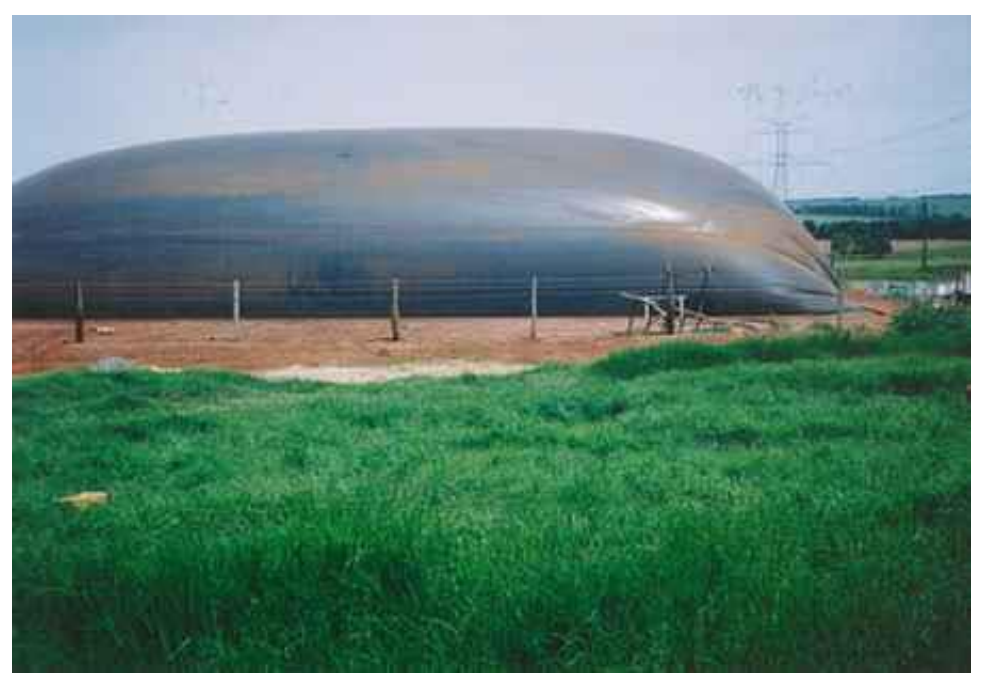

Para Lindemeyer (2008), o modelo canadense com cobertura de lona de PVC, em substituição às campânulas (metálica ou de fibra de vidro), vem ganhando maior espaço em virtude dos menores custos e facilidade de implantação (LINDEMEYER, 2008).

Desta forma, o modelo sugerido por esse estudo será o canadense, que possui custo para construção de $R \$ 16.000,00$, acrescido da manta de PVC flexível modelo $200 \mathrm{m3}$ e área de $480 \mathrm{~m} 2$ que custa em média $\mathrm{R} \$ \quad 8.300,00$, totalizando $\mathrm{R} \$ 24.300,00$. Associado a este sistema de tratamento esta o conjunto motor/gerador composto por um motor de 4,9l e 55cv de potência a 1800 RPM, tradicionalmente utilizado no veículo F-1000 a gasolina e um gerador de $60 \mathrm{~Hz}$ com capacidade de gerar $44 \mathrm{kWh}$ em regime continuo com custo de implantação em torno dos $\mathrm{R} \$ 20.000,00$. Desta maneira, o custo total para implantar o sistema seria de $\mathrm{R} \$ 44.300,00$.

As dimensões do biodigestor foram obtidas a partir dos dados constantes das tabelas 4, 6 e 7. Cabendo ressaltar que para dimensionar o biodigestor optou-se por utilizar a quantidade mínima de biogás produzido por um eqüino.

Tabela 6: Dimensionamento do biodigestor.

\begin{tabular}{|c|c|c|c|c|c|}
\hline $\begin{array}{c}\text { Volume } \\
\left(\mathbf{m}^{\mathbf{3}}\right)\end{array}$ & $\begin{array}{c}\text { Profundidade } \\
(\mathbf{m})\end{array}$ & $\mathbf{C} 1(\mathbf{m})$ & Largura L1 $(\mathbf{m})$ & $\mathbf{C} 2(\mathbf{m})$ & Largura L2 $(\mathbf{m})$ \\
\hline 3,0 & 1,0 & 3,5 & 1,2 & 3,0 & 0,7 \\
\hline 7,0 & 1,0 & 6,0 & 2,0 & 4,8 & 0,8 \\
\hline 15,0 & 1,4 & 7,0 & 2,5 & 5,5 & 1,0 \\
\hline 20,0 & 1,5 & 8,0 & 3,0 & 6,0 & 1,0 \\
\hline 30,0 & 1,5 & 10,0 & 3,5 & 8,0 & 1,5 \\
\hline 100,0 & 2,0 & 15,0 & 5,0 & 13,0 & 3,0 \\
\hline 200,0 & 2,5 & 19,0 & 6,0 & 16,0 & 4,0 \\
\hline 300,0 & 3,0 & 21,0 & 7,0 & 18,0 & 5,0 \\
\hline
\end{tabular}

Fonte: Almeida et al. (2008) 
Tabela 7: Estimativa de biogás produzido por eqüinos da cavalaria do Estado de São Paulo.

\begin{tabular}{|c|c|c|}
\hline Número de eqüinos & Biogás por animal $\left(\mathrm{m}^{3}\right)$ & Total de biogás produzido $\left(\mathrm{m}^{3}\right)$ \\
\hline 300 & $0,36^{*}$ & 108 \\
\hline 300 & $0,79^{\star \star \star}$ & 237 \\
\hline 300 & $1,225^{\star *}$ & 367,5 \\
\hline
\end{tabular}

\subsection{VIABILIDADE ECONÔMICA}

A análise econômica do empreendimento consiste em fazer estimativas de todo o gasto envolvido com o investimento inicial, operação e manutenção e receitas geradas durante um determinado período de tempo.
O Payback quer dizer retorno do investimento, ou seja, quanto tempo será necessário para que o capital investido inicialmente seja recuperado. O Payback pode ser calculado conforme a expressão:

Onde:

$$
P B=\frac{\text { Inv.Inicial }}{\sum F C_{A n o}}
$$

Investimento Inicial = custo do investimento inicial, em $\mathrm{R} \$$

$F C=$ fluxo de caixa ao ano, em $R \$$

É importante registrar que o payback não considera o valor do dinheiro no tempo (GITMAN, 2002), normalmente é empregado para calcular o retorno de pequenos investimentos, pois é um método simples de avaliação.

De acordo com Lindemeyer (2008), a implantação de uma unidade geradora se viabiliza economicamente pelo equivalente em quilowatts/hora evitados no consumo tradicional. A economia é grande quando, por exemplo, a energia gerada é utilizada para suprir a demanda durante o horário de ponta (entre as 18 e as 21 horas), em que o custo da eletricidade chega a sete vezes o valor do horário normal. Utilizar a eletricidade gerada pela biomassa apenas em determinados horários só é possível porque essa fonte, sob esse aspecto, assemelha-se muito a outra renovável, a hidreletricidade. Assim como a energia é armazenada na forma de água nos reservatórios das usinas hidrelétricas, ela pode ser armazenada na forma de biogás em gasômetros.
Em termos de condições técnicas e operacionais, a ANEEL, através do Decreto Federal no 5.163/04 e pela Norma Técnica 167/05, reconheceu e regulamentou a geração de energia próxima ao local de consumo. Em julho de 2008, a Agência emitiu a Resolução no 1.482, autorizando a Companhia Paranaense de Energia Elétrica (COPEL) a implantar projeto-piloto que prevê a compra da energia excedente produzida em pequenas propriedades rurais no Paraná a partir de dejetos de animais. Com isso abrese a possibilidade para pequenos produtores de energia vender para a concessionária local o excedente de energia produzida e não consumida.

A receita com energia elétrica, que servirá como fluxo de caixa, para o payback foi calculada e servirá para economizar no consumo da Organização Militar. Conforme dados da tabela 8 é possível estabelecer a quantidade de energia gerada a produção de biogás. 
Tabela 8: Produção de energia a partir do biogás produzido pelos eqüinos.

\begin{tabular}{|c|c|c|c|}
\hline Quantidade biogás & Fator Kwh & $154 \mathrm{kwh}$ & $4620 \mathrm{kwh}$ \\
\hline $108 \mathrm{~m}^{3}$ & 1,428 & $338 \mathrm{Kwh}$ & $10140 \mathrm{kwh}$ \\
\hline $237 \mathrm{~m}^{3}$ & 1,428 & $525 \mathrm{kwh}$ & $15750 \mathrm{kwh}$ \\
\hline $367,7 \mathrm{~m}^{3}$ & 1,428 & Quantidade dia & Quantidade mês \\
\hline
\end{tabular}

Para auferir a receita, foi utilizada a taxa de $\mathrm{R} \$ 0,22$, conforme constante no sítio eletrônico da ANEEL. Para $108 \mathrm{~m}^{3}$ é possível obter uma redução de $\mathrm{R} \$ 1.016,40$ ao mês e $\mathrm{R} \$ 12.196,80$. Conforme dito anteriormente, foi somente utilizado o valor mínimo de produção do biogás para se obter o cálculo da receita e estabelecer o payback, estimado em 44 meses ( 3 anos e 8 meses). Caso considerado o valor médio de biogás produzido, o payback seria menor que 2 anos, e com o valor máximo de biogás produzido, o payback seria de 1 ano.

\subsection{CRÉDITOS DE CARBONO}

De acordo com a EMBRAPA (2002), emissões de metano a partir dos processos digestivos de todos os animais têm sido estimadas entre 65 e 100 Tg/ano (média de 85 Tg/ano), representando cerca de $15 \%$ das emissões totais de metano. As emissões de metano a partir de dejetos animais, estimadas em $25 \mathrm{Tg}$ (20 - 30 Tg) (IPCC, 1995), estão associadas com o manejo de animais confinados, onde os dejetos são manipulados como líquidos.

A possibilidade de auferir receitas extras através da venda de créditos de carbono provenientes do não lançamento de gases do efeito estuda é outro aspecto que contribui para o aumento no interesse pela tecnologia. Para obter receitas com créditos de carbono é preciso ter um projeto de Mecanismo de Desenvolvimento Limpo (MDL).

De forma resumida é possível obter ganho com o metano, a partir da energia gerada ao mês 4620 kwh, para o valor mínimo de biogás produzido. Em um ano estima-se que seja produzida 55,44 Mwh. Conforme instruções da United Nations Framework Convention on Climate Change, o fator de correção $(0,27)$ aplicado ao valor de 55,44 Mwh/ano, obtemos 14,96 total RCE $\mathrm{CO}_{2}$ (Reduções Certificadas de Emissões).

Fazendo a conversão de $14,96 \times$ Fator de correção para metano (327,45 Euros), obtemos 4898,65 euros, convertendo a uma taxa de câmbio $R \$ 2,75$, podemos obter $R \$ 13.471,28$.

Se considerarmos o valor obtido com os créditos de carbono no payback, o retorno no investimento passa a ser em 39 meses (3 anos e 3 meses). Caso seja considerado os ganhos com energia e créditos de carbono, o retorno do investimento seria em aproximadamente 20 meses.

\section{CONCLUSÕES}

Embora haja custos para implantação do sistema, o uso de biodigestores é: uma possível solução para o problema da destinação dos resíduos dos eqüinos; uma fonte de energia renovável; e uma fonte de recursos com a venda dos créditos de carbono, em função da não emissão de metano.

A viabilidade ambiental do trabalho não foi apresentada, todavia $O$ atendimento a legislação atinente aos resíduos sólidos; a eliminação ou redução de esterco, com a produção de biofertilizante e não considerado com uma possível fonte de receita para a Organização Militar; e a minimização dos gases de efeito estufa, por si só já representam características que justifiquem a viabilidade ambiental do projeto.

Não foram levados em consideração a mãode-obra e os custos para manutenção do sistema, por entender que há pessoal qualificado para tais atividades. Mesmo assim, o investimento é considerado baixo para o retorno com a energia elétrica que poderá ser economizada.

O estudo manteve o valor mínimo de biogás produzido como referência por entender que há uma gama de atividades, em diversos horários para os eqüinos e, portanto sem uma produção de esterco em ciclos homogêneos.

A dificuldade na obtenção de dados para eqüinos é um fator que limitou o desenvolvimento do trabalho, todavia apresenta lacunas que poderão ser 
preenchidas com pesquisa mais aprofundada, entre elas: acompanhamento da rotina dos animais, sua alimentação e atividades, para que se possa entender o ciclo dos cavalos que prestam atividades nas

\section{REFERÊNCIAS}

[1]. AGÊNCIA BRASIL. Estrume de cavalos do exército gera energia e fertilizante. Brasília, 2007. Disponível em: http://www.cabecadecuia.com/noticias/3395/estru me-de-cavalos-do-exercito-gera-energia-efertilizante.html. Acessado em: 10 de dezembro de 2010.

[2]. BARRERA, Paulo. Biodigestores: Energia, Fertilidade e Saneamento Para Zona Rural. São Paulo: Ícone, 1993.

[3]. BATISTA, L. F. Manual técnico construção e operação de biodigestores. Brasília, 1981, 54p.

[4]. CASTANHO, D. S.; ARRUDA, H. J. Biodigestores. In: Anais da VI Semana de Tecnologia em Alimentos. UTFPR, 2008. Disponível em: http://www. pg.utfpr.edu.br/setal/docs/artigos/2008/a2/004.pdf. Acesso em: 10 de dezembro de 2013.

[5]. CENBIO. Nota Técnica VIII: Biogás e o mercado de crédito de carbono. São Paulo, 2008. Disponível em: http://cenbio.iee.usp.br/download/documentos/nota tecnica_viii. pdf. Acesso em: 10 de dezembro de 2013.

[6]. CEPEA. Estudo do complexo do agronegócio cavalo. 2006. Disponível em: http://www.cepea.esalq.usp.br/pdf/cavalo_resumo. pdf. Acesso em: 28 de dezembro de 2014.

[7]. COLDEBELLA, A.; SOUZA, S. N. M.; SOUZA, J. Viabilidade da cogeração de energia elétrica com biogás da bovinocultura de leite. In: AGRENER GD 2006 - 6을 Congresso Internacional sobre Geração Distribuída e Energia no Meio Rural. UNICAMP, Campinas, 2006.

[8]. COSTA, D. F. Geração de Energia Elétrica a Partir do Biogás do Tratamento de Esgoto. Dissertação de Mestrado, USP, São Paulo, 2006.

[9]. CURY, M. Cavalaria completa 118 anos sem parar no tempo. São Paulo, 2010. Disponível em: $\quad$ http://www.marcelocury.com/cavalariacompleta-118-anos-sem-parar-no-tempo/. Acesso em: 18 de dezembro de 2014.

[10]. EMBRAPA - Empresa Brasileira de Agropecuária. Primeiro inventário brasileiro de emissões antrópicas de gases de efeito estufa. Relatórios de Referência - Emissão de metano da pecuária. Ministério de Ciência e Tecnologia/MCT, 2002.

[11]. EXÉRCITO BRASILEIRO, 2010. Boas Práticas - Biodigestor. Disponível em: ruas do Estado de São Paulo; obtenção de financiamento para colocação de um biodigestor nas unidades que possuem eqüinos em São Paulo para que seja possível verificar se o retorno in situ é positivo.

http://www.exercito.gov.br/03ativid/meioambiente/ materias/biodigestor.htm. Acesso em: 30 de setembro de 2014.

[12]. FREYRE, G.M. Nordeste : aspectos da influência da cana sobre a vida e a paisagem do nordeste do Brasil. Rio de Janeiro : Jose Olympio, 1937.

[13]. GASPAR , R. M. B. L. Utilização de biodigestores em pequenas e médias propriedades rurais com ênfase na agregação de valor: Um estudo de caso na região de Toledo-PR. Pós-Graduação em engenharia de produção e sistemas da Universidade Federal de Santa Catarina. Florianópolis, 2003, 119p.

[14]. GITMAN, Lawrence J. Principios de administração financeira. São Paulo: Harbra, 2002.

[15]. IBGE - Instituto Brasileiro de Geografia e Estatística. Censo Agropecuário. 2006.

[16]. IPCC, 1995. Climate Change 1994. Radiative Forcing of Climate Change. Cambridge: University Press. 339p.

[17]. LA FARGE, B. Le Biogaz - Procedes de Fermentation Méthanique. Paris, Masson, 1979.

[18]. LEAL, B. B. Avaliação do bem-estar dos eqüinos de cavalaria da Polícia Militar de Minas Gerais: indicadores etológicos, endocrinológicos e incidência de cólica. Dissertação de Mestrado apresentada ao Programa de Pós-Graduação em Veterinária-UFMG, 2007.

[19]. LINDEMEYER, R. M. Análise da viabilidade econômico-financeira do uso do biogás como fonte de energia elétrica. Trabalho de Conclusão de Curso de Administração, UFSC, 2008.

[20]. LUCAS JÚNIOR, J. Estudo comparativo de biodigestores modelos indiano e chinês. Tese (Doutorado em Produção Vegetal) - Faculdade de Ciências Agrárias e Veterinárias, Universidade Estadual Paulista, Jaboticabal, 1987.

[21]. LUCAS JÚNIOR, J.; SOUZA, C. F.; LOPES, J. D. S. Construção e operação de biodigestores. Série energia alternativa, manual 441. Viçosa-MG, CPT, 2003, 176 p.

[22]. MOURA, J.P. \& PANNIR SELVAM, P.V.P., Sistema integrado de energia usando fundamentos de engenharia ambiental. Bioenergy World Américas, 2006. Disponível em: www.bioenergyworld.com/americas /2008/IMG/. Acesso em: 12 de dezembro de 2014. 
[23]. NOGUEIRA, L. A. H. Biodigestão: a alternativa energética. São Paulo: Nobel, 1986.

[24]. NOGUEIRA, C. E. C., ZÜRN, H. H.. Modelo de dimensionamento otimizado para sistemas energéticos renováveis em ambientes rurais. Engenharia Agrícola, Jaboticabal, v.25, n.2, p.341348, maio/ago, 2005.

[25]. OLIVEIRA, P. A. V. Tecnologias para o manejo de resíduos na produção de suínos: manual de boas práticas. Concórdia, Embrapa Suínos e Aves, 2004, 109p.

[26]. PARANÁ ON LINE. Projeto do Lactec para produção de biogás será usado pela Polícia Militar. 2007. Disponível em: http://www.paranaonline.com.br/editoria/cidades/ news/250831/?noticia=PROJETO+DO+LACTEC+PARA+ PRODUCAO

+DE+BIOGAS+SERA+USADO+PELA+POLICIA+MILITA R. Acesso em: 23 de dezembro de 2014.
[27]. REVISTA EXAME. Dejetos da cavalaria real britânica vão gerar energia. 2010. Disponível em: http://exame.abril.com.br/economia/meio-ambientee-energia/noticias/ dejetos-cavalaria-real-britanicavao-gerar-energia-580828. Acesso em: 23 de dezembro de 2014.

[28]. SALOMON, K. R. Avaliação técnicoeconômica e ambiental da utilização do biogás proveniente da biodigestão da vinhaça em tecnologias para geração de eletricidade. Itajubá. 219 p. Tese de Doutorado (Doutorado em Conversão de Energia) - Instituto de Engenharia Mecânica, Universidade Federal de Itajubá, 2007.

[29]. SGANZERLA, E. Biodigestor: uma solução. Agropecuária, Porto Alegre, 1983.

[30]. TEIXEIRA, E. N. Adaptação de estruturas existentes (esterqueiras) em biodigestores. Tese de Mestrado. UNICAMP, Campinas, 1985. 


\section{Capítulo 3}

\section{"QUEM NÃO SE COMUNICA SE TRUMBICA!": COMUNICAÇÃO, TREINAMENTO E GESTÃO AMBIENTAL EM ORGANIZAÇÃO MILITAR DO ESTADO DE SÃO PAULO}

\section{Romero de Albuquerque Maranhão}

\section{Norberto Stori}

Resumo: A comunicação ambiental serve para informar e motivar continuamente a gestão, bem como divulgar os benefícios práticos e econômicos de sua adoção. Este trabalho tem por objetivo conhecer como ocorre o processo de comunicação ambiental em uma Organização Militar do Estado de São Paulo, visando o estabelecimento de uma política de comunicação ambiental que possa contemplar as partes interessadas, produzindo melhoria no desempenho ambiental da instituição e ampliando sua responsabilidade socioambiental. A pesquisa conclui que apesar de existir um processo de comunicação ambiental na Organização Militar, vinculado a prática de gestão ambiental, torna-se necessária a divulgação dos resultados dessas práticas, o estabelecimento de uma política de comunicação mais efetiva e a intensificação dos treinamentos ambientais como ferramenta de um Programa de Educação Ambiental crítico e construtivo.

Palavras-chave: comunicação, educação; gestão ambiental; organização militar. 


\section{INTRODUÇÃO}

A comunicação sobre questões ambientais atravessa vários níveis de interação - desde uma simples conversa entre agricultores sobre culturas biológicas até estudos integrados de avaliação sobre problemas globais (ex. buraco na camada de ozônio) refletindo a complexidade e o caráter holístico do Ambiente. Neste contexto pode-se inferir que a comunicação ambiental pode tomar a forma de um discurso mediado, desenvolvido para facilitar a negociação e decisão sobre problemas ambientais concretos; o debate sobre a preservação de uma paisagem natural; ou a discussão sobre a relevância estratégica de determinados impactos ambientais (COPPOLA, 2000).

Desta forma, a comunicação ambiental vem se constituindo como um amplo campo de práticas e estudos ainda pouco explorado na literatura acadêmica brasileira, na qual predominam pesquisas empíricas sobre jornalismo ambiental e o papel da mídia na educação ambiental (AGUIAR e CERQUEIRA, 2012).

Inseridos na maioria dos Sistemas de Gestão Ambiental (SGA), especialmente na norma ISO 14.001 (1996), estão os requisitos sobre a comunicação ambiental. De acordo com Campos (2007), a comunicação ambiental é o processo de compartilhar informações sobre temas ambientais entre organizações e suas partes interessadas, visando construir confiança, credibilidade e parcerias, para conscientizar os envolvidos, e então, utilizar as informações no processo decisório.

Para Sammalisto e Brorson (2008) treinamento e comunicação são elementos essenciais para a adoção de Sistemas de Gestão Ambiental (SGA). De acordo com os autores a comunicação serve para informar e motivar continuamente a gestão, e colaboradores internos e externos acerca forças motrizes do SGA, bem como demonstrar os benefícios práticos e econômicos de sua adoção.

Desta forma Sammalisto e Brorson (2008) registram que as informações podem ser disseminadas através dos Programas de Educação Ambiental (PEA), com a finalidade de possibilitar aos indivíduos a aquisição de conhecimentos, valores, habilidades e experiências para participar da solução dos problemas ambientais; possibilitar a mudança de atitudes para o desenvolvimento sustentável; e integrar diferentes saberes e vivências, pois a questão ambiental agrega variados conhecimentos.

Sendo importante registrar que:

Comunicação não pode ser simplesmente confundida com informação, pois informação pode ser transmitida mecanicamente e até de forma impessoal. Entretanto, informação é uma excelente matéria-prima para a comunicação, pois quem está informado está bem mais preparado para o diálogo, está em melhores condições para entender e confiar no interlocutor, ainda mais se houver a confiança de que o interlocutor passou todas as informações necessárias e não apenas as que lhe interessavam, pois, nesse caso, ainda haverá manipulação e não uma atitude nobre com o intuito de convocar o outro para o diálogo ou ação cooperativa e comunitária (SILVA, 1997).

Segundo a norma ISO 14.063 (2006) a comunicação ambiental é o processo de partilha de informação para construir confiança, credibilidade e parcerias, para sensibilização, e instrumento na tomada de decisão. Os processos utilizados e o conteúdo da comunicação variam de acordo com os objetivos e as circunstâncias da organização e deve ser construído tendo como base informação substantiva. Para assegurar o sucesso dos processos de comunicação ambiental, é importante para a organização considerar-se parceira responsável na sociedade e corresponder às expectativas ambientais das partes interessadas.

Assim, Moreira (2001) defende que a comunicação ambiental é importante nos processos que regem as relações corporativas e a comunicação com seu público externo e interno, bem como a obtenção de informações úteis à tomada de decisão em gestão ambiental participativa.

Para García e Santiso (2010) comunicação ambiental é um processo de gestão integral e responsável, envolvendo antecipação e satisfação das necessidades do receptor, do público e da sociedade, de uma forma integrada e sustentável.

Neste sentido, o presente trabalho tem por objetivo conhecer como ocorre o processo de comunicação ambiental em uma Organização Militar do Estado de São Paulo, visando o estabelecimento de uma política de comunicação ambiental que possa contemplar as partes interessadas, 
produzindo melhoria no desempenho ambiental da instituição e ampliando sua responsabilidade socioambiental.

\section{REVISÃO DA LITERATURA}

Os problemas ambientais estão cada vez mais presentes na vida dos cidadãos. A preocupação com o planeta é tema abordado freqüentemente. Porém, a falta de conscientização e até descaso de grande parte da população com ações efetivas, dificulta a solução e a melhoria de grande parte desses problemas. Diante disso, as interfaces entre comunicação e meio ambiente ganham importância para o fomento de ações conscientizadoras (MORALES et al., 2014).

A comunicação ambiental é um dos elementos - chave de estratégias ecoorientadas, ao lado de fatores como a ecoeficiência, os sistemas de controle ambiental, entre outros fatores que têm se tornado uma questão de competitividade nas empresas (ROTONDARO e TURATTI, 2005).

Para Andreoni et al. (2008), a relevância da comunicação ambiental é justificada, entre outros aspectos, pela necessidade de se utilizar termos, expressões e vocábulos, sejam os mesmos científicos ou não, mais adequados ao contexto ambiental - global e local - e eficazes no sentido de produzirem uma reação ou sentimento na massa que conduza à ação, à manifestação, à transformação. Pois, o uso aleatório ou malicioso de um discurso específico pode significar o velamento de determinadas questões ou problemas ambientais, através de eufemismos, por exemplo.

A prática da comunicação ambiental pressupõe a utilização dos fundamentos comunicacionais a favor do exercício da cidadania planetária, que estimule ações transformadoras pela sustentabilidade do nosso meio (LIMA et al., 2013).

Fernandes et al. (2014), registram em seu estudo que a comunicação é implementada de forma instrumental, pragmática, direcionada para a resolução de problemas pontuais e assume um caráter informativo e de divulgação de mensagens de interesse das empresas. Outra questão apontada pelos autores diz respeito à abrangência da comunicação, que não permeia todo o processo de licenciamento ambiental, se restringindo somente a contribuir para minimizar e compensar os impactos ambientais na comunidade próxima do local de implantação do empreendimento. Além disso, a comunicação acontece de forma desorganizada e não planejada.

Para alguns autores, a comunicação ambiental precisa ser planejada, desenhada e gerenciada estrategicamente, sem que isso signifique que os únicos objetivos a alcançar sejam os corporativos (FERNANDES et al., 2014).

De acordo com Lara (2004), a comunicação ambiental tornou-se nos últimos anos parte estratégica e de grande relevância dentro do planejamento da comunicação corporativa das empresas. Entre seus objetivos mais importantes, está a otimização dos resultados obtidos a partir da instalação de sistemas de gestão ambiental nas indústrias.

\section{METODOLOGIA}

O presente trabalho é de natureza estudo exploratório-interpretativa, onde se buscou analisar se ocorre e como ocorre o processo de comunicação ambiental utilizado para a disseminação das informações em uma instituição militar.

O estudo classifica-se também em pesquisa bibliográfica, pois conforme afirmou Martins (2000) "a leitura é uma das maneiras mais utilizadas para se conhecer a realidade". Procurou-se recolher, selecionar, analisar e interpretar as contribuições teóricas já existentes, de modo a aperfeiçoar os conhecimentos dos autores, com vistas a garantir o sucesso da aplicação prática na instituição.

Os estudos de casos (descritivos) não precisam ficar limitados a uma única fonte de evidências, quanto maior a variedade maior a confiabilidade fornecida pelo estudo, pois as fontes de evidências são revisadas e analisadas em conjunto, de forma que as descobertas do estudo de caso sejam oriundas da convergência das informações destas diferentes fontes (YIN, 2001).

Para Yin (2001), um estudo de caso é uma investigação empírica que investiga um fenômeno contemporâneo dentro de um contexto de vida real, especialmente quando os limites entre o fenômeno e o contexto não estão claramente definidos. O estudo de caso representa uma maneira de se investigar um 
tópico empírico, através de procedimentos específicos.

Diante disto, esta pesquisa caracteriza-se também como estudo de caso, pois esta tem como objetivo primordial investigar um fenômeno, dentro do contexto, de um ambiente Militar situado na cidade de São Paulo - SP. Para atingir o objetivo almejado foi aplicado um questionário aos militares que servem na Organização Militar (OM) com o intuito de conhecer se ocorre comunicação ambiental e de que forma ocorre, além disso, buscou-se analisar a percepção que os mesmos possuem do seu ambiente de trabalho.

É importante destacar que a Organização Militar em estudo vai ser denominada de OM-

Figura 1. Distribuição etária dos militares da OM.

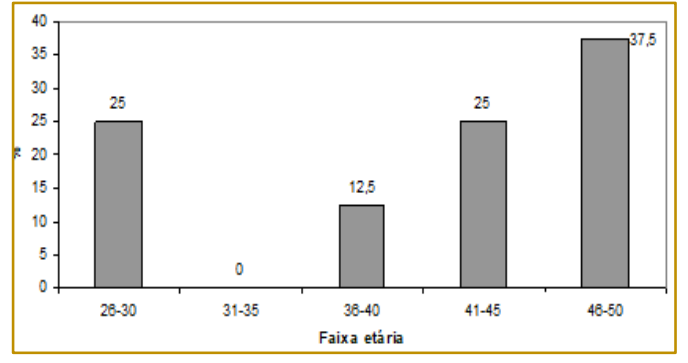

\section{ANÁLISE DOS RESULTADOS E DISCUSSÃO}

Alguns militares que responderam 0 questionário já serviram em Organizações Militares que realizam processos de conscientização ambiental, todavia, quando indagados sobre a participação em tais processos, somente $49 \%$ registraram que já participaram (fig. 3). Contudo, 100\% dos militares mencionou que os processos de conscientização são importantes para mudança de mentalidade, corroborando com Berna (2011), ao afirmar que a opinião pública está cada vez mais consciente e sensível às questões ambientais e cobra das empresas, políticos e governos cada vez maior responsabilidade ambiental.

Buscando conhecer em que local o militar participou do processo de conscientização e
SP, e sua missão é coordenar o esforço de integração das Forças Armadas com as indústrias, as Instituições de Ensino Superior e as Instituições de Pesquisas do Estado de São Paulo, em áreas acadêmicas, científicas e tecnológicas, portanto na área administrativa. Atualmente, servem nessa OM 16 militares e $50 \%$ desse efetivo respondeu voluntariamente o questionário.

Os militares que responderam o questionário são todos do sexo masculino (100\%) e com idade compreendida entre 26 - 50 anos, distribuídos de acordo com os dados apresentados na figura 1 e nível de escolaridade majoritariamente com o Ensino Médio completo, conforme gráfico da figura 2.

Figura 2. Nível de escolaridade dos militares da OM.

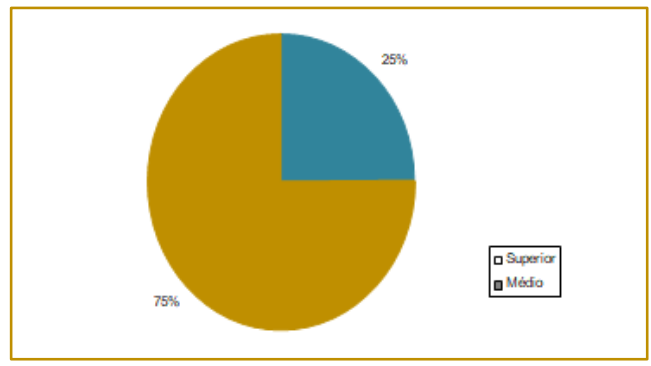

se há algum processo em seu local de trabalho, $75 \%$ dos militares afirmaram que participaram em outros locais e $25 \%$ em casa, portanto registram que não há comunicação ambiental na OM-SP (fig. 4). Mas, é preciso investigar se as empresas e governos já mudaram de atitude e adotaram políticas ambientais sérias, contudo não investiram adequadamente na divulgação de seus resultados e continuam sendo vistos como vilãos do meio ambiente (BERNA, 2011).

Além disso, é preciso entender se as ações de gestão ambiental não são visíveis para seu público interno ou se não conseguem atingir as expectativas dos militares por intermédio dos treinamentos e campanhas de comunicação ambiental. 
Figura 3. Militares da OM-SP que já participaram de processo de conscientização ambiental.

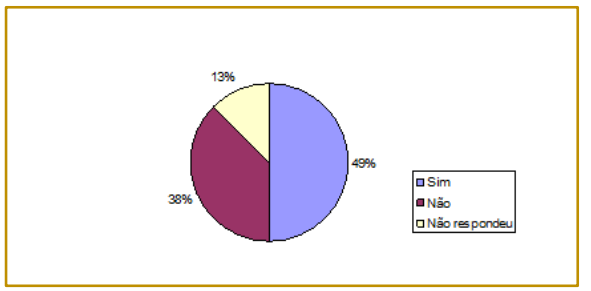

Com essa concepção o estudo investigou, sabendo que a OM-SP é do setor administrativo, qual a percepção dos militares em relação ao consumo de água, energia, papel e material descartável. Em relação ao consumo de água 50\% dos militares (fig. 5) registraram que seu consumo no local de trabalho é muito baixo ou baixo, em consonância com a atividade exercida estritamente administrativa.

Quanto ao consumo de energia (fig. 6), é preciso mencionar que a OM possui diversas

Figura 5. Percepção dos militares quanto ao consumo de água.

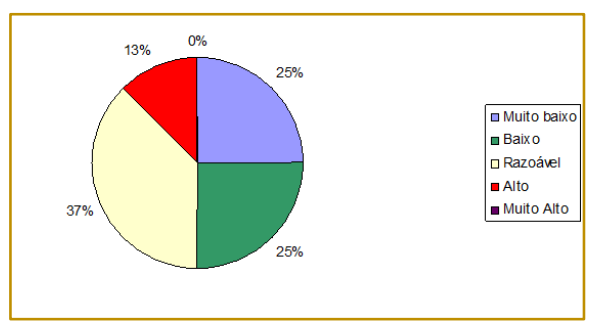

Em relação ao consumo de papel $37 \%$ dos militares (fig. 7) mencionaram que apresentam alto consumo e $37 \%$ registraram que possuem baixo. Esse antagonismo se deve as tarefas exercidas pelos militares na OM-SP, pois nem todos lidam com a confecção de documentos, relatórios, reprodução de manuais, livros, apostilas, dissertações ou teses.
Figura 4. Local em que participou de processo de conscientização.

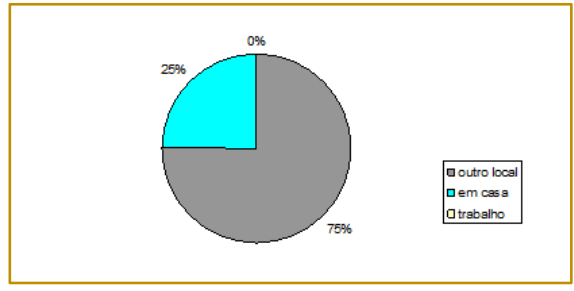

estações de trabalho com microcomputador, em média uma para cada militar e, portanto apresenta consumo de energia razoável, conforme respondido por $74 \%$ dos militares, pois as máquinas são novas ou semi-novas e com configuração para economizar energia caso não esteja em uso.

Além disso, é preciso registrar que apesar dos militares não mencionarem, há cartazes afixados próximos aos interruptores com a seguinte expressão: "a luz que você apaga, a organização não paga”.

Figura 6. Percepção dos militares quanto ao consumo de energia.

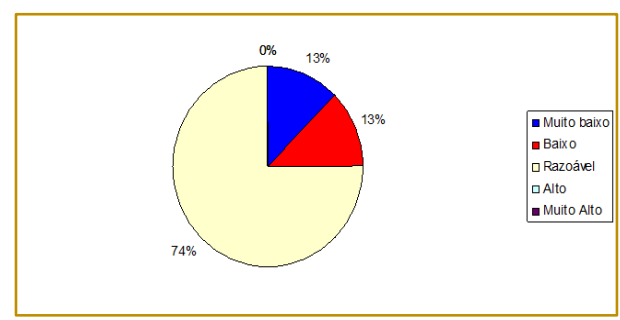

Já em relação ao uso de material descartável, $50 \%$ dos militares (fig. 8) disseram que é muito baixo ou baixo e, portanto coerente com o horário de expediente dos militares na instituição e suas atividades laborais que não exigem consumo excessivo de água no caso dos copos descartáveis, bem como toalhas de papel. 
Figura 7. Percepção dos militares quanto ao consumo de papel.

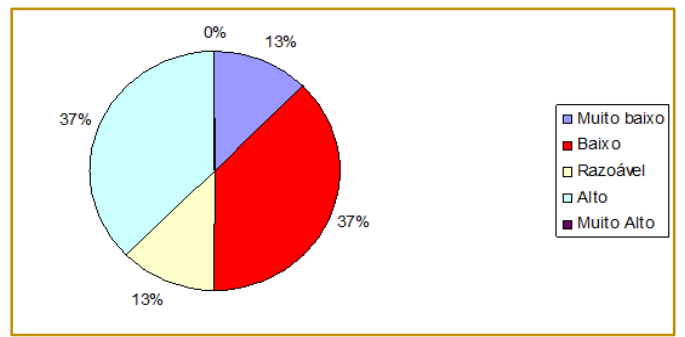

Ainda com o intuito de verificar a percepção dos militares quanto à geração de resíduos orgânicos no local de trabalho, ficou evidente que $62 \%$ geram muito pouco e $25 \%$ pouco (fig.9).

Quanto à geração de resíduos recicláveis, $49 \%$ dos militares acreditam ser baixo e $25 \%$

Figura 9. Percepção dos militares quanto à geração de resíduos orgânicos.

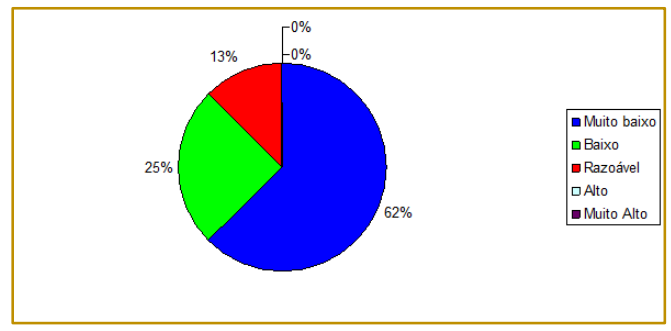

Em contrapartida, em função da missão da OM-SP, a geração de papel apresenta números compatíveis com tal atividade, pois $62 \%$ dos militares registraram que é razoável
Figura 8. Percepção dos militares quanto ao consumo de material descartável.

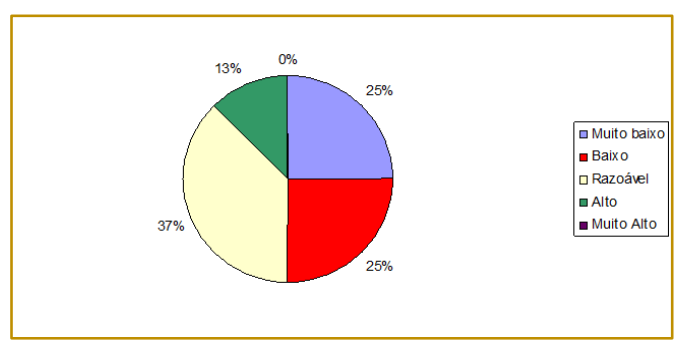

acham que é razoável (fig. 10), sugerindo que plásticos, alumínios e vidros podem ter origem não da atividade laboral, mas de consumo particular, como refrigerantes, embalagens para conservar comida, bebidas energéticas e produtos de higiene pessoal.

Figura 10. Percepção dos militares quanto à geração de resíduos recicláveis.

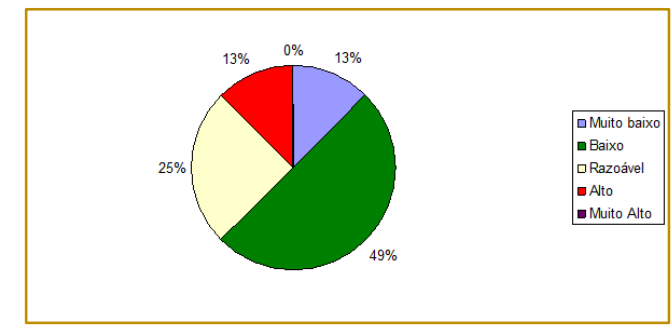

a geração de papel na Organização e 13\% consideraram alto os resíduos de papel gerado (fig. 11).

Figura 11. Percepção dos militares quanto à geração de papel.

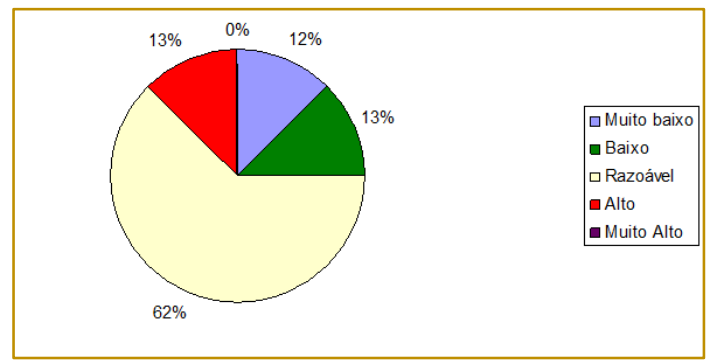

Buscando subsidiar a elaboração de um Programa de Educação Ambiental (PEA), investigou-se a relação que os militares estabelecem entre os diferentes aspectos do cotidiano com a questão ambiental. Observase que a percepção dos militares é, ainda, descritiva dos processos da natureza, sem inserir a pessoa e suas relações no contexto da questão ambiental (fig. 12). Tal situação corrobora com os dados obtidos por Busato \& Arigoni (2008), ao pesquisarem a opinião dos funcionários de uma fábrica de cimento em Minas Gerais em relação a participação dos mesmos na questão ambiental. 
Figura 12. Relação entre diferentes aspectos do cotidiano com a questão ambiental.

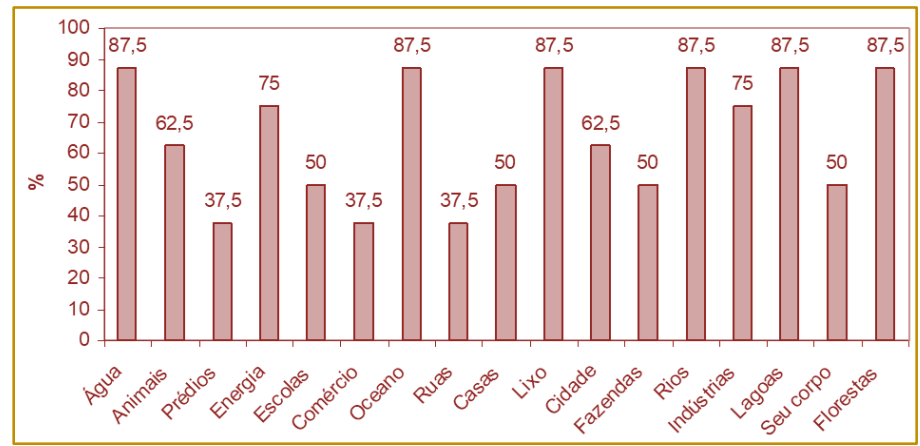

Enquanto isso, ao serem perguntados sobre a quem compete resolver os problemas ambientais da sua realidade, os militares se incluem na construção das soluções (fig. 13).
Essa postura também é encontrada no trabalho realizado por Busato \& Arigoni (2008).

Figura 13. Opinião acerca da competência para solucionar os problemas ambientais.

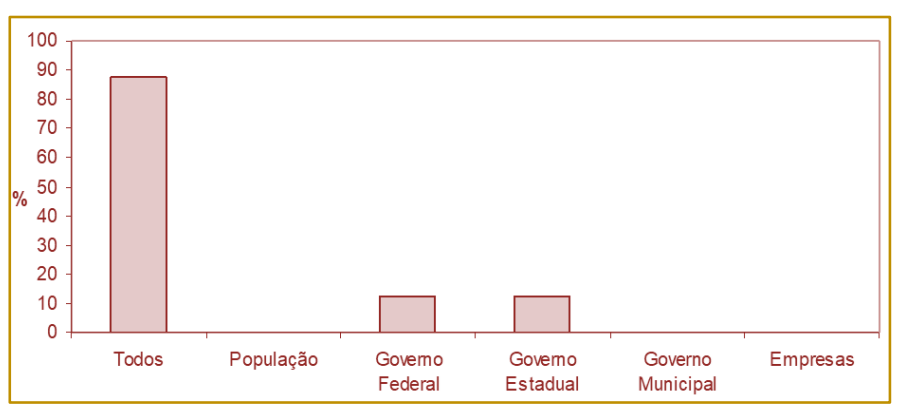

Essa visão mostra que, apesar de não se perceber como parte da questão ambiental, há certa disposição de participar na solução dos problemas. Além disso, ao incluir-se como um dos agentes de transformação para a construção da sustentabilidade, o militar admite enxergar-se como parte do problema.

Com isso, foi perguntado aos militares se há no local de trabalho algum processo de conscientização ambiental e $87 \%$ responderam que não, apenas 13\% disseram que sim (fig. 14) e exemplificaram com a explicação de que existem cestos para coleta de material reciclado - papel e plástico. Interessante registrar que os militares não mencionam os cartazes e avisos para economizar energia. Ou seja, não conseguem perceber que tais informativos seja um processo de conscientização ambiental.

Isso demonstra que a OM-SP necessita ampliar seus processos de comunicação, para que seu público possa perceber as iniciativas já em andamento na instituição. Pois, para Berna (2011), as organizações têm o direito e o dever de se comunicarem adequadamente com o público interessado, informando sobre como estão gerenciando o meio ambiente. Ao fazerem isso, podem contribuir para a formação de consciência ambiental na população e mesmo dar o exemplo para outros, estimulando novos investimentos em meio ambiente, num efeito cascata. Qualquer plano ou campanha de Comunicação Ambiental deve estar baseado no desejo sincero em se comunicar com seus diversos públicos. Adotar o silêncio como estratégia para se proteger de problemas, pode até dar certo em alguns casos, mas, quando não dá, pode ser tarde demais ou custar muito mais caro.

O autor também ressalta que só democratizar a informação ambiental pode não ser suficiente para produzir as mudanças necessárias de opinião. Pois, a simples veiculação de informação ambiental desassociada de um compromisso com a cidadania crítica e participativa como defende a educação ambiental, pode agravar a degradação do meio ambiente (BERNA, 2011).

Verificou-se que dentre as formas de poluição mais comum no local de trabalho (fig. 15) estão à poluição sonora com $62 \%$ e a 
poluição visual com $38 \%$, em virtude da falta de segregação dos setores de trabalho e conseqüente ruído produzido pelo atendimento ao público, conversas ao

Figura 14. Campanha de conscientização ambiental no local de trabalho.

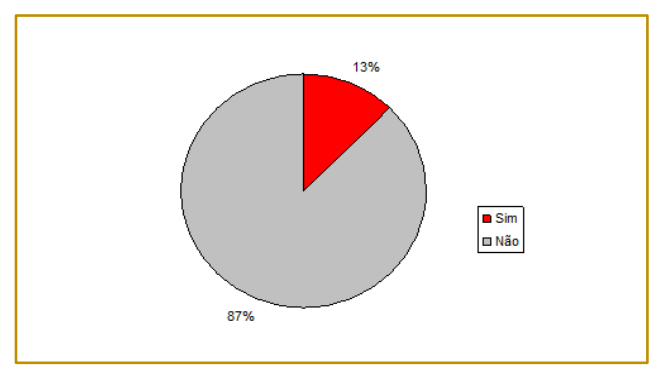

\section{CONCLUSÕES}

De acordo com Leff (2001), o ambiente emerge como um saber reintegrador da diversidade, de novos valores éticos e estéticos e dos potenciais sinergéticos gerados pela articulação de processos ecológicos, tecnológicos e culturais. O saber ambiental ocupa seu lugar no vazio deixado pelo progresso da racionalidade científica, como sintoma de sua falta de conhecimento e como sinal de um processo interminável de produção teórica e de ações práticas orientadas por uma utopia: a construção de um modelo sustentável, democrático, igualitário e diverso.

Para que possamos ampliar o saber ambiental é necessário ampliar e divulgar as ferramentas de comunicação da Organização. De acordo com Maranhão (2011) os seguintes canais poderão ser utilizados como forma de atingir eficácia das comunicações: intranet, informativos internos, quadros murais, caixas de sugestões, mala direta eletrônica para os colaboradores.

Neste contexto, o estudo sugere a implantação de uma política de comunicação ambiental local e de um Programa de Educação Ambiental, vinculados ao Sistema de Gestão Ambiental, que resultem em ações concretas para a redução de impactos telefone e outros sons. Quanto à poluição visual o amontoado de papel nas mesas é o que mais incomoda alguns entrevistados.

Figura 15. Poluição mais comum no ambiente de trabalho.

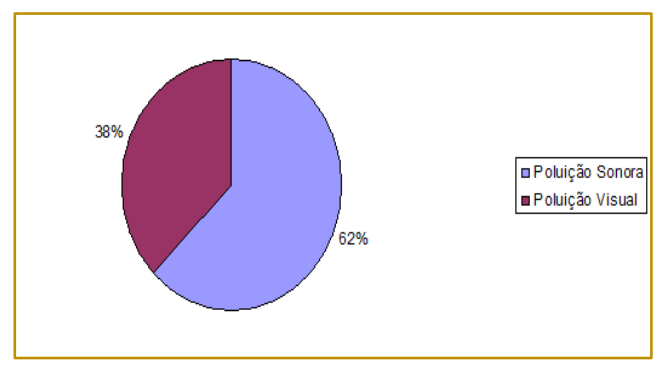

ambientais adversos decorrentes do consumo e geração de resíduos dentro da instituição.

Além disso, com os resultados obtidos nesta avaliação preliminar sugerem a intensificação da comunicação ambiental através de jornais periódicos internos, reuniões diárias, página da intranet que proponham e relatem as ações de melhoria contínua no que diz respeito às questões de consumo sustentável, geração e disposição de resíduos, bem como campanhas para reduzir o consumo de água e energia.

Esta pesquisa teve como objetivo conhecer se há um processo de comunicação ambiental em uma Organização Militar do Estado de São Paulo, visando o estabelecimento de uma política de comunicação ambiental que possa contemplar as partes interessadas, produzindo melhoria no desempenho ambiental da instituição e ampliando sua responsabilidade socioambiental.

Assim, a pesquisa conclui que apesar de existir um processo de comunicação ambiental, vinculado a prática de gestão ambiental torna-se necessária a divulgação dos resultados dessas práticas, o estabelecimento de uma política de comunicação mais efetiva e a intensificação dos treinamentos ambientais como ferramenta de um Programa de Educação Ambiental crítico e construtivo. 
REFERÊNCIAS

[1]. AGUIAR, S. \& CERQUEIRA, J. F. Comunicação ambiental como campo de práticas e de estudos. Comunicação \& Inovação, São Caetano do Sul, v. 13, n. 24, p.11-20, 2012.

ANDREONI, M.; REIS, J. M. S. P.; ELHAJJI, M. Introdução à Comunicação Ambiental. Anais... XXXI Congresso Brasileiro de Ciências da Comunicação em Natal, 2008. Disponível em: http://www.intercom.org.br/papers/nacionais/2008/r esumos/r3-1638-6. pdf. Acesso em: 28 de março de 2015.

[3]. BERNA, V. Dez mandamentos da Comunicação Ambiental. 2011. Disponível em: http://www.escritorvilmarberna.com.br/artigos/comu nicacao-ambiental/dez-mandamen tos-dacomunicacao-ambiental.html. Acesso em: 30 de outubro de 2014.

[4]. BUSATO, L. C. \& ARIGONI, E. N. Foco e ética no desenvolvimento de Programas de Educação Ambiental Empresarial: reflexões acerca das forças indutoras, posturas, resultados e sinergismo. In: PEDRINI, A. G. Educação ambiental empresarial no Brasil. Editora Rima, 2008.

[5]. CAMPOS, M. K. S. A Comunicação Ambiental no Brasil e o Potencial de Aplicação da Norma ISO 14063. Palestra ministrada durante o Seminário Internacional "Tendências da International for Standardization - ISO em Normalização Ambiental Internacional e as Ações no Brasil, FIESP, São Paulo. 2007.

[6]. COPPOLA, N. W. Rhetorical Analysis of Stakeholders in Environmental Communication: A Model. In: COPPOLA, N. W. E KARIS, B. (eds.) Technical communication, deliberative rhetoric, and environmental discourse: connections and directions, p.21-36. 2000.

[7]. FERNANDES, B. R.; SMITH, V. P. B.; ULSEN, P. "Comunicação" por um licenciamento ambiental sustentável. Anais... XVIII Colóquio Internacional da Escola Latino-Americana de Comunicação, São Paulo, 2014. Disponível em: http://www2.metodista.br/unesco/pensacom2014/ar quivos/Trabalhos/Backer,\%20Pedro\%20e\%20Vivia n_Comunica\%C3\%A7\%C3\%A30\%20por\%20um\%2 Olicenciamento\%20ambiental\%20sustent\%C3\%A1v el.pdf. Acesso em: 23 de março de 2015.

[8]. GARCÍA, J. S.; SANTISO, M. S. Comunicação ambiental para o século XXI. Comunicação \& Educação, ano XV, n. 2, maio/ago, 2010.

[9]. International Organization for Standardization (ISO) 14063. Comunicação Ambiental - Diretrizes e exemplos. 2006.

[10]. LARA, G. O ambiente como vitrine. 2004. Disponível em: http://www.mbc.org.br /mbc/uploads/biblioteca/1164635738.9946A. pdf. Acesso em: 30 de junho de 2015.

[11]. LEFF, E. Saber Ambiental: sustentabilidade, racionalidade, complexidade, poder. Tradução de Lúcia Mathilde Endlich Orth Petrópolis, RJ: Vozes, 2001.

[12]. LIMA, M. D. V.; LOOSE, E. B.; JÚNIOR, P. S; DUARTE, V.; SCHNEIDER, T.; MEI, D. A comunicação ambiental como forma de enfrentamento dos dilemas socioambientais. Anais... 20 Encontro Interdisciplinar de Comunicação Ambiental (EICA), Sergipe. Aracaju: Universidade Federal de Sergipe, p. 1-13, 2013. Disponível em: http://www.rica.eco.br/rica/arquivos/anaiseica2013/ EICA\%202013-04-Enfrenta

mento\%20dos\%20dilemas\%20socioambientais. pdf . Acesso em: 23 de março de 2015.

[13]. MARANHÃO, R. A. Proposta de Sistema de Gestão Ambiental para Usina de Produção de Hexafluoreto de Urânio do Centro Tecnológico da Marinha em São Paulo. Anais... VII Congresso Nacional em Excelência de Gestão, 2011. Disponível em: http://www.excelenciaemgestao.org/Portals/2/docu ments/cneg7/anais/T11_0353_1649.pdf. Acesso em: 23 de março de 2015.

[14]. MARTINS, G. A. Manual para elaboração de monografias e dissertações. 2000.

[15]. MORALES, A. G.; BERNARDO, C. H. C.; SCIENZA, R. C. Análise da identidade visual do programa Olhar Ambiental: uma interface entre comunicação e meio ambiente. Revista Comunicação Midiática, v.9, n. 1, p. 134-156, 2014.

[16]. MOREIRA, M. S. Estratégia e Implantação do Sistema de Gestão Ambiental. Editora de Desenvolvimento Gerencial, Belo Horizonte. 2001.

[17]. ROTONDARO, A.; TURATTI, L. F. Comunicação ambiental: aplicação de modelo de planejamento sistêmico - análise de caso na indústria da construção civil. Anais... II Simpósio Internacional de Ciências Integradas da Unaerp Campus Guarujá, 2005. Disponível em: http://www.unaerp.br/index.php/sici-

unaerp/edicoes-anteriores/2005/secao-1-1/880comunicacao-ambiental-aplicacao-de-modelo-deplanejamento-sistemi co-analise-de-caso-naindustria/file. Acesso em: 23 de março de 2015.

[18]. SAMMALISTO, K.; BRORSON, T. Training and communication in the implementation of environmental management systems (ISO 14001): a case study at the University of Gävle, Sweden. Journal of Cleaner Production, v. 16, p. 299-309, 2008.

[19]. SILVA, L. M. Comunicação, mobilização e mudança social. In: MONTORO, T. S. (Org.). Série Mobilização Social, Comunicação, Cultura, Cidadania e Mobilização Social. Brasília/ Salvador: UnB, v. 2, 1997.

[20]. YIN, R. K. Estudo de Caso: planejamento e métodos. $2^{2}$ ed. Porto Alegre: Bookman, 2001. 


\section{Capítulo 4}

\section{DESENVOLVIMENTO SUSTENTÁVEL E RESPONSABILIDADE SOCIOAMBIENTAL NAS FORÇAS ARMADAS: UM ESTUDO NA MARINHA DO BRASIL}

\section{Romero de Albuquerque Maranhão}

\section{Norberto Stori}

Resumo: As Forças Armadas apresentam características comuns às demais organizações da administração pública, mas também especificidades que Ihe são peculiares, como as operações militares. Ao desenvolverem práticas de sustentabilidade e responsabilidade socioambiental utilizam estratégias visando à inserção em espaços sociais não comumente ocupados por eles. A presente pesquisa tem como objetivo mapear o interesse das Organizações Militares da Marinha do Brasil a respeito da temática socioambiental, por meio da análise das práticas socioambientais e representações sociais dos militares. A análise tem como fio condutor a Sociologia Reflexiva de Pierre Bourdieu e as contribuições teóricas de Mary Douglas sobre representações sociais. Os resultados obtidos indicam que as práticas socioambientais realizadas pelos militares possuem enfoques filantrópicos e ambientais, e estão relacionadas às atividades isoladas em algumas organizações militares, não sendo a totalidade da Força Armada. A pesquisa conclui que a falta de divulgação e mensuração das atividades socioambientais são entraves para o desenvolvimento sustentável.

Palavras-chave: Sustentabilidade; Responsabilidade Socioambiental; Forças Armadas. 


\section{INTRODUÇÃO}

A preocupação ambiental vem sendo tratada no âmbito internacional desde a realização da Conferência de Estocolmo em 1972, ganhando destaque na Conferência das Nações Unidas para o Meio Ambiente e Desenvolvimento (RIO-92), onde a proposta da sustentabilidade foi consolidada como diretriz para a mudança de rumo no desenvolvimento, com a aprovação da Agenda 21. Desde então, o conceito de desenvolvimento sustentável passou a ser um referencial para todos os países (COSTA et al., 2012).

Na Conferencia de Estocolmo foi estabelecida uma agenda ambiental patrocinada pelo Programa das Nações Unidas para o Meio Ambiente (PNUMA). Foi uma agenda multilateral que determinou as ações para as décadas seguintes a fim de solucionar os problemas ambientais vigentes: a proteção da fauna silvestre, a contaminação e o tratamento das águas, a contaminação do ar, a eliminação e tratamento dos resíduos sólidos.

A RIO 92 ou ECO 92 veio reforçar os princípios do desenvolvimento sustentável e possibilitou a emissão de importantes declarações e tratados firmados pelos 113 países participantes. Além disso, motivou a incorporação de temas da proteção ambiental em diversos setores e segmentos da sociedade brasileira, dentre eles, as Forças Armadas (FA) do Brasil.

De acordo com Simões (2010), o Estado brasileiro, de uma forma geral, vem desenvolvendo projetos de responsabilidade social, sem prejuízo quanto à objetividade da missão institucional de seus órgãos. Neste contexto Jacobi (2005) registra que a incorporação do marco ecológico nas decisões e instituições políticas implica reconhecer que as conseqüências ecológicas do modo como a população utiliza dos recursos do planeta estão associadas ao modelo de desenvolvimento.

No âmbito governamental a sustentabilidade pode ser um diferencial da nova gestão pública, onde os administradores passam a serem os principais agentes de mudança, por intermédio de pequenas ações diariamente, como por exemplo, o uso eficiente da água e da energia, a coleta seletiva, o consumo responsável de produtos e serviços, entre outros, contribuem para este processo.
A administração pública, principalmente as Forças Armadas (FA), tem sido freqüentemente omitida nas pesquisas sobre desenvolvimento sustentável e responsabilidade socioambiental, o que gera uma lacuna na literatura cientifica. Todavia, a administração pública além de ser uma grande consumidora de bens e serviços, é responsável por colocar em prática as políticas públicas.

As FA brasileiras são constituídas por Marinha, Exército e Aeronáutica, instituições nacionais permanentes e regulares que possuem missão definida pela Constituição Federal. As três armas são encarregadas da defesa nacional externa e podem realizar intervenções internas para garantir a lei e a ordem.

De acordo com a Lei Complementar no 97/99, as FA podem, ainda, realizar ações subsidiárias que completam o esforço nacional de desenvolvimento, como por exemplo: apoio de saúde às comunidades ribeirinhas da Amazônia pela Marinha, construção de ferrovias pelo Exército, e o serviço de Correio Aéreo Nacional (CAN) pela Aeronáutica (COSTA, 2005).

Ao desenvolverem práticas de sustentabilidade e responsabilidade socioambiental, as FA utilizam estratégias visando à inserção em espaços sociais não comumente ocupados por elas. A presente pesquisa tem como objetivo mapear o interesse das Organizações Militares da Marinha do Brasil a respeito da temática socioambiental, por meio da análise das práticas socioambientais e representações sociais dos militares.

O artigo está organizado, além desta introdução, em uma base teórica sobre desenvolvimento sustentável, responsabilidade social e responsabilidade socioambiental. Em seguida apresenta os procedimentos metodológicos, os dados da pesquisa, a análise dos resultados e por último as considerações finais do estudo.

\section{DESENVOLVIMENTO SUSTENTÁVEL}

A preocupação pública pelos problemas de deterioração ambiental vem crescendo desde meados da década de 1960, quando começa a revolução ambiental norte-americana, expandindo-se para os outros países desenvolvidos na década de 1970 e culminando na década de 1980, quando 
atinge os países da América Latina e os demais continentes em desenvolvimento (VIOLA, 1992).

Como resultado dessa preocupação, emerge e desenvolve-se uma série de iniciativas de diversos atores sociais, que representam o movimento ambientalista global, o qual, com o passar do tempo, se transformou num movimento multissetorial capilarizado. Isto permitiu que o antigo debate dos anos 1970, que de certa forma tinha pensado isoladamente as questões ambientais e de desenvolvimento, fosse substituído por outro mais convergente e otimista, preocupado fundamentalmente com a questão de como alcançar um desenvolvimento sustentável (VIOLA e LEIS, 1995).

A I Conferência Mundial das Nações Unidas sobre Meio Ambiente, realizada em Estocolmo (1972), estabelece a origem de um processo de gestão planetária dos problemas ambientais - como a criação do Programa das Nações Unidas Para o Meio Ambiente ou de âmbito nacional ou regional, no qual a poluição urbana, industrial, de rios e oceanos, entre outras, passa a mobilizar não só especialistas, mas diferentes agrupamentos sociais originários de estratos de comunidades locais.

A proposição de que é necessário e possível intervir e direcionar o processo de desenvolvimento econômico, de modo a conciliar eficiência econômica, desejabilidade social e prudência ecológica, passa a ter uma aceitação generalizada, sendo este processo denominado desenvolvimento sustentável.

Entretanto, de forma previsível, existem as divergências, principalmente no que concerne aos mecanismos dessa intervenção. Tais divergências estão relacionadas especialmente ao entendimento do aparente paradoxo entre crescimento econômico e meio ambiente. As dificuldades desse entendimento revelam-se não apenas nas incontáveis definições de desenvolvimento sustentável, mas, principalmente, nas diferenças de interpretação de uma mesma definição. No Relatório Brundtland (CMMAD, 1991:46), por exemplo, ele é definido como "aquele que atende às necessidades do presente sem comprometer a possibilidade de as gerações futuras atenderem a suas próprias necessidades".

A expressão desenvolvimento sustentável reforça a relação entre economia, tecnologia, sociedade e política chamando atenção para uma nova postura que leve em conta a ética em relação à preservação ambiental. Apesar das críticas ao conceito de desenvolvimento sustentável, devido ainda não se ter uma definição precisa deste, trata-se de um avanço, uma vez que considera a complexa relação entre desenvolvimento e o meio ambiente numa variedade de áreas, destacando a sua pluralidade, diversidade, multiplicidade e heterogeneidade (JACOBI, 2006).

Tendo em vista as dificuldades em definir e interpretar a expressão desenvolvimento sustentável, nessa pesquisa adotaremos como referência o conceito de desenvolvimento de Amartya Sen - "o desenvolvimento como liberdade" -, o aumento da capacidade de as pessoas fazerem escolhas, inclusive em relação ao meio ambiente. Para o autor, o "desenvolvimento tem que estar relacionado, sobretudo, com a melhoria da vida que levamos e das liberdades que desfrutamos. Expandir as liberdades que temos razão para valorizar não só torna nossa vida mais rica e desimpedida, mas permite que sejamos seres sociais mais completos, pondo em prática nossas volições, interagindo com o mundo em que vivemos e influenciando esse mundo" (SEN, 2000:29).

Neste contexto desenvolvimento sustentável é um processo de transformação no qual a exploração dos recursos, a direção dos investimentos, a orientação do desenvolvimento tecnológico e a mudança institucional se harmonizam e reforçam o potencial presente e futuro, a fim de atender às necessidades e aspirações sociais (CMMAD, 1991). Nesse sentido, a palavra sustentabilidade ganha uma dimensão maior, e se torna um dos principais temas de discussão no dia-a-dia das empresas e na academia.

De acordo com Rezende e Santos (2006), a adesão das empresas à sustentabilidade, equivale a um compromisso com a integridade do meio ambiente e com os princípios da responsabilidade social. Isso diz respeito à aderência das organizações a um projeto de comprometimento social.

\section{RESPONSABILIDADE SOCIAL}

O princípio da responsabilidade social baseia-se na premissa de que as organizações são instituições sociais que 
existem com autorização da sociedade, utilizam os recursos da sociedade e afetam a qualidade de vida da sociedade (MAXIMIANO, 2006).

Na revisão do conceito de responsabilidade social, Godói-de-Souza et al.(2009) concluem que primeiramente a responsabilidade social organizacional era sinônimo de caridade, visão influenciada pelo aporte das entidades religiosas. Com o transcorrer do tempo, as práticas de responsabilidade social se transformaram em formas mais assertivas de pensar os problemas sociais, o que foi conceituado como filantropia organizada.

Assis (2010) registra que após a II Guerra Mundial a discussão sobre responsabilidade social é direcionada às definições de responsabilidade da organização junto à sociedade, através do interesse legislativo em regulamentar as corporações. As crises econômicas, a guerra e as degradações ambientais atribuídas ao processo produtivo levaram a sociedade a pressionar as organizações que, de alguma forma, estavam ligadas a estes fatores. Pressões políticas e públicas favorecem a concepção mais concreta do conceito de responsabilidade social.

Archie Carroll definiu, em 1979, que a responsabilidade social empresarial abrange a expectativa econômica, legal, ética e discricionária (filantrópica) que a sociedade tem da organização em um determinado momento no tempo (CARROLL; BUCHHOLTZ, 2006, p.35). Nesse contexto, Carroll dividiu a responsabilidade social da organização em quatro dimensões (CARROLL; BUCHHOLTZ, 2006, p.35-37):

- A responsabilidade econômica envolve as obrigações da organização em produzir bens e serviços que a sociedade deseja e vendêlos a um preço justo, mas que haja lucro suficiente para a perpetuação da empresa em longo prazo e ampliação dos ganhos dos investidores.

- A responsabilidade legal corresponde às expectativas da sociedade de que as organizações cumpram suas obrigações de acordo com as legislações existentes.

- A responsabilidade ética refere-se a que as organizações tenham um comportamento de acordo com as normas, padrões e expectativas da sociedade.

- A responsabilidade discricionária (filantrópica) reflete a expectativa da sociedade de que as organizações participem voluntariamente de atividades sociais não exigidas pela lei ou pela ética, através da filantropia

O termo filantropia, de origem religiosa, trata a ideia de que a qualidade de vida da sociedade depende do grau com o qual cada um de seus integrantes genuinamente se preocupa com o bem-estar de seu próximo. A filantropia seria a ação ou a atitude daqueles que são solidários, expressando-se sob a forma de doação ou caridade (FERREIRA, 1977).

Já Rothgiesser (2004) define filantropia como investimento de uma empresa em ações pontuais periódicas, como campanhas de arrecadação de bens e alimentos, assim como as doações de ordem material e/ou financeira. Comumente não obedecem a um processo sistematizado de atuação social e sim reativo, em momentos de maior demanda da sociedade.

Neste estudo adotaremos filantropia como uma ação de caridade dirigida à comunidade, desvinculada do planejamento estratégico da empresa. A responsabilidade social preconiza que as empresas possuem deveres para com a sociedade (SANTOS, 2003).

De acordo com o Instituto Ethos, responsabilidade social é uma forma de gestão que se define pela relação ética e transparente da organização com todos os públicos com os quais ela se relaciona e pelo estabelecimento de metas compatíveis com o desenvolvimento sustentável da sociedade, preservando recursos ambientais e culturais para as gerações futuras, respeitando a diversidade e promovendo a diminuição das desigualdades sociais (GONÇALVES, 2006, p.5).

Para Young (2004), as organizações têm coresponsabilidade na solução dos problemas sociais e ambientais, pois têm poder político e habilidade de mobilizar recursos financeiros e tecnológicos para desenvolverem ações que podem ser replicadas pelos outros atores sociais. Nesse sentido emerge a responsabilidade socioambiental.

\section{RESPONSABILIDADE SOCIOAMBIENTAL}

Responsabilidade Socioambiental pode ser definida como "a integração voluntária de preocupações sociais e ambientais por parte das empresas nas suas operações e na sua 
interação com outras partes interessadas", ou seja, as empresas decidem, numa base voluntária, contribuir para uma sociedade mais justa e um ambiente mais limpo (ATP, 2011).

As organizações que se envolvem em projetos de responsabilidade socioambiental estão dispostas a integrar os valores do desenvolvimento sustentável na sua gestão. Deste modo, as organizações "responsáveis" não trabalham apenas para satisfazer as suas próprias necessidades, mas também para 0 bem-estar da sua geração e das gerações futuras (ATP, 2011)

Ser socialmente responsável não se restringe ao cumprimento de todas as obrigações legais, implica ir mais além através de um maior investimento em capital humano, no ambiente e nas relações com outras partes interessadas e comunidades locais (ATP, 2011).

A Responsabilidade Socioambiental pode ser considerada uma ferramenta para o desenvolvimento humanitário, além de, uma oportunidade de negócios na esfera empresarial, incitando o uso gradual das organizações em prol da sociedade. $\mathrm{Na}$ esfera das organizações não empresariais, o trabalho social, em uma primeira análise, não estaria relacionado à oportunidade de converter as demandas sociais em oportunidade de negócio, visto que o objetivo principal delas não é o lucro. A responsabilidade socioambiental estaria, neste caso, relacionada ao voluntarismo, direcionado a projetos sociais, projetos construtivos, cujo compromisso ético, moral e social coadunam para o melhoramento da imagem de uma organização. Além disso, o voluntarismo usufrui de princípios os quais asseguram a capacidade de assimilar o crescimento e processá-lo de forma lógica e coerente, agregando valor ético e moral (MIRANDA et al., 2013).

As práticas sustentáveis podem ser direcionadas para o público interno e para o público externo, desta forma, a organização estaria não somente agindo em prol dos seus funcionários, mas da sociedade local, conseqüentemente contribuindo para o desenvolvimento sustentável.

\section{METODOLOGIA}

A análise dos dados desta pesquisa tem como fio condutor a Sociologia Reflexiva de
Pierre Bourdieu e as contribuições teóricas de Mary Douglas sobre representações sociais.

Para Bourdieu, o cientista possui um grande papel na sociedade. Cabe a ele destruir as pré-noções e o senso comum, buscando elaborar novas maneiras de compreender suas instituições, suas relações, seu modo de vida, sua sociedade e a si próprio.

A sociologia reflexiva de Bourdieu significa a constante vigilância em relação ao cientista como ser produtor de conhecimento, em relação ao próprio campo científico e ao objeto de estudo, que deve ser trabalhado em todas as suas nuances até a exaustão.

Nesta pesquisa serão considerados os conceitos de "espaço social", "campo" e de habitus. Bourdieu afirma que as variáveis não devem ser analisadas isoladamente, mas consideradas dentro de um amplo contexto, percebendo as relações existentes. Uma pesquisa que ignora "o mundo relacional" possui limitações, já que o "real é relacional". De acordo com Bourdieu, "Se é que o real é relacional, pode acontecer que eu nada saiba de uma instituição acerca da qual se julga saber tudo, porque ela nada é fora das suas relações com o todo." (BOURDIEU, 1989, p. 31).

A noção de campo, por sua vez, busca englobar - para além da esfera da sociedade - o campo de produção (de mercadorias ou de cultura) como espaço social de relações, como um universo relativamente autônomo de relações práticas. Já o habitus é um conjunto de conhecimentos adquiridos, são disposições incorporadas ao longo do tempo. Através deste conceito Bourdieu desejava evidenciar as capacidades criadoras, ativas, inventivas do habitus e do agente, que não seriam contempladas pela noção comum de "hábito". Este poder criador não é o de um espírito universal ou de uma natureza, mas sim o de um agente em movimento, em ação. $\mathrm{Na}$ lógica de Bourdieu há uma relação de mão dupla entre as estruturas objetivas (campo) e as estruturas subjetivas (habitus) (BOURDIEU, 1989; BOURDIEU, 2002a; BOURDIEU, 2002b; BOURDIEU, 2004).

A Sociologia Reflexiva de Bourdieu serve de base para identificar e analisar as variáveis envolvidas na construção do discurso dos militares a respeito da responsabilidade socioambiental e sustentabilidade, além de seu habitus em relação às questões ambientais. 
Acrescido as reflexões propostas por Bourdieu será levado em consideração, também, as contribuições de Mary Douglas que auxiliará na busca pela compreensão de influências das instituições sobre o indivíduo, ao propor um entendimento de como a temática ambiental se insere na organização. Para Mary Douglas, as instituições em si não têm propósitos, objetivos, pois somente os indivíduos podem elaborar estratégias conscientemente (DOUGLAS, 1998).

Contudo, ao analisar o funcionamento das instituições Mary Douglas registra o quanto os seres estão sujeitos às convenções sociais e ressalta que a independência intelectual, defendida pela filosofia moral, é algo a ser conquistado através da resistência dos indivíduos ao procurar descobrir como o controle institucional é imposto à mente dos mesmos (DOUGLAS, 1998).

A pesquisa foi realizada a partir de levantamento e revisão bibliográfica para identificação do objeto de pesquisa e construção teórica. O estudo de caso contou com a leitura documental dos registros de práticas socioambientais realizadas por Organizações Militares da Marinha do Brasil e da observação de caráter etnográfico, participando do planejamento das atividades a serem empreendidas pelas Organizações e nas reuniões após as atividades.

A pesquisa documental, por intermédio da análise de conteúdo, trás subsídios importantes para a pesquisa, pois, "há de se considerar que os documentos constituem fonte rica e estável de dados como os documentos substituem ao longo do tempo, tornam-se a mais importante fonte de dados em qualquer pesquisa de natureza histórica" (GIL, 2006, p. 46)

A etnografia é a ferramenta metodológica fundamental utilizada nas pesquisas antropológicas, mas nesta pesquisa será utilizada de maneira não convencional, pois se trata de uma pesquisa qualitativa na área de Gestão. Não há a pretensão de desenvolver uma etnografia, mas sim de utilizar alguns preceitos metodológicos da Antropologia como a descrição e a observação do cotidiano estudado (MINAYO, 2007).

\subsection{MARINHA DO BRASIL}

As Forças Armadas do Brasil são constituídas pelo Comando da Marinha, pelo Exército
Brasileiro (EB) e pela Força Aérea Brasileira (FAB), instituições nacionais, permanentes e regulares que têm como missão constitucional zelar pela defesa da Pátria, pela garantia dos poderes constitucionais e, por iniciativa destes, da lei e da ordem.

O Comando da Marinha é o órgão da União responsável pela Marinha do Brasil (MB). O órgão foi criado em 10 de junho de 1999, através da extinção do Ministério da Marinha e sua respectiva transformação em Comando. Está diretamente subordinado ao Ministro da Defesa e é comandado por um Almirante-deEsquadra nomeado pelo Presidente da República.

A missão primordial da Marinha é garantir a defesa da Pátria juntamente com as demais Forças Armadas. Para o cumprimento de sua missão constitucional a Marinha deve preparar e aplicar o Poder Naval. Cabe ainda à Marinha, como missão secundária, cooperar com o desenvolvimento nacional e a defesa civil, na forma determinada pelo Presidente da República (BRASIL, 2011a; BRASIL, 2011b).

Como o Brasil não possui um órgão exclusivo para organizar, fiscalizar e orientar a Marinha Mercante e policiar a costa brasileira e águas interiores, ela também exerce o papel de "Guarda Costeira". Estas funções são definidas como atribuições subsidiárias particulares e são discriminadas a seguir: Orientar e controlar a Marinha Mercante e suas atividades correlatas, no que interessa à defesa nacional; - Prover a segurança da navegação aquaviária; - Contribuir para a formulação e condução de políticas nacionais que digam respeito ao mar; e - Implementar e fiscalizar $o$ cumprimento de leis e regulamentos, no mar e nas águas interiores, em coordenação com outros órgãos do poder executivo, Federal ou Estadual, quando se fizer necessária, em razão de competências específicas (BRASIL, 2011a; BRASIL, 2011b).

Sua visão de futuro é: " $A$ Marinha do Brasil será uma Força moderna, equilibrada e balanceada, e deverá dispor de meios navais, aeronavais e de fuzileiros navais compativeis com a inserção político-estratégica do nosso País no cenário internacional e, em sintonia com os anseios da sociedade brasileira, estará permanentemente pronta para atuar no mar e em águas interiores, de forma singular ou conjunta, de modo a atender aos propósitos estatuídos na sua missão" (BRASIL, 2011a, p. 3-2). 
A Marinha conta atualmente com um efetivo de aproximadamente 60.0000 militares dispostos em mais de 300 Organizações Militares (OM) (BRASIL, 2011b) distribuídas pelo território nacional em nove distritos navais. As OM são agrupadas em operativas, ou seja, aquelas precipuamente destinadas ao emprego de meios em operações militares em geral. São elas: os meios navais (como navios e submarinos), meios aeronavais, Fuzileiros Navais e Forças Especiais como o Grupamento de Mergulhadores de Combate.

As demais OM, administrativas ou de apoio, visam a contribuir para o sucesso das operações militares, fornecendo o necessário auxílio para a atividade fim da instituição. Por conseguinte, é formada toda uma rede de suporte com OM de pesquisas, hospitais, bases navais ou aeronavais, depósitos diversos (depósitos de gêneros alimentícios, peças sobressalentes, fardamento e combustíveis, por exemplo), laboratório farmacêutico, centro de munição, estabelecimentos de ensino para diversos postos ou graduações, adidâncias navais, sanatório naval, arsenal de marinha e várias outras OM.

\section{ANÁLISE DOS RESULTADOS E DISCUSSÃO}

As práticas analisadas, a partir do registro documental, foram divididas para o público interno e público externo. Para o público interno as atividades estão relacionadas, em sua maioria, ao meio ambiente, com a finalidade de estimular hábitos que contribuam para a preservação do meio ambiente por parte da tripulação (conjunto dos marinheiros, Oficiais e Praças, de um navio, todavia, a expressão também é empregada para as Organizações Militares de terra), de acordo com os dados constantes do quadro 1.

Quadro 1: Práticas socioambientais para o público interno.

\begin{tabular}{|c|c|c|}
\hline Atividade & Ação & Justificativa \\
\hline $\begin{array}{l}\text { Lixeira para } \\
\text { descarte de pilhas e } \\
\text { baterias }\end{array}$ & $\begin{array}{l}\text { Aquisição de } \\
\text { lixeiras }\end{array}$ & $\begin{array}{l}\text { Sabe-se que as substâncias encontradas no interior de pilhas e } \\
\text { baterias são tóxicas e prejudiciais ao meio-ambiente e à saúde. } \\
\text { Se não forem descartados corretamente, esses materiais correm } \\
\text { o risco de amassar ou estourar, deixando vazar o líquido tóxico } \\
\text { de seus interiores. Portanto, a utilização de uma lixeira } \\
\text { específica para tal finalidade visa evitar que possíveis danos } \\
\text { físicos ao material descartado se configurem em risco e } \\
\text { contaminação para o meio-ambiente e, conseqüentemente, para } \\
\text { os seres humanos. }\end{array}$ \\
\hline Regata Ecológica ${ }^{1}$ & $\begin{array}{l}\text { Coleta de lixo } \\
\text { da Baía de } \\
\text { Guanabara }\end{array}$ & $\begin{array}{l}\text { Comemoração do Dia Mundial do Meio Ambiente (DMMA), } \\
\text { principal celebração das Nações Unidas que busca estimular a } \\
\text { ação e conscientização sobre o meio ambiente. }\end{array}$ \\
\hline $\begin{array}{l}\text { Programa "Papa } \\
\text { pilhas/Baterias" }\end{array}$ & $\begin{array}{l}\text { Aquisição de } \\
\text { coletores para } \\
\text { pilhas e baterias } \\
\text { e afixação de } \\
\text { cartazes }\end{array}$ & $\begin{array}{l}\text { Conscientizar a tripulação e o público externo sobre a } \\
\text { importância do assunto e contribuir com a adequada destinação } \\
\text { desses materiais, cujos resíduos tóxicos trazem riscos ao meio } \\
\text { ambiente e à saúde pública, incutindo em todos a filosofia da } \\
\text { responsabilidade pessoal e coletiva, sustentabilidade e } \\
\text { preservação da vida humana. }\end{array}$ \\
\hline $\begin{array}{l}\text { Sistema de } \\
\text { captação de água } \\
\text { da chuva }\end{array}$ & $\begin{array}{l}\text { Instalação de } \\
\text { um reservatório } \\
\text { com a } \\
\text { capacidade de } \\
3.600 \text { litros }\end{array}$ & $\begin{array}{l}\text { Reduzir o consumo de água potável e conseqüentemente os } \\
\text { gastos, e ainda preservar o meio ambiente reduzindo a } \\
\text { escassez dos recursos hídricos. }\end{array}$ \\
\hline $\begin{array}{l}\text { Palestra sobre o } \\
\text { impacto da } \\
\text { Operação Lei Seca } \\
\text { na Sociedade } \\
\text { Fluminense }\end{array}$ & $\begin{array}{l}\text { Conscientização } \\
\text { do público } \\
\text { interno }\end{array}$ & $\begin{array}{l}\text { Conscientizar o público interno a respeito dos danos causados } \\
\text { pela combinação bebida e direção. }\end{array}$ \\
\hline $\begin{array}{l}\text { Palestra sobre o } \\
\text { câncer de mama }\end{array}$ & $\begin{array}{l}\text { Conscientização } \\
\text { do público } \\
\text { interno }\end{array}$ & $\begin{array}{l}\text { Fomentar a importância da detecção precoce do câncer de } \\
\text { mama. }\end{array}$ \\
\hline
\end{tabular}


Legenda: 1 - O evento também contou com a participação das seguintes Instituições: Instituto Baía de Guanabara, Laboratório de Mamíferos Aquáticos e Bioindicadores MAQUA (UERJ), Projeto Grael, ONG Guardiões do Mar, Equipe da Recicloteca, Capitania dos Portos do Rio de Janeiro, Escola Estadual Fernando Magalhães e as Escolas Municipais Deodoro e Profa Lúcia Maria Silveira Rocha, que abrilhantaram a regata com exposições e oficinas relacionadas às questão ambiental. Foram coletados $363 \mathrm{Kg}$ de resíduos.

As práticas listadas no quadro 1 apresentam um caráter predominante ambiental, cerca de $60 \%$ das atividades identificadas e $40 \%$ relacionadas à questões de saúde, ou seja social, o que implica numa preocupação com o próprio ser humano. Tais atividades indicam uma representação social vinculada, predominantemente, à natureza e aos problemas decorrentes do ambiente à saúde do indivíduo. Além disso, tais atividades não estão diretamente relacionadas com os exercícios e atividades militares, porém, as atividades militares causam impacto ao meio ambiente.

Para os militares, em relação à colocação de lixeira para descarte de pinhas e baterias, há a seguinte concepção: "as substâncias encontradas no interior de pilhas e baterias são tóxicas e prejudiciais ao meio-ambiente e à saúde. Se não forem descartados corretamente, esses materiais correm o risco de amassar ou estourar, deixando vazar o líquido tóxico de seus interiores. Portanto, a utilização de uma lixeira específica para tal finalidade visa evitar que possíveis danos físicos ao material descartado se configurem em risco e contaminação para o meioambiente e, conseqüentemente, para os seres humanos".

Apesar do apelo ambiental fica implícita uma preocupação com o meio ambiente e com a saúde dos trabalhadores, ou seja, a Organização assume seu compromisso com o bem-estar dos seus servidores e uma postura ética. Tal perspectiva corrobora visão de Carrol et al. (2006), segundo os quais a responsabilidade ética refere-se a que as organizações tenham um comportamento de acordo com as normas, padrões e expectativas da sociedade.

Quanto à captação de água das chuvas, os militares ressaltam que a água é um "rico recurso captado terá fins domésticos, tais como torneiras de jardins, lavagens de calçadas e viaturas". Com este sistema de captação os militarem esperam reduzir o consumo de água potável e, conseqüentemente, os gastos e ainda preservar o meio ambiente reduzindo a escassez dos recursos hídricos.

Em relação à palestra sobre o câncer de mama cabe registrar que o objetivo não foi atingir apenas o público interno, mas também seus familiares. De acordo com o registro realizado pela Organização Militar: "o Centro Materno Infantil Enfermeiro Laércio Foss proferiu uma palestra nas dependências da Delegacia, sobre a importância da detecção precoce do câncer de mama, tendo como público-alvo a Família Naval. Esta atividade fez parte do "Outubro Rosa", que consiste em diversas ações realizadas pelo Ministério da Saúde, órgãos e entidades que conscientizam a população sobre o assunto supracitado".

Tais atividades corroboram entendimento de Young (2004), de acordo com este autor as organizações têm co-responsabilidade na solução dos problemas sociais e ambientais, pois têm poder político e habilidade de mobilizar recursos financeiros e tecnológicos para desenvolverem ações que podem ser replicadas pelos outros atores sociais.

Em relação ao público externo as atividades realizadas pelos militares em prol da sociedade estão listadas no quadro 2. De acordo com os militares, as atividades têm como base principal as Responsabilidades Socioambiental, ética e de controle social, demonstrando o empenho da OM e de toda sua tripulação com o desenvolvimento social. 
Quadro 2: Práticas socioambientais para o público externo.

\begin{tabular}{|c|c|c|}
\hline Atividade & Ação & Justificativa \\
\hline $\begin{array}{l}\text { Campanha de Doação } \\
\text { de Sangue Voluntária }\end{array}$ & $\begin{array}{l}\text { Identificar voluntários } \\
\text { para doação }\end{array}$ & $\begin{array}{l}\text { Levar voluntários para realizaram coleta de sangue, sendo } \\
\text { respeitados os critérios que permitem ou impedem a } \\
\text { doação de sangue, determinados por normas técnicas do } \\
\text { Ministério da Saúde. }\end{array}$ \\
\hline Doação de Alimentos ${ }^{1}$ & $\begin{array}{l}\text { Arrecadar alimentos } \\
\text { para instituições } \\
\text { carentes }\end{array}$ & $\begin{array}{l}\text { Estimular o comportamento ético, implementando práticas } \\
\text { voltadas para o crescimento social por meio de projetos e } \\
\text { atividades sociais com comunidades. }\end{array}$ \\
\hline $\begin{array}{l}\text { Recreação para } \\
\text { crianças do morro } \\
\text { Chapéu Mangueira }\end{array}$ & $\begin{array}{l}\text { Oferecer atividades } \\
\text { de Recreação no } \\
\text { campo de esportes e } \\
\text { parque aquático }\end{array}$ & $\begin{array}{l}\text { A Marinha do Brasil firmou uma parceria junto ao jornalista } \\
\text { Ivan de Jesus Costa com o objetivo de manter viva, em } \\
\text { crianças e jovens, a esperança de um futuro melhor. } \\
\text { Dedicado à inclusão social, o jornalista organiza, desde } \\
\text { 1999, a colônia de férias do morro Chapéu Mangueira. }\end{array}$ \\
\hline $\begin{array}{c}\text { Projeto "Uma Tarde no } \\
\text { Museu" }\end{array}$ & $\begin{array}{l}\text { Oferecer visitas } \\
\text { guiadas ao Museu } \\
\text { Naval }\end{array}$ & $\begin{array}{l}\text { Oferecer visita guiada, com historiadores, pela exposição } \\
\text { "O Poder Naval na Formação do Brasil", Oficina de Arte e } \\
\text { Educação. }\end{array}$ \\
\hline "Projeto Cidade Limpa" & $\begin{array}{l}\text { Realizar campanhas } \\
\text { de Educação } \\
\text { Ambiental (EA) }\end{array}$ & $\begin{array}{l}\text { Conscientizar sobre os impactos que o descarte } \\
\text { inadequado de lixo e a falta de responsabilidades com o } \\
\text { ambiente podem causar principalmente o perigo aviário, é } \\
\text { realizada uma campanha de educação ambiental (ciclo de } \\
\text { palestras, Gincanas etc.). }\end{array}$ \\
\hline Gincana Solidária² & $\begin{array}{l}\text { Arrecadar } \\
\text { brinquedos }\end{array}$ & $\begin{array}{l}\text { Levar bem estar ao próximo, incentivar a doação e } \\
\text { colaborar com novas estratégias para o desenvolvimento } \\
\text { social. }\end{array}$ \\
\hline Dia da Bandeira & $\begin{array}{l}\text { Realizar cerimônia } \\
\text { alusiva ao Dia da } \\
\text { Bandeira }\end{array}$ & $\begin{array}{l}\text { Intensificar parceria entre as diversas instituições e a } \\
\text { Marinha do Brasil, com o objetivo de ampliar a } \\
\text { mentalidade estudantil ao culto aos símbolos da } \\
\text { identidade brasileira e do nacionalismo. }\end{array}$ \\
\hline $\begin{array}{c}\text { Ação Cívico-Social } \\
\text { (ACISO) }\end{array}$ & $\begin{array}{l}\text { Prestar atendimentos } \\
\text { médico-odontológico } \\
\text { em crianças, adultos } \\
\text { e idosos, } \\
\text { gratuitamente }\end{array}$ & Dar apoio à população na área médico-odontológico. \\
\hline $\begin{array}{l}\text { Programa "Papa } \\
\text { pilhas/Baterias" }\end{array}$ & $\begin{array}{l}\text { Aquisição de } \\
\text { coletores para pilhas } \\
\text { e baterias e afixação } \\
\text { de cartazes }\end{array}$ & $\begin{array}{l}\text { Conscientizar a tripulação e o público externo sobre a } \\
\text { importância do assunto e contribuir com a adequada } \\
\text { destinação desses materiais, cujos resíduos tóxicos } \\
\text { trazem riscos ao meio ambiente e à saúde pública, } \\
\text { incutindo em todos a filosofia da responsabilidade pessoal } \\
\text { e coletiva, sustentabilidade e preservação da vida } \\
\text { humana. }\end{array}$ \\
\hline
\end{tabular}

Legenda: 1 - Foram arrecadados $600 \mathrm{Kg}$ de alimentos. 2 - Foram arrecadados 972 brinquedos para meninos e meninas de diversas faixas etárias. Dentre as instituições agraciadas estavam a Casa Geração Vida, a Creche Lar do Anjo Rafael, o Lar Integrado Amor Puro, o Instituto Dr. March e o Projeto Criançando, todas responsáveis por amparar e cuidar de menores sem família no Estado do Rio de Janeiro.

De acordo com as atividades listadas no quadro 2, percebe-se um forte apelo filantrópico. Tais atividades estão em consonância com o preconizado em parte ao postulado por Rothgiesser (2004) ao explicitar que filantropia é um investimento da organização em ações pontuais periódicas, como campanhas de arrecadação de bens e alimentos, assim como as doações de ordem material.
Em relação às atividades sociais relacionadas aos atos de civismo e apoio de saúde, cabe registrar que são atividades em cooperação com as lideranças locais, para instigar o espírito comunitário do cidadão brasileiro, com o escopo de preparar a comunidade para auto-assistir e manter, em qualquer situação, a normalidade da vida comunitária, tal qual como preconizado por Simões (2010). 
Essas atividades denominadas de ACISO, de caráter temporário, apresentam o objetivo de cooperar com as autoridades governamentais na solução de problemas que assolam a população e, ao mesmo tempo, no desenvolvimento do espírito comunitário do cidadão brasileiro. Para Simões (2010) estas atividades não devem acarretar prejuízo para a atividade fim da Força, mas contribuir para o desenvolvimento socioeconômico da comunidade.

Os profissionais militares e servidores civis participantes das ACISO na área de saúde e na região amazônica devem contribuir e estimular o reforço dos vínculos do paciente com sua comunidade, partindo da idéia que a saúde não se restringe apenas aos aspectos biológicos. É um imperativo que as atividades ofereçam subsídios para que as lideranças desempenhem fortemente o seu papel de agentes transformadores de suas comunidades, tal afirmação também corrobora entendimento de Simões que analisou as ACISO realizadas pelo Exército na região do Amazonas.

\section{CONCLUSÕES}

A Marinha do Brasil há muito tempo contribui para o bem-estar da sociedade em algumas regiões do País, onde, muitas vezes, o Poder Público não se faz presente. Os resultados obtidos, neste estudo, indicam que as

\section{REFERÊNCIAS}

[1]. ASSIS, K. G. Da filantropia à responsabilidade social. Dissertação de Mestrado, Programa de Pós-Graduação em Engenharia de Produção da Universidade Federal de São Carlos, 2010.

[2]. ATP (Associação Têxtil e Vestuário de Portugal). Manual de Responsabilidade Social. 2011. Disponível em: http://www.pofc.qren.pt/resourcesuser/2011_docu mentos/servicos_as_pme/manuais/20110715_manu alatp_resp onsabilidadesocial.pdf. Acesso em: 11 de abril de 2015.

[3]. BRASIL. Marinha do Brasil. Estado Maior da Armada. EMA-134- Manual de Gestão Administrativa da Marinha. Brasília. 2011a.

[4]. Marinha do Brasil. Secretaria Geral da Marinha. SGM-107- Normas Gerais de Administração. Brasília. 2011b. práticas socioambientais realizadas pelos militares possuem enfoques filantrópicos e ambientais, e estão relacionadas às atividades isoladas de algumas organizações militares, não sendo a totalidade da Força Armada.

Todavia, em consonância com Simões (2010), a princípio quem age com responsabilidade social assume postura adequada para 0 desenvolvimento sustentável e contribui para a melhoria do ambiente, trazendo benefícios a todos e sendo merecedor de elogios e de admiração social.

Os resultados desta pesquisa não podem ser generalizados por representar uma parcela das atividades realizadas pelos servidores civis e militares da Marinha do Brasil, mas podem fornecer subsídios para pesquisas futuras e possíveis comparações com as atividades realizadas pelas demais Forças Armadas do Brasil e de outros países.

A pesquisa conclui que a falta de divulgação e mensuração das atividades socioambientais realizadas pelos militares são entraves para o desenvolvimento sustentável, mesmo sabendo que os militares possuem prestígio e respeito junto à população. As atividades em prol da sociedade realizada pelos militares demonstram a seriedade, o respeito, a probidade, a dedicação e o profissionalismo, exercido pelos militares da Marinha, no exercício das suas funções constitucionais e de Responsabilidade Socioambiental.

[5]. BOURDIEU, P. Os usos sociais da ciência: por uma sociologia clínica do campo científico. São Paulo: Ed. da UNESP, 2004.

[6]. A gênese dos conceitos de habitus e de campo. In: . O poder simbólico. 5. ed. Rio de Janeiro: Bertrand Brasil, p.59-73, $2002 a$.

[7]. Introdução a uma Sociologia Reflexiva. In: O poder Simbólico. Rio de 5.ed. Rio de Janeiro: Bertrand Brasil, p.17-58, 2002b.

[8]. 1994 Lições da aula. São Paulo: Ática,

[9]. CARROLL, A. B.; BUCHHOLTZ, A. K. Corporate citizenship. In: Business \& Society. Ethics and stakeholder management. 6.ed. Ohio: Thomson South-Western, p. 30-64, 2006.

[10]. CMMAD (Comissão Mundial sobre Meio Ambiente e Desenvolvimento). Nosso futuro 
comum. Relatório Brundtland. Rio de Janeiro, FGV, 1991.

[11]. COSTA, J. F. S. O papel do Exército Brasileiro na proteção do meio ambiente. Revista do Centro Regional de Cultura / Faculdades de Ciências Sociais Aplicadas do Sul de Minas, Ano 05, v. 07, p. 45-59, 2005

[12]. COSTA, J. F. S.; ANDERSEN, S. M.; OKI, C. S. Da Rio 92 à Rio + 20: a construção do pensamento acadêmico-militar sobre o meio ambiente. Hiléia: Revista do Direito Ambiental da Amazônia, no. 18, 2012.

[13]. DOUGLAS, M. Como as instituições pensam. São Paulo: EDUSP, 1998.

[14]. FERREIRA, A. B. de O. Dicionário Aurélio. Rio de Janeiro: Editora Nova Fronteira, 1977.

[15]. GIL, A. C. Como elaborar projetos de pesquisa. 4 ed. São Paulo: Atlas, 2006.

[16]. GODÓI-DE-SOUSA, E.; PEDREIRA, L. S.; CAMPOS, H. H.; MATTERN, D. A Qualidade dos Relatórios de Sustentabilidade: uma Avaliação em Empresas do Ramo de Energia Elétrica. In: ENCONTRO ANPAD, XXXIII, Rio de Janeiro. Anais...ENANPAD. Rio de Janeiro, 2009. Disponível em:

http://www.anpad.org.br/admin/pdf/EOR662.pdf. Acesso em: 11 de abril de 2015.

[17]. GONÇALVES, B. S. Responsabilidade social empresarial nos processos gerenciais e cadeias de valor. 2006. Disponível em: http://www3.ethos.org.br/cedoc/ responsabilidadesocial-empresarial-nos-processos-gerenciais-enas-cadeias-de-valor-junho2006/\#.VSsBpNzF8us. Acesso em: 11 de abril de 2015.

[18]. JACOBI, P. R. Educação Ambiental: o desafio da construção de um pensamento crítico, complexo e reflexivo. Educação e Pesquisa, v.31, n.2, 17, p. 233-250, 2005.

[19]. JACOBI, P. R. Educação Ambiental e o Desafio da Sustentabilidade Socioambiental. O mundo da Saúde São Paulo. Out/dez, 30 (4), p.524-531, 2006.

[20]. MAXIMIANO, A. C. A. Introdução à Administração. São Paulo: Atlas, 2006.
[21]. MINAYO, M. C. Pesquisa Social: teoria, método e criatividade. Petrópolis: Vozes, 2007.

[22]. MIRANDA, C. R.; LUCIANO, M. R.; SEVERINO, O. F. Responsabilidade Social nas Engenharias das Forças Armadas: o discurso da boa cidadania corporativa. Pós em Revista, n. 8, 2013. Disponível em: http://blog.newtonpaiva.br/pos/e8-gest07/. Acesso em: 11 de abril de 2015.

[23]. REZENDE, I. A. C.; SANTOS, L. S. R. Análise da rentabilidade e performance dos investimentos socialmente responsáveis: um estudo empírico no mercado brasileiro. In: ENANPAD, 30., 2006, Salvador. Anais...Rio de Janeiro: ANPAD, 2006. CD-ROM.

[24]. ROTHGIESSER, T. L. Sociedade Civil. A sociedade civil brasileira e o terceiro setor. São Paulo, 2004.

[25]. SANTOS, E. C. R. M. Responsabilidade Social ou Filantropia? Curitiba: Sanare, 2003.

[26]. SEN, A. Desenvolvimento como liberdade. São Paulo, Companhia das Letras, 2000

[27]. SIMÕES, J. C. M. Responsabilidade Social: Exército Brasileiro nas Ações Cívico Sociais na Região Amazônica. Monografia de especialização em Gestão Pública. Universidade Cândido Mendes, 2010. Disponível em: http://www.avm.edu.br/docpdf/monografias_public adas/c205866.pdf. Acesso em: 11 de abril de 2015.

[28]. VIOLA, E. A dinâmica do ambientalismo e o processo de globalização. São Paulo em Perspectiva. São Paulo, Seade, 6(1), 1992.

[29]. VIOLA, E.; LEIS, H. R. A evolução das políticas ambientais no Brasil, 1971-1991: do bissetorialismo preservacionista para o multissetorialismo orientado para o desenvolvimento sustentável. In: Hogan, D. J. \& Vieira, P. F. (orgs.). Dilemas socioambientais e desenvolvimento sustentável. 2 ed. Campinas, Unicamp, p. 73-102, 1995

[30]. YOUNG, R. Dilemmas and advances in corporate social responsibility in Brazil: the work of the Ethos institute. Natural Resources Forum, v.28, p.291-301, 2004. 


\section{Bapítulo 5}

\section{GESTÃO DE RESÍDUOS DE SERVICCO DE SAÚDE: UM ESTUDO DE CASO NA CONSTRUCÃ̃O DO ESTALEIRO E BASE NAVAL DA MARINHA EM ITAGUAI}

\section{Romero de Albuquerque Maranhão}

\section{Norberto Stori}

Resumo: A busca de uma solução adequada para a destinação correta dos Resíduos de Serviços de Saúde constitui uma medida importante para o dia a dia de uma unidade de saúde. O presente artigo busca analisar a gestão de resíduos de serviços de saúde em um canteiro de obra. A unidade de análise do estudo de caso foi o Posto de Atendimento Médico do Estaleiro e Base Naval, localizado em Itaguaí - Rio de Janeiro. Os resultados mostram que a gestão dos resíduos de serviço de saúde está sendo aplicada e o Plano de Gerenciamento de Resíduos implantado evita problemas ambientais e atende as exigências legais, pois gera aumento no tempo de vida útil dos aterros sanitários, em função da correta separação e destinação final dos resíduos gerados, bem como benefícios ambientais à sociedade. 


\section{INTRODUÇÃO}

A busca de uma solução adequada para a destinação correta dos Resíduos de Serviços de Saúde (RSS) constitui uma medida importante para o dia a dia de uma unidade de saúde, contribuindo para manter a saúde pública, recuperar o ambiente e beneficiar a qualidade de vida dentro e fora da unidade (SISINNO e MOREIRA, 2005; VIRIATO e MOURA, 2011).

Conforme Silva \& Hoppe (2005) os RSS são gerados por prestadores de assistência médica, odontológica, laboratorial, farmacêutica e instituições de ensino e pesquisa na área de medicina relacionadas tanto à população humana quanto à veterinária, bem como canteiros de obras que possuem enfermaria ou posto médico.

De acordo com Castro (2003), os serviços de assistência médica são um dos grandes geradores de resíduos perigosos, com práticas que colocam em risco o meio ambiente, apesar de imprescindíveis ao desenvolvimento humano (CALEGARE et al., 2005). Os RSS, apesar de representarem uma pequena parcela em relação ao total de resíduos gerados em uma comunidade, são fontes potenciais de contaminação ao meio ambiente e apresentam um risco adicional aos trabalhadores dos serviços de saúde e a comunidade em geral, quando gerenciados de forma inadequada (SILVA e HOPPE, 2005; ALI e KUROIWA, 2009).

Estes resíduos podem conter microrganismos patogênicos com capacidade de disseminação de doenças infectocontagiosas no caso de restos de cirurgias e autopsias, seringas, roupas descartáveis, gazes, bandagens. Além disso, alguns constituintes apresentam características de toxidade, inflamabilidade, corrosividade e reatividade no caso de ácidos, remédios vencidos, além de outros resíduos (ALI e KUROIWA, 2009; CAMARGO et al., 2009).

O êxito no manejo adequado em uma unidade de saúde ultrapassa os seus limites, beneficiando a comunidade local e o entorno. Em diversos estabelecimentos de saúde, a baixa eficiência no gerenciamento dos RSS, em especial na etapa de segregação, é decorrente do acondicionamento do resíduo comum juntamente com o biológico-infectante (ALI e KUROIWA, 2009; VIRIATO e MOURA, 2011).
No Brasil a gestão dos RSS teve como marco a Resolução CONAMA n. 5/1993 (BRASIL, 1993), sendo atribuídas responsabilidades específicas aos vários segmentos envolvidos como: geradores, autoridades sanitárias e ambientais. Entretanto, a Resolução CONAMA $\mathrm{n}^{\circ}$. 358/2005complementa os procedimentos do gerenciamento, estabelecendo as diretrizes para o tratamento e disposição dos RSS (BRASIL, 2005). Já a RDC n. 306/2004 da ANVISA dissemina o Regulamento Técnico para o gerenciamento dos RSS e, recentemente, a Lei Ordinária Federal $n^{\circ}$. 12.305, de agosto de 2010, institui a Política Nacional de Resíduos Sólidos (PNRS) que solidifica o princípio poluidor pagador (MACEDO et al., 2007; VIRIATO e MOURA, 2011).

A Resolução CONAMA n 358/2005 trata do gerenciamento dos RSS sob o prisma da preservação dos recursos naturais e do meio ambiente e define as competências dos órgãos ambientais estaduais e municipais, para estabelecerem critérios para o licenciamento ambiental dos sistemas de tratamento e destinação final dos RSS. Além disso, tal Resolução preconiza que os resíduos infectantes devem ser submetidos a processos de tratamento que promova redução de carga microbiana, antes de serem encaminhados para aterro sanitário, bem como menciona que a redução na fonte (reduzir ou evitar a produção de resíduos) poderá aumentar a eficiência dos equipamentos e dos processos.

A RDC n 306/2004 concentra sua regulação no controle dos processos de segregação, acondicionamento, armazenamento, transporte, tratamento e disposição final. Estabelece procedimentos operacionais em função dos riscos envolvidos e concentra seu controle na inspeção dos serviços de saúde.

A PNRS preconiza, no seu Art. $1^{\circ}$, que estão sujeitas à observância da lei as "... pessoas físicas ou jurídicas, de direito público ou privado, responsáveis, direta ou indiretamente, pela geração de resíduos sólidos e as que desenvolvam ações relacionadas à gestão integrada ou ao gerenciamento de resíduos sólidos".

O presente artigo busca analisar a gestão de RSS em um canteiro de obra. A unidade de análise do estudo de caso foi o Posto de Atendimento Médico, do Canteiro de Obra do "Estaleiro e Base Naval para Construção de Submarinos Convencionais e com Propulsão 
Nuclear" (EBN), localizado na Ilha da Madeira, no Município de Itaguaí, no Estado do Rio de Janeiro. O estudo justifica-se, pela verificação da apropriada implementação de um plano que evita problemas ambientais e atende às exigências legais. Além disso, registra-se que não foram identificados, na literatura nacional, artigos relacionados à Gestão de Resíduos Sólidos de Saúde no setor da Construção Civil, o que gera uma oportunidade de pesquisa.

Este estudo ganha relevância à medida que, segundo Alves (2008), o gerenciamento dos resíduos nos estabelecimentos de saúde é uma realidade ainda pouco explorada no Brasil.

\section{REVISÃO BIBLIOGRÁFICA}

A questão da redução da geração dos resíduos sólidos ou até mesmo da sua não geração é atualmente um dos maiores desafios, tanto para o setor público como para o setor privado de fornecimento de bens e serviços. A partir da publicação da Política Nacional de Resíduos Sólidos, esse desafio tornou-se uma necessidade premente, uma vez que metas de redução - com vistas a diminuir a quantidade de resíduos encaminhados para disposição final - passou a ser demandada para todas as esferas (SISINNO et al., 2011).

Em vários estabelecimentos de saúde, a baixa eficiência no gerenciamento dos RSS pode acarretar diversos problemas de ordem econômica, social e ambiental. De acordo com Hossain et al. (2011) a gestão de RSS continua a ser um grande desafio, particularmente, na maioria das instalações de saúde dos países em desenvolvimento. Inúmeras pesquisas têm sido realizadas sobre a gestão de resíduos de saúde. A destinação final inadequada desses resíduos, bem como o manuseio impróprio e o descarte indevido têm aumentado significativamente os riscos à saúde e poluição ambiental devido à natureza infecciosa dos resíduos.

Embora, haja iniciativas significativas em relação à manipulação e destinação final dos RSS, na prática a gestão é insatisfatória, ficando evidente a partir da coleta inicial até a disposição final. Na maioria dos casos, os principais motivos para uma gestão insatisfatória são a falta de legislação adequada, de funcionários especializados, e de consciência e controle efetivo. Além disso, a maioria dos centros de saúde em países em desenvolvimento têm enfrentado dificuldades financeiras na procura de métodos eficientes de eliminação de resíduos hospitalares (TAGHIPOUR e MOSAFERI, 2009a; HOSSAIN et al., 2011).

Para Ananth et al. (2010), que avaliaram doze países asiáticos, os riscos dos resíduos associados com a saúde e sua gestão ganharam a atenção de todo o mundo em vários eventos, fóruns locais e internacionais. No entanto, embora ainda lentamente, a necessidade de gestão adequada dos RSS vem ganhando reconhecimento, devido aos problemas associados com as práticas inapropriadas, incluindo a exposição a agentes infecciosos e substâncias tóxicas.

Apesar da magnitude do problema, em muitos países, especialmente nas nações em desenvolvimento, as práticas, capacidades e políticas para lidar com a destinação final dos RSS são ainda inadequadas e requerem intensificação e providências urgentes (ANANTH et al., 2010). Corrobora tal entendimento os estudos realizados por Taghipour e Mosaferi (2009a) no Irã, Ndidi et al. (2009) na Nigéria e Ali et al. (2009) no Paquistão, na Tailândia e na Mongólia. Mohamed et al. (2009) avaliando a questão no Bahrein registra que os problemas de má gestão (segregação, manuseio, transporte e destinação final) são identificados em instituições públicas e privadas de saúde. Taghipour e Mosaferi (2009a) também evidenciam os mesmos problemas nos hospitais iranianos.

Além disso, Uysal e Tinmaz (2004), estudando hospitais da Turquia, registraram que os RSS não recebem a devida atenção por parte do poder público e são eliminados junto com o lixo municipal e industrial. Para Abd El-Salam (2010), que estudou as características físicoquímicas dos resíduos hospitalares no Egito, quase dois terços dos RSS são semelhantes aos resíduos domésticos. Taghipour e Mosaferi (2009b) constataram que aproximadamente $70 \%$ dos resíduos provenientes das instituições de saúde (públicas, privadas e militares) no Irã são considerados resíduos domésticos, enquanto $30 \%$ dos resíduos são considerados infecciosos.

Outrossim, Abd El-Salam (2010), constatou também que a segregação dos RSS não obedece procedimentos ou padrões, sendo descartados como lixo doméstico. Observou, 
ainda, que os resíduos líquidos são encaminhados para o sistema municipal de esgoto sem tratamento prévio, tal fato corrobora com as pesquisas realizadas por Uysal e Tinmaz (2004), e Abdulla et al. (2008).

Taghipour e Mosaferi (2009a) registram que não existem instruções práticas, ou de supervisão adequada, sobre os diferentes níveis de gestão de resíduos nos hospitais do Irã. Todavia, registram que em quase todos os hospitais há um gestor para a Gestão de RSS, porém o programa de treinamento de pessoal não é eficiente. Ressaltam, também, que não são satisfatórias as condições de armazenamento temporário dos RSS, nem os equipamentos de proteção para o pessoal envolvido no manuseio e transporte do material.

\section{GESTÃO E GERENCIAMENTO DE RSS}

A GESTÃO de RSSs abrange atividades referentes à tomada de decisões estratégicas com relação aos aspectos institucionais, administrativos, operacionais, financeiros e ambientais, ou seja, à organização do setor para esse fim, envolvendo políticas, instrumentos e meios (FERREIRA, 2007).

Enquanto o GERENCIAMENTO engloba os aspectos tecnológicos e operacionais da questão, envolvendo fatores administrativos, gerenciais, econômicos, ambientais e de desempenho: produtividade e qualidade, por exemplo, e relaciona-se à prevenção, redução, segregação, reutilização, acondicionamento, coleta, transporte, tratamento, recuperação de energia e destinação final de resíduos sólidos (FERREIRA, 2007).

De acordo com a ANVISA, gerenciamento de RSS é um conjunto de procedimentos de gestão, planejados (integrados) e implementados a partir de bases científicas e técnicas, normativas e legais, com o objetivo de minimizar a produção de resíduos e proporcionar aos resíduos gerados, um encaminhamento seguro, de forma eficiente, visando à proteção dos trabalhadores, a preservação da saúde pública, dos recursos naturais e do meio ambiente (BRASIL, 2004).

A concepção, operação e monitoramento do sistema de gerenciamento devem estar previsto e descritos em um Plano de GRSS, que tem como propósito fundamental reduzir o máximo possível, os riscos à saúde de pacientes, funcionários e comunidade em geral, oriundos do manejo inadequado, principalmente de resíduos que possuem elevado grau de periculosidade. Este Plano deve ser estruturado pelos geradores de RSS e deve conter ações relativas ao manejo de tais resíduos, considerando suas características e os aspectos referentes ao processo de geração, segregação, acondicionamento, coleta, armazenamento, transporte, tratamento e destinação final, além da proteção à saúde pública e ao meio ambiente (BRASIL, 2004). Em toda a sua estrutura, devem ser considerados princípios que levem a minimização e soluções integradas ou consorciadas que visem 0 tratamento e a disposição final destes resíduos de acordo com as diretrizes estabelecidas pelos órgãos competentes (BRASIL, 2004).

Desta maneira, é possível inferir que a Gestão antecede o Gerenciamento de RSS e que são atividades correlatas e não correntes. A Gestão está relacionada ao nível estratégico da Organização e o Gerenciamento ao nível operacional (MARANHÃO, 2012). Todavia, Ferreira (2007) ressalta que a Gestão é uma etapa fundamental durante o processo de manejo dos resíduos e está diretamente atrelada com a tomada de decisão acerca dos resíduos, o que propicia alcançar um Gerenciamento (operacionalização) mais eficaz, na busca de atender os aspectos legais em vigor.

\section{MÉTODOS DA PESQUISA}

De acordo com Morin (1996, 2000) o método é o caminho percorrido para a construção do saber. Do ponto de vista de seu objetivo esta pesquisa é classificada como descritiva e exploratória. Conforme Gil (2002) a pesquisa descritiva é útil quando se objetiva descrever as características de determinado fenômeno.

Essa pesquisa exploratória foi desenvolvida por intermédio da abordagem de estudo de caso único. Registra-se que esse tipo de pesquisa facilita a compreensão do fenômeno investigado. Nesse caso, optou-se por um estudo de caso único, pela natureza e magnitude do fenômeno (YIN, 2005).

A escolha do Posto de Atendimento Médico do Canteiro de Obras do EBN como unidade de análise, deve-se ao fato de ser a um canteiro de obra pertencente ao maior projeto de construção civil do setor de defesa do Brasil. Além disso, os dados sobre as 
quantidades de RSS, disponibilizados pela Marinha, possibilitam uma análise e interpretação sobre o tema no setor da construção civil. Desta forma, o Posto em questão reúne condições de ser estudado, por se mostrar como um caso decisivo, de acordo com Yin (2005), e satisfazer as condições para testar os objetivos propostos.

O estudo de caso único adotado aqui representa uma maneira de investigar um tópico empírico, pois "... o estudo de caso, permite uma investigação para se preservar as características significativas da vida real" (YIN, 2005), por meio de trabalhos explanatórios (causais), exploratório ou descritivo, sendo indicados para os casos em que o foco se encontra em fenômenos contemporâneos inseridos em um contexto real.

Para a realização deste trabalho utilizou-se diversas fontes de evidências, possibilitando o desenvolvimento de linhas convergentes de investigação, por meio de um processo de triangulação de informações de fontes de dados (YIN, 2005). Os instrumentos de coletas de dados utilizados foram: documentos, registros em arquivos, entrevistas, observação direta e participativa.

Um roteiro para as entrevistas foi elaborado por meio de informações obtidas na pesquisa bibliográfica. As entrevistas foram compostas por questões relacionadas ao PGRSS visando permitir a caracterização das etapas do gerenciamento de RSS. Os conteúdos das perguntas buscaram informações sobre 0 nível de gerenciamento dos RSS no Canteiro de Obras e não o entendimento dos entrevistados. Foram entrevistados os gestores de resíduos do Canteiro de Obras e o gestor do Posto de Atendimento Médico localizado no mesmo Canteiro

As duas maneiras de observação direta (a formal e a informal) foram utilizadas para este estudo de caso. A observação formal contemplou a participação em reuniões pertinentes aos assuntos do Sistema de Gestão Ambiental (SGA) e do Plano de Gestão de Resíduos do Serviço de Saúde (PGRSS). De maneira informal observou-se a área de armazenamento de resíduos, o manuseio dos resíduos e os setores produtores de resíduos. A observação participante também foi utilizada, pois o autor participou das atividades de auditoria ambiental de SGA, na qualidade de auditor. Assim, a triangulação foi realizada utilizando os resultados obtidos com as entrevistas, análise de documentos e registros em arquivos, como sugere Yin (2005).

\section{RESULTADOS E DISCUSSÃO}

Nesta seção são apresentados os resultados obtidos na pesquisa, bem como uma análise do PGRSS, a classificação e os tipos de resíduos gerados pelo Posto de Atendimento Médico em questão, além das estratégias empregadas para o tratamento dos seus RSS.

\subsection{ANÁLISE DO PGRSS}

O PGRSS do Posto de Atendimento Médico, do Canteiro de Obras do EBN, apresenta-se de acordo com as diretrizes da RDC $n^{\circ}$ 306/2004 da ANVISA. Em relação ao aspecto segregação, os RSS são separados de acordo com a classificação apresentada na Resolução CONAMA no 358/2005. Para a identificação e reconhecimento visual dos recipientes de acondicionamento e armazenamento temporário são utilizadas etiquetas, em consonância com a simbologia prevista na RDC nํ 306/2004 da ANVISA.

As principais características do gerenciamento dos RSS no Posto em estudo corroboram os resultados de Garcia e ZanettiRamos (2004), ao afirmarem que o PGRSS deve ser elaborado com base nas características e volume dos RSS gerados, estabelecendo as diretrizes de manejo desses resíduos, incluindo as medidas de: segregação, acondicionamento, identificação, transporte interno, armazenamento intermediário, armazenamento temporário, tratamento, armazenamento externo, coleta e transporte externo e destinação final.

De acordo com o relato dos entrevistados e as visitas realizadas no Posto de Atendimento Médico, são apresentadas as principais características da gestão dos RSS:

(a) Segregação - Os resíduos sólidos são separados em recipiente específico para cada tipo de resíduo, identificando os resíduos conforme suas características e potencial infectante;

(b) Acondicionamento e Armazenamento - Os resíduos são armazenados em embalagens de plástico e papel seguindo uma padronização de cores, conforme o tipo de resíduo sólido, de acordo com a legislação vigente; e o Posto possui lixeiras com tampas 
plásticas, para o armazenamento dos resíduos, identificadas conforme o tipo de resíduo;

(c) Coleta e armazenagem externa - Os resíduos são recolhidos dos recipientes de armazenamento por profissionais qualificados e colocados em local de armazenamento temporário. Esses resíduos são armazenados em um depósito de armazenamento externo para seu, posterior, destino final. Esse local está localizado na área externa ao Posto e é de fácil acesso aos funcionários da empresa de coleta; e

(d) Tratamento e destino final - Os RSS são recolhidos por empresa especializada e credenciada pelo Órgão Ambiental para posterior incineração.

Desta forma, o PGRSS do Posto Médico de Atendimento visa minimizar a produção de resíduos, tratá-los e encaminhá-los de forma segura ao destino final, com a finalidade de prevenir e controlar riscos ocupacionais, à saúde pública e ao meio ambiente.

\subsection{ANÁLISE DOS RESÍDUOS GERADOS}

Todos os RSS gerados pelo Posto são quantificados e os dados consolidados em planilhas de controle mensal. Os dados referentes aos anos de 2011, 2012, 2013 e 2014, em litros, são apresentados na tabela 1.

Tabela 1: Quantidades mensais de RSS produzidos no período de 2011 até 2014.

\begin{tabular}{|c|c|c|c|c|}
\hline Mês / Ano & 2011 & 2012 & 2013 & 2014 \\
\hline JAN & 240 & 480 & 0 & 480 \\
\hline FEV & 240 & 720 & 0 & 0 \\
\hline MAR & 0 & 960 & 1200 & 480 \\
\hline ABR & 240 & 1200 & 0 & 0 \\
\hline MAI & 240 & 1200 & 1200 & 720 \\
\hline JUN & 0 & 960 & 0 & 0 \\
\hline JUL & 480 & 680 & 0 & 480 \\
\hline AGO & 0 & 720 & 480 & 0 \\
\hline SET & 0 & 1680 & 0 & 720 \\
\hline OUT & 0 & 0 & 480 & 480 \\
\hline NOV & 480 & 0 & 0 & 0 \\
\hline DEZ & 0 & 720 & 720 & 480 \\
\hline TOTAL & 1920 & 9320 & 4080 & 3840 \\
\hline
\end{tabular}

De acordo com os dados da tabela 1 não é possível relacionar as quantidades produzidas com os atendimentos de procedimentos médicos realizados no Posto. A ausência do registro dos atendimentos não possibilita interpretar o aumento na produção de RSS de 2011 para 2012 em aproximadamente $485 \%$. Também não foi realizada uma pesquisa para relacionar 0 possível aumento na produção de resíduos com alguma epidemia ou surto. Já a produção de resíduos entre os anos de 2013 e 2014 estão em consonância com o decréscimo de contratações e a consequente redução dos atendimentos realizados no Posto.

\subsection{TRATAMENTO DOS RESÍDUOS}

O tratamento consiste na aplicação de método, técnica ou processo que modifique as características dos riscos inerentes aos resíduos, reduzindo ou eliminando o risco de contaminação, de acidentes ocupacionais ou de danos ao meio ambiente. No Posto não é realizado o tratamento dos resíduos gerados, apenas o armazenamento temporário para tratamento externo.

A coleta dos resíduos no Posto, devidamente acondicionados em bombonas, é executada de forma mecanizada, atendendo à 
programação pré-definida e às freqüências estabelecidas entre a empresa coletora e o gestor do Posto, garantindo formas adequadas e seguras para o seu manuseio. Depois de acondicionados em recipientes, de acordo com sua tipologia, os RSS são transportados por veículos devidamente preparados e identificados, seguindo roteiros pré- determinados, com motoristas treinados em transporte de cargas perigosas. O tratamento externo dos resíduos é feito por empresa de transporte devidamente registrada no órgão ambiental. A destinação final dos resíduos é a incineração, de acordo com as informações dos entrevistados e registros.

O processo de incineração obedece à Resolução CONAMA no 316/2002, sendo seus equipamentos dotados de analisadores contínuos de emissões gasosas e sistema de intertratamento. O tempo de residência dos gases na câmara secundária é de 2 segundos. Depois da queima, os gases são submetidos a um resfriamento brusco, através de torres de lavagem. Os líquidos utilizados no processo de lavagem são destruídos no próprio equipamento, num circuito fechado.

O tratamento de resíduos realizado pelo Posto não corrobora com os estudos realizados por Abd El-Salam (2010) e Uysal \& Tinmaz (2004), pois se constatou que a segregação dos RSS obedece procedimentos estabelecidos pelos requisitos legais e não são descartados como

\section{REFERÊNCIAS}

[1]. ABD EL-SALAM, M. M. Hospital waste management in El-Beheira Governorate, Egypt. Journal of Environmental Management, v.91, n.3, p. 618-629, 2010.

[2]. ABDULLA, F.; ABU QDAIS, H.; RABI, A. Site investigation on medical waste management practices in northern Jordan. Waste Management, v.28, n.2, p. 450-458, 2008.

[3]. ALI, M.; KUROIWA, C. Status and challenges of hospital solid waste management: case studies from Thailand, Pakistan, and Mongolia. Journal of Material Cycles and Waste Management, v.11 p. 251-257, 2009.

[4]. ALMEIDA, F. O bom negócio da sustentabilidade. Rio de Janeiro: Nova Fronteira, 2002.

[5]. ALVES, M. L. A saúde ambiental e os resíduos de serviços de saúde nos três níveis de complexidade do sistema único de saúde - SUS. 2008. 96 fls. Dissertação (Mestrado em resíduo doméstico. Registra-se, ainda, que os resíduos líquidos são encaminhados para Estação de Tratamento de Efluentes (ETE) do Canteiro de Obras do EBN e essa iniciativa vai ao encontro da pesquisa realizada por Abdulla et al. (2008).

\section{CONCLUSÃO}

O objetivo desta pesquisa foi analisar a gestão de RSS em um Posto de Atendimento Médico localizado em canteiro de obras. Os resultados mostram que a gestão dos RSS está sendo aplicada e o PGRSS implantado evita problemas ambientais e atende às exigências legais, pois gera aumento no tempo de vida útil dos aterros sanitários, em função da correta separação e destinação final dos resíduos gerados, bem como benefícios ambientais à sociedade.

Observa-se que os dados aqui registrados não devem ser considerados definitivos, por se tratar de um estudo exploratório. Outras limitações desta pesquisa são próprias do estudo de caso, como a não possibilidade de generalizações. Apesar disso, a questão analisada é de grande importância, abrindo diversas opções de análises empíricas, que poderão explorar outras indagações, a partir desse início, uma vez que, segundo Joshi (2013), a questão dos resíduos sólidos é preocupante e urgente.

Desenvolvimento e Meio Ambiente) - Universidade Federal do Rio Grande do Norte, Natal, 2008.

[6]. ANANTH, A. P.; PRASHANTHINI, V.; VISVANATHAN, C. Healthcare waste management in Asia. Waste Management, v.30, n.1, p.154-161, 2010.

[7]. BARBIERI, J. C. Gestão Ambiental empresarial: conceitos, modelos e instrumentos. 2 ed. São Paulo: Saraiva, 2007.

[8]. BRASIL. Resolução CONAMA No. 05/1993. Define as normas mínimas para tratamento de resíduos sólidos oriundos de serviços de saúde, portos e aeroportos e terminais rodoviários. Diário Oficial da União, 31 ago., Seção 1. Brasília; 2001.

[9]. BRASIL. Resolução RDC no 306/2004. Disposição sobre o regulamento técnico para o gerenciamento de resíduos de serviços de saúde. Diretoria Colegiada da Agência Nacional de 
Vigilância Sanitária - ANVISA. Diário Oficial da União, 10 dez., Seção 1. Brasília; 2004.

[10]. BRASIL. Resolução CONAMA No. 358/2005. Dispõe sobre o tratamento e a destinação final dos resíduos dos serviços de saúde. Diário Oficial da União, 01 out., Seção 1. Brasília; 2005.

[11]. BRASIL. Lei No. 12.305 de agosto de 2010. Institui a Política Nacional de Resíduos Sólidos. Diário Oficial da União, 3 ago., Seção 1. Brasília; 2010.

[12]. CALEGARI, L.; GODOY, L. P.; SILVEIRA, D. D. Sistema de gerenciamento ambiental (SGA): uma contribuição para a melhoria dos serviços de saúde hospitalar e atendimento à legislação ambiental. Anais do XII SIMPEP - Bauru, SP, 2005.

[13]. CAMARGO, M. E.; MOTTA, M. E. V.; LUNELLI, M. O.; SEVERO, E. A. Resíduos Sólidos de Serviço de Saúde: Um Estudo Sobre o Gerenciamento. Scientia Plena, vol.5, no. 7, 2009.

[14]. CASTRO, J. M. A. Resíduos Perigosos no Direito Ambiental Internacional. Porto Alegre: Formato Artes Gráficas, 2003, p.52.

[15]. COLARES, A. C. V.; MATIAS, M. A.; CUNHA, J. V. A. Análise das práticas gerenciais ambientais de empresas brasileiras sob a ótica da Ecoeficiência. VIII Congresso Nacional de Excelência em Gestão, Anais... 2012. Disponível em:

http://www.excelenciaemgestao.org/Portals/2/docu ments/cneg8/anais/T12_0481_2877.pdf. Acesso em: 18 set. 2012

[16]. DEMAJOROVIC, J. Ecoeficiência em serviços: diminuindo impactos e aprimorando benefícios ambientais. In: VILELA JR, A; DEMAJOROVIC, J. (Org.). Modelos e Ferramentas de Gestão Ambiental: Desafios e Perspectivas para as Organizações. São Paulo: Editora SENAC, 2006.

[17]. FERREIRA, E. R. Gestão e Gerenciamento dos Resíduos de Serviços de Saúde em Presidente Prudente - SP. Dissertação de Mestrado. Programa de Pós-graduação em Geografia, UNESP. Presidente Prudente - SP, 2007.

[18]. FERREIRA, J. A. Solid Waste and Nosocomial Waste: An Ethical Discussion. Caderno de Saúde Pública, Rio de Janeiro, 11 (2): 314-320, 1995.

[19]. GARCIA, L. P.; ZANETTI-RAMOS, B. G. Gerenciamento dos resíduos de serviços de saúde: uma questão de biossegurança. Caderno de Saúde Pública, Rio de Janeiro, 20(3):744-752, 2004

[20]. GIL, A. C. Métodos e técnicas de pesquisa social. São Paulo: Atlas, 2002.

[21]. HOSSAIN, M. S.; SANTHANAM, A.; NIK NORULAINI, N. A.; OMAR, A. K. Clinical solid waste management practices and its impact on human health and environment - A review. Waste Management, v.31, n.4, p. 754-766, 2011.

[22]. JOSHI, H. D. Health care waste management practice in Nepal. Journal of Nepal Health Research Council, v. 11, n. 23, p. 102-108, 2013.

[23]. MACEDO, L. C.; LAROCCA, L. M.; CHAVES, M. M. N.; PERNA, P. O.; MUNTSCH, S. M. A.; DAMACENO, E. F. C.; SOUZA, T. S.; POLIGUESI, C. B.; TRUPPEL, T. C.; SOUZA, C. Segregação de resíduos nos serviços de saúde: a Educação Ambiental em um Hospital-Escola. Cogitare Enfermagem. Abr/Jun; v.12, n.2, p. 183188, 2007

[24]. MARANHÃO, R. A. Gestão de Resíduos de Serviço de Saúde em Organização Militar da Marinha do Brasil: um estudo na Base Naval do Rio de Janeiro. Monografia de MBA em Gestão e Tecnologias Ambientais, Escola Politécnica da Universidade de São Paulo, 2012.

[25]. MOHAMED, L. F.; EBRAHIM, S. A.; ALTHUKAIR, A. A. Hazardous healthcare waste management in the Kingdom of Bahrain. Waste Management, v.29, n.8, p. 2404-2409, 2009.

[26]. MORIN, E. O método. Lisboa: EuropaAmérica, 2ª ed. 1996.

[27]. MORIN, E. Ciência com consciência. Rio de Janeiro: Bertrand Brasil, 4ª . ed., 2000.

[28]. NDIDI, N.; NELSON, O.; PATRICIA, O.; SUNDAY, J. Waste management in healthcare establishments within Jos Metropolis, Nigeria. African Journal of Environmental Science and Technology, v. 3, n.12, p. 459-465, 2009.

[29]. PRATT, L. Nueva vision para la Sostenibilidad: el Sector Privado y Medio Ambiente. Centro Latinoamericano para la Competitividad y el Desarrollo Sostenible (CLACDS). Nueva Orleans, Luisiana, 2000.

[30]. SCHNEIDER, V. E. Sistemas de gerenciamento de resíduos sólidos de serviços de saúde: contribuição ao estudo das variáveis que interferem no processo de implantação, monitoramento e custos decorrentes. Tese de Doutorado. Departamento de Engenharia de Recursos Hídricos e Saneamento, Porto Alegre: IPH/UFRGS, 2004.

[31]. SILVA, C. E. ; HOPPE, A. E. Diagnóstico dos Resíduos de Serviços de Saúde no interior do Rio Grande do Sul. Revista de Engenharia Sanitária Ambiental, v.10, n. 2, p.146-151, 2005.

[32]. SISINNO, C. L. S.; BARROS, R. L. P. Ecoeficiência em Laboratórios e Estabelecimentos de Saúde. Bionotícias, n.66, p.8-9, 2004.

[33]. SISINNO, C. L. S.; MOREIRA, J.C. Ecoeficiência: um instrumento para a redução da geração de resíduos e desperdícios em estabelecimentos de saúde. Cadernos de Saúde Pública, v.21, n.6, p.1893-1900, 2005. 
[34]. SISINNO, C. L. S.; RIZZO, A. C. L.; SANTOS, R. L. C. Ecoeficiência aplicada à redução da geração de resíduos sólidos. Rio de Janeiro: CETEM/MCT, 2011.

[35]. TAGHIPOUR, H.; MOSAFERI, M. The challenge of medical waste management: a case study in northwest Iran-Tabriz. Waste Management \& Research, v. 27, n.4, p.328-335, 2009a.

[36]. TAGHIPOUR, H.; MOSAFERI, M. Characterization of medical waste from hospitals in Tabriz, Iran. Sci Total Environ, v.15 n.5, p. 1527$1535,2009 b$.
[37]. UYSAL, F.; TINMAZ, E. Medical waste management in Trachea region of Turkey: suggested remedial action. Waste Management \& Research, v.22, n.5, p. 403-407, 2004.

[38]. VIRIATO, A.; MOURA, A. Ecoeficiência e economia com a redução dos resíduos infectantes do Hospital Auxiliar de Suzano. O Mundo da Saúde, v.35 n.5, p.305-310, 2011.

[39]. YIN, R. K. Estudo de caso: planejamento e métodos. $2^{a}$ edição, Porto Alegre: Bookmam, 2005. 


\section{Eapítulo 6}

\section{VIOLENACIA DOMESTICA E AS IMPLICACÕOES NA SAÚDE FISICA E EMOCIONAL DE MULHERES: INFERENCIAS DE ENFERMAGEM}

\section{Ana Cláudia Ribeiro Paiva \\ Vaneska Ribeiro Perfeito Santos \\ Sandra Mara dos Santos}

Resumo: Este estudo se propõe a descrever o fenômeno da violência doméstica, principalmente contra as mulheres que, atualmente, apresenta-se como um problema de saúde pública. Após longo período de sofrimento na intimidade dos lares, a violência contra a mulher começou a ganhar notoriedade e compreensão, despertando a sociedade para tal acontecimento na intimidade das famílias. A Lei Maria da Penha, sancionada em 2006, regulamenta as ações de saúde voltadas para a assistência e o cuidado às vítimas, buscando também levar informações às mesmas, com o intuito de diminuir a ocorrência de agressões e implicações em sua saúde física e emocional. É importante ressaltar que a atuação de profissionais de saúde configura-se como um importante objeto da Saúde Coletiva, com vistas ao enfrentamento deste problema, particularmente, pela atuação do enfermeiro que deve se pautar por ações planejadas, por capacitação pessoal e interação com a equipe interdisciplinar, com a família e com o paciente. Trata-se de um estudo de revisão bibliográfica, de caráter analítico-descritivo, sobre a temática em questão, o que possibilitou uma reflexão acerca das perspectivas para a atuação da enfermagem diante de situações de violência doméstica, afim de não permitir a banalização de tais fatos.

Palavras-chave: Violência Doméstica; Violência contra a Mulher; Saúde Pública; Cuidados de Enfermagem. 


\section{INTRODUÇÃO}

A violência sexual e/ou doméstica é um fenômeno de conceituação complexa e multicausal, cuja compreensão atravessa uma trama de aspectos religiosos, sociais, culturais e econômicos. Mostra-se como uma atitude persistente em nossa atualidade, promovendo danos que afetam de modo significante a saúde da população, gerando prejuízos e preocupação para com as políticas públicas e setores de apoio.

Por apresentar significativa expressão epidemiológica, segundo dados do Ministério da Saúde (BRASIL, 2011a, p.5), a violência sexual e/ou doméstica contra crianças, adolescentes e mulheres adultas é considerada um grave problema de saúde pública.

Em destaque, a violência doméstica e/ou sexual elucida aspectos relacionados ao gênero ou às suas vulnerabilidades, apontando as mulheres como destinatárias principais da ação. Este fato pode, também, revelar desigualdades impressas na sociedade pelas relações patriarcais que multiplicam as sensações de medo e sofrimento.

A violência sexual pode produzir consequências traumáticas e indeléveis para quem a sofre e, apesar de inquestionáveis avanços neste assunto, ainda é um grande desafio reconhecer uma vida sem violência, com respeito aos direitos humanos (BRASIL, 2011b, p.11).

A repercussão da violência sexual pode ser sentida na saúde física, quer por contaminação por DST's ou gravidez indesejada, e na saúde mental da pessoa, com quadros de depressão, síndrome do pânico ou ansiedade. Desta forma, torna-se importante compreender o contexto familiar e/ou social que a mulher vive para uma intervenção dos serviços de saúde de maneira satisfatória.

Segundo Brasil (2011b, p.14), o impacto da violência também sobrecarrega o sistema de saúde tanto em termos de recursos econômicos e humanos, quanto em custos sociais, como em decorrência de produtividade perdida para a sociedade em geral.

Nesse sentido, a atuação dos profissionais de saúde, em uma abordagem interdisciplinar se faz relevante nas estratégias e ações de enfrentamento à violência contra as mulheres.
É essencial o processo de acolhimento, escuta e orientação profissional, livre de julgamentos ou valores morais, bem como utilização de instrumentos do processo de cuidar em enfermagem, como base para o encontro de possibilidades para o enfrentamento do problema, de forma positiva.

Torna-se evidente a necessidade de uma integração de ações sobre violência de gênero, fortalecimento de fontes formais e informais de apoio e relacionamentos interdisciplinares, para a condução de uma saúde pública que contemple seus princípios de igualdade, universalidade e integralidade.

Portanto, este estudo tem como escopo, conceituar a violência doméstica, especificamente contra mulheres, suas implicações físicas e emocionais na saúde destas mulheres vitimadas. Do mesmo modo, fazer uma abordagem do papel do enfermeiro diante de casos de violência doméstica, possibilitando o acréscimo de informações e fornecimento de subsídios para novas pesquisas e questionamentos nesta área, contribuindo para que tal violência não continue sendo negligenciada e perpetuada no silêncio dos lares.

\section{VIOLÊNCIA: BREVES CONSIDERAÇÕES}

$\mathrm{Na}$ sociedade atual, a violência apresenta-se como um fenômeno que atinge homens, mulheres, crianças, adolescentes e idosos. Segundo a Coleção Protocolos Hospital Municipal e Maternidade Escola (HMEC/SMSSP, 2012, p. 3), a violência sexual é um fenômeno universal que atinge, indistintamente, mulheres de todas as classes sociais, etnias, religiões e culturas.

Uma maior divulgação do assunto pela mídia tornou claro o que antes se apresentava de forma muitas vezes velada, embora ainda se mostre como um tabu, principalmente, pelo fato da maioria das vítimas serem mulheres.

A violência pode acontecer na intimidade de pessoas com laços afetivos, podendo ser cometida pelos maridos, companheiros, namorados, filhos ou alguém próximo à vítima.

Segundo Ferraz et al (2009, p.756) a violência é definida pela Organização Mundial da Saúde (OMS) como:

O uso da força física, do poder real ou ameaça, praticado contra si ou contra outra pessoa, ou ainda, contra um grupo ou uma 
comunidade, que resulte ou tenha possibilidade de resultar em lesão, morte, dano psicológico, deficiência de desenvolvimento ou privação. É compreendida também como uma violação dos direitos do ser humano, uma vez que é um meio aplicado para coagir ou submeter outra pessoa ao domínio sem seu consentimento.

Entendendo que a violência e a agressividade impõem medo, frustrações e agravos, inclusive socialmente, percebe-se que dentre os indivíduos vitimizados, as mulheres ainda são as maiores vítimas, sendo relatado por Araújo (2013, s.p.) que, a violência contra a mulher continua sendo um grave problema social no Brasil e no mundo, apesar da luta feminista em torno da questão.

Desde 1990, a Organização Mundial de Saúde já reconhece a violência contra a mulher como um problema de saúde pública que exige dos governantes políticas públicas mais eficientes no combate e prevenção do fenômeno. Além de causar sofrimento físico e psíquico à mulher - e conseqüentemente a seus filhos e família - esse tipo de violência é também uma violação dos direitos humanos.

A violência, pelo número de vítimas e importância de sequelas orgânicas e emocionais que produz, também adquiriu caráter endêmico [...] e, ainda para a Organização Pan-Americana de Saúde (OPAS), o setor saúde pode ser visto como o ponto de confluência de todos os problemas da violência, pela pressão que exercem sobre os serviços de urgência, de atenção especializada, reabilitação física, psicológica e de assistência social (OPAS, 1993 apud Mochnacz, 2009, p.37).

Diante do exposto, podemos dizer que esta agressão, em sua maioria, acontece na intimidade das relações, ou seja, nos lares, onde se espera ser um local de aconchego, segurança e também de qualidade de vida.

Sobre o termo violência doméstica Grossi (1998) apud Araújo (2013, s.p.), esclarece que, no Brasil, o termo começou a ser usado no final dos anos 70 e difundiu-se rapidamente em função das mobilizações feministas contra o assassinato de mulheres e impunidade dos agressores, freqüentemente os próprios maridos, comumente absolvidos em nome da "defesa da honra".

No cotidiano das cidades, do país e do mundo, o drama da violência é percebido pela sociedade como algo que faz parte da vida, tornando-se banal. Mesmo sendo um fenômeno antigo, ficou velado ao longo da história, sendo que no Brasil apenas na década de 1980, iniciaram-se as pesquisas sobre a ocorrência das agressões (FERRAZ et al, 2009, p. 756).

Azevedo (1985) apud Araújo (2013, s.p.) ainda completa que, no início dos anos 80 tais mobilizações se estenderam para a denúncia de maus tratos conjugais, formas também muito comuns de violência contra a mulher. Com isso, o termo passou a ser usado como sinônimo de violência doméstica em função da maior incidência deste tipo de violência ocorrer no espaço doméstico e/ou familiar.

"Apesar de toda a complexidade e diversidade de estruturas e funções estabelecidas e desempenhadas em cada grupo familiar, podemos identificar a existência ou não de uma família saudável" (SALCEDO-BARRIENTOS et al, 2011, p. 357), cabendo aí, intervenções por parte da equipe de saúde.

Diante do exposto é necessário compreender a violência doméstica, suas características e nuances.

\section{ENTENDENDO A VIOLÊNCIA DOMÉSTICA}

Mesmo sendo um fenômeno antigo em nossas sociedades, a violência não era percebida como algo lesivo ou deletério à saúde, mas como uma "punição merecida", caso ocorresse um deslize por parte do indivíduo subjugado, sendo que pela própria compleição física e submissão tradicional nas sociedades patriarcais, a mulher sempre foi a maior vítima dessa violência, sofrendo maus tratos que se estendiam, inclusive aos filhos, tal forma abusiva de poder praticado no seio das famílias, sendo realizado sempre pelo "senhor", ou seja, o cônjuge, considerado como poder máximo dentro das famílias.

De acordo com Mochnacz (2009, p. 10), muitos estudos tem se dedicado a apontar a magnitude da violência doméstica e suas consequências mensuráveis, como altos custos hospitalares e prejuízos econômicos aos países, e as não mensuráveis, como a dor e o sofrimento humanos.

Araújo (2013, s.p.) reitera que a violência de gênero produz-se e reproduz-se nas relações de poder onde se entrelaçam as categorias de gênero, classe e raça/etnia. Expressa uma 
forma particular de violência global mediatizada pela ordem patriarcal, que delega aos homens o direito de dominar e controlar suas mulheres, podendo para isso usar a violência.

Após longo período de sofrimento na intimidade dos lares, a violência contra a mulher começou a ganhar notoriedade e compreensão, principalmente após os movimentos feministas, que despertaram a sociedade para tal acontecimento na intimidade das famílias.

Debert e Gregori (2008, p.168), nos dizem que a definição de violência contra a mulher no Brasil foi elaborada em meio a uma experiência política inovadora na década de 1980, em que, ao lado de práticas de sensibilização e de conscientização, militantes feministas atendiam mulheres que sofriam violências nos chamados SOS-Mulher. O conjunto de ideias que deu suporte e substância a essa expressão foi elaborado a partir de uma compreensão particular acerca da opressão sofrida pelas mulheres no âmbito do patriarcalismo - noção sintonizada com as discussões feministas em cenário internacional.

Após o desenvolvimento de estudos de gênero, vários autores passaram a utilizar a partir de 1990, violência de gênero como um conceito ampliado de violência contra a mulher (SAFFIOTI e ALMEIDA, 1995 apud ARAÚJO, 2013, s.p.).

O conceito de gênero abrange não apenas as mulheres, mas crianças e adolescentes, que no Brasil são objetos da violência masculina, constituindo assim as relações de gênero (ARAÚJO, 2013, s.p.). Tal conceito também pode ser utilizado para definir a violência conjugal, pois engloba várias formas de violência que envolvem as relações de gênero e poder. Entretanto, podemos dizer que a violência contra a mulher é uma das principais formas de violência de gênero.

Devido ao impacto que causa na saúde física e emocional das vítimas, a violência vem interferindo significativamente na vida de indivíduos vitimizados, fazendo com que governantes voltem sua atenção para essa situação, com vistas à diminuição dos índices de co-morbidades, bem como de mortalidade, principalmente em mulheres.

Fato este corroborado por Ferraz et al (2009, p.756) ao expor que estima-se, mundialmente, que pelo menos uma em cada três mulheres já foi espancada, coagida ao sexo ou sofreu alguma forma de abuso durante sua vida". No Brasil, a violência contra a mulher é tipificada como um crime, tendo por objetivo punir os agressores, mas, principalmente proteger as vítimas, assim como diminuir a incidência destes agravos.

"Objetivando garantir os direitos da mulher na sociedade, foi sancionada, pelo Presidente da República, a Lei no 11.340, de 7 de agosto de 2006, conhecida como Lei Maria da Penha, que entrou em vigor em 22 de setembro do mesmo ano" (FERRAZ et al, 2009, p. 756).

A Lei 11.340 define que ações de saúde devem ser planejadas e implementadas com o objetivo de assistir e cuidar das vítimas, buscando também levar informações às mesmas com 0 intuito de diminuir a ocorrência de agressões e implicações na saúde física e emocional das vítimas.

Salcedo-Barrientos et al (2011, p. 354), ainda colaboram que, no contexto familiar, apresenta-se como negligência, abuso sexual ou violência física contra crianças e adolescentes, contra mulheres, idosos e pessoas com necessidades físicas e mentais, constituindo um importante impacto no bemestar físico e emocional dessa população.

Todos os tipos de agressão imposta aos indivíduos, principalmente aquela ocorrida nos lares e denominada violência doméstica, sem dúvida, causam danos à saúde dos envolvidos direta ou indiretamente. Tais prejuízos podem ser de ordem física ou emocional, entre outras, sendo essas as principais, exigindo dos profissionais de saúde um complexo entendimento acerca da temática, além de sensibilidade ao prestar assistência, oferecendo acolhimento, respeito, segurança, além de um olhar humanizado e holístico.

\section{IMPLICAÇÕES FÍSICAS E EMOCIONAIS NA SAÚDE DE MULHERES VIITIMAS DE VIOLÊNCIA DOMÉSTICA}

Para entender o que se passa física e emocionalmente com as pessoas que sofrem agressões, é necessário um olhar voltado ao indivíduo, ao ser humano, aquele ser pensante e com sentimentos que foram atingidos por meio de uma agressão física ou psicológica.

As consequências biopsicossociais são difíceis de mensurar, embora afetem a maioria 
das vítimas e suas famílias. A violência sexual produz efeitos intensos e devastadores, muitas vezes irreparáveis, na esfera emocional. Para a saúde, os danos do abuso sexual têm particular impacto sobre a saúde sexual e reprodutiva, como a gravidez indesejada, infecção por DST's/ AIDS, somadas a severas consequências físicas e emocionais. (PROTOCOLOS HMEC/SMS-SP, 2012).

É notória a ocorrência de alta incidência de violência contra a mulher, em todo o mundo, não sendo levadas em conta classes sociais, culturas ou raças. A Organização PanAmericana da Saúde (OPAS), nos fala de números alarmantes, sendo que uma em cada três mulheres é vítima de violência em países do continente americano (ARAÚJO, 2013, s.p.).

O mesmo autor (2013, s.p.) complementa que, contabilizar e aferir os números da violência não é tarefa fácil, principalmente em relação à forma de registro de tais números e, às vezes achamos que um determinado local tem alto índice de violência, quando na verdade, o registro é que se apresenta de forma mais contínua e regular.

Já no Brasil, apesar de inúmeras pesquisas realizadas, os números obtidos não são suficientes para delinear um perfil real e global deste acontecimento. "A violência física é a mais freqüente ou pelo menos a mais denunciada (58\% no total, sendo 32\% com lesão corporal). A violência psicológica aparece com $36 \%$ e a sexual com $6 \%$ entre os boletins de ocorrência (BO's) pesquisados" (ARAÚJO, 2013, s.p.).

Oliveira (2009) apud Reis, Carolina da Rosa (2013, p.3) refere que "as mulheres vítimas de violência têm queixas, distúrbios e patologias, físicas e mentais, e utilizam os serviços de saúde com maior frequência do que aquelas sem esta experiência".

Os motivos da agressão são os mais variados. De acordo com Araújo (2013, s.p.), 69\% dos casos resultam de discussões motivadas por ciúme, ameaça de separação, problemas de dinheiro, questões relacionadas aos filhos, etc. Alcoolismo, distúrbio mental e desemprego também aparecem como motivos, mas em menor incidência. O fator realmente preponderante é a relação de poder que o homem tem sobre a mulher e que Ihe dá o "direito" de agredi-la por qualquer motivo.
Vier (2011, s.p.) esclarece que, dentre as modalidades de violência mais frequentes, $16 \%$ de mulheres já levaram tapas, empurrões ou foram sacudidas, $16 \%$ foram xingadas e ofendidas devido a sua conduta sexual e 15\% foram controladas a respeito do local aonde iam e com quem saíam. Além disso, 13\% sofreram ameaças de surra e $10 \%$, de fato, foi espancada ao menos uma vez na vida.

A mesma autora ainda completa que 29 a $43 \%$ das mulheres que sofreram violência psíquica, dão continuidade ao vínculo marital; sendo que a manutenção do vínculo com o agressor também permanece em 20\% dos casos de espancamento e mais de $30 \%$ diante de diferentes formas de controle e cerceamento.

Fica claro que a violência deixa de ser percebida como forma de abuso e passa a ser encarada com naturalidade por todos os membros da família. Cardoso (1997 apud MENEZES, 2000) citado por Fonseca e Lucas (2006, p.6) relata que o fato de um indivíduo estar inserido em um ambiente familiar no qual, constantemente, os pais são agressivos entre si, ou mesmo com os filhos, favorece a uma concepção naturalizada da violência. Desta forma, o apanhar passa a não simbolizar desamor, mas sim uma forma de se estruturar como pessoa, em que o subjugarse ao outro é um modelo de relação aprendido na infância, tornando as pessoas inseguras, com baixa autoestima, com ausência de senso crítico e dificuldades de estabelecer relações positivas. Essas consequências repercutem na reação da mulher frente à violência, assim como na escolha de seu futuro marido.

Conforme percebido, torna-se um ciclo natural e vicioso entre as famílias, estendendo-se inclusive às futuras gerações.

\section{VIOLÊNCIA CONTRA A MULHER: CARACTERÍSTICAS E FORMAS}

A violência contra a mulher pode ser entendida como uma relação de forças que convertem as diferenças entre os sexos em desigualdade.

Com o objetivo de manter e exercer controle sobre a mulher, o agressor imprime comportamentos sistemáticos, seguindo um padrão específico. Iniciando-se com as tensões normais dos relacionamentos, tais como o desemprego, preocupações financeiras, hábitos irritantes e diferentes 
opiniões que fazem surgir as agressões psicológicas (MILLER, 1999 apud FONSECA E LUCAS, 2006, p.7).

As interações violentas em um relacionamento surgem a partir do momento em que a relação de poder e subordinação precisam ser confirmadas (FONSECA e LUCAS, 2007, p. 7). Observa-se que as diferentes formas de violência sofridas por mulheres, manifestamse de diferentes maneiras e com graus variados de intensidade. É evidente que tais atos de violência não acontecem isoladamente, mas em um movimento crescente no número de episódios de ocorrência, sendo o ato mais extremado, o homicídio.

Dentre os inúmeros casos referentes à violência contra a mulher, podem-se destacar:

Violência de gênero, que consiste em uma manifestação de relações de poder historicamente desiguais entre homens e mulheres, em que a subordinação não implica na ausência absoluta de poder.

Violência intrafamiliar, que pode ser cometida dentro ou fora de casa por algum membro da família, incluindo pessoas que passam a assumir função parental, ainda que sem laços de consangüinidade, e em relação ao poder à outra, prejudicando o bem-estar, a integridade física, psicológica ou a liberdade e o direito ao pleno desenvolvimento de outro membro da família.

Violência doméstica, que se distingue da intrafamiliar pelo fato de incluir outros membros do grupo que, mesmo sem função parental, convivem no espaço doméstico, tais como empregados e agregados, podendo acontecer dentro da casa e sendo geralmente praticada por um membro da família que conviva com a vítima. Tais agressões domésticas incluem o abuso sexual, físico e psicológico, além da negligência e do abandono (UFRJ, 2014, s.p.).

O mesmo autor ainda evidencia que a ocorrência de violência física, muitas vezes recorrente, pode ser advinda de uma relação de poder entre indivíduos, causando de forma não acidental tentativas de agredir o outro, por intermédio de armas ou força física, podendo ou não causar lesões internas ou externas. Podemos destacar também que o castigo repetido, porém não severo, pode ser considerado como agressão física, podendo manifestar-se de várias formas, a saber:
Tapas, Empurrões, Socos, Mordidas, Chutes, Queimaduras, Cortes, Estrangulamento, Lesões por armas e objetos, Obrigar a tomar remédios desnecessários ou inadequados, álcool, drogas ou outras substâncias, inclusive alimentos, Tirar de casa à força, Amarrar, Arrastar, Arrancar a roupa, Abandonar em lugares desconhecidos, Danos à integridade corporal decorrentes de negligência (omissão de cuidados e proteção contra agravos evitáveis como situações de perigo, gravidez, doenças, alimentação, higiene, entre outros) (UFRJ, 2014).

A violência sexual compreende uma variedade de atos ou tentativas de relação sexual sob coação ou fisicamente focada, no casamento ou em outros relacionamentos. [...] é cometida na maioria das vezes por autores conhecidos das mulheres envolvendo vínculo conjugal (esposo e companheiro) no espaço doméstico, contribuindo para sua invisibilidade. De acordo com UFRJ (2014, s.p.), dentre os atos sexualmente violentos podemos citar:

- Estupro dentro do casamento ou namoro,

- Estupro cometido por estranhos,

- Investidas sexuais indesejadas ou assédio sexual, inclusive exigência de sexo como pagamento de favores,

- Abuso sexual de pessoas mental ou fisicamente incapazes,

- Abuso sexual de crianças,

- Casamento ou coabitação forçados, inclusive casamento de crianças,

- Negação do direito de usar anticoncepcionais ou de adotar outras medidas de proteção contra doenças sexualmente transmissíveis,

- $\quad$ Aborto forçado,

- Atos violentos contra integridade sexual das mulheres, inclusive mutilação genital feminina e exames obrigatórios de virgindade,

- Prostituição forçada e tráfico de pessoas com fins de exploração sexual,

- Estupro sistemático durante conflito armado.

De acordo com o Portal CNJ (2014, s.p.), a violência psicológica, pode ser entendida como qualquer conduta que the cause dano 
emocional e diminuição da autoestima, ou que Ihe prejudique e perturbe 0 pleno desenvolvimento, ou que vise degradar ou controlar suas ações, comportamentos, crenças e decisões, mediante ameaça, constrangimento, humilhação, manipulação, isolamento, vigilância constante, perseguição contumaz, insulto, chantagem, ridicularização, exploração e limitação do direito de ir e vir ou qualquer outro meio que the cause prejuízo à saúde psicológica e à autodeterminação.

A violência patrimonial é entendida como qualquer conduta que configure retenção, subtração, destruição parcial ou total de seus objetos, instrumentos de trabalho, documentos pessoais, bens, valores e direitos ou recursos econômicos, incluindo os destinados a satisfazer suas necessidades. E a violência moral, entendida como qualquer conduta que configure calúnia, difamação ou injúria (PORTAL CNJ, 2014, s.p.).

Atualmente, é possível observar três setores envolvidos no enfrentamento da violência doméstica contra a mulher: a Saúde, a Justiça e a Sociedade Civil organizada. Em cada um dos setores, os profissionais exercem suas funções em serviços específicos ou estabelecem fluxos de encaminhamentos entre os serviços para a busca de soluções para o problema (MOCHNACZ, 2009, p.11).

Diante de todas as características e formas de violência acima relacionadas, percebemos que as equipes de saúde ainda não estão preparadas para atender situações evidenciadas por tais atos e que dão entrada diariamente nos serviços de saúde. Fica claro, que as equipes de saúde precisam melhor capacitar-se, além de oferecer aos vitimizados uma assistência pautada pela qualidade, bem como ter uma visão holística sobre o acontecimento sem, no entanto, deixar de voltar seu "olhar" para as vítimas e o contexto dos fatos.

O enfermeiro, especialmente por ser o profissional que encontra-se mais tempo com os pacientes, bem como a equipe de enfermagem, devem estar preparados para prestar assistência no momento em que ela se fizer necessária.

\section{PAPEL DO ENFERMEIRO DIANTE DE VITIMIZADOS POR VIOLÊNCIA DOMÉSTICA}

É importante ressaltar, que a violência acarreta danos às famílias, assim como causa impacto na saúde física e emocional dos mesmos gerando, por conseguinte, um impacto também nos serviços de saúde do país.

Ressalta-se a importância dos serviços de saúde como elementos fundamentais à composição da rede de atendimento às mulheres vítimas de violência doméstica. Deste modo, as Unidades de Saúde da Atenção Básica devem representar o contato preferencial dos usuários, "a principal porta de entrada e centro de comunicação da Rede de Atenção à Saúde" (BRASIL, 2012, s.p.).

A assistência a esta forma de violência se reveste de especial importância por transcender a área da saúde em vistas das repercussões psicológica e sociais que acarreta.

Salcedo-Barrientos et al (2011, p. 354) apontam que no âmbito da saúde, deve ser considerado o impacto que a violência causa na sociedade e nos seus serviços, tanto em termos de custo das ações de prevenção, tratamento ou promoção de uma política de paz entre os sujeitos.

Desta forma, a atuação de profissionais da Atenção Básica, configura-se como um importante objeto da Saúde Coletiva, com vistas ao enfrentamento e superação deste problema e, por ser esta, a principal porta de entrada aos serviços de saúde do país. Diante de tal perspectiva, ações efetuadas pelos setores de saúde devem estar integradas a outros setores da sociedade, sendo necessário o desenvolvimento de tais parcerias a fim de promover o bem-estar, a saúde e a manutenção da qualidade de vida da população (SALCEDO - BARRIENTOS et al, 2011, p. 354).

Telles e Melo (2003) apud Ferraz et al (2009, p.756) nos dizem que: "O drama da violência faz parte do cotidiano das cidades, do país e do mundo, é banalizado e percebido pela sociedade como algo que naturalmente faz parte da vida".

Diante de tal afirmação, mister se faz que o enfermeiro perceba sua importância diante de situações de violência, estando o mesmo capacitado para atuar de forma acertiva, não permitindo que a banalização de tais atos, seja fato comum em seu cotidiano profissional, fazendo com que o mesmo mova-se em direção ao auxílio adequado a quem necessite.

Reis $(2013$, p.12) relata em seu trabalho que as usuárias dos serviços de saúde, vítimas da 
violência, somente relatavam sua situação após sucessivas aproximações com o profissional de saúde quando, então, se dava o início de um acompanhamento sistematizado para o caso, de forma interdisciplinar e com perspectiva ampliada.

O enfermeiro tem um importante papel no acolhimento das vítimas, pois são os primeiros profissionais a atender e manter contato direto com as mulheres, promovendo o início das atuações multiprofissionais na abordagem de tal ocorrência.

Ainda conforme o autor supracitado (2013, p. $12)$, as mulheres quando escutadas, no cotidiano de trabalho das unidades de saúde, sentiam-se acolhidas e expressavam o que realmente Ihes angustiavam.

Quanto à assistência e aos cuidados de enfermagem Ferraz et al (2009, p. 756) asseveram que: "O cuidado de enfermagem às vítimas de violência deve ser planejado para promover segurança, acolhimento, respeito e satisfação das suas necessidades individuais". Para a proteção das vítimas e prevenção de futuros agravos, o enfermeiro deverá refletir sobre o planejamento da assistência, baseado em instrumentos básicos de enfermagem, nas políticas púbicas de saúde, além da legislação vigente.

De acordo com Schraiber et al (2002) apud Ferraz et al (2009, p. 757), estima-se que o problema da violência cause mais mortes de mulheres do que o câncer, a malária, os acidentes de trânsito e as guerras. Por ser tratado como um problema de saúde pública, cada vez mais é abordado pelos profissionais da área de saúde que podem se sentir pouco preparados para oferecer atenção que cause impacto efetivo na saúde das vítimas.

Percebe-se que a formação acadêmica pode estar relacionada com as dificuldades dos profissionais enfermeiros em cuidar das vítimas, pois durante a formação, raramente temáticas sobre a violência são incluídas, bem como ainda é pequena a produção de conhecimento técnico e específico sobre o assunto (FAÚNDES et al, 2006 apud FERRAZ et al, 2009, p. 757).

Dias (2007) apud Ferraz et al (2009, p. 759) aponta que, atualmente, o cuidado das mulheres que sofreram violência sexual em sua maioria, ainda está sob a responsabilidade da polícia ou dos serviços de emergência, os quais também podem possuir limitações para responder às reais necessidades das vítimas. O despreparo profissional para cuidar destas mulheres se reflete em pré-conceitos como o de culpar a vítima, desestimulando-a a denunciar o agressor. Muitas vezes a perseguição ao agressor está em primeiro plano e a atenção às necessidades da vítima fica limitada ao tratamento de eventuais traumas sofridos.

Para que durante o processo de trabalho dos enfermeiros, os mesmos sejam capazes de identificar e intervir em casos de violência, e pelo fato dos mesmos manifestarem-se em variados graus e não apenas em casos extremos, como os homicídios, é importante que o profissional esteja instrumentalizado para que possa ter a compreensão de suas múltiplas manifestações (SALCEDOBARRIENTOS et al, 2011, p. 358).

Os princípios gerais para a atenção à violência, segundo Coleção Protocolos HMEC/SMS-SP (2012, p.5) são:

- Adequado acolhimento, trato digno, não discriminatório,

- Facilitar expressão de sentimentos,

- Garantir a confiabilidade,

- Dar crença à vítima,

- Comunicação empática.

Andrade (2009) apud Salcedo-Barrientos et al (2011, p. 358) afirma que: "A efetiva relação entre os profissionais da saúde e as mulheres vítimas de violência só acontecerá no momento em que houver uma mudança organizativa no sistema e no atendimento".

Salcedo-Barrientos et al (2011, p. 358) asseguraram que: "Quando as relações forem estreitadas de modo a proporcionar uma relação mais simétrica e de diálogo entre os usuários e os profissionais [...]", com práticas voltadas a integração de vários setores da sociedade, aí então o problema poderá ser minimizado.

Entretanto, percebe-se que existe uma necessidade de se discutir com os enfermeiros, em seu ambiente de trabalho e em suas práticas cotidianas, sobre o receio que os mesmos apresentam em lidar com o tema da violência, o que pode ser justificado pela falta de estrutura e organização dos setores de saúde, no que tange aos serviços preventivos e curativos, levando o profissional a afastar-se ou apresentar um sentimento de negação, o que fica evidenciado pela baixa 
qualidade dos atendimentos nos serviços de saúde (OLIVEIRA, 2005 apud SALCEDOBARRIENTOS et al, 2011, p. 358).

É inegável que os enfermeiros caracterizam suas ações com uma impotência paralisante, evidenciada pela falta de preparo para a atuação nos processos de trabalho, baseados nos valores existentes na sociedade atual.

De acordo com Protocolos HMEC/SMS-SP (2012, p. 21), a equipe multidisciplinar, composta por médicos, enfermeiros, psicólogas e assistentes sociais, desde que devidamente preparada, pode promover a recuperação e resgate da autoconfiança e autoestima. É possível que seja dado um enfoque prioritário na saúde pública, sem, contudo, deixar de considerar que a violência doméstica e/ou sexual seja uma violação dos direitos humanos e da cidadania.

A família faz parte de uma rede social e precisa ser entendida neste contexto, diante disso, a equipe de saúde deve agir de forma multidisciplinar, utilizando-se de todos os recursos disponíveis, bem como dos saberes dos profissionais, promovendo parcerias com outros setores, como o Conselho Tutelar, para os casos de quaisquer que sejam os tipos violência sofrida pelos indivíduos.

O trabalho do enfermeiro deve abranger a família e o indivíduo e seu contexto familiar, com encaminhamento aos profissionais da equipe multidisciplinar, caso haja necessidade. Quanto à violência doméstica, o trabalho intersetorial também se faz importante, visto que parcerias com os Conselhos Tutelares mostraram-se importantes para o auxílio dos indivíduos e dos profissionais durante a conduta dos casos (SALCEDO-BARRIENTOS et al, 2011, p. 360).

Fica claro que cabe a cada setor distinguir e assumir as responsabilidades e funções, baseados nas interfaces e nos compartilhamentos, para que o sistema possa funcionar. Qualquer ação dos profissionais visa apoiar os indivíduos e as famílias vitimizadas pela violência, com vistas à transformação desta realidade.

O Ministério da Saúde, através das Políticas de Saúde faz orientações para a prática profissional e refere que a violência doméstica pode ser repetitiva e deve ser detectada precocemente com prevenção de agravos futuros. As vítimas devem ser orientadas sobre a violência, seu curso e os recursos existentes na comunidade, como grupos de autoajuda, cuidado de enfermagem, atendimento médico, psicológico, do serviço social e de outros membros da equipe multiprofissional, com vistas a prevenir novos episódios (BRASIL, 2001 citado por FERRAZ et al, 2009, p. 757).

Ainda de acordo com os autores supra citados (2001 apud 2009, p.758), existem alguns passos que podem integrar as ações de cuidado de enfermagem e dos demais profissionais de saúde, os quais devem:

[...] envolver o acolhimento e a possibilidade de apoio por parte da equipe; auxiliar a vítima a estabelecer vínculo de confiança individual e institucional para poder avaliar o histórico da violência e as possibilidades de mobilizar recursos sociais e familiares; dialogar com a mulher sobre as opções de lidar com o problema, permitindo the fazer escolhas e fortalecer sua autoestima; apoiar a vítima que deseja fazer registro policial do fato; fazer encaminhamentos à outros órgãos competentes quando necessário, Delegacias da Mulher, Instituto Médico- Legal; incentivar a construção de vínculo com as redes de assistência, acompanhamento, proteção e redes de apoio; encaminhar para atendimento clínico os casos de lesões graves, com necessidade de reabilitação, que não puderem ser atendidos na unidade; sugerir à vítima atendimento para o casal ou família no caso de continuidade da relação; propor acompanhamento psicológico; fazer visitas domiciliares constantes para cuidar e acompanhar o caso.

Tais passos citados, acima, são fortalecidos pela Lei 11.340, onde fica estabelecido que Estados e Municípios têm o dever de assegurar os direitos à saúde da mulher, planejando e implementando as redes que servem de apoio, bem como de programas de saúde que tenham por objetivo proteger e cuidar das vítimas, reduzindo os índices de criminalidade (BRASIL, 2007 apud FERRAZ et al, 2009, p. 758).

$\mathrm{O}$ cuidado às vitimas deve ser planejado com vistas ao respeito aos valores e às crenças dos indivíduos em relação à vida, morte, saúde, doença e cura, exigindo do enfermeiro a utilização de instrumentos importantes para a realização do exercício profissional, significando meios para que os objetivos propostos sejam atingidos.

Para Ferraz et al (2009, p. 758) esses instrumentos envolvem a observação, o 
cuidado emocional, o toque terapêutico, o corpo, o bom senso, a liderança, o caráter humanitário, a solidariedade, a sensibilidade, a técnica, a relação educativa e as dimensões psicossocial e psicoespiritual.

Assistir vítimas de violência implica em cuidar do ser humano em sua totalidade, elaborando e aplicando "[...] medidas de promoção e prevenção que podem ser potencializadas pela educação permanente, com esclarecimentos sobre os direitos e prerrogativas das vítimas" (FERRAZ et al, 2009, p. 758).

É importante que a vítima sinta-se assistida, estabelecendo-se uma relação de cuidado, fazendo com que a vítima consiga se expor e, mesmo diante de tal situação, sinta-se amparada.

Deslandes (1999) apud Mochnacz (2009, p.63) aponta para necessidade de investimentos nas questões de violência, como: capacitação e sensibilização dos profissionais, criação de rotinas institucionais de acordo com as responsabilidades dos membros da equipe, articulação de listas de referências de instituições e serviços para futuros encaminhamentos e melhoria dos registros de atenção à saúde para o subsídio de planejamento de ações futuras.

Ferraz et al (2009, p. 758) reafirmam que, utilizar instrumentos do processo de cuidar em enfermagem é a base para o encontro de possibilidades para o enfrentamento do problema de forma positiva, com a criação de um elo entre cuidador e o assistido, sendo necessário que a disponibilidade, a intenção, a receptividade, a confiança e a aceitação entre as partes fiquem claras. Ressaltando-se que o saber técnico-científico, além das habilidades e competências profissionais, favorece a percepção do ser humano nos aspectos biológico, psicológico, social e espiritual.

\section{CONSIDERAÇÕES FINAIS}

Após análise e estudo do assunto em questão, podemos observar a alta prevalência da violência contra a mulher e da invisibilidade do problema na saúde pública.

A violência sexual pode vitimizar, de forma silenciosa as mulheres, trazendo graves consequências físicas e psicológicas à sua saúde. Frequentemente, este tipo de violência está associado a outros tipos de violência, como sexual urbana, doméstica, intrafamiliar, de gênero, dentre outros.

A violência psicológica pode ser considerada a mais frequente e causar profundo sofrimento, se revelando por xingamentos e humilhações, corroborando para a caracterização do impacto da violência doméstica no panorama de saúde brasileiro.

Os profissionais de saúde têm importância fundamental na assistência, apoio e orientações, não apenas à mulher vitimizada, como também aos familiares envolvidos em todo o processo. Percebeu-se que o enfermeiro tem papel de grande relevância quando se trata de vítimas de violência, especialmente aqueles enfermeiros que atuam em programas dentro das comunidades, bem como nos serviços públicos, que são considerados portas de entrada para as vítimas.

Diante de tais afirmações, observa-se que o profissional enfermeiro deve estar capacitado para deparar-se com tais situações, por muitas vezes chocantes e deletérias ao ser humano e que, por vezes, o enfermeiro também depara-se com a impossibilidade de auxílio e a falta de recursos para prestar a assistência, cabendo portanto ressaltar que, mesmo diante de tantos obstáculos e desafios, o enfermeiro deve colocar-se em posição de apoio aos vitimizados.

Este artigo buscou trazer informações sobre a realidade da violência doméstica no Brasil, especificamente contra a mulher, mostrando que vários atores e setores, privados e/ou públicos, estão envolvidos no entendimento e resolutividade do problema, sendo que as ações de enfermagem podem possibilitar a aproximação das vítimas aos instrumentos de atendimento e superação dos problemas físicos e psicológicos gerados por esta violência.

E por fim, pode-se dizer que a violência é algo que permeia nossa sociedade, e cabe ao enfermeiro não somente inferir em tais situações, como também servir como agente de mudanças, através de ações tanto educativas, quanto assistenciais, buscando a mudança de paradigma no que tange à violência doméstica e suas vítimas. 


\section{REFERÊNCIAS}

[1]. ARAÚJO, M. F. Gênero e violência contra a mulher: perigoso jogo de poder e dominação. Universidade Estadual Paulista (UNESP). Assis São Paulo - (Brasil). Revista Eletrônica Internacional de La Union Latinoamericana de Entidades de Psicologia, 2013.

[2]. BRASIL. Ministério da Saúde. Secretaria de Políticas de Saúde. Violência intrafamiliar: orientações para prática em serviço / Secretaria de Políticas de Saúde. -Brasília: Ministério da Saúde, 2001.

[3]. Ministério da Saúde. Epidemiologia e serviços de saúde. Revista do Sistema Único de Saúde. Janeiro/ março 2007, v. 16, n. 1.

[4]. Ministério da Saúde. Secretaria de Atenção à Saúde. Departamento de Ações Programáticas Estratégicas. Aspectos jurídicos do atendimento às vítimas de violência sexual: perguntas e respostas para profissionais de saúde. 2 ed. Brasília: Editora do Ministério da Saúde, $2011 \mathrm{a}$.

[5]. Ministério da Saúde. Secretaria de Atenção à Saúde. Departamento de Ações Programáticas Estratégicas. Prevenção e tratamento dos agravos resultantes da violência sexual contra mulheres e adolescentes: norma técnica. 3 ed. Brasília: Ministério da Saúde, 2011b.

[6]. Ministério da Saúde. Secretaria de Atenção à Saúde. Departamento de Atenção Básica. Política Nacional de Atenção Básica / Ministério da Saúde. Secretaria de Atenção à Saúde. Departamento de Atenção Básica. Brasília : Ministério da Saúde, 2012.

[7]. DIAS, M. B. A Lei Maria da Penha na justiça: a efetividade da Lei 11.340/2006 de combate à violência doméstica e familiar contra a mulher. São Paulo: Revista dos Tribunais, 2007.

[8]. FAÚNDES, A.; ROSAS, C. F.; BEDONE, A. J.; OROZCO, L.T. Violência sexual: procedimentos indicados e seus resultados no atendimento de urgência de mulheres vítimas de estupro. Rev Bras Ginecol Obstet. 2006, 28(2):126-35.

[9]. FONSECA, P. M. da; LUCAS. T.N.S. Violência doméstica contra a mulher e suas conseqüências psicológicas. TCC Escola Bahiana de Medicina e Saúde Pública. Salvador, 2006.

[10]. DEBERT, G. G.; GREGORI, M. F. Novas propostas, velhos dilemas. Revista Brasileira de Ciências Sociais, São Paulo, v. 23, n. 66, p. 165185, jan. 2008.

[11]. MOCHNACZ, S. Caracterização do atendimento a mulheres vítimas de violência doméstica pela rede intersetorial de serviços. [tese]. São Paulo: Centro Universitário İtalo Brasileiro, 2009.

[12]. OLIVEIRA, C.C. Práticas dos profissionais de saúde da família voltadas para mulheres em situação de violência sexual: uma abordagem de gênero [tese]. São Paulo: Universidade de São Paulo, Escola de Enfermagem, 2005.

[13]. PORTAL CNJ. Formas de violência contra a mulher. Disponível em:

[14]. < http://www.cnj.jus.br/programas-de-a-az/pj-lei-maria-da-penha/formas-de-violencia>

Acesso em: 31 de mar. 2014

[15]. REIS, C.R. Violência doméstica contra mulher - Reflexões a partir da análise de documentos de uma unidade básica de saúde da Zona Norte de Porto Alegre/RS. Programa de Residência Integrada em Saúde do Grupo Hospitalar Conceição/Ministério da Saúde, Porto Alegre, 2013.

[16]. SALCEDO-BARRIENTOS, D.M. et al. Violência doméstica e enfermagem: da percepção do fenômeno à realidade cotidiana. Open Journal Systems. Disponível em: <http://www.revistas.unal.edu.co/index.php/avenfer m/article/view/35830/37098>. Acesso em: 20 de maio 2014

[17]. SECRETARIA MUNICIPAL DE SAÚDE/PREFEITURA DE SÃO PAULO. Normas e rotinas para o atendimento das vítimas de violência sexual. Coleção Protocolos - Hospital Municipal e Maternidade Escola Dr. Mário de Moraes Altenfelder Silva. São Paulo, 2012

[18]. SCHRAIBER, L.B; D'OLIVEIRA, A.F.P.L; FRANÇA-JUNIOR, I; PINHO, A.A. Violência contra a mulher: estudo em uma unidade de atenção primária à saúde. Rev Saúde Públ. 2002, Ago, 36(4):470-7

[19]. TELES, M.A.A; MELO, M. O que é violência contra a mulher. São Paulo: Brasiliense; 2003.

[20]. UNIVERSIDADE FEDERAL DO RIO DE JANEIRO. PREVENÇÃO À VIOLÊNCIA SEXUAL CONTRA A MULHER. Disponível em: <http://www.ess.ufri.br/prevencaoviolenciasexual/in dex.php/tipos-de-violencia-cometida-contra-amulher>. Acesso em: 31 de mar. 2014.

[21]. VIER , S. "Ideia de posse" é o principal motivo de agressão de homens contra mulheres, afirma pesquisador. Publicado em 28 de fev. 2011. Disponível em: < http://www.redebrasilatual.com.br>. Acesso em: 20 de jun. 2013. 


\section{Gapítulo 7}

\section{LOGISTICA REVERSA DE PNEUS INSERVIVEIS: UM SINAL DE CONSCIENCIA ESTRATEGIA ECONOMMICA?}

\section{Luís Carlos de Andrade Silva}

\section{Antônio Lisboa da Silva}

\section{Elvia Florencio Torres Ximenes}

\section{Liliane Araújo Pinto}

Tales Antão de Alencar Carvalho

\section{Cléverson Vasconcelos da Nóbrega}

Resumo: Mediante a ascensão dos conceitos da logística reversa que permeiam o setor de pneus, essa pesquisa intencionou identificar os reais objetivos de empresas revendedoras de pneus que adotam a prática da logística reversa: lucratividade ou consciência socioambiental. Essa pesquisa foi aplicada no contexto das maiores empresas do ramo de pneus em uma cidade brasileira de médio porte, utilizando a entrevista semiestruturada como coleta de dados, e mostrou que apenas cinco das principais revendas de pneus aplicam a logística reversa. Por fim, a lucratividade está sempre presente nos interesses dos empresários, já os fatores socioambientais nem sempre são contemplados.

Palavras-chave: Logística Reversa de Pneus. Consciência Socioambiental. Estratégia Econômica. 


\section{INTRODUÇÃO}

Nas últimas décadas, a logística reversa vem ganhando grande relevância. Leite (2009) expõe que os primeiros estudos sobre o tema foram registrados nas décadas de 1970 e 1980, tendo como foco principal o retorno de produtos a serem processados em reciclagem de materiais, denominados e analisados como canais de distribuição reversos.

O tema "Logística Reversa" passou a ser estudado de forma mais intensa tanto no ambiente acadêmico quanto no empresarial a partir da década de 1980, quando as abordagens passaram a apresentar além das questões ambientais ou ecológicas, as questões legais, econômicas, entre outras (TADEU ET AL, 2012).

Assim, o estudo da logística reversa e da sustentabilidade tem ganhado grande notoriedade. Diversos autores, em seus estudos, têm contribuído com o tema, acarretando discussões e debates sobre diferentes enfoques e modelos de cadeia de suprimentos sustentáveis (DHOUIB, 2014; GOVINDAN, ET AL 2012). A Logística Reversa tem sido, de forma frequente e crescente, citada em conferências e simpósios internacionais, em artigos, livros modernos e revistas especializadas em Logística Empresarial, demonstrando o crescente interesse de estudo e sua utilidade e aplicabilidade tanto para a economia empresarial e como para a preservação ambiental.

A logística reversa possui atributos que estimulam a produção de novos produtos com a utilização de resíduos que chegaram ao fim de sua vida útil, além do aprimoramento de produtos inservíveis. Esta temática está em ascensão devido às pressões vindas das massas ambientalistas, das legislações vigentes voltadas para o cuidado com 0 planeta e das exigências dos consumidores que estão mais preocupados com o meio ambiente e com a forma que as organizações atuam. Nesse cenário cabe questionar o real objetivo dos empresários em investirem em logística reversa: seria uma ação de consciência ambiental ou busca por interesses econômicos?

Para o desenvolvimento dessa problemática escolheu-se o segmento de pneus, tendo em vista que um pneu descartado de forma incorreta na natureza leva em torno de 600 anos para se decompor. (SCAGLIUSI, 2011).
Somam-se a isso a poluição causada, a moradia de animais, insetos como vetores de diversas doenças, além de outros impactos ambientais. (GOTO E SOUZA, 2008). Por outro lado, os pneus inservíveis quando bem administrados podem servir de matériasprimas para diversos processos produtivos.

Nesse contexto, a presente pesquisa apresenta sua devida importância, buscando expor os reais objetivos das empresas revendedoras de pneus de uma cidade de médio porte que trabalham com a logística reversa. Assim, este trabalho analisa as práticas por estas empresas, procurando identificar a intenção dos empresários do setor de revenda de pneumáticos, se esses estão preocupados com o desenvolvimento socioambiental, a lucratividade ou com ambos, relacionando as práticas adotadas pelas empresas com os conceitos e práticas de logística reversa no ambiente empresarial.

\section{FUNDAMENTAÇÃO TEÓRICA}

O termo logística reversa não possui uma definição universal. Diversos autores consideram apropriada a definição apresentada pelo Reverse Logistics Executive Council, que apresenta a logística reversa como sendo o processo de planejar, implementar e controlar a eficiência e os custos do fluxo de matérias-primas, estoques, produtos acabados e as informações correlacionadas do ponto de consumo ao ponto de origem, com o objetivo de recapturar valor ou para um descarte apropriado (CAMPOS, 2006).

A Lei 12.305, de 02 de agosto de 2010, que institui a Política Nacional de Resíduos Sólidos, descreve a logística reversa como sendo um instrumento de desenvolvimento econômico e social, caracterizado por um conjunto de ações, procedimentos e meios destinados a viabilizar a coleta e a restituição dos resíduos sólidos ao setor empresarial, para reaproveitamento, em seu ciclo ou em outros ciclos produtivos, ou outra destinação final que seja ambientalmente adequada.

Vale resaltar que ela se diferencia da gestão de resíduos, pois enquanto esta se refere principalmente à recolha e ao tratamento de resíduos de forma eficiente e eficaz, aquela se concentra nas correntes onde há algum valor a ser recuperado e os resultados são introduzidos na nova cadeia de suprimentos (BRITO e DEKKER, 2002). 
Com isso, percebe-se que as variadas definições de logística reversa mostram que o seu conceito ainda está em evolução, em virtude dos novos meios de negócios relacionados com o crescente interesse organizacional, pessoal (devido ao interesse por melhorias no meio ambiente) e ainda do interesse acadêmico e governamental. Entende-se assim, que a logística reversa é um processo adicional à logística tradicional, pois essa tem o papel de levar produtos dos fornecedores até os clientes intermediários ou finais, e a logística reversa deve completar o ciclo, ou seja, revertê-lo, trazendo de volta os produtos já utilizados dos diferentes pontos de consumo a sua origem.

De acordo com Leite (2009), a sociedade, em todas as partes do globo, tem se preocupado cada vez mais com o equilíbrio ecológico e está gradualmente se tornando mais consciente. Essas preocupações têm se tornado uma importante forma de incentivo à estruturação dos canais de logística reversa de pós-consumo, ou seja, as empresas sentem a necessidade de adequar-se às exigências de mercado.

Nesse sentido, Menezes e Ferreira (2004) afirmam que a missão de qualquer sistema de logística, seja ela reversa ou tradicional, é sempre para servir e personalizar o cliente/consumidor, pois o papel do consumidor e o desafio a sua personalização são particularmente importantes no sistema de logística reversa por três razões: inicialmente porque o consumidor é o primeiro e decisivo elo da cadeia logística global e sem a sua participação o sistema não existe; segundo, em paralelo com os custos logísticos da operação reversa, o serviço ao consumidor é uma medida do desempenho do sistema; e finalmente, o serviço ao cliente é fundamental para agregar valor aos produtos oferecidos. Assim, se a sociedade está ecologicamente mais consciente, o sistema logístico precisa se adaptar a isso.

Nos últimos anos, vem evoluindo um crescente interesse do governo e das indústrias em processos de recuperação de produtos que chegam ao fim de sua vida útil, sendo por meio de reparação, de recondicionamento, remanufatura, canibalização e reciclagem (SASIKUMAR, KANNAN e HAQ, 2010), pois atuando como players de grande porte no cenário econômico, os governos poderão catalisar ações que incentivem a aquisição de produtos e materiais reaproveitados para seu próprio uso ou para o uso em suas redes operacionais (LEITE, 2009).

Nesse contexto, a remanufatura é uma emergente área de negócio, atraente tanto a nível econômico quanto a um ponto de vista ambiental, pois é um dos campos mais importantes para a recuperação de produtos, ou seja, os produtos usados (ou suas partes e componentes) são restaurados para um estado que podem ser comercializados tendo novamente as mesmas características de um novo produto, em termos de qualidade técnica e desempenho (SASIKUMAR, KANNAN e HAQ, 2010).

Assim, a adoção das práticas da logística reversa é uma realidade no mundo dos negócios. É notória a importância que essa prática tem conquistado na sociedade, tanto na perspectiva econômica como no âmbito social (CAMPOS, 2006). Soma-se a isso a obrigação dos empresários em adotarem procedimentos de logística reversa para se adequarem a legislações ambientais que frequentemente vão sendo adicionadas na Constituição, influenciando diretamente nos modelos de negócio das empresas (BRAGA E MEIRELLES, 2012).

\subsection{PNEUMÁTICOS}

O pneu tornou-se um elemento fundamental para o desenvolvimento da sociedade moderna, seja no transporte de passageiros ou de cargas (SOUZA e D'AGOSTO, 2013). Dada essa realidade, o consumo de pneus acontece em grandes proporções em todo planeta.

Freires e Guedes (2008) ressaltam que quando os pneus usados são deixados em locais inadequados, estes servem como lugar para a procriação de mosquitos e outros vetores de doenças, representando também um constante risco de incêndio, quando são deixados ao ar livre, além de contaminar o solo.

Os pneus inservíveis não devem ser destinados aos aterros sanitários, pois apresentam dificuldade em sua decomposição e, por isso, passam muito tempo degradando o meio ambiente. Viana (2009) expõe que os pneus não são adequados para serem descartados em aterros sanitários, tendo em vista que os pneumáticos são compostos por materiais resistentes, o que dificulta o processo de compactação junto ao lixo como um todo, 
provocando espaços vazios no solo. Isso pode comprometer o aterro dado o risco de explosões.

Uma solução parcial para o problema dos pneumáticos inservíveis seria o processo da trituração antes de destiná-los aos aterros, no intuito de facilitar sua compactação, mas a dissolução da borracha junto ao lixo gera óleos com potencial de poluir córregos ou lençóis freáticos (VIANA, 2009).

De modo geral, problemas ambientais relacionados aos resíduos de pneus e suas alternativas de reciclagem e destinação têm sido um problema. Essa realidade se dá por causa de uma combinação complexa de materiais de diferentes naturezas, tais como: vários tipos de borrachas, cabo de aço, elastômeros, produtos têxteis e outros componentes menores orgânicos e inorgânicos. Dessa forma, os pneumáticos têm sido alvo de muitos estudos na área de gestão de resíduos (DHOUIB, 2014).

Atualmente, os danos provocados ao meio ambiente por produtos descartados incorretamente vêm fazendo com que a sociedade exija dos órgãos competentes formas de controle e redução dos impactos, bem como formas de reverter esses danos. Com isso, surgem as legislações ambientais e regulamentações voltadas para a adequada destinação dos produtos usados.

Algumas normas legais têm sido desenvolvidas em resposta aos impactos ambientais, com intuito de adequar o crescimento econômico às variáveis ambientais. Tais legislações regulamentam normas para a utilização de "selos verdes para indicar os produtos de pós-consumo que podem ou não ser depositados em aterros sanitários" (LEITE, 2009, p.23).

As legislações ambientais são específicas para cada produto, devendo considerar seus diferentes aspectos, desde a sua vida útil até a sua disposição final. Isso porque cada um desses possui uma característica específica e também um grau do dano que pode causar ao meio ambiente caso seja destinado de forma incorreta após sua vida útil.

\subsection{LEIS QUE REGULAM A COMERCIALIZAÇÃO DE PNEUS NO BRASIL}

No Brasil, o órgão que regulamenta a destinação dada aos pneus junto aos fabricantes é o Conselho Nacional do Meio
Ambiente (CONAMA). Conforme Aguiar (2010), no dia 26 de agosto de 1999, o Conselho publicou a primeira resolução voltada aos pneumáticos, a 258, obrigando os fabricantes e importadores de pneus a darem uma destinação correta aos pneus usados. Desde então, aconteceram alterações e criação de novas resoluções: a 301, de 21 de março de 2002 e a 416, de 30 de setembro de 2009.

A Resolução 416 considera pneu inservível aquele pneu usado que apresente danos irreparáveis em sua estrutura, não servindo mais para rodar ou para reformar (CONAMA, 2009), ou seja, o pneu que está sem condições para ser utilizado em sua atividade principal.

Segundo a Resolução 416, os fabricantes e importadores de pneumáticos devem dar uma correta destinação aos pneus inservíveis. Seu artigo $3^{\circ}$ expõe que para cada pneu novo comercializado para o mercado de reposição, as empresas fabricantes ou importadoras deverão dar destinação adequada a um pneu inservível, sendo que para efeito de fiscalização, a quantidade de que trata o caput deverá ser convertida em peso de pneus inservíveis a serem destinados (CONAMA, 2009).

Ainda conforme a Resolução do CONAMA, $n$. $^{\circ}$ 416, de 30/09/2009, no seu artigo $1^{\circ}$, as empresas que fabricam e/ou que importam pneus novos com peso unitário superior a $2 \mathrm{~kg}$, ficam na obrigação de dar destinação adequada aos pneus inservíveis.

O Instituto Brasileiro do Meio Ambiente e dos Recursos Naturais Renováveis (IBAMA, 2010) complementa na Instrução Normativa n.. 01/2010, no art. $2^{\circ}$, que a obrigatoriedade de coleta e destinação de pneus inservíveis atribuída aos importadores e fabricantes de pneus refere-se àquelas empresas que importam ou produzem pneus novos com peso unitário superior a $2 \mathrm{~kg}$, que se enquadram na posição 4011 da Nomenclatura Comum do Mercosul (NCM).

De acordo com a resolução do CONAMA n. 23, de 12 de dezembro de 1996, como consta nos artigos 5 e 6을 as empresas fabricantes e importadoras de pneus devem também declarar anualmente o que é feito com os pneus inservíveis, prezando pelo destino ambientalmente correto dos materiais pneumáticos. 
De acordo com a Instrução normativa do IBAMA n. 1, de 18 de Março de 2010, no artigo 6ำ, a comprovação da destinação de pneumáticos inservíveis será efetuada pelos fabricantes e importadores de pneus no ato do preenchimento do 'Relatório de Comprovação de Destinação de Pneus Inservíveis' disponível no Cadastro Técnico Federal (CTF), contendo as seguintes informações:

a) quantidade destinada, em peso;

b) tipo de destinação;

c) empresas responsáveis pela destinação;

d) quantidade de pneus inservíveis, armazenados temporariamente, em lascas ou picados, quando couber;

e) endereço da empresa responsável pelo armazenamento;

f) pontos de coleta.

De acordo com a norma do CONAMA (2009) e do IBAMA (2010), os fabricantes de pneus possuem a obrigação de darem uma destinação adequada à determinada quantidade de pneus inservíveis de acordo com sua fabricação e/ou importação. Para isso, os importadores contam com a ajuda dos seus representantes, isto é, com a ajuda dos revendedores os fabricantes conseguem cumprir as exigências das regulamentações e dar uma destinação correta aos pneus inservíveis. Feito isso, os fabricantes e destinadores junto aos órgãos competentes devem comprovar anualmente o destino dado aos pneus. E O IBAMA encaminha à Secretaria do Comércio Exterior do Ministério da Indústria do Comércio e do Turismo (SECEX/MICT) uma relação atualizada das empresas cadastradas e aptas a realizar importações de pneumáticos.

Vale salientar que todas as normas citadas são referentes à importação e comercialização de pneus novos, pois conforme a Resolução n.․ 23 do CONAMA (2010) é proibida a importação de pneus usados em todo o território nacional, sob qualquer forma e para qualquer fim.

Com isso, deve-se ressaltar que no Brasil existe um grande conflito entre as indústrias do mercado de reposição de pneumáticos, onde os principais protagonistas desse conflito nos últimos anos são representados pela Associação Nacional da Indústria de Pneumáticos (ANIP), que conta com os fabricantes de pneus novos, e pela Associação Brasileira da Indústria de Pneus (ABIP), que reúne os fabricantes de pneus remoldados, e que utilizam como matériaprima pneus usados importados (VIANA, 2009).

De acordo com Viana (2009), a ABIP defende a importação de pneus usados no Brasil, para que sejam restaurados e comercializados, pois o pneu nacional usado é de baixa qualidade, dada a qualidade dos pisos e estradas no país.

Já a ANIP, contrária a essa importação, alega que há pneus de meia-vida em demasia no país, o que dispensa a necessidade de sua importação. A ANIP ressalta ainda a rapidez com que os pneus usados importados se transformam em passivo ambiental, além de tornarem o Brasil um depósito de lixo mundial. Soma-se a isso o argumento de que se a importação de pneus usados fosse um bom negócio, os próprios países de origem fariam as suas remoldagens (VIANA, 2009).

ABIP vê os pneus remoldados como competitivos diante dos pneus novos nacionais, uma vez que possuem garantia compatível, por preço $40 \%$ inferior, e uma opção ao mercado interno com economia de recursos ambientais.

Consoante Viana (2009), o mais importante é que para a logística os pneus inservíveis, sejam eles originados de fábricas nacionais ou estrangeiras, produzem o mesmo efeito ao meio ambiente e merecem os mesmos cuidados pós-consumo.

Por isso, não importa a procedência dos pneus, esses causam os mesmos danos ao meio ambiente e à sociedade, e deve-se ter o maior cuidado possível para que não sejam destinados de forma incorreta ao término de sua vida útil.

\section{METODO DE PESQUISA}

O presente trabalho tem como objetivo identificar os reais objetivos das empresas revendedoras de pneus que adotam a prática da logística reversa em uma cidade brasileira de médio porte. A caracterização da pesquisa se deu mediante os aspectos relativos aos fins objetivados e aos meios necessários, conforme recomenda Vergara (2007).

Quanto aos fins, a pesquisa foi exploratória e descritiva: exploratória por não se ter muita informação sistematizada sobre o tema, 
buscando mostrar maiores informações sobre a logística reversa de pneus; e descritiva porque se pretende descrever as informações e características do assunto estudado. E conforme Andrade (2010), a pesquisa exploratória é o passo inicial para todo e qualquer trabalho científico, tendo tal tipo de pesquisa a finalidade de proporcionar maiores informações sobre o assunto.

E quanto aos meios, o desenvolvimento da referida pesquisa se deu em duas etapas principais, a revisão da literatura e a pesquisa de campo. A revisão da literatura constituiu-se na busca de informações referente aos pressupostos teóricos fundamentais já elaborados sobre o tema. E o levantamento de campo, realizado na segunda etapa, constituiu-se pela entrada em campo, feita a partir de duas fontes diferenciadas: uma entrevista semiestruturada e observação não participante. Conforme Gil (2011), as pesquisas em que se utilizam o levantamento de campo se caracterizam pela interrogação direta das pessoas cujo comportamento se deseja conhecer.

O referido trabalho trata-se de uma pesquisa de abordagem qualitativa com levantamento de dados junto a gerentes e proprietários de revendedoras de pneus em uma cidade brasileira de médio porte. Por essa razão, a técnica escolhida para a coleta de dados foi o roteiro de entrevista, aplicado em cinco revendas de pneus e na Secretaria de Meio Ambiente e Recursos Hídricos da cidade, que é responsável pela coleta de pneus em alguns pontos da cidade.

O critério para a escolha das empresas pesquisadas foi o porte e o fato de utilizarem a Logística Reversa. Em princípio, foram contatadas as sete maiores empresas do ramo de pneus de uma cidade de médio porte. Essa amostra foi selecionada tendo como base o cadastro das empresas na junta comercial da cidade, porém somente cinco, dos sete empreendimentos visitados, confirmaram adotar a prática de Logística Reversa. Assim, a amostra se reduziu para cinco empresas.

As entrevistas foram realizadas no período de 01 a 19 de Julho de 2013, com o auxílio de gravadores que permitiram captar todos os detalhes da entrevista, visando saber o funcionamento dos processos das empresas pesquisadas. Foi realizada também uma entrevista à Secretária de Meio Ambiente e Recursos Hídricos do município, buscando mostrar qual o destino dado aos pneus que são recolhidos nas empresas que não aplicam o processo de logística reversa, bem como nas empresas que destinam os pneus à prefeitura para que essa possa dar a destinação correta ao pneu inservível.

Para a análise e interpretação dos dados foi utilizada a Análise de Conteúdo, que se caracteriza como um conjunto de técnicas de análise das comunicações, que visa obter, por meio de procedimentos sistêmicos e objetivos de descrição de conteúdo das mensagens, indicadores que permitam as inferências de conhecimentos relativos às condições de produção/recepção destas mensagens (BARDIN, 2004).

\section{RESULTADOS DA PESQUISA}

Em três das empresas selecionadas, o próprio dono da empresa respondeu às perguntas da entrevista, e as demais colocaram à disposição o profissional responsável pelo cargo de gerência.

A pesquisa abrangeu também o responsável pela Secretaria de Meio Ambiente e Recursos Hídricos. Nessa repartição foi feita uma entrevista pré-estruturada com o membro responsável pelo recolhimento dos pneus inservíveis na cidade, com intuito de saber qual a destinação dos pneus recolhidos das revendas.

$\mathrm{Na}$ entrevista, o Secretário informou que existe uma parceria da Prefeitura do município com a ANIP, que por meio do programa Reciclanip (um programa de reciclagem de pneus criado em março de 2007 pela ANIP, originado do Programa Nacional de Coleta e Destinação de Pneus Inservíveis de 1999) realiza a coleta, a destinação e o acompanhamento dos avanços da reciclagem de pneus no país, sendo a função da prefeitura coletar os pneus pela cidade.

O Secretário esclareceu ainda que não é obrigação da prefeitura recolher os pneus inservíveis nas revendas, visto que estas empresas têm por obrigação, prevista em lei, dar uma destinação adequada aos mesmos conforme já citado nas resoluções do CONAMA (2009). Os pneus que são coletados pela prefeitura são deixados em um local até que o caminhão da Reciclanip venha recolher.

Ciente da existência desse programa para coleta de pneus prosseguiu-se com as 
análises dos dados coletados junto às empresas estabelecendo os seguintes pontos: análise das ações de logística reversa para destinação de pneus usados; identificação dos motivos que levaram as empresas a adotarem a logística reversa; por fim, a verificação do consentimento dos empresários com as leis que regulamentam a comercialização de pneus no Brasil. Assim, será apresentada cada questão com as devidas respostas obtidas, objetivando corroborar o resultado obtido na pesquisa com o referencial teórico adotado.

\subsection{AS AÇÕES DE LOGÍSTICA REVERSA PRATICADAS PARA A DESTINAÇÃO DE PNEUS USADOS}

A logística reversa de pneus usados trata-se de procedimentos técnicos em que estes são descaracterizados de sua forma inicial, e que seus elementos constituintes são reaproveitados, reciclados ou processados por outras técnicas admitidas pelos órgãos ambientais competentes, observando a legislação vigente e normas operacionais específicas de modo a evitar danos ou riscos à saúde pública e à segurança, e a minimizar os impactos ambientais adversos (CONAMA, 2009). Nesse contexto, perguntou-se aos gestores acerca da aplicação do processo de logística reversa em suas respectivas empresas. Os seguintes discursos foram coletados:

Figura 01: Ações de logística reversa praticadas pelas empresas pesquisadas.

\begin{tabular}{|c|c|}
\hline Empresas & Discursos \\
\hline Empresa 1 & $\begin{array}{l}\text { A gente tem um convênio com a ANIP, que por meio do programa reciclanip ela recolhe } \\
\text { os pneus inservíveis para dar a destinação adequada, sendo que na maioria das vezes } \\
\text { os pneus são triturados para virar composto de asfalto. }\end{array}$ \\
\hline Empresa 2 & $\begin{array}{l}\text { Os pneus são enviados para a central em Brasília, e lá eles dão a destinação correta. A } \\
\text { empresa possui parceria com fabricantes de objetos derivados da borracha, tais como } \\
\text { sandálias, borracha asfáltica. }\end{array}$ \\
\hline Empresa 3 & Encaminhamos para a prefeitura, onde a mesma dá a destinação correta ao pneu. \\
\hline Empresa 4 & $\begin{array}{l}\text { A recapagem, e quando não servem para recapagem as carcaças são trituradas aqui } \\
\text { mesmo na empresa, e são entregues às academias para fazer aqueles ringues, ou são } \\
\text { entregues a criadores para fazer cocheiros, ou então a empresa queima os pneus. }\end{array}$ \\
\hline Empresa 5 & $\begin{array}{l}\text { Nós trabalhamos com a reforma, e quando o pneu é recusado para reforma, a orientação } \\
\text { da autorizada é que a gente devolva para a prefeitura, onde ela dá a destinação ao } \\
\text { pneu. }\end{array}$ \\
\hline
\end{tabular}

Nota. Fonte: dados da pesquisa, setembro de 2013.

Com base nas respostas, percebe-se que os pneus inservíveis têm seguido os mais diversos destinos, tais como: asfalto, sandálias, cocheiros e até queimados, sendo que as empresas que não possuem coletores próprios acabam enviando os pneus para a prefeitura, para uma adequada destinação. Os gestores das Empresas 4 e 5 possuem formas de reaproveitamento dos pneus inservíveis na própria empresa, fazendo reciclagem por meio da recapagem e/ou reforma.

O proprietário da Empresa 1 demonstrou deter um maior conhecimento acerca das questões legais, demonstrando no ato da entrevista, ser conhecedor dos preceitos do ramo de negócio, bem como de gestão empresarial como um todo.

O gestor da Empresa 4 declarou que adota a logística reversa por meio do procedimento de recapagem, bem como encaminha às academias, porém afirmou ainda que em alguns casos esses pneus são queimados. Contudo, a legislação cita que a queima de pneus não é um procedimento ambientalmente correto para a destinação final desses produtos, pois uma destinação adequada deve evitar danos ou riscos à saúde pública e à segurança, bem como minimizar os impactos ambientais adversos (CONAMA, 2009).

E para que haja uma maior efetividade na prática de logística reversa de pneus 
inservíveis, a Resolução 416/2009 do CONAMA diz que as empresas fabricantes e revendedoras deverão elaborar um plano de gerenciamento de coleta, armazenamento e destinação de pneus inservíveis, contendo a descrição dos programas educativos a serem desenvolvidos junto aos agentes envolvidos e, principalmente, junto aos consumidores. Sabendo disso, buscou identificar as políticas que a empresa adota no intuito de estimular os consumidores a devolver o pneu usado.

Figura 02: políticas adotadas pelas empresas que estimulem a devolução do pneu.

\begin{tabular}{|c|c|}
\hline Empresas & Discursos \\
\hline Empresa 1 & $\begin{array}{l}\text { Quando o cliente vem comprar ou trocar o pneu, a empresa o orienta a não levar para } \\
\text { casa e nem deixar no carro, pois como o pneu já teve contato com o solo, este leva para } \\
\text { dentro de casa bactérias e vírus. A empresa o orienta a deixar o pneu na empresa, que } \\
\text { esta se encarregará de dar a destinação adequada. }\end{array}$ \\
\hline Empresa 2 & $\begin{array}{c}\text { Ainda não temos nenhum programa de incentivo para estimular o cliente a devolver os } \\
\text { pneus inservíveis. }\end{array}$ \\
\hline Empresa 3 & $\begin{array}{l}\text { Adotamos uma política de reciclagem do pneu inservível, assim diminuindo o impacto ao } \\
\text { meio ambiente. }\end{array}$ \\
\hline Empresa 4 & A gente fala que o pneu não serve mais e que o cliente corre riscos. \\
\hline Empresa 5 & $\begin{array}{c}\text { Não existe nenhuma política, até porque o pneu é dele, a orientação é que não pode ser } \\
\text { jogado no lixo porque vai poluir. }\end{array}$ \\
\hline
\end{tabular}

Nota. Fonte: dados da pesquisa, setembro de 2013.

Analisando as respostas, percebe-se que em nenhuma das empresas entrevistadas há políticas efetivas que objetivem estimular 0 consumidor a devolver o pneu inservível. Nota-se que a forma utilizada pelas empresas para estimular os clientes a devolverem os pneus na revenda é uma mera argumentação com palavras, procurando explicar informalmente aos consumidores que a má destinação dos pneus pode causar danos a todas as pessoas, visto que isso aumenta cada vez mais os impactos ao meio ambiente.

O proprietário da Empresa 2 informou que ainda não possui nenhuma forma de incentivar o consumidor a devolver o pneu inservível, nem mesmo de maneira informal, demonstrando que a preocupação da mesma para com a sociedade e o meio ambiente é pequena.

O gestor da Empresa 5 demonstrou um completo desinteresse em relação a estimular a conscientização do consumidor a deixar o pneu inservível na revenda, bem como não se preocupar com o que o consumidor fará com o pneu velho, como mostra a frase: "até porque o pneu é dele!"

Os pneus que são deixados nas empresas devem ser analisados por profissionais competentes para verificar se são produtos inservíveis ou servíveis, no caso de produtos com meia-vida, que podem ser recauchutados (LAGARINHOS e TENÓRIO, 2013). A esse respeito Goto e Souza (2008) afirmam que o Brasil é o segundo maior reformador de pneus do mundo, mesmo perante a dificuldade que esse produto tem em entrar no mercado pela rejeição dos compradores que julgam esses pneus como tendo uma qualidade duvidosa, apesar de que algumas reformadoras possuem certificação pelo INMETRO.

Frente a esse cenário buscou-se verificar quais os procedimentos realizados após a chegada dos pneus à empresa. 
Figura 03: procedimentos realizados após a chegada dos pneus.

\begin{tabular}{|c|c|}
\hline Empresas & Discursos \\
\hline Empresa 1 & $\begin{array}{l}\text { A gente guarda em um galpão próprio da empresa, separado dos pneus novos e espera } \\
\text { o caminhão da reciclanip vir buscar. }\end{array}$ \\
\hline Empresa 2 & A empresa acumula e espera o caminhão para levá-los para a central. \\
\hline Empresa 3 & $\begin{array}{c}\text { É feito a identificação do pneu que em seguida é lançado ao relatório de carcaças } \\
\text { inservíveis e assim mandado para a reciclagem. }\end{array}$ \\
\hline Empresa 4 & Eles são examinados por um profissional especializado. \\
\hline Empresa 5 & Os pneus são examinados para ver se há condição de reforma. \\
\hline
\end{tabular}

As empresas um, dois e três não possuem formas de recuperação dos pneus no próprio estabelecimento, por conta disso, elas apenas separam os pneus dos novos e posteriormente encaminham para o local, onde são feitos os procedimentos adequados. As demais revendas possuem profissionais especializados na própria empresa que examinam para saber se estes podem ser reutilizados e/ou recuperados e novamente lançados no mercado.

O programa Reciclanip citado pelo Empresário 1, foi explicado pelo Secretário de Meio Ambiente e Recursos Hídricos da cidade estudada como um destino correto e seguro para os pneus inservíveis. A Reciclanip conta hoje com 815 pontos de coleta em todo território nacional, além de parcerias com prefeituras municipais e outros órgãos governamentais (RECICLANIP, 2014).

Vale salientar que o CONAMA, em sua Resolução n.416 de 2009, considera pneu inservível, aquele pneu usado que apresente danos irreparáveis em sua estrutura, não se prestando mais para rodar ou reformar. Ou seja, quando o pneu que está sem condições para ser utilizado em sua atividade principal. Por conta disso, buscou-se saber quais os critérios que as empresas utilizam para classificar um pneu como inservível.

Os empresários das Empresas 1 e 2 consideram um pneu inservível quando ele atinge uma marca conhecida como TWI, que é a marca limite para rodagem, sendo que a da Empresa 1 adiciona que o pneu é inservível quando está estourado ou rasgado. Já os demais gestores responderam que para considerar um pneu como inservível, verificase apenas se há ou não condições de reforma ou quando estavam muito gastos.

De acordo com a ANIP (2013), o TWI (Tread Wear Indicator) refere-se a um indicador que mostra o limite de segurança para rodagem, estando na hora de trocá-lo, e que abaixo dessa medida o pneu é considerado "careca" e o veículo pode ser apreendido.

\subsection{MOTIVOS QUE LEVARAM A EMPRESA A ADOTAR A LOGÍSTICA REVERSA}

No intuito de minimizar os impactos de processos ou produtos danosos à sociedade ou ao meio ambiente, as empresas têm buscado responder às reações da sociedade, onde estas se manifestam principalmente pelo comportamento do consumidor ou por legislações restritivas.

O novo cliente e consumidor está gradativamente passando a exigir uma maior responsabilidade empresarial, um maior rigor em legislações ambientais e estratégias que privilegiem o favorecimento do retorno de produtos e o equacionamento desse retorno de maneira organizada (LEITE, 2009). A partir deste contexto, procurou-se saber quais os motivos que levaram as empresas a praticarem a logística reversa. 
Figura 04: motivos que levaram à adoção da logística reversa

\begin{tabular}{|c|l|}
\hline Empresas & \multicolumn{1}{|c|}{ Discursos } \\
\hline Empresa 1 & $\begin{array}{l}\text { Quando a empresa assina o contrato de revendedor, há uma cláusula específica no } \\
\text { contrato dizendo que a empresa deve guardar o pneu inservível para quando a } \\
\text { Reciclanip passar recolher o pneu. }\end{array}$ \\
\hline Empresa 2 & $\begin{array}{l}\text { Devido à grande quantidade de pneus inservíveis existentes e ao fato de não poder } \\
\text { jogá-los em qualquer lugar. }\end{array}$ \\
\hline Empresa 3 & Em respeito ao meio ambiente e às normas da empresa. \\
\hline Empresa 4 & $\begin{array}{l}\text { As leis ambientais. } \\
\text { É determinação da concessionária autorizada da nossa bandeira, porque o pneu não } \\
\text { pode ser jogado no lixo e nem guardado, ele tem de ser encaminhado para um lugar } \\
\text { adequado. }\end{array}$ \\
\hline
\end{tabular}

Nota. Fonte: dados da pesquisa, setembro de 2013.

A partir das respostas obtidas, percebeu-se que são vários os motivos pelos quais as empresas praticam a logística reversa. Os gestores das Empresas 1 e 5 praticam tal processo por conta das normas e especificações da concessionária autorizada, ou seja, a empresa distribuidora central, e o gestor da Empresa 3 especifica que é em respeito ao meio ambiente e também que é norma da própria empresa. Já o gestor da Empresa 4 afirma que o motivo que levou a adotar a logística reversa foi as leis ambientais, embora não saiba quais são essas leis e nem o porquê existem essas leis. Já a proprietário da Empresa 2 informou que pratica a logística reversa simplesmente porque já existem pneus inservíveis em demasia e eles não podem ser jogados em qualquer lugar.
Percebe-se, então, que na maioria das empresas a prática da logística reversa é adotada basicamente porque as empresas são "obrigadas" a dar uma destinação adequada aos pneus inservíveis, seja por conta das legislações vigentes ou pelo fato de as concessionárias distribuidoras exigirem das revendas uma destinação ambientalmente correta para tais produtos.

Porém, são inúmeros os benefícios que a logística reversa proporciona às empresas que a adota, pois agrega-lhes valores de diversas naturezas, tais como: valor econômico, de prestação de serviços, ecológico, legal, logístico, de imagem corporativa entre outros (LEITE, 2009). Por conta disso, procurou-se saber como as empresas visualizavam os benefícios oriundos da adoção da prática da logística reversa. E foram obtidas as seguintes argumentações:

Figura 05: benefícios da logística reversa

\begin{tabular}{|c|c|}
\hline Empresas & Discursos \\
\hline Empresa 1 & $\begin{array}{l}\text { Principalmente diminuir o impacto ambiental, ser uma empresa sociorresponsável } \\
\text { devido a isso, e não ficar acumulando lixo, doenças e problemas no ambiente de } \\
\text { trabalho. }\end{array}$ \\
\hline Empresa 2 & A questão de tá atualizada com o meio ambiente, fazendo as coisas corretas. \\
\hline Empresa 3 & $\begin{array}{l}\text { Respeito ao cliente, meio ambiente, manter a empresa sempre limpa de pneus e, } \\
\text { assim, todos se beneficiam com isso. }\end{array}$ \\
\hline Empresa 4 & Através da recapagem traz benefícios tanto para a empresa como para o consumidor. \\
\hline Empresa 5 & $\begin{array}{l}\text { Não temos nenhum benefício, porque não temos nenhum incentivo e nenhuma } \\
\text { bonificação, nem nada. Eu acho que talvez isso aqui seja mais direcionado ao } \\
\text { distribuidor autorizado de pneus novos, distribuidor mesmo. }\end{array}$ \\
\hline
\end{tabular}

Nota. Fonte: dados da pesquisa, setembro de 2013.

Percebe-se que a maioria dos empresários vê a logística reversa não somente como forma de ganhos financeiros, mas como forma de redução do impacto ambiental e de diminuição da poluição causada por esses pneus. Porém, tem-se o caso do empresário da Empresa 5 que analisa como benefícios advindos da logística reversa apenas os 
ganhos financeiros da empresa, chegando a comentar que a empresa não tem nenhum benefício, pois não recebe nenhum incentivo ou bonificação.

Nota-se ainda, que a maioria dos empresários enfatizou a questão dos impactos ambientais principalmente por conta da ascensão do tema e das constantes notícias e comentários sobre o que é ser uma empresa 'ambientalmente responsável', não analisando os inúmeros outros benefícios que a adoção de tal prática traz para a sociedade como um todo.
Atualmente, a preocupação com a imagem corporativa está aumentando em comparação aos anos anteriores. Pesquisas realizadas recentemente no Brasil mostram que empresas de diferentes setores empresariais apontam a imagem corporativa como uma das mais fortes motivações dos programas de logística reversa (LEITE, 2009). Diante deste contexto, perguntou-se como os gestores visualizavam suas respectivas empresas na sociedade.

Figura 06: visão dos gestores quanto à imagem corporativa de sua empresa perante a sociedade.

\begin{tabular}{|c|l|}
\hline Empresas & \multicolumn{1}{c|}{ Discursos } \\
\hline Empresa 1 & $\begin{array}{l}\text { Como ela está cumprindo tanto seu dever de obrigações sociais, obrigações de } \\
\text { impostos, como também obrigações com o meio ambiente, possui uma imagem de } \\
\text { empresa sociorresponsável. }\end{array}$ \\
\hline Empresa 2 & $\begin{array}{l}\text { Como uma empresa que se preocupa com o meio ambiente, a organização faz } \\
\text { bastantes trabalhos na área de meio ambiente e é bastante conceituada na sociedade. }\end{array}$ \\
\hline Empresa 3 & $\begin{array}{l}\text { Uma empresa que faz a destinação ambientalmente correta de todas as carcaças } \\
\text { inservíveis dentro da empresa. }\end{array}$ \\
\hline Empresa 4 & $\begin{array}{l}\text { Como uma empresa responsável e de credibilidade. } \\
\text { Empresa 5 }\end{array}$ \\
\hline
\end{tabular}

Percebe-se que a maioria das empresas visualiza a imagem corporativa apenas como meio de seguir as normas impostas pelas leis e pelo fato de ser uma empresa que se preocupa com o meio ambiente. As revendas 1, 2 e 3 mencionaram em preocupação com o meio ambiente e, no caso da Empresa 1, em obrigações de cunho social.

Os gestores das Empresas 4 e 5 se referiram principalmente quanto a ter credibilidade no mercado. Isso mostra que os interesses financeiros e de imagem corporativa das empresas estão sempre evidentes, porém os fatores socioambientais nem sempre são contemplados.

\subsection{LEIS QUE REGULAMENTAM A COMERCIALIZAÇÃO DE PNEUS NO BRASIL}

No Brasil, o órgão que regulamenta a destinação dada aos pneus junto aos fabricantes é o Conselho Nacional do Meio Ambiente (CONAMA), que em sua Resolução n- 416 de 2009, e por meio da Instrução Normativa $\mathrm{n}^{\circ} 01$ de 2010 do IBAMA, os fabricantes de pneus possuem a obrigação de darem uma destinação adequada à determinada quantidade de pneus inservíveis de acordo com sua fabricação e/ou importação. Com isso, procurou saber se as empresas tinham conhecimento das regulamentações que atuam sobre a empresa em relação à disposição final dos pneus inservíveis. 
Figura 07: regulamentações que atuam sobre as revendas de pneus.

\begin{tabular}{|c|l|}
\hline \multicolumn{2}{|c|}{ Empresas } \\
Empresa 1 & $\begin{array}{l}\text { Tem uma lei ambiental do IBAMA que diz que dos pneus que a empresa coloca no } \\
\text { mercado ela tem que recolher determinada quantidade. Sendo assim, a fábrica orienta } \\
\text { os revendedores a recolherem os pneus inservíveis. }\end{array}$ \\
\hline Empresa 2 & $\begin{array}{l}\text { A ANIP possui umas normas sobre a regulamentação, mas eu não sei detalhar sobre } \\
\text { isso. }\end{array}$ \\
\hline Empresa 3 & Resolução CONAMA 416/2009. \\
\hline Empresa 4 & $\begin{array}{l}\text { Tem uma lei do CONAMA, se não me engano. } \\
\text { Apenas a legislação municipal de meio ambiente, que não pode ser jogado fora o } \\
\text { pneu, pois como é um lixo tóxico, não é permitido jogar na rua. }\end{array}$ \\
\hline
\end{tabular}

Nota. Fonte: dados da pesquisa, setembro de 2013.

Nota-se que nenhuma das empresas tem total conhecimento das legislações que regem o segmento de mercado no qual a sua empresa atua. As empresas um e três mostraram ser mais entendidas a respeito das leis que as regulamentam, no entanto, o proprietário da Empresa 1 não soube especificar qual a lei que determina o recolhimento dos pneus inservíveis.

Os gestores das Empresas 2, 4 e 5 mostraram desconhecer essas leis. A Empresa 2 respondeu que a ANIP é quem possui normas de regulamentação, enquanto o gestor da Empresa 4 disse, sem certeza, que o CONAMA tem uma lei. Já o gestor da Empresa 5 disse haver uma legislação municipal que proíbe jogar os pneus fora e na rua.
Assim, fica claro que a maioria das empresas pratica a logística reversa por conta das pressões da mídia e das leis existentes, mesmo que, na maioria dos casos, estas empresas nem mesmo sabem para que realmente essas leis servem.

A Resolução 416/2009 do CONAMA estabelece que os fabricantes e importadores de pneus novos deverão declarar ao IBAMA, numa periodicidade máxima de 01 (um) ano, por meio do CTF, a destinação adequada dos pneus inservíveis.

No que se refere à comprovação dada pelas empresas com relação à coleta e à destinação de pneus inservíveis, foram coletados os seguintes discursos:

Figura 08: comprovação da coleta de pneus inservíveis

\begin{tabular}{|c|c|}
\hline Empresas & Discursos \\
\hline Empresa 1 & $\begin{array}{l}\text { Quando a Reciclanip vem recolher os pneus ela deixa um recibo de coleta, e esse } \\
\text { recibo de coleta a gente envia para a fábrica. }\end{array}$ \\
\hline Empresa 2 & $\begin{array}{l}\text { A cada tantos pneus novos a serem comprados a empresa deve dar destinação } \\
\text { adequada a tantos pneus usados, mas eu não sei lhe informar em termos de } \\
\text { quantidade. A empresa que recolhe os pneus aqui possui licença do meio ambiente. }\end{array}$ \\
\hline Empresa 3 & É o RCl - Relatório de Carcaças Inservíveis. \\
\hline Empresa 4 & Através de um documento anexo. \\
\hline Empresa 5 & $\begin{array}{l}\text { Para minha empresa, que é uma revenda, comprar os pneus novos independe de } \\
\text { comprovar a destinação de coisa nenhuma. Em nosso caso, a concessionária } \\
\text { autorizada é quem manda os pneus novos para a empresa. }\end{array}$ \\
\hline
\end{tabular}

Nota. Fonte: dados da pesquisa, setembro de 2013.

Os gestores das Empresas 1, 3 e 4 informaram que comprovam a destinação dos pneus inservíveis por meio de documentos, e o gestor da Empresa 4 até especificou o nome desse documento, que é o $\mathrm{RCl}$ - Relatório de Carcaças Inservíveis. O proprietário da Empresa 2 informou que deve 
comprovar a destinação dos pneus inservíveis, porém não sabia informar a quantidade. E por fim, o gestor da Empresa 5 declarou que, como trata-se de uma revenda, não é de responsabilidade do mesmo comprovar tal destinação, ficando por responsabilidade da concessionária autorizada, e que esta é quem manda os pneus novos para a empresa.

Com isso, fica claro o despreparo dos gestores e proprietários das revendas de pneus da cidade em estudo, visto o desconhecimento das leis que atuam sobre a empresa, bem como os impactos que a incorreta destinação destes produtos podem causar à sociedade e ao meio ambiente.

\section{CONSIDERAÇÕES FINAIS}

Este artigo buscou identificar os reais objetivos dos empresários do ramo de revenda de pneus em uma cidade brasileira de médio porte, investigando as ações de logística reversa desenvolvidas por essas

Figura 09: análise dos reais interesses das empresas pesquisadas.

\begin{tabular}{|c|c|c|c|c|}
\hline Empresas & $\begin{array}{c}\text { Interesse } \\
\text { social }\end{array}$ & $\begin{array}{l}\text { Interesse } \\
\text { ambiental }\end{array}$ & $\begin{array}{l}\text { Interesse } \\
\text { econômico }\end{array}$ & Interesse central \\
\hline Empresa 1 & Alto & Alto & Moderado & $\begin{array}{l}\text { A empresa demonstra um alto interesse quanto aos } \\
\text { ganhos sociais e ambientais, podendo dizer então } \\
\text { que a prática da logística reversa deve-se } \\
\text { principalmente aos ganhos recebidos pela sociedade. }\end{array}$ \\
\hline Empresa 2 & Moderado & Moderado & Moderado & $\begin{array}{l}\text { A empresa adota a logística reversa principalmente } \\
\text { porque deve adequar-se às legislações restritivas e } \\
\text { também no intuito de ser uma empresa } \\
\text { ambientalmente responsável. Porém não tem } \\
\text { conhecimento das legislações ambientais que regem } \\
\text { o seu negócio. }\end{array}$ \\
\hline Empresa 3 & Moderado & Alto & Moderado & $\begin{array}{l}\text { O interesse da empresa está voltado principalmente à } \\
\text { imagem corporativa que a adoção da logística reversa } \\
\text { proporciona perante a sociedade e as leis ambientais, } \\
\text { visto que a empresa menciona o meio ambiente em } \\
\text { várias respostas no decorrer da entrevista. }\end{array}$ \\
\hline Empresa 4 & Baixo & Baixo & Alto & $\begin{array}{l}\text { O interesse demonstrado pela empresa é em relação } \\
\text { principalmente aos ganhos financeiros, que são } \\
\text { obtidos por meio da recapagem. A mesma ainda diz } \\
\text { preocupar-se com o meio ambiente, porém afirma que } \\
\text { em alguns casos queima os pneus, deixando evidente } \\
\text { que essa preocupação com o meio ambiente e a } \\
\text { sociedade é mínima. }\end{array}$ \\
\hline Empresa 5 & Baixo & Baixo & Alto & $\begin{array}{l}\text { A empresa demonstra um completo interesse } \\
\text { financeiro com a prática da logística reversa, pois } \\
\text { afirma que a mesma não tem nenhum incentivo ou } \\
\text { bonificação para realizar tal prática. Informando ainda } \\
\text { que fazem a logística reversa porque é determinação } \\
\text { da concessionária central. }\end{array}$ \\
\hline
\end{tabular}

Nota. Fonte: dados da pesquisa, setembro de 2013. empresas e evidenciando as leis ambientais voltadas para a comercialização de pneus. De acordo com o que foi mostrado na pesquisa, todas as empresas trabalham com a logística reversa, porém nem todas encaram tal prática como processo essencial ao bom desempenho da empresa bem como cuidar do meio ambiente. A pesquisa mostra também que a logística reversa ainda é vista pela maioria das empresas como uma forma de custos adicionais. Embora elas sejam obrigadas a darem uma correta destinação aos pneus usados, ainda há algumas que ignoram as normas regulamentadoras.

Com isso, optou-se por fazer uma análise paralela dos interesses dessas empresas, considerando separadamente o grau de importância referente aos ganhos social, ambiental e econômico demonstrados pelas revendas, buscando assim identificar o real e central objetivo dos empresários, como mostra o Figura 09. 
A pesquisa mostrou que as empresas adotam a logística reversa principalmente por conta da ascensão do conceito de ser uma empresa ambientalmente responsável, e também devido ao fato das legislações restritivas estarem cada vez mais presentes e buscarem fazer com que as empresas degradem menos o meio ambiente. Com isso, notou-se que em três das empresas estudadas há o equilíbrio entre a consciência socioambiental e o retorno financeiro, porém as outras duas empresas restantes são movidas basicamente pelos fatores econômicos. O que demonstra que a lucratividade está sempre presente nos interesses dos empresários, já os fatores socioambientais nem sempre são contemplados.

Percebe-se também 0 fato de os consumidores estarem buscando cada vez mais empresas ambientalmente responsáveis,

\section{REFERÊNCIAS}

[1]. AGUIAR, A. M. dos S.; FURTADO, C. F. do C. Aplicação da logística reversa nas revendas de pneus em Fortaleza. In: SEMEAD, 13., 2010, Fortaleza. Anais... Fortaleza, 2010.

[2]. ANDRADE, M. M. de. Introdução à metodologia do trabalho científico: elaboração de trabalhos na Graduação. 10. ed. São Paulo: Atlas, 2010 .

[3]. ANIP - Associação Nacional da Indústria de Pneumáticos. Disponível em: $<$ http://www.anip.com.br/index. php?cont=detalhes _noticias\&area $=21 \&$ titulo_pagina=FAQ\&id_noticia = 401>. Acessado em 26 de agosto de 2013.

[4]. BARDIN, Laurence. Análise de conteúdo. 3 ed. Lisboa: Edições 70, 2004.

[5]. BRAGA, A. C. S.; MEIRELlES, D. S. e. Logística Reversa e Mudanças no Modelo de Negócio: um estudo de caso na indústria de pneumáticos. In: EnANPAD, 36., 2012, Rio de Janeiro. Anais... Rio de Janeiro: ANPAD, 2012.

[6]. BRASIL. Lei no 12.305, de 02 de agosto de 2010, Política Nacional de Resíduos Sólidos. Câmara dos Deputados. 2.ed. Brasília: Câmara dos Deputados, Edições Câmara, 2012.

[7]. BRITO, M. P. de; DEKKER, R.. Reverse Logistics, a framework. Erasmos University Rotterdam. Rotterdam: Econometric Institute Report, 2002.

[8]. CAMPOS, T. de. Logística reversa: aplicação ao problema das embalagens da CEAGESP. São Paulo. 2006. 154 f. Dissertação. (Mestrado em Engenharia). Escola Politécnica da Universidade de São Paulo. São Paulo, 2006. fazendo com que essas adotem procedimentos os quais minimizem os impactos causados à sociedade. Dessa forma, a logística reversa é um dos principais procedimentos adotados pelas empresas na atualidade.

Acredita-se que esta pesquisa possa contribuir para discussões posteriores sobre a necessidade de práticas de logística reversa no setor de revenda de pneus e outros segmentos de mercado, bem como ações que contribuam sustentavelmente para o desenvolvimento da sociedade. $E$ que tal debate possa leva a novas pesquisas e reflexão acerca da criação de políticas de incentivo por parte de empresas e outras autoridades, para investimentos em logística reversa como parte da solução para vários problemas ambientais.

[9]. CONAMA - Conselho Nacional do Meio Ambiente. Resolução n. ${ }^{\circ} 416$, de 30 de setembro de 2009. Disponível em: <http://www.mma.gov.br/port/conama/legiabre.cfm ?codlegi=616> . Acesso em 26 de Junho de 2013.

[10]. CONAMA - Conselho Nacional do Meio ambiente. Resolução n. 23, de 12 de dezembro de 1996. Disponível em: <http://www.mma.gov.br/port/conama/legislacao/C ONAMA_RES_CONS_1996_023.pdf>. Acesso em 17 de Julho de 2013.

[11]. DHOUIB, D. An extension of MACBETH method for a fuzzy environment to analyze alternatives in reverse logistics for automobile tire wastes. Omega The International Journal of Management Science. v.42, n. 1, p.25-32, 2014.

[12]. FREIRES, F. G. M.; GUEDES, A. P. S. Power and trust in reverse logistics systems for scraptires and its impact on performance. Journal of Operations and Supply Chain Management. v.1, n.1. p.57-65, 2008.

[13]. GIL, A. C. Métodos e técnicas de pesquisa social. 6. ed., São Paulo: Atlas, 2011.

[14]. GOTO, A. K.; SOUZA, M. T. S. de. A Contribuição da Logística Reversa na Gestão de Resíduos Sólidos: uma Análise dos Canais Reversos de Pneumáticos. In: EnANPAD, 32., 2008, Rio de Janeiro. Anais... Rio de Janeiro: ANPAD, 2008.

[15]. GOVINDAN, K. et al. Analysis of third party reverse logistics provider using interpretive structural modeling. International Journal of Production Economics. v.140, n.1, p.204-211, 2012. 
[16]. IBAMA - Instituto Brasileiro do Meio Ambiente e dos Recursos Naturais Renováveis.

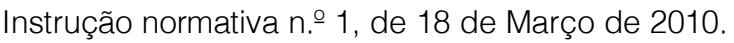
Disponível em: <http://servicos.ibama.gov.br/ctf/manual/html//N_01 2010_DOU.pdf.>. Acesso em 17 de Julho de 2013.

[17]. LAGARINHOS, C. A. F; TENÓRIO, J. A. S. Logística reversa de pneus usados no Brasil. Polímeros Ciência e Tecnologia. São Paulo, v. 23, n. 1, p.49-58, 2013.

[18]. LEITE, P. R. Logística Reversa: meio ambiente e competitividade. São Paulo: Pearson Prentice Hall, 2009.

[19]. MENEZES, J.; FERREIRA, L. Needs for Logistics in Portuguese Tire Reverse Supply Chain. A Dynamic Systems Approach. Economia Global e Gestão. Lisboa. v.4, n.3, p.65-77, 2004.

[20]. RECICLANIP, Pontos de coleta no Brasil. Disponível

em:

$<$ http://www.reciclanip.org.br/v3/pontos-

coleta/brasil> Acesso em: 21 de abril de 2014.

[21]. SASIKUMAR, P.; KANNAN, G.; HAQ, A. $\mathrm{N}$. A multi-echelon reverse logistics network design for product recovery: a case of truck tire remanufacturing. The International Journal of Advanced Manufacturing Technology. v.49, n.9, p. 1223-1234, 2010.

[22]. SCAGLIUSI, S. R. Reciclagem de pneus inservíveis: alternativa sustentável à preservação do meio ambiente. São Paulo. 2011. 155 f. Tese (Doutorado em ciências e Tecnologia Nuclear) Universidade de São Paulo. São Paulo, 2011.

[23]. SOUZA, C. D. R. de; D'AGOSTO, M. D. A. Value chain analysis applied to the scrap tire reverse logistics chain: an applied study of coprocessing in the cement industry. Resources, Conservation and Recycling. v.78, n.1, p.15-25, 2013.

[24]. TADEU, H. F. B. et al. Logística reversa e sustentabilidade. São Paulo: Cengage Learning, 2012.

[25]. VERGARA, S. C. Projetos e relatórios de pesquisa em administração. 8. ed. São Paulo: Atlas, 2007.

[26]. VIANA, L. O. A logística reversa e o tratamento de pneus inservíveis no Estado do Piauí. Fortaleza. 2009. 159 f. Dissertação (Mestrado em Administração). Universidade de Fortaleza. Fortaleza, 2009. 


\section{Capítulo 8}

\section{RESPONSABILIDADE SOCIAL COMO ESTRATÉGIA DE RELACIONAMENTO COM O COLABORADOR: UM ESTUDO À LUZ DA PERCEPÇÃO DA GERÊNCIA DE RECURSOS HUMANOS}

\section{Ana Valéria Vargas Pontes}

Daiane Souza do Vale Carneiro

Ingrid de Oliveira

Marcelle Rosso Ferreira

Tatiane Dias da Cunha Vieira

Resumo: A Responsabilidade Social Empresarial (RSE) tem se tornado foco de muitas discussões no meio acadêmico, este trabalho procura relacionar essa temática com as políticas de gestão de pessoas. Esta pesquisa se propõe a descrever o conceito e a importância da RSE, abordar sobre a gestão de pessoas e sua interface com a responsabilidade social com foco no público interno e pesquisar quais são as ações de responsabilidade social desenvolvida por uma empresa multinacional localizada no interior do estado do Rio de Janeiro voltada para seus colaboradores. A metodologia utilizada quanto ao objetivo foi pesquisa exploratória, e em relação aos procedimentos bibliográficas e uma pesquisa de campo, para tanto foi desenvolvido um questionário semiestruturado para dar suporte a entrevista. Ao longo do estudo verifica-se que a empresa tem aplicado várias ações e que seus resultados podem ser facilmente percebidos.

Palavras-chave: Colaborador. Treinamento. Responsabilidade Social. Gestão de pessoas. 


\section{INTRODUÇÃO}

As empresas têm passado por grandes transformações tanto, no seu ambiente interno como no ambiente externo, uma das mudanças a ser considerada é a questão da Responsabilidade Social Empresarial.

Neste cenário as organizações participam como atores no âmbito sociocultural, econômico e ambiental, relacionando-se com outras instituições, com seus colaboradores, em fim com os seus stakeholders de forma geral. Nesta perspectiva, observa-se que as empresas têm investido cada vez mais em responsabilidade social, que abarca sete vetores, dentre eles, destaca-se a responsabilidade relacionada a investimento da organização no bem estar dos colaboradores e seus dependentes, bem como num ambiente de trabalho agradável.

Dai surge, então, a questão de investigação: como a gestão de pessoas pode contribuir para a responsabilidade social interna? E para tanto, este trabalho tem como objetivos descrever o conceito e a importância da responsabilidade social empresarial, abordar sobre gestão de pessoas e sua interface com a responsabilidade social com foco no público interno e pesquisar quais são as ações de responsabilidade social voltadas aos colaboradores desenvolvidas por uma empresa multinacional no interior do estado do Rio de Janeiro.

A metodologia utilizada para a elaboração deste artigo foi exploratória de cunho bibliográfico utilizando autores como Melo Neto; Brennand (2004) Melo Neto; Froes (2001); Limongi-França (2009), Marras (2000), Dutra (2006), dentre outros. Também realizouse uma pesquisa de campo cujo instrumento foi uma entrevista semiestruturada com a gerente de recursos humanos, a fim de verificar quais são as ações de responsabilidade social desenvolvidas pela empresa com foco em seus colaboradores.

\section{RESPONSABILIDADE SOCIAL}

Responsabilidade social pode ser entendida de várias maneiras, como obrigação legal, comportamento ético ou intenção de ser consciente.

Uma das definições de responsabilidade social é
[...] forma de gestão que se define pela relação ética e transparente da empresa com todos os públicos com os quais ela se relaciona e pelo estabelecimento de metas empresariais compatíveis com o desenvolvimento sustentável da sociedade, preservando recursos ambientais e culturais para as gerações futuras, preservando a diversidade e promovendo a redução das desigualdades sociais (PATENTE; GELMAN 2006, p.21).

É necessário que as organizações e os colaboradores nela inserido, tenham a consciência sobre os resultados de suas atividades na sociedade e no meio ambiente e também dos impactos positivos do seu trabalho na sociedade.

Para Ashley et al.(2002, p. 6), a responsabilidade social é "a obrigação do homem de negócios de adotar orientações, tomar decisões e seguir linhas de ação que sejam compatíveis com os fins e valores da sociedade". Assim, percebe-se que as organizações sentem a necessidade de criar ações que venham ao encontro dos seus objetivos valorizando o meio em que está inserida.

No que tange ao conceito de responsabilidade social é fundamental que se tenha a preocupação com todos, não somente, pensar nos interesses dos acionistas, passando a se envolver e a se comprometer com todos os seus stakeholders. Orchis et al. (2002) corrobora ao afirmar que responsabilidade social está relacionado com o comportamento ético da empresa com todos os grupos de interesse que influenciam ou são compactados pela sua atuação (stakeholders) assim como o respeito ao meio ambiente e investimentos em ações sociais. Stakeholders são os grupos que se relacionam, afetam ou são afetados pela organização e suas atividades. Os stakeholders são compostos por acionistas, empregados, fornecedores, concorrentes, governo, comunidade, sociedade, grupos e movimentos (ORCHIS et al,2002, p.56).

Nessa perspectiva que responsabilidade social é um comportamento ético e é preciso entender como são as partes que compõem essa estrutura.

Melo Neto e Froes (2001) destacam que são sete os vetores da responsabilidade social de uma empresa: 
V1 apoio ao desenvolvimento da sociedade onde atua; V2 preservação do meio ambiente; V3 investimento no bem-estar dos funcionários e seus dependentes e num ambiente de trabalho agradável; V4 comunicações transparentes; V5 retorno aos acionistas; V6 sinergia com os parceiros; V7 satisfação dos clientes e/ou consumidores (MELO NETO e FROES, 2001, p. 78).

Pode-se perceber no vetor três a importância da empresa investir no bem estar dos colaboradores e seus dependentes, bem como num ambiente de trabalho agradável.

Visto que os colaboradores são fundamentais para o desenvolvimento da organização, observa-se que a cultura da responsabilidade social deve estar inserida no ambiente corporativo, de forma a incentivar e comprometer seus colaboradores.

Somente podem chamar de colaboradores, em vez de funcionários, as organizações que buscam entender os anseios, as necessidades e as motivações dos seus funcionários, para que estes venham a desempenhar um novo papel, observado através do prisma de colaboradores ou parceiros de negócios (ZARPELON, 2006, p.50).

Acreditar no potencial de cada colaborador, reconhecê-los e motivá-los são fatores essenciais. De acordo com Hanashiro; Teixeira; Zaccarelli (2008) é preciso que haja "mudanças intencionais responsáveis promovidas no ambiente físico e social, no ambiente interno e externo".

As autoras salientam que:

Uma empresa com preocupações em responsabilidade social com relação a seus funcionários deve, portanto, cumprir com a legislação referente à saúde e segurança e, indo mais longe, deve englobar temas ligados a Qualidade de Vida no Trabalho (QVT) (HANASHIRO; TEIXEIRA; ZACCARELLI, 2008 p. 99).

Nota-se que a responsabilidade social vai bem além do que pode-se pensar, pois devese preocupar com a vida do colaborador dentro e fora de seu ambiente de trabalho. Nesta perspectiva, fez-se necessário abordar sobre a gestão de pessoas na empresa, bem como o papel das pessoas, o papel da empresa neste contexto de abordagem sobre a responsabilidade social e as políticas de relacionamento com os colaboradores.

\section{GESTÃO DE PESSOAS NAS EMPRESAS}

A gestão de pessoas é um assunto bastante em evidência nos últimos tempos e tem passado por constantes evoluções. Portanto, a necessidade de pesquisar sobre a gestão de pessoas nas organizações.

Entende-se por modelo de gestão de pessoas a maneira pela qual uma empresa se organiza para gerenciar e orientar o comportamento humano no trabalho. Para isso, a empresa se estrutura definindo princípios, estratégias, políticas e práticas ou processos de gestão. Por meio desses mecanismos, implementa diretrizes e orienta os estilos de atuação dos gestores em sua relação com aqueles que nela trabalham (FISCHER, 2012).

Ainda de acordo com o autor, o que distingue um modelo de outro são as características dos elementos que os compõem e sua capacidade de interferir na vida organizacional dando-lhe identidade própria. O modelo deve sim, por definição, diferenciar a empresa em seu mercado, contribuindo para a fixação de sua imagem e de sua competividade.

O conceito de gestão pessoas ou administração de recursos humanos, é uma associação de habilidades e métodos, políticas, técnicas e práticas definidas, com o objetivo de administrar os comportamentos internos e potencializar o capital humano nas organizações. Robbins (2004) confirma este posicionamento ao afirmar que:

Se a empresa contratar pessoas cujas habilidades são inadequadas, o desempenho não será bom, independentemente dos esforços da administração em proporcionar motivação e liderança, criar grupos eficazes ou projetar atividades desafiadoras. (ROBBINS, 2004, p. 225).

Percebe-se então, que a gestão de pessoas começa no planejamento, inclusive no recrutamento e seleção, para que sejam selecionados profissionais com perfil e habilidades necessárias para o cargo, oferecendo-Ihes frequentes treinamentos, de forma que a organização consiga atingir o desenvolvimento pessoal de cada colaborador, valorizando o mesmo e obtendo o resultado desejado da organização.

A gestão de pessoas pode ser analisada também pelos aspectos comportamental e administrativo. Limongi-França (2009, p, 5) traz uma discussão nesse sentido ao afirmar que "comportamento humano é baseado no 
que se percebe; as pessoas são diferentes entre si; as pessoas não se comportam por acaso; existem diferentes formas de influenciar o ser humano". Nota-se que cada um é realmente único. A autora ainda continua ao afirmar:

A gestão de pessoas deve ocorrer a partir da visão integrada das pessoas e de questões como: as expectativas sobre as relações de trabalho, o contrato psicológico entre o que a pessoa quer da empresa e o que esta quer de seu pessoal, perfis e tipos de personalidade, grupos, equipes, lideranças, processos de cooperação, apatia, cultura organizacional, valores, questões éticas, entre outros aspectos ligados à vida social. (LIMONGIFRANÇA, 2009, p, 4 e 6).

Observa-se, portanto, a importância deste estudo, pois a diversidade de pessoas torna o planejamento uma ferramenta essencial para atingir as expectativas nas relações de trabalho e a vida social.

\subsection{PAPEL DAS PESSOAS}

Segundo Ulrich (2003) o papel relativo á contribuição das pessoas passou por uma grande mudança no passado recente. Começaram a perceber que o capital intelectual e a valorização do indivíduo como parte integrante e atuante do processo geram maior lucratividade e bons negócios para a organização, desde então, a moderna gestão procura tratar as pessoas como pessoas e não apenas como recursos, além de perceberem que as mesmas não funcionam sozinhas, os cargos não tem vida própria, equipes, empresas, corporações são resultado de um trabalho de um grupo de pessoas e que as pessoas e suas atitudes irão contribuir para o sucesso ou fracasso da empresa.

As pessoas contribuem para o funcionamento de uma organização, pois são elas que gerenciam, controlam e executam os processos e atividades, além de consumir os seus produtos. Prado Filho (2007, p. 32) afirma que "a mão de obra deixou de ser considerada como um simples recurso ou insumo dos processos produtivos e passou a ser valorizada, pois é ela que tem a responsabilidade de gerenciar ações empresariais".

Observa-se que a organização é um organismo vivo, pois depende totalmente das pessoas para o desenvolvimento e execução de suas atividades, são elas que promovem transformações e potencializam a empresa a tomar decisões necessárias em direção ao sucesso, portanto deve-se valorizar o trabalho das mesmas nas diversas áreas apresentadas. As pessoas sentem necessidade de participar, de se sentir parte do processo, de saber que sua opinião é importante e que pode ser usada para melhorias e implementação de novos processos, essa participação pode favorecer nos resultados da organização.

De acordo com Bordenave (2008, p. 16):

A participação é o caminho natural para o homem exprimir sua tendência inata de realizar, fazer coisas, afirmar-se a si mesmo e dominar a natureza e o mundo. Além disso, sua prática envolve a satisfação de outras necessidades não menos básicas, tais como a interação com os demais homens, autoexpressão, o desenvolvimento do pensamento reflexivo, o prazer de criar e recriar coisas, e, ainda, a valorização de si mesmo pelos outros.

Nota- se que a participação das pessoas é essencial para o crescimento e a execução das atividades dentro de uma organização e a mesma está cada vez mais reconhecendo que o fator humano é fundamental para o bom funcionamento dos processos.

No ambiente empresarial mutável, global e tecnologicamente exigente, a obtenção e retenção de talentos são as armas no campo de batalha competitivo. "As empresas bem sucedidas serão aquelas mais experientes em atrair, desenvolver e reter indivíduos com habilidades, perspectiva e experiência suficientes para conduzir um negócio global" (ULRICH, 2003, p.29).

\subsection{PAPEL DAS EMPRESAS}

Ao refletir sobre o papel das empresas neste contexto cabe ressaltar o posicionamento de Dutra (2008, p. 17) "à empresa cabe o papel de estimular e dar suporte necessário para que as pessoas possam entregar o que têm de melhor, ao mesmo tempo em que recebem - que a organização tem de melhor a oferecer-lhes". Nesta perspectiva é necessário ter mútua interação com seu pessoal, juntamente da aplicação correta de diversas ferramentas para a alavancagem de aprendizado e competitividade.

A empresa pode assumir uma responsabilidade de suporte na busca de 
"conhecimentos", gerando nas pessoas satisfação de suas necessidades.

As organizações contam com uma série de ferramentas que as auxiliam na gestão de pessoas.

Dentre elas destaca-se a seleção de pessoal que:

é uma atividade de responsabilidade do sistema de Administração de Recursos Humanos, que tem por finalidade escolher sob metodologia específica, candidatos a emprego recebidos pelo setor de recrutamento, para atendimento das necessidades internas da empresa. (MARRAS, 2000, p. 79).

Ainda, de acordo com o autor nesse processo, faz-se uma análise de exigências do cargo, e das características dos candidatos, a partir da coleta de dados individuais. Para possibilitar a coleta de dados são utilizados instrumentos como: entrevista de Seleção estruturada e não estruturada, testes diversos de aferição, análise comportamental e dinâmicas de grupo.

Outra ferramenta utilizada na gestão de pessoas, trata-seda avaliação de desempenho em que Marras (2000), mostra que o desempenho humano está diretamente ligado a duas condições: querer fazer e saber fazer. Para medir esse desempenho foi criada a Avaliação de Desempenho. Este instrumento tem como objetivo principal mensurar o resultado dos colaboradores na organização para então, direcioná-los ao treinamento necessário.

Após analisar as características da organização, é possível obter um método para a aplicação da avaliação de desempenho, ao aplicá-la a empresa obtém a possibilidade de trabalhar habilidades e competências para a obtenção de resultados relacionados ao conhecimento e comportamento seus colaboradores.

Daí surge a necessidade de treinamento que de acordo com Marras (2000, p. 145), "o treinamento é um processo de assimilação cultural a curto prazo, que objetiva repassar ou reciclar conhecimentos, habilidades e atitudes relacionadas diretamente à execução de tarefas ou à otimização do trabalho".

Os treinamentos têm por objetivo alcançar e suprir a necessidade de conhecimento para a execução das tarefas elencadas em cada cargo. Ainda segundo o autor, podem ser específicos ou genéricos, e são divididos por etapas em sua aplicação como: diagnóstico do treinamento, planejamento e programação, execução do treinamento, avaliação do treinamento.

É importante ressaltar a importância do processo de treinamento, mas também do planejamento para arcar com seus custos, em busca de um melhor desenvolvimento para seus colaboradores.

\subsection{POLÍTICA DE VALORIZAÇÃO NA EMPRESA}

Há anos atrás as empresas eram menos suscetíveis às mudanças e as tomadas de decisões eram centralizadas e para alguns gestores o funcionário era visto apenas como um recurso dentro do processo produtivo.

De acordo com Limongi-França (2009, p.65) essa visão tem mudado e pode ser observada uma nova postura sobre o colaborador na qual, "[...], atualmente ele é tratado como fonte de vantagem competitiva. Já não há mais dúvidas de que o empregado é o principal agente no desempenho organizacional, de que é ele quem faz o diferencial".

Devido a essas mudanças e a grande competitividade despertou nas organizações a necessidade de investir e valorizar cada vez mais o capital humano, para o crescimento organizacional, desta forma as empresas precisam de mecanismos para manter seus colaboradores motivados e produtivos para ajudar no crescimento da empresa. Chiavenato (2010, p. 274) afirma que "os processos de oferecer recompensas ocupam lugar de destaque entre os principais processos de gerir as pessoas dentro das organizações, [...] a recompensa é fundamental", e poderá acontecer de várias formas: cargo ocupado, tempo de trabalho, nível de escolaridade, desempenho, entre outros itens que variam de acordo com a realidade de cada organização.

Para Limongi-França (2009, p.65) é importante diferenciar recompensas, remuneração e salário, onde estes muitas vezes se confundem:

Salário é basicamente a parte fixa da remuneração, paga em dinheiro e de forma regular (geralmente mensal). A remuneração envolve, além de salário, a remuneração variável (participações nos lucros e resultados, participação acionária) e os benefícios (assistência médica, valetransporte, seguro de vida em grupo etc.). E a 
remuneração, como foi visto é uma das formas de recompensa.

Cabe salientar que todo benefício tem um custo para a empresa e para implementá-los é necessário planejamento, a fim de se alcançar a eficácia.

Melo Neto; Brennand (2004) destacam que as empresas socialmente responsáveis são bastante focadas nas ações de recursos humanos, e para tanto, algumas práticas são observadas como eticamente necessárias como: seleção, contratação, remuneração direta e indireta, capacitação, treinamento e desenvolvimento de pessoal, pesquisas de clima organizacional, ações para a melhoria da qualidade de vida no trabalho, bem como as questões sobre ergonomia, alimentação, segurança e higiene, atividades de lazer, avaliação de desempenho.

Nesta perspectiva, surge também, o desafio de empresas trabalharem a gestão da diversidade que para Hays-Thomas (2006 apud Marinez; Limongi-França 2009) se refere aos processos e estratégias que fazem as diferenças entre as pessoas um ativo valioso, mais que um ônus para as organizações. E, portanto, cabe a empresa planejar e incrementar programas no sentido de aumentar a interação entre essas pessoas, para fazer essa diversidade um recurso de criatividade, complementaridade e aumento de efetividade organizacional, progresso e satisfação dos colaboradores, mais que uma força de tensão, conflito, desentendimentos, ou restrição de eficácia.

\section{A RELAÇÃO ENTRE RESPONSABILIDADE SOCIAL E GESTÃO DE PESSOAS}

A responsabilidade social numa perspectiva do colaborador precisa de efetiva gestão de pessoas para que possa cumprir de forma eficaz seu compromisso com seu público interno.

Para Melo Neto; Brennand (2004) a Gestão de Pessoas realiza um papel fundamental para a empresa, colaborando constantemente para o desenvolvimento do seu potencial e nos processos que garantem a realização de suas propostas no campo da Responsabilidade Social. Sendo assim, funciona como setor estratégico, não somente, formando equipes sintonizadas com a Responsabilidade Social, mas oferecendo capacitação adequada ao público interno, promovendo políticas de reconhecimento individual e coletivo, inserindo-o em uma cultura participativa e criativa. De acordo com o autor Melo Neto; Brennand (2004, p.109):

Como agentes sociais, empregados e seus dependentes desempenham papéis dentro e fora da empresa. São promotores da responsabilidade social corporativa ao trabalharem como voluntários em programas sociais, ao difundirem valores éticos em suas relações com os diversos públicos da empresa, ao assumirem comportamentos sociais responsáveis em seu cotidiano de vida e de trabalho.

Nota-se que os colaboradores, e seus dependentes são vistos como agentes sociais, cujo comportamento gera um impacto relevante, tanto na empresa, quanto na comunidade e na sociedade em que está inserida. $E$ que os mesmos divulgam suas ações sociais e sentem seus benefícios junto a seus familiares e vizinhos.

Ainda segundo o autor, o aumento da produtividade é o maior retorno obtido pela empresa em todo o processo de gestão dos investimentos sociais no seu público interno. Além deste retorno, Melo Neto; Brennand (2004) ressaltam que a empresa que tem como prioridade a Responsabilidade Social interna obtém outros tipos de retorno, como por exemplo:

a) Retenção de talentos.

b) Melhoria na qualidade de vida dos seus empregados.

c) Maior integração de vida no trabalho e de sua família e de ambos na comunidade.

d) Aumento da autoestima dos empregados.

e) Melhoria no clima organizacional.

f) Retorno sob a forma de cidadania profissional (transformação dos empregados em empregados-cidadãos), entre outros.

$\mathrm{Na}$ medida em que se investe nas pessoas, a empresa transforma-as em seu principal ativo, não apenas humano e intelectual, mas também social. Suas atitudes e seus comportamentos agregam valores à empresa e conseqüentemente retornos favoráveis para a sociedade em que está inserida.

O foco interno é uma das facetas mais importantes da prática de responsabilidade social por parte das empresas, pois representam políticas e ações focadas em seu próprio corpo de trabalhadores, que devem permear a concepção da gestão de pessoas nas organizações, abrangendo o comportamento humano, o sentido do trabalhado e os desafios que a gestão de 
recursos humanos enfrenta para propiciar a inclusão social no ambiente interno das empresas.(CHANLAT, 2005, p.49)

Nota-se que a Gestão de Pessoas de uma empresa pode oferecer uma contribuição importante ao gerenciar a Responsabilidade Social interna, como por exemplo, melhorias no ambiente organizacional junto a missão social da organização, melhoria na integração, no relacionamento e participação de todos os membros da organização.

A Responsabilidade Social interna caracteriza - estágio inicial da cidadania empresarial. Para Melo Neto (2004, p.80) o primeiro estágio do processo de gestão empresarial tem como foco "as atividades regulares da empresa, saúde e segurança dos funcionários e qualidade do ambiente de trabalho".

Muitas empresas cometem o erro de investir somente no gerenciamento externo, gerando descontentamento entre os colaboradores, e um quadro conflituoso, por falta de motivação.

Com isso pode-se dizer que a Responsabilidade Social tem como foco trabalhar o público interno, desenvolvendo um modelo de gestão baseada no reconhecimento de seus colaboradores, por meio de uma comunicação transparente e os motivando a alcançar desempenhos favoráveis que possam refletir positivamente na sociedade em que estão inseridos.

Sendo assim, pode-se entender que a ideia principal da Responsabilidade Social para a área de Gestão de Pessoas é baseada na ética e no respeito pelo colaborador.

Uma empresa que cria um ambiente agradável de trabalho e valoriza seus stakeholders é capaz de desenvolver um modelo de gestão integrado, onde as pessoas têm um papel decisivo no seu compromisso com relação à sociedade de uma maneira geral.

\section{APRESENTAÇÃO E ANÁLISE DOS RESULTADOS}

\subsection{METODOLOGIA}

A metodologia da pesquisa é, de acordo com Gil (2008), um conjunto de ações propostas para encontrar a solução de um problema, que tem por base métodos científicos, racionais e sistemáticos. Este trabalho foi realizado a partir de uma pesquisa de caráter exploratória realizada em determinado campo em que há pouco conhecimento acumulado e sistematizado (VERGARA, 2007), e também descritiva que de acordo com Gil (2008, p. 44):

As pesquisas deste tipo têm como objetivo primordial a descrição das características de determinada população ou fenômeno. [...] As pesquisas descritivas são juntamente com as exploratórias, as que habitualmente realizam os pesquisadores sociais preocupados com a atuação prática.

Quanto aos meios uma pesquisa bibliográfica que envolveu os trabalhos Melo Neto; Brennand (2004), Melo Neto; Froes (2001) Limongi-França (2009), Marras (2000), Dutra (2006), dentre outros, com o intuito de compreender o conceito da responsabilidade social empresarial, entender a importância da gestão de pessoas e sua interface com a responsabilidade social com foco no público interno.

Foi utilizada como metodologia uma análise qualitativa das informações levantadas por meio de um questionário semiestruturado, a fim de nortear a entrevista que buscou trazer esclarecimentos sobre responsabilidade social como estratégia de relacionamento com o colaborador. Este método possibilita identificar as características de determinado público.

Essa pesquisa foi realizada em uma unidade que faz parte de um grupo de empresas, ou seja, é uma Joint Venture, líder do mercado norte americano no seu ramo de atuação. A entrevista foi realizada com a gerente de Recursos Humanos da unidade localizada no interior do estado do Rio de Janeiro, esta planta conta com aproximadamente 220 colaboradores. A missão desta empresa é fornecer produtos de alta qualidade; o melhor suporte técnico para as operações de seus clientes; inovações tecnológicas com criação de vantagens competitivas; serviços que beneficiem e superem as expectativas de seus clientes, e por isso possui equipamentos de alta precisão e tecnologia de ponta; aplicam as diretrizes estabelecidas pela organização, possui equipe treinada e qualificada, além de ser moderna e eficiente nos serviços prestados.

\subsection{ANÁLISES DA PESQUISA}

A pesquisa qualitativa teve 0 intuito de explorar as ações de Responsabilidade Social como estratégia de relacionamento com o 
colaborador à luz da percepção da gerência de Recursos Humanos. Para tanto, foi realizada uma entrevista com a gestora de Recursos Humanos da empresa em foco. Como instrumento de pesquisa foi construído um questionário semiestruturado baseado nos indicadores do Instituto Ethos (2013), que são ferramentas de avaliação e aprendizado da empresa no que tange à inclusão de práticas de Responsabilidade Social. A internalização desses conceitos por parte dos gestores, de acordo com o Instituto Ethos pode fomentar mudanças na forma de gerenciar os negócios, como também, na tomada de decisão colaborando, assim, para o nascimento de novos valores sociais e também para a redução das desigualdades.

Este instrumento de avaliação é composto de oito indicadores de Responsabilidade Social Empresarial com foco no público interno. Passa-se então, a análise da pesquisa.

\section{INDICADOR 1: GESTÃO PARTICIPATIVA}

$\mathrm{Na}$ entrevista quando questionada sobre as ideias de melhorias para a empresa, foi dito que existe um programa de sugestões onde os colaboradores podem sugerir melhorias nos quatro pilares aplicados pela empresa, sendo estes: processo, qualidade, segurança e produção. Estas sugestões são avaliadas mensalmente e no final do ano as quatro melhores sugestões dadas no decorrer do ano são implementadas, o colaborador é reconhecido, sendo homenageado na festa de final de ano com troféu e certificado. Percebe-se ainda na fala que, a organização trabalha com um programa inteligente para que estas sugestões deem resultados positivos ao negócio. O que é confirmado na fala de Bordenave (2008, p.16) ao afirmar que

A participação é o caminho natural para o homem exprimir sua tendência inata de realizar, fazer coisas, afirmar-se a si mesmo [...] tais como a interação com os demais homens, autoexpressão, o desenvolvimento do pensamento reflexivo, o prazer de criar e recriar coisas, e, ainda, a valorização de si mesmo pelos outros.

\section{INDICADOR 2: VALORIZAÇÃO DA DIVERSIDADE}

Quando indagada sobre a prática da diversidade na empresa, pôde-se notar na fala da entrevistada que a organização utiliza critérios no sentido de não fazer nenhum tipo de discriminação seja por raça, cor, religião, situação econômica entre outras diferenças sociais, sendo esta, uma estratégica da diretoria de recursos humanos juntamente com outras diretorias da organização, mesmo que um ou outro diretor não concorde, ele tem que se adequar, pois esta é uma política da empresa. Foi colocado que os colaboradores estão acostumados com a diversidade sendo esta atitude comum na prática da empresa.

$\mathrm{O}$ que pode ser confirmado por Hays-Thomas (2006 apud Marinez; Limongi-França 2009) ao se referirem a diversidade aos processos e estratégias que fazem as diferenças entre as pessoas um ativo valioso, mais que um ônus para as organizações. E, portanto, cabe a empresa aumentar a interação entre essas pessoas, para fazer essa diversidade um recurso de criatividade, complementaridade e aumento de efetividade organizacional.

Nesse sentido pode-se observar que a diversidade é bem trabalhada, pois se trata de uma das políticas da empresa, e, portanto, não é uma novidade a questão da diversidade de raça, cor, religião e situação econômica.

\section{INDICADOR 3: CRITÉRIOS DE CONTRATAÇÃO}

A empresa realiza seleção interna, com o objetivo de valorizar seu colaborador, e externa, quando há outras demandas de contratação que não foram possíveis preencher com a seleção interna.

Na questão que abrange a contratação pode se perceber que são selecionados profissionais que atendam as exigências de cada cargo, e caso seja necessário são redirecionados para outras vagas que sejam mais compatíveis com os respectivos perfis dos candidatos.

De acordo com Fleury, "as competências devem agregar valor econômico para a organização e valor social para o indivíduo". (FLEURY; FLEURY, 2001, p. 21).

São utilizadas algumas ferramentas para que seja possível identificar as habilidades do candidato. As ferramentas utilizadas dependem da vaga que se pretende preencher. Em caso do perfil do candidato ser diferente do perfil que é exigido, existe a possibilidade de aplicar treinamentos ou orientações para auxiliar na adaptação à vaga. 
De acordo com o cargo a ser preenchido aplica- se provas escritas ou práticas. Após a contratação são realizadas algumas ações de integração de $\mathrm{RH}$, Segurança e Qualidade, conhecimentos teóricos e práticos de acordo com a função.

\section{INDICADOR 4: COMPROMISSO COM A NÃO DISCRIMINAÇÃO DA EQUIDADE RACIAL, DE GÊNERO E OUTROS.}

Questionada sobre a contratação responsável, ou seja, de deficientes, negros, menor aprendiz, aposentados entre outros foi dito que não é uma cultura institucionalizada da empresa, portanto, não há obrigação da contratação dessas pessoas, porém a empresa é responsável socialmente e o $\mathrm{RH}$ como guardião das políticas da empresa, mesmo que essas não estejam inscritas ou institucionalizadas, é preciso defender essa questão, portanto contratam aprendizes, deficientes e aposentados, hoje a empresa possui dois aposentados em seu quadro de funcionários. Além, das contratações mencionadas anteriormente os colaboradores que apresentam problemas com dependência química recebem ajuda de clínicas junto à empresa.

Embora caiba ressaltar que não se trata de diretrizes optativas, pois segundo (BRASIL, 1991) na lei 8.213/91, em seu artigo 93, regula a obrigatoriedade das empresas com 10 ou mais empregados a contratar pessoas portadoras de deficiência física.

\section{INDICADOR 5: POLÍTICA DE REMUNERAÇÃO, BENEFÍCIOS E CARREIRAS}

Nota-se na fala da entrevistada que na empresa remuneração direta é o salário, considerado um dos melhores na região, o plano de benefícios envolve plano de saúde, plano odontológico, seguro de vida, previdência privada, participação nos resultados, transporte e alimentação e com as políticas da empresa as pessoas são beneficiadas com salários indiretos. Marras (2000) enfatiza que um planejamento adequado de remuneração e benefícios pode contribuir para a satisfação do colaborador. Na perspectiva de investimento na carreira é ressaltado que $\mathrm{o}$ funcionário tem a oportunidade de construir uma carreira sólida, pois o mesmo conta com bolsa de graduação, bolsa de idiomas, treinamentos externos específicos de acordo com o seu desenvolvimento e desempenho na organização.

\section{INDICADOR 6: COMPROMISSO COM DESENVOLVIMENTO PROFISSIONAL E A EMPREGABILIDADE}

Nota-se na fala da entrevista que a empresa tem preocupação com aperfeiçoamento e capacitação de seus colaboradores quando investem em treinamentos específicos para cada área e atividade, disponibilidades de estudos como graduação, língua estrangeira, cursos técnicos para aqueles que obtiverem melhores notas na Avaliação, buscando proporcionar ao colaborador desenvolvimento profissional e consequentemente obter uma equipe mais capacitada, possuem avaliações de desempenho $360^{\circ}$, pesquisa organizacional com o intuito de proporcionar a análise do ambiente, a fim de subsidiar a tomada de decisão com informações necessárias.

De acordo com Chiavenato (2010), a empregabilidade surgiu em resposta a diferença entre a velocidade das mudanças tecnológicas, as quais exigem do indivíduo novos conhecimentos e habilidades e a velocidade da reaprendizagem, ou seja, a busca constante do desenvolvimento de habilidades e competências agregadas por meio do conhecimento específico e pela multifuncionalidade, as quais tornam o profissional apto à obtenção de trabalho dentro ou fora da empresa. .

\section{INDICADOR 7: ENVOLVIMENTO COM AÇÃO SOCIAL}

A responsabilidade social vem sendo assunto de interesse de muitas empresas. Percebe- se que uma sociedade empobrecida, com renda mal distribuída, violenta, não é uma sociedade propícia para os negócios. (GRAJEW, 2001, p. 56).

A responsável pelo $\mathrm{RH}$, a respondente, salienta o envolvimento dos colaboradores na ação social conhecida como Praça Ativa, a qual é um projeto de sustentabilidade, meio ambiente e cidadania que acontece em praça pública levando para as comunidades recreação, arte, serviços de utilidade pública e projetos socioambientais desenvolvidos localmente. A Praça Ativa expressa o conjunto de valores da empresa, por meio das ações desenvolvidas por ocasião desse evento, 
como: educação, respeito ao meio ambiente, segurança e qualidade de vida são caminhos pelos quais a empresa conduz seus negócios e se relaciona com as comunidades do entorno de suas unidades fabris. Esse projeto valoriza a arte, a cultura e o conhecimento produzidos nas cidades onde é realizado e, por isso, apresentam projetos de expositores e artistas locais através de shows musicais, apresentações de danças, oficinas de reciclagem, brinquedos $e$ atividades voltadas à saúde e cidadania.

Observa-se então a preocupação da empresa segundo Zarpelon (2006), em assumir diante da sociedade, a preocupação com melhor qualidade de vida, crescimento e desenvolvimento da comunidade, e Ashley (2002), continua ao afirmar que a Responsabilidade Social pode ser vista como toda e qualquer ação que venha a contribuir com a melhoria da qualidade de vida da população, representado através de ações e atitudes que tragam algo de positivo para qualquer comunidade, demonstrando uma postura coerente da organização.

\section{INDICADOR 8: ACESSO A INFORMAÇÃO}

Quanto à questão de circulação de informação pode-se perceber que a empresa se preocupa e prioriza a disseminação da informação. Utiliza-se de quadros de avisos, e-mail, TV corporativa, e reuniões antes do início dos turnos para comunicar aos colaboradores as prioridades do dia.

O sigilo ás informações é um aspecto que preocupa as organizações. Cumprir com o sigilo é reconhecer o código de ética, além de se comportar de acordo com o voto de confiança que a empresa concedeu ao colaborador.

Ficou evidente que existe uma relação de comunicação entre a empresa e o colaborador, conhecido também, como Endomarketing. Esta busca adaptar estratégias e elementos do marketing tradicional, para uso no ambiente interno das corporações.

\section{CONSIDERAÇÕES FINAIS}

Após a revisão da literatura e a pesquisa de campo que teve como questão de investigação: como a gestão de pessoas pode contribuir para a responsabilidade social interna? Pode-se perceber nas várias falas da entrevistada, responsável pela gestão de pessoas, que a empresa tem realizado várias ações de responsabilidade social empresarial com foco no público interno. Como descrito na análise da pesquisa o questionário foi embasado nos indicadores do Instituto Ethos (2013) que avalia as ações da empresa no que tange às práticas de Responsabilidade Social voltadas para 0 público interno. O que permitiu observar com os dados coletados que a gestão de pessoas da empresa, foco desse estudo, tem implementado uma série de ações de Responsabilidade Social propostas e avaliadas nos oito indicadores.

Cabe salientar que apenas no indicador dois que trata da valorização da diversidade, percebe-se que a organização não descrimina, mas também não utiliza essa diversidade a favor de uma equipe que poderia ser mais criativa por ter na sua essência pessoas com habilidades e competência diferenciadas. No entanto, dentre os outros sete indicadores nota-se que a gestão de pessoas tem efetivamente trabalhado na perspectiva de incentivar e comprometer seus colaboradores, e também tem se interessado pela vida do funcionário dentro e fora do seu ambiente de trabalho, dessa forma proporcionando crescimento, aprendizado, e respeito ao seu público interno, seus colaboradores.

E por fim, entende-se que a gestão de pessoas tem o objetivo de gerenciar e organizar o comportamento humano dentro da empresa, ou seja, administrar e potencializar o capital humano, promovendo e garantindo a realização das propostas e políticas de Responsabilidade Social Empresarial interna, e possibilitando como resultado obter a satisfação do colaborador, bem como o diferencial de competitividade organizacional. Espera-se que este trabalho possibilite uma melhor compreensão a respeito do tema Responsabilidade Social Empresarial e sua relação com as práticas de Gestão de Pessoas. Vale registrar que não se teve a intenção de esgotar o tema, e sim de contribuir e instigar para que outras pesquisas sejam desenvolvidas a partir desta perspectiva. 


\section{REFERÊNCIAS}

[1] Almeida, Marcus Garcia de. Pedagogia empresarial: Saberes, Práticas e Referências. Rio de Janeiro: Brasport, 2006.

[2] Ashley, Patrícia Almeida et al. Ética e responsabilidade social nos negócios. São Paulo: Saraiva, 2002.

[3] Bordenave, Juan E. Diaz. O que é participação. 8aㅡ ed. São Paulo: Brasiliense, 2008.

[4] Brasil. Ministério da Justiça. Lei 8213 de 24 de julho de 1991. Disponível em http://www.planalto.gov.br/ccivil_03/leis//8213cons. htm. Acesso: 15/03/2015.

[5] Chanlat, Jean-François. Revista GV Executivo. São Paulo, v. 4, n. 1, p. 49, fev/abr. 2005.

[6] Chiavenato, Idalberto. Gestão de Pessoas: o novo papel dos recursos humanos nas organizações. 3. ed. Rio de Janeiro: Elsevier, 2010.

[7] Dutra, Joel Souza. Gestão de pessoas: modelo, processos, tendências e perspectivas. São Paulo: Atlas, 2008.

[8] Fischer, A. L. Um resgate conceitual histórico dos modelos de Gestão de Pessoas. In: Fleury, M. T. L. (Org.). As pessoas na organização. São Paulo: Gente, 2012.

[9] Gil, Antônio Carlos. Métodos e técnicas de pesquisa social. 6 ed. São Paulo: Atlas ,2008.

[10] Grajew, O. Responsabilidade Social nas Empresas. São Paulo: Atlas, 2001.

[11] Hanashiro, Darcy MitikoMori; Teixeira Maria Luisa Mendes; Zaccarelli Laura Menegon. Gestão do fator humano: uma visão baseada nos 2.ed.-São Paulo: Saraiva, 2008.

[12] Limongi-França, Ana Cristina. Práticas de Recursos Humanos PRH: Conceitos, ferramentas e procedimentos/Ana Cristina Limongi França -!. Ed. - 3. Reimpr- São Paulo: Atlas, 2009.
[13] Marras, Jean Pierre. Administração de Recursos Humanos: do operacional ao estratégico. 3. ed. São Paulo: Futura, 2000.

[14] Martinez, Victor de La Paz Richarte; Limongi-França, Ana Cristina. Diversidade e Socialização nas Organizações: a inclusão e permanência de pessoas com deficiência. XXXIII Encontro da Anpad, Enanpad, 2009.

[15] Melo Neto, Francisco Paulo de; Froes, César. Gestão da Responsabilidade social corporativa: o caso brasileiro. Rio de Janeiro: Qualitymark, 2001.

[16] Melo Neto, Francisco de Paula; Brennand, Jorgiana Melo. Empresas Socialmente Responsáveis. O novo desafio da Gestão Moderna. Rio de Janeiro: Qualitymark, 2004.

[17] Orchis, M. et al. Impactos da responsabilidade social nos objetivos e estratégias empresariais. In. Responsabilidade social nas empresas: a contribuição das universidades. São Paulo: Peirópolis, 2002.

[18] Patente, Juraci; Gelman, Jacob Jacques. Varejo e responsabilidade social. Porto Alegre: Bookmann, 2006.

[19] Prado Filho, Hayrton Rodrigues do. A valorização do capital humano no ambiente empresarial. São Paulo, ano XVII, n. 185, 2007.

[20] Robbins, Stephen P.. Fundamentos do Comportamento Organizacional. 7.ed. São Paulo: Pearson Prentice Hall, 2004.

[21] Ulrich, D. Uma nova ordem para recursos humanos. In: Ulrich, D. (Org.). Recursos humanos estratégicos: novas perspectivas para os profissionais de RH. São Paulo: Futura, 2003.

[22] Vergara, Sylvia C. Projetos e relatórios de pesquisa em Administração. 8. ed. São Paulo: Atlas, 2007.

[23] Zarpelon, Márcio Ivanor. Gestão e responsabilidade social: NBR16.001/SA 8.000. Rio de Janeiro: Qualitymark, 2006. 


\section{Bapítulo 9}

\section{A Vila AUtÓdROMO, SEU Histórico de LUTA E REMOÇÕES.}

\section{Moyses Jaime Zeitune}

Lincoln de Lima Faria

Guilherme Faria Souza Mussi de Andrade

Joás Lessa Martins

Resumo: Este artigo apresenta o histórico de tentativas de remoções dos moradores da Vila Autódromo desde a criação da comunidade, as garantias dadas por diferentes prefeitos no decorrer de seus mandatos e, sobretudo, mostrar o direito desses moradores segundo as leis específicas. Além dos próprios conflitos urbanos e de moradia dessa comunidade, principalmente após a notícia de que o Rio de Janeiro sediaria as Olimpíadas 2016.

Palavras-chave: Remoção, Direito de Moradia; Remoção; Olimpíadas. 


\section{INTRODUÇÃO}

A Vila Autódromo é uma comunidade consolidada na Baixada de Jacarepaguá há mais de 40 anos. Originalmente uma vila de pescadores, Vila Autódromo torna-se, nos anos 1970, uma oportunidade para a moradia de centenas de migrantes operários e trabalhadores informais que chegaram à região para a construção do autódromo de Jacarepaguá, do metrô e dos novos empreendimentos imobiliários que despontavam no local. Outras famílias foram ali assentadas em razão da remoção de outra comunidade, chamada Cardoso Fontes. Pescadores, operários, desempregados, trabalhadores informais, famílias removidas e migrantes formam a rede social que irá paulatinamente urbanizar e garantir as condições de vida na comunidade. O sistema utilizado é o denominado "mutirão", pelo qual os moradores constroem não só suas casas, mas todo o espaço urbano, incluindo ruas, calçadas, rede de distribuição de água, sistema sanitário, creches, escolas e espaços de convívio, como o campo de futebol, a igreja e a sede da associação de moradores.

Além de ser um espaço construído pelo trabalho contínuo dos moradores, Vila Autódromo aparece também como uma rede diversificada de trabalhadores da cidade: eletricistas, bombeiros, mecânicos, porteiros, pedreiros, costureiras, pequenos comerciantes, entre outros, realizam uma dinâmica prestação de serviços fundamentais para a vida urbana. $O$ trabalho de construção da cidade se confunde, aqui, com as atividades prestadas para a cidade.

Para clarificar as questões que cercam a luta dos moradores da Vila Autódromo ao reivindicar o direto de moradia, na contramão dos interesses específicos de um planejamento urbano para sediar as Olímpiadas 2016, é fundamental mostrar os instrumentos de política pública urbana que conferem certa legalidade à remoção, conforme será apresentado a seguir.

\section{INSTRUMENTOS DE POLÍTICA URBANA}

\section{1. ÁREAS DE ESPECIAL INTERESSE}

As Áreas de Especial Interesse, permanentes ou transitórias, são espaços da Cidade perfeitamente delimitados sobrepostos em uma ou mais Zonas ou Subzonas, que serão submetidos a regime urbanístico específico, relativo à implementação de políticas públicas de desenvolvimento urbano e formas de controle que prevalecerão sobre os controles definidos para as Zonas e Subzonas que as contêm.

As Áreas de Especial Interesse, conforme disposto no art. 70 do Plano Diretor de Desenvolvimento Urbano Sustentável se dividem em:

$$
\begin{aligned}
& \text { Área de Especial Interesse } \\
& \text { Urbanístico - AEIU; } \\
& \text { AEIS; } \quad \text { Área de Especial Interesse Social - } \\
& \text { - AEIA; } \\
& \text { - AEIT; } \quad \text { Área de Especial Interesse Ambiental } \\
& \text { - AEIF; } \quad \text { Área de Especial Interesse Funcional } \\
& \text { - AEIG; } \quad \text { Área de Especial Interesse Agrícola - } \\
& \text { - AEIC. Área de Especial Interesse Cultural - }
\end{aligned}
$$

A declaração das áreas sujeitas à intervenção numa das categorias previstas neste artigo se dará através de instrumento legal específico ou da legislação de uso e ocupação do solo local, que definirão sua abrangência. A legislação de uso e ocupação do solo local poderá indicar as áreas sujeitas à intervenção através da declaração de Áreas de Especial Interesse.

\section{2. ÁREA DE ESPECIAL INTERESSE SOCIAL}

Área de Especial Interesse Social (AEIS), é aquela ocupada por favelas, loteamentos irregulares e conjuntos habitacionais, destinada a programas específicos de urbanização e regularização fundiária, ou ainda aquela que apresenta terrenos não utilizados ou subutilizados e considerados necessários à implantação de programas habitacionais de baixa renda, e são previstas no Plano Diretor e demarcadas na Lei de Zoneamento.

As edificações e ocupações situadas em áreas de risco, faixas marginais de proteção de águas superficiais, faixas de domínio de estradas municipais, estaduais e federais, faixas de domínio da linha férrea e em áreas de recuo deverão ser objeto de programas que promovam sua relocação para áreas em condições de habitabilidade adequadas de acordo com as premissas e diretrizes estabelecidas pelo Plano Diretor de 
Desenvolvimento Urbano Sustentável e pelo Plano Municipal de Habitação, no que concerne ao reassentamento de moradias.

A declaração de Área de Especial Interesse Social, através de lei de iniciativa do poder executivo, definirá os limites da área e poderá estabelecer parâmetros de uso e ocupação do solo específicos para a AEIS.

Em suma, os parâmetros de uso e ocupação do solo definidos para as Áreas de Especial Interesse Social deverão ser considerados quando da elaboração da legislação de uso e ocupação do solo local.

Mais adiante, será observado que tal instrumento é utilizado para viabilizar a remoção dos moradores da Vila Autódromo em prol dos projetos urbanos complementares à Olimpíada 2016. Como contraponto, a seguir, será apresentado os instrumentos que de certa forma deveriam assegurar o direito de moradia dessa comunidade.

\section{INSTRUMENTOS DE POLÍTICAS PÚBLICAS: PRERROGATIVAS PARA EVITAR AS REMOÇÕES DOS MORADORES DA VILA AUTÓDROMO.}

\subsection{O DIREITO À MORADIA}

O direito à moradia é um direito humano protegido pela Constituição Brasileira de 1988 e pelos Instrumentos Internacionais. Os cidadãos brasileiros são sujeitos de direito internacional aptos a exigir processualmente a promoção e o cumprimento de seus direitos humanos junto aos organismos internacionais de proteção. Essa relação entre indivíduos, Estados Nacionais e Organismos Internacionais decorre da adoção pelas Nações Unidas dos Pactos Internacionais de Direitos Civis e Políticos e de Direitos Sociais, Econômicos e Culturais (1966), cujo fundamento é a Declaração Universal dos Direitos Humanos.

Desse modo, os direitos humanos econômicos, sociais e culturais constituem-se pretensão dos indivíduos ou da coletividade perante o Estado, os quais são reconhecidos pelas Constituições democráticas modernas e integram a legislação positiva de grande parte dos Estados contemporâneos. Entretanto, a positivação destes direitos não tem significado sua efetivação e concretização para as pessoas que habitam os países em desenvolvimento.
Vale ressaltar que, na Constituição Brasileira de 1988, o direito à moradia está previsto como um direito social, a exigir a ação positiva do Estado por meio da execução de políticas públicas habitacionais. É obrigação do Estado impedir a regressividade do direito à moradia e também tomar medidas de promoção e proteção deste direito.

Além disso, os compromissos que constam nos Tratados e Convenções internacionais têm natureza vinculante aos países signatários, acarretando obrigações e responsabilidades aos Estados pela falta de cumprimento das obrigações assumidas.

Com base no exposto, é possível afirmar que o Estado brasileiro tem a obrigação de adotar políticas públicas de habitação que assegurem a efetividade do direito à moradia. Tem também responsabilidade de impedir a continuidade de programas e ações que excluem a população de menor renda do acesso a uma moradia adequada.

Portanto, verifica-se que a dimensão dos problemas urbanos brasileiros contém a questão habitacional como um componente essencial da atuação do Estado Brasileiro como promotor de políticas voltadas para a erradicação da pobreza, a redução das desigualdades e a justiça social. A cidade informal evidencia a necessidade de construção de uma política urbana que vise a inclusão social e territorial da população, tendo como meta a regularização fundiária e a urbanização dos assentamentos de baixa renda.

\subsection{INSTRUMENTOS DE CUMPRIMENTO DA FUNÇÃO SOCIAL DA PROPRIEDADE URBANA}

O Estatuto da Cidade estabelece princípios e diretrizes que expressam uma nova concepção dos processos de uso, desenvolvimento e ocupação do território urbano que deve orientar a ação dos agentes públicos e privados na reconstrução das cidades sob a ótica da justiça, democracia e sustentabilidade. Cidade e propriedade adquirem novo significado e alcance no contexto da ordem jurídico urbanística brasileira frente à exigibilidade constitucional de que ambas têm de atender a funções sociais quanto ao acesso, utilização e distribuição de suas riquezas e possibilidades. 
A nova lei apresenta quatro inovações fundamentais: a consolidação de um novo marco jurídico-político relativo à propriedade urbana, que deve orientar a formulação de normas de Direito Urbanístico; a instituição e regulamentação de instrumentos que vão garantir a sustentação de uma ordem urbana socialmente justa e includente pelos municípios; a garantia da gestão democrática das cidades pelos agentes que a produzem, constroem e utilizam; e a regulamentação de instrumentos de regularização fundiária dos assentamentos informais em áreas urbanas municipais.

O Estatuto define os instrumentos que o poder público, especialmente o Município, deve utilizar para enfrentar os problemas de desigualdade social e territorial nas cidades:

- Instrumentos de garantia do cumprimento da função social da propriedade - plano diretor, parcelamento e edificação compulsórios, imposto sobre a propriedade imobiliária urbana progressivo no tempo, desapropriação com títulos da dívida pública, direito de preempção, outorga onerosa do direito de construir (solo criado);

- Instrumentos de regularização fundiária usucapião urbano, concessão especial para fins de moradia, concessão do direito real de uso, zonas especiais de interesse social;

- Instrumentos de gestão democrática da cidade - conselhos de política urbana, conferências da cidade, orçamento participativo, audiências públicas, iniciativa popular de projetos de lei, estudo de impacto de vizinhança.

A Lei Federal 6.766/79, alterada pela Lei Federal no 9.788/99, prevê a possibilidade do poder público assumir a regularização fundiária de loteamentos clandestinos implantados sem a observância das normas urbanísticas e sem a autorização da Prefeitura e Registro de Imóveis, em benefício das pessoas que adquiriram terrenos de boa-fé. Essa legislação protege o direito à moradia e a segurança da posse da população que reside em conjuntos habitacionais ou terrenos localizados em loteamentos irregulares. Também estabelece medidas penais que devem ser aplicadas contra os proprietários que praticam crimes urbanísticos, vendendo terrenos em áreas não parceladas ou urbanizadas, além de considerar esta prática como crime contra a Administração Pública.
Quanto à proteção aos despejos forçados, o Estatuto da Cidade prevê a utilização de dois instrumentos:

- Usucapião urbano, que pode ser invocado como matéria de defesa em ações que visem a remoção da população moradora em áreas irregulares. A sentença judicial que reconhecer o usucapião urbano valerá como título para registro da propriedade em nome do ocupante no Registro de Imóveis;

- Zonas especiais de interesse social uma vez instituídas sobre áreas com ocupação irregular de baixa renda, garantem a permanência legal das pessoas que vivem nestes locais.

Distante dessa perspectiva, os referidos instrumentos de políticas públicas não asseguraram 0 direito de moradia dos moradores da Vila Autódromo que vem traçando a sua história de luta e resistência desde 1990 até o presente como será visto a seguir.

\section{A RESISTÊNCIA DA VILA AUTÓDROMO FRENTE ÀS REMOÇÕES}

A partir dos anos 90, com o prefeito César Maia, a comunidade passou a conviver com a ameaça constante de ser removida devido a sua privilegiada posição geográfica, alvo constante do expansivo setor imobiliário.

Ainda nos anos 90, o Governo do Estado finalmente concedeu aos moradores o uso da área por 99 anos. Anos mais tarde, em 2005, a Câmara de Vereadores aprovou a lei complementar 74/2005, que transformou a comunidade em Área Especial de Interesse Social.

Quando o Rio de Janeiro foi eleito para sediar as Olimpíadas de 2016, o fantasma da remoção apareceu novamente. O plano da Prefeitura previa demolir o antigo autódromo de Jacarepaguá para construir o Parque Olímpico, uma série de obras públicas em seu entorno e a remoção completa da Vila Autódromo. No primeiro semestre de 2013, em conjunto com uma equipe técnica da Universidade Federal Fluminense (UFF) e da Universidade Federal do Rio de Janeiro (UFRJ), os moradores da Vila Autódromo apresentaram 0 Plano Popular de Urbanização, uma alternativa ao plano do governo municipal para que a comunidade não precisasse ser removida. O projeto, cuja implantação não chegava a 14 milhões de reais. 
Diante das evidências, é possível constatar também que a Vila Autódromo, com seu terreno plano, ruas abertas, casas bem estruturadas, além de uma população unida, é perfeitamente urbanizável, sendo importante a conscientização do poder público frente as necessidades da comunidade.

Para o geógrafo britânico David Harvey, autor do livro "Cidades rebeldes", o capitalismo em crise tenta resolver seus problemas através do avanço sobre as cidades para transformálas em ativos financeiros. É a lógica de que a cidade não deve servir para as pessoas, mas para os negócios.

Harvey (2016) nos ajuda a entender as transformações por que passa o Rio. A cidade, que recebeu diversos megaeventos nos últimos anos, o mais importante será as Olimpíadas, despertou o interesse de grandes grupos empresariais que, em associação com o poder público e grupos de comunicação, fizeram do espaço público fonte de lucro, e ainda explica:

"A preocupação é construir uma cidade em que se possa especular, em vez de construir cidades decentes para as pessoas viverem. O capital global depende pesadamente da urbanização para se estabilizar. A resposta à crise de 2008 foi criar dinheiro e pressão pela valorização do dinheiro. O capital está com dificuldade de encontrar lugares lucrativos para sua valorização, e a urbanização é um desses lugares." (HARVEY, 2016)

\subsection{O PLANO POPULAR VILA AUTÓDROMO}

O Plano Popular Vila Autódromo, uma alternativa à tentativa de remoção da comunidade da Zona Oeste do Rio de Janeiro, foi idealizado pelos moradores da comunidade e contou com a participação decisiva do Núcleo Experimental de Planejamento Conflitual (NEPC), que faz parte do Instituto de Planejamento Urbano e Regional (Ippur) da UFRJ, além da contribuição da Universidade Federal Fluminense (UFF).

Desenvolvido a partir de 2011, o Plano Popular consolida uma alternativa de planejamento urbano da Vila Autódromo. A ideia é que a população, assessorada por pesquisadores e professores especializados, possa elaborar soluções para a sua própria comunidade.
Um dos motivos alegados para a remoção da vila é a ocupação de uma parte da faixa marginal de proteção de 15 metros de largura ao longo da Lagoa de Jacarepaguá. O plano alternativo prevê o reassentamento, dentro da própria comunidade, dos moradores que estão nesta área, resguardando uma faixa de proteção da lagoa de Jacarepaguá, uma área de proteção ambiental, recuperando o mangue e a vegetação nativa. Além disso, um parque com vegetação nativa seria criado no local.

O projeto foi enviado para o governo municipal ainda em 2013, então a Prefeitura apresentou uma proposta onde sobrava muito pouco da Vila, muitos teriam que sair. Isso porque, entre as intervenções previstas, estão as vias de acesso ao Parque Olímpico, que deveriam passar por dentro da favela.

Os moradores apresentaram então uma segunda versão do plano que resguardava tudo aquilo que o governo municipal anunciava como imprescindível, como o acesso independente ao Parque Olímpico dos atletas, de jornalistas e do público, entre outras coisas, mas sem atingir tanto a Vila Autódromo. Mas na solução da Prefeitura, ficava claro a intenção de retirar um grande número de famílias.

Depois que apresentaram esta última versão do plano ainda em 2013, as negociações foram rompidas e o governo municipal passou a negociar individualmente com os moradores. Começou, a partir de então, um assédio cotidiano dos funcionários da Prefeitura, segundo relatam os moradores.

Segundo moradores, eles eram coagidos a aceitar a indenização e esses funcionários diziam que a família deveria sair senão iriam perder tudo, faziam pressão, dentro da comunidade e dentro das famílias.

Essa pressão é a mesma estratégia aplicada em outras desocupações: as pessoas acabam cedendo e abandonam o lugar, as casas são demolidas e vários pertences são deixados na rua. Os que ficam passam a viver em um insuportável cenário de guerra, ao mesmo tempo que são pressionados a fazer o mesmo. Os moradores vão ficando uns contra os outros e a favela acaba dividida. E assim, pouco a pouco, vai sendo removida.

Os moradores da Vila Autódromo se surpreenderam com a decisão de Eduardo Paes. O prefeito, que antes prometera que não tiraria nenhum morador da localidade, a 
não ser que os próprios moradores quisessem, utilizou o decreto-lei no.3.365, de 21 de junho de 1941, para expulsar os moradores da vila autódromo, no artigo 5을 do decreto, constam as possibilidades da administração pública desapropria em caso de utilidade pública.

As remoções na Vila Autódromo começaram em fevereiro de 2014 e, desde então, cerca de dois terços de sua população deixou a comunidade, os moradores calculam 390 famílias, enquanto que a Prefeitura fala em 590. O governo municipal ainda mantém o discurso oficial de que não tem a intenção de desapropriar a área por completo. Os moradores têm certeza que o objetivo é a remoção completa das famílias para que, finalmente, algum tipo de empreendimento imobiliário seja realizado.

A maioria dos que deixaram a vila foi reassentada no Parque Carioca, um conjunto habitacional a um quilômetro de distância com área verde, piscina, espaço gourmet, creche e espaço comercial. Outros optaram por receber a indenização em dinheiro.

O valor total das compensações é de 96 milhões de reais, muito superior, portanto, ao plano de urbanização apresentado. Essas compensações, no entanto, são uma exceção: a maioria dos cidadãos que são obrigados a deixar suas casas nas favelas do Rio de Janeiro são reassentados em áreas distantes da cidade, onde são construídos os edifícios do programa Minha Casa, Minha Vida (Governo Federal) ou Morar Carioca (Prefeitura do Rio), e sem poder de escolha.

Esses programas habitacionais são um instrumento de segregação espacial, uma vez que libera as áreas mais valorizadas da cidade para a especulação imobiliária e remove a população mais humilde para as

\section{REFERÊNCIAS}

[1] http://www.rio.rj.gov.br/dlstatic/10112/4224 287/4103827/ProjetodeLeiComplementar33_2013L UOS

[2] http://fatoonline.com.br/conteudo/667/disp uta-entre-moradores-e-prefeitura-do-rio-atrasaobra-das-olimpiadas

[3] http://web-

direito.blogspot.com.br/2011/04/o-que-e-uma-areade-especial-interesse.html

[4] http://www.rio.rj.gov.br/dlstatic/10112/1393 39/DLFE229591.pdf/LeiComplementar1112011Plan oDiretor.pdf margens da área urbana, longe de suas relações sociais, familiares e de trabalho. No caso da Vila Autódromo, a resistência de seus vizinhos fez com que as compensações fossem mais justas. Mas para os que ainda mantêm a esperança de continuar na comunidade, a questão não é conseguir uma boa indenização, mas sim de respeitar o direito de permanecer onde desejam.

Caso os últimos moradores da Vila Autódromo resistam até as Olimpíadas, os escombros deixados pelas remoções serão todo um espetáculo para os meios de comunicação internacionais, que estarão instalados em um edifício construído ao lado da comunidade.

\section{CONSIDERAÇÕES FINAIS}

Observou-se que apesar das inúmeras promessas dadas por diferentes governantes, de acordo com os interesses específicos vigentes das épocas, os moradores da Vila Autódromo sempre estiveram sob constante tensão, com a possibilidade de perderem suas casas e sem saberem o que realmente aconteceria com a comunidade, e mesmo que embasados pelas leis apresentadas, o poder público se distância do cumprimento do dever de assegurar o direito de moradia, utilizando para tanto outros instrumentos de forma tendenciosa para priorizar os interesses específicos, mas contraditórios à justiça social e bem comum.

Por outro lado, constata-se o fortalecimento da comunidade e maior mobilização da sociedade, buscando alternativas legais que possam fazer cumprir tal direito, com destaque para o Plano Popular Vila Autódromo.

[5] http://www.fna.org.br/site/uploads/noticias/ arquivos/Direito_a_Moradia_no_Brasil.pdf

[6] http://brasil.elpais.com/brasil/2015/06/20/p olitica/1434753946_363539.html

[7] http://www.planalto.gov.br/ccivil_03/decret o-lei/Del3365.htm

[8] http://sergiohenriquepereira.jusbrasil.com. br/artigos/220005549/arquitetura-da-discriminacaojogos-olimpicos-de-2016-morro-da-favela-e-vilaautodromo

[9] http://seacidadefossenossa.com.br/2016/0 3/da-cidade-negocio-a-cidade-de-direitos/ 


\title{
Gapítulo 10
}

\section{LOGÍSTICA SUSTENTÁVEL: A UTILIZAÇÃO DE BIODIESEL NA OPERAÇÃO DE UMA REDE DE RESTAURANTES FAST FOOD}

\author{
Agostinho Augusto Figueira \\ Beatriz Monica Schuchmann \\ Marcos Roberto Buri
}

Ranulfo Soares da Fonseca Junior

Rosa Maria Maia de Oliveira

Resumo: Este artigo discorre sobre a importância de ações sustentáveis na área de logística, tomando como exemplo o reaproveitamento de gorduras para transformação em Biodiesel em uma rede de restaurantes. Destaca-se o papel do Prestador de Serviços Logísticos (PSL) na cadeia de suprimentos (CS), por meio da gestão colaborativa. Para tanto, utiliza-se o exemplo da rede de alimentação McDonalds, que realiza o projeto Biodiesel por meio do Operador Logístico MartinBrower. Aborda-se, de maneira sintética, a execução do projeto Biodiesel da rede McDonald's, idealizada pelo seu PSL Martin-Brower, a fim de identificar os requisitos necessários para que a implementação de ações sustentáveis seja efetivada. Ressalta-se o importante papel de um agente terceirizado que seja ativo na execução dos projetos logísticos visando a sustentabilidade. Desse modo, pretende-se abordar a forma como cada um dos atores envolvidos no projeto Biodiesel atua para alcançar as metas em relação à preservação ambiental e sustentabilidade, favorecendo resultados satisfatórios para todos os envolvidos no processo. Conclui-se que o PSL pode contribuir para as metas de sustentabilidade da empresa contratante, demonstrando ser um diferencial para empresas que buscam maior eficiência e agilidade na implementação e execução das ações relativas à Cadeia de Suprimentos.

Palavras-chave: Sustentabilidade; Cadeia de suprimentos; Logística. 


\section{INTRODUÇÃO}

Este artigo discorre sobre a atuação e importância do Prestador de Serviços Logísticos (PSL) na execução das diversas atividades logísticas da Cadeia de Suprimentos (CS), favorecendo a otimização de recursos, propiciando que a empresa contratante possa se dedicar exclusivamente ao seu negócio. Mesmo que indiretamente, isto traz resultados positivos para a empresa em relação a sustentabilidade, que, atualmente, tornou-se um diferencial competitivo e inovador para as organizações. As ações sustentáveis trazem mais negócios para a empresa que as adota.

Para tanto, apresenta-se um caso de sucesso, em que o PSL identificou uma possibilidade de ampliação de sua carteira de serviços a um cliente - a rede de restaurantes fast food McDonalds, oferecendo um serviço voltado para a sustentabilidade, o que se tornou um diferencial competitivo para ambas as partes.

No caso das redes de restaurantes fastfood, esse tipo de ação é muito importante, por atingirem a grande massa populacional, o que faz com que suas ações (positivas ou negativas) se repercutam rapidamente.

Deste modo, sendo realizado um estudo teórico sobre a CS, sustentabilidade e PSL, apresentando um caso prático de um ciclo fechado (closed-loop) em cadeia de suprimentos, norteado pelos princípios da preservação ambiental. Trata-se do projeto Biodiesel da Rede de Alimentação McDonald's e seu Operador Logístico Martin-Brower, visando abordar a atuação do cliente, do PSL e agentes da CS, destacando os requisitos que permitam ao PSL prover ações sustentáveis junto aos seus clientes.

A importância do estudo deve-se à necessidade atual das empresas em incluir as práticas de preservação ambiental e a sustentabilidade, sem perder o foco do próprio negócio.

A contratação de um agente terceirizado de serviços logísticos na realização dos projetos de sustentabilidade clientes torna-se muito interessante, pois contribuem, mesmo que indiretamente, para a competitividade da organização.

Pretende-se, então, procurar conhecer a maneira como os diversos atores (cliente, PSL e agentes da CS) se alinham a fim de atender as metas organizacionais. Certamente, há diversas formas de atuação, porém, neste momento, a ideia é trazer a lume algumas possibilidades, a fim de ampliar a visão do leitor a respeito do tema.

Atualmente, além da sustentabilidade e preservação ambiental, as empresas precisam ser inovadoras, buscando todos os meios e estratégias possíveis para conquistar o cliente, assegurando a competitividade no mercado, sem perder de vista a lucratividade.

A preocupação com a sustentabilidade demonstra ao público uma faceta positiva, agregando valor à marca. As refeições rápidas (fastfoods) que costumam ser oferecidas são compostas por alimentos muito gordurosos e de alto valor calórico, muitas vezes, trazem consigo uma conotação negativa, por não atenderem aos requisitos de uma dieta equilibrada. Neste quesito, a rede McDonalds, como uma das pioneiras no nicho de negócio, já passou por diversos questionamentos da opinião pública, trazendo alguns prejuízos à marca, muitas vezes atrelada aos ideais do capitalismo inescrupuloso, que vêm sendo enfrentados com ações vinculadas a sustentabilidade visando a manutenção de uma imagem positiva. (COHEN, 2004).

Diante das diversas questões ou especulações que possam surgir, o investimento em práticas que aumentem a credibilidade e confiança neste tipo de empresa torna-se fundamental.

As medidas voltadas para a sustentabilidade são bem-vindas em um cenário altamente competitivo, com um mercado e consumidores cada vez mais exigentes e conscientes da necessidade de práticas que demonstrem o respeito à saúde das pessoas, o que também envolve o meio ambiente.

Nesse cenário, o Prestador de Serviços Logísticos (PSL) tem à sua frente uma infinidade de possibilidades de negócio, que o permitem atender às necessidades dos mais diversos tipos de clientes que necessitam implementar a sustentabilidade, por meio de sua Cadeia de Suprimentos (CS).

O gerenciamento da frota de veículos de transporte, com a utilização do Biodiesel, realizado pelo PSL pode ser muito importante para a efetivação de projetos com esse tipo de combustível.

Trata-se de um tema bastante novo e específico, por isso há dificuldades em 
encontrar estudos que atendam a todas as necessidades dos diversos tipos de organizações (WOLF; SEURING, 2010).

\section{SUSTENTABILIDADE NO CONTEXTO ATUAL EM CADEIA DE SUPRIMENTOS}

A globalização tem favorecido a inserção das empresas brasileiras nos mercados mundiais, de forma competitiva, o que vem exigindo das mesmas recursos e estratégias que possibilitem 0 atendimento das demandas, inclusive em relação ao quesito sustentabilidade, que envolve a responsabilidade social, cultural, ambiental e econômica.

Neste contexto, muitas vezes, torna-se necessário fazer escolhas, que podem representar o abandono de práticas e posturas há muito arraigadas. Quando se trata de competitividade e sustentabilidade, a questão dos trade-offs surge, com valores antagônicos, exigindo a tomada de posição, quando o ideal seria manter a competitividade de maneira sustentável, porém, isso nem sempre é possível. (LIEB e LIEB, 2010).

Nas operações logísticas, a redução dos ciclos de atendimento/entrega, aumento da precisão/confiabilidade dos prazos e a administração dos fluxos reversos, de modo a favorecer a geração de valor para ações de sustentabilidade são fatores desafiadores. Neste âmbito, vem aumentando a importância dos processos logísticos na gestão das cadeias de suprimento. (PIRES, 2009).

E, segundo, Schier (2012, p. 2):

O processo logístico inicia-se na escolha correta e no estabelecimento de parcerias de longo prazo com os componentes de uma cadeia produtiva, exigindo-se que o canal de distribuição esteja apto a atender as necessidades e expectativas do cliente final.

As ações de sustentabilidade necessitam considerar a visão atual sobre o CS e gestão colaborativa para a construção de práticas operacionais que agreguem projetos que valorizam o uso responsável dos recursos naturais, demonstrando a responsabilidade das empresas, inclusive na logística reversa.

\subsection{CADEIA DE SUPRIMENTOS E GESTÃO COLABORATIVA}

Atualmente, a confiança e o compromisso vêm se tornando pontos centrais da gestão colaborativa na CS. A cooperação entre empresas envolve a troca de informações básicas entre fornecedores e clientes, que é facilitado pela tecnologia da informação e comunicação (TIC). Este relacionamento entre empresas permite a elaboração de estratégias conjuntas, gerando confiança e compromisso, que se traduz na colaboração, como algo que ultrapassa a ideia de cooperação. (SINGH; POWER, 2009).

A importância da colaboração é observada por Muniz e Cruz (2016), como um fator de impacto na competitividade, representando uma importante ferramenta no ambiente de negócios. (MUNIZ; CRUZ, 2016).

A confiança e o compromisso, juntamente com a estratégia adequada promovem a interdependência,

compatibilidade operacional e a comunicação. Esta proximidade operacional auxilia no aumento da confiança, mas não interfere no compromisso, que se consolida na confiança mútua. (RUY et al., 2009)

O desenvolvimento da confiança e do compromisso entre duas empresas promove a colaboração e ajuda a sustentar o relacionamento colaborativo. (VIVALDINI; PIRES, 2012).

A integração, nos âmbitos internos e externos, baseada nas relações de confiança e compromisso permite a disponibilização de dados e informações mais detalhados, que possibilitam a melhoria do desempenho da CS. Na integração interna, os departamentos e funções devem atuam de forma alinhada ao negócio da empresa, visando o desempenho operacional e dos negócios, promovendo a conexão da cadeia, por meio da estratégia de colaboração, bem como pela gestão dos processos internos e externos das organizações. Desse modo, enfatiza-se a importância da interação e proximidade com clientes e fornecedores, o que se vincula ao desempenho da cadeia, abrangendo três importantes aspectos: cliente, supridores e a integração interna (VIVALDINI, 2015).

O compromisso dos fornecedores é muito importante para o comprador, mesmo que não resulte em aumento dos negócios, tratase de um quesito fundamental para se 
promover a satisfação e a melhoria do desempenho.

As múltiplas interações aumentam a confiança e a reciprocidade, mesmo quando não há transparência nessas relações, como quesito importante para a construção dos negócios e alianças e joint-ventures, que ligam empresas diferentes e independentes. A confiança se refere a uma expectativa positiva, acreditando que o outro não agirá de maneira oportunista. Trata-se, ainda, de uma variável que se altera mediante novas situações, podendo ser construída com base em experiências em longo prazo. (VIVALDINI, 2015).

Os diferentes tipos de relacionamentos entre empresas decorrem de diferentes situações, pois exigem tipos e graus de investimentos também diversos, originando resultados distintos (GOLIC; MENTZER, 2006).

Numa rede de empresas ocorrem diferentes tipos de colaboração, que surgem de cada ponto da CS, que pode desencadear diferentes comportamentos e tipos de colaboração (POLER et al., 2008).

Um processo colaborativo requer fornecedores, produtores, distribuidores e clientes alinhados aos mesmos objetivos, que levem a resultados positivos para todos os integrantes da CS. Por isso, todas as estratégias adotadas precisam considerar, não apenas o resultado individual, mas contemplar toda a cadeia. (SAHAY, 2003).

\subsection{SUSTENTABILIDADE E LOGÍSTICA REVERSA NA CADEIA DE SUPRIMENTOS}

Segundo Vivaldini (2015), as práticas sustentáveis e as movimentações na CS que caracterizam a logística reversa trazem algumas questões, como a responsabilidade das empresas, o relacionamento entre os profissionais da área, a ética na contratação dos fornecedores, bem como os aspectos sociais.

Conforme Halberstadt et al. (2015, p.300):

A sustentabilidade requer um repensar da noção de sucesso empresarial, desempenho organizacional e um esclarecimento sobre o seu significado para o negócio e para a sociedade em geral. (...) ela é vista ainda como a capacidade dos diversos sistemas da terra, incluindo as economias e sistemas culturais humanos de sobreviverem e se adaptarem às condições ambientais de mudanças.

Dentre as iniciativas ambientais muitas empresas têm realizado modificações em suas CS para operar em um ciclo fechado (closed loop), o que exige a integração estratégica com os diversos agentes, planejamento, atuando em ambos os sentidos da cadeia. (ELTANTAWY et al., 2009).

Neste sentido, vêm sendo criadas medidas de gestão da CS diferentes das tradicionais, como a inclusão de processos de remanufatura ou recuperação de produtos, contemplando o foco dos negócios e sua contribuição para a sociedade, por meio de ações conjuntas que favorecem a sustentabilidade (DEFEE; ESPER; MOLLENKOFF, 2009).

Entretanto, o desafio quanto se encontra na implementação de ações sociais e ambientais, apesar do esforço das organizações em colocar em prática as teorias existentes, o que parece ser consolidado apenas em algumas organizações (ANDERSEN; SKJOETTLARSEN, 2009).

A sustentabilidade ambiental se refere a preservação de bens ambientais importantes para esta e as futuras gerações, sendo que a gestão ambiental envolve os âmbitos internos e externos na CS (upstream e downstream). (VIVALDINI, 2015).

Por sua vez, a legislação e a sociedade pressionam as empresas a adotarem práticas baseadas na sustentabilidade, o que pode favorecer a elas uma imagem positiva relacionada à responsabilidade social. Aos poucos vêm surgindo projetos para novos produtos produzidos de forma sustentável, inclusive em relação ao descarte, por meio da logística reversa. (HOLT; GHOBADIAN, 2009).

O conceito de sustentabilidade ainda não é muito compreendido em muitas empresas, devido à falta de atenção às políticas de reciclagem, bem como à ausência de padrões nos processos e tecnologias, de recursos, pessoas e monetários, além da preocupação com as questões legais. Neste sentido, o PSL pode favorecer a organização desse processo dentro de uma empresa, apesar da dificuldade na seleção deste tipo de prestador de serviço. A associação ou aliança estratégica com um grupo de empresas permite o gerenciamento das questões relacionadas à logística reversa, 
reduzindo os investimentos das empresas na operação e centralização dos negócios. (LAU; WANG, 2009).

Um sistema de coleta próximo dos consumidores auxilia com o processo de reciclagem, uma vez que o processo de reciclagem passa por diferentes etapas, que geram custos, que, depois, são incluídos no valor do produto final, tais como: transporte para uma unidade recicladora, classificação, estocagem, desmontagem, remoção de partes desnecessárias e consolidação das partes separadas. (BRODIN; ANDERSON, 2008).

A logística reversa exige mão-de-obra especializada ao tipo de produto e ao motivo de seu retorno. Quanto ao conceito de logística reversa, esta se refere a:

(...) área da logística empresarial que planeja, opera e controla o fluxo e as informações logísticas correspondentes, do retorno dos bens de pós-venda e de pós-consumo ao ciclo de negócios ou ao ciclo produtivo, por meio dos canais de distribuição reversos, agregando-lhes valores de diversas naturezas: econômico, de prestação de serviços, ecológicos, legal, logístico, de imagem corporativa, dentre outros. (LEITE, 2009 apud HARBERSTADT, 2015, p.302).

O valor logístico decorre da redução de custos ou aumento de vendas, sendo necessárias melhorias no serviço de entrega, sem demandar ou exigir compensação financeira do consumidor para a realização da logística reversa, que é o ponto em que se concentram diversas questões ambientais, exigindo que as empresas maior efetividade nas ações. (BRODIN; ANDERSON, 2008).

Nos processos de logística reversa torna-se muito importante o uso tecnologia da informação, como internet, EDI (Electronic Data Interchange) e RFID (Radio-Frequency IDentification) pois permitem a troca de informações em tempo real com clientes e fornecedores. Nesse passo, a colaboração e confiança entre os agentes, especialmente as relações de longo prazo, são muito importantes, pois favorecem a efetivação das ações. (LI; OLORUNNIWO, 2008).

O relacionamento entre vendedor e varejista favorece o processo, de forma a considerar as variáveis, inclusive no tocante a logística reversa. Os centros de reciclagem em centros de distribuição (varejo) realizam este tipo de trabalho, com o envolvimento dos fornecedores. (HSU et al., 2008).

A colaboração entre os parceiros da cadeia abrange a logística reversa, cuja gestão deve incluir toda a operação, contando com o apoio da empresa. (LAU; WANG, 2009; LI; OLORUNNIWO, 2008).

A responsabilidade social nas CS deve ser internalizada por toda organização, não se limitando a uma atividade corporativa ou do staff das empresas, ou seja, abrangendo as esferas internas e externas, como filiais e fornecedores. (ANDERSEN; SKJOETTLARSEN, 2009).

Para a realização de ações sustentáveis, as CS fechadas exigem a atuação das organizações parceiras, sob a liderança da empresa foco, inclusive porque cada tipo de ação ou retorno de produto requer um processo diferente. Este tipo de CS necessita manter uma filosofia e processos que incentivem o comprometimento, o que ajudará na gestão dos riscos, nos relacionamentos e maior flexibilidade nas negociações. (DEFEE et al., 2009).

A cadeia deve focalizar os vários fluxos, primeiramente em relação aos fornecedores e, depois, aos clientes. Trata-se de uma tarefa árdua, especialmente nos fluxos reversos, considerando a responsabilidade ambiental e a integração de ambos os sentidos da cadeia. Por isso, uma liderança influente na cadeia de suprimentos é muito importante, para conseguir a adesão das demais às propostas apresentadas. (DEFEE et al., 2009).

\section{OS OPERADORES LOGÍSTICOS}

A aquisição de serviços logísticos é uma atividade bastante complexa, por abranger a compra de um processo, que envolve muitas variáveis, o que é muito diferente, por exemplo, da compra de componentes. (VIVALDINI; PIRES, 2010).

Quando uma empresa busca a terceirização das atividades da cadeia de suprimentos por operadores logísticos, ela busca excelência no nível dos serviços de armazenagem, transporte e comunicação, como explicam Oliveira Neto et al. (2012, p. 3):

A utilização de sistema de informação eficaz é fundamental para que a empresa possa mensurar o desempenho dos operadores logísticos. À medida que as empresas 
tentaram adotar as técnicas do just in time, descobriram que as reorganizações internas à planta eram apenas parte do programa. Essas técnicas demandavam mudanças na cadeia de suprimentos, que dependem de relacionamentos compartilhados com os fornecedores, trazendo vantagem competitiva para a organização.

Quanto aos operadores logísticos - ou Prestador de Serviços Logísticos - PSL, explicam os mesmos autores:

Operador logístico é o fornecedor de serviços especializado em gerenciar e executar todas as atividades logísticas nas várias fases na cadeia de abastecimento de seus clientes, e deve ter competência para, no mínimo, prestar simultaneamente serviços nas três atividades básicas: controle de estoque, armazenagem e gestão de transporte. Os demais serviços que porventura sejam oferecidos funcionam como diferenciais de cada operador; pode-se citar como exemplo, gerenciamento, análise e projeto de administração de estoques e de informação e rastreamento de pedidos, que podem se estender até ao gerenciamento da cadeia logística (FLEURY; WANKE; FIGUEIREDO, 2006 apud OLIVEIRA NETO et al., 2012, p. 3).

Um Prestador de Serviços Logísticos - PSL pode fornecer um conjunto de transações, que requer do contratante a utilização de interfaces e monitoramentos sofisticados. Para que a terceirização obtenha sucesso, as partes envolvidas devem ter clareza quanto aos objetivos, finalidade, expectativas, além das capacitações necessárias (VIVALDINI; PIRES, 2010).

A seleção dos prestadores de serviços depende da complexidade do processo, dos serviços necessários e do tipo de relacionamento que se busca desenvolver. Para a contratação dos fornecedores nãoestratégicos ou "executores de tarefas", geralmente se emprega a análise de cotação de tarifas como única ferramenta de escolha. (FIGUEIREDO, 2005).

Dentre os fatores que influenciam a decisão, se encontra o custo mais baixo, e aspectos de curto prazo, para simplificar os serviços contratados e facilitar a substituição do fornecedor, se necessário. A seleção de fornecedores estratégicos pode envolver investimentos mais significativos, bem como um processo de seleção mais complexo. (FIGUEIREDO, 2005).
A terceirização de serviços logísticos é uma forma de facilitar os processos e reduzir os custos das empresas, favorecendo que a mesma utilize seu capital humano para o desenvolvimento do próprio negócio e na conquista de novos mercados. Este tipo de terceirização também diminui os investimentos em ativos não diretamente relacionados ao nicho da empresa. (OLIVEIRA NETO et al., 2012; VIVALDINI, 2015).

Além disso, a própria Cadeia de Suprimentos é otimizada, ao delegar parte das atividades a uma empresa contratada, agregando valor às operações existentes, dentre outros benefícios, tais como: flexibilização e consolidação do processo de expedição e atividades logísticas; operações de retorno de produtos; coordenação das atividades logísticas no âmbito global; melhoria e controle dos serviços e atividades logísticas; melhoria no acesso a novas tecnologias de informação e comunicação (TIC) e conhecimento logístico. Para tanto, sendo importante a comunicação eficaz e o bom relacionamento com $O$ agente logístico. (JAAFAR; RAFIQ, 2005; VIJAYVARGIYA; DEY, 2010; VIVALDINI, 2015).

A organização não precisa manter uma grande estrutura logística, podendo contratar um (ou mais) Prestador de Serviços Logísticos - PSL, especializado para realizar os serviços, que se tornará parceiro do negócio. (BALLOU, 2001).

O PSL se refere a uma organização externa que realiza todas ou parte das atividades e funções logísticas da empresa que a contratou (LANGLEY et al., 2001).

A otimização do processo operacional e dos serviços logísticos, por meio dos PSL, favorece o aumento da confiabilidade no processo operacional, permitindo, também, a ampliação dos serviços prestados. Desde meados da década de 1990 os PSL têm aumentado os serviços para atender às necessidades do cliente e, atualmente, as empresas industriais têm disponibilizado outros serviços, no final da sua cadeia de suprimentos, como instalação de equipamentos, reparos, montagem de kits etc. (VIVALDINI, 2015).

Deste modo, os PSL têm se especializado em algumas áreas, o que vem se tornando um diferencial competitivo, também, para estas empresas, como ocorre em relação aos 
operadores que executam ações mediante aos princípios de sustentabilidade e preservação ambiental. (LIEB, 2008; VIVALDINI, 2015).

\subsection{OPERADORES LOGÍSTICOS E SUSTENTABILIDADE}

Muitos Prestadores de Serviços Logísticos, especialmente de grande porte, passaram a assumir maiores compromissos com programas de sustentabilidade, por diversos motivos, mas, principalmente, porque a sociedade (e os clientes) tem valorizado as ações em favor da coletividade, como é o caso da preservação ambiental. Além disso, trata-se de uma questão ética, que contribui para a melhoria e consolidação da marca no mercado, servindo, ainda, como estratégia competitiva. (LIEB e LIEB, 2010).

O desenvolvimento dos processos de produção, dos sistemas de comunicação e controle, a liberação do comércio e o aumento da competitividade impulsionaram mudanças na forma de gerenciamento dos negócios, com a realização de parcerias com fornecedores e terceirização de negócios, de modo que "as operações logísticas deixaram de ser consideradas assessórias e passaram a ser consideradas estratégicas" (OLIVEIRA NETO, 2008 apud OLIVEIRA NETO et al., 2012, p.3).

Dentre as ações que envolvem a sustentabilidade, se encontram: a avaliação de softwares, check-list ambiental e benchmarketing com empresas para crédito de carbono. Outras ações envolvem o uso de combustíveis alternativos e veículos eficientes, redução da kilometragem através da melhoria dos processos, compartilhamento de carga, modais eficientes, segurança profissional e da sociedade (limite de velocidade e qualidade da frota), reciclagem e produtos de consumo e demais ações que atendam aos quesitos da preservação ambiental e sustentabilidade. (LIEB; LIEB, 2010).

Destaca-se a importância da legislação para regular a atuação dos PSL, para que a sustentabilidade seja privilegiada, como, por exemplo: restrições no tráfego das grandes cidades, com restrição ao tráfego de caminhões e automóveis em dias e horários pré-estabelecidos, limites para a emissão de poluentes e uso de combustíveis alternativos, como o biodiesel, que, no Brasil, já é acrescentado ao diesel na proporção de 5\% (WOLF; SEURING, 2010).

Entretanto, ainda há necessidade de uma legislação mais efetiva e específica para as empresas de transporte, muito embora muitas empresas que contratam o PSL, por iniciativa própria, colocam em seus contratos uma cláusula referente a redução de carbono. Mas esta é uma medida que precisa ser regulamentada, obrigando a todos os PSL a cumprirem tal requisito. (WOLF; SEURING, 2010).

Muitas organizações atuam de maneira conjunta com os PSL, mantendo programas de sustentabilidade que atendam a objetivos comuns, tais como: Apoio aos esforços dos clientes para redução de emissão de carbono; Diminuir o consumo de combustível, água e eletricidade; Ajudar os clientes a cumprir os programas e certificação; Cuidados com produtos perigosos; Melhorar o desempenho dos veículos; Buscar fontes renováveis de energia e outras facilidades. O PSL precisa se capacitar para atender aos anseios dos clientes, ao mesmo tempo que oferece preços competitivos, com clareza quando aos desafios e prioridades ambientais, além de divulgar as práticas de sustentabilidade. (LIEB; LIEB, 2010).

\section{METODOLOGIA}

Para a realização deste artigo, optou-se pela pesquisa exploratória de revisão bibliográfica, de caráter qualitativo.

Foram pesquisados artigos científicos, nacionais e internacionais, sobre os conceitos e aspectos que envolvem a sustentabilidade na área de logística e cadeia de suprimentos, destacando-se artigos com pesquisas de campo em uma rede de fast food, que utiliza o PSL.

Dentre as fontes de pesquisa utilizadas, destaca-se o estudo de caso realizado por Mauro Vivaldini (2015), na rede de restaurantes McDonald's e seu operador logístico Martin-Brower, que apresenta dados sobre a cadeia de suprimentos desta rede, para demonstrar a importância da gestão colaborativa como facilitadora da integração e o compromisso das empresas parceiras. 
5 A UTILIZAÇÃO DO BIODIESEL NA OPERAÇÃO DA EMPRESA MCDONALD'S

No modelo adotado pela empresa McDonald's, os PSL compõem uma rede formada por oito empresas, que são lideradas pela empresa Martin-Brower, que é responsável pelas operações logísticas no Brasil. Estas empresas elaboraram um projeto de sustentabilidade para toda a rede de restaurantes do grupo, visando a geração do biodiesel a ser utilizado na frota de veículos da Cadeia de Suprimentos da empresa contratante. (VIVALDINI, 2015).

Neste projeto de sustentabilidade, as empresas são co-participantes de todo o processo, assumindo compromissos que estão alinhados aos objetivos da McDonald's, no atendimento às necessidades dos clientes e, por fim, na melhoria dos resultados, tanto para a empresa contratante quanto para 0 grupo dos PSL.

\subsection{BIODIESEL}

Biodiesel é um combustível alternativo, que não é derivado do petróleo, mas pode ser misturado ao mesmo, para utilização em motores a diesel.

Na definição de Tavares e Silva:

O biodiesel é um combustível natural usado em motores diesel, produzido através de fontes renováveis, que atende as especificações da Associação Nacional do Petróleo (ANP).

(...) é um combustível renovável derivado de óleos vegetais, gordura animal ou residual, usado em motores a diesel em qualquer concentração de mistura com o diesel, produzido através de um processo químico que remove a glicerina do óleo. (TAVARES; SILVA, 2008, p.33)

Além dos benefícios ao meio ambiente, o biodiesel por ser um recurso renovável, biodegradável e com reduzida emissão de gás carbônico, como se observa a seguir:

Ao abastecer sua frota urbana de ônibus com a mistura de $20 \%$ de biodiesel no diesel fóssil (B20), as 40 cidades brasileiras com mais de 500 mil habitantes podem diminuir em até $70 \%$ as emissões de CO2 causadas pela produção do combustível e ainda cerca de $15 \%$ na queima dessa mistura de biodiesel e diesel. (EMBRAPA, 2015, p.1)
A utilização do biodiesel também contribui para reduzir a poluição do ar, e também favorece o homem do campo, ao gerar emprego e renda, além da geração de vantagens econômicas para o país.

O biodiesel utiliza matérias-primas que derivam de óleos vegetais, gordura animal e resíduos de gorduras provenientes de frituras (lanchonetes, restaurantes etc.), que são compostos por triglicérides, ésteres de glicerol e ácidos graxos. (TAVARES; SILVA, 2008).

Quanto às fontes de matérias-primas para a produção de biodiesel, observa Vivaldini (2015, p. 142):

Algumas possíveis fontes dos óleos e gorduras residuais são: lanchonetes e cozinhas industriais, indústrias onde ocorre a fritura de produtos alimentícios, os esgotos municipais onde a nata sobrenadante é rica em matéria graxa, e águas residuais de processos de indústrias alimentícias.

A produção do biodiesel segue normas de padrão internacional, como a ASTM (American Society for Testing and Materials), sendo uma alternativa de combustível "limpo", por não contaminar o meio ambiente, além de impedir que os óleos residuais de frituras contaminem o meio ambiente. (VIVALDINI, 2015).

No Brasil, a redução de emissões decorrentes do uso de biodiesel deve contribuir para a diminuição das emissões entre 36,1\% a $38,9 \%$ até 2020, de acordo com o compromisso voluntário firmado em 2009, na Conferência do Clima. (EMBRAPA, 2015).

\subsection{CADEIA DE SUPRIMENTOS MCDONALD'S}

Conforme Vivaldini (2015), nos restaurantes da rede McDonalds, o sistema de abastecimento é realizado pelo PSL (Prestador de Serviços Logísticos), atendendo o restaurante e a corporação, inclusive atuando junto aos fornecedores. O PSL controla a demanda dos pontos de venda e suas variações sazonais. A matriz da rede McDonalds envia as informações sobre as demandas, para que o PSL realize as compras junto aos fornecedores que, por sua vez, os entrega nos seus centros de distribuição. Em seguida, o PSL faz a distribuição dos pedidos aos pontos de venda do McDonald's. 
Além disto, o PSL analisa os pedidos e solicitações dos restaurantes, recebe e processa as ordens e o faturamento, carrega o caminhão e entrega no ponto de venda nos horários pré-estabelecidos, que são fielmente cumpridos, para assegurar o suprimento ideal dos estoques.

A governança da cadeia é realizada pela corporação McDonald's, que estipula as responsabilidades dos seus agentes, assim como a gestão de preços, margens de lucro, qualidade e conflitos.

Nesta operação, o compromisso e o nível de relacionamento entre fornecedores e a PSL requer cooperação e confiabilidade, sendo necessário que cada agente participante da cadeia de suprimentos atenda aos pressupostos exigidos pela Corporação McDonald's, relativos aos seguintes aspectos:

- Rede de fast food: operação dos restaurantes, promoções e propagandas, escolha de fornecedores, preços e produtos, desenvolvimento de novos produtos, planos estratégicos, avaliação e padronização dos processos, bem como resolução de conflitos na cadeia.

- PSL: Gestão de compras e estoques, atendimento aos restaurantes, armazenagem, distribuição e transporte, transferências a outros centros de distribuição no País, gestão financeira da cadeia, planejamento logístico, planejamento fiscal, serviço de campo e coordenação das operações de abastecimento na cadeia.

- Fornecedores: Manufatura com qualidade assegurada, desenvolvimento de novos produtos e gestão da cadeia de suprimentos a montante. (VIVALDINI, 2015)

Deste modo, a contribuição do PSL na prestação de serviços na Cadeia de Suprimentos favorece o relacionamento do cliente com seus consumidores, bem como ajuda na melhoria dos resultados da empresa.

\subsection{O PROJETO BIODIESEL}

A finalidade do projeto é transformar o óleo de fritura coletado nos restaurantes da rede McDonald's em Biodiesel, para abastecimento dos veículos que realizam a logística da rede, mantendo um ciclo fechado (closed loop) na cadeia de suprimentos, sendo esta uma iniciativa pioneira de operação. Para tanto, todas as fases da operação precisam ser definidas, assim como a gestão dos processos e parceiros do grupo. (VIVALDINI, 2015)

O conceito de ciclo fechado (closed loop) adotado tem como diferencial o fato de que a gordura da fritura não volta para o fabricante da gordura, mas seria utilizada para a fabricação do Biodiesel, que abastece nos caminhões que realizam a logística da rede McDonald's. Assim, os próprios caminhões que realizam as entregas, também retiram a gordura descartada, que volta ao Centro de Distribuição e é armazenada em tanques específicos. Depois, o fabricante do Biodiesel retira a gordura a produz o Biodiesel, sem misturas com gorduras de outros locais, ou seja, é utilizada apenas a gordura descartada de frituras da rede McDonald's. O Biodiesel produzido é estocado e é utilizado pelos caminhões sempre que estiverem a serviço da rede McDonald's. (VIVALDINI, 2015).

Além de manter este ciclo de reaproveitamento, o projeto também busca resultados indiretos, com a redução do impacto ambiental decorrente do descarte da gordura de fritura, transformando-o em um recurso renovável; criação de um padrão para descarte desta gordura nos restaurantes; promoção da marca McDonald's e das empresas envolvidas na CS perante o mercado e seus acionistas, bem como a aquisição de créditos de carbono gerados pela operação. (VIVALDINI, 2015)

Ressalta-se, entretanto, que este projeto foi idealizado após a percepção da PSL sobre a oportunidade existente. Assim, com o aval e liderança da rede McDonald's no Brasil, foi contratada uma empresa de consultoria técnica especializada, que auxiliou nos aspectos tecnológicos, sendo delegada a PSL a coordenação para a execução do projeto. (VIVALDINI, 2015)

\section{CONSIDERAÇÕES FINAIS}

Este artigo demonstrou a efetiva participação do PSL na intermediação das operações de logística reversa, o que também representa um importante diferencial competitivo para o mesmo.

As ações visando a sustentabilidade se tornaram fundamentais para as organizações que pretendem se estabelecer em um mercado altamente competitivo. Apesar de haver uma legislação ambiental vigente, ainda 
há muitas lacunas que precisam ser preenchidas e as empresas que têm percebido onde podem melhorar seus processos estão dando um passo à frente, o que pode fazer toda a diferença perante os clientes e consumidores finais.

O projeto Biodiesel realizado pela rede McDonald's por meio de seu PSL MartinBrower traz a lume a necessidade de uma parceria baseada na confiança, compromisso e colaboração, cujos resultados beneficiam a todos os participantes da Cadeia de Suprimentos.

Por outro prisma, o Projeto Biodiesel também agrega valor à marca McDonald's, bem como aos seus parceiros, que demonstram, na prática, que é possível atuar mediante padrões éticos e que beneficiam não só as empresas envolvidas, mas toda a coletividade.

A iniciativa para a realização de ações sustentáveis pode se originar de qualquer

\section{REFERÊNCIAS}

[1] Andersen, M.; Skjoett-Larsen T. Corporate social responsibility in global supply chains. Supply Chain Management: An International Journal. 14/2, pp. 75-86, 2009.

[2] Ballou, R. H. Gerenciamento da Cadeia de Suprimentos. Porto Alegre, Bookman, 2001.

[3] Brodin, M. H.; Anderson H. Recycling calls for revaluation, Supply Chain Management: An International Journal, Vol. 13, n. 1, pp.9-15, 2008.

[4] Cohen, D. O desafio de defender a imagem. Revista Exame, 21.04.2004. Disponível em: $\quad$ http://exame.abril.com.br/revistaexame/edicoes/816/noticias/o-desafio-de-defendera-imagem-m0054609. Acesso em 27 jun.2016.

[5] Collis, J.; Hussey, R. Pesquisa em Administração. Porto Alegre: Bookman, 2005.

[6] Defee, C.C.; Esper T.; Mollenkopf, D. Leveraging closed-loop orientation and leadership for environmental sustainability. Supply Chain Management: An International Journal. 14/2, pp. 87-98, 2009.

[7] Eltantawy, R.; Fox, G. L.; Giunipero, L. Supply Management ethical responsibility: Reputation and performance impacts. Supply Chain Management: An International Journal. 14/2, pp. 99-108, 2009.

[8] Embrapa - Empresa Brasileira de Pesquisa Agropecuária. Biodiesel reduz em 70\% a emissão de gases do efeito estufa. Portal Embrapa, agente vinculado à cadeia de suprimentos de uma organização, mesmo que externo, mas que tenha identificado uma necessidade e a oportunidade, como ocorreu neste caso. Assim, o PSL Martin-Brower passou de mero prestador de serviço a parceiro, o que fez toda a diferença, inclusive, para que a rede McDonald's o mantenha como responsável pela movimentação e logística de seus produtos em todos os seus pontos de venda.

O modelo close-up também favoreceu o PSL, ao estabelecer que seus caminhões coletariam a gordura descartada e a disponibilizariam para a transformação em Biodiesel. E, então, criando mais uma prestação de serviços à rede de restaurantes, o que se tornou um importante diferencial competitivo para o PSL.

Portanto, este case de sucesso deve servir de exemplo para que outras ações visando a sustentabilidade sejam criadas por outros agentes da cadeia de suprimentos.

$2015 . \quad$ Disponível em: https://www.embrapa.br/busca-de-noticias//noticia/2723697/biodiesel-reduz-em-70-a-emissaode-gases-do-efeito-estufa. Acesso em: 25 jun..2016.

[9] Figueiredo, R. Seleção de Prestadores de Serviços Logísticos - Adequando o Processo Seletivo a Cada Necessidade. Artigos CelCoppead - UFRJ - 2005. Disponível em: www.celcoppead.com.br. Acesso em: 15 jun. 2016.

[10] Flynn, B.B.; Huo, B.; Zhao, X. The Impact of supply chain integration on performance: a contingency and configuration approach. Journal of Operations Management, v. 28, pp.58- 71, 2010.

[11] Golic, S. L. \& Mentzer, J. T. An Emperical Examination of Relationship Magnitude. Journal of Business Logistics, V. 27, n. 1, p. 81, 2006.

[12] Halberstadt, K. F.; Silva, V. A.; Santos, M. B.; Scherer, F. L.; Carpes, A. M.; Oliveira, M.C.S.F.. Práticas sustentáveis na destinação de resíduos resultantes da cadeia produtiva do arroz. Revista Eletrônica em Gestão, Educação e Tecnologia Ambiental Santa Maria, v. 19, n. 3, set-dez. 2015, p. 298-312.

[13] Holt, D.; Ghobadian, A. An empirical study of green supply chain management pratices amongst UK manufactures. Journal of Manufacturing Technology Management, v. 20, n. 7, pp. 933-956, 2009.

[14] Hsu, H.S.; Alexander, C. A.; Zhu, Z. Understanding the reverse logistics operations of 
retailer: a pilot study. Industrial Management \& Data Systems, v.109, n. 4, pp. 515-531, 2008.

[15] Jaafar, H.S.; E Rafiq, M. Logistics Outsourcing Practices in the UK: a Survey. International Journal of Logistics: Research and Applications, vol. 8, n. 4, pg. 299-312, 2005.

[16] Lau, K.; Wang, Y. Reverse Logistics in the electronic industry of China: a case study. Supply Chain Management: An International Journal, 14/6, pp. 447-465, 2009

[17] LI, X.; Olorunniwo, F. An exploration of reverse logistics pratices in three companies. Supply Chain Management: An International Journal, 13/5, pp. 381-386, 2008.

[18] Lieb, K. J.; Lieb, R.C. Environmental sustainability in the third-party logistics (3PL) industry. International Journal of Physical Distribution \& Logistics management. Vol. 40, n. 7 , pp.524-533, 2010.

[19] Lieb, R. The year 2007 survey - Provider CEO perspectives on the current status and future prospects of the third party logistics industry in the Asia-Pacific region. International Journal of Physical Distribution \& Logistics Management, vol. 38, n.6, pp. 495-512, 2008

[20] Muniz, E. F. A.C.; Cruz, G. R. Estudo crítico sobre relacionamentos colaborativos na cadeia de suprimentos e seus impactos no processo decisório logístico. Projeto de Graduação em Engenharia de Produção. Universidade Federal do Rio de Janeiro, 2016.

[21] Nyaga, G. N.; Whipple, J.M.; Lynch, D.F Examining supply chain relationships: do buyer and supplier perspectives on collaborative relationships differ? Journal of Operations Management. V. 28, pp. 101-114, 2010.

[22] Oliveira Neto, G. C.; Shibao, F. Y.; Santos, J. P.; Costabile, L. T.. Fatores de decisão na terceirização de serviços logísticos: um estudo de caso sob a ótica do operador logístico. IX SEGET 2012 - Simpósio de Excelência em Gestão e Tecnologia. Disponível em; http://www.aedb.br/seget/arquivos/artigos12/62616 797.pdf. Acesso em 20 jun. 2016.

[23] Pires, S. Gestão da cadeia de Suprimentos (Supply Chain Management): conceitos, estratégias, práticas e casos. 2 ed. São Paulo: Atlas, 2009

[24] Poler, R.; Hernandez, J. E.; Mula, J.; Lario, F. C. Collaborative forecasting in networked manufacturing enterprises. Journal of manufacturing technology management, vol.19, n. 4, pp.514-528, 2008.
[25] Ryu, I.; SO, S.; Koo, C.. The role of partnership in supply chain performance. Industrial Management \& Data Systems. v. 109, n. 4, p. 496514,2009

[26] Sahay, B.S. Supply chain collaboration: The key to value creation. Work Study, Vol.52, n.1, pp.76-83, 2003.

[27] Schier, C. U. C. Logística integrada na cadeia de suprimentos. Disponível em: http://www.opet.com.br/faculdade/revista-ccadm/pdf/n7/LOGISTICA-INTEGRADA-Na-Cadeiade-Suprimentos.pdf. Acesso em: 20 jul. 2016.

[28] Selviaridis, K.; Spring M. Third party logistics: a literature review and research agenda. The International Journal of Logistics management, vol. 18, n. 1, pp. 125-150, 2007.

[29] Singh, P. F.; Power, D. The nature and effectiveness of collaboration between firms, their customers and suppliers: a supply chain perspective. Supply Chain Management: An International Journal, 14/3, p.189-200, 2009.

[30] Soosay, C.A.; Hyland, P.W.; Ferrer, M. Supply chain collaboration: capabilities for continuous innovation. Supply Chain Management: An International Journal, 13/2, pp. 106- 169, 2008.

[31] Tavares, B. M; Silva, S.R.R. Biodiesel: fonte de combustível limpo atuando como rica contribuição estratégica, social e ecológica na região de Lins. Centro Universitário Católico Salesiano Auxilium. Lins, 2008.

[32] Vijayvargiya A.; Dey A.K. An analytical approach for selection of a logistics provider, Management Decision, Vol. 48, n. 3, pp.403-418, 2010

[33] Vivaldini, M.; Pires, S.R.I. Operadores logísticos: Integrando operações em cadeias de suprimento. São Paulo: Atlas, 2010.

[34] Vivaldini, M. Logística sustentável - a utilização de biodiesel na operação McDonald's. ReFAE - Revista da Faculdade de Administração e Economia, 131 ReFAE - Revista da Faculdade de Administração e Economia, v. 6, n. 2, p. 128-154, 2015

[35] Vivaldini, M.; Pires, S.R. Gestão da demanda, colaboração e CPFR (Collaborative Planning, Forecasting, and Replenishment): Um estudo em empresas de alimentação. Revista Eletrônica: Sistemas \& Gestão 7 (2012), pp. 312324.

[36] Wolf; C.; Seuring, S. Environmental impacts as buyng criteria for third party logistical services. International Journal of Physical Distribution \& Logistics Management. V. 40, n. 1/2, pp.84-104,

2010 . 


\section{Bapítulo 11}

\section{OS DESAFIOS DA GESTÃO DO TERCEIRO SETOR: UM ESTUDO DE CASO DA INSTITUIÇÃO EUNICE WEAVER (EDUCANDÁRIO CARLOS CHAGAS)}

Aline Cristina de Oliveira Souza

Ana Valeria Vargas Pontes

Juliana Maioli Laval Bernardo

Luciana Novaes Vieira Ferreira

Resumo: As instituições sem fins lucrativos que formam o terceiro setor, vem sofrendo constantes desafios para se manterem sustentáveis. É preciso fazer mais com menos. A fim de entender essas questões o objetivo deste estudo consiste em investigar os principais desafios enfrentados pelo Educandário Carlos Chagas, instituição do terceiro setor localizada na cidade de Juiz de Fora, MG, que atende pessoas adultas com deficiência mental e/ou física. Para tanto, foi realizada uma pesquisa bibliográfica e um estudo de caso de cunho qualitativo com a instituição a partir de uma entrevista. Após pesquisa, pode-se observar que o maior desafio enfrentado é a captação de recursos, assim, constatou-se que uma gestão proativa e dinâmica, o apoio dos setores privado e governamental e o reconhecimento da sociedade possibilitam a continuação e a sustentabilidade da instituição.

Palavras-chave: Desafios. Terceiro Setor. Captação de recursos. 


\section{INTRODUÇÃO}

O cenário do terceiro setor no Brasil sofreu diversas transformações ao longo do tempo, para que fosse possível permanecer em um ambiente hostil e competitivo, garantir a continuidade da missão institucional das organizações sociais, captar recursos, e manter sua autossustentabilidade. A fim de manter uma gestão organizacional efetiva, o comportamento deste segmento teve que implantar melhorias, capacitando seus dirigentes, bem como toda equipe.

A escolha do tema justifica-se pela necessidade de reconhecimento das organizações do terceiro setor, em relação à importância das práticas de gestão que podem auxiliá-las na administração de seus recursos.

Diante desse cenário que apresenta diversas dificuldades para o alcance de uma gestão eficiente e eficaz, busca-se responder a seguinte questão de investigação: $O$ terceiro setor possui práticas de gestão para enfrentar as dificuldades e os desafios do seu cotidiano institucional?

Este trabalho tem como objetivo investigar os principais desafios enfrentados pela gestão do Educandário Carlos Chagas, instituição do terceiro setor localizada na cidade de Juiz de Fora, MG que atende pessoas adultas com deficiência mental e/ou física.

O artigo está estruturado em cinco seções. Na seção um é apresentada a introdução. A seção dois estabelece os conceitos do terceiro setor e a situação do setor no Brasil. Já a seção três apresenta os desafios da gestão do terceiro setor. A seção quatro aponta os procedimentos metodológicos e o estudo de caso da instituição Educandário Carlos Chagas. E por fim, a seção cinco traz as considerações finais.

\section{TERCEIRO SETOR}

De acordo com Costa Júnior (1998), é de visível notoriedade que não existe um consenso quanto ao abarcamento do conceito e às terminologias adotadas para se mencionar às instituições que formam o terceiro setor.
É possível verificar alguns conceitos que foram emergindo de muitas pesquisas, como Albuquerque (2006) ao definir o terceiro setor como organizações sem fins lucrativos e não governamentais, que tem como objetivo gerar serviços de caráter público. O termo terceiro setor é de origem americana, Third Sector, seu conceito é um assunto atual e vem ganhando identidade no campo acadêmico. Este setor contribui com ações para as comunidades menos favorecidas onde o Estado não conseguiu alcançar, por meio de ações solidárias, portanto, possui um papel fundamental na sociedade.

Esse pensamento é partilhado por Tenório (2006) ao afirmar que as instituições do terceiro setor não fazem parte do Estado e nem a ele estão atreladas, mas se mostram de caráter público, porque objetivam a satisfação do bem coletivo. Trabalham com causas e problemas sociais, que apesar de serem sociedades privadas não tem como objetivo fins econômicos, e sim o acolhimento das necessidades da população carente.

Albuquerque (2006) destaca que foi elaborado pela Divisão de Estatísticas da Organização das Nações Unidas o Manual sobre as instituições sem fins lucrativos no sistema de contas nacionais, que caracteriza as instituições do terceiro setor com os seguintes critérios e características: deve ser organizado formalmente, com uma estrutura interna, nível de formalização de regras e procedimentos, para assegurar a sua permanência por um período mínimo de tempo.

Para Tachizawa (2014) a organização também deve apresentar uma estrutura básica não governamental, ser privada, realizando sua própria gestão, não sendo controlada externamente. Assim, a geração de lucros ou excedentes financeiros precisa ser reinvestida integralmente na organização, dessa forma, as entidades não podem distribuir dividendos de lucros aos seus dirigentes e devem ter um alto grau de participação cidadã ou voluntariado.

Diante disso, Melo Neto; Froes (1999) apontam os principais elementos definidores do conceito e das características do terceiro setor, que tem seu foco em bem estar público buscando 
um interesse comum. Suas questões centrais são a pobreza, exclusão e desigualdade social. Seu nível de atuação é o comunitário e de bases, nas quais suas ações praticadas são de caráter público e privado, associativas e voluntaristas e as entidades que participam são empresas privadas, Estado, ONGs e sociedade civil.

Os autores destacam, também, algumas das diversas causas que tem gerado 0 crescimento do Terceiro Setor no Brasil, como o crescimento das necessidades socioeconômicas, decorrente do crescimento populacional e das consequências do capitalismo de mercado; tais como do agravamento dos problemas sociais e econômicos. Observase, então que o Estado não vem sendo capaz de suprir a população com os serviços sociais básicos e ainda, o fracasso de políticas econômicas e sociais responsáveis pelo combate a inflação e o crescimento do emprego, que não vêm cumprindo o seu papel de assistir, criar estratégias sociais e planos de ação para a população.

De acordo com Salamon (1998), essas realidades desanimadoras incitaram 0 repensar de estratégias para o progresso econômico. E como resultado, tem-se renovado o interesse no desenvolvimento participativo, uma forma de auxílio que destaca o engajamento de energia e a criação de organizações nãogovernamentais. Podendo ser percebido um crescente consenso a respeito das limitações do Estado como agente de desenvolvimento e da necessidade da inclusão das instituições do Terceiro Setor para superar essa deficiência.

Melo Neto; Froes (1999) ainda apontam que o aumento da degradação ambiental, seguido do crescente aumento da violência no país, que ameaça a segurança da população, diante destes fatores há uma crescente adesão das classes alta e média a iniciativas sociais, formando assim um interesse solidário. A mídia tem noticiado muitas iniciativas deste setor, divulgando ações e pesquisas sociais, com uma maior participação de empresas que buscam a cidadania empresarial. A partir dessas colocações, tem-se a necessidade de se conhecer a situação do terceiro setor no Brasil.

\subsection{A SITUAÇÃO DO TERCEIRO SETOR NO BRASIL}

Durante as últimas décadas, houve no Brasil, diversas transformações nas políticas econômicas e sociais. Diante disso, Albuquerque (2006) afirma que juntamente com essas alterações políticas, ocorreram também mudanças no papel das ONGs. A partir destas mudanças o autor afirma que foram iniciados debates sobre assuntos que antes não eram discutidos, e hoje tem uma visibilidade maior na mídia, na sociedade e no governo, como o meio ambiente, gênero e raça, sendo fortalecidos pela construção de fóruns globais das Nações Unidas.

Segundo Falconer (1999), as organizações do terceiro setor no Brasil podem ser descritas como Igrejas e instituições religiosas, organizações nãogovernamentais e movimentos sociais, empreendimentos sem fim lucrativos e fundações empresariais.

Assim, o autor afirma que instituições ligadas ao protestantismo, espíritas afrobrasileiras e demais religiões têm tido um papel importante para o terceiro setor, embora sejam em número menor. Costa e Visconti (2001) corroboram ao afirmar que as Santas Casas são modelos de uma praxe clássica, em parcerias com as irmandades estabeleceram o início dos serviços de assistência social.

Os autores citam que no Brasil, o Estado dava apoio para que a igreja pudesse abarcar a maior parte das instituições que proporcionavam algum tipo de serviço para as comunidades carentes. O Estado e a Igreja Católica tiveram um predomínio no atendimento e assistência social a população carente no período que perpassou o Brasil colonial até o início do século XIX.

Paralelamente a isso, Falconer (1999) aborda que a Igreja Católica teve um papel decisivo para a formação não só das instituições religiosas, mas também, do terceiro setor que a partir do pioneirismo das Santas Casas criaram-se as primeiras organizações sem fins lucrativos no Brasil.

Ivamoto (1998) destaca que a primeira Santa Casa de Misericórdia surgiu em Santos, SP, em 1543, que eram mantidas por meio de doações de pessoas abastadas da sociedade. 
De acordo com Del Porto (2006), a partir de 1964, com o regime militar no poder, e mais tarde, com a crise no desenvolvimento econômico nos anos de 1980, conhecida como a década perdida, o aumento da inflação gerando uma má distribuição de renda, juntamente com os problemas daí decorrentes, como a pobreza e as desigualdades sociais no Brasil foram maximizados e seus resultados tiveram consequências de longo prazo.

Costa e Visconti (2001) apontam que nesse cenário, em 1980 a política é redemocratizada e surgem movimentos da Sociedade Civil, promovida pelo sociólogo Hebert de Souza, o Betinho, como o Movimento da Ação da Cidadania contra a Fome e a Miséria e pela Vida, com a finalidade de enfrentar as questões resultantes desse contexto. Após a redemocratização do Brasil, as organizações da sociedade civil brasileiras iniciaram um processo de articulação, e como resultado aparecem com ações voltadas para o Terceiro Setor.

Para Falconer (1999), o terceiro setor é composto por ações não-governamentais e movimentos sociais, têm sua origem no âmbito popular e social, atuando na defesa de direitos, mobilização popular e articulação política disseminados em centros de educação popular e de promoção social.

Os empreendimentos sem fins lucrativos também são descritos pelo autor, como tendo foco na prestação de serviço que pode ser observada em casos como instituições culturais, entidades recreativas, entre outras, levantando a ideia de uma organização de caráter comercial.

Por fim, o autor aborda a atuação das chamadas "cidadania empresarial" ou "filantropia empresarial", ou seja, as fundações empresariais, que estão ligadas ao terceiro setor, sendo controladas pela própria empresa do setor privado, mas que trabalham em ações para benefício da população.

$\mathrm{Na}$ seção seguinte serão abordados os desafios na sustentabilidade do terceiro setor que perpassa por estratégias de gestão.

\section{OS DESAFIOS DA GESTÃO DO TERCEIRO SETOR}

Diversos autores descrevem os desafios da gestão do terceiro setor através das décadas, dentre eles Sandoval (1988 apud TENORIO, 2006) aponta que na década de 70 na América Latina as ações eram direcionadas tanto para o desenvolvimento comunitário quanto para as atividades no âmbito do consumo, educação e saúde.

Diante disso, Souza (1991) descreve que a partir da década de 80 surgem novas características no setor como déficit do crédito do Banco Mundial no que diz respeito aos recursos empregados no desenvolvimento social, inserção de uma política neoliberal, aumento da inflação e decorrente disso, aumento do setor informal e intensificação da pobreza. Assim o autor acrescenta que o Banco Mundial descobriu que as ONGs poderiam ser um "remédio" para as dificuldades do desenvolvimento social, portanto as instituições do terceiro setor se viram forçadas a reconsiderar sua missão, ações e funcionamento. Pois com o afastamento do estado na economia e com problemas econômicos e políticos existentes, o terceiro setor passa a ser um agente fundamental de desenvolvimento econômico, por isso é necessário se reinventar.

Para Armani (2001) as organizações não governamentais têm sido desafiadas a se manterem sustentáveis num contexto de crise política, econômica e social. Para o desenvolvimento da missão, visão e valores, as entidades precisam contar com pessoas, parcerias com empresas, governo, apoio de instituições religiosas e também, gerar renda própria.

Souza (1991) atesta dizendo que na década de 90 o terceiro setor teve que desempenhar de forma clara suas atividades e seus ideais, demonstrando, portanto sua participação no âmbito social, dessa forma não determinando suas ações não apenas no micro, mas também colaborando para uma nova vivência em busca de um macro desenvolvimento.

Para Tenório (2006), firmar os ideais das instituições sem fins lucrativos se torna um desafio, pois nem sempre é visualizada com clareza a melhor forma de estabelecer seus objetivos e metas para 
que sejam analisados os resultados obtidos.

O autor aponta que uma das fragilidades do setor está na equipe, que é formada por funcionários e voluntários. Pelo fato de boa parte das ações serem realizada por voluntários, nem todos possuem competências e habilidades adequadas ao desempenho das funções requeridas.

Outra questão apontada por Tenório (2006), é que com a preocupação de ajudar a comunidade, surge um desgaste, por causa da disponibilidade de cada voluntário, que acaba por vezes trabalhando em excesso, não podendo identificar seu retorno. A organização muitas vezes trabalha sem um planejamento de gestão de pessoas, dessa forma não são estabelecidas as funções de cada funcionário o que dificulta avaliar o trabalho em longo prazo.

Barbosa (2010) confirma ao narrar sobre as dificuldades na legislação que muitas vezes não contribui em relação aos critérios de concessões de recursos no que tange ao gozo de benefícios fiscais.

Camargo (2001) dá prosseguimento ao mostrar por meio de suas pesquisas que em uma grande parte das entidades pesquisadas (71\%), a escassez de recursos é a principal dificuldade encontrada e logo depois vem seguida do baixo investimento do governo (37\%).

Diante disso, Tachizawa (2014) contribui afirmando que as organizações do terceiro setor enfrentam na atualidade como um de seus maiores desafios a captação e mobilização de recursos. Assim, as organizações se vêem obrigadas a inovar as formas de captação de recursos, por conta do aumento do número de entidades no setor e a escassez destes. Para tanto, o autor corrobora apontando que o sucesso das ações do terceiro setor depende do relacionamento com seus doadores e que se o país não está bem economicamente as doações tendem a cair.

O autor acredita que deve-se elaborar um plano de comunicação adequado no qual seja apresentado aos potenciais doadores os problemas que a entidade procura solucionar, bem como suas ações para o enfrentamento dos desafios. É preciso compartilhar os objetivos, missão e valores da instituição com seus parceiros.
Albuquerque (2006) relata que a captação de recurso do terceiro setor no Brasil nos anos de 1990 se dava pelo apoio de voluntários, dos fundadores, o que tornava muito precário e não conseguia suprir as necessidades apresentadas pelas entidades. E como consequência muitas instituições foram obrigadas a restringir suas ações por falta de infraestrutura, de recursos econômicos financeiros e de pessoas para desenvolver as atividades planejadas. O autor aponta que mais do que captar recursos é preciso aperfeiçoar os recursos já mobilizados.

De acordo com o Grupo de Estudos do Terceiro Setor

Nos últimos anos, vem ganhando força a expressão "mobilização de recursos", que tem um sentido mais amplo do que "captação de recursos". "Mobilizar recursos não diz respeito apenas assegurar recursos novos [...], mas também a otimização [...] dos recursos existentes [...]; à conquista de novas parcerias e à obtenção de fontes alternativas de recursos financeiros. É importante lembrar que o termo "recursos" refere-se a recursos financeiros ou "fundos" mas também a pessoas (recursos humanos), materiais e serviços (GETS, 2002, p. 14).

Pode-se observar com os relatos de Falconer (1999), que o contexto do terceiro setor tem passado por transformações. Atualmente outro desafio do terceiro setor é garantir uma gestão que tenha eficiência e eficácia. Num passado recente as doações eram feitas sem o atrelamento com o resultado alcançado com 0 emprego destes recursos.

Nanus; Dobbs (2000) apontam que é responsabilidade do gestor manter a organização eficiente, prestar serviços úteis para a comunidade com menor custo e com qualidade possível, sendo essa a principal responsabilidade do gestor para manter uma organização eficiente. Para isso, os autores afirmam que para alcançar o êxito, as organizações do terceiro setor precisam de uma boa liderança juntamente com uma boa administração. Diante disso, os autores confirmam:

Olhe para qualquer organização bemsucedida e a resposta, na maioria das vezes, será a mesma: a organização não 
teria atingido o êxito sem uma liderança efetiva, sem o grande viabilizador para estimulá-la, permitindo-a atingir seu pleno potencial para fazer uma diferença real em sua comunidade. (NANUS; DOBBS, 2000, p.19)

Contudo os autores argumentam que uma organização do terceiro setor deve avaliar seu sucesso em termos do bem social, e não somente no cumprimento de suas obrigações e lucros. E "cada caso apresenta um desafio único e requer tratamento especial" (NANUS; DOBBS, 2000, p.26), por se distinguir das outras organizações e possuírem uma clientela variada com limites imprecisos e interesses variados.

Para os autores, as expectativas e necessidades da organização do terceiro setor ultrapassam muito seu orçamento limitado, e as organizações beneficentes operam naturalmente sob restrições financeiras. Por isto, os líderes desse setor devem ser ousados, engenhosos e cooperadores, pois as organizações beneficentes possuem muitos desafios.

Assim pode-se observar que:

Se os problemas de gestão são muitos é porque as dificuldades são grandes. Mas não há nada que uma gestão eficiente e eficaz não possa resolver. $O$ que falta às empresas é uma pratica gerencial bem estruturada, inovadora e condizente com as demandas sociais de hoje. (MELO NETO; FROES, 2001, p.79)

Nesta perspectiva, Williams (1990) cita o Banco Mundial como avaliador do desempenho das ONGs. No que tange a eficiência destaca elementos relacionados ao processo operacional que podem sofrer algumas restrições administrativas como capacitação de pessoal, desempenho gerencial e redução de custos indiretos.

Tenório (2006) considera que para superar os desafios que ameaçam a existência e eficiência da organização devem-se criar mecanismos que possibilitem melhorar suas ações, objetivos, avaliar sua atuação, aumentar sua visibilidade e promover seu produto e serviço.

Por fim, Nanus; Dobbs (2000) abordam que uma organização para melhorar o desempenho deve ser estimulada, superando os obstáculos a fim de se alcançar o progresso, desenvolvendo o aprendizado e o crescimento.

\section{PROCEDIMENTOS METODOLÓGICOS}

A metodologia segundo as autoras Marconi; Lakatos (2006) é base da formação do discente atuando não só na prática, mas também no mundo das ideias, sendo uma disciplina que introduz procedimentos sistemáticos e racionais, afigurando-se como 0 mais lógico, racional, eficiente e eficaz para qualquer tomada de decisão. Neste sentido, podese afirmar que, a metodologia visa responder a questão de investigação e atingir os objetivos formulados.

Gil (2008) corrobora ao afirmar que o método científico é formado por uma série de procedimentos do intelecto e de técnicas usados para alcançar o conhecimento. No campo do conhecimento científico é preciso determinar o método adotado para se alcançar os objetivos propostos.

Este estudo contou com uma pesquisa descritiva que segundo Vergara (2007), expõe os atributos de determinada população, amostra ou fenômeno. "Não têm o compromisso de explicar os fenômenos que descreve, embora sirva de base para tal explicação". Cita como exemplo a pesquisa de opinião (VERGARA, 2008, p.47). Que ao ver da autora ela se caracteriza também como exploratória concretizada em campo no qual há pouco conhecimento organizado.

Este estudo contou com uma pesquisa bibliográfica que de acordo com (SEVERINO, 2000, p.39) "constitui em um acervo de informações sobre livros, artigos e demais trabalhos que existem sobre determinados assuntos". Essa revisão descritiva no segmento do terceiro setor envolveu trabalhos de Albuquerque (2006); Falconer (1999); Nanus; Dobbs (1999); Melo Neto; Froes (2001); Tachizawa (2014) entre outros; com o intuito de compreender o conceito e a importância da gestão do terceiro setor e discutir os desafios enfrentados pelas organizações sem fins lucrativos.

Outro procedimento metodológico adotado foi um estudo de caso que segundo (PARRA FILHO; SANTOS; 1998; p.102) tem 
por finalidade "observar os fatos tal como ocorrem", este realizado em campo, por meio de uma análise qualitativa que de acordo com Marconi; Lakatos (2006) tem o intuito de agregar qualidade ao estudo transformando quantidade em qualidade, na instituição Eunice Weaver (Educandário Carlos Chagas), situada na cidade de Juiz de Fora, Minas Gerais. O instrumento de pesquisa utilizado foi uma entrevista realizada na entidade no dia 23 de março de 2015. Segundo os autores, o uso da entrevista permite dar mais segurança ao entrevistado para expor sua vivência em relação ao assunto explorado. Perguntas foram feitas diretamente à gestora da instituição: Elisângela Leite de Souza Costa, na qual foi relatada suas experiências e vivências sobre os desafios enfrentados pela gestão do terceiro setor.

\subsection{ESTUDO DE CASO}

Segundo Elisângela Leite de Souza Costa gestora da instituição, a Sociedade de Assistência aos Lázaros e Defesa Contra a Lepra foi constituída em 03 de abril de 1932, sendo inaugurada oficialmente em 04 de abril de 1943, pelo Ministro da Educação e Saúde Dr. Gustavo Capanema, e neste ano de 2017 completou 85 anos. O Educandário Carlos Chagas teve início com o programa de assistência e defesa contra a lepra criado pela senhora Eunice Weaver de Juiz de Fora. Hoje o grupo Eunice Weaver é composto por vinte e sete sociedades em todo o país, das quais vinte e três mantém educandários e são afiliados à Federação das Sociedades "Eunice Weaver", com sede na cidade do Rio de Janeiro, que é presidida pela senhora Marietta Cavalcanti de Albuquerque Coutinho.

A Instituição foi fundada com o intuito de acolher os filhos de mulheres com hanseníase (lepra) que não possuíam a doença. Na época, a lepra era uma doença muito grave e contagiosa, e as mães que engravidavam, eram separadas de seus bebês quando estes nasciam, uma vez que, eles não podiam ter contato com os pais para não contrair a doença. Estima-se que nessa época o Educandário chegou a atender cerca de 600 crianças, mas, com o tempo e erradicação da doença, o Abrigo passou a cuidar dessas pessoas, uma vez que muitos deles nasceram com algum tipo de deficiência física ou mental, e as dificuldades para inseri-los na sociedade eram muitas. Já os sadios, tinham o suporte do Abrigo somente até completarem 18 anos, depois disso, tinham que deixar a Instituição.

Com a erradicação da doença, a partir de 1970, a instituição passou a receber crianças e/ou adolescentes em situação de risco social, a maioria vinda de famílias sem condições financeiras e psicológicas. Em 2009 houve uma reestruturação dos abrigos, e em Juiz de Fora, optou-se por atender um perfil determinado, somente pessoas adultas com deficiência mental e/ou física.

\subsubsection{MISSÃO, VISÃO E VALORES DA INSTITUIÇÃO}

Alguns autores citados anteriormente neste artigo destacam a importância da missão, visão, valores, a transparência com a prestação de contas e manutenção de uma boa estrutura para que seus funcionários trabalharem de forma correta para que a organização do terceiro setor possa assim, estabelecer seus ideais e firmar parcerias. A entrevistada comprova essa ideia e afirma que o uso dessas práticas é de suma relevância para a sobrevivência da Instituição tornando possível manter o certificado de filantropia que é fundamental para o alcance de benefícios. Para tanto o Educandário possui como:

a) Missão - Cuidar e atender pessoas com deficiência físicas, mentais e auditivas, na sua maioria carente e abandonada, gerando qualidade de vida, dignidade, amor e respeito. Nosso objetivo é reinserilos na vida social e promover seu bem estar.

b) Visão - Nossa visão reflete a própria Declaração dos Direitos Humanos, em seu artigo 10 "Todos os seres humanos nascem livres e iguais em dignidade e direitos. São dotados de razão e consciência, devem agir em relação uns aos outros com espírito de fraternidade" O Educandário Carlos Chagas não é uma empresa, portanto não visa lucro, mas visa melhorar a cada dia a qualidade do atendimento dos seus assistidos. 
c) Valores - Valorização e respeito, pois, somente através disto estas pessoas poderão se sentir importantes em todos os aspectos. Trabalhamos com a verdade e integridade, justiça e igualdade, seriedade e transparência, alegria e amor ao próximo.

A fim de fazer um atendimento de qualidade, o Educandário conta com: cuidadoras, cozinheiras, lavadeiras, profissionais de serviços gerais, enfermeiras, assistente social, pedagogo, fonoaudiólogo, professores (cedidos pela Secretaria Municipal de Educação da Prefeitura de Juiz de Fora), bem como alguns voluntários que são responsáveis por atividades recreativas e religiosas.

A gestora destaca que todos os funcionários, exceto os voluntários e os cedidos pela Secretaria de Educação, são remunerados pelos serviços prestados e têm todos os direitos trabalhistas garantidos pela a instituição.

A parte contábil do Educandário Carlos Chagas é realizada pela Tecol, que é uma empresa de contabilidade tradicional na cidade de Juiz de Fora. É esta empresa que realiza os balancetes, balanços e envia para a conferência da instituição. Este trabalho de conferência é realizado por um superintendente da instituição. A instituição tem que prestar contas, através de relatórios, demonstrativos e documentações, aos órgãos competentes.

Em relação ao formato jurídico, apresentase como Associação, possui registros no Conselho Nacional e Municipal de Assistência Social, além do Ministério da Justiça. Esse registro resultou em certificação, no qual permite que a instituição mantenha convênios com outras entidades.

Segundo Elisângela, as ações de marketing desenvolvidas pelo Educandário têm como objetivo otimizar as doações. A instituição possui uma central de Telemarketing que foi implantada em 2008 para ajudar na captação de recursos para a entidade. Outro meio de divulgação são as redes sociais, cabe destacar o facebook, que possibilita uma aproximação com possíveis doadores. A panfletagem se caracteriza como um meio de divulgar a instituição. Além disso, são realizadas campanhas diversificadas, como para arrecadação de fraldas geriátricas, material de higiene pessoal, material de limpeza e alimentos, insumos indispensáveis para a manutenção da instituição.

De acordo com a entrevistada, o benchmarking é realizado pela superintendente que participa do Conselho de Assistência Social e cuida das relações externas. Nas reuniões do conselho é propiciado o compartilhar de experiências pelas associadas, e dessa forma, pode-se buscar formas de melhorias para os processos que são desenvolvidos pelo Educandário.

\subsubsection{DIFICULDADES E DESAFIOS ENFRENTADOS PELA INSTITUIÇÃO}

Elisângela destaca primeiramente, que um dos maiores desafios do Educandário está na captação e mobilização de recursos financeiros para a manutenção da instituição, o que pode ser observado na seção 3 "Os desafios da gestão do terceiro setor" onde Tachizawa (2014) afirma este fato.

A mesma narra que em 2004, a Belgo Siderurgia S/A, hoje Arcelor Mittal, implantou na instituição o programa "Construindo o Futuro" que consiste em proporcionar o primeiro emprego para adolescentes carentes da região e portadores de deficiências que residem no Educandário.

Este programa possibilita não só 0 desenvolvimento profissionalizante dos adolescentes, como gera renda para as suas famílias. Atualmente, esse projeto, Construindo o Futuro, assiste a 15 adolescentes.

Em 2006 foi firmada também uma parceria com a Guarda Mirim, e em 2007 com as Creches Assistenciais de Juiz de Fora. A instituição atua como administradora indireta, cuidando somente da parte trabalhista dos dois projetos, sendo essa mais uma fonte de recurso para o Educandário, recursos estes que são repassados mensalmente pela prestação de serviços.

Em 2009, foi criado o programa "Crescer com Cidadania" em parceria com Onduline do Brasil objetivando o primeiro emprego para adolescentes com idade igual ou superior a 16 anos. Hoje o projeto conta 
com 10 adolescentes, este funcionava na sede da Onduline, e a partir de 20 de agosto de 2012 passou a funcionar nas dependências da Instituição.

Para participar dos projetos da Arcelor Mittal e Onduline os adolescentes devem estar obrigatoriamente estudando ou ter concluído o ensino médio. Os adolescentes também se alimentam na Instituição que fornece a eles, lanche da manhã// tarde e almoço.

De acordo com visitas domiciliares realizadas pela Assistente Social da Instituição às famílias, os adolescentes demonstram grande satisfação com os projetos, pois, com o salário recebido ajudam na renda familiar.

Dos projetos com os adolescentes da Arcelor Mittal e da Onduline, é repassado um valor para o Educandário, do qual uma parte é retirada para atender os direitos trabalhistas dos adolescentes, e outra parte fica na Instituição para a manutenção dos gastos, e também, realização de obras, melhorias para melhor funcionamento da mesma, que preza pela qualidade dos assistidos.

Além do repasse financeiro feito pelos projetos atendidos pela instituição que funcionam como renda fixa mensal, o abrigo recebe um repasse municipal que complementa a renda. A captação de recurso também vem de doações de pessoas físicas.

Elisângela, a respondente, destaca que a falta de quaisquer desses recursos abala a situação financeira da Instituição, pois é por meio deles que os compromissos assumidos são honrados, e que mesmo com esses repasses financeiros a organização enfrenta dificuldades.

A entrevistada acredita que o papel de uma gestão eficiente é necessário no enfrentamento da captação e manutenção de recursos, que requer procedimentos de transparência e de um bom relacionamento com parceiros, o que é citado também na seção três desse artigo por diversos autores, dentre eles, destacase Nanus; Dobbs (2000).

Hoje o Educandário Carlos Chagas abriga 30 pessoas com variados tipos de deficiência, sendo que os recursos financeiros arrecadados, nem sempre, conseguem suprir os custos, o que pode vir a comprometer a qualidade no atendimento dos assistidos.

O segundo desafio destacado na entrevista é o do preconceito histórico vivido pelo abrigo, pelo fato de no passado ter recebido os filhos da lepra, e por hoje receber pessoas com algum tipo de deficiência. Isto muitas vezes dificulta a aproximação de parte da população, que por falta de informações, acaba por fazer uma imagem do abrigo diferente da realidade.

Em terceiro, é pontuado ainda, a falta de urbanização ao redor da instituição, que acaba isolada, e por isso, sendo de difícil acesso, uma vez que nem mesmo os ônibus urbanos chegam até o abrigo. Esse fato também dificulta a aproximação das pessoas, que poderiam ser simpatizantes pela causa e se tornarem doadores.

Os internos atendidos pelo Educandário necessitam de tratamentos com um alto custo de medicamentos e muitos deles usam fraldas geriátricas. Estes insumos são repassados pelo SUS (Sistema Único de Saúde), no entanto, nem sempre consegue fornecer o necessário, sendo observado como um quarto desafio.

E por último, é percebido o quinto desafio relatado pela entrevistada, a evasão dos voluntários. Ela destaca que ao firmar compromissos com a organização, muitas vezes não são capacitados para tal atividade, não se identificam com a causa, ou encontram dificuldades de lidar com pessoas portadoras de necessidades especiais. Estes colaboradores nem sempre dispõem de tempo regular para dar continuidade à ação de voluntariado e acabam por interromper as atividades. Este viés é abordado na revisão da literatura por Tenório (2006) ao afirmar a dificuldade de um planejamento de gestão de pessoas, tendo em vista o que aqui foi pontuado.

A partir das vivências e experiências sobre os desafios e dificuldades relatados pela a entrevistada no decorrer do estudo de caso, mostra-se, também, as práticas de gestão que a entidade utilizou para o enfrentamento das mesmas. Ficando claro, que essas ferramentas administrativas auxiliaram a entidade a se manter no mercado ao longo do tempo, a despeito de 
todas as dificuldades e desafios passados pela instituição.

\section{CONSIDERAÇÕES FINAIS}

Este estudo teve como objetivo investigar os principais desafios enfrentados pelo Educandário Carlos Chagas, instituição do terceiro setor localizada na cidade de Juiz de Fora, MG que atende pessoas adultas com deficiência mental e/ou física.

Diante de todas as informações pesquisadas pode-se observar que a maior dificuldade enfrentada pela instituição é a captação de recursos, ponto que é discutido por diversos autores ao decorrer do estudo. A arrecadação financeira é necessária para a manutenção da organização sem fins lucrativos e se torna muitas vezes um impedimento para dar continuidade a um trabalho de qualidade.

Observou-se que em muitas instituições do terceiro setor o produto, ou serviço oferecido não é comercializado, e sua fonte de recursos depende de doações e parceiras.

Pode-se notar, também, que o atraso das instituições muitas vezes impacta fortemente nas questões financeiras dessas entidades, quando as mesmas não cumprem com seus deveres.

Já quando se fala do setor privado, segundo setor, as ações de responsabilidade social praticadas podem

\section{REFERÊNCIAS}

[1] Albuquerque, Antonio Carlos Carneiro de. Terceiro setor: historia e gestão de Organizações / Antonio Carlos Carneiro de Albuquerque. 2 $2^{\underline{a}}$ Ed. São Paulo: Summus 2006.

[2] Armani, D. O desenvolvimento institucional como condição de sustentabilidade das ONGs no Brasil. 2001. Acesso: 10/02/2017. Disponível:

http://www.aids.gov.br/biblioteca/sustenta/dese nol.htm

[3] Barbosa, M.N. Terceiro Setor e as Transformações do Estado. São Paulo: OABOnline 2010. Acesso: 10/02/ 2017. Disponível: http://www.oabsp.org.br/comissoes2010/direitoterceiro-setor/artigos/terceiro-setor-e-astransformacoes-do-estado-dra.-201marianazare-lins-barbosa. impactar positivamente no terceiro setor. Como pode ser observado no estudo de caso, sobre as ações das empresas Arcelor Mittal e Onduline, nas quais trouxeram benefícios para o Educandário.

Portanto, as parcerias sejam elas com o governo, empresas ou sociedade são fundamentais para a continuidade e sustentabilidade do terceiro setor. Parcerias que sejam consolidadas na missão, visão e valores dessas entidades do terceiro setor.

Cabe ressaltar que a pesquisa identificou que para uma gestão capacitada, proativa e dinâmica deve-se gerenciar a organização de maneira a adaptar-se às diversas mudanças e desafios no contexto social. A direção do Educandário Carlos Chagas, que tem importância histórica e social para a comunidade juizforana, tem realizado uma gestão eficaz e que tem demonstrado a preocupação com o bem estar da sociedade. A mesma busca cumprir seus deveres com responsabilidade priorizando sempre 0 bem estar de seus internos. Mesmo com todas as dificuldades cotidianas, o Educandário segue contornando os desafios, demonstrando ser uma organização sólida. Desafios estes, que seriam mais facilmente resolvidos, se a instituição fosse melhor atendida pelos órgãos públicos e privados e maior reconhecimento da sociedade.

[4] Camargo, Mariângela Franco de. Gestão do terceiro setor no Brasil. São Paulo: Futura, 2001.

[5] Costa Júnior, L. C. Caderno do III setor - terceiro setor e economia social. São Paulo: Fundação Getúlio Vargas/Escola de Administração de Empresas de São Paulo, n. 2, abr. 1998.

[6] Costa, Cláudia Soares; Visconti, Gabriel Rangel. Terceiro Setor e Desenvolvimento Social. São Paulo: AS/GESET, 2001.

[7] Del Porto, E. B. A Trajetória do Programa Comunidade Solidária 1995-2002. 2006, 233 f., Dissertação (Mestrado em Economia Social e do Trabalho) - Universidade 
Estadual de Campinas, Instituto de Economia/UNICAMP, Campinas, SP, 2006. Acesso: 15/03/2017. Disponível: https://portalseer.ufba.br/index.php/rigs/article/ download/10976/11563

[8] Falconer, Andrés Pablo. A promessa do terceiro setor: um estudo sobre a construção do papel das organizações sem fins lucrativos e de seu campo de gestão. Dissertação (Mestrado em Administração) - Universidade de São Paulo, São Paulo 1999.

[9] Gil, Antonio Carlos. Como elaborar projetos de pesquisa. 4. ed. São Paulo: Atlas, 2008.

[10] Gets: Grupo de estudos do terceiro setor. São Paulo: Graphbox Caran, 2002

[11] Ivamoto, Henrique Seiji. The Santa Casa da Misericórdia de Santos: historicalsynopsis. Acta Medica Misericordia1(1):7-10, $1998 . \quad$ Acesso: 15/03/2017 Disponível http://www.actamedica.org.br/noticia.asp?codig $\mathrm{o}=104$

[12] Marconi, Marina de Andrade; Lakatos, Eva Maria. Fundamentos de metodologia científica. 6 ${ }^{\underline{a}}$ Ed. 3a reimpr. - São Paulo: Atlas, 2006.

[13] Melo Neto, Francisco Paulo de, Froes, César. Gestão da responsabilidade social corporativa: o caso brasileiro. $2^{2}$ Ed. Rio de Janeiro: Quality Mark, 2001.

[14] Nanus, Burt, Dobbs, Sthephen M. Liderança para o terceiro setor: estratégia de sucesso para organizações sem fins lucrativos. São Paulo: Futura, 2000.
[15] Neto, Francisco Paulo de Melo, Froes, César. A responsabilidade social e cidadania empresarial: administração do terceiro setor. 1a Ed. Rio de Janeiro: Quality Mark, 1999.

[16] Parra Filho, Domingos; Santos, João Almeida. Metodologia Científica. 3a Ed. São Paulo: Futura, 1998

[17] Salamon, Lester. A emergência do terceiro setor - uma revolução associativa global. Revista de Administração.São Paulo, v. 33, n. 1, p 5-11. Janeiro/Março 1998.

[18] Severino, Antônio Joaquim. Metodologia do trabalho científico. 21를. Ver. E ampl. São Paulo: Cortez, 2000.

[19] Souza, Herbert de. As Ongs na década de 90. Políticas Governamentais. Rio de Janeiro: Ibase, abr./maio, 1991.

[20] Tachizawa, ElioTakeshy. Organizações não governamentais e terceiro setor: criação de ONGs e estratégias de atuação. 6a ${ }^{a}$ Ed. São Paulo: Atlas, 2014

[21] Tenório, Fernando G., org. Gestão de ONGs: principais funções gerenciais. 10ª Ed. Rio de Janeiro: Editora FGV, 2006.

[22] Vergara, S. C, Projeto e Relatórios de Pesquisas Em Administração - $10^{\circ}$ Ed.São Paulo, Atlas- 2008.

[23] Vergara, S. C. Métodos de pesquisa em administração. 2. ed. São Paulo: Atlas, 2007.

[24] Williams, Aubrey. Cresce a participação das ONGs no desenvolvimento. Finanças \& Desenvolvimento. Rio de Janeiro: FMI, Banco Mundial, dez., 1990. 


\section{Capítulo 12}

\section{RANKING DO SANEAMENTO DO MÉDIO PARAÍBA DO SUL \\ Lucas Pereira de Almeida \\ Lunara de Andrade Silva \\ Ana Paula da Silva Souza Costa \\ Juliana Gonçalves Fernandes}

Resumo: Atualmente há uma grande preocupação em relação à água e sua utilização. Com isso, órgãos públicos de cunho municipal, muitas vezes com o auxílio de empresas privadas, passaram a controlar melhor a coleta, distribuição, uso e devolução da água ao seu ciclo natural, visando sempre a sustentabilidade do sistema hídrico e a saúde da população. Contudo, infelizmente nem todas as cidades tratam do assunto com a mesma seriedade, realizando atividades que prejudicam fortemente o ciclo da água e consequentemente a população, elevando despesas com a área da saúde. Os municípios, titulares dos serviços de saneamento, ou as concessionárias dos serviços, anualmente enviam informações do sistema ao SNIS (Sistema Nacional de Informações sobre Saneamento), sendo este o banco de dados oficial sobre os serviços de saneamento no Brasil. Dessa forma, com o interesse de levar a população às informações da situação do saneamento na região do Médio Paraíba do Sul, este trabalho aplica a metodologia do Instituto Trata Brasil (Trata Brasil, 2016) para levantar dados sobre saneamento em um Ranking.

Palavras-chave: Ranking. Esgotamento sanitário. Abastecimento de água. 


\section{INTRODUÇÃO}

O SNIS é a base de dados sobre saneamento mais completa do Brasil, por isso, suas informações, que são coletadas diretamente com cada prestador de serviço estadual, regional e municipal anualmente e dispostas ao público de forma gratuita, foram utilizadas para as análises.

O resumo dos indicadores divulgados pelo SNIS, bem como sua breve explicação, pode ser visto no Quadro 1.

Quadro 1 - Resumo dos Indicadores

\begin{tabular}{|c|c|c|c|}
\hline Grupo & Indicador & $\begin{array}{c}\text { Indicadores/ Informações } \\
\text { SNIS }\end{array}$ & Breve Explicação \\
\hline \multirow{5}{*}{ Nível de cobertura } & Água Total & IN055 & $\begin{array}{l}\text { População urbana e rural atendida } \\
\text { por abastecimento de água }\end{array}$ \\
\hline & Água Urbano & IN023 & População urbana atendida por água \\
\hline & Coleta Total & IN056 & $\begin{array}{l}\text { População urbana e rural atendida } \\
\text { por coleta de esgoto }\end{array}$ \\
\hline & Coleta Urbano & IN024 & $\begin{array}{l}\text { População urbana atendida por } \\
\text { coleta de esgoto }\end{array}$ \\
\hline & Tratamento & IN046/IN056 & $\begin{array}{l}\text { Volume de esgoto tratado em } \\
\text { relação ao volume de água } \\
\text { consumido controlado pelos indices } \\
\text { de coleta }\end{array}$ \\
\hline \multirow{3}{*}{ Melhora da cobertura } & Investimentos/Arrecadação & FN006/FN033/FN048/FN058 & $\begin{array}{l}\text { Porcentagem da arrecadação do } \\
\text { municipio investida no sistema }\end{array}$ \\
\hline & $\begin{array}{l}\text { Novas Ligações de } \\
\text { Água/Ligações Faltantes }\end{array}$ & AG021/IN055 & $\begin{array}{l}\text { Porcentagem realizada do número } \\
\text { de ligações faltantes para } \\
\text { universalização do serviço de água }\end{array}$ \\
\hline & $\begin{array}{l}\text { Novas Ligações de Esgoto/ } \\
\text { Ligações Faltantes }\end{array}$ & ES009/IN056 & $\begin{array}{l}\text { Porcentagem realizada do número } \\
\text { de ligaçôes faltantes para } \\
\text { universalização do serviço de esgoto }\end{array}$ \\
\hline \multirow{4}{*}{ Nivel de Eficiência } & Perdas na Distribuição & IN049 & $\begin{array}{l}\text { Água consumida medida em } \\
\text { porcentagem da água produzida }\end{array}$ \\
\hline & Perdas de Faturamento & AG006/AG011/AG018 & $\begin{array}{l}\text { Água faturada medida em } \\
\text { porcentagem da água produzida }\end{array}$ \\
\hline & $\begin{array}{l}\text { Evolução Perdas de } \\
\text { Faturamento }\end{array}$ & AG006/AG011/AG018 & $\begin{array}{l}\text { Evolução das perdas de faturamento } \\
\text { dos municipios }\end{array}$ \\
\hline & $\begin{array}{l}\text { Evolução Perdas de } \\
\text { Distribuição }\end{array}$ & IN049 & $\begin{array}{c}\text { Evolução das perdas na distribuição } \\
\text { dos municípios }\end{array}$ \\
\hline
\end{tabular}

Fonte: Instituto Trata Brasil. São Paulo, 2016

Os indicadores retirados do SNIS, apresentados no Quadro 1, são os utilizados como base de cálculos para que um município seja ranqueado em relação aos outros. Portanto, cada indicador possui um peso específico e de acordo com a capacidade do município em executá-lo, sua nota no Ranking é alterada. Por exemplo, os indicadores de Coleta e Tratamento de Esgoto, juntos somam 50\% da nota de um município. Caso um município possua eficientes coleta e tratamento, sua nota será consideravelmente elevada, do contrário sua nota cairá.

A título de curiosidade, os índices de Coleta e Tratamento possuem um valor tão elevado para a base de cálculo devido ao desafio da universalização do serviço de esgoto presente no Brasil atualmente.
Estas são fases vitais para a manutenção do ciclo das águas e que por muitas vezes são deixadas de lado pelo poder público, afetando diretamente no bem-estar da população. Portanto, quando este parâmetro é superado, é merecido o reconhecimento frente a nota dada ao município.

\section{METODOLOGIA}

A metodologia aplicada para obtenção dos dados e realização do Ranking do Saneamento da região do Médio Paraíba do Sul é a mesma aplicada pelo Instituto Trata Brasil, que ranqueia todo ano as mudanças no cenário do saneamento nos 100 maiores municípios do Brasil. 


\subsection{MUNICÍPIOS CONSIDERADOS PARA O ESTUDO}

Para este Ranking, foram considerados os municípios que estão inseridos na Região Hidrográfica III, chamada de Médio Paraíba do Sul, localizada ao sul do estado do Rio de Janeiro.

Nela estão contidos integralmente os municípios de Itatiaia, Resende, Porto Real, Quatis, Barra Mansa, Volta Redonda,
Pinheiral, Valença, Rio das Flores e Comendador Levy Gasparian, e ainda, os municípios de Rio Claro, Piraí, Barra do Piraí, Vassouras, Miguel Pereira, Paty do Alferes, Paraíba do Sul, Três Rios e Mendes, inseridos parcialmente (Resolução no 107/2013 do Conselho Estadual de Recursos Hídricos do Estado do Rio de Janeiro - CERHI/RJ), como pode ser visualizado na Figura 1.

Figura 1 - Região Hidrográfica III - Médio Paraíba do Sul

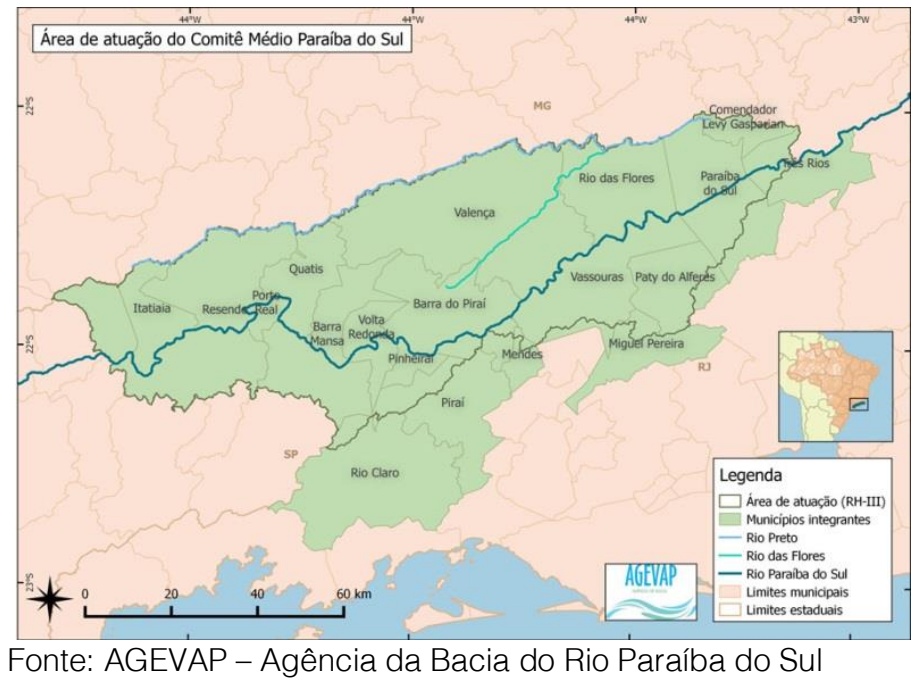

A Região possui em sua hidrografia, além do próprio rio Paraíba do Sul, outros rios de domínio federal, como o Preto e o Bananal, e de domínio estadual, como o Pirapetinga, o Turvo, o das Flores e o Ubá.

\section{RESULTADOS: O RANKING DO SANEAMENTO}

Esta seção apresenta os resultados obtidos com o Ranking do Saneamento da região do Médio Paraíba do Sul. Serão também apresentadas análises dos três melhores e piores municípios, uma síntese dos resultados obtidos e por fim, alguns dados que merecem destaque.

É importante ressaltar que dos 19 municípios contidos na região do Médio
Paraíba do Sul, apenas dois não continham informações na base de dados do SNIS, estes são Piraí e Rio Claro, ambos com menos de 20.000 habitantes. Além disso, também é importante reforçar que os dados presentes na base de dados são auto declaratórios, ou seja, ficam a cargo da própria instituição de saneamento declarar seus dados e zelar por sua legitimidade.

\subsection{RANKING DO SANEAMENTO 2016}

O Quadro 2 apresenta o Ranking do Saneamento 2016 da Região Hidrográfica III. 
Quadro 2 - Ranking do Saneamento do Médio Paraíba do Sul

\begin{tabular}{|c|c|c|c|c|c|c|c|c|c|c|c|c|c|c|c|c|c|c|c|c|c|c|}
\hline E & & $\frac{2}{5}$ & 500 & $=8$ & & & & & $0^{\circ}$ & & & & 0 & & & & & & 5 & 읨 & & \\
\hline 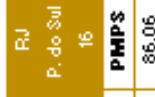 & $\frac{9}{8}$ & $\frac{n}{50}$ & 0. & $=$ & & & & & 0 & $=$ & $\circ$ & $\circ$ & $\circ$ & & & $\circ=$ & & 0 & $=g$ & 0 & $\circ$ & \\
\hline & & 0. & $=\overline{\bar{\Delta}}$ & $:$ & & & & & 0 & 0 & $\circ$ & 0 & 0 & & & $\circ$ & $\circ$ & 0 & $=$ & 0 & $\circ$ & \\
\hline & & 0. & 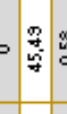 & 8 & & & & & $=0$ & 0 & 0 & $\circ$ & 0 & $=4$ & 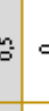 & 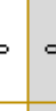 & & . & $=$ & 0 & . & : \\
\hline & & $\circ 0$ & $=0$ & 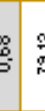 & & & & & 0 & 0 & $\circ$ & 0 & 0 & 0 & $\stackrel{\circ}{\circ}$ & $\circ=$ & & $g$ & 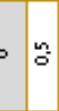 & 0 & $\circ$ & \\
\hline & & 要 & : & $=$ & & & & & 00 & 0 & 0 & $\circ$ & 0 & & & -0 & & d. & $\frac{n}{5}$ & $\overline{\underline{s}}$ & . & \\
\hline & & 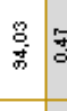 & 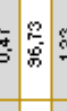 & 0 & & & & & $\stackrel{8}{\circ}$ & 0 & 0 & 0 & $\circ$ & $\stackrel{5}{\circ}$ & $\stackrel{5}{\circ}$ & $\stackrel{8}{\circ}$ & & dִ & $8:$ & & $\circ$ & $\circ$ \\
\hline & & 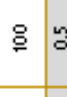 & 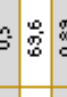 & 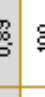 & & & & & 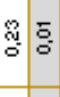 & 0 & $\circ$ & 0 & 0 & & 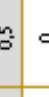 & $\circ$ & $\circ$ & $\begin{array}{c}y_{0}^{\circ} \\
\end{array}$ & 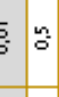 & $\bar{s}$ & $\circ$ & ğ \\
\hline & & $\circ=$ & $\circ \%$ & 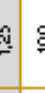 & & & & & $=0$ & 0 & $\approx$ & 0 & 0 & & 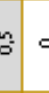 & 。 & $\circ$ & ك̆ & $=\cong$ & 0 & . & g. \\
\hline & & 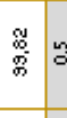 & 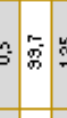 & 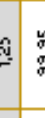 & & & & & $\frac{{ }_{0}^{\circ}}{5}$ & 0 & $\circ$ & 0 & 0 & 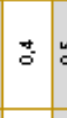 & $a$ & 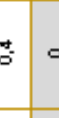 & $\circ$ & $:$ & $\$ \frac{m}{5}$ & 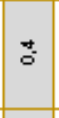 &. & $\circ$ \\
\hline E & & $\stackrel{\circ}{\circ}$ & 5 & 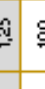 & & & & & e & 0 & $\stackrel{n}{s}$ & 0 & 0 & 营 & 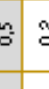 & gy & $\circ$ & हूँ & 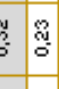 & & 。 & \\
\hline & & 营 & 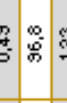 & 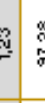 & & & & & : & 0 & 0 & 0 & 0 & $\bar{E}$ & 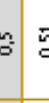 & $\overline{5}$ & $\circ$ & : & $\mathrm{E}$ & & . & : \\
\hline & & 商 & $\stackrel{5}{8}$ & $=$ & & & & & $\overline{5}$ & s. & $\circ$ & 0 & 0 & $\stackrel{\frac{\Phi}{\sigma}}{\square}$ & 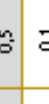 & $\bar{E}$ & $\circ$ & & 9 & $\overline{0}$ & . & \\
\hline & & 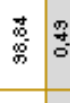 & : & \pm & & & & & $\stackrel{8}{8}$ & 0 & 0 & 0 & 0 & $\bar{c}$ & 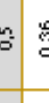 & 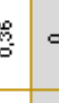 & $\circ$ & 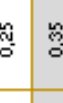 & $\bar{c}$ & 苦 & $\stackrel{2}{\circ}$ & ๘્ \\
\hline & & $\stackrel{2}{g}$ & $=$ & $0:$ & & & & & $8:$ & $\circ$ & 0 & $\circ$ & 0 & $\frac{9}{8}$ & a. & $f$ & 0 & 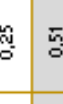 & 5 & $\frac{y}{0}$ & 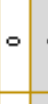 & 。 \\
\hline & & $\stackrel{9}{\circ}$ & 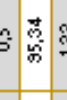 & $\mathbb{y}$ & & & & & $\overline{5}$ & 0 & 0 & 0 & 0 & 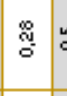 & $\cong$ & 幽 & $\stackrel{t}{5}$ & ợ & $\stackrel{\mathscr{B}}{\circ}$ & 矛 & $\approx$ & 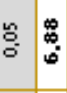 \\
\hline 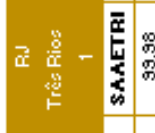 & & 总量 & : & 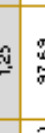 & & & & & $\frac{g^{\circ}}{5}$ & $\circ$ & 0 & 0 & - & $\stackrel{8}{\circ}$ & 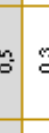 & 8 & & 兽 & : & $\stackrel{\mathbb{g}}{\mathrm{g}}$ & $0^{\circ}$ & s̄ \\
\hline & 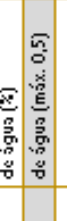 & 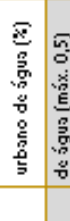 & 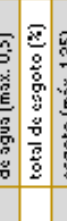 & & & & & & & & & & $=\frac{x}{\frac{2}{2}}$ & 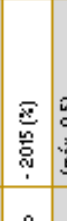 & 跣 & 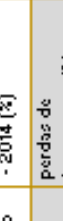 & & $\frac{2}{2}$ & 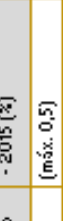 & 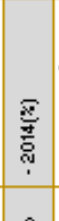 & & 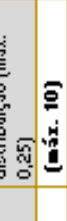 \\
\hline 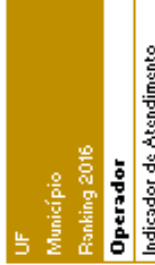 & & 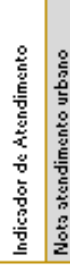 & 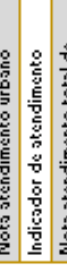 & & & & & & & & 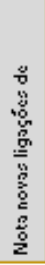 & & 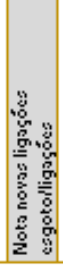 & 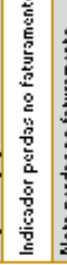 & 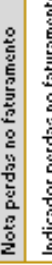 & & 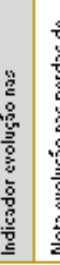 & 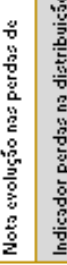 & 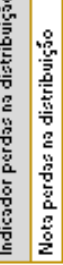 & 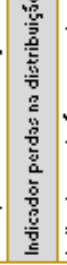 & 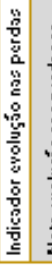 & 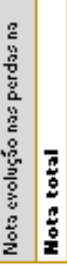 \\
\hline
\end{tabular}




\subsection{OS 3 MELHORES E OS 3 PIORES}

Para avaliação dos 3 melhores e dos 3 piores colocados no Ranking do Saneamento 2016, serão analisados mais detalhadamente os indicadores de água, coleta, tratamento e perdas. Estes indicadores representam 70\% da nota total do Ranking e são os mais utilizados pelo setor para avaliar a qualidade do saneamento em determinado município.

O Quadro 3 mostra os três melhores e os três piores colocados no Ranking do Saneamento RH III - Médio Paraíba do Sul 2016.

\section{Quadro 3 - Melhores e Piores Colocados no Ranking do Saneamento 2016}

\begin{tabular}{|c|c|c|c|c|c|c|c|c|c|c|c|}
\hline $\begin{array}{l}\frac{\frac{0}{0}}{\frac{0}{0}} \\
\frac{5}{5} \\
\frac{1}{2}\end{array}$ & 岇 & 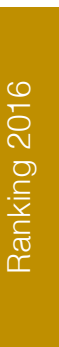 & 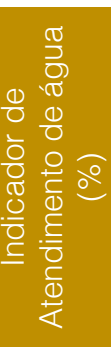 & 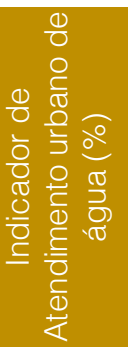 & 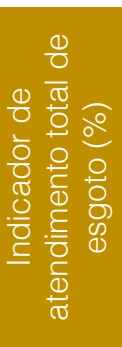 & 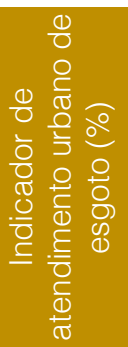 & 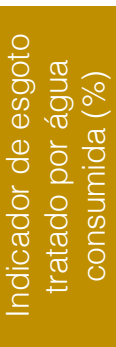 & 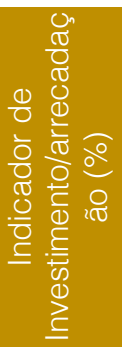 & 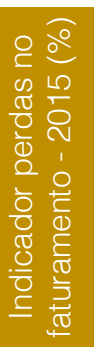 & 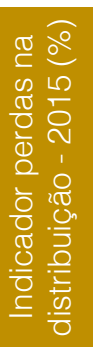 & 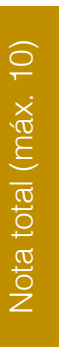 \\
\hline Três Rios & RJ & 1 & 99,98 & 97,69 & 99,04 & 97,69 & 10 & 0,19 & 0,3 & 0,28 & 8 \\
\hline Resende & RJ & 2 & 95,55 & 100 & 95,34 & 100 & 9,55 & 1,56 & 0,48 & 0,51 & 6,9 \\
\hline $\begin{array}{c}\text { Volta } \\
\text { Redonda }\end{array}$ & RJ & 3 & 99,95 & 100 & 98,96 & 99 & 9,69 & 0,39 & 0,28 & 0,36 & 6,8 \\
\hline $\begin{array}{c}\text { Indicador } \\
\text { Médio }\end{array}$ & & & 98,5 & 99,23 & 97,78 & 98,9 & 9,74 & 0,71 & 0,35 & 0,38 & \\
\hline $\begin{array}{l}\text { Paty do } \\
\text { Alferes }\end{array}$ & RJ & 15 & 0 & 0 & 65,11 & 25,38 & 0 & 0,2 & 0,81 & 0,81 & 2,7 \\
\hline $\begin{array}{c}\text { Paraíba } \\
\text { do Sul }\end{array}$ & RJ & 16 & 86,06 & 96,15 & 0 & 0 & 0 & 0 & 0 & 0 & 2,4 \\
\hline Mendes & RJ & 17 & 21,45 & 21,73 & 0 & 0 & 0 & 0 & 0 & 0 & 2,4 \\
\hline $\begin{array}{l}\text { Indicador } \\
\text { Médio }\end{array}$ & & & 35,84 & 39,3 & 21,7 & 8,46 & 0 & 0,06 & 0,27 & 0,27 & \\
\hline
\end{tabular}

\subsubsection{ANÁLISE DOS MELHORES COLOCADOS}

Quando se trata do indicador total de água, constata-se que os três melhores municípios, que são Três Rios, Resende e Volta Redonda, possuem porcentagens maiores que 95\% de atendimento de água.

Isto significa que mais de 95\% da população total dos municípios, que somam 455.004 habitantes aproximadamente (IBGE, 2010), quase $50 \%$ da população total da região, são atendidos por abastecimento de água potável, seguindo regulamentação da Portaria do Ministério da Saúde oㅡ 2914.

Pode-se observar também que 0 indicador médio de atendimento de água é $98,50 \%$, de modo que tais municípios se mostram na dianteira da universalização deste serviço na região RH III - Médio Paraíba do Sul.
Para comparação, de acordo com o SNIS 2015, a média nacional para o indicador de atendimento de água é de $83,3 \%$. Portanto, percebe-se que os municípios estão acima do padrão nacional para este quesito.

Já para o indicador urbano de água, os mesmos três municípios aparecem acima de 95\% de atendimento. Contudo, Resende e Volta Redonda apresentam o serviço já universalizado, ou seja, com atendimento urbano total de $100 \%$.

Quanto ao indicador de atendimento de esgoto total, os três melhores municípios reportaram indicadores de coleta superiores a 95\%. Dentre os três, destacam-se os municípios de Três Rios e Volta Redonda, que sob gestão pública de saneamento e diante de tantos problemas e entraves políticos mostram-se engajados com a causa. 
De modo comparativo, as cidades em destaque estão superiores à média nacional neste quesito, que segundo o SNIS 2015, é de $50,3 \%$.

Por sua vez, para o indicador de atendimento urbano de esgoto, os municípios apresentaram índices também acima de 95\%. O indicador médio foi de 98,9\%, bem acima da média nacional que segundo o SNIS 2015 é de $58 \%$.

Com relação ao indicador de tratamento, a situação dos municípios não é tão boa quando comparada as dos indicadores de abastecimento de água e coleta de esgoto. $\mathrm{O}$ indicador médio é de 9,74\%, bem abaixo da média nacional reportada pelo SNIS 2015 de $42,7 \%$.

No que diz respeito ao indicador de perdas de faturamento e de distribuição, todos os municípios possuem perdas menores que $15 \%$, o que é considerado adequado.

\subsubsection{ANÁLISE DOS PIORES COLOCADOS}

Com relação ao atendimento total de água dos três piores municípios, apenas Paraíba do Sul está acima dos $80 \%$ de atendimento, os outros possuem menos que $25 \%$ para o indicador, sendo que um deles (Paty do Alferes) não apresenta nenhum sistema de abastecimento de água.

O indicador médio é de 35,84\%, valor bem abaixo da média nacional, que segundo o SNIS 2015, é de 83,3\%. Este valor mostra uma deficiência nesses municípios quanto ao quesito abastecimento de água total.
Já para o atendimento urbano de água, apenas um município apresenta um atendimento satisfatório, atendendo mais que 95\% da população (Paraíba do Sul - 96,15\%).

Quando se trata da coleta total de esgoto e do indicador de tratamento, dados alarmantes surgem quando se tratam das cidades menos pontuadas no Ranking. Dois dos municípios (Paraíba do Sul e Mendes) não declararam possuir algum tipo de tratamento de efluentes ou até mesmo algum tipo de coleta.

De maneira semelhante, os indicadores de atendimento urbano de esgotos também são baixos. O indicador médio é de $8,46 \%$, bem inferior à média nacional divulgada pelo SNIS 2015 de $58 \%$.

No que diz respeito ao indicador de perdas de faturamento e de distribuição, todos os municípios possuem perdas menores que $15 \%$, o que é considerado adequado.

\subsubsection{ANÁLISES COMPLEMENTARES}

Alguns pontos da pesquisa merecem ser tratados com maior abrangência, considerando toda a amostragem de municípios para uma melhor visualização da situação atual do saneamento. Por isso, a seguir serão apresentados gráficos e suas respectivas análises.

\section{a) Atendimento total de água:}

No Quadro 4, está representado o histograma para o índice de atendimento total de água.

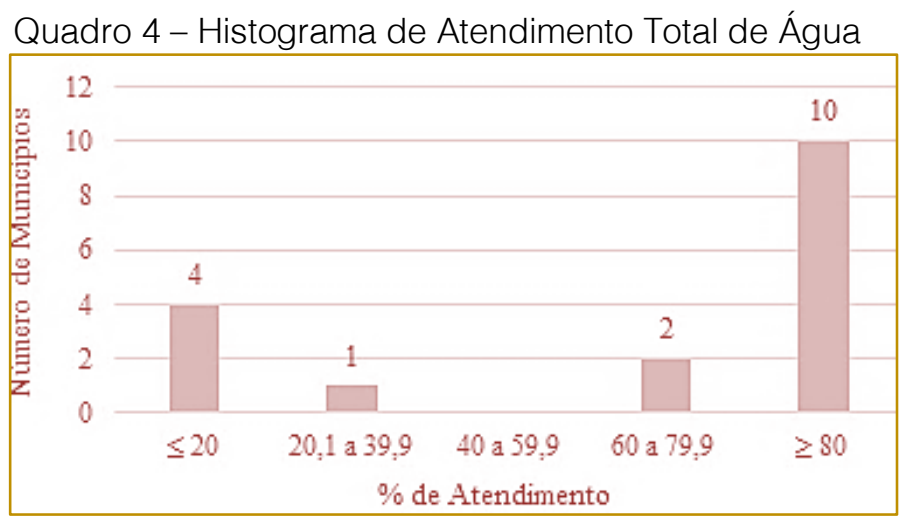


Apresentado dessa forma, é possível visualizar o contexto geral da situação do abastecimento total de água nos municípios da região.

A maioria (10) dos municípios possuem acima de $80 \%$ de atendimento para o serviço, mostrando uma boa tendência para a sua universalização.

\section{b) Atendimento total de esgoto:}

Abaixo, no Quadro 5, está representado o histograma para o índice de total de coleta de esgoto.

\section{Quadro 5 - Histograma de Coleta Total de Esgoto}

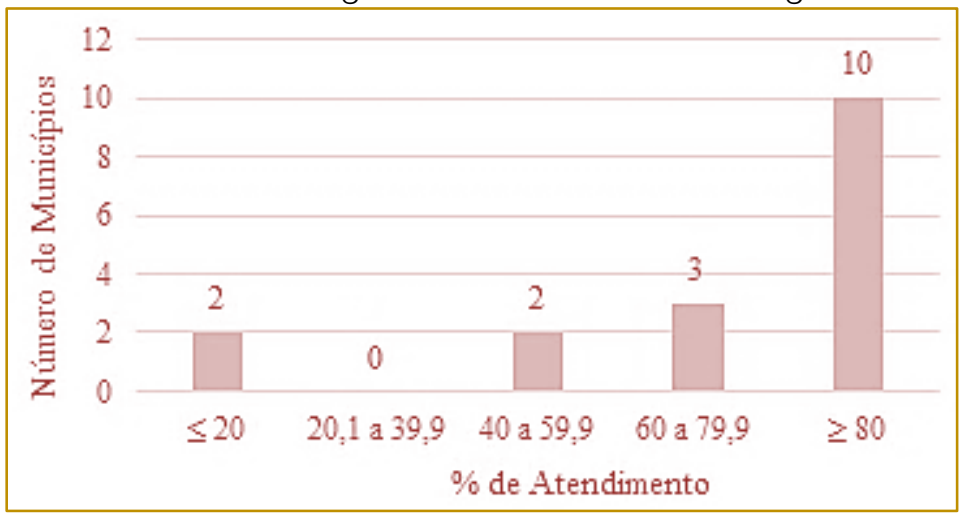

Tratando-se de esgoto, a região também se encontra, no geral, em situação satisfatória.

A grande maioria dos municípios (10) apresentam mais de $80 \%$ de atendimento para este serviço, o que é considerado bom, pois se o esgoto está sendo coletado, a possibilidade de ele estar sendo tratado e retornado em boas condições para o sistema hídrico é grande. Apesar disso, ainda existem municípios que estão bem longe da universalização do serviço.

Este tipo de descaso gera a poluição dos corpos hídricos, eutrofização da água e contaminação do solo, atingindo diretamente a população, provocando doenças como a diarreia infecciosa, elevando custos para a manutenção da saúde no município e diminuindo a qualidade de vida da população.

\section{c) Tratamento de esgoto:}

Abaixo, no Quadro 6, está representado o histograma para o índice de tratamento de esgoto.

Quadro 6 - Histograma do Tratamento de Esgoto

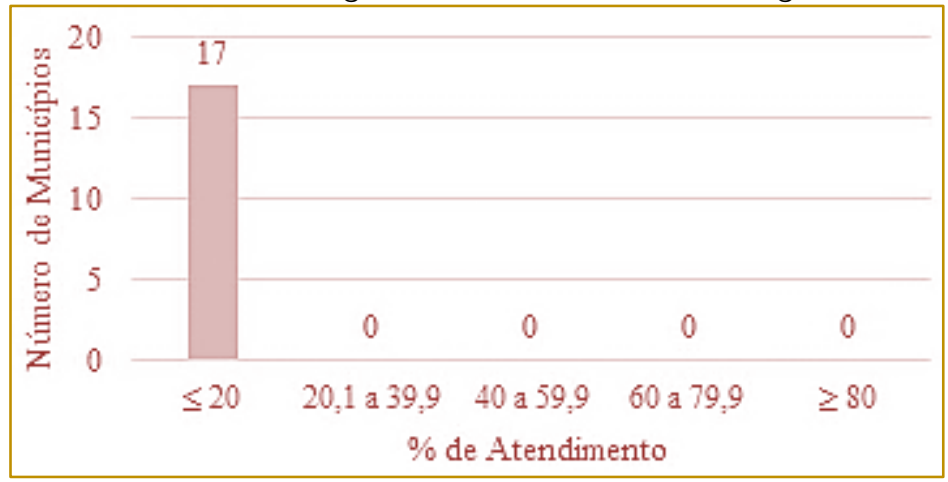

O tratamento dos efluentes ainda é uma

para atingir níveis aceitáveis. Todos os situação que precisa ser muito trabalhada municípios da região apresentaram índices de 
tratamento menores que $20 \%$, esse valor pode ser dado pela real falta de preocupação com o esgotamento sanitário, ou ainda com uma provável coleta sem correta destinação.

\section{d) Investimentos e arrecadação:}

Abaixo, no Quadro 7, está representado o histograma para o índice de investimentos no sistema de saneamento sobre a arrecadação do município.

Quadro 7 - Histograma do Investimento/Arrecadação

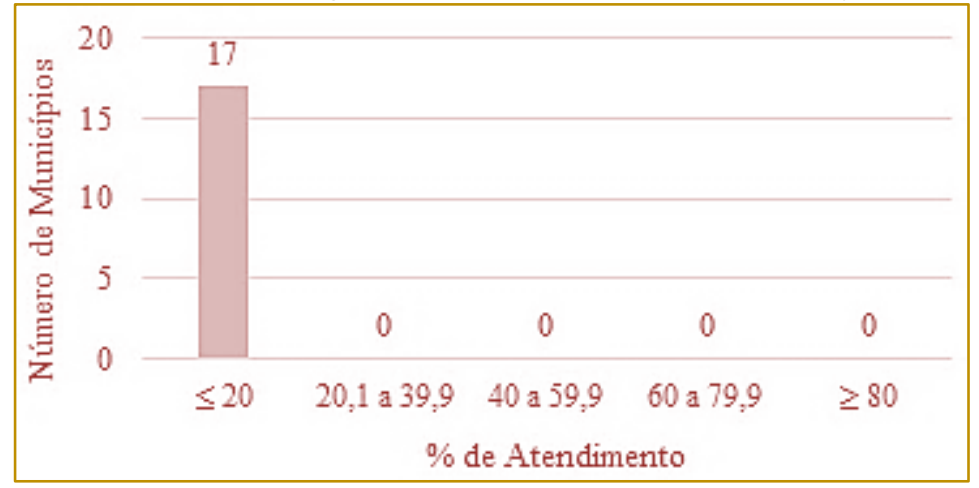

Este quesito mede a quantidade de investimento realizado no sistema de esgotamento sanitário e abastecimento de água quando comparado a arrecadação do município.

No histograma podemos visualizar que todos os municípios estão investindo menos de $20 \%$ de suas arrecadações em seus sistemas de saneamento.

\section{e) Novas ligações de água e esgoto/ ligações faltantes:}

Este indicador mede a variação no número de novas ligações de esgoto e de água, divididos pelos totais de ligações que deveriam ser feitas para universalizar o serviço.

O ideal seria que os municípios aumentassem certa porcentagem de sua quantidade de ligações de água e esgoto, demonstrando bom uso das arrecadações municipais na área de saneamento e comprometimento com a universalização dos serviços.

Contudo, todos os municípios apresentaram uma redução em seu número de ligações, tanto de água quanto de esgotamento sanitário.

As possíveis explicações para esse fato são possíveis problemas de correção de cadastro, corte de ligações inadimplentes, ou eventualmente até um problema no preenchimento dos formulários do SNIS por parte das prestadoras de serviços.

\section{CONCLUSÃO}

A partir de dados como estes, diversos estudos realizados pelo Instituto Trata Brasil, em associação com outras fundações de fomento à pesquisa, comprovam que no País a universalização do saneamento básico é uma meta que será dificilmente alcançada, graças a falta de priorização dos gestores no cumprimento das metas estabelecidas.

Para atingir a universalização do saneamento, ou seja, prover água potável encanada e ligação a rede de esgoto em todos os domicílios brasileiros, o País precisaria mais do que dobrar os investimentos na área, necessitando de comprometimento total do governo por um longo período de tempo.

Como reflexo, a situação na Região do Médio Paraíba do Sul, que tem passado por melhoras significativas ao longo dos anos, ainda é precária. O resultado, como mostrado nas pesquisas, não atende ainda a um padrão nem próximo ao da universalização dos serviços, principalmente quando se trata do esgotamento sanitário.

Como dito, os problemas persistem por que os investimentos continuam baixos, e o comprometimento das políticas nacionais em os aumentar ainda não é, de fato, uma 
prioridade. Cabendo então a sociedade civil exercer a sua cidadania, informando-se,

\section{REFERÊNCIAS}

[1] Ministério das Cidades. Diagnóstico dos serviços de água e esgotos - 2015. Sistema Nacional de Informações sobre Saneamento 2014. Disponível em: <http:/www.snis.gov.br>. Acesso em: março 2017.

[2] Instituto Trata Brasil. Relatório Completo do Ranking do Saneamento nas 100 Maiores Cidades do Brasil. Disponível em: < http://www.tratabrasil.org.br/datafiles/estudos/ranki cobrando e acompanhando de perto os investimentos em saneamento.

ng/2016/relatorio-completo.pdf>. Acesso em: março 2017.

[3] Comitê Médio Paraíba do Sul. Disponível em: < http://www.cbhmedioparaiba.org.br >. Acesso em: março 2017.

[4] Instituto Brasileiro de Geografia e Estatística. Disponível em: < http://www.ibge.gov.br >. Acesso em: março 2017.

[5] Agevap. Disponível em: < http://www.agevap.org.br >. Acesso em: março 2017. 


\section{Gapítulo 13}

\section{A EFICÁCIA DA LOGÍSTICA REVERSA NA CADEIA DE LÂMPADAS FLUORESCENTES: UM ESTUDO NA REGIÃO DO VALE DO PARAÍBA}

\section{Henrique Martins Galvão}

Camila de Paula Conrado Rosa

Juliana Vieira Braz

Thais Eugênio de Moraes

\section{Paládia de Oliveira Romeiro da Silva}

Resumo: O presente estudo aborda questões referentes à logística reversa de lâmpadas fluorescentes e seus principais desafios e dificuldade. A motivação do estudo foi diagnosticar a eficácia da logística reversa na cadeia de lâmpadas fluorescentes com base na Política Nacional de Resíduos Sólidos - PNRS e legislações pertinentes ao tema. A metodologia aplicada foi a pesquisa de campo, de caráter exploratório quantitativo, tendo como população de estudo os agentes de cada fase da cadeia de lâmpadas fluorescentes, a saber: fornecedores; revendedores; consumidores e recicladoras. Para a coleta de dados foram utilizados questionários com perguntas fechadas de múltipla escolha direcionadas a cada agente da referida cadeia. Com os resultados obtidos concluiu-se que a legislação referente ao pós-consumo das lâmpadas fluorescentes encontra-se distanciada da efetividade do seu cumprimento por parte dos integrantes que compõem a cadeia da logística reversa. Sendo constatado que o seu processo de gerenciamento tem sido ineficaz do início ao fim, principalmente devido à falta de informações compartilhadas entre os elos da cadeia e da insuficiência da fiscalização.

Palavras-chave: Resíduos; Lâmpadas fluorescentes; PNRS; Logística reversa. 


\section{INTRODUÇÃO}

Ao longo dos anos a sociedade reconhece que os grandes avanços científicos e tecnológicos impulsionaram 0 progresso econômico e elevaram padrões de bem-estar social, tornam a vida melhor e mais confortável. Também se reconhece a insuficiência do progresso econômico para gerar bem-estar social para grande parte da população mundial. Visto de outro modo, os benefícios desse progresso geram novos comportamentos com mudanças de hábitos da sociedade; desperta desejos e cria novas necessidades (CAPRA, 2002; MARCOVITCH, 2011).

Mas essa perspectiva é acompanhada pelo excesso da extração de recursos naturais para suprir a fabricação em larga escala e consumo de produtos em massa. Esses fatores criam externalidades ambientais negativas com efeitos sociais e econômicos significativos, principalmente quando se trata dos elevados níveis de descarte de resíduos pós-consumo. Em face à grande quantidade de resíduos urbanos, também os industriais, a destinação adequada tem sido uma das maiores preocupações da sociedade contemporânea. Com isso, nos últimos anos os governos, em especial na esfera federal, têm se empenhado na elaboração de políticas para regulamentação das atividades de diversos setores, visando o controle da poluição e o estímulo a ações mais sustentáveis. Atenta-se ao fato que o descarte dos produtos pós-consumo requer cuidados especiais em razão de elementos nocivos nos produtos e quando descartados inadequadamente se tornam potencialmente danosos ao meio ambiente e à saúde humana.

À vista disto, a coleta do lixo comum tem sido a maneira adotada pelos governos municipais para destinação final dos resíduos. O grande volume de resíduos e sua destinação eficaz se transformaram num dilema para a gestão pública, uma vez que são frequentemente descartados e acumulados em aterros controlados ou em lixões a céu aberto, na maioria dos municípios brasileiros. Nesse caso, as atividades de reciclagem do lixo e reaproveitamento de materiais pós-consumo surgem como alternativas econômicas vantajosas e vistas como maneira de mitigação ou eliminação dos riscos de contaminação. Entretanto, existem produtos, como no caso das lâmpadas fluorescentes, que necessitam passar por processo de descontaminação e por isso precisam dispor de infraestrutura adequada de coleta seletiva e de reciclagem, que incluem também tecnologias apropriadas e serviços especializados para manuseio, transporte, separação e descontaminação. No caso das lâmpadas fluorescentes, o Brasil adotou iniciativas de intenso estímulo em substituição às lâmpadas incandescentes, pois são mais econômicas, duráveis e oferecem luminosidade superior, inclusive levando à proibição do comércio das lâmpadas incandescentes no ano de 2016 (INMETRO, 2016). O uso das lâmpadas fluorescentes (compactas, tubulares ou circulares) está em ascensão e estima-se que anualmente seu consumo cresce de 12 a 14\%. Em 2013 estimou-se o consumo de cerca de 350 milhões de unidades e em 2014 foram consumidas mais de 250 milhões somente das lâmpadas fluorescentes compactas. (GRANT THORNTON, 2011; ABILUX, 2015). Mas, as lâmpadas fluorescentes possuem mercúrio na sua composição com teor elevado, sendo altamente tóxico e bioacumulativo nos seres vivos. Exigem cuidados especiais no seu manuseio, transporte e armazenagem, evitando quebrálas ou danificá-las e por isso precisam ser adequadamente segregadas e a coleta deve ser feita com segurança para ser tratada e descontaminada por empresa credenciada.

Neste contexto, insere-se a Política Nacional de Resíduos Sólidos - PNRS, Lei $n^{\circ}$ 12.305/2010, fixando diretrizes e interações entre os diversos atores, públicos e privados, acerca dos resíduos pós-consumo. A PNRS coloca a logística reversa como a principal ferramenta prevista em lei para que empresas contribuam com a responsabilidade compartilhada do retorno dos produtos após o uso pelo consumidor e independente do serviço público de coleta. Também é necessário que as empresas estendam iniciativas para além das suas fronteiras organizacionais.

Diante do exposto, esse estudo trata especificamente das lâmpadas fluorescentes, que devido ao elevado risco inerente aos resíduos perigosos há necessidade da coleta e reciclagem diferenciada de outros produtos mencionados na PNRS. Torna-se relevante difundir o conhecimento e a consciência da segurança ambiental e de saúde, uma vez que as lâmpadas fluorescentes representam sérios riscos quando manuseadas e 
descartadas de maneira incorreta. A principal questão de estudo consiste em diagnosticar como a logística reversa de lâmpadas fluorescentes está organizada de maneira eficaz. Nesse sentido, a pesquisa busca evidenciar as lacunas existentes para a eficácia da logística reversa. Além disso, o objetivo central de estudo visa verificar os principais desafios e dificuldades acerca do processo logístico reverso dos envolvidos na cadeia de lâmpadas fluorescentes.

\section{REVISÃO DA LITERATURA}

\subsection{GERAÇÃO DE RESÍDUOS E REGULAÇÃO AMBIENTAL}

O aumento do consumo, a menor durabilidade dos produtos e a rápida obsolescência tornaram-se frequentes, fatores estes que geram intenso descarte de produtos pós-consumo e acúmulo de resíduos no meio ambiente (TROMBETA e LEAL, 2014). Reconhece-se que os impactos ambientais tem se agravado pelo consumo exacerbado e intensa geração de resíduos, causando sérios problemas à biodiversidade e à saúde humana. Com base no Conselho Nacional do Meio Ambiente - Conama (1986) em seu Art. 1‥, Resolução no. 1, os impactos ambientais são definidos como qualquer forma de modificação das propriedades físicas, químicas e biológicas do meio ambiente oriundas das atividades humanas que de alguma maneira afetam e colocam em risco seres humanos, atividades sociais e econômicas, assim como possam prejudicar de qualquer modo o ambiente natural. Os impactos ambientais causados pelo descarte das toneladas de resíduos sólidos estão presentes em maior escala nas proximidades de áreas urbanas, acentuando as dificuldades ambientais já existentes e contribuindo para o surgimento de outras (LEITE, 2011; TROMBETA e LEAL, 2014).

Existe grande diversidade de resíduos que se encontram nos estados sólido e semissólido, que resultam de atividades de origem industrial, doméstica, hospitalar, comercial, agrícola, de serviços de limpeza pública e de rua (ABNT, 2004). Os resíduos sólidos são materiais indesejáveis, que podem ser gerados por diferentes tipos de atividades e locais, e que se descartados de maneira inadequada, podem causar uma série de riscos à saúde pública e ao meio ambiente. De acordo com Associação Brasileira de
Normas Técnicas - ABNT (2004), os resíduos sólidos, podem ser classificados como perigosos e não perigosos. Os resíduos perigosos são aqueles que possuem propriedades físicas, químicas e infectocontagiosas que representam riscos à saúde pública e ao meio ambiente, por meio de caraterísticas como inflamabilidade, corrosividade, reatividade, toxicidade e patogenicidade (ABNT, 2004). Já os resíduos não perigosos são os que não possuem nenhum de seus componentes solubilizados a concentrações superiores aos padrões de potabilidade de água, ou que apresentam características como biodegradabilidade, combustibilidade ou solubilidade em água (ABNT, 2004).

Nesse sentido, a Associação Brasileira de Empresas de Limpeza Pública e Resíduos Especiais - ABRELPE (2015) aponta que em 2014 foram gerados no Brasil cerca de 78,6 milhões de toneladas de resíduos sólidos, representando um aumento de 2,9\% em relação ao ano anterior. A destinação final dos resíduos se revela preocupante. Com base nos dados da Pesquisa Nacional de Saneamento Básico - PNSB (IBGE, 2015), no ano de 2008 a destinação final dos resíduos era feita de forma inadequada em $50,8 \%$ dos municípios brasileiros. No ano de 2014, a ABRELPE (2015) verificou melhora da situação, mas o percentual se manteve elevado com $41,6 \%$ dos resíduos sólidos urbanos nos municípios destinados para lixões ou aterros controlados.

Para enfrentar os problemas dos resíduos pós-consumo, os governos têm atuando na formulação de políticas públicas. No caso brasileiro, tem-se a aprovação da Política Nacional de Resíduos Sólidos - PNRS, sancionada e regulamentada em 2010. Tratase de um marco regulatório que reúne o conjunto de diretrizes e ações com vistas a induzir práticas de gestão visando à adequação da destinação dos resíduos sólidos, bem como prevenir e controlar a poluição, proteger e recuperar a qualidade ambiental e mitigar ou eliminar os riscos à saúde pública (MANSOR, 2010; IPEA, 2012). Observa-se que as legislações e regulamentações ambientais são instrumentos adotados que encorajam as empresas adequarem as suas práticas de gestão de modo a assegurar a internalização dos impactos ambientais em longo prazo. 
Diante disso, a PNRS estabelece a coleta, reciclagem, reutilização e destinação adequadas e viabilizadas por meio da logística reversa, incluindo os resíduos de lâmpadas fluorescentes.

\subsection{LOGÍSTICA REVERSA E RESPONSABILIDADES COMPARTILHADAS}

A PNRS institui a responsabilidade compartilhada pelo ciclo de vida do produto, isto é, obrigam os fabricantes, importadores, distribuidores e vendedores a tomarem ações que minimizem o volume de resíduos sólidos e, assim, igualmente seus impactos à saúde e ao meio ambiente (BRASIL, 2010). O descumprimento das obrigações previstas na PNRS pode acarretar aos infratores, reclusão de até cinco anos e multa (BRASIL, 2010). Os resíduos compreendidos pela PNRS são os agrotóxicos, seus resíduos e embalagens, lâmpadas fluorescentes de vapor de sódio e mercúrio de luz mista, pilhas e baterias, pneus, óleos lubrificantes, seus resíduos e embalagens, produtos eletrônicos e seus componentes (BRASIL, 2010). A PNRS também prevê os intitulados acordos setoriais que caracterizam atos de natureza contratual firmados entre o poder público e fabricantes, importadores, distribuidores e vendedores de produtos, com o objetivo de implantar a responsabilidade compartilhada sobre o ciclo de vida do produto, responsabilidade firmada por meio de um sistema de logística reversa (BRASIL, 2010).

De acordo com o Sistema Nacional de Informações Sobre a Gestão dos Resíduos Sólidos - SINIR, atualmente todos os setores de produtos compreendidos pela PNRS possuem regulamentos específicos que regem seu processo de logística reversa e em alguns casos, estes processos já estão em plena execução, como por exemplo, nos setores de pneus, agrotóxicos, óleos lubrificantes contaminados, pilhas e baterias e lâmpadas fluorescentes (SINIR, 2015). No entanto, em alguns outros setores os regulamentos se encontram ainda em fase de estruturação como no caso das embalagens plásticas de óleos lubrificantes, embalagens em geral, produtos eletroeletrônicos e seus componentes (SINIR, 2015). O acordo setorial, por permitir grande participação social, tem sido o instrumento preferencial para a implantação da logística reversa, sendo esta, por sua vez, uma das etapas essenciais para $\mathrm{O}$ alcance eficaz dos objetivos propostos pela PNRS (SINIR, 2015). A logística reversa, no que se refere aos produtos de pós-consumo, é um dos principais instrumentos viabilizadores da PNRS, uma vez que visa a destinação adequada desses resíduos (BRASIL, 2010).

Conforme Leite (2011), a logística reversa é uma subárea da logística empresarial, constituída pelo processo de planejamento, implementação e controle de procedimentos, serviços e informações relacionados à movimentação de materiais, mas com ênfase no fluxo reverso, ou seja, refere aos esforços desenvolvidos para que materiais voltem à sua origem. Em um sistema de logística reversa, os bens de pós-vendas são aqueles que retornam à sua origem com pouca ou nenhuma utilização, devido a defeitos, não conformidades, erros de emissão de pedido, entre outros (PEREIRA, 2012). Já os bens de pós-consumo, são aqueles que retornam à sua origem após a utilização do consumidor, ou seja, tendo expirado seu período de vida útil (FONTANA e AGUIAR, 2013). Os bens de pós-consumo, de acordo com Leite (2011), seguem um dos seguintes fluxos: a) Reuso - o produto usado ainda apresenta condições de utilização, ou seja, não atingiu o fim de seu ciclo de vida útil e destinado, dessa forma, ao comércio de segunda mão; b) Remanufatura o produto pode ser reaproveitado mediante substituição de alguns de seus componentes, e; c) Reciclagem - materiais extraídos a partir dos produtos e transformados em matérias prima secundária ou recicladas, destinadas à fabricação de novos produtos.

Se o produto não se enquadrar em nenhum desses grupos, o mesmo segue para a disposição final, que é o último estágio para o qual vão os produtos, materiais ou resíduos que não possuem condições de revalorização (LEITE, 2011). No caso da disposição final de resíduos, Fontana e Aguiar (2013) explicam que a diminuição do tempo de vida útil dos produtos, decorrentes das constantes inovações no mercado, aumenta-se o nível de resíduos gerados e com isso a capacidade dos sistemas tradicionais de disposição final fica altamente comprometida, sendo necessário buscar novas alternativas para os problemas de ordem ambiental.

Conforme exposto, Leite (2011) e Fontana e Aguiar (2013) afirmam que a preocupação quanto à poluição tem se tornado um incentivo à logística reversa, pois a logística combinada com recursos como a reciclagem 
pode reduzir significativamente parte da poluição gerada por certos resíduos. Como no caso dos resíduos sólidos provenientes do pós-consumo das lâmpadas fluorescentes e compreendidos pela PNRS vinculam-se aos acordos setoriais acompanhados pelo Sistema Nacional de Informações Sobre a Gestão dos Resíduos Sólidos - SINIR.

\subsection{LÂMPADAS FLUORESCENTES E LEGISLAÇÃO AMBIENTAL ESPECÍFICA}

De acordo com Ferreira (2014) a lâmpada fluorescente foi inventada pelo sérvio Nikola Tesla em 1856 e introduzida no mercado por volta de 1938. Segundo Magueijo (2010), as lâmpadas fluorescentes têm uma eficiência elevada com relação a outros tipos de lâmpadas, pois consomem menos energia elétrica e tem maior vida útil, durando em média de 8 a 10 vezes mais e proporcionando uma economia de $85 \%$ de energia. As lâmpadas fluorescentes foram inseridas no mercado brasileiro em 2001 como uma alternativa para conter riscos de apagão e devido aos problemas relacionados com o consumo excessivo de energia elétrica (FERREIRA, 2012). As lâmpadas fluorescentes se caracterizam pelas descargas de baixa intensidade e compostas por um tubo de vidro revestido internamente com pó de fosforo e com eletrodos de fio de tungstênio, constituindo-se, basicamente, por quatro elementos: vidro (solda e sílica), pó de fósforo, o metal pesado (mercúrio) e a base (latão ou alumínio).

Figura 1: Composição de uma lâmpada fluorescente

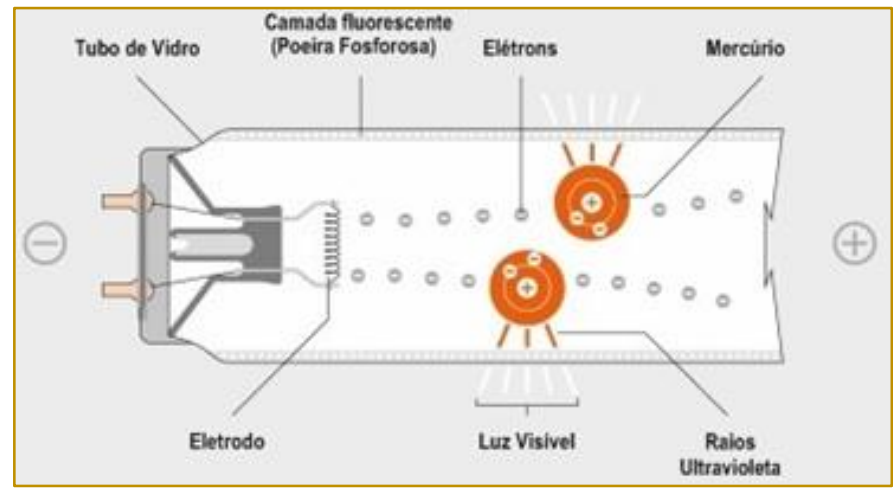

Fonte: Adaptado de Osram, 2015

As lâmpadas fluorescentes são classificadas como um resíduo sólido perigoso Classe I (NBR 10.004/04), pois contém mercúrio em sua composição (ABNT, 2004). O mercúrio é um elemento extremamente tóxico e traz sérios riscos à saúde humana, pois tem efeito acumulativo e a exposição prolongada ao mesmo causa danos pulmonares, renais e neurológicos. Com relação ao meio ambiente, - mercúrio contido nas lâmpadas tem potencial para contaminar o solo, o lençol freático, as plantas, os animais e a água. As lâmpadas fluorescentes, tanto as compactas, quanto as tubulares e circulares, as de vapor de sódio e mercúrio e as de luz mista apresentam mercúrio, bem como ocorre absorção por outros componentes da lâmpada. Durão Junior e Windmöller (2008) observam que o chumbo está presente no vidro e excede os limites fixados pela ABNT e o pó de fósforo contém mercúrio e cádmio. Destaca-se que dependendo do fabricante, os níveis de incidência do mercúrio podem variar de lâmpada para lâmpada. Logo, as lâmpadas fluorescentes nunca devem ser quebradas, uma vez que ocorre a liberação do vapor de mercúrio. A PNRS atribui responsabilidades dos fabricantes, importadores, distribuidores, lojistas e consumidores, exigindo cuidados desde o manuseio, armazenamento, transporte, reciclagem até o destino final (APLIQUIM, 2015). 
Figura 2 - Coleta e etapas do processo de reciclagem

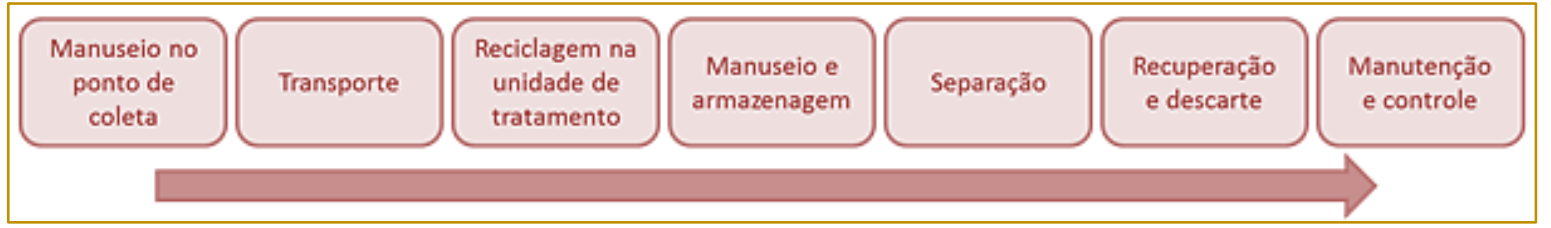

Fonte: Grant Thornton (2011)

Diante de destes fatos, de acordo com o SINIR (2015), foi assinado em 27/11/2014 o acordo setorial para regulamentar a implantação de um sistema de logística reversa de lâmpadas fluorescentes de nível nacional e publicado no Diário Oficial da União em 12/03/2015. O documento tem como objetivo garantir que a destinação final dos resíduos dessas lâmpadas seja feita de forma ambientalmente correta. $\mathrm{O}$ acordo setorial referente às lâmpadas fluorescentes estabelece que as empresas fabricantes e revendedores de lâmpadas fluorescentes (importadoras, comerciantes e distribuidoras) devem em comum acordo escolher ou criar uma entidade gestora, com personalidade jurídica própria e sem fins lucrativos que funcione como intermediadora entre consumidores, fornecedores e empresas recicladoras. Os envolvidos devem atuar de modo a administrar a implantação do sistema de logística reversa, cuidando para que este cumpra com as responsabilidades, condições e prazos que o acordo setorial determina. E a descrição das ações, procedimentos e atividades são detalhadas no Manual de Diretrizes Operacional para Implantação e Operação do Sistema de Logística Reversa (SINIR, 2015).

O sistema de logística reversa para lâmpadas fluorescente define a criação de fundos necessários para execução do processo, os quais são de responsabilidade dos fabricantes e com estes fundos, os fabricantes, em conjunto com a entidade gestora, devem implantar pontos de coleta de lâmpadas fluorescentes nos estabelecimentos de seus revendedores, sendo de responsabilidade destes a manutenção e controle dos pontos, com funcionários devidamente treinados para essa função (SINIR, 2015). Os fabricantes e revendedores devem promover campanhas de divulgação e sensibilização da população consumidora, informando quanto ao recolhimento das lâmpadas, os riscos e danos que as mesmas podem causar e os procedimentos corretos para o manuseio, armazenamento e devolução aos pontos de coleta.
Os consumidores devem encaminhar suas lâmpadas inservíveis aos pontos de coleta, de forma adequada, ou seja, separadamente de outros resíduos e em embalagem apropriada, preferencialmente a original do produto (SINIR, 2015). Quando os pontos de coleta atingem sua capacidade máxima, os responsáveis pelo mesmo, isto é, os revendedores, comunicam a entidade gestora, que por sua vez aciona uma empresa terceira para efetuar a coleta e posterior reciclagem das lâmpadas (SINIR, 2015). A empresa terceira (recicladora de lâmpadas) deve executar a reciclagem e descontaminação dos produtos em unidades licenciadas e devidamente autorizadas pelos órgãos ambientais, apresentando a documentação exigida por lei para exercer a atividade. Além disso, essas empresas devem respeitar os princípios firmados pela PNRS, por meio da adoção, desenvolvimento e aprimoramento de tecnologias limpas que minimizem os impactos ambientais e reduza o volume de resíduos perigosos (SINIR, 2015). As empresas recicladoras devem disponibilizar, quando requisitado pela entidade gestora, informações relacionadas ao processo de reciclagem das lâmpadas e disposição final de seus rejeitos (SINIR, 2015).

De modo a comprovar a efetivação de todo o processo, os associados ao acordo setorial devem anualmente publicar entre si e também junto ao Ministério do Meio Ambiente um relatório contendo os resultados da avaliação do cumprimento das metas estabelecidas pelo acordo, bem como prestar informações específicas ao IBAMA e ao SINIR (SINIR, 2015). O não cumprimento das obrigações previstas no sistema de logística reversa acarreta multa de até 50 mil reais aos infratores (BRASIL, 2008). Estima-se que ao final de 2016, estejam implantados em todo o país cerca de 3.804 pontos de coleta de lâmpadas vinculados ao acordo setorial, dos quais 101 sejam localizados na Região Metropolitana do Vale do Paraíba e, em especial, na cidade de Lorena estão previstos 2 pontos de coletas (SINIR, 2015). 


\section{METODOLOGIA DA PESQUISA}

O tipo de pesquisa empregado neste trabalho é de caráter exploratório com abordagem quantitativa, uma vez que possibilita aos pesquisadores conhecer com maior profundidade o assunto, assim como clarificar suas inter-relações ou estabelecer novas questões para o desenvolvimento da pesquisa (MARCONI e LAKATOS, 2010). De acordo com Rampazzo (2002), um estudo exploratório consiste em registrar fatos reais sem que o pesquisador utilize meios técnicos especiais ou precise fazer perguntas diretas. Ainda segundo o autor, o estudo exploratório proporciona um maior conhecimento do tema abordado. Como parte do estudo, a pesquisa se caracteriza como pesquisa bibliográfica, constituída principalmente de livros e artigos, que permitiu subsidiar a revisão da literatura (GIL, 1999).

Para o alcance dos objetivos, adotou-se a estratégia de pesquisa de campo, cuja coleta de dados ocorre em uma situação não controlada, na qual os sujeitos se encontram em seu ambiente natural e não podem ser observados pelo pesquisador (APPOLINÁRIO, 2012). Assim, fez-se uso de questionários com perguntas fechadas de múltipla escolha, direcionadas aos agentes atuantes na cadeia de lâmpadas fluorescentes, isto é, fabricantes, revendedores, consumidores e recicladoras. Para cada um dos agentes, foi utilizado questionário específico para levantamento dos dados pertinentes à pesquisa.

Para Appolinário (2012), um questionário é um documento com perguntas ordenadas a serem respondidas por escrito pelos entrevistados. Ainda segundo $\mathrm{O}$ autor, perguntas fechadas são as que oferecem opções de resposta pré-definidas. Neste trabalho foi utilizado uma amostra nãoprobabilística e definida pelo critério de intencionalidade dos pesquisados. Em relação aos fabricantes e às recicladoras, levou-se em conta o porte das empresas e se as mesmas forneciam produtos/serviços para a região do Vale do Paraíba. Quanto aos revendedores, adotou-se o critério da localização das empresas na cidade de Lorena-SP. Quanto aos consumidores, o questionário foi direcionado aos residentes das cidades circunvizinhas à Lorena-SP.

A coleta de dados foi executada em quatro etapas, sendo: etapa 1: coleta de dados com fabricantes; etapa 2: coleta de dados com revendedores; etapa 3: coleta de dados com consumidores finais; e etapa 4: coleta de dados com empresas recicladoras. $\mathrm{Na}$ primeira etapa, considerou-se uma população de 24 empresas de grande porte, fabricantes de lâmpadas fluorescentes e que são aderentes ao acordo setorial, localizadas em seis Estados de três regiões diferentes do Brasil, sendo eles: Bahia (1), Pernambuco (1), Paraná (2), Rio de Janeiro (1), Santa Catarina (1) e São Paulo (18). Nesta etapa, os sujeitos responderam a 09 questões relacionadas ao fornecimento de produtos para a região do Vale do Paraíba; posse de certificações ou títulos semelhantes; práticas de gestão ambiental sugeridas pela lei referente às lâmpadas fluorescentes tais como: promoção de capacitação/treinamento junto aos revendedores, promoção da logística reversa das lâmpadas e promoção de projetos de conscientização ambiental. Além disso, foram questionados quanto à existência de fiscalização ambiental periódica, destinação das lâmpadas utilizadas nas dependências da empresa e o fator de maior influência na conduta da empresa.

$\mathrm{Na}$ segunda etapa, considerou-se como população 29 empresas revendedoras de lâmpadas fluorescentes, todas situadas no município de Lorena-SP. Nesta etapa, os sujeitos responderam a 10 questões, nas quais foram indagados quanto à posse de certificações ou títulos semelhantes; volume lâmpadas revendidas anualmente; capacitação/treinamento dos funcionários do estabelecimento; coleta de lâmpadas fluorescentes pós-consumo; promoção de projetos de conscientização ambiental; existência de fiscalização ambiental periódica; e destinação das lâmpadas utilizadas nas dependências da empresa.

$\mathrm{Na}$ terceira etapa, considerou-se uma população de 94 pessoas residentes das cidades de Aparecida, Cachoeira Paulista, Guaratinguetá e Lorena. Os sujeitos foram questionados quanto à utilização de lâmpadas fluorescentes em suas próprias residências; conhecimento dos componentes das lâmpadas fluorescentes e seus riscos à saúde; conhecimento de procedimentos de manuseio/armazenamento das lâmpadas fluorescentes; conhecimento de alguma legislação a cerca das lâmpadas fluorescentes; conhecimento de campanhas de conscientização ambiental a cerca de lâmpadas fluorescentes; destinação das lâmpadas pós-consumo utilizadas na 
residência e a frequência com que tal procedimento é realizado.

$\mathrm{Na}$ quarta etapa, considerou-se uma população de 13 empresas prestadoras de serviço de reciclagem e/ou disposição final de lâmpadas fluorescentes pós-consumo, localizadas nos Estados de Minas Gerais (2), Paraná (3), Rio de Janeiro (1), Rio Grande do Sul (2) e São Paulo (5). Nesta etapa, os sujeitos responderam a 08 questões relacionadas à posse de certificação ou títulos semelhantes; prestação de serviços para a região do Vale do Paraíba; origem das lâmpadas recebidas para tratamento; vínculo com outras organizações; conceitos ambientais adotados pela empresa; comprovação do descarte ambientalmente correto; existência de fiscalização ambiental periódica; e fator de maior influência na conduta da empresa.

Nas etapas 1 e 4, os questionários foram aplicados através de e-mails e contato eletrônico por meio dos sites das empresas envolvidas na pesquisa. Já nas etapas 2 e 3, a aplicação foi realizada de modo tradicional, ou seja, in loco. Os questionários tinham como principal objetivo, coletar dados que permitissem comparar a realidade praticada por cada agente da cadeia logística (consumidores, fabricantes, revendedores e recicladoras) com as exigências impostas pela legislação referente às lâmpadas fluorescentes pós-consumo, visando analisar se de fato a logística reversa proposta pela lei é funcional para este setor.

\subsection{RESULTADOS E DISCUSSÃO}

Com o levantamento realizado pode-se perceber o que realmente acontece com as lâmpadas fluorescentes quando estas se tornam inutilizáveis, além de tornar visíveis os procedimentos adotados por cada agente da cadeia analisada.

\section{Etapa 1 - Fabricantes}

$\mathrm{Na}$ etapa 1, no que diz respeito aos fabricantes, das 24 empresas inicialmente selecionadas para a pesquisa, apenas 5 (21\%) manifestaram interesse em colaborar com o estudo. Dentre as demais, 2 (8\%) se recusaram a participar e 17 (71\%) não manifestaram nenhum posicionamento. Das 5 empresas que participaram efetivamente da pesquisa, todas afirmaram fornecer lâmpadas fluorescentes para a região do Vale do Paraíba, o que justifica a preocupação dos órgãos ambientais em estabelecer um número considerável de pontos de coletas de lâmpadas fluorescentes na região (SINIR, 2015). Quando questionadas a respeito da posse de certificações ou títulos semelhantes, as 5 empresas (100\%) afirmaram possuir licença ambiental para funcionamento. Destas, 4 (80\%) alegaram que além da licença ambiental possuem também plano de gerenciamento de resíduos sólidos e 1 (20\%) declarou ter todos os itens anteriores e ser certificada ISO 14001. Houve ainda uma parcela de $40 \%$ que relatou possuir outros tipos de certificações. Estes percentuais comprovam que as empresas adotam práticas de gestão ambiental como tentativas de melhorar sua imagem corporativa no que tange à sustentabilidade, conforme afirmam Leite (2011) e Fontana e Aguiar (2014).

Com relação às práticas de gestão ambiental que são sugeridas pela Lei que trata das lâmpadas fluorescentes, a Tabela 1 apresenta a realidade vivenciada pelos fabricantes:

Tabela 1: Realidade praticada por fabricantes de lâmpadas fluorescentes

\begin{tabular}{|l|l|l|c|}
\hline \multirow{3}{*}{ Capacitação/Treinamento dos revendedores } & Sim & 1 & $(20,0)$ \\
\cline { 2 - 4 } & Não & 4 & $(80,0)$ \\
\cline { 2 - 4 } & Total & 5 & $(100,0)$ \\
\hline \multirow{3}{*}{ Logística Reversa dos produtos } & Sim & 4 & $(80,0)$ \\
\cline { 2 - 4 } & Não & 1 & $(20,0)$ \\
\cline { 2 - 4 } & Total & 5 & $(100,0)$ \\
\hline \multirow{3}{*}{ Parceria com recicladora } & Sim & 3 & $(60,0)$ \\
\cline { 2 - 4 } & Não & 2 & $(40,0)$ \\
\hline \multirow{3}{*}{ Projetos de conscientização ambiental } & Total & 5 & $(100,0)$ \\
\cline { 2 - 4 } & Sim & 3 & $(60,0)$ \\
\cline { 2 - 4 } & Não & 2 & $(40,0)$ \\
\cline { 2 - 4 } & Total & 5 & $(100,0)$ \\
\hline
\end{tabular}

Fonte: Dados da pesquisa. 
Conforme exposto na Tabela 1, 80\% das empresas participantes efetivas alegaram promover projetos de logística reversa de seus produtos e $60 \%$ possui parceria com empresas recicladoras de lâmpadas fluorescentes. Estes dados evidenciam o cumprimento parcial das exigências impostas pelo acordo setorial de lâmpadas fluorescentes, pois conforme estabelece o SINIR (2015), todas as empresas que fabricam lâmpadas deste tipo, devem promover a logística reversa de seus produtos com o intuito de encaminhá-los à reciclagem e posteriormente à disposição final. No requisito capacitação/treinamento, apenas 1 empresa (20\%) declarou promover esta ação junto aos seus revendedores a respeito dos riscos das lâmpadas fluorescentes. Além disso, 3 empresas (60\%) afirmaram promover projetos de conscientização ambiental na região em que estão localizadas. O Acordo Setorial determina que todas as empresas associadas devem promover tais ações e não apenas parte delas (SINIR, 2015).

Quanto à fiscalização ambiental, 3 (60\%) das 5 empresas afirmaram receber visitas periodicamente e 2 (40\%) afirmaram não receber visitas com frequência. Isto evidencia falha por parte dos órgãos fiscalizadores, os quais de acordo com a PNRS deveriam multar as empresas que não se enquadram nas exigências da lei. Quanto às lâmpadas utilizadas nas dependências da empresa, todas as participantes (100\%) afirmaram encaminhar as lâmpadas pós-consumo para a reciclagem, prática considerada relevante segundo Leite (2011) e Fontana e Aguiar (2013), como alternativa para reduzir parte da poluição gerada por resíduos sólidos. Ao final, quando questionadas quanto aos fatores que mais influenciam a conduta adotada pela empresa, $40 \%$ referiu considerar a legislação, a ética e o diferencial estratégico, fatores fundamentais para a responsabilidade social empresarial. Do restante, também 40\% afirmou considerar a legislação e a ética os fatores primordiais e $20 \%$ declarou considerar apenas a ética o fator que mais influencia sua conduta.

\section{Etapa 2 - Revendedores}

$\mathrm{Na}$ etapa 2, referente aos revendedores, dos 29 estabelecimentos selecionados, 25 (86\%) participaram efetivamente da pesquisa e 4 (14\%) não souberam responder. Conforme o Gráfico 1, dentre os 25 estabelecimentos que participaram efetivamente da pesquisa, uma parcela de $56 \%$ afirmou revender mais de 100 unidades de lâmpadas fluorescentes anualmente, 20\% afirmou revender de 51 a 100 unidades anualmente e $24 \%$ declarou revender até 50 unidades anualmente.

Gráfico 1 - \% de revendedores pela quantidade de lâmpadas fluorescentes revendidas

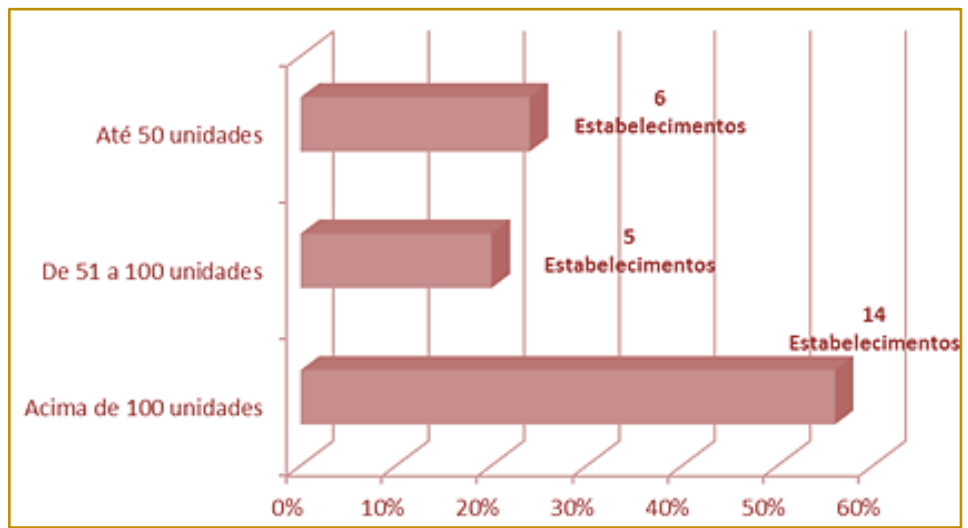

Fonte: dados da pesquisa

Quando questionados a respeito da posse de certificações ou títulos semelhantes, dos 25 estabelecimentos, 16 (64\%) declararam não possuir nenhum tipo de certificação/título, 7 (28\%) referiram possuir licença ambiental para funcionamento, 1 (4\%) afirmou possuir plano de gerenciamento de resíduos sólidos e também 1 (4\%) afirmou possuir certificação
ISO 14001. A quantidade expressiva de empresas que não possuem nenhum tipo de certificação é corroborada pela ausência das práticas de gestão ambientais sugeridas pela Lei que trata das lâmpadas fluorescentes. A Tabela 2 apresenta a realidade vivenciada pelos revendedores: 
Tabela 2: Realidade praticada por revendedores de lâmpadas fluorescentes

\begin{tabular}{|l|c|c|c|}
\hline \multirow{4}{*}{ Variáveis } & & $N$ & $\%$ \\
& Sim & 11 & $(44,0)$ \\
\cline { 2 - 4 } & Não & 14 & $(56,0)$ \\
\cline { 2 - 4 } & Total & 25 & $(100,0)$ \\
\hline \multirow{3}{*}{ Membro de associação/projeto de logística reversa } & Sim & 5 & $(20,0)$ \\
\cline { 2 - 4 } & Não & 20 & $(80,0)$ \\
\cline { 2 - 4 } & Total & 25 & $(100,0)$ \\
\hline \multirow{3}{*}{ Ponto de coleta próprio } & Sim & 7 & $(28,0)$ \\
\cline { 2 - 4 } & Não & 18 & $(72,0)$ \\
\cline { 2 - 4 } & Total & 25 & $(100,0)$ \\
\hline \multirow{3}{*}{ Projetos de conscientização ambiental } & Sim & 1 & $(4,0)$ \\
\cline { 2 - 4 } & Não & 24 & $(96,0)$ \\
\cline { 2 - 4 } & Total & 25 & $(100,0)$ \\
\hline
\end{tabular}

Fonte: Dados da pesquisa.

De acordo com a Tabela 2, 44\% dos estabelecimentos afirmaram promover capacitação/treinamento para seus funcionários a respeito dos riscos das lâmpadas fluorescentes e 56\% afirmaram não promover treinamentos. Estes percentuais demonstram que mais da metade dos estabelecimentos não estão procedendo em conformidade com o acordo setorial, pois assim como os fabricantes, os revendedores também devem promover treinamento para seus colaboradores (SINIR, 2015). Com relação à logística reversa das lâmpadas fluorescentes pós-consumo, $80 \%$ dos estabelecimentos afirmaram não participar de associações ou projetos que promovem tal atividade e $72 \%$ afirmou não possuir ponto de coleta próprio para recolhimento das lâmpadas fluorescentes no estabelecimento. Verifica-se que os estabelecimentos não se encontram em conformidade com a Lei para instaurar a logística reversa dos produtos pósconsumo até o fabricante. A parcela considerável de 96\% diz não promover projetos de conscientização ambiental na região e somente $4 \%$ afirmou realizar eventos deste tipo, o que caracteriza o descumprimento do acordo setorial, pois o mesmo determina que todas as empresas revendedoras devem promover a conscientização da população local (SINIR, 2015).

Quanto à fiscalização ambiental, apenas 4 (16\%) dos 25 estabelecimentos afirmaram receber vistas periodicamente e 21 (84\%) afirmaram não receber visitas com frequência. No que diz respeito às lâmpadas utilizadas nas dependências do estabelecimento, 13 (52\%) revendedores afirmaram encaminhar as lâmpadas pós-consumo para a reciclagem, 6 (24\%) referiram armazená-las em depósito, 1 (4\%) alegou doar à associações de catadores de lixo e 5 (20\%) declaram descartar as lâmpadas fluorescentes em lixo comum. Com isto, verificou-se que nem todas as empresas destinam as lâmpadas de maneira correta, isto é, encaminhando-as à reciclagem ou à disposição final ambientalmente adequada (LEITE, 2011).

\section{Etapa 3 - Consumidores}

$\mathrm{Na}$ etapa 3, referente aos consumidores finais, todos os 94 entrevistados (100\%) responderam ao questionário e desses, 82 (87\%) afirmaram utilizar lâmpadas fluorescentes em suas residências e 12 (13\%) afirmaram não utilizar este tipo de lâmpada. No entanto, 83 (88\%) admitem não ter conhecimento sobre a existência de projetos de reciclagem de lâmpadas fluorescentes e apenas $11(12 \%)$ alegaram ter conhecimento de projetos deste caráter.

Referente aos materiais que compõe as lâmpadas fluorescentes, das 94 pessoas, 15 $(16 \%)$ declararam ter conhecimento dos materiais em questão e 79 (84\%) afirmaram não possuir conhecimento algum quanto a estes materiais. Apesar disso, 66 (70\%) alegaram estar cientes da periculosidade das lâmpadas fluorescentes e 28 (30\%) afirmaram não conhecer tal risco.

Com relação a campanhas e instruções acerca do descarte de lâmpadas fluorescentes, 88 (94\%) afirmaram que não receberam projetos deste tipo em sua cidade e apenas uma minoria de 6 pessoas (6\%) alegaram ter recebido orientações deste tipo e, quando questionadas sobre a maneira de manusear e armazenar as lâmpadas fluorescentes, 45 (48\%) afirmaram não conhecer a maneira correta de realizar estes procedimentos e 49 (52\%) alegaram conhecer a maneira correta de realizar os procedimentos. No que diz respeito à coleta e reciclagem das lâmpadas fluorescentes, 54 
(57\%) pessoas declararam não saber da existência de legislação específica que trata do assunto e 40 (43\%) declararam saber da existência dessa legislação. O Gráfico 2 mostra os procedimentos de descarte praticados pelos consumidores finais,

Gráfico 2 - Procedimentos de descarte praticados por consumidores finais

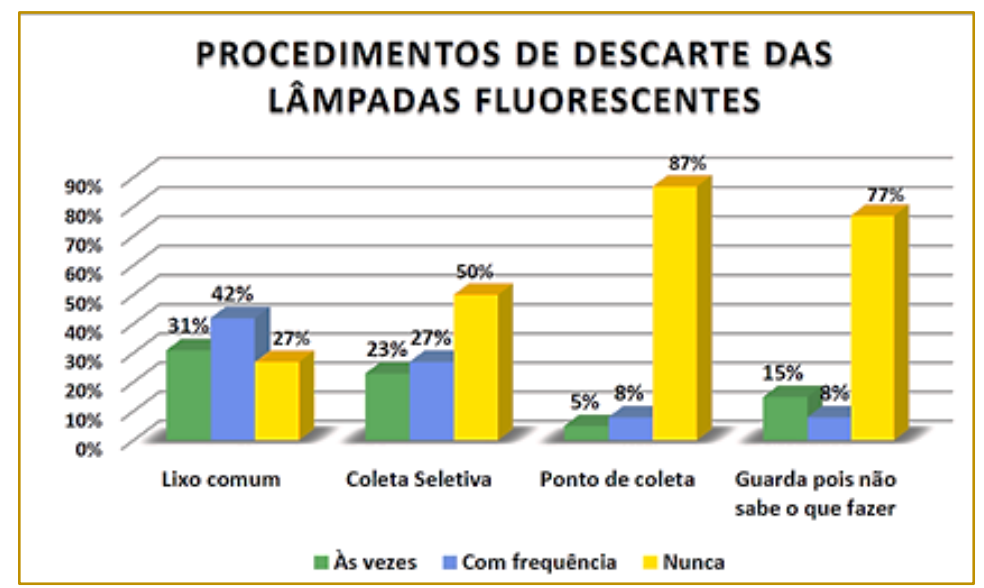

Fonte: Dados da pesquisa.

Observa-se no gráfico acima, quanto ao lixo comum, a maioria dos consumidores (42\%) referiu utilizar com frequência este procedimento para descartar as lâmpadas fluorescentes. Quanto à coleta seletiva, metade dos consumidores, ou seja, 50\%, afirmou nunca fazer uso deste procedimento, assim como $87 \%$ declararam nunca encaminhar as lâmpadas fluorescentes a pontos de coleta em estabelecimentos. Estes dados demonstram que o retorno das lâmpadas à cadeia é ineficaz e são baixos os percentuais de resíduos dispostos de forma ambientalmente correta (ABRELPE, 2014). Ao final, 67 (71\%) consumidores afirmaram que não possuíam conhecimento prévio quanto às lâmpadas fluorescentes antes de participarem da pesquisa e 27 (29\%) afirmaram que já possuíam algum conhecimento sobre o tema em questão.

Com base nos dados acima, verifica-se que os consumidores não estão agindo de acordo com o estabelecido pelo Sistema Nacional de Informações sobre a Gestão dos Resíduos Sólidos (SINIR), o qual impõe que os consumidores encaminhem as lâmpadas fluorescentes aos pontos de coleta. No entanto como não há pontos de coleta disponíveis nos estabelecimentos de revenda e a maioria dos consumidores não possuem conhecimento da legislação pertinente, as lâmpadas são frequentemente encaminhadas ao lixo comum.

\section{Etapa 4 - Recicladoras}

$\mathrm{Na}$ etapa 4, dos 13 questionários enviados às recicladoras, não obteve-se nenhum resultado, pois nenhuma das empresas selecionadas retornou o questionário respondido. Sendo que, 2 se recusaram formalmente a responder, outras 2 manifestaram interesse em analisá-lo e posteriormente não se pronunciaram mais e o restante não se manifestou em momento algum. Silva (2010) ao realizar uma pesquisa similar a esta, verificou o mesmo posicionamento omisso por parte de empresas recicladoras do Estado de Pernambuco. O Gráfico 3 abaixo ilustra a situação verificada. 
Gráfico 3 - Retorno de questionários enviados às recicladoras de lâmpadas fluorescentes

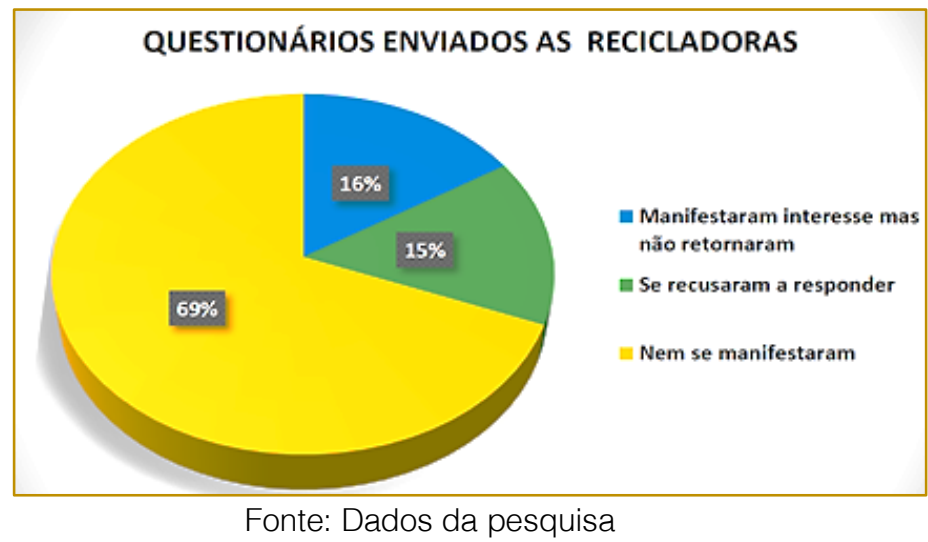

\section{CONSIDERAÇÕES FINAIS}

O presente artigo fundamentou-se numa pesquisa de campo onde foram analisadas as realidades vivenciadas pelos agentes da cadeia de lâmpadas fluorescentes (fabricantes, revendedores, recicladoras e consumidores) no que diz respeito às práticas de gestão ambiental sugeridas pela lei referente às lâmpadas fluorescentes, tendo como principal referência a Política Nacional de Resíduos Sólidos - PNRS. Conforme o objetivo da pesquisa que consistia em verificar os principais desafios e dificuldades acerca do processo logístico reverso de lâmpadas fluorescentes, constatou-se que de fato há muitos obstáculos a serem superados neste setor devido às inúmeras falhas em todas as fases do processo.

Estes fatos foram evidenciados pela pesquisa de campo, onde um percentual considerável de entrevistados em toda cadeia admitiu não atender a todas as exigências específicas impostas pela Política Nacional de Resíduos Sólidos e pelo Acordo Setorial no que diz respeito às lâmpadas fluorescentes, o que de fato comprova a ineficiência da fiscalização ambiental e a impunidade para aqueles que estão em desacordo com a lei. Além disso, a ausência de informações referentes ao manuseio, descarte e disposição final das lâmpadas fluorescentes caracteriza uma das principais dificuldades do processo. Uma vez que haja falha por parte dos fabricantes e revendedores em não promover projetos de conscientização ambiental e divulgação de informações a cerca do assunto junto à população, os consumidores, por sua vez permanecem sem o conhecimento das responsabilidades que the cabem perante a lei e assim, acabam de mesma forma não cumprindo com as obrigações exigidas.
Outro ponto a salientar é a indisponibilidade de pontos de coleta de lâmpadas nos municípios, o que configura novamente 0 descumprimento da legislação. Em tese, estes pontos deveriam ser de responsabilidade dos revendedores, no entanto como a maior parte destes não promove tal ação, os consumidores ficam impossibilitados de retornar suas lâmpadas inservíveis à cadeia. A coleta seletiva também se mostrou uma opção inválida para retornar as lâmpadas à cadeia, pois apesar dos municípios onde os consumidores residem possuir tal ação, a falta de informação, divulgação, e até mesmo a falta de planejamento tornam-se obstáculos que impedem o sucesso efetivo destes programas.

Sendo assim, conclui-se que o diagnóstico quanto à eficácia da logística reversa na cadeia de lâmpadas fluorescentes nos municípios estudados caracteriza um processo imaturo e falho que deve transpassar barreiras não só de processos, atividades ou regulamentos, mas também as barreiras culturais já adquiridas por cada indivíduo.

As empresas e a sociedade de modo geral precisam despertar sua consciência ambiental e atentarem-se ao assunto, de modo que ações de conservação ambiental sejam adotadas e que a lei seja cumprida, pois vale ressaltar que as ações adotadas hoje, impactarão no longo prazo, no futuro das empresas, na sociedade e principalmente no o meio ambiente. Sendo assim a Logística Reversa deve ser desenvolvida permanentemente e não compreendida como um modismo. 


\section{REFERÊNCIAS}

[1] Abilux - Associação Brasileira da Indústria de lluminação. 10 formas de reduzir o consumo de energia elétrica. Disponível em: http://www.abilux.com.br/portal/abilux-namidia/2/10-formas-de-reduzir-o-consumo-deenergia-eletrica. Acessado em: 31/05/2015. [2] Apliquim Brasil Recicle. Sobre as Lâmpadas. Porto Alegre, 2015. Disponível em http://www.apliquimbrasilrecicle.com. br/saibamais. Acessado em: 01/06/2015.

[3] Appolinario, F. Metodologia da ciência: filosofia e prática de pesquisa. 2 ed. São Paulo: Cengage Learning, 2012.

[4] Abrelpe - Associação Brasileira de Empresas de Limpeza Pública e Resíduos Especiais. Panorama dos resíduos sólidos no Brasil em 2013. São Paulo, 2014. Disponível em: http://www.abrelpe.org.br/Panorama/panorama201 3.pdf. Acessado em: 08/05/2015.

[5] Abnt - ASSOCIAÇÃO BRASILEIRA DE NORMAS TÉCNICAS. NBR 10004. Resíduos sólidos - Classificação. 2. ed. Rio de Janeiro, 2004. Disponível em: http://www.aslaa.com.br/legislacoes/NBR\%20n\%20 10004-2004.pdf. Acessado em: 20/04/2015.

[6] Brasil. Decreto no 6.514, de 22 de julho de 2008. Dispõe sobre as infrações e sanções administrativas ao meio ambiente, estabelece o processo administrativo federal para apuração destas infrações, e dá outras providências. Diário Oficial da União, Brasília, DF, 23 jul. 2008. Disponível em: http://www.planalto.gov.br/ccivil_03/_ato2007-

2010/2008/decreto/D6514.htm. Acessado em: 01/06/2015.

[7] Brasil. Lei no 12.305, de 02 de agosto de 2010. Institui a Política Nacional de Resíduos Sólidos, altera a lei no 9.605, de 12 de fevereiro de 1998. Diário Oficial da União, Brasília, DF, 03 ago. $2010 . \quad$ Disponível em: http://www.planalto.gov.br/ccivil_03/_ato20072010/2010/lei/112305.htm. Acessado em: 04/03/2015.

[8] Brasil. Lei no 6.938, de 31 de agosto de 1981. Dispõe sobre a Política Nacional do Meio Ambiente, seus fins e mecanismos de formulação e aplicação, e dá outras providências. Diário Oficial da União, Brasília, DF, 02 set. 1981. Disponível em: http://www.planalto.gov.br/ccivil_03/leis/l6938.htm. Acessado em: 20/04/2015.

[9] Capra, F. O ponto de mutação. São Paulo: Cultrix, 2002.

[10] Conama - Conselho Nacional do Meio Ambiente. 1986. Resolução Conama oo 001, de 23 de janeiro de 1986. Diário Oficial da União, Brasília, DF, 17 fev. 1986. Disponível em: http://www.mma.gov.br/port/conama/legiabre.cfm? codlegi=23. Acessado em: 20/04/2015.

[11] Dornier, P. P. et all. Logística e operações globais. São Paulo: Atlas, 2013.
[12] Durão Junior, W. A.; Windmöller, C. C. A Questão do mercúrio em lâmpadas fluorescentes, Revista Química Nova na Escola, n. 28, maio, 2008.

[13] Ferreira, J. Z. Estudo comparativo entre Lâmpadas Fluorescentes Tubulares T8 e Tubulares de Led. 2014. 59 f. Monografia (Pós Graduação em Construções Sustentáveis) - Universidade Tecnológica Federal do Paraná, 2014. Disponível em:

http://repositorio.roca.utfpr.edu.br/jspui/bitstream/1/ 3428/1/CT_CECONS_III_2014_11.pdf. Acessado em: 08/05/2015.

[14] Fontana, A. M.; Aguiar, E. M. Logística, transporte e adequação ambiental. In CAIXETAFILHO, J. V.; MARTINS, R. S. (organizadores). Gestão logística do transporte de cargas. São Paulo: Atlas, 2013.

[15] Gil, Antonio Carlos. Métodos e técnicas de pesquisa social. São Paulo: Atlas, 1999.

[16] Grant Thornton. Estudo de viabilidade: Viabilidade técnica e econômica em logística reversa na organização da coleta e reciclagem de resíduos de lâmpadas no Brasil. 1.ed. São Paulo, $2011 . \quad$ Disponível em: http://www.sinir.gov.br/documents/10180/13560/EV TE_LAMPADAS/. Acessado em 25/05/2015.

[17] Ibge - Instituo Brasileiro de Geografia e Estatística. Pesquisa Nacional de Saneamento Básico de 2008.2 Disponível: http://www.sidra.ibge.gov.br/bda/pesquisas/pnsb/. Acessado em: 13/05/2015.

[18] Inmetro - Instituto Nacional de Metrologia, Qualidade e Tecnologia. 1o de julho: lâmpadas incandescentes de 60W deixam o mercado. Disponível em: http://www.inmetro.gov.br/imprensa/releases/Lamp adas_incandescentes_de_60W_deixam_o_mercad o.pdf. Acessado em 03/08/2016.

[19] Leite, Paulo Roberto. Logística Reversa: Meio Ambiente e competitividade. 2 ed. São Paulo: Pearson, 2011.

[20] Magueijo, V. et al. Medidas de eficiência energética aplicáveis à indústria portuguesa: um enquadramento tecnológico sucinto. ADENE Agência para a energia. Algés, Portugal, 2010. Disponível

http://efinerg2011.aeportugal.pt/Areas/Projecto/Doc umentos/Publica\%C3

\%A7\%C3\%A3oMedidasEfici\%

C3\%AAnciaEnerg\%C3\%A9ticalnd\%C3\%BAstria-

SGCIE.pdf. Acessado em: 31/05/2015.

[21] Mansor, M. T. C. et all. Secretaria do Meio Ambiente do Estado de São Paulo. Cadernos de educação ambiental 6: Resíduos sólidos. São Paulo, 2010. Disponível em: http://www.ambiente.s.pgov.br/wpcontent/uploads/publicacoes/sma/6ResiduosSolidos.pdf. Acessado em: 08/05/2015. [22] Marconi, M. de A.; LAKATOS, E. M. Fundamentos de metodologia científica. 7 ed. São Paulo: Atlas, 2010. 
[23] Ministerio do Meio Ambiente - MMA. Política nacional de resíduos sólidos: principais aspectos. São Paulo, 2015. Disponível em: http://www.mma.gov.br/pol\%C3\%ADtica-deres\%C3\%ADduos-s\%C3\%B3lidos. Acessado em: 20/04/2015

[24] Pereira, A. L. et al. Logística reversa e sustentabilidade. 2. ed. São Paulo: Cengage Learning, 2012.

[25] Rampazzo, L. Metodologia científica para alunos dos cursos de graduação e pós graduação. São Paulo: Loyola, 2002.

[26] Silva, F. M. Análise do descarte de lâmpadas fluorescentes na cidade do Recife. 2010. 84 f. Dissertação (Mestrado em Engenharia da Produção) - Universidade Federal de Pernambuco. Recife, 2010. Disponível em: http://repositorio.ufpe.br/xmlui/bitstream/handle/ 123456789/5492/arquivo561_1.pdf?sequence=1\&is Allowed=y. Acessado em: 21/05/2015.
[27] Sinir - Sistema Nacional de Informações sobre a Gestão dos Resíduos Sólios. Ministério do Meio Ambiente. Sistemas de logística reversa em implantação. Brasília, 2015. Disponível em http://sinir.gov.br/web/guest/logistica-reversa Acessado em: 20/04/2015

[28] Ministério do Meio Ambiente. Acordo setorial de lâmpadas fluorescentes de vapor de sódio e mercúrio e de luz mista. Brasília, 2015. Disponível em: http://www.sinir.gov.br/documents/10180/23979/02 ++Acordo+Setorial+de+L\%C3\%A2mpadas.pdf/47 7cd170-4078-4ff0-a23a-9acf67bf523a. Acessado em: 20/04/2015.

[29] Trombeta, L. R.; LEAL, A. C. Gestão dos Resíduos Sólidos Urbanos: Um olhar sobre a coleta seletiva no Município de Presidente Prudente, São Paulo, Brasil. Rev. Formação, Presidente Prudente, v. 1 n. 21, p. 143-169, 2014. Disponível em: http://revista.fct.unesp.br/index.php/formacao/articl e/view/2361/2542. Acessado em: 08/05/2015. 


\section{Bapítulo 14}

\section{DETERMINANTES DA DIVULGAÇÃO VOLUNTÁRIA DO BALANÇO SOCIAL NO BRASIL}

\section{Dilciléria da Rosa de Oliveira \\ Joyce Gonçalves Altaf}

Resumo: O objetivo deste estudo é identificar os fatores determinantes para divulgação voluntária do balanço social no Brasil. Foram verificadas as variáveis: preocupação com a imagem, tamanho, setor, porte da empresa de auditoria, lucratividade e Internacionalização. Para esse estudo realizou-se um referencial teórico baseado na teoria do julgamento (VERRECCHIA, 2001), assim, a divulgação do balanço social é tida como endógeno e os incentivos que os gerentes e ou a empresa têm para divulgar a informação. A metodologia consiste em uma pesquisa quantitativa que foi realizada por meio da coleta de dados de empresas listadas na BM\&FBOVESPA pertencentes a setores de atividades potencialmente poluidoras e utilizadoras de recursos ambientais no período de 2008 a 2010, representadas por 145 empresas em cada ano. A metodologia econométrica baseou-se na estimação de um modelo probit aplicado aos dados em painel. Conclui-se assim que, estatisticamente, a preocupação com a imagem e empresas auditadas por Big Four tem relação positiva com a divulgação do balanço social.

Palavras-Chave: Balanço social; teoria do julgamento e BM\&FBOVESPA. 


\section{INTRODUÇÃO}

O presente estudo identificou os fatores determinantes para a divulgação voluntária do balanço social no Brasil. Atualmente não há obrigatoriedade legal para que as empresas divulguem relatórios de natureza social e ambiental em suas demonstrações contábeis. Contudo, percebe-se uma continuidade em algumas companhias em permanecer com a divulgação do referido balanço.

Nesse contexto, a presente pesquisa irá versar sobre quais variáveis podem estar influenciando tal prática por parte das empresas listadas na Bolsa de Valores, Mercadorias e Futuros BM\&FBOVESPA pertencentes a setores de atividades potencialmente poluidoras e que utilizam de recursos ambientais conforme o anexo VIII da Lei 10.165/2000.

O balanço social é definido como um relatório que disponibiliza informações sociais e ambientais sobre as empresas. Ribeiro e Lisboa (1999, p.1) explicam que:

O balanço social é um instrumento de informação da empresa para a sociedade, por meio do qual a justificativa para sua existência deve ser explicitada. Em síntese, esta justificativa deve provar que o seu custobenefício é positivo, porque agrega valor à economia e à sociedade, porque respeita os direitos humanos de seus colaboradores e, ainda, porque desenvolve todo $\mathrm{o}$ seu processo operacional sem agredir o meio ambiente.

Segundo Dye (2001), espera-se que os benefícios gerados pela divulgação de informação não obrigatória sejam superiores aos seus custos, visto que na teoria da divulgação voluntária, a entidade tende a divulgar voluntariamente apenas informações positivas. Nossa (2002, p. 86), em sua pesquisa, destaca que, geralmente, no disclosure voluntário é exposto apenas o que a companhia apresenta de positivo. Há pesquisas, entretanto, que avaliam de outra forma tais causas.

Segundo Salotti e Yamamoto (2005), quando o processo de divulgação passa a ser tratado como endógeno questiona-se a veracidade da informação contida nos demonstrativos.

Cunha e Ribeiro (2008) demonstraram em seus estudos que a evidenciação de informações voluntárias pode ser explicada por características da própria empresa, tais como porte, desempenho, práticas de governança corporativa dentre outros. A pesquisa dos referidos autores analisou os motivos da divulgação voluntária do balanço social nas empresas brasileiras no período de 2003 a 2006, listadas na BMF\&BOVESPA. Os resultados apontaram que a divulgação voluntária do balanço social está associada positivamente ao nível de governança corporativa, ao desempenho, e à divulgação em período anterior.

Murcia et al (2009) pesquisaram os fatores determinantes do nível de disclosure voluntário das companhias abertas no Brasil no findo de 2007 e constataram que a regulação setorial influencia positivamente 0 nível da divulgação. $O$ autor relata, no entanto, que os resultados da pesquisa não devem ser generalizados para outras empresas e outros períodos de tempo e assim, mais pesquisas devem ser realizadas.

Suliani Rover, Murcia et al (2012) em sua pesquisa identificou os fatores que determinam a divulgação voluntária ambiental pelas empresas brasileiras potencialmente poluidoras no período de 2003 a 2007 e concluiu que o tamanho da empresa, empresa de auditoria são significantes para explicar o disclosure voluntário de informações ambientais.

Liu e Anbumozhi (2009) investigaram os fatores determinantes da divulgação voluntária dos relatórios sociais e identificaram que as variáveis determinantes foram o tamanho da empresa e a sensibilidade da indústria ao meio ambiente, dentre outras variáveis como a alavancagem financeira, localização da empresa, concentração dos acionistas dentre outras que não foram significantes.

Em um estudo realizado em Nova Zelândia, Hackston (1996) verificou as variáveis determinantes do nível de divulgação social e ambiental em algumas empresas, e o resultado indicou que tanto o tamanho quanto a natureza da atividade estão associados com o nível de divulgação social e ambiental, enquanto o desempenho não apresenta significativa relevância.

Segundo Michelon (2007), o tamanho das empresas é uma variável encontrada em muitas pesquisas, e apresenta uma correlação positiva com as divulgações socioambientais. Nesse sentido, infere-se, portanto, uma relação tênue entre o grau de divulgação e o tamanho apresentado pela companhia. 
O disclosure de algumas empresas excede o requerido por lei, e a tendência é que empresas maiores apresentem maior grau de divulgação, levando em consideração que o custo de preparação e transmissão da informação é menor relativamente a seu tamanho do que empresa de menor porte (LANG, LUNDHOLM, 1993).

Uma série de estudos tem indicado que as grandes empresas estão mais sujeitas ao social e a pressão política do que as empresas de pequeno porte. Trotman e Bradley (1981) e Cowen et al (1987) acham que o tamanho da empresa tem sido uma variável explicativa e significativa em seus estudos de divulgação de responsabilidade social. O último autor, por sua vez, também diz que "as grandes empresas tendem a receber mais atenção do público em geral e, portanto, a estar sob maior pressão pública para expor a responsabilidade social". Além disso, em uma meta-análise de 29 estudos de divulgação, Ahmed e Courtis (1999) dizem que o tamanho é um dos indicadores mais importantes de divulgação em nível corporativo do relatório anual. Como as grandes empresas são preparadas para enfrentar pressões maiores do que as empresas menores, consequentemente, aumentarão suas divulgações para estabelecer um bem social de forma mais incisiva, vis-a-vis empresas de menor porte. $\mathrm{O}$ objetivo por trás de tal prática se resume em considerar a imagem como parte de sua estratégia de negócios.

Percebe-se que a discussão acerca do tema é extensa, com as mais diversas opiniões, tanto sobre as variáveis que determinam a divulgação voluntária quanto sobre a concepção dos balanços sociais. Nesse sentindo, o referido estudo contribuirá para aprofundar um assunto propondo uma metodologia econométrica, a partir dos dados disponíveis, com o objetivo de refinar a atual discussão e verificar o que de fato estimula uma empresa a submeter tal demonstrativo para o mercado.

Como destacado, existem divulgações voluntárias dos relatórios sociais em vários países. Embora muitas divulgações sejam obrigatórias, é importante entender os determinantes para fornecer a informação na ausência de regulamentação, e assim explicar os motivos de disclosure das companhias.

Independentemente do modelo de balanço social divulgado pelas empresas, levando-se em consideração os custos e benefícios da divulgação do balanço social, este trabalho responderá a seguinte questão de pesquisa: Quais são os determinantes da divulgação voluntária do balanço social no Brasil por empresas listadas na BM\&FBOVESPA?

O objetivo desta pesquisa é identificar os determinantes da divulgação voluntária do balanço social no Brasil por empresas listadas na BM\&FBOVESPA, pertencentes a setores de atividades potencialmente poluidoras e utilizadoras de recursos ambientais conforme o anexo VIII da Lei 10.165/2000.

No Brasil as empresas não têm obrigação legal de divulgar o balanço social. No entanto, embora não haja essa obrigação, existem focos de divulgação voluntária, conforme verificado pelas pesquisas de Salotti e Yamamoto (2005); Cunha e Ribeiro (2008) e Murcia (2009).

Ao considerar o fato da existência de evidências empíricas da divulgação do balanço social pelas empresas brasileiras, questionam-se os incentivos que as empresas no país recebem para divulgarem voluntariamente informações sociais e ambientais. A nível nacional, percebe-se poucas pesquisas fundamentadas na Teoria da Divulgação Voluntária, o que nos instiga verificar quais são os determinantes influenciadores para divulgação voluntária do balanço social no Brasil.

Conforme um estudo realizado pela KPMG (2005) foi realizado um levantamento com empresas de diversos países e observou-se que os setores de alto impacto ambiental lideram a divulgação de informações sociais e ambientais.

Contribuindo com a pesquisa de Cunha e Ribeiro (2008) que analisaram a divulgação do balanço social e disseram que outras relações devem ser pesquisadas, como porte da empresa de auditoria, preocupação com a imagem, lucratividade e setor, a proposta desta pesquisa baseia-se em encontrar os fatores determinantes da divulgação voluntária do balanço social no Brasil considerando empresas listadas na BM\&FBOVESPA pertencentes a setores de atividades potencialmente poluidoras e utilizadoras de recursos ambientais.

Como já salientado, o tema escolhido é pouco explorado em âmbito nacional, portanto, entender os motivos para divulgação voluntária do balanço social é um assunto de 
interesse para a evolução da pesquisa contábil no Brasil.

\section{REVISÃO BIBLIOGRÁFICA}

As empresas européias têm a preocupação em prestar esclarecimentos à sociedade e ao Estado com o mesmo nível de exigência que servem aos seus acionistas. Hendriksen e Breda (1999, p. 515) apresentam algumas considerações a respeito da divulgação a grupos de interesses sobres os países do referido continente:

Outras partes do mundo, particularmente a Europa, tendem a dar uma resposta mais ampla à pergunta "Para quem"? em particular, tendem a colocar os interesses dos funcionários e do estado no mesmo nível dos acionistas. A importância da participação dos acionistas na propriedade da empresa é diminuída em favor da noção mais ampla de preocupações de vários grupos de interesse. O efeito dessa posição é a alteração da natureza do processo de divulgação. As empresas francesas, por exemplo, são obrigadas a apresentar um balanço social a um conselho de funcionários da empresa a cada ano. Esses conselhos são compostos por trabalhadores e executivos.

O trabalho de Verrecchia (2001) destaca-se quando nos referimos a respeito da Teoria da
Divulgação Voluntária, apresentando uma percepção analítica observando os modelos matemáticos desenvolvidos pela teoria para explicar e prever fenômenos relacionados ao disclosure.

Verrecchia (2001) classifica os trabalhos anteriores sobre o assunto em três classes: pesquisa sobre divulgação baseada em associação, tendo como objetivo principal estabelecer uma relação entre a divulgação e as alterações na conduta dos investidores, principalmente através da performance dos preços dos ativos em equilíbrio e do volume de negociação.

A pesquisa sobre divulgação baseada em julgamento, que abrange estudos que apresentaram os motivos da divulgação, ou seja, procuram examinar com detalhes os gestores e/ou empresas que decidem divulgar determinadas informações.

A pesquisa sobre divulgação baseada em eficiência, que compreende que as pesquisas a respeito das configurações de divulgação são as preferidas, na ausência de conhecimento passado sobre a informação, ou seja, como a divulgação não foi realizada pode ser caracterizada, portanto como sendo ex ante, essa categoria discute quais os tipos de divulgação mais eficientes.

Figura 1: Características da Divulgação das Categorias de Pesquisa

Categorias de Pesquisa

Momento de Ocorrência da divulgação (ex ante ou ex post)

\section{Características da Divulgação} ex post

\begin{tabular}{|c|c|c|}
\hline Associação & ex post & Exógeno \\
\hline Julgamento & ex post & Endógeno \\
\hline Eficiência & ex ante & não aplicável \\
\hline
\end{tabular}

Fonte: Salotti e Yamamoto (2005, p.56).

A pesquisa sobre a divulgação voluntária do balanço social enquadra na classe proposta por Verrecchia (2001), divulgação baseada em julgamento. Assim, a divulgação do balanço social é tida como endógena e quais, incentivos que os gerentes e ou a empresa têm para divulgar a informação.

O autor ainda afirma que as pesquisas sobre divulgação baseada em julgamento demonstram que as empresas podem escolher publicar ou não uma informação e, tal prática, pode ser explicada por algumas características da própria empresa, tais como: capacidade, desempenho, dentre outros atributos.

Dye (2001, p. 184) discorda parcialmente de Verrecchia (2001) ao ressaltar que a teoria das divulgações voluntárias é um caso especial da teoria dos jogos com a premissa central de que qualquer entidade contemplando fazer uma divulgação, irá divulgar informação favorável à empresa e não as informações desfavoráveis. Esta teoria é mais interessante na luz que ela lança sobre como interpretar o silêncio ou, mais 
geralmente, menos do que a divulgação completa.

Dye (2001) demonstra um exemplo de aplicação dessa teoria ao considerar um vendedor de carros que exalta a confiabilidade de um carro, mas não menciona o seu desempenho. A teoria permite-nos concluir que o desempenho do carro não é muito bom.

De acordo com Salotti e Yamamoto ( 2005, p. 67-68), os jogos apresentam algo característico de um conjunto de regras que definem quais são os jogadores, as suas ações possíveis e o conjunto de resultados disponíveis para cada jogador. O processo de divulgação poderia ser entendido como um jogo de dois jogadores (o jogador 1 são a firma e/ou gestores versus jogador 2 que são os investidores). Os estudos baseados em julgamento tratam como endógeno o processo de divulgação e procuram examinar de que maneira os gestores e/ou empresas decidem divulgar determinados resultados. Segundo os autores, neste caso, o jogo é estudado do ponto de vista do jogador 1 , isto é, a empresa e/ou gestores avaliam a sua decisão com base na ações dos investidores.

Segundo a Teoria da Divulgação Voluntária (VERRECCHIA, 2001; DYE, 2001), as empresas divulgam poucas informações negativas a seu respeito de forma voluntária.

Estudos foram realizados em outros países sobre o tema. Um deles é o de Campbell (2004) referente ao Reino Unido, que analisou os relatórios anuais de 10 companhias no período de 1974 a 2000 e registrou o volume da divulgação voluntária. Os resultados obtidos indicaram um aumento no volume geral da divulgação social e ambiental neste período. Além disso, indicaram uma associação positiva entre divulgação social e ambiental e o nível de vulnerabilidade de alguns setores à ocorrência de passivos ou críticas ambientais.

De acordo com Neimark (1992), o tema social e ambiental permite à contabilidade uma oportunidade de reflexão acerca de sua importância como instrumento de mensuração e divulgação das informações.

Em Hong Kong, Gao, Heravi e Xiao (2005) pesquisaram os determinantes do disclosure ambiental e social corporativo nos relatórios anuais de algumas companhias listadas em bolsas, e identificaram que existe uma correlação positiva entre 0 tamanho da empresa e o nível de disclosure.

Rafournier (1995) em sua pesquisa verificou a extensão da divulgação voluntária, e o resultado encontrado foi que o tamanho e o grau de internacionalização foram variáveis relevantes para a divulgação voluntária. $\mathrm{O}$ autor examinou também o endividamento, lucratividade e porte de auditoria das empresas.

Cunha e Ribeiro (2008) pesquisaram os motivos que levariam as companhias negociadas no mercado de capitais brasileiro a divulgar informações de natureza social. A amostra verificada pelos autores foi composta de 183 companhias, excluídas as empresas do setor energético e de participações, abrangendo vários outros setores. Os autores analisaram períodos de divulgação voluntária do balanço social nas empresas brasileiras até 2006 e destacam que outras relações devem ser estudadas como: índice Bovespa de responsabilidade social, obtenção de recursos em órgãos internacionais de fomento/desenvolvimento, porte da empresa de auditoria, preocupações com a imagem, lucratividade e setor.

No Brasil, conforme as normas contábeis, a divulgação do balanço social não é obrigatória. No entanto, existem orientações para a publicação dos relatórios ambientais, tais como: a Orientação no 15/87 da CVM (Comissão de Valores Mobiliários) já que um dos itens citados é a divulgação de informação sobre a proteção do meio ambiente por parte da empresa; a Norma e Procedimento de Auditoria no 11 do Instituto dos Auditores Independentes do Brasil e a Resolução no 1003/04 do Conselho Federal de Contabilidade, que aprovou a Norma Brasileira de Contabilidade Técnica no 15 da Comissão de Valores Mobiliários.

A CVM apóia e incentiva a divulgação voluntária do balanço social, como também considera que o balanço social apresentado em conjunto com as Demonstrações Financeiras se torna um instrumento completo de divulgação e avaliação das atividades empresariais.

O setor elétrico no Brasil segue a regulamentação de um agente, a Agência Nacional de Energia Elétrica e, conforme a resolução 444/01, obriga esse setor a divulgar o balanço social de acordo com o Manual de Elaboração do Relatório Anual de 
Responsabilidade Socioambiental das Empresas de Energia Elétrica.

O Comitê de Pronunciamentos Contábeis (CPC), através do Pronunciamento Técnico (CPC 09), estabelece critérios para a elaboração e apresentação da Demonstração do Valor Adicionado (DVA) que faz parte do balanço social. A DVA contempla a riqueza gerada pela empresa e como esta é distribuída.

A Internacionalização dos padrões de qualidade ambiental descrito na ISO14000, a Lei 10.165/2000 que trata sobre a Política Nacional de Meio Ambiente, a globalização e a conscientização dos consumidores permitem antecipar a exigência futura da divulgação do balanço social. $\mathrm{Na}$ contabilidade, os meios usuais de divulgar as informações são os demonstrativos contábeis, a contabilidade tem passado por grandes avanços no que se refere à responsabilidade social e ao meio ambiente, um exemplo de mudanças foi a Lei 11638/07 que alterou a Lei 6.404/76 e, a partir dela, tornou obrigatória a elaboração e divulgação da DVA (Demonstração do Valor Adicionado) somente para companhias abertas, sendo a DVA um demonstrativo que é um componente do balanço social.

Segundo o IBASE, o balanço social é um demonstrativo divulgado de forma voluntária anualmente por algumas empresas do Brasil. Nele a empresa divulga os gastos e investimentos feitos em benefício dos funcionários e em benefício da sociedade, demonstrando que a empresa busca melhorar a qualidade de vida para todos e ainda proporciona informações sobre o meio ambiente e a formação e distribuição da riqueza gerada pelas empresas, que é o Valor Adicionado.

No Brasil existem três modelos mais utilizados de balanço social (GRI, Instituto Ethos e IBASE), entretanto, apesar dos modelos existentes, algumas empresas criam formatos próprios para elaboração do balanço social.

Segundo o Instituto Ethos de Empresas e Responsabilidade Social (2011), o Global Reporting Initiative (GRI) é um modelo de balanço social que demonstra os indicadores de desempenho econômico, e as fontes de referência, sendo ainda considerado bastante divulgado internacionalmente, e considerado o mais completo e abrangente.
O Instituto Ethos de Empresas e Responsabilidade Social (2011) expõe um modelo de balanço social que demonstra as ações da organização e o contexto das tomadas de decisão.

De acordo com o Instituto Brasileiro de Análises Sociais e Econômicas, o modelo IBASE evidencia os números associados à responsabilidade social da organização, informações sobre a folha de pagamentos, gastos com funcionários e participação nos lucros, informa as despesas com controle ambiental e os investimentos em várias áreas.

Segundo o IBASE (2011), no Brasil, a elaboração anual de demonstrativos com informações sociais se destacou no momento que o sociólogo Hebert de Souza, o "Betinho" começou uma campanha pela divulgação voluntária do balanço social.

O IBASE criou o "selo balanço social Ibase/Betinho" para as empresas que publicam o balanço social todo ano no padrão da organização. Sendo assim, as empresas utilizam deste selo em propagandas por meio de suas embalagens, anúncios, dentre outros. Não existe consenso quanto ao padrão para divulgação do balanço social, se é livre ou padronizado, ou sobre o que ele deve conter. Várias empresas brasileiras já vêm divulgando seus balanços sociais e o fazem no modelo IBASE ou similar.

O IBASE, em parceria com vários setores da sociedade, desenvolveu um modelo para divulgação das informações com a intenção de estimular o maior número de empresas a publicar seu balanço social, seja qual for o ramo de atividade ou tamanho da empresa.

Segundo o IBASE os analistas de mercado e os órgãos de financiamento como o Banco Nacional de Desenvolvimento (BNDES), o Banco Interamericano de Desenvolvimento (BID) e a International Finance Corporation (IFC) já adicionaram o balanço social na lista dos documentos necessários para se avaliar e conhecer as projeções e riscos de uma empresa.

\section{METODOLOGIA}

A presente pesquisa pode ser caracterizada como uma pesquisa quantitativa e de caráter explicativo. Nesta pesquisa serão analisados os potenciais determinantes da divulgação voluntária do balanço social no Brasil por empresas listadas na BM\&FBOVESPA e 
pertencentes a setores de atividades potencialmente poluidoras e utilizadoras de recursos ambientais, as quais divulgam voluntariamente o balanço social. A metodologia econométrica baseou-se na estimação de um modelo probit aplicado aos dados em painel, o período analisado foi de 2008 a 2010.

Para a definição da amostra da presente pesquisa utilizou-se como referência a Lei $n$ o 10.165/2000, que classifica as atividades econômicas e trata sobre a Política Nacional do Meio Ambiente.

Foram excluídas da amostra as empresas do setor de energia elétrica, de acordo com a Resolução no 444 de 26 de dezembro de 2001 da Agência Nacional de Energia Elétrica (ANNEL) existe a obrigatoriedade da divulgação do Balanço Social para esse setor.

Nesse sentido a amostra utilizada contém 145 empresas para os anos de 2008, 2009 e 2010 perfazendo um total de 435 observações pertencentes à categoria de atividades potencialmente poluidoras e utilizadoras de recursos ambientais listadas na BM\&FBOVESPA.

A maioria das pesquisas é realizada com empresas de capital aberto com ações negociadas na Bovespa, pois as empresas de capital fechado não têm obrigação de publicar suas demonstrações contábeis e financeiras. Portanto, as informações por empresas de capital aberto estão disponíveis para pesquisa.

O quadro 2 apresenta a quantidade de empresas dos setores estudados que publicaram ou não o Balanço Social. Os dados foram coletados através dos sítios das próprias empresas listadas na BM\&FBOVESPA.

Figura 2: Número de empresas que realizaram disclosure e que não realizaram disclosure em 2008, 2009 e 2010, pertencentes as categorias de atividades potencialmente poluidoras e utilizadoras de recursos ambientais.

\begin{tabular}{|c|c|c|c|}
\hline ANO & № empresas & $\begin{array}{c}\text { Realizou } \\
\text { disclosure }\end{array}$ & $\begin{array}{c}\text { Não realizou } \\
\text { disclosure }\end{array}$ \\
\hline 2008 & 159 & 31 & 128 \\
\hline 2009 & 165 & 35 & 130 \\
\hline 2010 & 165 & 47 & 118 \\
\hline
\end{tabular}

Fonte: Elaborado pelo autor, com base nos dados da pesquisa.

O método para a estimação da amostra será um probit sobre dados em painel. A técnica de utilização com dados em tal formato é subdividida em duas categorias: painel balanceado e painel desbalanceado.

Para o estudo em questão, elegeu-se utilizar o painel balanceado, onde todas as empresas da amostra divulgaram o balanço social nos três anos em estudo. Caso fossem utilizadas todas as empresas pertencentes aos três quadros supracitados, haveria necessidade de utilizar técnicas para dados em painel desbalanceado, pois não há uniformidade no período de divulgação em todas as empresas, ou seja, há empresas que divulgaram apenas em um único ano, mas não nos demais e assim por diante.

Com tal configuração, trataríamos a amostra como painel desbalanceado, mas implicaria em utilização de técnicas econométricas não convencionais e, principalmente, os resultados obtidos não seriam assintoticamente confiantes, pois a amostra utilizada, em face do problema de pesquisa, não é grande o suficiente para a aplicação de tais técnicas (WOOLDRIDGE, 1999).

A coleta de dados ocorreu pela base de dados Economática, e a partir da amostra de cada ano, foram verificadas no sítio da BM\&FBOVESPA as empresas elegíveis ao ISE e por meio das demonstrações financeiras as empresas de Auditoria, a verificação da divulgação do balanço social foram por meio do sítio IBASE e os sítios das próprias empresas.

\subsection{MODELOS PROBIT}

Nesse sentido o presente estudo utilizará a seguinte equação para realizar as estimações:

$D_{i t}=\alpha+\beta_{1} I S E_{i t}+\beta_{2} B F_{i t}+\beta_{3} A T_{i t}+$ $\beta_{4} L U C_{i t}+\beta_{5} D 1_{i}+\beta_{6} B R_{i}+\varepsilon_{i t}$, onde 
$D_{\text {it }}$ é a variável dependente $(Y)$, ou seja: $D_{\text {it }}$ é 1 se a empresa divulga e 0 se não divulga 0 balanço social.

$I_{\text {SE }}$ it é se a empresa participa do índice ou não;

$\mathrm{BF}_{\text {it }}$ se a empresa é auditada pelas "Big Four" ou não;

$A T_{i t}$ é o Ativo total da companhia valores em reais;

LUC $_{\text {it }}$ é o valor obtido pela divisão do lucro líquido sobre a receita líquida (lucratividade);

$\mathrm{D} 1_{\mathrm{i}}=$ Dummy utilizada para captar os efeitos de dois setores outliers da variável $L U_{\text {it }}$ apresentadas na seção resultados;

$\mathrm{BR}_{\mathrm{i}}$ se a empresa é nacional ou não;

O termo erro $\varepsilon_{i t}$ é uma variável aleatória distribuída de forma independente e com média igual a zero.

Nesta pesquisa foram definidas as seguintes variáveis: preocupação com a imagem, tamanho, setor, porte da empresa de auditoria, lucratividade e internacionalização.

A divulgação do balanço social será medida por uma variável dicotômica, que assume valor zero caso a empresa não divulgue o balanço social, ou valor um, se a divulgação voluntária do balanço social ocorrer.

Empresas que fazem parte do índice de sustentabilidade empresarial (ISE) Bovespa será uma proxy para a variável preocupação com a imagem. Nota-se que algumas empresas têm procurado associar sua imagem empresarial a idéia de sustentabilidade. Empresas integrantes do ISE são aquelas comprometidas com a sustentabilidade, diferenciando-os em termos de qualidade, nível de compromisso com o desenvolvimento sustentável, transparência e prestação de contas, natureza do produto, além do desempenho empresarial nas dimensões econômico-financeira, social e ambiental (BM\&FBOVESPA,2012). Seria como ter uma qualidade reconhecida pelos stakeholders, o ISE é considerado referência de boas práticas de sustentabilidade e responsabilidade social corporativa no Brasil.

O Ativo total será uma proxy utilizada para definir o tamanho da empresa. Barako (2006) investigou em sua pesquisa que quanto maior a empresa, o mais provável é que elas vão fazer divulgações voluntárias. Com base no estudo realizado em todo o mundo, por exemplo, Ho e Wong (2001) sugeriram as razões pelas quais as empresas maiores divulgam mais informações. As razões propostas são de que os gestores de grandes empresas são mais propensos a realizar os possíveis benefícios de uma melhor divulgação e pequenas empresas são mais propensas a sentir que a divulgação completa de informações poderia pôr em risco a sua posição competitiva. Neste estudo, o Ativo Total será utilizados como medida do tamanho da empresa.

A atividade econômica será uma proxy utilizada para a variável setor. Empresas de auditoria pertencentes ao grupo das Big Four, nomenclatura utilizada para se referir às quatro maiores empresas especializadas em auditoria (KPMG, Pricewaterhousecoopers, Deloitte Touche e Erns \& Young) será uma proxy utilizada para a variável auditoria. $O$ lucro líquido dividido pelo valor total de vendas é uma proxy utilizada para a variável lucratividade.

\section{ANÁLISE DOS RESULTADOS}

Os dados em painel permitem acompanhar a mesma unidade de referência, no nosso caso a divulgação do balanço social, ao longo do tempo. A vantagem da utilização dessa metodologia é a possibilidade de explorar a dimensão temporal e espacial dos dados, o nosso estudo é a divulgação voluntária (divulgar ou não). Os dados em painel podem dar-se por efeitos fixos ou aleatórios.

Quando utilizamos como variáveis dependentes qualitativas binárias, resposta sendo 1 (um) para sim e 0 (zero) para não, como é o caso se divulgar ou não o balanço social, é recomendável a utilização de modelo Probit. Com esse método é possível obter a probabilidade de que um determinado evento ocorra.

O modelo Probit no painel estimará os efeitos das variáveis na probabilidade de divulgar o balanço social.

De forma preliminar, os dados mostram a evolução da divulgação do balanço social nos três anos apurados, conforme Gráfico 1. 


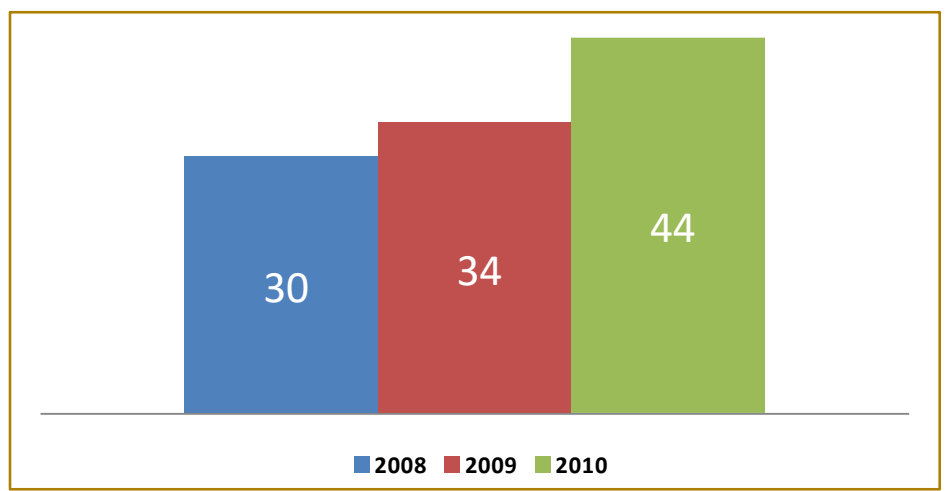

ronte: tlaborado pelo autor com base nos dados da pesquisa.

Dentre os totais divulgados, é possível analisar qual setor da amostra para o presente estudo é mais intensivo em divulgações conforme Gráfico 2.

Figura 4 - Divulgação do balanço Social por setor.

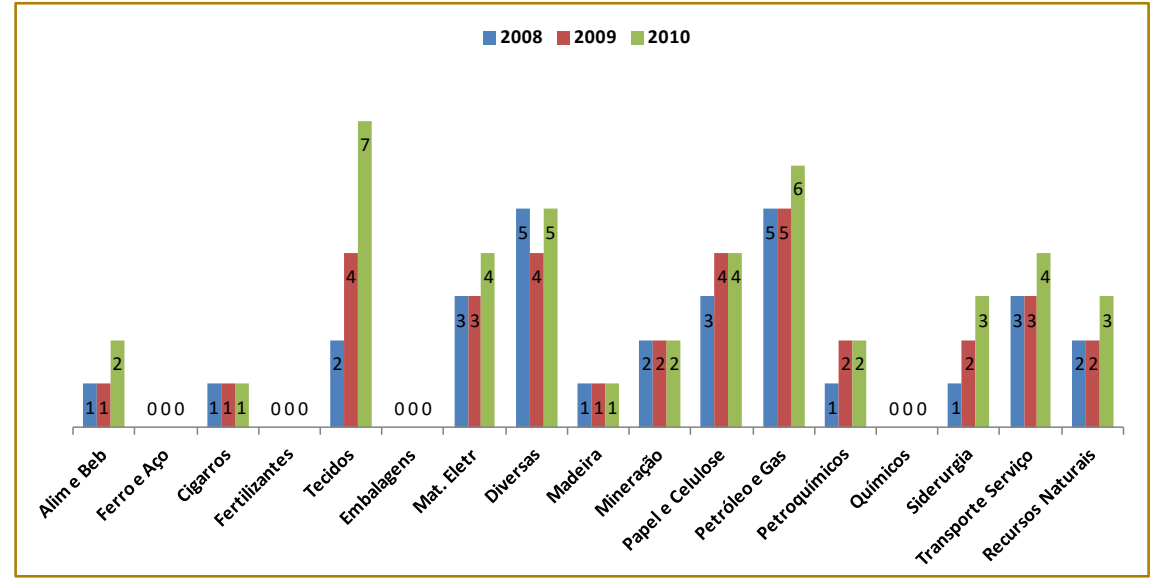

Fonte: Elaborado pelo autor com base nos dados da pesquisa.

De modo a analisar tal relação com as variáveis explicativas do modelo temos o seguinte comportamento para o Ativo Total e para a Lucratividade conforme gráficos 3 e 4 respectivamente. 
Figura 5 - Ativo total por setor em $\mathrm{R} \$ 000$

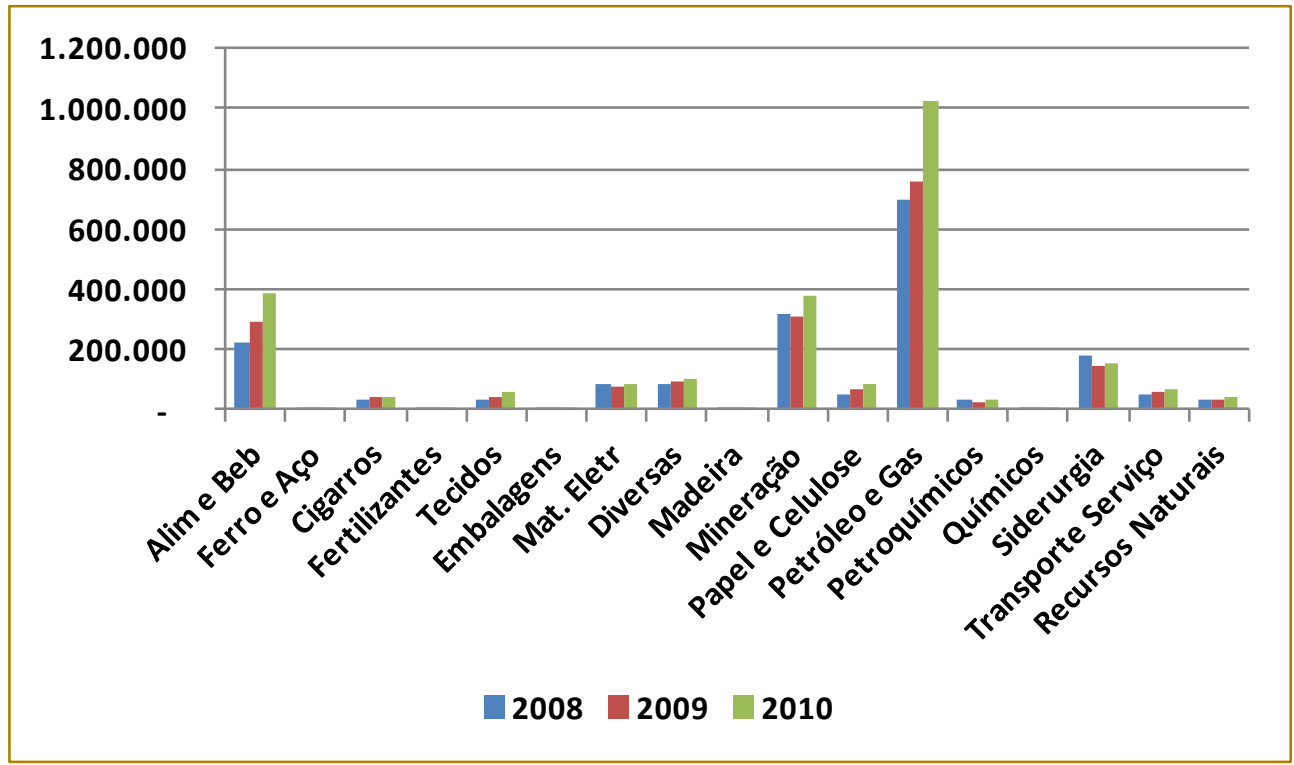

Fonte: Elaborado pelo autor com base nos dados da pesquisa.

Figura 6 - Lucratividade por setor em \%.

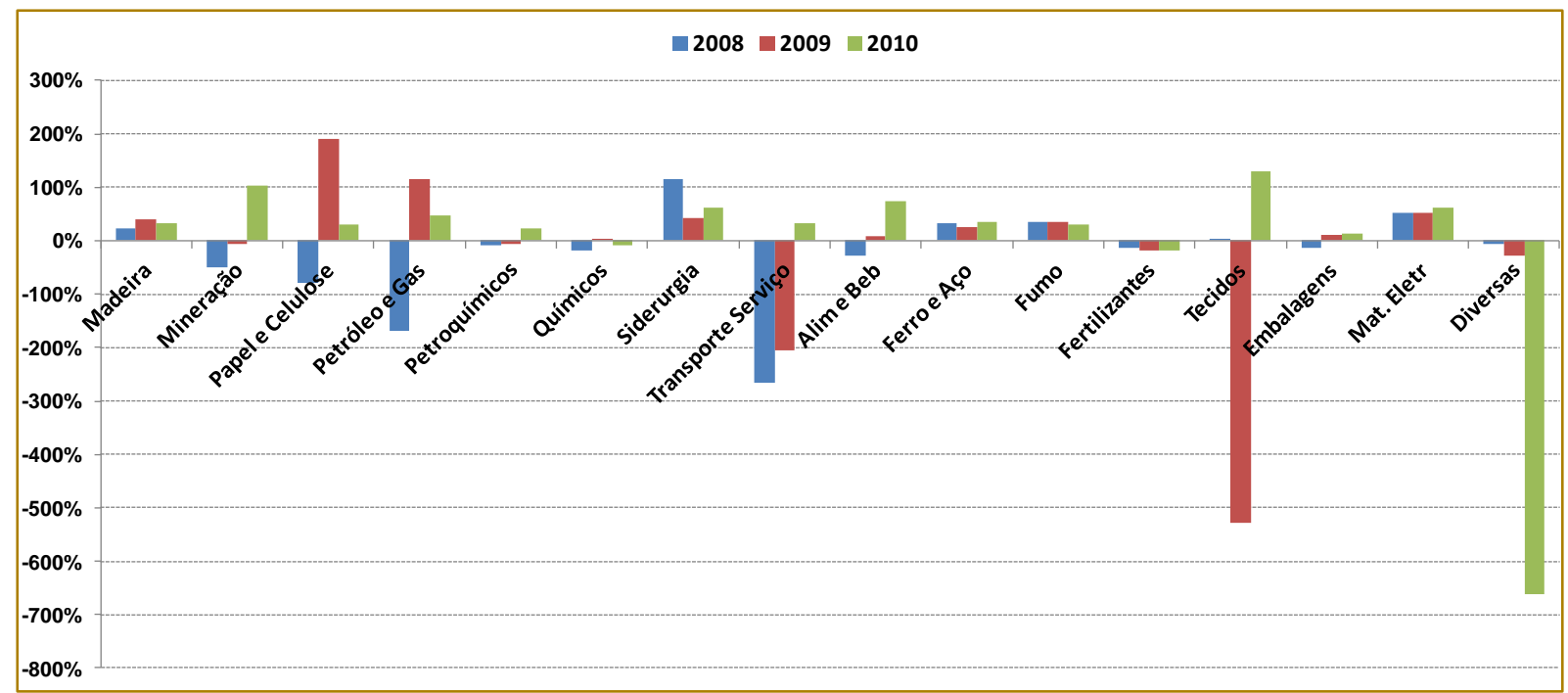

Fonte: Elaborado pelo autor com base nos dados da pesquisa.

Os gráficos acima apresentam o comportamento das variáveis quantitativas para a estimação do modelo. Previamente, faz-se necessário tal análise, para que sejam apuradas o comportamento de ambas para que não ocorra problemas na inferência dos resultados em virtude do comportamento característicos das variáveis.

A variável lucratividade é a razão entre o lucro líquido e a receita líquida. Quando analisamos graficamente o comportamento dessa variável no gráfico 5 percebemos um comportamento característico dessa variável entre os setores, onde, especificamente, o setor de Tecidos e o Diversos (outliers) apresentam um comportamento que pode prejudicar a estimação do modelo.

Para capturar esse efeito de modo a não prejudicar a inferência do modelo proposto, utilizou-se uma dummy (D1) para que tal variação abrupta dos mesmos não gere uma tendência nas estimações (WOOLDRIDGE, 1999).

No tocante a variável AT, não se fez necessário a utilização de tal recurso (dummy), isso por que o setor de Petróleo e 
Gás apresentou o mesmo comportamento em todos os anos. Não houve um único comportamento característico em que pudesse gerar problemas dessa variável quando da estimação da função estrutural. Diferentemente do ocorreu com a variável lucratividade onde dois setores não apresentaram o mesmo comportamento característico nos três anos de análise.

Conforme salientado no início da seção metodologia, realizou-se a análise com os dados em painel para verificarmos se a interpretação deve ser feita considerando efeitos fixos ou efeitos aleatórios.
Para o presente estudo, considerou-se como estimador a ser testado o modelo de efeitos aleatórios e o estimador alternativo como sendo os efeitos fixos. Nesse sentido, ao apurarmos o referido teste, contatamos que o estimador por efeitos fixos é mais consistente do que para efeitos aleatórios.

Mas para interpretarmos a magnitude de cada variável sobre a probabilidade de divulgar ou não, é necessário realizar o cálculo dos efeitos marginais, conforme salientado na seção de metodologia.

Aplicado o modelo probit para a amostra selecionada temos os seguintes resultados conforme Tabela 1.

TABELA 1: CÁLCULOS DOS EFEITOS MARGINAIS

\begin{tabular}{|c|c|c|c|}
\hline & \multicolumn{1}{|c|}{$\mathrm{dy} / \mathrm{dx}$} & Erro padrão & Significância \\
\hline ISE & 1.868904 & 0.64126 & 0.004 \\
\hline BF & 1.235667 & 0.6610 & 0.062 \\
\hline AT & $6.27 \mathrm{e}-08$ & 0.00000 & 0.087 \\
\hline LUC & 0.5668966 & 0.69034 & 0.412 \\
\hline BR & 2.030754 & 2.53413 & 0.423 \\
\hline D1 & 0.0278989 & 0.74809 & 0.970 \\
\hline
\end{tabular}

Fonte: Resultados da pesquisa

Com a Tabela 1 acima podemos analisar a relevância das variáveis para responder se sua variação aumenta ou diminui a probabilidade de uma determinada empresa da amostra divulgar o balanço social. Percebemos que as variáveis relevantes são a participação no índice ISE, ser auditada por uma das quatro grandes empresas do ramo (variável BF) e o tamanho da companhia (variável AT).

Podemos então inferir que a empresa que participa do ISE apresenta 1,86 pontos percentuais de probabilidade em divulgar 0 balanço Social. Por sua vez, empresas auditadas pelas quatro maiores empresas de auditoria apresentam 1,23 pontos percentuais, sendo ambas as variáveis de maiores pesos para determinar a probabilidade em realizar a divulgação.
O Resultado significativo da variável Big Four corrobora com a pesquisa de Ahmad, Hassan e Mohammad (2003) a respeito da divulgação das informações ambientais, onde o autor identificou que companhias auditadas por empresas de auditoria pertencentes ao grupo Big Four tem um maior nível de disclosure.

A variável $A T$, embora significativa para $O$ modelo, não apresentou grande relevância, sendo o seu valor apurado pelos efeitos marginais muito baixo, o que não corrobora com a teoria sobre o tamanho da empresa influenciar de forma determinante sobre a decisão de divulgar o balanço social.

As demais variáveis: lucratividade, dummy e internacionalização das companhias, apresentaram uma relação não significativa no modelo. Tal fato permite inferir que não há uma preocupação do ponto de vista financeiro em aderir ou não a divulgação 
voluntária. Ademais, o setor diversas e tecidos não apresentam uma relação determinante quando comparados aos demais setores coletados, por sua vez, a internacionalização das empresas também não influencia na decisão em aderir a divulgação do Balanço Social por apresentar um valor estatístico não significativo no modelo proposto.

A despeito dos resultados, o trabalho procurou seguir a linha de pesquisa de Cunha e Ribeiro (2008), onde o autor desenvolveu uma abordagem quantitativa no tocante a Teoria da Divulgação Voluntária, descrevendo modelos matemáticos para explicar e prever fenômenos relacionados ao disclosure.

Nesse sentido, tal pesquisa segue o mesmo preceito em realizar inferências sobre as variáveis utilizadas para o estudo de modo a interpretar o comportamento das companhias frente a essa nova modalidade de divulgação.

Ressalta-se, acerca dos resultados encontrados, tratar-se de uma aproximação estatística que não devem ser analisadas como relação de causalidade absoluta e particular de cada empresa. Embora os resultados apresentados sejam robustos e estatisticamente significativos, conforme descrito acima, não se preocupou em investigar com mais profundidade a peculiaridade de cada empresa e cada setor.

Possivelmente, uma nova proposta de modelo com outras variáveis e um período maior de apuração possa levar a resultados discrepantes ou concomitantes com o presente estudo.

\section{CONCLUSÃO}

O presente estudo propôs uma metodologia econométrica que possa explicar o comportamento das empresas para a divulgação do balanço social. No tocante aos resultados da pesquisa, conclui-se que o tamanho da empresa não é uma variável determinante para as empresas aderirem ao balanço social, mas sim sua preocupação com a imagem (conforme a significância e o resultado da variável ISE) e as empresas auditadas por Big Four conforme resultados (BF).

Com o achado, no presente estudo, ressaltase a importância da investigação econométrica acerca de variáveis quantitativas (e qualitativas) sobre a apuração do comportamento das companhias sobre a divulgação voluntária e seus interesses frente à referida prática.

Percebe-se ainda que muitos preceitos teóricos que se fazem senso-comum na cultura de governança, na grande maioria das corporações, são desmistificados ao testarmos estatisticamente a relação de causalidade frente á um cenário real. Nesse sentido, como os resultados encontrados não foram consonantes com 0 que a teoria preconiza como de certo, fazem-se necessárias novas contribuições para que, especificamente no mercado brasileiro, possamos subsidiar com novas técnicas e novas variáveis de análise o estudo sobre a divulgação voluntária bem como a importância da divulgação de qualquer informação relevante para o mercado de capitais nacional.

Para futuras pesquisas, deixa-se a sugestão para que outros métodos sejam testados e outras teorias sejam testadas, como por exemplo, o modelo probit multinominal, e um universo maior de amostra possa ser utilizado para verificar a empiricidade da Teoria da Divulgação Voluntária e inferir como tal prática pode ser melhor difundida.

A metodologia proposta por Dye (2001), também é passível de ser testada, muito embora para realizar a aplicação de teoria dos jogos para inferir sobre a tomada de decisão em fazer ou não a divulgação, pode ser demasiadamente complexa, e, por ventura, necessitar de novas variáveis que ainda não estão disponíveis publicamente, como por exemplo, informações detalhadas dos custos das companhias. 


\section{REFERÊNCIAS}

[1]. AHMAD, Z.; HASSAN, S.; MOHAMMAD, J. Determinants of environmental reporting in Malaysia. Internacional Journal of Business Studies, perth, V. 11, n. 1 p. 69-90, June 2003.

[2]. AHMED, K.; COURTIS, J.K. Associations between corporate characteristics and disclosure levels in annual reports: a meta-analysis, British Accounting Review, V. 31, p. 35-61, 1999.

[3]. Balanço Social. Disponível em: $<$ http://www.balancosocial.org.br/cgi/cgilua.exe/sys /start.htm>. Acesso em 21 jul. 2011

[4]. BARAKO, D. G. Factors influencing voluntary corporate disclosure by Kenyan companies. Corporate Governance: An International Review. 14 (2), 107-125, 2006.

\section{[5]. BNDES. Disponível em} <http://www.bndes.gov.br/SiteBNDES/bndes/bndes ...pt/.../Perfil/porte.html>. Acesso em 10 jun. 2012

[6]. BOVESPA. Dados de companhias abertas. Disponível em : $<$ http://www.bmfbovespa.com.br/Ciaslistadas/empr esas-

listadas/Buscaempresalistada.aspx?idioma=pt-br>. Acesso em 18 mar. 2012

[7]. CAMPBELL, D. A Longitudinal and crosssectional analysis of environmental disclosure in companies - a research note. The Britsh Accounting Review. v. 36, p. 107-117, 2004.

[8]. Comissão de Valores Mobiliários. Disponível em: <http://www.cvm.gov.br/indexpo.asp>. Acesso em 19 jul. 2010

[9]. Comitê de Pronunciamentos Contábeis. Disponível em: <http://www.cpc.org.br/index.php>. Acesso em 10 out. 2011

[10]. COWEN, S.S; FERRERI, L.B.; PARKER, L.D. The impact of corporate characteristics on social responsibility disclosure: a typology and frequency based analysis. Accounting, Organisations and Society, V.12, N.2, p. 111-122, 1987.

[11]. CUNHA, J. V. A. da; RIBEIRO, M. de S. Divulgação voluntária de informações de natureza social: um estudo nas empresas brasileiras. Revista de Administração - Eletrônica. São Paulo, v.1, n.1, art.6, jan./jun. 2008. Disponível em: <http://www.rausp.usp.br/Revista_eletronica/v1n1/a rtigos/v1n1a6.pdf>. Acesso em 30 jun. 2011.

[12]. Decreto Lei no 10.165/2000. Disponível em:

<http://www.planalto.gov.br/ccivil_03/leis/L10165.ht m>. Acesso em 17 nov. 2011.

[13]. DYE, R. Na evaluation of " essas on disclosure and the disclosure literature in accounting. Journal accounting. and Economics, V, 32, p. 181-235, 2001.
[14]. ETHOS. Instituto Ethos de Empresas e Responsabilidade Social. Disponível em: <http://www1.ethos.org.br/EthosWeb/Default.aspx> . Acesso em 12 de novembro 2011.

[15]. GAO, S.S.; HERAVI, S; XIAO, J.Z. Determinants of corporate social and environmental reporting in Hong Kong: a research note. Accounting Forum. V. 29, p. 233-242, 2005.

[16]. GUJARATI, D. N. Econometria Básica. São Paulo: Pearson Makron Books. Ed.3. 2005.

[17]. GRI - Global Reporting Initiative. Disponível em: <http://www.globalreporting.org/Home>. Acesso em 12 de novembro de 2011.

[18]. HACKSTON, D.; MILNE, M. J. Some determinants of social and environmental disclosures in New Zealand companies. Accounting, Auditing \& Accountability Journal. V.9, n. 1, p. $77-108,1996$

[19]. HENDRIKSEN, E. S.; BREDA, M. F.V. Teoria da Contabilidade. Tradução de Antonio Zoratto Sanvicente. São Paulo: Atlas, 1999. 515p.

[20]. Ho, S.S.M., \& Wong, K.S. A study of corporate disclosure practices and effectiveness in Hong Kong. Journal of International Financial Management and Accounting, 12(1), 75-101, 2001.

[21]. IBASE - Instituto Brasileiro de Análises Sociais e Econômicas. Disponível em: $<$ http://www.ibase.br/index.php>. Acesso em: 21 jul. 2011.

[22]. KPMG. KPMG - International Survey of Corporate Responsibility Reporting 2005. Disponível em: <http://www.kp'mg.com.au/Portals/O/KPMG\%20sU RVEY\%202005_3.PDF>. Acesso em: 10 mar. 2012.

[23]. LANG, M; LUNDHOLM, R. Cross-sectional determinants of analyst ratings of corporate disclosure. Journal of Accounting Research, USA, v.31, n.2, p.246-271, Autumn 1993.

[24]. LIU, X.; ANBUMOZHI, V. Determinant factores of corporate environmental information disclosure; an empirical study of chinese listed companies. Journal of Cleaner Production, v. 17 (6), p.593-600, 2009

[25]. MICHELON, G. Sustainability Disclosure and Reputacion, a comparative study. Universita Deglo Studidi padova. Whorking Paper n. 44, set. 2007.

[26]. MURCIA, F. D. Fatores determinantes do nível de disclosure voluntário de companhias abertas no Brasil. 182p. 2009. Tese (Doutorado em Controladoria e Contabilidade). Faculdade de Economia e Administração. Universidade de São Paulo, São Paulo, 2009. Disponível em: $<$ http://www.teses.usp.br/teses/disponiveis/12/1213 
6/tde-16122009-121627/>. Acesso em: 17 Nov 2011.

[27]. NEIMARK, M. The Hidden Dimensions of Annual Reports. London, 1992.

[28]. NOSSA, V. Disclosure ambiental: uma análise do conteúdo dos relatórios ambientais de empresas do setor de papel e celulose em nível internacional. 2002. 86p Tese (Doutorado em Controladoria e Contabilidade) - Faculdade de Economia, Administração e Contabilidade, Universidade de São Paulo, São Paulo. 2002.

[29]. RAFOURNIER, B. The determinants of voluntary financial disclosure by Swiss listed companies. Europan Accounting Review, Spain, v.4, n.2, p.261-280 Jun. 1995.

[30]. SALOTTI, B. M.; YAMAMOTO, M. M. Ensaio sobre a Teoria da Divulgação. Brazilian Business Review. V.2, n.1, p.53-70, Jan/Jun. 2005.

[31]. RIBEIRO, M. de S., LISBOA, L. P. Balanço Social: instrumento de divulgação da interação da empresa com a sociedade. In: encontro ANPAD, 23ㅇ, 1999, Rio de Janeiro. Anais, 1999.
[32]. SULIANI, R.; TOMAZZIA, E. ; MURCIA, F. D. R. ; BORBA, José Alonso . Explicações para a divulgação voluntária ambiental no Brasil utilizando a análise de regressão em painel. RAUSP-e (São Paulo), v. 47, p. 16-30, 2012.

[33]. TROTMAN, K.; Bradley, G. W. Associations between social responsibility disclosure and characteristics of companies. Accouting, Organizations and Society, v.6, n.4, p. 355, 1981

[34]. VERRECCHIA, Essays on disclosure. Journal of Accouting and Economics, USA, v32, n. 1-3, p.97-180, Nov.2001.

[35]. WOOLDRIDGE, J. M. Asymptotic Properties of Weighted M-Estimators for Variable Probability Samples. EconometricaSimple solutions to the Initial Conditions Problem in Dynamic Nonlinear Panel Data Models with Unobserved Heterogeneity. Journal of Applied Econometrics, v.2670, p. 13985-140654, 1999. 


\section{Capítulo 15}

\section{ANÁLISE COMPARATIVA DOS INDICES DE MÉRITO DE DUAS INSTALAÇÕES FOTOVOLTAICAS: CASOS UTFPR NEOVILLE X LAR JUNSHIN}

\section{Fabricio Fontoura dos Santos}

Günther Kaltmaier Junior

Jair Urbanetz Junior

\section{Juliana D'Angela Mariano}

Resumo: Este artigo descreve as principais características do Sistema Fotovoltaico Conectado à Rede (SFVCR) instalado na mais nova sede da UTFPR (Sede Neoville) e também do sistema instalado na Casa de Repouso Lar Santa Mãe Junshin, quanto às suas características de instalação e de equipamentos, seu princípio de funcionamento, suas configurações e respectivos componentes elementares, histórico de funcionamento e principalmente, estabelecendo um comparativo entre suas capacidades de produção energética e índices de mérito, através de suas avaliações de desempenho. Seu principal objetivo é verificar se estes sistemas apresentam índices de mérito satisfatórios e compatíveis com as instalações de referência.

Palavras-chave: Sistemas Fotovoltaicos, UTFPR Neoville, Lar Junshin, Índices de Mérito 


\section{INTRODUÇÃO}

A atual conjuntura econômica do Brasil e o desejo por atingir novos patamares em termos de desenvolvimento sustentável, tornam cada vez mais importantes o desenvolvimento de tecnologias e a divulgação das soluções atuais para utilização de fontes renováveis e menos poluentes de energia (MACHADO e CORREA, 2015).

A UTFPR, preocupada com estas questões, desenvolveu com base em sólidos conhecimentos adquiridos, a instalação de SFV no Escritório Verde da UTFPR. A instituição pública em parceria com a ELCO Engenharia investiu novamente na tecnologia de sistemas fotovoltaicos conectados à rede, agora na tentativa de realizar uma instalação em condições ótimas de operação, ou seja, com a intenção de obter os melhores resultados possíveis atendendo a todas as especificações $e$ às limitações, em maximização dos resultados do processo de geração de energia.

Por outro lado, a Casa de Repouso LAR JUNSHIN, realizou a instalação de um sistema fotovoltaico conectado à rede (SFVCR), também com equipamentos semelhantes aos instalados na UTFPR, também doados pela empresa ELCO Engenharia, porém em função das características arquitetônicas da edificação não foi possível realizar esta instalação sem que houvesse uma pequena diferença na inclinação dos painéis.

Este artigo possui o objetivo de comparar os resultados obtidos entre estas duas instalações, utilizando o sistema NEOVILLE como referência em uma análise de dados obtidos desde o mês de abril de 2016 até o mês de abril de 2017.

\section{REVISÃO BIBLIOGRÁFICA}

\subsection{SISTEMAS FOTOVOLTAICOS}

Basicamente um sistema fotovoltaico para geração de energia elétrica é um conjunto integrado de equipamentos, painéis fotovoltaicos e outros componentes, projetados para converter a energia solar em eletricidade.

O princípio físico de funcionamento dos painéis fotovoltaicos é denominado efeito fotovoltaico (foto=luz; volt=eletricidade). Estes painéis fotovoltaicos são construídos com determinados materiais modificados quimicamente, que quando expostos à luz produzem eletricidade (JOVIC, 2016).

Por ser um sistema de geração de energia que depende basicamente da luz do sol, o sistema fotovoltaico deve ser sempre um sistema complementar da energia elétrica fornecida pela rede da concessionária. Quando a intensidade da luz solar é máxima, - sistema fotovoltaico pode gerar uma quantidade de energia elétrica que é maior que o consumo das cargas a ele conectadas e, portanto, pode fornecer este excedente de energia elétrica para a rede da concessionária. Por outro lado, quando há falta ou pouca incidência de sol, o sistema pode recuperar da rede da concessionária aquela energia excedente anteriormente fornecida e que agora é necessária à alimentação de suas cargas, num sistema de compensação de energia (JOVIC, 2016).

A diretoria da Agência Nacional de Energia Elétrica (ANEEL) aprovou em 24/11/2015, aprimoramentos na Resolução Normativa no 482/2012 que criou o Sistema de Compensação de Energia Elétrica, permitindo que $O$ consumidor instale pequenos geradores (tais como painéis solares fotovoltaicos e microturbinas eólicas, entre outros) em sua unidade consumidora e troque energia com a distribuidora local com objetivo de reduzir o valor da sua fatura de energia elétrica (ANEEL, 2015)

Segundo MARIANO (2017), é uma fonte de energia renovável, abundante, silenciosa, limpa, inextinguível e que não interfere diretamente no meio ambiente.

\subsubsection{TIPOS DE SISTEMAS FOTOVOLTAICOS}

Existem duas categorias principais de sistemas fotovoltaicos: Sistemas Isolados (SFVI) ou Sistemas Conectados à Rede Elétrica (SFVCR). De acordo com Pinho e Galdino (2014) ambos os casos podem operar apenas como fonte fotovoltaica ou combinada com outras fontes de energia, quando são chamados de híbridos. A escolha da configuração a ser utilizada depende principalmente da disponibilidade de recursos energéticos, da aplicação em questão e das restrições do projeto. 


\subsubsection{SISTEMA FOTOVOLTAICO ISOLADO (SFVI)}

Estes sistemas também conhecidos como autônomos, são comumente utilizados em áreas sem acesso à rede elétrica como fazendas, ilhas e comunidades isoladas. Uma das principais vantagens é a substituição dos geradores movidos a combustíveis fósseis, fornecendo energia de forma mais silenciosa e menos poluente, entretanto a principal desvantagem é o alto custo de manutenção dos componentes (MACHADO e CORREA, 2015).

O esquema de montagem desse sistema é apresentado na Figura 1, indicando o caminho percorrido pela corrente elétrica do painel até a carga.
Segundo MACHADO e CORREA (2015) existem sistemas fotovoltaicos isolados com vários tipos de armazenamento como, por exemplo, de energia potencial gravitacional, ou até mesmo sem armazenamento, usados em situações bastante restritas, quando o momento de geração coincide com o de consumo. Porém na maioria dos casos, esse armazenamento é feito através de baterias, suprindo a demanda de períodos em que a geração é baixa ou inexistente além de evitar o desperdício da energia gerada em períodos de baixo consumo. Para que não ocorram sobrecargas ou descargas excessivas na bateria, é necessário instalar um controlador de carga entre ela e o painel fotovoltaico, ajudando também a prolongar a vida útil do equipamento.

Figura 1 - Sistema Fotovoltaico Isolado.

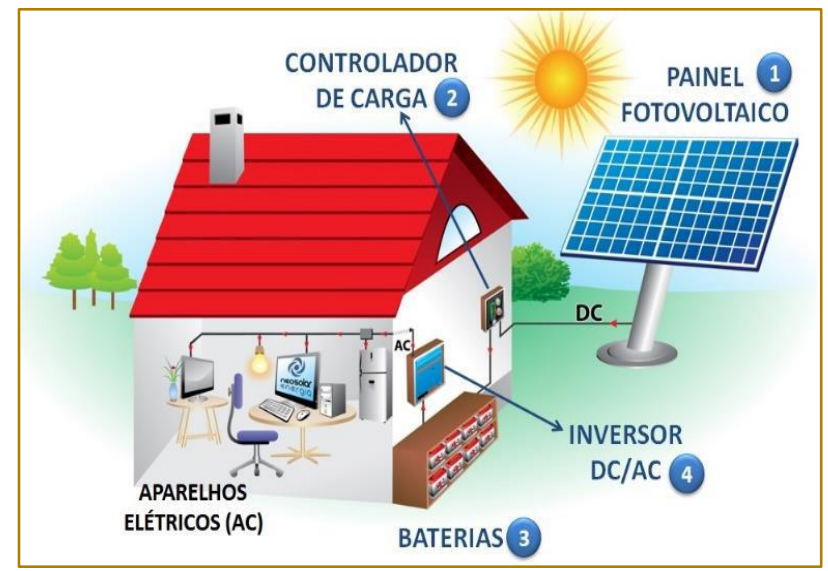

Fonte: NEOSOLAR, 2016.

A partir dessa configuração é possível alimentar cargas CC de maneira direta, pois ao contrário dos painéis, a tensão de saída da bateria é constante. Contudo, esses sistemas também são capazes de alimentar cargas CA, exigindo apenas a introdução de um inversor ao sistema, responsável por converter a tensão contínua em tensão alternada (MACHADO e CORREA, 2015).

\subsubsection{SISTEMA FOTOVOLTAICO CONECTADO À REDE ELÉTRICA (SFVCR)}

Os SFCRs são constituídos basicamente por: painel FV e inversor. Não são utilizados elementos para armazenar a energia elétrica. Basicamente, a rede elétrica da concessionária é vista como o elemento armazenador, pois toda a energia gerada é colocada em paralelo com a energia da rede. As principais vantagens desse tipo de sistema são: a elevada produtividade (toda a energia disponibilizada pelos módulos é utilizada) e a ausência do conjunto de baterias (um elo frágil no SFI devido à baixa vida útil em relação a dos módulos $\mathrm{FV}$ e dos inversores). (URBANETZ JR, 2010).

Os Sistemas Fotovoltaicos Conectados à Rede Elétrica têm grande aplicação no ambiente urbano como geradores de energia elétrica junto ao ponto de consumo. São facilmente integrados à edificação, não necessitando de área adicional, visto que são normalmente instalados sobre a cobertura da edificação. Possuem elevada confiabilidade e operam de forma limpa e silenciosa (URBANETZ JR e CASAGRANDE JR, 2012). 
A configuração mais aplicada é conhecida como Sistema Aplicado à Edificação na qual os painéis são aplicados sobre a edificação e não compõem o envoltório da construção. Cujo esquema de montagem é apresentado na Figura 2.

Nesta configuração a geração está próxima ao ponto de consumo, eliminando gastos e perdas com linhas de transmissão. A potência instalada nesses casos costuma ser mais baixa (kW), pois visa basicamente a alimentação das cargas existentes na residência ou na indústria onde o sistema fotovoltaico está instalado (RÜTHER, 2004).

Figura 2 - Sistema Fotovoltaico Conectado à Rede.

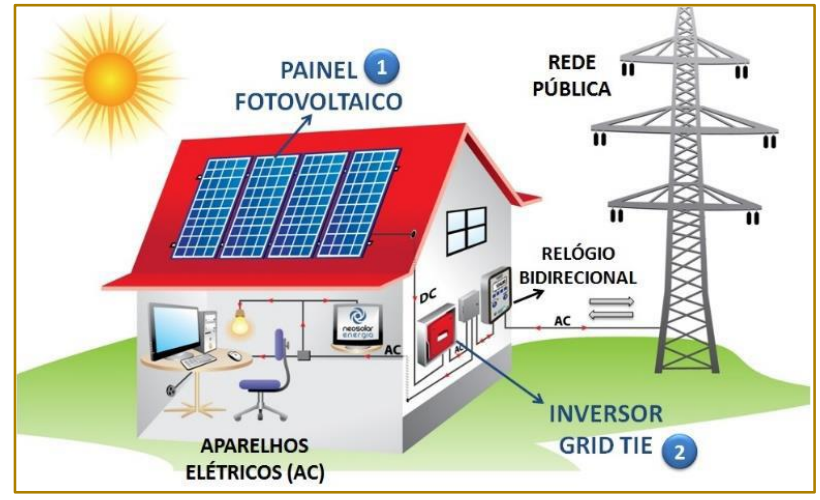

Fonte: NEOSOLAR, 2016.

Segundo MACHADO e CORREA (2015) os principais componentes desse tipo de sistema são:

- Painel fotovoltaico: é responsável por converter a energia solar em energia elétrica através do efeito fotovoltaico.

- Inversor: converte a energia CC em CA para a alimentação das cargas e éresponsável pelo sincronismo do sistema com a rede elétrica. Além disso, possui outra função de extrema importância, pois independente da configuração ou da potência instalada, o inversor deve se desligar automaticamente na ausência da rede elétrica, evitando o fenômeno conhecido como "ilhamento".

- Medidor bidirecional: responsável por medir a energia consumida da rede elétrica pública nos momentos de baixa geração, bem como a energia injetada nela durante os momentos em que a geração do sistema fotovoltaico excede o consumo da instalação à qual pertence. Isso é necessário para que o micro ou o mini gerador possa participar do Sistema de Compensação de Energia, no qual o excedente injetado na rede é convertido em créditos de energia (kWh) para o consumidor, que poderá utilizá-los para abater o consumo nas faturas dos próximos meses. Este crédito de energia tem uma validade de 60 meses.

\section{3 ÍNDICES DE MÉRITO}

Os índices de mérito são calculados individualmente para cada sistema através dos valores de energia gerada, potência instalada e irradiação incidente. São necessários para que se possa equalizar e comparar o desempenho de um SFVCR com outro sistema de características distintas ou que esteja instalado em outra localidade (MACHADO e CORREA, 2015). Ainda segundo Tonin (2016), a análise do desempenho entre sistemas deve utilizar os valores de energia gerada para o período de avaliação e os valores de irradiação incidentes nos painéis FV. A partir da energia gerada e da irradiação incidente, calculam-se os índices de mérito do SFVCR, que são: yield (produtividade); performance ratio (taxa de desempenho) e fator de capacidade.

\subsection{PRODUTIVIDADE OU YIELD}

É a relação da energia gerada (kWh) também expressa pela integral da potência entregue ao sistema em um dado tempo medido por $(\mathrm{kW})$ e a potência instalada $(\mathrm{kWp})$ de cada 
painel fotovoltaico do sistema. Esse índice está vinculado a um intervalo de tempo e quando calculado para um ano é obtido através da Equação 1 (MACHADO e CORREA, 2015).

$$
Y_{F}==\frac{\int_{0}^{8760} P(t) d t}{P_{N}}=\frac{\text { Energia }}{\text { Potência instalada }}(\mathrm{kWh} / \mathrm{kWp})
$$

O YF é a energia produzida no sistema no que diz respeito ao seu tamanho, conseqüentemente ele é uma maneira de comparar energia produzida pelos sistemas fotovoltaicos de tamanhos diferentes (MACHADO; CORREA, 2015).

\subsection{TAXA DE DESEMPENHO PERFORMANCE RATIO}

É a relação entre a produtividade $(\mathrm{kWh} / \mathrm{kWp})$ e a quantidade de horas de sol a $1.000 \mathrm{~W} / \mathrm{m}^{2}$ incidentes no painel FV, normalmente vinculada a um ano de operação. Esta grandeza é expressa em porcentagem e pode ser obtida pela Equação 2 (URBANETZ; ET al., 2014).

$$
P_{R}=\frac{Y_{F}}{H(t) / \text { Gref }}=\frac{\text { Yield }}{\text { Irradiação } / 1000}(\%)
$$

(2)

De outra forma pode-se também dizer que este valor representa o desempenho descontando as perdas existentes no sistema tais como: perdas nos inversores, nas conexões, e principalmente perdas devido à elevação da temperatura nos painéis devido à temperatura ambiente, entre outras perdas (TIEPOLO, 2015).

\subsection{FATOR DE CAPACIDADE}

É o índice em percentagem que representa a capacidade de gerar energia sobre a energia nominal em um intervalo de tempo, normalmente um ano em horas. É o responsável pela comparação das diferentes fontes de energia e suas gerações. Nota-se que há uma relação entre o fator de capacidade e a produtividade, e esta relação (Equação 3) é direta, ou seja, obtendo o valor da produtividade obtém-se o valor do fator de capacidade (MACHADO; CORREA, 2015).

$$
C_{F}=\frac{\int_{0}^{T} P(t) d t}{P_{N} x T}=\frac{Y_{F}(h)}{8.760 h}=\frac{\text { Energia }}{\text { Potência } x \text { Tempo }}(\%)
$$

(3)

No Brasil os SFVCR's possuem $C_{F}$ entre 13\% e $18 \%$ variando de acordo com a disponibilidade do recurso solar, da tecnologia e forma de dimensionamento adotado (BENEDITO, 2009).

\section{OS SISTEMAS DA UTFPR NEOVILLE X LAR JUNSHIN}

4.1 DESCRITIVO/HISTÓRICO NEOVILLE:

O SFVCR da sede NEOVILLE foi cedido e instalado pela Empresa ELCO Engenharia, e entrou em operação no dia 29/02/2016. 
Trata-se de um sistema composto por 34 painéis solares de silício policristalino, (um conjunto de 17 painéis em série, conectados a um Buscador do Ponto de Máxima Potência, e outro conjunto de 17 painéis em série, conectados a um segundo Buscador do Ponto de Máxima Potência, ambos no mesmo inversor), com capacidade total de 10,2 kWp instalados sobre o telhado existente do barracão principal do Campus, conforme ilustrado na Figura 3a.

Os painéis foram estrategicamente posicionados, com a devida orientação voltada para o norte e fixados através de uma estrutura metálica com uma inclinação específica de $25^{\circ}$ (figura 3b). Os dois conjuntos (strings) de 17 painéis estão suficientemente espaçados um do outro (Figura 3c) de modo a evitar que possa ocorrer sombreamento provocado por um painel sobre 0 outro. Todas estas características de posicionamento visam maximizar o tempo e a área de exposição dos painéis aos raios solares, de modo a se obter as melhores condições de produção de energia pelo sistema.

Os painéis estão interligados a um inversor de 10kW (Figura 4a), sem transformador, com interface homem máquina (IHM) mostrada na Figura 4b, no qual são apresentados todos os parâmetros monitorados pelo inversor. Esta ligação é realizada através de cabos e conectores adequados, cada conjunto em uma entrada específica com buscador de máxima potência (Figura4c) de modo a garantir que um eventual problema em um dos strings não venha a interferir na produtividade do outro, e a saída do inversor (Figura 4d) é ligada diretamente ao Painel de Distribuição mais próximo (Figura 5a).

Figura 3: a) Arranjo físico dos Painéis do SFVCR, b) Estrutura de Fixação e c) Espaçamento entre os painéis

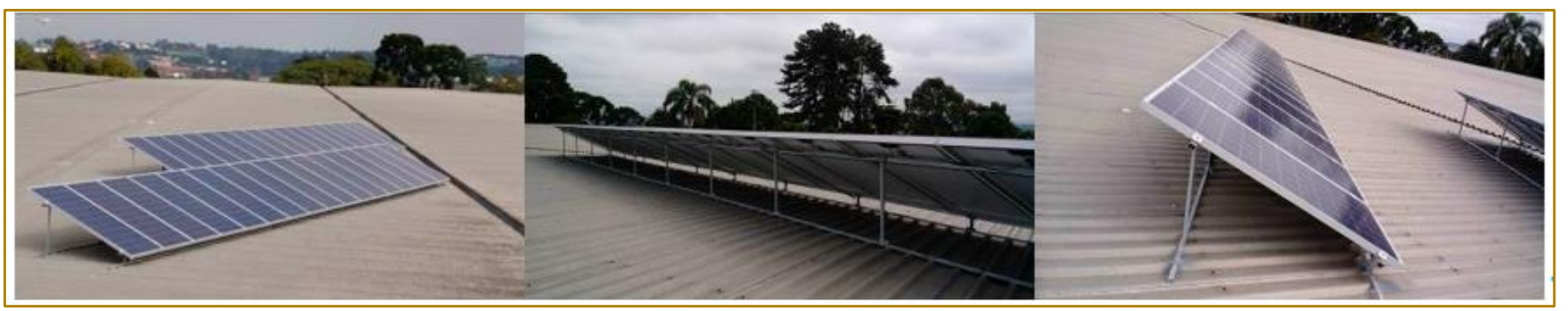

Fonte: Os Autores (2017)

Figura 4: a) Inversor, b) IHM do Inversor, c) Entradas do Inversor e d) Saída do Inversor

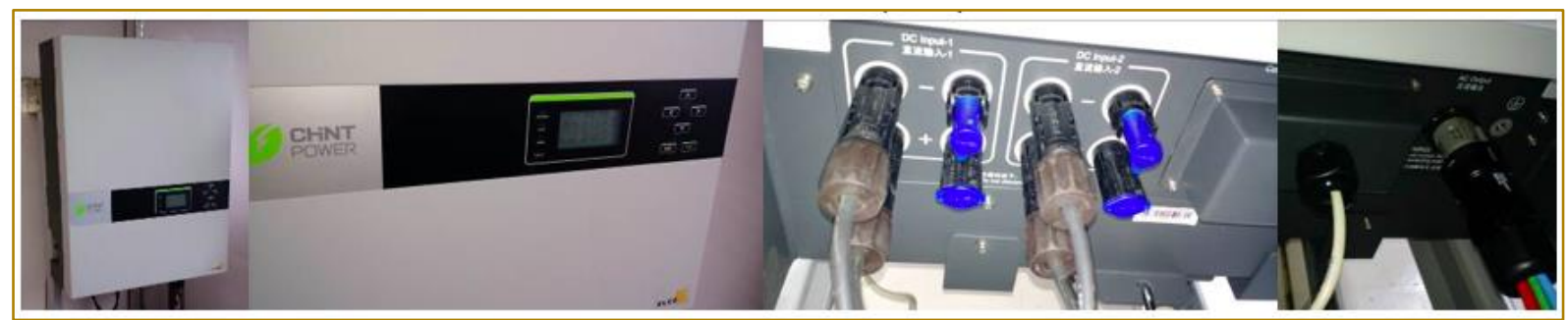

Fonte: Os Autores (2017)

Também é conectado ao inversor um Data Logger (Figura 5b), o qual é responsável por reunir, armazenar e transmitir os valores obtidos dos parâmetros físicos e elétricos (tensão e corrente em três fases) em um intervalo de tempo (Figura 5c), fornecidos pelo inversor através de um módulo de comunicação serial (Figura 4d) e finalmente transmitidos por Wi-Fi para um banco de dados (Figuras 6 e 7 a seguir) para posteriores avaliações. 
Figura 5: a) Distribuidor Geral, b) Data Logger e c) Parâmetros do Inversor

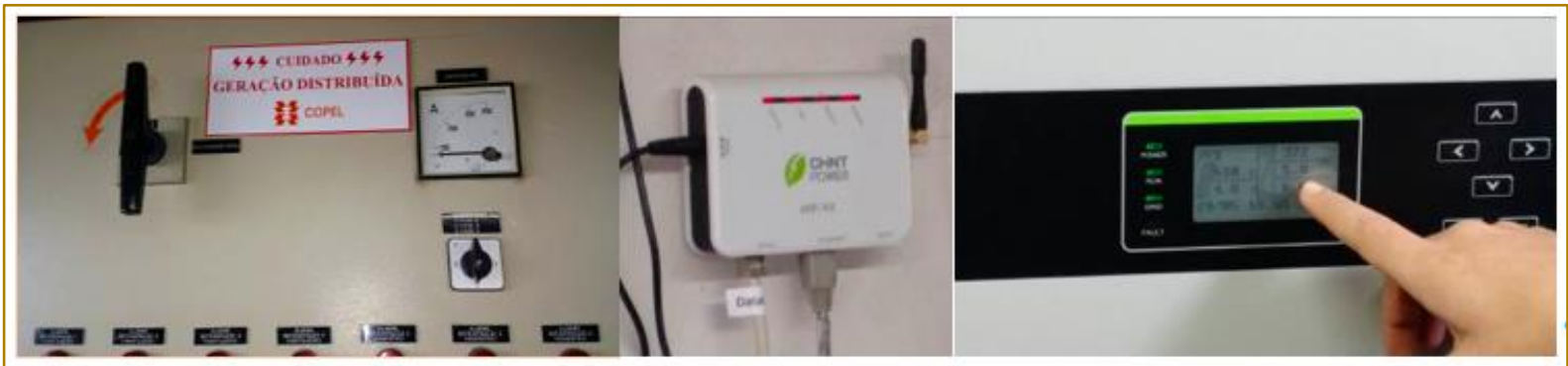

Fonte: Os Autores (2017)

A Agência Nacional de Energia Elétrica classifica esse sistema conforme o tamanho da instalação em micro geração, ou seja, para potências de até $75 \mathrm{~kW}$, (MACHADO; CORREA, 2015)

\subsection{DESCRITIVO/HISTÓRICO LAR JUNSHIN:}

O SFVCR do LAR JUNSHIN foi cedido e instalado pela Empresa ELCO Engenharia, e entrou em operação no dia 29/10/2015. Assim

Figura 6: Energia Produzida em abril/2017, Sistema NEOVILLE (Monitor. Chintpower Software da Web para armazenamento e análise dos parâmetros do inversor).

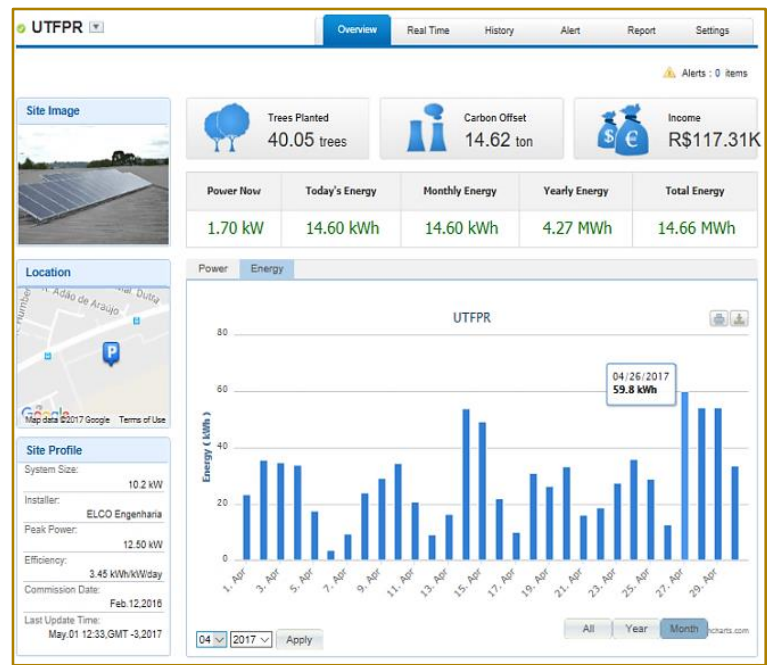

Fonte: MONITOR. CHINTPOWER UTFPR (2017) como no caso do sistema NEOVILLE, trata-se de um sistema composto por 34 painéis solares de silício policristalino, (um conjunto de 17 painéis em série, conectados a um Buscador do Ponto de Máxima Potência, e outro conjunto de 17 painéis em série, conectados a um segundo Buscador do Ponto de Máxima Potência, ambos no mesmo inversor). Os painéis foram instalados sobre o telhado existente da edificação principal do complexo, com capacidade total instalada de 10,2 kWp conforme ilustrado na Figura $8 a$.

Figura 7: Energia Produzida ao longo de 2016 e 2017Sistema NEOVILLE (Monitor. Chintpower Software da Web para armazenamento e análise dos parâmetros do inversor).

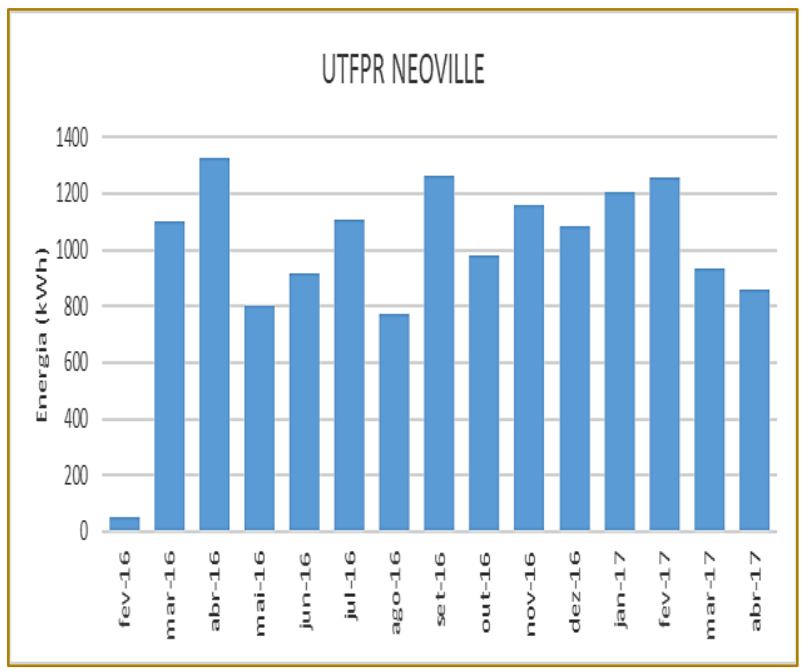

Fonte: Adap. de MONITOR. CHINTPOWER UTFPR (2017)

específica de $19^{\circ}$ acompanhando a inclinação do telhado (Figura8b). Todos os painéis dos dois conjuntos (strings) de 17 painéis estão colocados no mesmo plano de modo a evitar
Desta vez, os painéis foram estrategicamente posicionados, com a devida orientação voltada para o norte e fixados através de uma estrutura metálica com uma inclinação 
que possa ocorrer sombreamento provocado por um painel sobre o outro. Todas estas características de posicionamento visam maximizar o tempo e a área de exposição dos painéis aos raios solares, de modo a se obter as melhores condições de produção de energia pelo sistema naquele local, contudo segundo relatos dos usuários, em alguns momentos do dia ocorre sombreamento parcial do sistema devido à existência de alguns pinheiros nas proximidades da instalação (Figura8c).

Figura 8: a) Arranjo físico dos Painéis do SFVCR, b) Estrutura de Fixação, c) Sombreamento Parcial

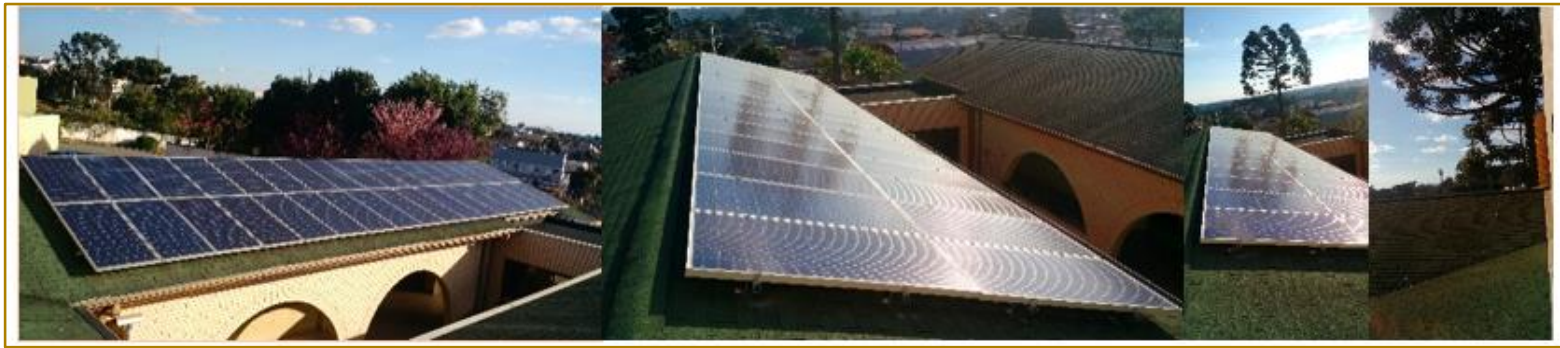

Fonte: Os Autores (2017)

Os painéis do LAR JUNSHIN, assim como no caso do NEOVILLE, também estão interligados a um inversor de $10 \mathrm{~kW}$ (Figura9a), de mesmo modelo e através dos mesmos tipos de conexão no qual se pode verificar através de sua IHM os valores instantâneos de produção conforme apresentado na Figura9b.

Figura 9: a) Inversor, b) IHM do Inversor, c) Entradas e Saída do Inversor

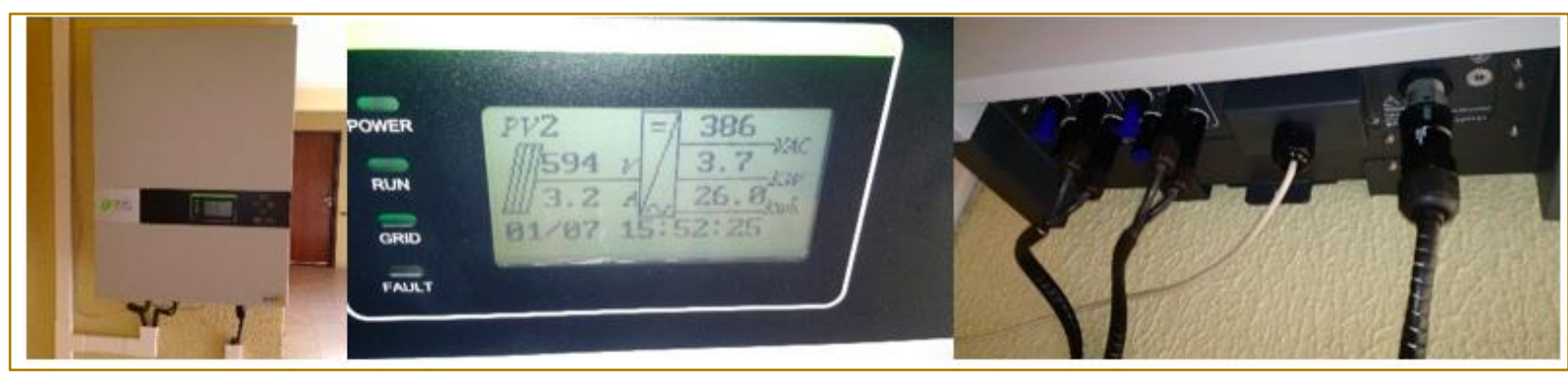

Fonte: Os Autores (2017)

A interligação do sistema é realizada através de cabos e conectores adequados, cada conjunto em uma entrada específica com buscador de máxima potência (Figura9c) de modo a garantir que um eventual problema em um dos strings não venha a interferir na produtividade do outro.

Na Figura10 é possível se ter um panorama geral das conexões do inversor, onde é possível perceber que o inversor é interligado a um Data Logger (acima do inversor), e que sua saída está ligada diretamente a um transformador trifásico de 12,5 kVA - 380$220 / 127 \mathrm{~V}$, o qual se conecta diretamente ao quadro de distribuição geral da instalação. Também podemos classificar esse sistema conforme o tamanho da instalação em micro geração, ou seja, com potência inferior a 75kW, (MACHADO; CORREA, 2015) 
Figura 10: Visão geral da instalação do inversor

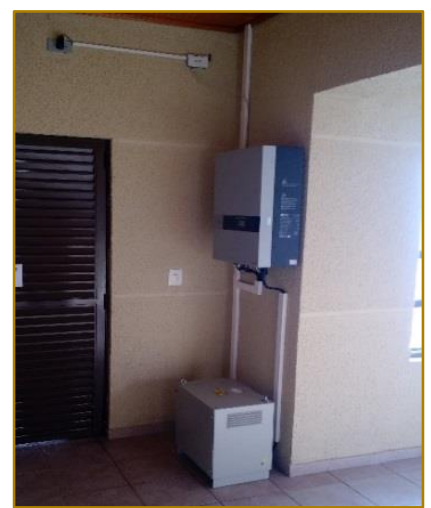

Fonte: Os Autores (2017)

Apesar do sistema do LAR JUNSHIN ter entrado em operação no dia 29/10/2015 somente a partir do dia 25/05/2016 o sistema passou a ter seus dados devidamente registrados, pois no período anterior o sistema estava sem data logger. Como o equipamento cedido pela ELCO Engenharia foi reaproveitado de outra instalação os dados armazenados no site da ChintPower não correspondem, em sua totalidade, à realidade produtiva do sistema. Sendo assim, neste estudo, somente serão considerados, para efeito de cálculos, os dados obtidos a partir de 25 de maio de 2016 conforme ilustrados nas Figuras 11 e 12.
Figura 11: Energia Produzida em abril/2017, Sistema LAR JUNSHIN (Monitor. Chintpower Software da Web para armazenamento e análise dos parâmetros do inversor).

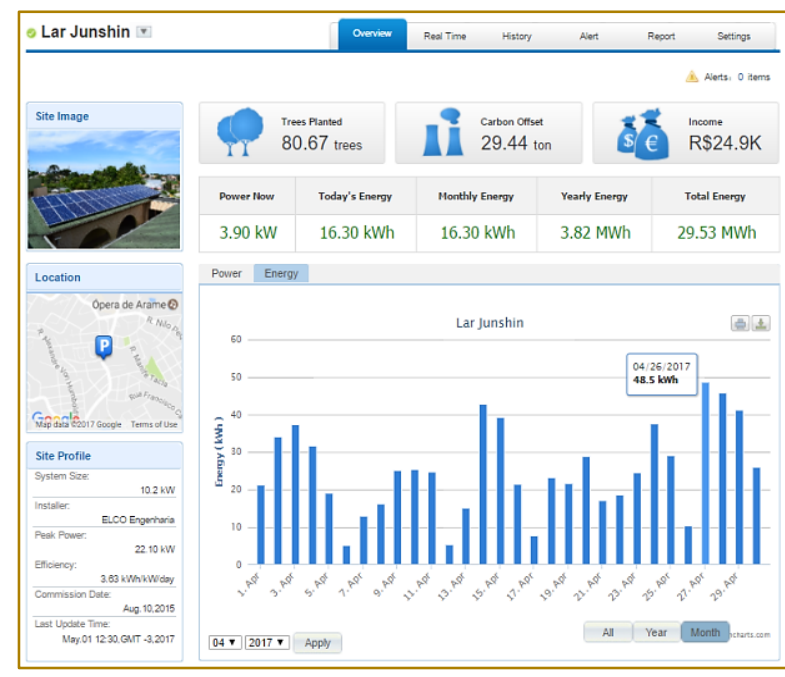

Fonte: MONITOR. CHINTPOWER LAR JUNSHIN (2017)

\section{CARACTERÍSTICAS DOS EQUIPAMENTOS:}

Os equipamentos utilizados tanto no sistema NEOVILLE quanto no LAR JUNSHIN foram importados e distribuídos pela ELCO Engenharia.
Figura 12: Energia Produzida ao longo de 2016 e 2017 Sistema LAR JUNSHIN* (Monitor Chintpower - Software da Web para armazenamento e análise dos parâmetros do inversor).

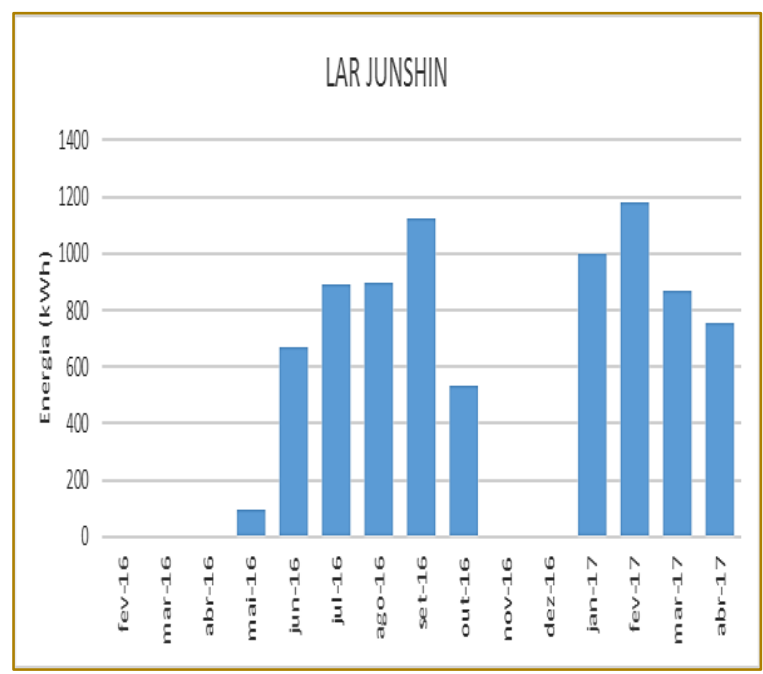

Fonte: Adaptado de MONITOR CHINTPOWER LAR JUNSHIN (2017)

Os painéis Fotovoltaicos utilizados são do tipo policristalino, Modelo: ELCO-A300P com as características elétricas e mecânicas apresentadas na Figura 13. 
Figura 13: Características elétricas e mecânicas do painel fotovoltaico

\begin{tabular}{|c|c|c|c|}
\hline \multicolumn{4}{|c|}{ CARACTERÍSTICAS ELÉTRICAS } \\
\hline Máxima potência & $300 \mathrm{~W}$ & Máxima potência & $209,5 \mathrm{~W}$ \\
\hline Tensão de máxima potência & $35,74 \mathrm{~V}$ & Tensão de máxima potência & $32,63 \mathrm{~V}$ \\
\hline Corrente de máxima potência & $8,4 \mathrm{~A}$ & Corrente de máxima potência & $6,42 \mathrm{~A}$ \\
\hline Tensão de circuito aberto & $45,16 \mathrm{~V}$ & Tensão de circuito aberto & $41,44 \mathrm{~V}$ \\
\hline \multicolumn{2}{|c|}{ 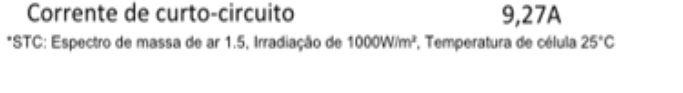 } & \multicolumn{2}{|c|}{ 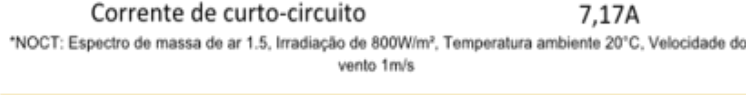 } \\
\hline \multicolumn{2}{|c|}{ CARACTERÍSTICAS MECÂNICAS } & Coeficiente de Temperatura (Pm) & $-0,451 \% /{ }^{\circ} \mathrm{C}$ \\
\hline Célula (mm) & 152,4×152,4 Policristalino & Coeficiente de Temperatura (Voc) & $-0,332 \% /{ }^{\circ} \mathrm{C}$ \\
\hline Dimensões $(C \times L \times A)$ & $1956 \times 994 \times 50 \mathrm{~mm}$ & Coeficiente de Temperatura (Isc) & $+0,087 \% /{ }^{\circ} \mathrm{C}$ \\
\hline Peso & $23,5 \mathrm{~kg}$ & \multirow{2}{*}{$\begin{array}{l}\text { Temperatura Nominal de } \\
\text { Operação da Célula }\end{array}$} & \multirow{2}{*}{$46 \pm 2^{\circ} \mathrm{C}$} \\
\hline Bitola do cabo de conexão & $4 \mathrm{~mm}^{2}$ & & \\
\hline Num. de células e conexões & $72(6 \times 12)$ & \multirow[t]{2}{*}{ Tolerância de saída } & \multirow[t]{2}{*}{$0 \sim 5 W$} \\
\hline Num. de diodos & 6 & & \\
\hline \multicolumn{2}{|c|}{ QUALIFICAÇÃO } & \multicolumn{2}{|c|}{ GARANTIA } \\
\hline Eficiência do módulo & $15,4 \%$ & \multicolumn{2}{|c|}{ Queda de $3 \% /$ ano da potência nominal de saída no $1^{\circ}$ ano } \\
\hline Tensão Máxima do Sistema & $1000 \mathrm{Vcc}$ & \multirow{3}{*}{\multicolumn{2}{|c|}{$\begin{array}{c}\text { Queda de } 0,7 \% / \text { ano da potência nominal de saída do } 2^{\circ} \text { ao } 250 \text { ano } \\
\text { Livre de defeitos no material e manutenção por } 10 \text { anos }\end{array}$}} \\
\hline Fusivel Máximo em Série & $15 \mathrm{~A}$ & & \\
\hline Carga Máxima & $5400 \mathrm{~Pa}$ & & \\
\hline
\end{tabular}

Fonte: ELCO Engenharia (2016)

O inversor utilizado em ambos os sistemas é o inversor de $10 \mathrm{kWp}$ sem transformador Modelo: CPS SCA1OKTL-DO da CHINT
POWER com as características elétricas e mecânicas mostradas na Figura 14:

Figura 14: Características elétricas e mecânicas do inversor

\begin{tabular}{|c|c|}
\hline CARACTERÍSTICAS MECÂNICAS & \\
\hline Dimensão [LXAxP] & $500 \times 680 \times 216 \mathrm{~mm}$ \\
\hline Peso & $43 \mathrm{Kg}$ \\
\hline \multicolumn{2}{|l|}{ SISTEMA } \\
\hline Topologia & Sem transformador \\
\hline Máxima eficiência & $98,6 \% * \cdots / 98,3 \%$ \\
\hline Eficiência Européia & $98,2 \% \cdots / 97,9 \%$ \\
\hline Stand-by / Consumo noturno & $<20 \mathrm{~W} /<0,3 \mathrm{~W}$ \\
\hline \multicolumn{2}{|l|}{ ENTRADA CC } \\
\hline Potência nominal & $10,3 \mathrm{~kW}$ \\
\hline Potência máxima para cada MPPT & $6 \mathrm{~kW}$ \\
\hline Potência máxima & - \\
\hline Tensão máxima & $1000 \mathrm{Vcc}$ \\
\hline Faixa da tensão de operação & 250-950Vcc \\
\hline Start-up Tensăo / Potência & $320 \mathrm{~V} / 150 \mathrm{~W}$ \\
\hline Tensão nominal & $600 \mathrm{~V}$ \\
\hline Número de rastreadores MPP & 2 \\
\hline Faixa de tensão MPPT & $430-800 \mathrm{Vcc}^{*} / 320-800 \mathrm{Vcc}$ \\
\hline Corrente máxima & 17A/MPPT \\
\hline Corrente máxima por string & $17 \mathrm{~A}$ \\
\hline Numéro de entradas $\mathrm{CC}$ & $2 \times 2$ \\
\hline Tipo de desconexão CC & Interruptor incorporado \\
\hline Configuraşão do arranjo PV & Flutuante \\
\hline
\end{tabular}

\begin{tabular}{|c|c|}
\hline SAÍDA CA & \\
\hline Potência nominal & $10 \mathrm{~kW}$ \\
\hline Potência máxima & $10 \mathrm{~kW}$ \\
\hline Tensão nominal & $400 \mathrm{Vca}$ \\
\hline Faixa de tensão de saída & $320-460 \mathrm{Vca}^{*}$ \\
\hline Tipo de conexăo com a rede & $3 \phi / N / P E$ \\
\hline Corrente máxima & $15,2 \mathrm{~A}$ \\
\hline Frequência nominal & $60 \mathrm{~Hz}$ \\
\hline Faixa de frequência de saída & $47-53 \mathrm{~Hz} / 57-63 \mathrm{~Hz} \cdots$ \\
\hline Fator de potência & $>0,99( \pm 0,9$ ajustável) \\
\hline Corrente THD & $<3 \%$ \\
\hline Tipo de desconexăo CA & - \\
\hline \multicolumn{2}{|l|}{ AMBIENTE } \\
\hline Grau de proteção & IP65 \\
\hline Resfriamento & $\begin{array}{c}\text { Ventiladores de } \\
\text { velocidade variável }\end{array}$ \\
\hline Faixa de temperatura de operaçăo & $-25^{\circ} \mathrm{C}$ até $+60^{\circ} \mathrm{C}$ \\
\hline Humidade de operação & 0-95\%, sem condensaçăo \\
\hline Altitude de operação & $4000 \mathrm{~m}$ \\
\hline
\end{tabular}

Fonte: ELCO Engenharia (2016) 
6 ÍNDICES DE MÉRITO UTFPR NEOVILLE X LAR JUNSHIN

\subsection{PARÂMETROS DE CÁLCULO:}

Através do software Google Earth, foram verificadas as coordenadas dos locais de instalação dos dois sistemas apresentadas na Tabela 1e ilustradas na Figura 15. Também foi possível medir a distância entre as coordenadas dos dois sistemas, a qual resultou em aproximadamente $13 \mathrm{~km}$. A distância entre o Neoville e a estação do INMET é de aproximadamente $11 \mathrm{~km}$ enquanto que a distância entre o Lar Junshin e a estação do INMET é de aproximadamente $8,5 \mathrm{~km}$ :

Tabela 1 - Coordenadas geográficas

\begin{tabular}{|c|c|c|}
\hline \multicolumn{1}{|c|}{ Sistema } & Parâmetro & Valor \\
\hline \multirow{2}{*}{ NEOVILLE } & Latitude & $25^{\circ} 30^{\prime} 16,55^{\prime \prime} \mathrm{S}$ \\
\cline { 2 - 3 } & Longitude & $49^{\circ} 19^{\prime} 5,75^{\prime \prime} \mathrm{W}$ \\
\hline \multirow{2}{*}{ LAR JUNSHIN } & Latitude & $25^{\circ} 23^{\prime} 24,2^{\prime \prime} \mathrm{S}$ \\
\cline { 2 - 3 } & Longitude & $49^{\circ} 17^{\prime} 0,6^{\prime \prime} \mathrm{W}$ \\
\hline \multirow{2}{*}{ ESTAÇÃO INMET } & Latitude & $25^{\circ} 26^{\prime} 55,3^{\prime \prime} \mathrm{S}$ \\
\cline { 2 - 3 } & Longitude & $49^{\circ} 13^{\prime} 50,2^{\prime \prime} \mathrm{W}$ \\
\hline
\end{tabular}

Figura 15: Localização dos Sistemas Neoville, Junshin e Estação INMET

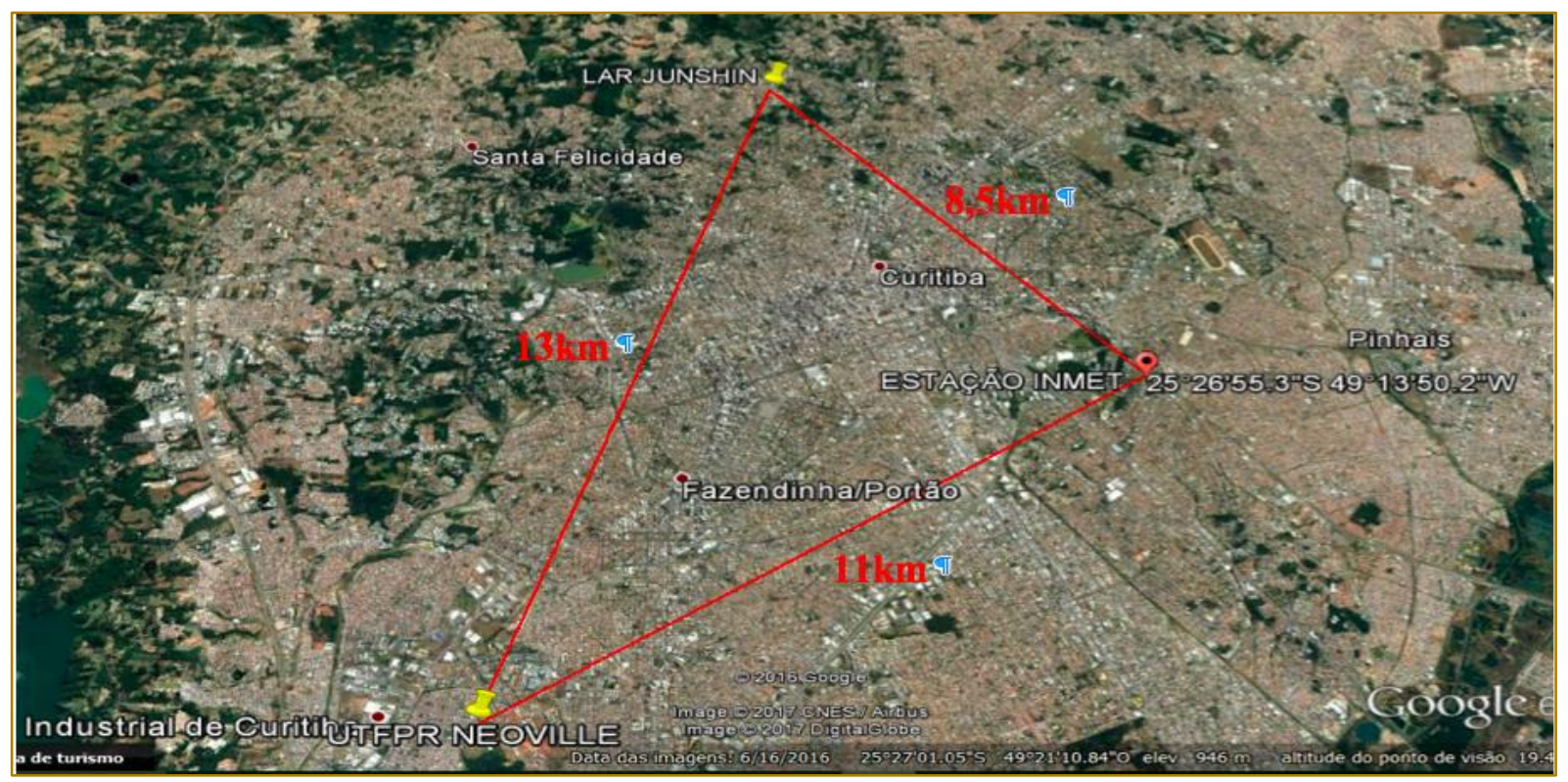

Fonte: Adaptado do Google Earth (2017)

Para se obter os valores de radiação incidentes no plano do painel fotovoltaico dos sistemas foi utilizado o software RADIASOL versão 2.1. Para que o software calcule a irradiação no plano do painel são necessários alguns parâmetros de entrada: a irradiação média diária mensal no plano horizontal e os ângulos de inclinação do painel e o desvio azimutal do norte geográfico. A tabela 2 apresenta os ângulos e a tabela 3 apresenta os índices de irradiação dos sistemas. 
Tabela 2 - Ângulo de inclinação do painel e ângulo do desvio azimutal do norte geográfico

\begin{tabular}{|c|c|c|}
\hline \multirow{2}{*}{ NEOVILLE } & Ângulo do desvio azimutal do Norte & $0^{\circ}$ \\
\cline { 2 - 3 } & Ângulo de inclinação do painel & $25^{\circ}$ \\
\hline \multirow{2}{*}{ LAR JUNSHIN } & Ângulo do desvio azimutal do Norte & $0^{\circ}$ \\
\cline { 2 - 3 } & Ângulo de inclinação do painel & $19^{\circ}$ \\
\hline
\end{tabular}

Devido ao fato de as distâncias entre os sistemas fotovoltaicos e a estação de referência serem relativamente próximas, para ambos os casos, sistema NEOVILLE e sistema JUNSHIN, foram utilizados os valores de irradiação diária média no plano horizontal para os meses que serão considerados na análise, ou seja, os meses de abril de 2016 até abril de 2017, obtidos do site do INMET
(Instituto Nacional de Meteorologia), referentes à irradiação média diária para cada um desses meses em $\mathrm{kWh} / \mathrm{m}^{2}$ dia.

Também se pode notar, na tabela 3 , que os valores de irradiação mínima e máxima no período analisado foram de $2,83 \mathrm{kWh} / \mathrm{m}^{2}$.dia e de $6,47 \mathrm{kWh} / \mathrm{m}^{2}$. dia para os meses de maio de 2016 e fevereiro de 2017 respectivamente.

Tabela 3 - Irradiação diária média no plano horizontal (kWh/m².dia)

\begin{tabular}{|c|c|c|c|c|c|c|c|c|c|c|c|c|c|c|}
\hline Sistema & Abr & Mai & Jun & Jul & Ago & Set & Out & Nov & Dez & Jan & Fev & Mar & Abr \\
\hline NEOVILLE & 4,72 & 2,83 & 3,65 & 4,11 & 4,02 & 5,92 & 4,35 & 6,16 & 6,11 & 5,31 & 6,47 & 4,70 & 4,18 \\
\hline LAR JUNSHIN & $\left({ }^{* 3}\right)$ & 2,83 & 3,65 & 4,11 & 4,02 & 5,92 & 4,35 & $\left({ }^{* 3}\right)$ & $\left({ }^{* 3}\right)$ & 5,31 & 6,47 & 4,70 & 4,18 \\
\hline
\end{tabular}

A partir desses dados foram criadas duas novas estações no Radiasol, denominadas NEOVILLE 2016 e NEOVILLE 2017 (Figuras 16a e 16b) e outras duas chamadas JUNSHIN 2016 e JUNSHIN 2017 (Figuras 17a e 17b).

Figura 16: a) NEOVILLE 2016, b) NEOVILLE 2017 - Estações criadas no Programa Radiasol
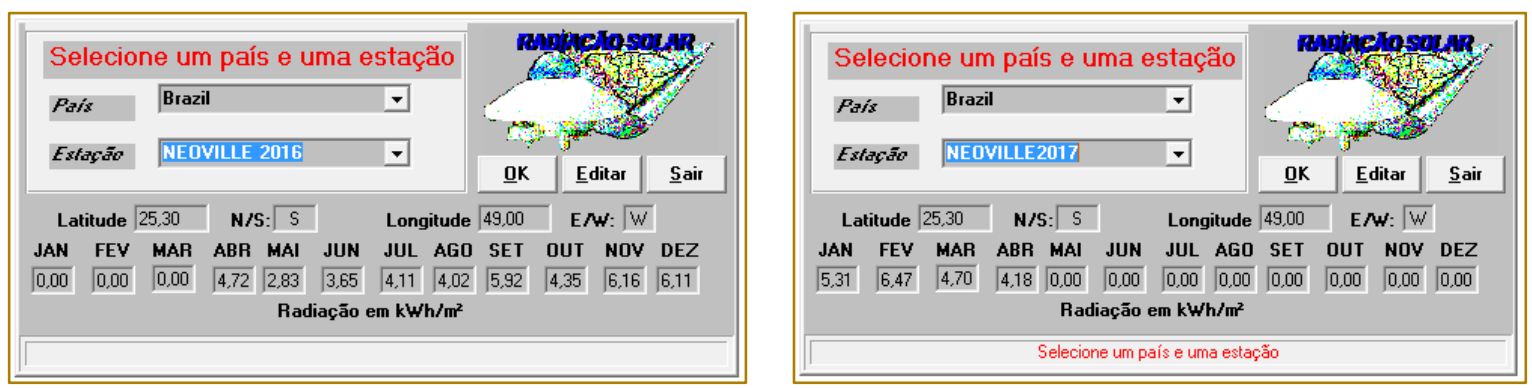

Fonte: Os Autores (2017) 
Figura 17: a) JUNSHIN 2016, b) JUNSHIN 2017 - Estações criadas no Programa Radiasol

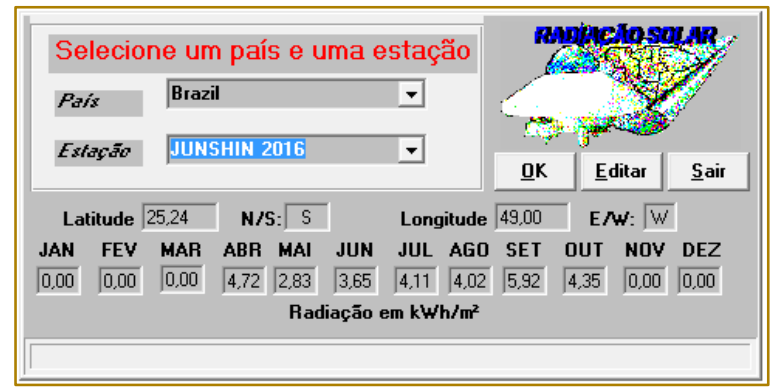

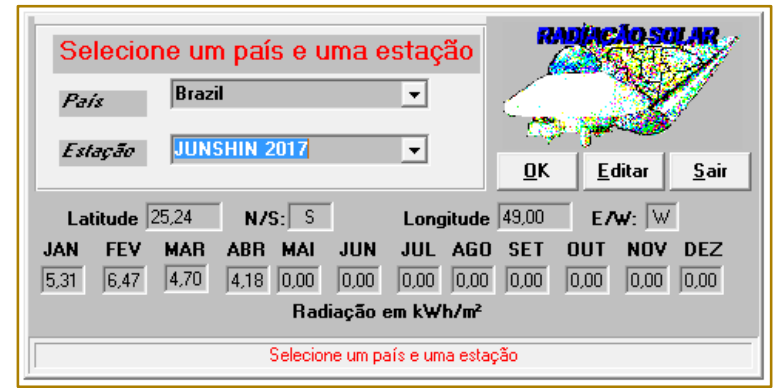

Fonte: Os Autores (2017)

As Figuras 18a e 18b mostram a interface do software e um gráfico de barras demonstrando os valores de irradiação diária média no plano dos painéis em relação aos meses do ano de 2016, de acordo com os dados inseridos para cada sistema. A tabela 4 expõe os valores calculados pelo programa para irradiação no plano do painel no período de análise.

Figura 18: a) NEOVILLE 2016, b) JUNSHIN 2016 - Interface do Programa Radiasol
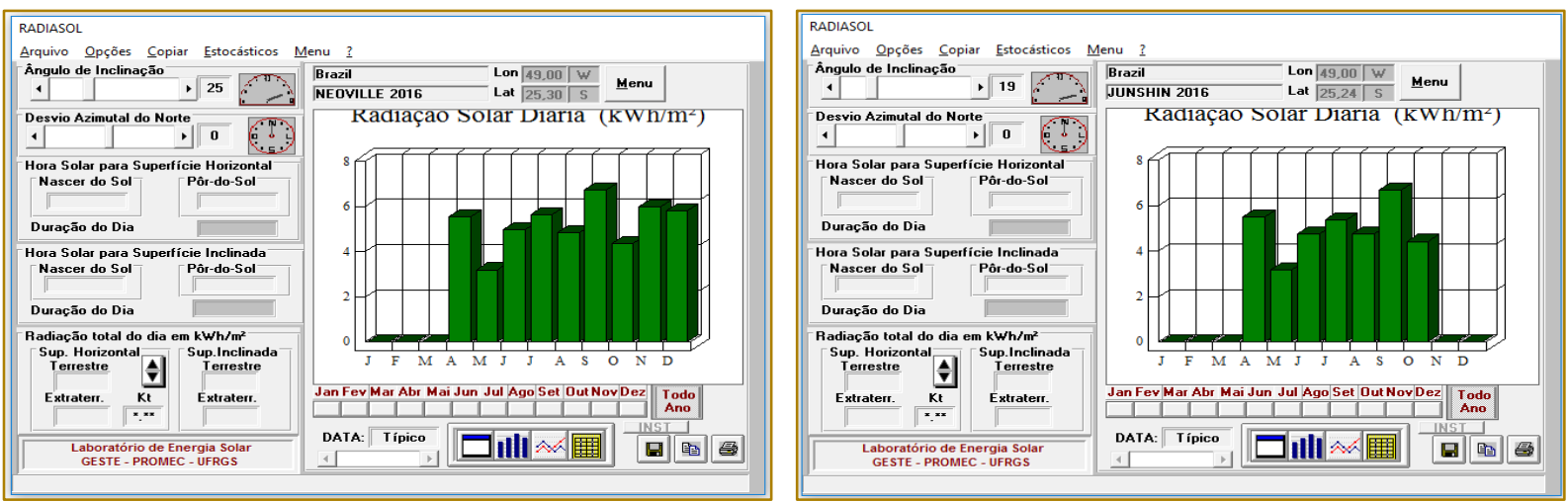

Fonte: Os Autores (2017)

Tabela 4 - Irradiação diária média no plano do painel ( $\mathrm{kWh} / \mathrm{m}^{2}$ dia)

\begin{tabular}{|c|c|c|c|c|c|c|c|c|c|c|c|c|c|}
\hline \multirow{2}{*}{ Sistema } & \multicolumn{9}{|c|}{2016} & \multicolumn{4}{|c|}{2017} \\
\hline & Abr & Mai & Jun & Jul & Ago & Set & Out & Nov & Dez & Jan & Fev & Mar & Abr \\
\hline NEOVILLE & 5,55 & 3,19 & 4,97 & 5,61 & 4,81 & 6,73 & 4,34 & 5,96 & 5,81 & 5,12 & 6,44 & 4,91 & 4,76 \\
\hline LAR JUNSHIN & $\left({ }^{* 3}\right)$ & 3,17 & 4,76 & 5,36 & 4,74 & 6,68 & 4,41 & $\left({ }^{* 3}\right)$ & $\left({ }^{* 3}\right)$ & 5,25 & 5,59 & 4,96 & 4,74 \\
\hline
\end{tabular}

De acordo com a Tabela 4, a partir do software RADIASOL obteve-se os valores de irradiação no plano do painel mínimos e máximos para o SFVCR do Neoville sendo de $3,19 \mathrm{kWh} / \mathrm{m}^{2}$. dia no mês de maio de 2016, e de $6,73 \mathrm{kWh} / \mathrm{m}^{2}$. dia para o mês de setembro de 2016 respectivamente. Para o SFVCR do Lar Junshin estes valores foram de 3,17
$\mathrm{kWh} / \mathrm{m}^{2}$.dia no mês de maio de 2016, e de $6,68 \mathrm{kWh} / \mathrm{m}^{2}$.dia para o mês de setembro de 2017 respectivamente.

A Tabela 5 expõe os valores de energia gerada mensalmente obtidos na página do site de cada sistema conforme ilustrado nas Figuras 7 e 12 anteriormente apresentadas. 
Tabela 5 - Energia total gerada por mês (kWh)

\begin{tabular}{|c|c|c|c|c|c|c|c|c|c|c|c|c|c|}
\hline \multirow{2}{*}{ Sistema } & \multicolumn{9}{|c|}{2016} & \multicolumn{4}{|c|}{2017} \\
\hline & $\mathrm{Abr}$ & Mai & Jun & Jul & Ago & Set & Out & Nov & Dez & Jan & Fev & Mar & Abr \\
\hline NEOV. & 1332,1 & 755,2 & 944,9 & 1117,4 & 778,5 & 1234,5 & 1008,5 & 1132,3 & 1098,3 & 1187,8 & 1253,9 & 932,6 & 863,4 \\
\hline $\begin{array}{c}\text { LAR } \\
\text { JUNSHIN }\end{array}$ & $\left({ }^{\star 3}\right)$ & 106,5 & 684,9 & 900,8 & 853,4 & 1146,6 & 508,7 & $\left({ }^{* 3}\right)$ & $\left({ }^{* 3}\right)$ & 1026,2 & 1173,9 & 863,1 & 765,7 \\
\hline
\end{tabular}

A Tabela 6 demonstra os resultados obtidos para o índice de produtividade mensal do SFVCR.

Tabela 6 - Yield ou produtividade mensal (kWh/kW)

\begin{tabular}{|c|c|c|c|c|c|c|c|c|c|c|c|c|c|}
\hline \multirow{2}{*}{ Sistema } & \multicolumn{9}{|c|}{2016} & \multicolumn{4}{|c|}{2017} \\
\hline & $\mathrm{Abr}$ & Mai & Jun & Jul & Ago & Set & Out & Nov & Dez & Jan & Fev & Mar & $\mathrm{Abr}$ \\
\hline NEOV. & 130,6 & 74,0 & 92,6 & 109,5 & 76,3 & 121,0 & 98,9 & 111,0 & 107,7 & 116,5 & 122,9 & 91,4 & 84,6 \\
\hline $\begin{array}{c}\text { LAR } \\
\text { JUNSHIN }\end{array}$ & $\left({ }^{* 3}\right)$ & $10,4^{(\star)}$ & 67,1 & 88,3 & 83,7 & 112,4 & $49,9^{(* 4)}$ & $\left({ }^{* 3}\right)$ & $\left({ }^{* 3}\right)$ & $100,6^{(* 4)}$ & 115,1 & 84,6 & 75,1 \\
\hline
\end{tabular}

A Tabela 7 demonstra os resultados obtidos para a taxa de desempenho mensal do SFVCR.

Tabela 7 - Taxa de desempenho mensal (\%)

\begin{tabular}{|c|c|c|c|c|c|c|c|c|c|c|c|c|c|}
\hline \multirow{2}{*}{ Sistema } & \multicolumn{9}{|c|}{2016} & \multicolumn{4}{|c|}{2017} \\
\hline & Abr & Mai & Jun & Jul & Ago & Set & Out & Nov & Dez & Jan & Fev & Mar & Abr \\
\hline NEOV. & 78,4 & 74,9 & 62,1 & 65,1 & $69,0^{(* 5)}$ & $62,0^{(* 5)}$ & 73,5 & 62,1 & 59,8 & 73,4 & 68,2 & 60,1 & 59,3 \\
\hline $\begin{array}{c}\text { LAR } \\
\text { JUNSHIN }\end{array}$ & $\left({ }^{* 3}\right)$ & $41,2^{(* 4)}$ & 47,0 & 53,1 & $63,0^{(* 5)}$ & 56,1 & $66,5^{(\star 4)}$ & $\left({ }^{* 3}\right)$ & $\left({ }^{* 3}\right)$ & $66,1^{(\star 4)}$ & 73,5 & 55,0 & 52,8 \\
\hline
\end{tabular}

A Tabela 8 demonstra os resultados obtidos para o fator de capacidade mensal.

Tabela 8 - Fator de capacidade mensal (\%)

\begin{tabular}{|c|c|c|c|c|c|c|c|c|c|c|c|c|c|}
\hline \multirow{2}{*}{ Sistema } & \multicolumn{9}{|c|}{2016} & \multicolumn{4}{|c|}{2017} \\
\hline & $\mathrm{Abr}$ & Mai & Jun & Jul & Ago & Set & Out & Nov & Dez & Jan & Fev & Mar & $A b r$ \\
\hline NEOV. & 18,1 & 10,0 & 12,9 & 15,2 & $13,8\left(^{*}\right)$ & $17,4\left({ }^{* 5}\right)$ & 13,3 & 15,4 & 14,5 & 15,7 & 18,3 & 12,3 & 11,8 \\
\hline $\begin{array}{c}\text { LAR } \\
\text { JUNSHIN }\end{array}$ & $\left({ }^{* 3}\right)$ & $16,3^{(* 4)}$ & 9,3 & 11,9 & $12,5\left({ }^{* 5}\right)$ & 15,6 & $12,2^{(* 4)}$ & $\left({ }^{* 3}\right)$ & $\left({ }^{* 3}\right)$ & $14,5^{(\star 4)}$ & 17,1 & 11,4 & 10,4 \\
\hline
\end{tabular}

Análise de Produção Energética:

Com os valores mencionados nas tabelas $3 \mathrm{e}$ 4 podemos perceber que o ângulo de inclinação do painel de $25^{\circ}$ para o sistema NEOVILLE melhora a captação da irradiação ao longo dos meses analisados, em média, 10,95\%. Já para o sistema do LAR JUNSHIN podemos perceber que o ângulo de inclinação do painel de 19 melhora a captação da irradiação ao longo dos meses analisados, em média, 10,93\%. Contudo, também é possível perceber que no sistema NEOVILLE, entre outubro e fevereiro houve um decréscimo de incidência de irradiação, médio de $2,48 \%$, nestes meses, nos módulos 
inclinados se comparado com a incidência de irradiação no plano horizontal.

Considerando que uma residência com 3 moradores de médio padrão gaste em média 10kWh/dia, podemos chegar a uma correlação da produção energética dos sistemas NEOVILLE e LAR JUNSHIN com a demanda de casas padrão e com o número de dias de consumo correspondente em cada mês, como mostrado na Tabela 9:

Tabela 9: Correlação da produção energética com o consumo de casas padrão para os sistemas NEOVILLE e LAR JUNSHIN

\begin{tabular}{|c|c|c|c|c|c|c|}
\hline Meses & $\begin{array}{c}\text { Energia gasta } \\
\text { residência } \\
\text { kWh/mês }\end{array}$ & $\begin{array}{c}\text { Energia gerada } \\
\text { NEOVILLE } \\
\text { kWh/mês }\end{array}$ & $\begin{array}{c}\text { Número casas } \\
\text { NEOVILLE } \\
\text { supriria }\end{array}$ & $\begin{array}{l}\text { Energia gerada } \\
\text { JUNSHIN kWh/mês }\end{array}$ & $\begin{array}{c}\text { Número casas } \\
\text { JUNSHIN } \\
\text { supriria }\end{array}$ & $\begin{array}{c}\text { Diferença \%JU } \\
\text { NSHIN X } \\
\text { NEOVILLE }\end{array}$ \\
\hline Abr/16 & 300,00 & 1332,10 & 4,44 & $\left({ }^{* 3}\right)$ & - & - \\
\hline Mai/16 & 310,00 & 755,20 & 2,44 & $106,50^{(\star 4)}$ & 0,34 & 14,1 \\
\hline Jun/16 & 300,00 & 944,90 & 3,15 & 684,90 & 2,28 & 72,5 \\
\hline Jul/16 & 310,00 & 1117,40 & 3,60 & 900,80 & 2,91 & 80,6 \\
\hline Ago/16 & 310,00 & $778,50\left({ }^{* 5}\right)$ & 2,51 & $853,40\left({ }^{\star 5}\right)$ & 2,75 & 109,6 \\
\hline Set/16 & 300,00 & $1234,50\left({ }^{* 5}\right)$ & 4,12 & 1146,60 & 3,82 & 92,9 \\
\hline Out/16 & 310,00 & 1008,50 & 3,25 & $508,70^{(* 4)}$ & 1,64 & 50,4 \\
\hline Nov/16 & 300,00 & 1132,30 & 3,77 & $\left({ }^{* 3}\right)$ & - & - \\
\hline Dez/16 & 310,00 & 1098,30 & 3,54 & $\left({ }^{\star 3}\right)$ & - & - \\
\hline Jan/17 & 310,00 & 1187,80 & 3,83 & $1026,20^{(* 4)}$ & 3,31 & 86,4 \\
\hline Fev/17 & 280,00 & 1253,90 & 4,48 & 1173,90 & 4,19 & 93,6 \\
\hline Mar/17 & 310,00 & 932,60 & 3,01 & 863,10 & 2,78 & 92,5 \\
\hline $\mathrm{Abr} / 17$ & 300,00 & 863,40 & 2,88 & 765,70 & 2,55 & 88,7 \\
\hline Total & 3950,00 & 13639,40 & 45,02 & 8029,80 & 26,59 & - \\
\hline
\end{tabular}

\section{CONSIDERAÇÕES FINAIS}

Os índices de mérito do SFVCR da UTFPR Neoville apresentaram valores adequados, e, semelhantes aos índices obtidos em outros sistemas conectados à rede em localidades próximas, como por exemplo, no caso do SFVCR do Escritório Verde da UTFPR. A média da produtividade (YELD) para os meses de abril de 2016 a abril de 2017 foi de $102,86 \mathrm{kWh} / \mathrm{kWp}$, a taxa de desempenho (PR) média foi de $66,75 \%$ e o fator de capacidade $\left(F_{C}\right)$ médio $14,50 \%$. Para efeito de comparação, os valores médios desses mesmos índices, obtidos em 2012 para o EV da UTFPR, segundo Urbanetz e Casagrande, foram respectivamente: 95,3 kWh/kWp, 66,4\% e $12,94 \%$.

Quanto ao sistema do LAR JUNSHIN pode-se observar que a média da produtividade (YELD) para os meses de maio de 2016 a abril de 2017 foi de 78,72 kWh/kWp, a taxa de desempenho (PR) média foi de $57,44 \%$ e o fator de capacidade $\left(F_{C}\right)$ médio $13,12 \%$. Contudo para que estes valores não fossem comprometidos, devido ao fato de que no mês de maio foram considerados apenas 8 dias, no mês de outubro apenas 17 dias e que no mês de janeiro de 2017 foram considerados apenas 29 dias de produção energética. $\mathrm{E}$, portanto, desconsiderando-se estes três meses obteve-se 89,47 kWh/kWp de produtividade (YELD), a taxa de desempenho (PR) média foi de $57,24 \%$ e o fator de capacidade $\left(F_{C}\right)$ médio $12,60 \%$.

\section{CONCLUSÕES}

Através deste estudo foi possível perceber que apesar dos sistemas possuírem os mesmos tipos de equipamentos, com as mesmas características técnicas e considerando apenas os meses com base de dados na mesma condição entre os sistemas, conforme indicado em azul na tabela 9, que o Sistema NEOVILE produziu $11,5 \%$ mais energia que o sistema LAR JUNSHIN. Portanto, pode-se concluir que uma pequena diferença na inclinação do painel (nesse caso 
de apenas $6^{\circ}$ ) pode ser um dos fatores que impactam significativamente no desempenho do SFVCR.

Ainda assim, os índices obtidos em ambos os sistemas, comprovam que os SFVCR's operam de forma satisfatória. Contudo, esta análise poderá ser ainda mais precisa quando os SFVCR em questão tiverem maior tempo de operação e conseqüentemente uma maior base de dados válidos.

Cabe ressaltar que uma das características do SFVCR do Neoville é utilizar um inversor trifásico sem transformador em $380 \mathrm{~V}$, de alto rendimento e com eficiência de $98 \%$. Tal tipo de inversor sem transformador tem menos perdas do que o inversor com transformador $\mathrm{e}$ em virtude disso, o rendimento do inversor sem transformador é superior aos inversores com transformador. Além do mais esses inversores são mais leves, mais compactos e usam componentes com mais tecnologia que os inversores com transformador. Essa é a

\section{REFERÊNCIAS}

[1]. ANEEL: Agência Nacional de Energia Elétrica. Amplia Possibilidades Para Micro e Minigeração Distribuída, Brasília, 2015. Disponível em: $<$ http://www2.aneel.gov.br/aplicacoes/noticias /Output_Noticias.cfm?Identidade=8955\&id_ar ea=90> Acesso em 14 mai. 2017.

[2]. BENEDITO, R. S., Caracterização da Geração Distribuída de Eletricidade por Meio de Sistemas Fotovoltaicos Conectados à Rede, no Brasil, sob os Aspectos Técnico, Econômico e Regulatório. Dissertação de Mestrado, USP, São Paulo, 2009.

[3]. ESCRITÓRIO VERDE ON LINE Disponível em: $<$ http://www.escritorioverdeonline.com.br/oque-e-o-escritorio-verde/> Acesso em 31 de maio de 2016.

[4]. JOVIC ENGENHARIA Disponível em: $<$ http://joviceng.com.br/blog/category/energia -fotovoltaica/> Acesso em 31 de maio de 2016.

[5]. MACHADO, Karla Suzane Van-Dall; CORREA, Nicoli. Análise do Desempenho de Sistemas Fotovoltaicos Conectados à Rede elétrica em Curitiba. 61 p. Trabalho de Conclusão de Curso (Engenharia Elétrica), Universidade Tecnológica Federal do Paraná. Curitiba, 2015. principal tendência do mercado de energia fotovoltaica no que diz respeito aos inversores, ou seja, utilizar inversores sem transformador com o objetivo de aumentar a eficiência do sistema.

Por fim, o acompanhamento e análise do primeiro ano de operação do SFVCR da Neoville e do Lar Junshin em Curitiba confirma o fato de o sistema do Lar Junshin ser um sistema de alta confiabilidade (opera de forma ininterrupta desde sua instalação), no qual a geração de energia elétrica está em conformidade com os valores esperados, opera de forma limpa e silenciosa e não necessita de área adicional, visto que o painel fotovoltaico foi instalado sobre o telhado da edificação. Estas características fazem da geração fotovoltaica, a forma mais promissora de geração distribuída para o ambiente urbano.

[6]. MARIANO, Juliana D’Angela. Análise do Potencial da Geração de Energia Fotovoltaica Para Redução dos Picos de Demanda e Contribuição Energética nas Edificações da UTFPR em Curitiba. 194 p. Dissertação de Mestrado (Programa de PósGraduação em Engenharia Civil), Universidade Tecnológica Federal do Paraná. Curitiba, 2017.

\section{[7]. MONITOR CHINTPOWER UTFPR} Disponível em: $<$ http://monitor.chintpower.com/Terminal/Termi nalMain.aspx?come=Public\&pid $=153>$ Acesso em 01 de maio de 2017.

[8]. MONITOR.CHINTPOWER LAR JUNSHIN Disponível em: <http://monitor.chintpower.com/Terminal/Termi nalMain .aspx?come $=$ Public\&pid $=99>$ Acesso em 01 de maio de 2017.

[9]. NEOSOLAR. Disponível em: <http:// http://www.neosolar.com.br/aprenda/saibamais/sistemas-de-energia-solar-fotovoltaica-eseus-componentes > Acesso em 24 de abril de 2016.

[10]. PINHO, João T.; GALDINO, Marco A. Manual de engenharia para sistemas fotovoltaicos. CRESESB. 2014. 
[11]. RÜTHER, R. Edifícios Solares Fotovoltaicos: o potencial da geração solar fotovoltaica integrada a edificações urbanas e interligada à rede elétrica pública no Brasil. 1. ed. Florianópolis: Editora UFSC - LABSOLAR, v. Único, 2004.

[12]. TIEPOLO, Gerson Máximo. Título: Estudo do potencial de geração de energia elétrica através de sistemas fotovoltaicos conectados à rede no estado do Paraná. Defesa: 17 de março de 2015. Total de folhas: 230 páginas. Tese Doutorado - Pontifícia Universidade Católica do Paraná. Rua Imaculada Conceição,1155 - Prado Velho.

[13]. TONIN, F. S., URBANETZ JR, J. "Caracterização de Sistemas Fotovoltaicos Conectados à Rede Elétrica - SFVCR". INDUSCON 2016, Curitiba;

[14]. URBANETZ Junior, Jair. Sistemas Fotovoltaicos Conectados a Redes de
Distribuição Urbanas: Sua Influência na Qualidade da Energia Elétrica e Análise dos Parâmetros que Possam Afetar a Conectividade. - Florianópolis, SC, 2010.

[15]. URBANETZ JR, J., CASAGRANDE JR, E. F., "Sistema Fotovoltaico Conectado à Rede Elétrica do Escritório Verde da UTFPR", VIII Congresso Brasileiro de Planejamento energético (VIII CBPE), Curitiba, agosto de 2012.

[16]. URBANETZ JUNIOR, Jair; CASAGRANDE JUNIOR, Eloy; TIEPOLO, Gerson M. Acompanhamento do desempenho do sistema fotovoltaico conectado à rede elétrica do escritório verde da UTFPR. IX Congresso Brasileiro de Planejamento Energético. 2014 


\section{Capítulo 16}

\section{UM MODELO DE SIMULAÇÃO COMPUTACIONAL PARA ANÁLISE DO CUSTO-BENEFICIO DA GERACÃO DE BIODIESEL POR UMA EMPRESA COLETORA DE RESIDDUOS SÓLIDOS URBANOS}

\section{Glauco Oliveira Rodrigues}

Eugenio De Oliveira Simonetto

Wellington Furtado Santos

Daniel Visentini De Barcelos

Adriano Pereira

Resumo: O trabalho apresenta a concepção, desenvolvimento e execução de um modelo computacional, o qual tem por funcionalidade principal analisar o custobeneficio da produção do próprio biodiesel para abastecer os veículos coletores de resíduos sólidos urbanos. Para o desenvolvimento dos modelos, utilizou-se o método de Dinâmica de Sistemas. Através do simulador Vensim (Vensim, 2016), foi possível desenvolver, documentar, simular e analisar os modelos, verificando os impactos causados pela coleta de resíduos nos municípios estudados. Os resultados foram satisfatórios e atenderam as expectativas dos projetistas.

Palavras-chave: Simulação computacional, biodiesel, coleta de resíduos sólidos 


\section{INTRODUÇÃO}

A dependência e o alto consumo de petróleo chamam a atenção de muitos estudiosos no mundo inteiro. Lee (2010), Lam (2010), Masjuki (2011) e Santos e Silva (2016) asseguram existir sinais de esgotamento nas jazidas de petróleo devido a sua utilização como fonte de matéria-prima e energética.

Os excessos da utilização de petróleo provocam mudanças drásticas no clima, como, por exemplo, o aquecimento global. Salienta-se, também, que o consumo de combustíveis fósseis coloca em risco a poluição ambiental dos oceanos causada pelos derramamentos de óleo. Porém, a poluição do ar nas grandes cidades é, sem dúvida, o mais visível impacto da queima dos derivados de petróleo através sua combustão em motores automotivos, trazendo à tona discussões sobre soluções para diminuir o uso desses combustíveis(SANTOS E SILVA, 2016).

Ante esse cenário de necessidade de alternativas para a redução da poluição ambiental, várias são as iniciativas de extensão do ciclo de vida de diferentes resíduos maléficos ao meio ambiente. Setores produtivos como o da coleta dos Resíduos Sólidos Urbano buscam alternativas, não apenas pelo apelo econômico, mas, especialmente, para mitigar os efeitos da degradação ambiental e poluição atmosférica.

Leite (2007) apresenta o biodiesel como sua expectativa por uma energia limpa. O biodiesel ganha espaço no mercado neste novo século, trazendo a opção de sua utilização em motores a diesel. Essa atitude auxilia a diminuição do uso do petróleo, aumenta a renda de famílias com trabalho agrário, além de diminuir as emissões de gases causadores do efeito estufa. Sua inserção na matriz energética mundial é de suma importância, ofertando uma nova energia limpa e sustentável. O biodiesl pode ser uma solução para a dependência de muitos países quanto ao petróleo (SOUZA et al, 2016). Existem diferentes maneiras de produzir biodiesel, como, por exemplo, a utilização do óleo de cozinha "pós-uso". Diversas pesquisas analisam o impacto desse processo de produção, como os trabalhos de Demirbas (2009), Zang e Kong (2010), Bechetet al (2010) e Mendes (2015).

Apesar de a questão ambiental ser muito importante, normalmente as empresas buscam ações sustentáveis verificando quais impactos financeiroselas terão dentro da organização. Ademais, o aumento dos preços do petróleo e a incerteza quanto a sua oferta têm levado os países a buscarem reduzir a dependência desse recurso fóssil, assunto este já tratado com a segurança nacional (MAIA, 2015).

Dentro desse contexto, o presente trabalho apresenta a proposta de um modelo de simulação computacional para a avaliação da relação entre custo e beneficio do aproveitamento do óleo de cozinha na geração do biodiesel necessário para suprir total ou parcialmente o diesel utilizado nos caminhões de coleta de lixo de alguns municípios da região central do estado do Rio Grande do Sul, realizando um comparativo entre o custo da coleta atual com o custo, de duas possibilidades, da geração do biodiesel pela própria organização.

\section{REFERENCIAL TEORICO}

Esta sessão trará um breve estudo bibliográfico sobre os temas à serem estudados neste artigo cientifico.

\subsection{BIODIESEL A ENERGIA SECULAR}

O biodiesel é visto, por muitos pesquisadores, como uma fonte de energia secular, que possui um crescimento recente. Dois motivos principais fazem com que este crescimento seja contínuo: aumento do valor do barril do petróleo e preocupações ambientais. Apesar da existência de diversas tecnologias, as forças da atualidade têm evidenciado o biodieselcomo um dos energéticos mais importantes, aguçando várias pesquisas em busca de uma energia verde adaptada aos temas econômicos, sociais e ambientais (VIDMANTAS et al, 2010). Outro apontamento sobre o biodiesel é o seguinte:

Além de ser menos nocivo ao meio ambiente este biocombustível apresenta vários aspectos positivos relacionados à sua produção e consumo. Como exemplo, ele é um forte motivador social e adapta-se facilmente as condições climáticas e de vegetação do semi-árido brasileiro, o que oferece uma potencial economia e fonte de renda para as regiões pobres. De acordo com Ferreira (2006) a utilização de áreas ociosas e a recuperação de áreas degradadas, somadas às ações do programa de produção 
e uso de biodiesel são caminhos dedesenvolvimento social e econômico(MENDES, 2015).

Tavares e Da Silva (2008) definem o biodiesel como um combustível natural usado em motores a diesel, obtido a partir de matériasprimas vegetais ou animais. As matériasprimas

vegetais são derivadas de óleos vegetais, tais como soja, mamona, palma (dendê), girassol, pinhão manso, amendoim, entre outros (BIODIESELBR). Para uma definição mais estendida sobre esse combustível natural, classificamos o mesmo como um combustível renovável derivado de óleos vegetais ou gordura animal, utilizado em motores a diesel produzido através da remoção da glicerina, que ocorre através de processos químicos.

O combustível secular (biodiesel) é uma alternativa aos combustíveis derivados do petróleo, emitindo menos gases poluidores. Ele está sendo testado em países como a Argentina, Estados Unidos, Malásia, Alemanha, França, entre outros (TAVARES E DA SILVA, 2008). O biodiesel é definido, segundo a lei no 11.097 de 13 de setembro de 2005, como um biocombustível derivado de biomassa renovável para uso em motores a combustão interna com ignição por compressão ou para geração de outro tipo de energia, que possa substituir parcial ou totalmente o combustível fóssil. É obtido através de processos, tais como o craqueamento, esterificação, ou pela transesterificação, sendo esse último o processo mais utilizado para a sua produção

Os motores a diesel que utilizam alguma mistura de biodiesel, possuem uma vida útil aumentada, nesses casos o biodiesel funciona como ótimo lubrificante para o motor e o risco de explosão é muito baixa, devido ao fato do biodiesel precisar de uma fonte de calor acima de $150{ }^{\circ} \mathrm{C}$ para que ocorra um risco de explosão. Esse fato facilita o transporte e armazenamento do produto (TAVARES e DA SILVA, 2008).

O biodiesel possui características que permitem substituir parcial ou totalmente o óleo diesel e derivados do petróleo em motores ciclodiesel automotivos(caminhões, tratores, camionetas, automóveis) ou estacionários (geradores de eletricidade, calor, entre outros) (DIAS et al, 2009). Em misturas de óleo diesel e biodiesel em proporção de até 10\% ocorreu uma redução no consumo de combustível e para proporções maiores que essa ocorreu um aumento no consumo, chegando a 4,77\% quando utilizado o biodiesel puro. Esse aumento no consumo é justificado pela diferença no poder calorífico do biodiesel que, em geral, apresenta-se menor que o poder calorífico do óleo diesel.

Agarwal e Das (2001) verificaram que o uso do combustível B20, testado em um motor a diesel, teve o melhor desempenho entre todas as misturas analisadas, com um benefício de 2,5\% na eficiência térmica máxima e uma redução significativa nos teores de fumaça. Dorado et a I(2002) concluíram que o motor a diesel, analisado sem nenhuma modificação, funcionou de maneira satisfatória com misturas de $10 \%$ de biodiesel de óleo de fritura e 90\% de óleo diesel. Ferrari, Oliveira e Scabio (2005) realizaram testes utilizando 5\% de biodiesel e $95 \%$ de diesel convencional (B5) durante um ano, tendo percorrido 19.240 $\mathrm{km}$ em condições normais de trabalho, e observaram que o veículo apresentou desempenho normal com redução da emissão de fumaça. Além disso, durante o período de realização dos testes não foram necessários reparos no motor, o que induziu os pesquisadores a concluir que os óleos vegetais transesterificados se adaptam perfeitamente ao motor.

Freitas (2008) descreve uma experiência realizada entre os anos de 2003 e 2006 no sistema de coleta do lixo hospitalar do Rio de Janeiro. Nesse caso, nove caminhões de lixo da marca Ford, com o motorCummins e sistema de injeção Bosch, foram divididos da seguinte maneira, cinco destes rodavam com diesel comum, outros dois com B5 de soja e os restantes com B5 de óleo de fritura, ambos passando pelos mesmos problemas e desafios para garantir os resultados serem precisos.Ao fim da observação, os pesquisadores chegaram a conclusões bastante favoráveis ao óleo de cozinha, descrevendo que o B5 do óleo de cozinha, obteve a redução de fuligem quatro vezes maior do que o esperado.

\subsection{SIMULAÇÃO COMPUTACIONAL}

A simulação computacional de sistemas consiste na utilização de um conjunto de métodos e técnicas matemáticas, com o objetivo de imitar o comportamento de sistemas reais, geralmente, utilizando-se de 
computadores e softwares (KELTON; SADOWSKI; SADOWSKI, 1998). Ela pode ser definida como um processo de projetar um modelo de um sistema real e procedimentos de experimentos com esse modelo, com o propósito de verificar o comportamento do sistema ou, até mesmo, avaliar estratégias para a sua operação (PEGDEN; SHANON; SADOWSKI, 1995).

Através do uso da simulação pode-se imitar o comportamento de, praticamente, qualquer tipo de operação ou processo do mundo real (LAW, 2015). Para Chwife Medina (2015) a simulação computacional, necessita de um computador para ser realizada, tendo como objetivo analisar o comportamento do objeto de estudo. Andrade et al(2006) afirma que um modelo computacional deve conter: painel de entrada; gráficos; tabela e controles de saída; modelagem das relações de causa e efeito. $A$ criação de um modelo lógico é uma das principais etapas de um estudo de simulação, este modelo deve ser formado por um conjunto de suposições e aproximações, todas devidamente estruturadas e quantificadas, o objetivo do modelo lógico é representar o comportamento do sistema real estudado com todas suas variáveis possíveis.

Deve-se utilizar modelos lógicos quando deseja-se aprender alguma coisa sobre o sistema real que não pode-se observar ou experimentar diretamente, inexistência do sistema real, dificuldade de sua manipulação, custo alto para executar determinados ensaios. Os resultados obtidos pelo modelo e sistema real, são influenciados pela quantidade de simplificações impostas ao modelo, por esse fato, esse método é uma das ferramentas de análise mais poderosas disponíveis para a representação de sistemas complexos

(KELTON;SADOWSKI; SADOWSKI, 1998). No cotidiano mundial, existem várias aplicações para a simulação computacional, como por exemplo, produção na área de alimentos, controle de trânsito, otimização de rotas utilizadas para entrega de encomendas, recolhimento de resíduos entre outras utilidades.

\subsubsection{MODELAGEM COMPUTACIONAL}

Modelagem Computacional é uma área de conhecimento multidisciplinar que trata da aplicação de modelos matemáticos e técnicas da computação à análise, compreensão e estudo da fenomenologia de problemas complexos em áreas tão abrangentes quanto às engenharias, ciências exatas, biológicas, humanas, economia e ciências. São representações incompletas e mais simples do que o objeto ou sistema em questão (Costa, 2004). Para Andrade et al(2006), a modelagem computacional é uma das ferramentas do pensamento sistêmico que adicionam aprendizado ao processo e por meio da mesma constroem-se micromundos do sistema real. Segundo Bliss e Ogborn(1989), os modelos podem ser desenvolvidos da forma Exploratória, em que - pesquisador explora 0 ambiente computacional através de um modelo computacional já pré-desenvolvido por um especialista. Outro modo é pela forma expressiva, ou seja, o pesquisador desenvolve um modelo computacional não existente. Blisset al(1992) explica que, através do raciocínio quantitativo, pode-se envolver uma variedade de aspectos desde o reconhecimento de relações entre variáveis, até a manipulação de relações algébricas. A manipulação de variáveis é um modo que existe para verificar o grau de mudança que existem entre elas, podendo assim obter maior conhecimento do modelo computacional desenvolvido.

Modelos podem ser físicos ou mentais. Modelos mentais são algo que não podemos tocar, normalmente, surge a partir de uma ideia criada através de algum conceito sobre o objeto de estudo, como, por exemplo, a ideia de governo, exército, família etc. Modelos mentais nos auxiliam a pensar e entender 0 assunto do qual estamos pesquisando ou falando. Estudos de Peter Senge afirmam que os modelos mentais atuam de forma independente e sua causalidade é numa única direção. Já os modelos físicos são as representações de uma estrutura já existente ou a representação criada a partir de um modelo mental (COSTA, 2004).

Chwife Medina (2015) em seu livro descrevem a modelagem computacional como uma apresentação de sistemas reais, possuindo grande importância para entender a complexidade do mundo real. Um modelo de simulação consegue capturar com mais fidelidade as características de tempo, estado e natureza. A partir de softwares essas características capturadas são repetidas em um computador com o mesmo comportamento que o sistema real apresenta, 
auxiliando assim o processo decisório (CHWIF e MEDINA (2015)).

Para pesquisadores como Andrade (2006), Maani e Cavana (2000) entre outros, os modelos podem apresentar dois tipos de modelagem, distintamente chamados de soft e hard. A modelagem soft refere-se a abordagens conceituais que buscam maior realismo, pluralismo e uma intervenção mais holística que a modelagem hard. Os conceitos soft e hard são também relacionados às ideias de qualitativo e quantitativo, respectivamente. Andrade diferencia as modelagens conforme a tabela 1.

Tabela 1. Principais distinções entre as abordagens Hard e Soft

\begin{tabular}{|c|c|c|}
\hline Critério & Abordagem hard & Abordagem soft \\
\hline $\begin{array}{l}\text { Definição do Problema } \\
\text { A organização O modelo } \\
\text { Resultado }\end{array}$ & $\begin{array}{l}\text { Vista como direta, unitária } \\
\text { Assumida tacitamente } \\
\text { Uma representação do mundo real } \\
\text { Um produto ou recomendação }\end{array}$ & $\begin{array}{l}\text { Vista como problemática, pluralista } \\
\text { Requer negociação Progresso pela } \\
\text { aprendizagem Progresso pela } \\
\text { aprendizagem }\end{array}$ \\
\hline
\end{tabular}

Fonte. Adaptado de Andrade (2006)

\section{MÉTODO DE PESQUISA}

Neste artigo, o método de pesquisa para o desenvolvimento do modelo computacional foi baseado na metodologia apresentada por Law (2015) para modelagem e simulação de sistemas, a qual é constituída pelos seguintes passos apresentados na figura 1.

Figura 1. Fluxograma das etapas de aplicação do método de pesquisa

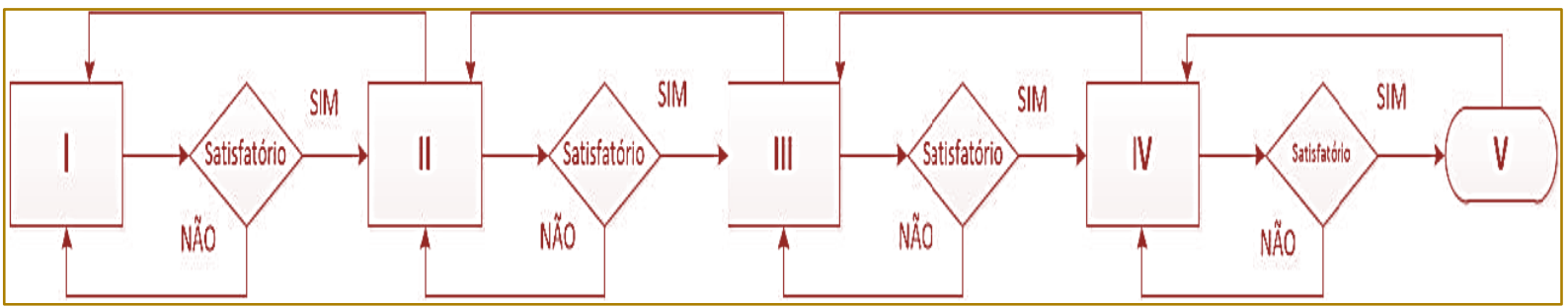

Fonte: Autor (2017)

A etapa (I) representa o estudo exploratório em artigos científicos, relatórios técnicos, entrevistas com stakeholders e observações do ambiente onde os dados foram coletados.

Através desses dados, o problema de pesquisa foi especificado e estruturado. As pesquisas exploratórias têm como principal finalidade desenvolver, esclarecer e modificar conceitos e ideias, tendo em vista a formulação de problemas mais precisos ou hipóteses pesquisáveis para estudos posteriores. Seu planejamento é, portanto, bastante flexível, de modo que possibilite a consideração dos mais variados aspectos relativos ao fato estudado (GIL, 2002). A etapa (II) apresenta o desenvolvimento da solução, através da construção de modelos formais capazes de representar o problema (definição das variáveis e seus relacionamentos). A implementação computacional da solução (etapa (III)), será realizada com o auxilio do simulador Vensim (VENTANA SYSTEMS, 2016) da área de Dinâmica de Sistemas. A etapa (IV) é responsável pela verificação e validação (v\&v) da solução, através de testes em laboratório e análise do comportamento histórico (com os dados que foram possíveis), para verificar se os resultados obtidos representam parte da realidade observada, bem como através da simulação de um experimento utilizando seis cenários para tal. Também foram entrevistados gestores das áreas envolvidas para garantir uma maior fidedignidade ao 
estudo. Por fim, a pesquisa será analisada na etapa (V) onde serão expostas as diferenças entre as possibilidades existentes.

\subsection{TIPO DE PESQUISA}

A pesquisa caracteriza-se por ser uma investigação de natureza exploratória, de abordagem quantitativa, que tem como objetivo investigar o processo de reciclagem do óleo de cozinha bem como as causas que dificultam o ganho de escala neste processo. Segundo Gil (2010), a pesquisa exploratória tem por finalidade ampliar o conhecimento a respeito de determinado fenômeno explorando uma determinada realidade. Para atingir o objetivo proposto pela pesquisa, utiliza-seo estudo de Dinâmica de Sistemas, definido por Ford (2009) como uma combinação de estoques e fluxos que utilizam uma estrutura computacional para serem simulados.

Utilizou-se a abordagem de Andrade et al(2006, pag.101), na qual o autor descreve a modelagem computacional como uma soma entre o trabalho qualitativo (mapa sistêmico) que tem por objetivo analisar e capturar os dados, e um modelo quantitativo, no caso o modelo computacional, que necessita de técnicas do campo da Dinâmica de Sistemas para sua execução. A modelagem em Dinâmica de Sistemas consiste em representar os processos de um sistema. Para seu desenvolvimento, é necessário reconhecer os fluxos que convertem recursos em diferentes estados, o que implica conhecer o seu mapa sistêmico desenvolvido.

\subsubsection{DINÂMICA DE SISTEMAS}

A Dinâmica de Sistemas (DS) estuda o comportamento dos sistemas ao longo do tempo. Tem raízes, entre outras, na teoria dos sistemas, na teoria geral dos sistemas e na teoria do controle. Teorias essas que deram embasamento ao pensamento holístico, citado em algumas áreas da literatura. A primeira publicação sobre a Teoria Geral dos sistemas (TGS) aconteceu em 1945, pelo biólogo Ludwig Von Bertalanffy, na qual o mesmo afirma que a TGS trata os sistemas vivos, como sendo sempre sistemas abertos, ao contrário da Teoria dos Sistemas que trata em especial dos sistemas fechados, focados em automação, engenharia de sistemas, na cibernética e na tecnologia dos computadores (VENSIM, 2004).

Desenvolvida na década de 50 pelo engenheiro Jay Forrester a metodologia dinâmica de sistemas(DS), teve sua primeira aplicação numa análise de uma empresa Americana, que verificou as oscilações nas vendas. A metodologia de Dinâmica de Sistemas (DS), segundo Costa (2004), surgiu quando Jay W. Forrester estava trabalhando em um artigo chamado "Industrial Dynamics, a Major Breakthrough for DecisionsMakers"para o livro "Industrial Dynamics". Nessa pesquisa de Jay, havia a necessidade de utilizar computadores para executar algumas simulações, com o auxílio de seu amigo Richard Bennett para codificar as equações necessárias. Através da necessidade de rodar os códigos complicados, Richard criou o simulador chamado SIMPLE (Simulationof Industrial Management ProblemswithLots os Equations). Esse simulador foi o marco de início da Dinâmica de Sistemas. Hoje, existem diversos softwares, como o Stella, iThink, PowerSim e VenSim, que podem ser utilizados em micros para a implementação de modelos de sistemas. Blois e Souza apresentam sua visão sobre a Dinâmica de Sistemas:

A Dinâmica de Sistemas busca entender a evolução de um sistema ao longo do tempo. A premissa central da abordagem é que o comportamento de um sistema é determinado por sua estrutura interna. Assim, usando de uma linguagem própria para a modelagem, é possível investigar o seu comportamento ao longo do tempo. A DS assume que a análise de uma situação pode ser empreendida de um ponto de vista objetivo externo e que a estrutura e os processos dinâmicos do mundo real podem ser recriados em diagramas com simbologia específica e modelos matemáticos. Além disso, a mesma compreender a estrutura e o comportamento dos sistemas compostos por enlaces de feedback interagentes. Para essa compreensão, utilizam-se dois tipos de notação: Diagramas de Enlace Causal (modelagem soft) e Diagramas de Estoque e Fluxo (modelagem hard).

Dinâmica de Sistemas permite o estudo do comportamento dos sistemas ao longo do tempo, permitindo a avaliação das consequências de nossas decisões. Por essa razão e a necessidade 
de estudar os impactos da reciclagem dos óleos vegetais em um horizonte temporal futuro, decidiu-se utilizá-la na modelagem e simulação computacional. A DS nos auxilia a construir modelos da maioria dos sistemas conhecidos, com apoio de alguns softwares para o uso de computadores pessoais, possamos simular o comportamento destes sistemas ao longo do tempo (VENSIM, 2004).

Um modelo de DS pode ser definido como a estrutura resultante da interação de políticas. Essa estrutura é formada por dois componentes principais, que são os estoques e os fluxos. Ford (2009) define os DS como uma combinação de estoques e fluxos que utilizam uma

estrutura computacional para serem simulados.Os estoques referem-se às variáveis do modelo que são acumuladas no sistema e os fluxos são as decisões ou políticas do sistema. Esses componentes podem estar organizados na forma de relações de causa e efeito, denominadas feedback de balanço ou de reforço e estão sujeitos às defasagens temporais no sistema em análise .

Diversos autores utilizam-se dessa metodologia para a análise de questões relacionadas ao meio-ambiente e a sustentabilidade, dentre os quais se podem citar os estudos de Sufian e Bala (2007); Abeliotiset al. (2009); Dyson e Chang (2005); Kum et al. (2005) e Simonetto (2014).

\subsection{COLETA DE DADOS}

A pesquisa contou com o auxilio de duas empresas privadas da cidade de Santa Maria, uma responsável pela coleta do óleo de cozinha na cidade e outra destinada a coletar resíduos sólidos de sete municípios da região central, a escolha das empresas partiu pelo fácil acesso aos dados e o interesse dos gestores em adaptar novos processos. A primeira etapa da pesquisa constituiu-se em um estudo exploratório, no qual o conceito de logística reversa (produção, coleta, transferência e armazenamento) de resíduos sólidos foi adquirido através de pesquisas bibliográficas, entrevistas e observações in loco do atual contexto logístico da coleta de resíduos sólidos. Verificando a quantidade de diesel gasto por coleta, além do custo total do processo e representando em forma textual para posteriormente ser transposto para um modelo computacional. O modelo computacional que será desenvolvido auxiliará os gestores no processo decisório referente à coleta de resíduos sólidos.

Os estudos exploratórios consistiram dos seguintes passos: a) verificação da existência do problema; b) definição e estruturação do problema; e c) especificação dos requisitos da solução. Na metodologia de pesquisa de Law (2015), os estudos exploratórios compreendem a primeira etapa da metodologia, denominada como formulação do problema.

\subsection{HIPÓTESE DINÂMICA}

Para Silva (2006), a hipótese dinâmica visa trabalhar o problema teoricamente, analisando o seu comportamento e observando quais variáveis fazem parte do sistema. Neste trabalho, incorporaram-se cinco variáveis básicas: (1) variação do uso de diesel por veículo na coleta do lixo da região central do Rio Grande do Sul; (2) emissão de CO2 por veículo; (3) quantidade de óleo queimado para reciclar; (4) biodiesel gerado; e (5) a economia de óleo diesel. O objetivo dessa etapa é formular uma hipótese que explique a dinâmica como consequência da estrutura interna do sistema por meio da interação entre as variáveis e os agentes representados no modelo. Assim, a hipótese dinâmica do modelo de systems dynamics deste trabalho é definida a seguir, como sendo: - A variação do impacto ambiental através da diminuição de detritos liberados na natureza e da emissão de $\mathrm{CO} 2$, além da economia gerada com a produção de biodiesel para substituir o diesel mineral.

\section{DESENVOLVIMENTO DO MODELO DE SIMULAÇÃO}

A crescente busca pela redução da exploração dos recursos naturais da Terra e a necessidade da redução do uso de combustíveis fósseis, fazem com que gestores públicos invistam recursos em novas técnicas para um futuro mais sustentável. Pesquisadores como Maia (2015) e Mendes (2015) apresentam o biodiesel como uma solução para redução dos custos e também do impacto ambiental gerado pelo consumo excessivo do petróleo. A substituição de combustíveis fósseis por renováveis é uma tendência internacional. Seguindo esse pensamento, apresenta-se o desenvolvimento 
do modelo de simulação, expondo a sua validação, cenários e avaliação dos impactos ambientais e financeiros.

Foram entrevistados stakeholders responsáveis pela coleta de resíduos sólidos de sete municípios da região central do Rio Grande do Sul paraentender o processo de coleta. Realizou-se um estudo bibliométrico com o objetivo de identificar as principais características da produção científica internacional relacionada ao biodiesel na última década e,também, buscou-se a base de dados de autores brasileiros como Maia (2015) e Mendes (2015). A partir de planilhas atualizadas fornecidas pelo governo do Brasil foi possível projetar o custo dos combustíveis em até 10 anos. Todas as equações geradas pelas variáveis estão expostas no quadro 1.

Quadro 1. Modelo de Equações

\begin{tabular}{|c|c|}
\hline (1) & DieselA $=$ CombustivelA $*$ TxDiesel \\
\hline (2) & BiodieselA $=$ CombustivelA $*$ TxBiodiesel \\
\hline (3) & DieselB $=$ CombustivelA $*$ TxDiesel \\
\hline (4) & BiodieselB $=$ Combustivel $\mathrm{A}^{*}$ TxBiodiesel \\
\hline (5) & DieselC $=$ CombustivelA ${ }^{*}$ TxDiesel \\
\hline (6) & BiodieselC $=$ CombustivelA $*$ TxBiodiesel \\
\hline (7) & DieselD $=$ CombustivelA $*$ TxDiesel \\
\hline (8) & BiodieselD $=$ CombustivelA $*$ TxBiodiesel \\
\hline (9) & $\begin{array}{l}\text { PreçoBiodieselS10 }=\quad \text { WITH } \\
(2027,10)],(2017,1.433),(2018,1.433),(2019,1.433),(2020,1.433),(2021,1.433),(2022,1.433),(2023,1.43 \\
3),(2024,1.433),(2025,1.433),(2026,1.433),(2027,1.433)))\end{array}$ \\
\hline$(10)$ & $\begin{array}{l}\text { PreçoDieselS10 }=\quad \text { WITH } \quad \text { LOOKUP } \\
(2027,10)],(2017,2.779),(2018,2.798),(2019,2.839),(2020,2.85),(2021,2.859),(2022,2.88),(2023,2.899),( \\
2024,2.949),(2025,2.959),(2026,2.969),(2027,2.977)))\end{array}$ \\
\hline (11) & $\begin{array}{l}\text { PreçoBiodiesel }=\quad \text { WITH } \\
(2027,10)],(2017,1.033),(2018,1.033),(2019,1.033),(2020,1.033),(2021,1.033),(2022,1.033),(2023,1.03 \\
3),(2024,1.033),(2025,1.033),(2026,1.033),(2027,1.033)))\end{array}$ \\
\hline (12) & $\begin{array}{l}\text { PreçoDiesel }=\quad \text { WITH } \\
(2027,10)],(2017,2.5),(2018,2.599),(2019,2.64),(2020,2.679),(2021,2.698),(2022,2.699),(2023,2.74),(20 \\
24,2.749),(2025,2.75),(2026,2.759),(2027,2.77)))\end{array}$ \\
\hline (13) & $\begin{array}{l}\text { Custo Usi/BIO 1(biobot) }=\text { WITH } \begin{array}{l}\text { LOOKUP } \\
(2027,200)],(2017,170),(2018,173),(2019,175),(2020,178),(2021,181),(2022,185),(2023,187),(2024,191 \\
),(2025,194),(2026,196),(2027,200))\end{array}\end{array}$ \\
\hline (14) & $\begin{array}{l}\text { Custo Usi/BIO } 2 \text { (usina) }=\text { WITH } \quad \text { LOOKUP } \quad \text { (TIME, ([(2017,0)- } \\
(2027,2000)],(2017,1500),(2018,1550),(2019,1580),(2020,1600),(2021,1620),(2022,1625),(2023,1635) \text {, } \\
(2024,1650),(2025,1670),(2026,1680),(2027,1700)))\end{array}$ \\
\hline$(15)$ & Custo Biodiesel $=$ BiodieselB $*$ PreçoBiodiesel \\
\hline (16) & CustoBiodieselS10 $=($ BiodieselA+BiodieselC+BiodieselD $) *$ PreçoBiodieselS10 \\
\hline (17) & CustoDiesel $=$ DieselB $*$ PreçoDiesel \\
\hline (18) & CustoDieselS10 = (DieselA+DieselC+DieselD $)^{*}$ PreçoDieselS10 \\
\hline (19) & $\begin{array}{l}\text { Custo da Operação }=(\text { Custo Biodiesel+CustoBiodieselS10+CustoDiesel+CustoDieselS10)+Custo } \\
\text { Usi/BIO }\end{array}$ \\
\hline
\end{tabular}

Fonte: Autor (2017)

\subsection{MODELO COMPUTACIONAL DESENVOLVIDO}

Foram utilizados dados atuais sobre a coleta de RSU na região central do estado do Rio Grande do Sul, com o objetivo de verificar a integração entre todas as variáveis compostas no modelo, bem como dos resultados gerados, já que foram avaliadas as saídas produzidas pelo modelo de simulação a partir de dados reais fornecidos. No total são totalizados sete veículos responsáveis pela coleta de lixo, os caminhões coletores são indicados nos Submodelos com as A, B e C e um veículo responsável pela coleta de óleo residual (indicado nos Submodelo com a letra D).

Este modelo tem por finalidade observar o impacto financeiro relativo à utilização de 
diferentes porções de biodiesel na coleta, provendo aos gestores da área os benefícios da utilização de biodiesel na coleta. Outra análise realizada é a geração do próprio biodiesel pela empresa, através da utilização do processador BIOBOT ou da construção de uma Usina pela própria empresa.

As variáveis auxiliares (PreçoBiodiesel, PreçoBiodieselS10, PreçoDiesel e PreçoDieselS10) são responsáveis por armazenar o custo do combustível nos 10 anos modelados. As Shadow Variables (DieselA, DieselB, DieselC, DieselD, BiodieselA, BiodieselB, BiodieselC,
BiodieselD) combinadas com as variáveis auxiliares citadas inicialmente, são responsáveis por alimentar as variáveis de fluxo (CustoDiesel, CustoDiesels10, CustoBiodiesel, CustoBiodieselS10).

A variável central deste submodelo (CustoOperação) tem por função apresentar o custo da operação. Através do software Vensimpoderá ser visualizada a variação do custo em dez anos, além de apresentar o comparativo do custo pela geração do biodiesel pela própria empresa, esse valor está representado na variável Usi/BIO.Essas interações estão expostas na figura 2.

Figura 2. Submodelo "CustoOperação

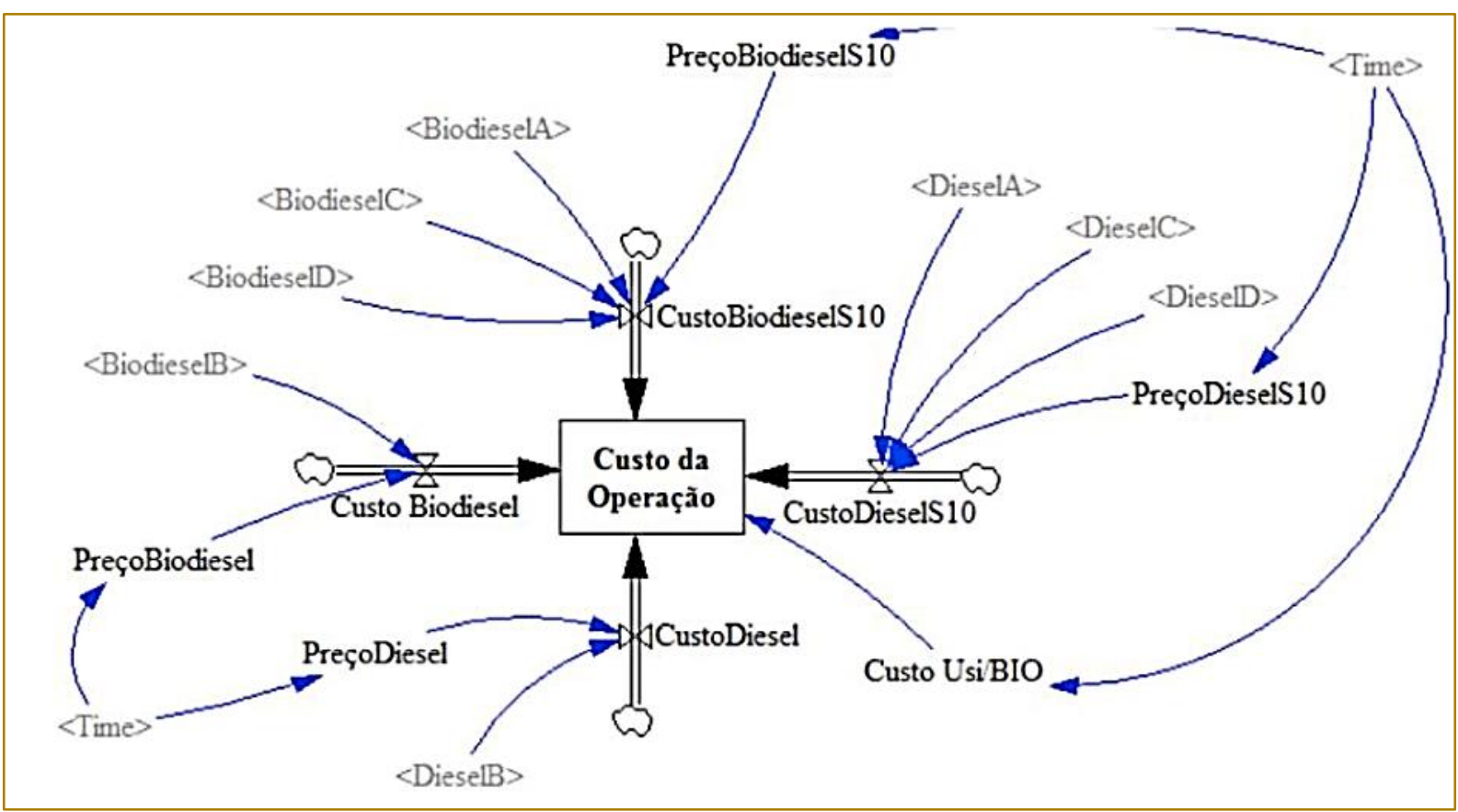

Fonte: Autor (2017)

\subsection{CENÁRIOS}

Técnicas prospectivas, como a geração de cenários, originaram-se entre os militares, durante a segunda Guerra Mundial. Utilizadas de forma sistemática, principalmente pelos Estados Unidos da América, para apoio a mecanismos de formação de estratégias bélicas (MARCIAL e GRUMBACH, 2005). Na França, segundo Godet (2000), esses artifícios eram utilizados em estudos de prospecção geográfica, a partir desse fato tal método foi utilizado em setores da indústria e agricultura.
No Brasil, as empresas utilizaram pela primeira vez a análise por cenários entre os anos de 1980 e 1987. Empresas como a Petrobrás e a Eletrobrás possuíam projetos de longo período e necessitavam de uma análise em grande espaço de tempo. Também no final dessa década, o trabalho elaborado pelo BNDES em 1989, de conteúdo mais econômico, teve grande impacto e abriu grande discussão política sobre os cenários do Brasil.(MORETTI, 2002)

Para a modelagem desenvolvida neste estudo geraram-se seis cenários divididos em 2 grupos. O primeiro grupo representa o comparativo do cenário atual com os cenários 
utilizando o BIOBOT 20 para geração de biodiesel, essa ferramenta é muito utilizada por pequenos produtores para refinar óleos vegetais através da transesterificação. O BIOBOT 20 tem capacidade de produção de vinte litros por hora. O processo de produção é dividido em algumas etapas: inicialmente, o óleo é colocado dentro da câmara de reação para aquecimento e mistura. Após essa etapa, o óleo é testado com o objetivo de verificar a quantidade de ácidos gordos livres, além de determinar a quantidade certa de catalisador de hidróxido de sódio necessário. Por fim, são misturados quatro litros de metanol até o combustível ficar pronto(BIOBOT.ORG.UK, 2016). Os cenários BIOBOT estão expostos na tabela 2.

Tabela2. Grupo de cenários B

\begin{tabular}{|l|c|c|c|c|c|c|}
\hline & \% Diesel & \%biodiesel & BIOBOT & Usina & AnáliseCO2 & AnálisePol. Água \\
\hline Coleta Atual & 93 & 7 & Sim & Não & Não & Não \\
\hline Coleta B10 & 90 & 10 & Sim & Não & Não & Não \\
\hline Coleta B15 & 85 & 15 & Sim & Não & Não & Não \\
\hline
\end{tabular}

Fonte: Autor (2017)

O último grupo de cenários apresenta a proposta de criação de uma usina de biodiesel, de pequeno porte, pela própria empresa. Segundo Vedana (2006), um projeto para construção de uma usina pequena de biodiesel é igual ao de uma grande usina, em ambos os casos deve-se buscar o máximo rendimento de biodiesel por unidade de óleo, além de produzir com alta qualidade de mercado.

Através da Usinagem é possível controlar as temperaturas de aquecimento do óleo vegetal, também se pode recircular a mistura reativa durante o tempo de reação desejado, assim podendo exercer uma ação diretamente no processo de transesterificação. A tabela 3 apresenta os dados dos cenários modelados.

Tabela 3. Grupo de cenários C

\begin{tabular}{|l|c|c|c|c|c|c|}
\hline & \%Diesel & $\%$ biodiesel & BIOBOT & Usina & AnáliseCO2 & AnálisePol.Água \\
\hline Coleta Atual & 93 & 7 & Não & Sim & Não & Não \\
\hline Coleta B10 & 90 & 10 & Não & Sim & Não & Não \\
\hline Coleta B15 & 85 & 15 & Não & Sim & Não & Não \\
\hline
\end{tabular}

\subsection{VALIDAÇÃO DO MODELO COMPUTACIONAL}

A validação em pesquisas envolvendo o desenvolvimento de modelos computacionais para representação de sistemas do mundo real é considerada uma das partes mais importantes para a verificação da qualidade do modelo. Um modelo é uma representação do mundo real ou de parte dele. Portanto, tudo que a validação precisa fazer é verificar se o comportamento do modelo e do mundo real ocorre sob as mesmas condições (PIDD, 1998). Segundo Finlay (1994), um modelo não representa o sistema real em sua totalidade, mas pode-se representar e definir relacionamentos entre os componentes do modelo. Somerville (2015) afirma que a validação deve garantir que todos os requisitos para o desenvolvimento do modelo estão devidamente contemplados no mesmo e que ele é isento de erros na sua concepção.
O modelo de simulação gerado foi validado em diferentes etapas, constituídas em: análises de artigos científicos, manuais técnicos referentes à área da gestão de resíduos sólidos, TIC's, bases do governo federal brasileiro, além de entrevistas com stakeholders da área. Para avaliar a coleta, foram utilizados dados reais coletados diretamente de uma empresa privada responsável pela destinação dos Resíduos dos municípios já apresentados.

A razão de transformação do óleo de cozinha em biodiesel, através da inserção do metanol é da ordem de $80 \%$ (OLIVEIRA;SOMMERLATTE, 2009), embora outras referências apresentem divergências nesse valor (ZUCATTO et al, 2013). Como subproduto no processo há também a geração de glicerina, correspondendo a aproximadamente $\quad 10 \% \quad$ (YANG; HANNA;SUN,2012). 
O combustível utilizado para a realização da coleta varia entre o Diesel comum e o Diesel S10, no qual a partir de 2016 o Conselho Nacional de Política Energética aprovou o índice de sete por cento de biodiesel no diesel. Até 2019, esse índice poderá chegar a quinze por cento, dependendo dos testes em motores a serem realizados (OGLOBO.COM, 2016). Desta forma, para cada litro de diesel B5 deverá ser adicionado 70 (setenta) $\mathrm{ml}$ do biodiesel produzido. Além da economia gerada pela redução da compra de diesel para a utilização nos veículos da coleta, existem outras vantagens adicionais que poderão ser obtidas pela utilização do biodiesel, uma delas é a redução do impacto ambiental resultante do descarte inapropriado, já que a utilização do biodiesel auxilia na diminuição da emissão do dióxido de carbono na atmosfera.

Para validar o custo dos combustíveis utilizados na simulação, foi realizada uma pesquisa no anuário estatístico brasileiro do petróleo, gás natural e biocombustíveis de 2016, além do boletim anual de preços de 2014 e 2015. O custo de produção do biodiesel é fortemente influenciado pelo custo da matéria-prima utilizada. Os custos envolvidos referentes ao processo e aos demais produtos necessários à reação química são estimados em torno de $\mathrm{R} \$ 0,30$ por litro de óleo, ou seja, aproximadamente $\mathrm{R} \$ 1,05$ por litro de biocombustível B100.

Dados publicados no site da ANP em 2015 apresentam a variação do custo do biodiesel B100 nos últimos leilões nacionais, trazendo um comparativo do preço do etanol, matériaprima necessária para a produção de biodiesel. Conforme pode ser observado na figura $x$, o preço do etanol manteve-se, na maior parte de 2014, na faixa de entre US\$ 0,40/galão e US\$ 0,60/galão, acompanhando de perto o preço do biodiesel.

Figura 3. Evolução dos preços de créditos de etanol (RIN D6) e biodiesel (RIN D4) (janeiro de 2013 a dezembro de 2014).

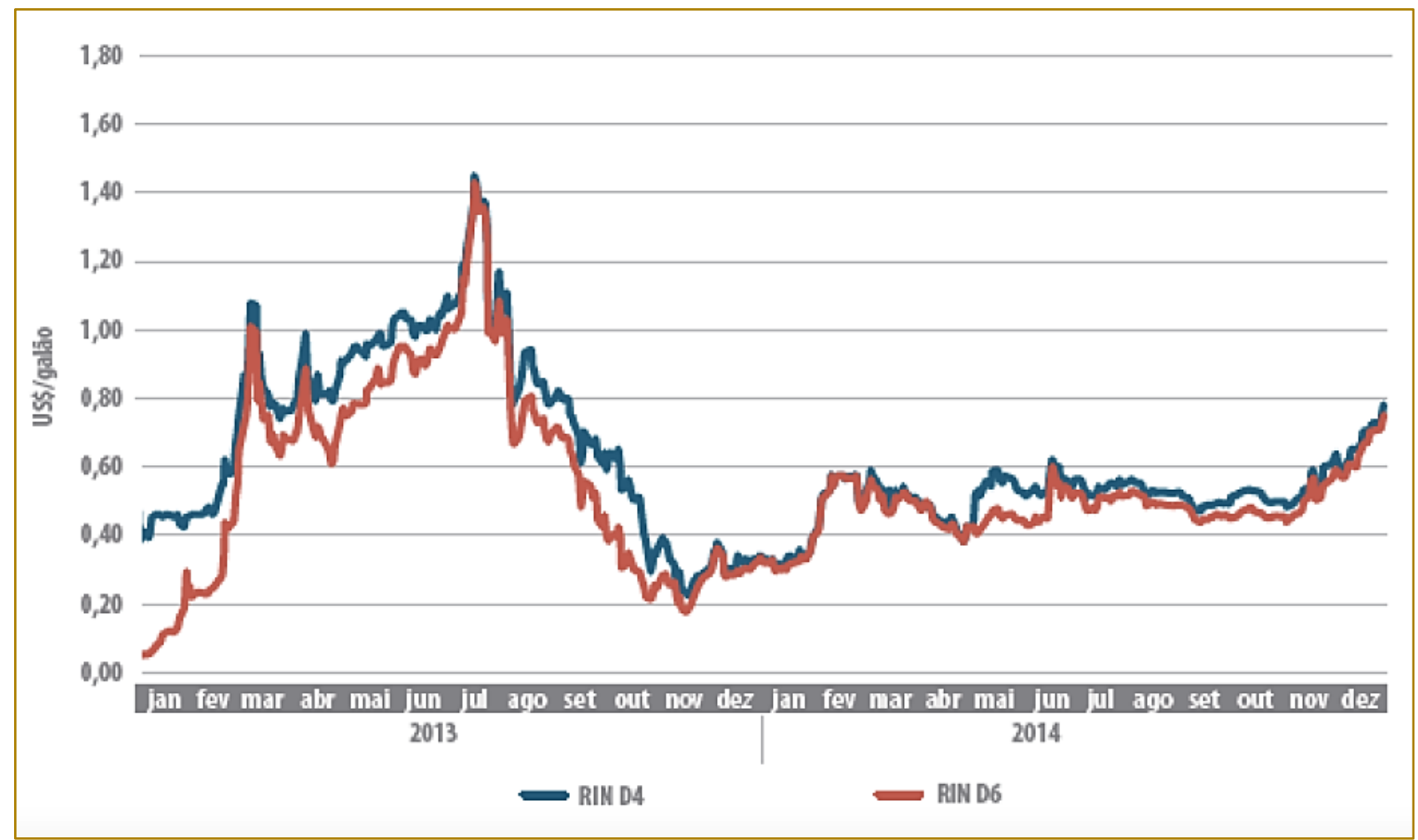

Fonte::ANP (2015)

Os custos relativos à produção do biodiesel através do BIOBOT 20 levam em consideração o processo total da produção. Quatro litros de metanol necessários custam em média \$3,50 e o hidróxido de sódio é executado por US \$0,50. O óleo vegetal é basicamente livre, portanto, um rendimento de 15 litros vai acabar num total de US \$ 1 por galão. Preço mais baixo que os do mercado atual, trazendo ao mercado uma nova solução 
para redução de custos na produção de biodiesel, o BIOBOT pode ajudar a alimentar a revolução do transporte alternativo (BIOBOT.ORG.UK, 2016).

\section{RESULTADOS}

Após a definição dos três cenários para a experimentação do modelo foram executadas as simulações no simulador Vensim (VENSIM,
2016) em um computador com processador Pentium Core i5 e 8 Gb de memória RAM. O tempo de execução da simulação foi na ordem de milionésimos de segundos. O horizonte de tempo simulado no experimento foi de 10 (dez) anos, porém a configuração dessa variável fica a cargo do projetista / usuário, pois a mesma depende da análise a ser feita. A análise dos cenários seguirá os passos apresentados no fluxograma da figura 4.

Figura 4. Fluxograma de análise dos cenários.

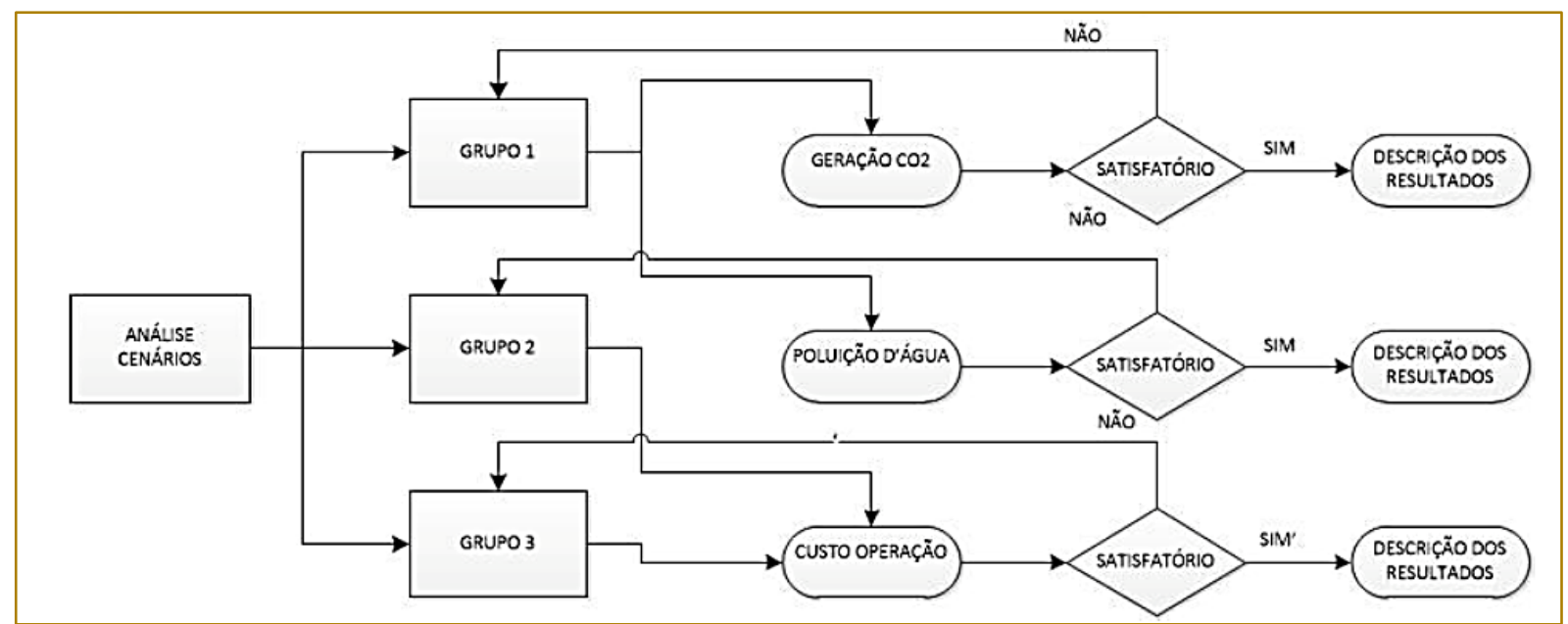

Fonte: Autor (2016).

As decisões, a partir dos resultados gerados pelo modelo, poderão envolver a adoção do combustível proposto (total ou parcialmente), incentivando um maior retorno financeiro. Outras decisões, tais como, redução de compra de diesel, redução na produção de combustível fóssil, também poderão ser sugeridas. Outras análises e observações de interesse dos gestores ambientais e/ou organizacionais, desde que as mesmas sejam passíveis de execução no modelo de simulação, poderão ser executadas, pois o modelo foi concebido buscando simplificar a interação usuário-modelo, para que análises do tipo what-ifsejam de simples execução.

Com objetivo de ofertar aos gestores da área da coleta de Resíduos Sólidos Urbanos, uma opção para a produção do seu próprio biodiesel, modelou-se 3 (três) cenários com a aquisição do BIOBOT 20 pela empresa. A figura 5 apresenta as diferenças no custo da operação para cada cenário. Fica claro que, até a metade do ano de 2020, a diferença entre o custo é praticamente o mesmo. Em 10 (dez) anos de coleta, o cenário que representa a coleta atual (ColetaLixoAtual) acumula o custo de aproximadamente vinte e seis milhões de reais.

O cenário "ColetaLixoB15_BIOBOT" apresenta uma redução de sessenta e dois mil reais ao mês quando comparado ao cenário com maior custo (ColetaLixoAtual). Comparando ao cenário moderado (ColetaLixoB15_BIOBOT) o mesmo apresentará uma economia de aproximadamente quatro milhões em 2027. Caso a empresa não tenha a intenção de aumentar a concentração de biodiesel no diesel utilizado para a coleta, projetou-se o cenário "ColetaLixoAtual_BIOBOT", que apresentou uma redução dos custos de cento e setenta e sete mil reais ao ano, apresentando-se como uma boa opção ao gestor. 
Figura 5. Custo Operação BIOBOT 20

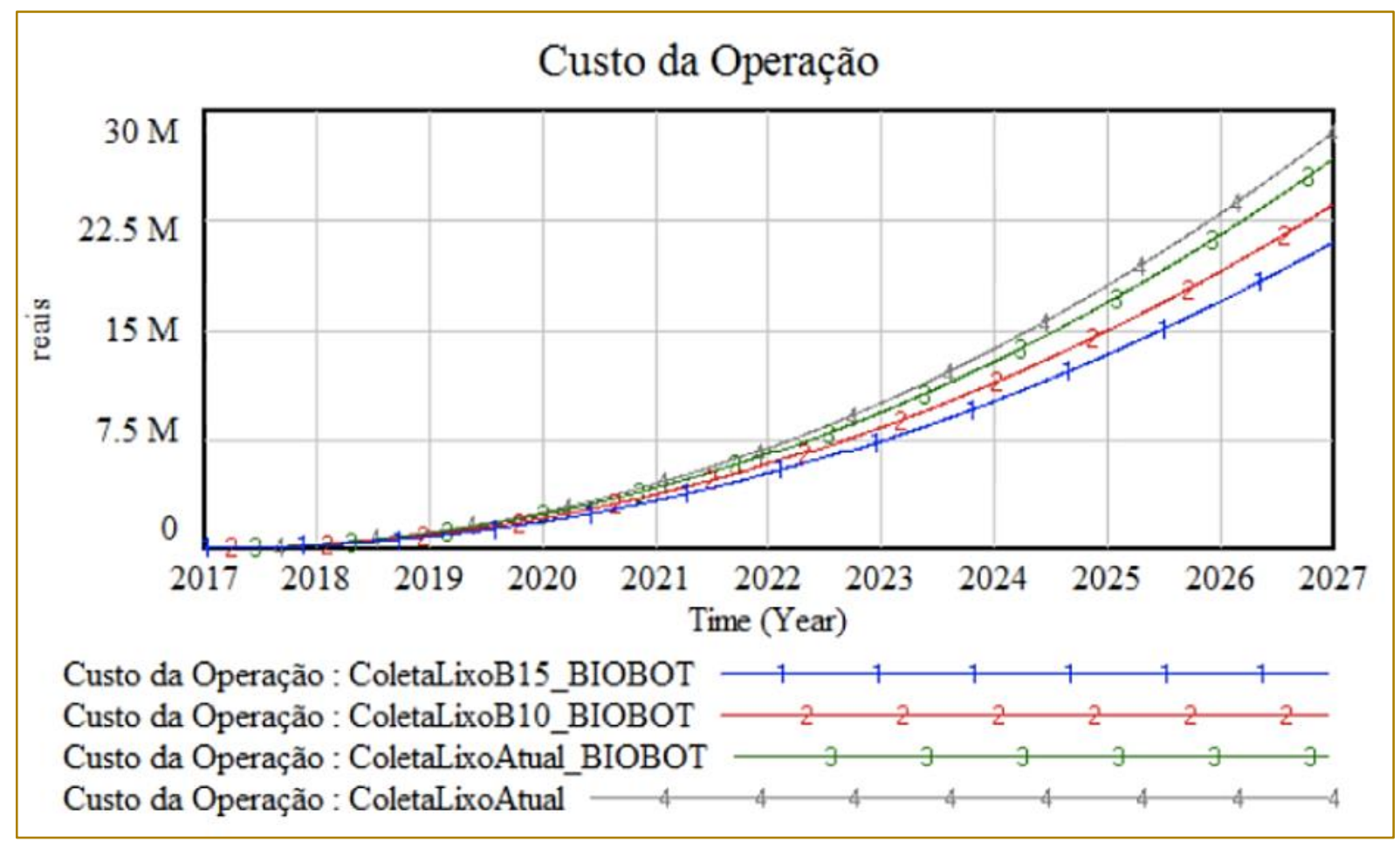

Fonte: Autor (2017)

O cenário atual no ano de 2027 apresenta o maior custo na coleta, apontando aos gestores o BIOBOT 20 como uma boa opção para redução nos custos da coleta total. A tabela 4 apresenta os valores finais do custo da operação total.

Tabela 4. Custo Operação BIOBOT até 2027 (Em Reais)

\begin{tabular}{|c|c|c|c|}
\hline & ColetaLixoAtual_BIOBOT & ColetaLixoB10_BIOBOT & ColetaLixoB15_BIOBOT \\
\hline CustoOperação & 26.684 .400 & 23.577 .800 & 20.986 .800 \\
\hline
\end{tabular}

Fonte: Autor (2017)

Por fim, analisa-se a possibilidade de a empresa gerar seu próprio combustível através da criação de sua própria usina de pequeno porte. Nota-se através da figura 6 a pequena diferença entre os cenários até o ano de 2025 (dois mil e vinte e cinco), a partir desse momento os cenários "ColetaLixoB15_USIBIO" " e " ColetaLixoB10_USIBIO "apresentam um menor custo.
A coleta de lixo que possui um menor custo é representada pelo "ColetaLixoB15_USIBIO" com uma média de redução no custo da operação, quando comparado à coleta atual, de, aproximadamente, cinquenta e dois mil reais mensais, alcançando uma redução acumulada de até seis milhões em 2027. Em comparação ao segundo melhor cenário ("ColetaLixoB10_USIBIO") a redução chega em até dois milhões de reais nos dez anos modelados. 
Figura 6. Custo Operação Usina

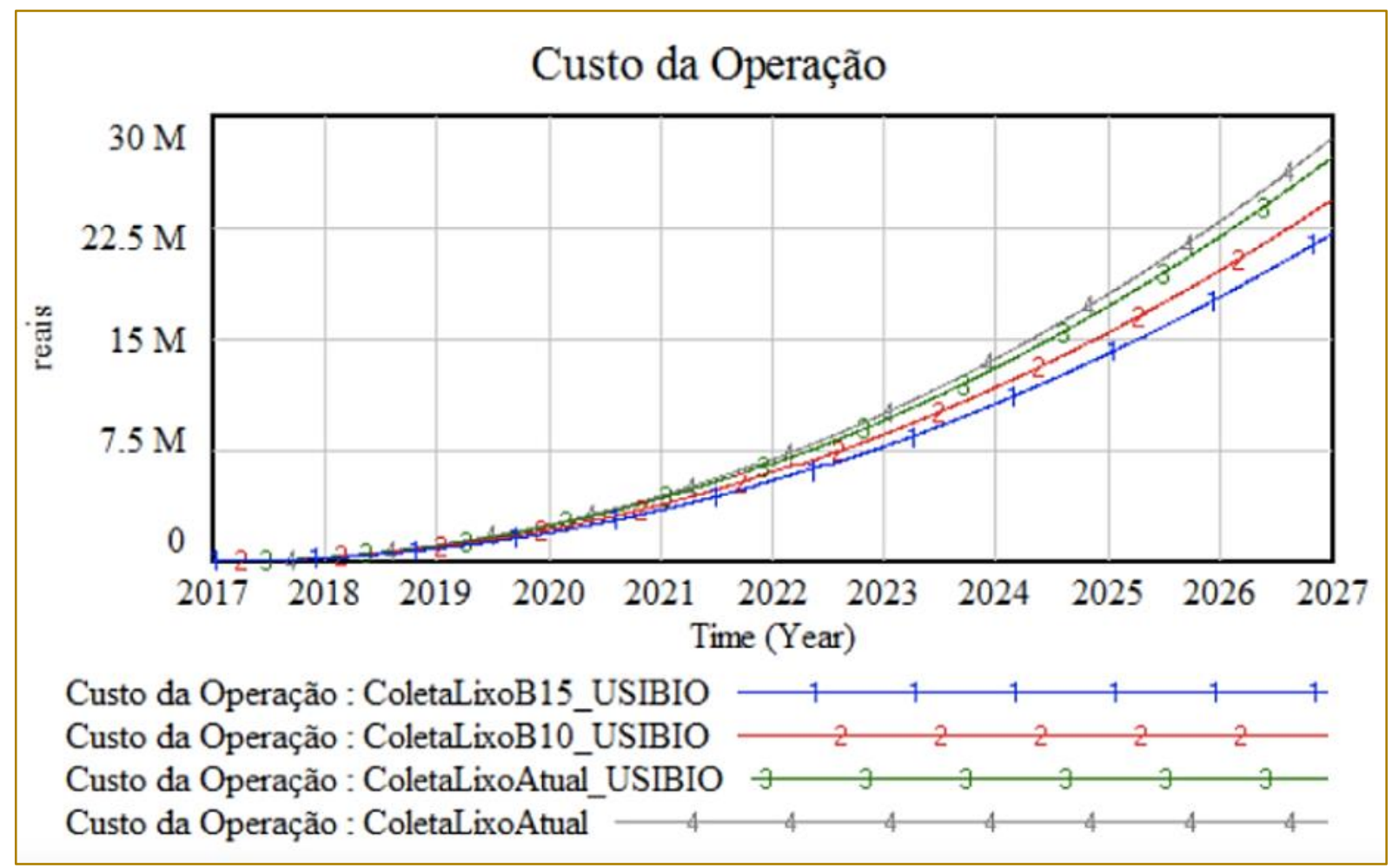

Fonte: Autor (2017)

Em contrapartida a empresa poderá utilizar a mesma porcentagem de biodiesel na coleta, já que o cenário "ColetaLixoAtual_USIBIO" apresenta uma redução mensal de 10 (dez) mil reais, acumulando um milhão e duzentos mil reais no final da modelagem executada. Utilizando quinze por cento de biodiesel a empresa economizará cerca de mil reais por dia, optando por empregar dez por cento de biodiesel a economia chega até quatrocentos mil reais por ano.

Os custos da coleta atual podem ser reduzidos caso os gestores achem interessante utilizar alguma das propostas dessa modelagem. Para deixar mais claro as diferenças entre os cenários simulados, apresenta-se na figura 7 um gráfico gerado pelo simulador Vensim-PLE com todos os cenários utilizados para representar o custo da coleta total. O cenário com maior impacto na economia da empresa é o "ColetaLixo_BIOBOT15", separado por uma diferença de aproximadamente 311 (trezentos e onze) reais diários quando comparado ao segundo melhor cenário ("ColetaLixo_USINA_15”), em relação ao terceiro melhor cenário ("ColetaLixoB15") e economia chega em até 600 (seiscentos) reais por dia. Nota-se que a coleta atual apresenta o maior gasto, comprovando que ao utilizar biodiesel, em maior porcentagem, existe a redução dos custos da operação. 
Figura 7. Custo Operação a de todos os cenários

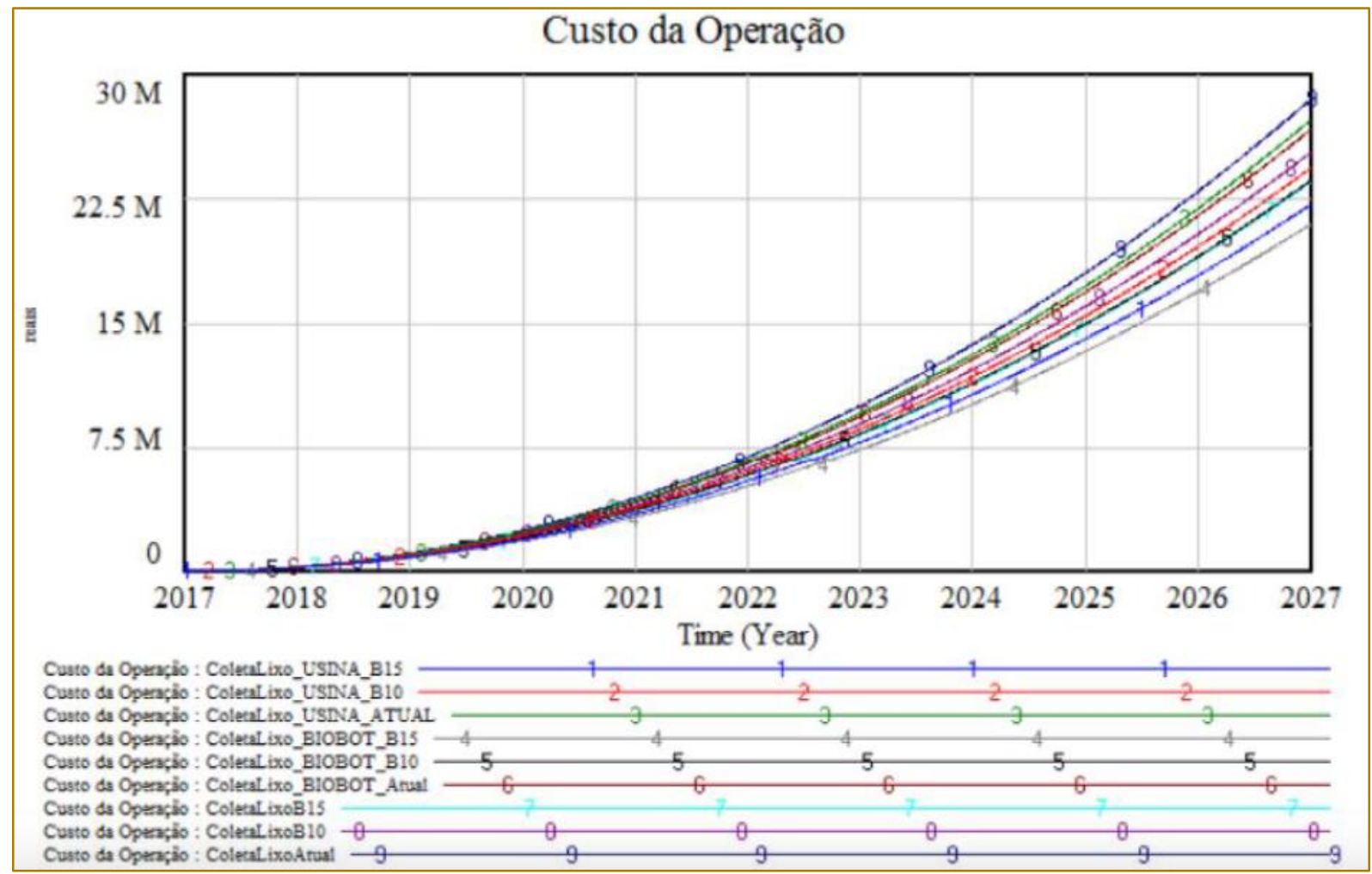

Fonte::Autor (2017)

O BIOBOT apresenta-se como a melhor opção para a empresa na produção do seu próprio combustível. A tabela 5 apresenta o custo de todos os cenários ficando expostas as diferenças de cada um.

Tabela 5. Custo Operação até 2027 de todos os cenários (Em Reais)

\begin{tabular}{|c|c|}
\hline Cenário & Custo \\
\hline ColetaLixo_BIOBOT_B15 & 20.986 .800 \\
\hline ColetaLixo_USINA_B15 & 22.123 .400 \\
\hline ColetaLixoB15 & 23.487 .600 \\
\hline ColetaLixo_BIOBOT_B10 & 23.577 .800 \\
\hline ColetaLixo_USINA_B10 & 24.384 .430 \\
\hline ColetaLixoB10 & 25.628 .000 \\
\hline ColetaLixo_BIOBOT_Atual & 26.684 .400 \\
\hline ColetaLixo_USINA_B10 & 27.222 .400 \\
\hline ColetaLixoAtual & 28.457 .500 \\
\hline
\end{tabular}

Fonte::Autor (2017)

Assim, o resultado denota a importância de possuir políticas de sustentabilidade ambiental e financeira, podendo diminuir o impacto ambiental e econômico.

\section{CONSIDERAÇÕES FINAIS}

O ser humano sempre precisou dos recursos ambientais para a sua sobrevivência. Porém, 
a partir da revolução industrial tomou uma dimensão muito maior e, dessa forma, a natureza não consegue se recuperar no mesmo ritmo da degradação (MASCARENHAS E SILVA, 2013). As diversas possibilidades de reaproveitamento do resíduo estão relacionadas à Sustentabilidade, pois abrangem 0 fator econômico, o fator social e o fator ambiental. Quando em contato com o meio ambiente, impermeabiliza solos propiciando enchentes e deslizamentos e, em contato com a água, além da poluição, o óleo fica na superfície impossibilitando a respiração dos seres desta fauna (MASCARENHAS E SILVA, 2013) Portanto, o objetivo principal deste artigo foi o desenvolvimento, verificação, validação e experimento de um modelo de simulação computacional com o propósito de avaliar grupos de cenários para o reaproveitamento do óleo de cozinha "pós-uso", transformandoo em biodiesel, proporcionando uma idéia de extensão do ciclo de vida desse produto. O biodiesel, segundo Martins e Junior (2014), é viável tecnicamente como combustível e, possivelmente, com vantagens em relação aos combustíveis derivados do petróleo. Dentre estas vantagens estão o fato de gerar um menor impacto ambiental e de ser proveniente de fontes renováveis (Fundação Getúlio Vargas, 2005). Além disso, apresenta alto potencial de biodegradabilidade e baixa toxidade relativa (MEYER, 2011).

A articulação do problema de pesquisa obteve-se através de dois aspectos importantes: Modos de referência e Horizonte de tempo. Modos de Referência: é definir o problema dinâmico, observando o histórico do comportamento dos conceitos e variáveis chaves e prevendo seu comportamento no futuro. Horizonte de Tempo: deve-se considerar o passado, o presente e o futuro do problema, mostrando assim, como o problema está se comportando e descrevendo os sintomas. E, captará o efeito do problema no futuro (SILVA, 2006).

Com relação à hipótese dinâmica, visou-se trabalhar a teoria do problema, analisando o seu comportamento e observando quais as variáveis fazem parte do sistema. A hipótese apresentada no método de pesquisa foi confirmada, pois a utilização de biodiesel na coleta de resíduos sólidos urbanos apresentou impacto ambiental e econômico, podendo ser viável para ser utilizado pela empresa privada estudada.
Para o desenvolvimento do modelo de simulação levou-se em consideração o conceito que modelos de Dinâmica de Sistemas são compostos por variáveis de estoque, fluxo, ambas variáveis endógenas. Um dos objetivos centrais da metodologia de Dinâmica de Sistemas é ter um modelo que consiga simular o comportamento real. Ou seja, a fonte dos problemas em um sistema seja uma parte inerente do modelo desenvolvido.

A metodologia de Dinâmica de Sistemas auxiliou a mapear as estruturas do sistema desenvolvido, procurando examinar sua interrelação em contexto amplo. Através da simulação desenvolvida, a dinâmica aplicada pretende compreender como o sistema em foco evolui no tempo e como as mudanças em suas partes afetam o seu comportamento. A partir dessa compreensão, foi possível diagnosticar e prognosticar o sistema, além de possibilitar simular mais cenários no tempo.

Foram gerados seis cenários, divididos em dois grupos para validação e avaliação do modelo, utilizando dados coletados através de entrevistas com stakeholders e revisão bibliográfica. Os resultados obtidos são condizentes com a realidade. As taxas utilizadas foram desenvolvidas pelo projetista do modelo para realização deste estudo. Cabe ressaltar que os cenários foram gerados para esse experimento, porém o modelo pode ser configurado conforme as necessidades de quem for utilizá-lo, ou seja, é um modelo reconfigurável e aberto.

Com relação específica aos resultados obtidos, para os cenários avaliados, o cenário contendo quinze por cento de biodiesel apresentou os melhores resultados. Caso a empresa decida gerar seu próprio combustível o melhor custo biodiesel é adquirir O BIOBOT 20, o mesmo causará um maior impacto financeiro na coleta. Mesmo que a empresa não deseje aumentar a porcentagem de biodiesel, a coleta atual poderá obter melhor desempenho financeiro caso queiram aderir o BIOBOT 20.

Como trabalhos futuros, pretende-se expandir o modelo a outras áreas de coleta que não foram considerados no estudo, tais como, a cidade de Santa Maria e, também, considerar na avaliação os benefícios sociais que podem ser gerados, como por exemplo, a geração de emprego. 


\section{REFERÊNCIAS}

[1]. ABELIOTIS, K. Decision Support Systems in Solid Waste Management: A Case Study at the National and Local Level in Greece.Global NEST Journal, v.11, n. 2, p. 117-126, 2009

[2]. AGARWAL, A. K.; DAS, L. M. "Biodiesel developmentandcharacterization for use as fuel in compressionignitionengines".J. Eng. GasTurb. Power-T. ASME, v.123, p.440-447, 2001.

[3]. ANDRADE, A.L; SELEME, A.; RODRIGUES, L.H.; SOUTO, R. Pensamento Sistêmico: caderno de campo: o desafio da mudança sustentada nas organizações e na sociedade. Porto Alegre, Bookman, 2006.

[4]. ANP. Agência Nacional do Petróleo, Gás Natural e Biocombustíveis. Boletim Anual de Preços 2015: preços do petróleo, gás natural e combustíveis nos mercados nacional e internacional/ Agência Nacional do Petróleo, Gás Natural e Biocombustíveis. Rio de Janeiro: ANP, 2015. 164 p.: il. color., gráficos, tabelas.

[5]. BECHET,Q.;SHILTON,A.;FRINGER,O.B.;M UNOZ,R.;GUIEYSSE,B.Mechanistic Modeling of Broth Temperature in Outdoor Photobioreactors. Environmental science\&technology, v.44, n.6, p.2197-2203, 2010.

[6]. BLISS, J.; OGBORN, J. Tools for Exploratory Learning.Journalod Computer Assisted Learning, Bristol, UK, v. 5, n. 1, p. 37-50, 1989.

[7]. BLISS, J.; OGBORN, J.; BOOHAN, R.; BRIGGS, J.; BROSNAN, T.; BROUGH, D.;

[8]. MELLAR, H.; MILLER, R.; NASH, C.; RODGERS, $\quad$ C.; $\quad$ SAKANIDIS, ReasoningSupportedby Computacional Tools.Computers in Education, UK, v. 18, n. 1, p. 19, 1992.

[9]. CHWIF, L.; MEDINA, A.C. Modelagem e Simulação de eventos discretos: Teoria e Aplicação, 4ed. Elsevier. Rio de Janeiro. 2015.

[10]. DEMIRBAS, M.F. Biorefineries for biofuel upgrading a critical review. Applied energy, v.86, n5151-5161, 2009.

[11]. DIAS, M.F.P.D.; JUNIOR, S.S.; ROSA, N.P.; MENDONÇA, E. ; SILVA, T.N. Análise da sustentabilidade da produção de biodiesel de soja no Brasil, Revista Administração, V.9, n. 14, p. 1345, 2009.

[12]. DORADO, M. P.; ARNAL, J. M.; GOMEZ, J.; GIL, A.; LOPEZ, F. J. The effectofwastevegetableoilblendwith diesel fuelonengineperformance. Trans. ASAE, v.45, p.525-529, 2002

[13]. DYSON, B., CHANG, N.B. Forecasting municipal solid waste generation in a fast-growing urban region with system dynamics modeling. Waste Management, v.25, n.7, p.669- 679, 2005.
[14]. FERRARI, R. A.; OLIVEIRA, V. S.; SCABIO, A. Biodiesel de Soja: taxa de conversão em ésteres etílicos, caracterização físico-química e consumo em gerador de energia. Quim. Nova, v. 28, n. 1, p. 19-23, 2005.

[15]. FORD, A. Modeling the environment, Second Edition.Island Press, 2009.

[16]. FREITAS, C. F.;BARATA, R. A.; L. NETO S.M, Utilização do óleo de cozinha usado como fonte alternativa na produção de energia renovável, buscando reduzir os impactos ambientais, inXXX ENCONTRO NACIONAL DE ENGENHARIA DE PRODUÇÃO, 2010

[17]. KELTON; SADOWSKI; SADOWSKI, A. Simulationwith Arena. New York: McGraw-Hill, 1998.

[18]. KUM, V.; SHARP, A.; HARNPORNCHAI, N. A. System Dynamics Study of Solid Waste Recovery Policies in Phnom Penh City.23rd International Conference of the System Dynamics Society, Boston.Proceedings SDS, 2005.

[19]. LAM, M.K. Homogeneous, heterogeneousandenzymaticcatalysis for transesterificationof high freefattyacidoil (wastecookingoil) to biodiesel.review BiotechnologyAdvancesVolume 28, Issue4, JulyAugust 2010, Pages 500-518, 2010

[20]. LAW, A.M. Simulation Modeling and Analysis.5Ed., McGraw-Hill, 2015.

[21]. LEITE, R.C.C. LEAL, M.R. L. V. O Biocombustível no Brasil.Revista Novos Estudos, Julho/2007

[22]. MAIA, R.R.S. Biodiesel no Brasil análise de custo-benefício. Editora annris, Curitiba, Paraná, 2015.

[23]. MENDES, P.A.S. Sustentabilidade na produção e uso do biodiesel. Curitiba. Annris. 2015.

[24]. PEGDEN, C. D.; SHANON, R. E.; SADOWSKI, R. P. Introduction to simulation using.SIMAN.2nd ed. McGraw-Hill, 1995.

[25]. SANTOS. R. S. Gerenciamento de resíduos: coleta de óleo de cozinha, 2009. Disponível

em:<http://www.poslogistica.com/web/TCC/20092/tcc-268.pdf> Acesso em 12 mai. 2015.

[26]. SANTOS, M.X; SILVA, J.GF.; Aproveitamento do óleo residual de fritura na produção de biodiesel. Rev. Eletrônica Mestr. Educ. Ambient. E-ISSN 1517-1256, v. 33, n.1, p. 299- 306, jan../abr., 2016.

[27]. SILVA, E.O impacto da gestão do tamanho da força policial na taxa de violência em Curitiba: Uma abordagem qualitativa sob o referencial da 
dinâmica de sistemas, Dissertação de Mestrado, Pontifícia Universidade Católica do Paraná, 2006.

[28]. SIMONETTO, E.O. Simulation computer to evaluate scenarios of solid waste - an approach using systems dynamics. International Journal of Environment and Sustainable Development, v.13, n.4, p.339-353, 2014.

[29]. SOUZA, V.H.A.S;SANTOS, L.T.S;CAMPOS, A.F.C;CAROLINO, J. Um panorama do biodiesel no Brasil e no mundo: esforços para a ampliação do setor e desafios, Rev. Augustus, Rio de Janeiro, v. 2 1, n . 41, 2016.

[30]. SUFIAN, M.A., BALA B.K. Modeling of urban solid waste management system: The case of Dhaka city. Waste Management, v.27, p.858-868, 2007.

[31]. TAVARES, B.M.; DA SILVA. S.R.R. Biodiesel: fonte de combustível limpo atuando como rica contribuição estratégica, social e ecológica na região de Lins, Monografia apresentada ao Centro Universitário Católico Salesiano Auxilium - UNISALESIANO, Lins- SP, para graduação em Administração, 2008.

[32]. VENSIM - Ventana Simulations (2014), Vensim simulation software. Disponível em: <http://www.vensim.com>, 2014. AcessadoemDez. 2014
[33]. VENTANA SYSTEMS.Vensim Simulation Software.Availableat: $\quad$ http://www.vensim.com Acessado em fev, 2016.

[34]. VIDMANTAS, J.B.D ; TIROLE, C.A.S ; BIGATÃO, D.A.R ; JUNIOR, M.F.J. Estudo do

[35]. Destino de Resíduos Oleosos em Estabelecimentos de Comida Rápida, Situados em Shopping na Cidade Dourados/MS, III Simpósio Intercâmbio Brasil-Japão em Sustentabilidade: Um Desafio da Humanidade, Campo Grande, Mato Grosso, 2010.

[36]. YANG, F.; HANNA,M. ;SUN,R. Valueadded uses for crude glycerol-a byproduct of biodiesel production.Biotechnology for Biofuels,5(1):13, 2012.

[37]. YIN, Robert K. Estudo de caso: planejamento e métodos. 3 ed. Porto Alegre: Bookman, 2005

[38]. ZHANG,L;KONG,S.C. Vaporization modeling of petroleum-biofuel drops using a hybrid multi-component approach.Combustionand Flame, v.3/, n-6, p.2448-2955, 2010.

[39]. ZUCATTO, L. C.;WELLE, I. ; SILVA, T. N. D. Cadeia reversa do óleo de cozinha: coordenação, estrutura e aspectos relacionais. RAE - Revista de Administração de Empresas, 53(5), 2013. 


\section{Capítulo 17}

\section{GESTÃO ESTRATÉGICA DE EMPRESAS DO TERCEIRO SETOR: UM ESTUDO DE CASO}

\section{Rosilane Chimene}

Ana Lúcia Magalhães

\section{Éber José dos Santos}

\section{Bruno Andreoni}

Resumo: O estabelecimento de uma cooperativa sólida e organizada a partir de catadores de lixo, que aconteceu na primeira década do século XXI no município de Guaratinguetá, SP, como o nome de Amigos do Lixo, foi não menos que uma façanha do voluntariado, da visão de sustentabilidade e mesmo da solidariedade humana. Existem, no entanto, ameaças importantes na possibilidade de redução de número de cooperados e, principalmente, na possibilidade de dirigentes municipais se desinteressarem pela cooperativa e retirarem o apoio. A possibilidade de crescimento e mesmo sobrevivência dessa iniciativa depende de tratamento da cooperativa em parâmetros crescentemente empresariais. Um modo particularmente eficiente de equacionar o problema e buscar soluções é a análise SWOT, ferramenta empresarial comprovadamente adequada às organizações do Terceiro Setor. Tal análise, para a Cooperativa Amigos do Lixo, revelou que são necessárias ações de alguma agressividade na busca de novos cooperados, implantação de áreas de reciclagem e conquista de maior número de empresas parceiras. Paralelamente a isso, deve haver um esforço de engenharia no sentido de proporcional maior agregação de valor aos recicláveis coletados.

Palavras Chave: Análise Swot - Sustentabilidade - Cooperativa - Terceiro Setor - 


\section{INTRODUÇÃO}

A democracia burguesa, liberal, derrotou os aristocratas (séculos XVI e XVII), a realeza (século XVIII e início do século XIX), o fascismo (1945) e o comunismo (1989). O filósofo Francis Fukuyama (1992) chegou a declarar, em livro famoso, que o fim da História havia chegado o fim, uma vez que a humanidade havia decidido qual a melhor forma de governar e de conduzir a Economia.

O desenrolar dos acontecimentos, logo em seguida, mostrou que Fukuyama havia se precipitado: surgiu a China como grande potência econômica. Com isso, a divisão internacional do trabalho sofreu grandes modificações, houve uma grande crise do capital, em 2008, e esse encadear de fatos mostrou, de forma categórica, que o mercado não é capaz de cuidar de tudo. Em 2013, o professor francês Thomas Piketty mostrou, com abundância de fatos e dados, que a própria dinâmica de acumulação do capital engendra inevitavelmente sua concentração em uma parte muito pequena da população.

Então, ainda que o mercado seja necessário para inovar e criar riqueza, é necessário que haja instituições que venham a exercer uma ação corretiva nos chamados excessos do mercado.

Este trabalho mostra uma instância em que uma iniciativa do Terceiro Setor estabeleceu parcerias de vários tipos com o mercado. Essa iniciativa, apesar de bem sucedida, apresenta fragilidades e potencial, exatamente o contexto organizacional em que se faz necessária uma análise SWOT, sigla formada por iniciais de palavras em Inglês que significam Forças, Fraquezas, Oportunidades e Ameaças.

A análise SWOT tem sido utilizada em organizações do Terceiro Setor como ferramenta para identificar os fatores positivos e negativos dentro das organizações, comunidades e sociedade em geral. É usada para explorar novas soluções para problemas, identificar barreiras que limitem metas e objetivos, auxiliar na decisão sobre caminhos mais efetivos e revelar possibilidades de mudanças $e$ as limitações associadas. A análise SWOT oferece mais segurança durante reuniões e apresentações com parceiros, doadores em potencial, autoridades e voluntários.

Bryson (2010) mostra que, mesmo nos Estados Unidos, a maioria dos esforços em desenvolver organizações do Terceiro Setor têm uma limitação básica na ausência de planejamento estratégico. Segundo esse autor, qualquer esforço em projetar o futuro dessas organizações passa pelo uso de ferramentas como a análise SWOT.

Liu e Takeda (2012) lembram que as organizações do Terceiro Setor devem buscar uma eficiência equivalente à das empresas do mercado, inclusive em efetividade das práticas gerenciais e procura de satisfação dos clientes.

É essa, portanto, a orientação deste trabalho o uso de uma ferramenta típica do mercado em uma instituição consolidada do Terceiro Setor. O item dois, a seguir, é uma breve apresentação da organização e do contexto. O trabalho prossegue com uma explanação da origem, objetivos e prática da análise SWOT. A quarta parte é a análise propriamente dita, seguida de recomendações e conclusões.

\section{CONTEXTO - A COOPERATIVA AMIGOS DO LIXO}

A Cooperativa Amigos do Lixo, localizada na cidade de Guaratinguetá, Vale do Paraíba, SP, foi criada em 2000 e teve como idealizadores o engenheiro André Luiz de Paula Marques, na época Secretário de Serviços Urbanos da cidade e a psicóloga e técnica da Caixa Econômica Federal, Ana Maria Lourenço de Almeida.

No início, a intenção do engenheiro era realizar um programa integrado de gestão de resíduos sólidos no município. Com a parceria da psicóloga, o objetivo se ampliou: mudar a realidade de uma grande quantidade de pessoas, inclusive crianças que, à procura de material reciclável, vasculhavam o chamado lixão da cidade, local que ficava a 8 quilômetros do centro e a 1 quilômetro do rio Paraíba do Sul, que abastece várias cidades do Vale do Paraíba e onde o material era acumulado.

O programa previa, entre outros objetivos, a coleta seletiva e a reciclagem do lixo em toda a cidade e a transformação do lixão em aterro sanitário.

As ações levadas a efeito em um primeiro momento foram: análise do mercado de produtos recicláveis; preparação da coleta seletiva, com a fabricação de 10 carrinhos manuais, financiados por um empresário da 
cidade; confecção de 3 mil adesivos para divulgar o Projeto e 800 folhetos explicativos sobre como separar o material reciclável, com a cooperação do Serviço de Águas da cidade; curso de capacitação profissional para os catadores, colaboração do SEBRAE e do SENAC utilizando-se metodologia e material fornecidos pelo Compromisso Empresarial para a Reciclagem (CEMPRE).

Os catadores formados pelo curso e então denominados agentes ambientais (o que foi muito positivo para a autoestima deles) foram apresentados aos moradores da região escolhida para a atuação do projeto. Houve envolvimento de estudantes e representantes de vários segmentos da sociedade. Responsáveis pelo projeto e voluntários conscientizaram os moradores sobre a importância da separação dos materiais recicláveis e da importância dos agentes. Com a divisão dos bairros da região em rotas de coleta, cada agente responsável por determinada rota passou a ter contato direto com os moradores e tornar-se conhecido.

$\mathrm{Na}$ Central de Triagem, implantada desde o início, são efetuadas pesagem, separação por tipo, prensagem e enfardamento para venda. Desse modo, é possível efetuar um rigoroso controle sobre a identificação do material que cada agente ambiental coletou. Os agentes ganham por produção, ou seja, por peso e valor de mercado do produto coletado.

Cumpre notar que a designação Agentes Ambientais, não é puramente promocional. Esses agentes efetivamente contribuem para reduzir a poluição em um rio que é manancial importante e serve uma população que se conta em oito dígitos. Agente da Sustentabilidade seria uma nomenclatura também adequada.

A cooperativa Amigos do Lixo conquistou o apoio de empresas, instituições e da própria prefeitura. Hoje atende $40 \%$ da população do município e conta com a participação de 44 agentes ambientais.

A cooperativa obteve um empréstimo do Banco do Povo (do governo estadual) e adquiriu um caminhão. As parcelas do empréstimo são pagas com o dinheiro da venda do papelão coletado na BASF, uma das maiores empresas da região. $\mathrm{Da}$ prefeitura, a cooperativa conseguiu um terreno emprestado para que fosse construída a central de recolhimento e outro caminhão (com motorista remunerado pela instituição) para complementar o transporte do material. Vários empresários doam ao Projeto, desde sua fundação, material de construção, uniformes e

equipamentos de segurança. Alguns voluntários chegaram a ministrar cursos de alfabetização para os agentes que não sabiam ler. A Associação Comercial de Guaratinguetá mobilizou os empresários para apoiarem o Projeto. Além disso, os agentes ambientais participaram de festas e eventos para divulgar o Projeto e recolher materiais recicláveis.

Até hoje, os coordenadores ministram palestras em escolas e empresas a fim de buscar novos parceiros. O objetivo dos coordenadores é o acesso à coleta seletiva de todos os bairros do município. Segundo estimativas, essa meta requer a participação de 100 agentes ambientais, a construção de mais duas centrais de triagem e a compra de mais um caminhão.

\section{A ANÁLISE SWOT}

Panagiotou (2003) mostrou a dificuldade de encontrar as origens da análise SWOT. Normalmente, o crédito pela concepção da ferramenta é dado a Albert Humphrey, da Stanford University, em seu trabalho nos anos 1960 e 1970. No entanto, já nos anos 50, dois professores da Harvard Business School, Smith Jr. e Christensen pesquisaram a técnica, com outro nome, e publicaram os conceitos básicos. No final dos anos 50 , outro professor de Harvard, Kenneth Andrews, desenvolveu aplicações para as teorias de Smith e Christensen. Todos eram professores de estratégia organizacional. Enfim, não há um momento na História em que se possa afirmar que a análise SWOT tenha sido criada.

A figura 1, a seguir, mostra a essência da análise SWOT, que tem o grande mérito de ser intuitiva. O esquema mostrado foi desenvolvido por Kotler \& Keller (2006). 
Figura 1: Esquema da análise SWOT

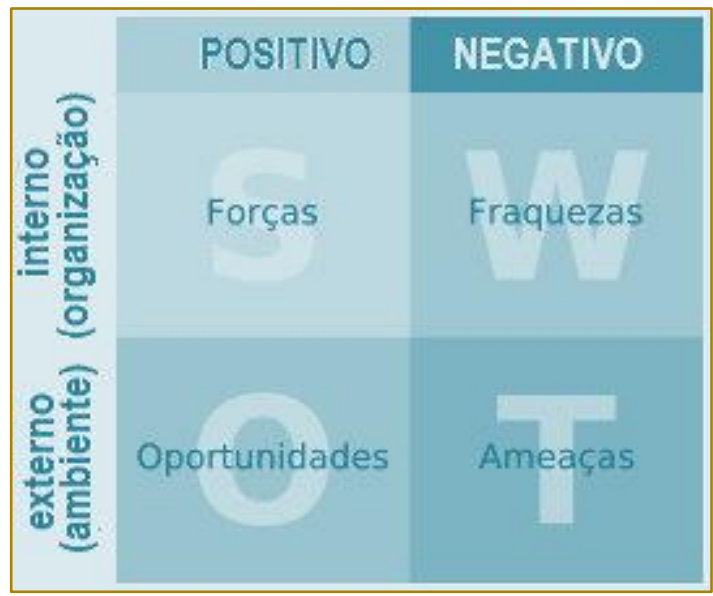

Sempre segundo Panagiotou (2003), e lembrando que a sigla consiste nas iniciais das palavras em Inglês, há fatores internos, que estão sob o controle da organização, como microambiente, e fatores externos, que são condicionantes não controláveis, como o macroambiente,. Ambos têm aspectos positivos e negativos.

A análise SWOT é, principalmente, uma exame desses fatores, que são grupados conforme mostra o diagrama.

Cumpre notar que a simplicidade do esquema comporta análises rápidas e até superficiais, mas também investigações complexas e com nuances.

\subsection{CRITÉRIOS PARA O ESTABELECIMENTO DE METAS}

Depois de realizada a análise SWOT, a empresa pode definir metas específicas para o período de planejamento. Essa etapa do processo é denominada estabelecimento de metas. Os gerentes utilizam o termo metas para descrever objetivos em termos de magnitude e prazo. A maioria das unidades de negócios procura um conjunto de objetivos que incluem lucratividade, crescimento das vendas, aumento na participação de mercado, contenção de riscos, inovação e reputação. As unidades de negócio estabelecem esses objetivos e, então, pratica a Administração por Objetivos (APO) (Kotler \& Keller, 2006).

Para que um sistema de Administração por Objetivo funcione, os vários objetivos da unidade devem atender a 4 critérios:
Organização dos objetivos: os objetivos devem ser organizados hierarquicamente, do mais importante para o menos importante. Agindo dessa maneira, o negócio pode migrar de objetivos amplos para objetivos mais específicos, voltados a departamentos e pessoas determinados. Por exemplo, o objetivo geral é aumentar a quantidade de bairros atingidos, o que leva ao objetivo específico de adquirir mais caminhões.

Quantificação dos objetivos: sempre que possível, os objetivos devem ser estabelecidos quantitativamente. Um bom exemplo é a receita que se pretende obter em um determinado horizonte de tempo.

Realismo: as metas devem ser realistas e surgir de uma análise das oportunidades e das forças da unidade de negócios, não de meros anseios. Um exemplo de meta irrealista seria estender o sistema a outras cidades da região em um prazo curto.

Consistência: os objetivos devem ser consistentes. Não é possível, por exemplo, aumentar o número de bairros atingidos e minimizar a quantidade de veículos para aumentar a remuneração dos agentes.

\section{ANÁLISE SWOT DA COOPERATIVA AMIGOS DO LIXO}

\subsection{MICROAMBIENTE}

A figura a seguir, desenvolvida a partir de informações obtidas em entrevista com o gestor, mostra os agentes envolvidos no funcionamento da Cooperativa. 
Figura 2: Esquema de relacionamento

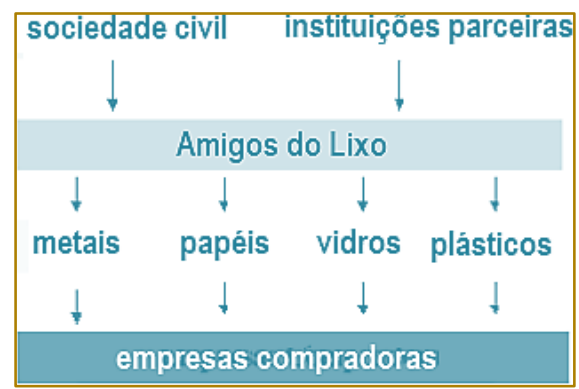

A sociedade civil é a fomentadora e realmente participa, organizando eventos, efetuando doações de artigos como móveis de escritório e peças de veículos e exercendo ações de voluntariado, como cursos de alfabetização. As instituições parceiras são o SEBRAE e o SENAI, que fornecem treinamento; o Banco do Povo, que concede financiamentos sem burocracia e a juros baixos; a Prefeitura, com o importantíssimo caminhão com motorista e a própria ação de enquadrar o trabalho da cooperativa no esquema municipal de coleta e tratamento de lixo.

As empresas compradoras visam o lucro e têm um relacionamento correto. As necessidades dessas empresas são o grande desafio de viabilidade da cooperativa.

\subsubsection{PERFIL DA COOPERATIVA}

Para facilidade no entendimento da estrutura da cooperativa, essa sessão está estruturada em tópicos como aspectos legais destacamse a razão social: Cooperativa Amigos do Lixo, a abrangência: cidade de Guaratinguetá e a gestão, que fica a cargo de um diretor presidente. os fornecedores (parceiros) são: a Prefeitura de Guaratinguetá, que fornece os galpões para uso como Ponto de Coleta de Material e o terreno para a infraestrutura da Cooperativa; a população da cidade, que proporciona o lixo, em alguns lugares ( $20 \%$ do total) já separado nos moldes de coleta seletiva e empresas: Basf, Liebherr, Perfilor, bancos e empresas comerciais de diversos ramos e portes separam material reciclável para coleta dos agentes ambientais.

A cooperativa não utiliza intermediários para estocagem e transporte de seu produto (operadores logísticos) e não usa revendedores. As tarefas pertinentes são realizadas pelos cooperados e funcionários.

Os recursos compreendem: 3 prensas, 1 balança e 50 carrinhos; Veículos: 3 caminhões fechados (2 próprios e 1 emprestado pela prefeitura, com motorista) e 2 utilitários (kombis); e conta com 1 sala de capacitação, 1 cozinha, 1 banheiro, 1 galpão como instalações.

Os recursos humanos estão mostrados no organograma da Figura 3, a seguir, que evidencia como estão distribuídos. Presidente, Vice-Presidente e diretores são voluntários. Apenas o gestor é remunerado. 
Figura 3: distribuição dos recursos humanos

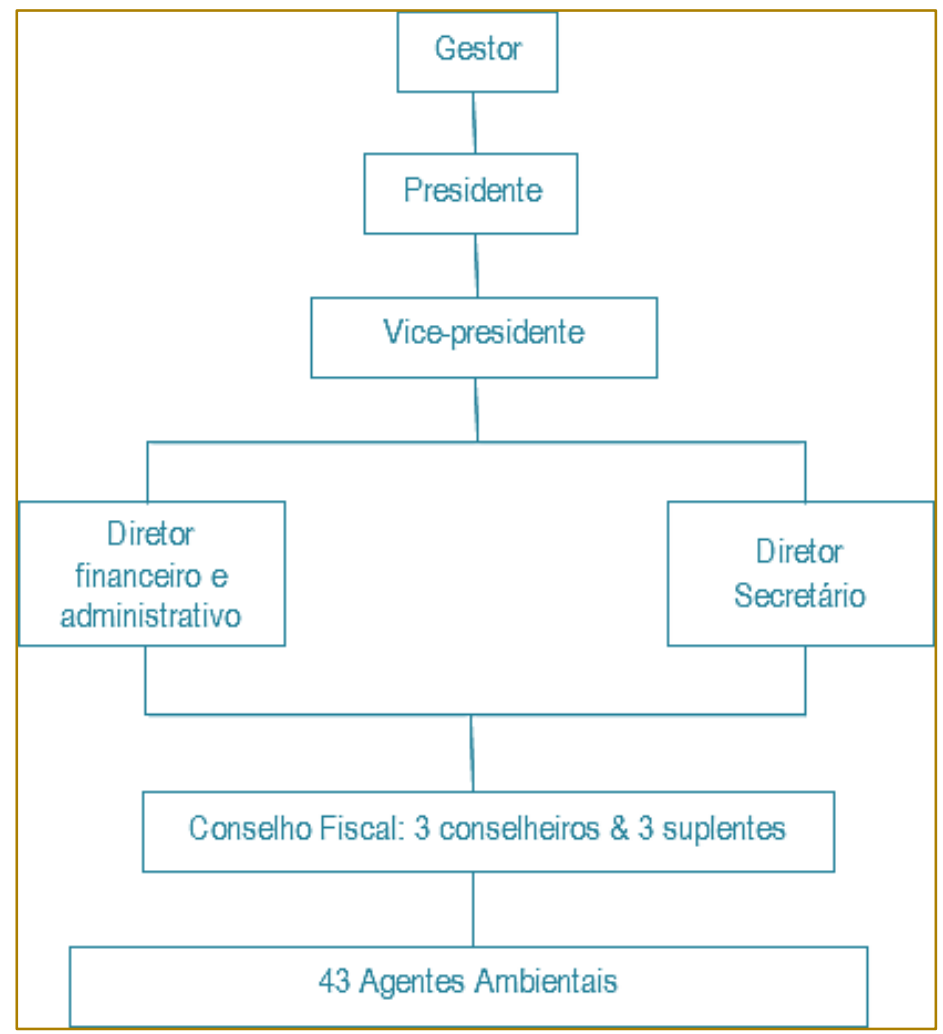

Atualmente não há qualquer plano de marketing em execução. Existem contatos pessoais do gestor em busca de parceiros. Conforme abordado anteriormente, o gestor lembra que no início do projeto houve um trabalho de marketing para lançamento e divulgação dainiciativa.

Os intermediários financeiros principais são descritos e comentados a seguir:

Banco do Povo: com a doação mensal de 30 toneladas de papel e papelão que recebe da BASF, empresa química que possui um parque fabril no município, a cooperativa montou um esquema de pagamento para um empréstimo do Banco do Povo, destinado à compra de um caminhão.

BNDES (Banco Nacional de Desenvolvimento Econômico e Social): após responder às exigências burocráticas do governo federal, a cooperativa foi beneficiada com uma doação deste banco, aqui considerado como intermediário financeiro de um subsídio do governo federal.

Os clientes são cadastrados e, por exigência dos parceiros, possuem as devidas licenças da entidade ambiental. Exemplos de clientes são as microempresas Madepar, Recivale,
Ipapéis, Aparas Frade e LG da Rocha. A relação com os clientes pode ser considerada como relação de mercado - a cooperativa agrega valor e oferece ao mercado um produto técnica e economicamente viável.

Não há concorrência para a cooperativa. Os responsáveis pela coleta, efetuada de maneira autônoma, já estão cadastrados e fazem parte da cooperativa. Ainda que não haja impedimento jurídico ou mesmo mercadológico para o surgimento de mais cooperativas, a quantidade de horas de trabalho voluntário demandada e os obstáculos fazem com que o surgimento de uma entidade semelhante seja altamente improvável. O objetivo de atingir 100\% dos bairros do município com a coleta seletiva não leva, portanto, em consideração a possibilidade de surgimento de concorrência.

Os públicos estão divididos em: interno, representado pelos agentes ambientais (diretoria e conselheiros) e externo, que compreende a comunidade, a prefeitura, as empresas parceiras (doadoras) e os clientes (compradores). 


\subsubsection{PERFIL DOS COOPERADOS}

O perfil foi construído com informações obtidas por meio de questionários aplicados à totalidade dos cooperados, em número de 21.

O cooperado típico tem sexo feminino, idade entre 40 e 50 anos (normalmente é mãe solteira chefe de família), apresenta escolaridade até a quarta série do ensino fundamental e soube da cooperativa por trabalhar no lixão no momento da criação ou por informações de outros cooperados. Está alocada na cooperativa há mais de seis anos. Declara conhecer a missão da cooperativa, mas tem dificuldade em verbalizar esse conhecimento.

Ainda segundo a pesquisa, tal cooperada típica conhece o gestor e os conselheiros, considera que tem relacionamento entre regular e bom com eles e, de um modo geral, tem bom relacionamento com os colegas. Preza o trabalho na cooperativa não apenas como fonte de renda, mas pela oportunidade se "ser alguém", participar de uma atividade reconhecida pela sociedade e pertencer a um grupo.

\subsection{MACROAMBIENTE}

\subsubsection{IDENTIFICAÇÃO DOS VETORES DECISIVOS}

A análise dos diversos contextos que constituem o macroambiente é aqui feita em função do Vetor Decisivo identificado, a coleta e venda de material reciclável, o único que pode gerar valor.

A Tabela 1 mostra as siglas utilizadas para essa análise.

Tabela 1: Siglas definidoras dos impactos

\begin{tabular}{|c|c|c|}
\hline \multirow{3}{*}{ 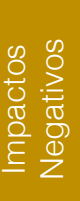 } & $P-$ & Pequena Intensidade \\
\hline & $M-$ & Moderada Intensidade \\
\hline & G - & Grande Intensidade \\
\hline \multirow{3}{*}{ 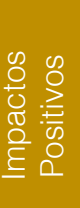 } & $P+$ & Pequena Intensidade \\
\hline & $M+$ & Moderada Intensidade \\
\hline & $G+$ & Grande Intensidade \\
\hline
\end{tabular}

Para cada contexto a seguir, são mostrados os impactos positivos e negativos.

\section{a) Macroambiente natural}

Neste contexto, a coleta de material reciclável depende, de modo decisivo, da geografia do município.

Impacto positivo $\left(\mathrm{M}_{+}\right)$: localização do município e qualidade de vida na área urbana.

Guaratinguetá é considerada como centro do Médio Vale do Paraíba Paulista, situada a meio caminho entre as cidades de Queluz e São José dos Campos. É avaliado como município de boa qualidade de vida e nível educacional elevado, além de atrair população qualificada. Segundo O IBGE (2011), seu IDH é 0,798, quando a média nacional é 0,699 e a do Estado de São Paulo, 0,783. A população de Guaratinguetá, somada à de Aparecida, município contíguo e que faz com Guaratinguetá uma única área urbana, é de 150 mil habitantes. Com isso, o lixo é diversificado e possui boa parcela de componentes recicláveis. A cidade tem, em seu território, um campus da Unesp, Universidade Estadual Paulista, e um da Fatec, Faculdade de Tecnologia do Estado de São Paulo. A população apresenta bom nível educacional, o que aumenta o potencial de ações voluntárias em favor da reciclagem.

Impacto negativo (G-): área extensa do município. Guaratinguetá tem uma superfície de cerca de $750 \mathrm{~km}^{2}$, o que dificulta a instalação de postos de reciclagem. Além disso, essa grande extensão atrapalha tanto a logística quanto a implantação de postos de coleta seletiva. É preciso lembrar que já houve uma experiência mal sucedida nesse sentido. 


\section{b) Macroambiente tecnológico}

A tecnologia está presente principalmente sob forma de produção de pequenos projetos de engenharia com base em tecnologias consagradas.

Impacto positivo $\left(\mathrm{M}_{+}\right)$: possibilidade de projeto e construção de instalações que agreguem valor ao lixo reciclado.

A pesquisa de reciclagem na atualidade é, em grande parte, acadêmica e, no mais das vezes, sua aplicação prática é inviabilizada por problemas logísticos. Caso típico é a compostagem de resíduos, que produz um humificante com possibilidades de aplicação, mas de valor muito baixo para tornar viáveis operações de transporte.

Existe um potencial na coleta de lixo eletrônico, por meio da recuperação de ouro. Processos artesanais, baseados em recuperação eletrolítica também podem ser refinados para uma operação industrial em pequena escala. A cooperativa pode agregar valor ao lixo separado com pequenas operações industriais de recuperação de materiais como plásticos e lâmpadas descartadas.

O ponto de vista pragmático, no caso, é utilizar a tecnologia disponível e, por meio de um trabalho de engenharia que pode ser feito, por exemplo, na Unesp ou Fatec, agregar maior valor ao lixo. Avanços tecnológicos importantes, que possam render patentes, são teoricamente possíveis, mas não devem ser o foco, ao menos neste momento. O foco deve estar mais na engenharia de processos existentes que no desbravamento tecnológico.

Impacto negativo ( $\mathrm{P}-\mathrm{)}$ : pesquisas para redução da quantidade de lixo

Esse tipo de pesquisa pode conduzir à utilização de produtos alternativos ou à descoberta de produtos degradáveis. Existe também uma preocupação em não aumentar o lixo. Nos dois

casos, não é de se esperar um impacto importante no conjunto da produção de lixo. Vale lembrar que o aumento da prosperidade, mesmo em um contexto de baixo crescimento do PIB, eleva a produção de lixo reciclável.

\section{c) Macroambiente cultural}

A cultura de preservação do meio ambiente tem sido implantada com solidez na sociedade, tanto por idealismo quanto por interesse político. O resultado é palpável e faz diferença quando da viabilização da reciclagem.

Impacto Positivo $(G+)$ : consciência ambiental

A preocupação corrente com a preservação do meio-ambiente e com as questões ecológicas criou uma cultura de valorização dos programas de reciclagem. A crescente conscientização da sociedade se reflete positivamente no ramo de negócio da cooperativa, devido principalmente a uma disposição cultural para colaborar com a coleta seletiva. No entanto, não é da coleta efetuada em residências que vem a maior parte do lucro da cooperativa, mas sim das doações das empresas parceiras. De qualquer forma, existe ambiente propício à doação e coleta seletiva e é preciso lembrar que a coleta domiciliar bem sucedida pode se tornar a evidência do cumprimento de um dos objetivos da cooperativa.

No caso das empresas, existe potencial para alcançar maior número de parcerias, por meio de busca de viabilização de empresas menores, com grande importância do aspecto logístico. A Fatec de Guaratinguetá forma tecnólogos em Logística e poderia estudar, por exemplo, a possibilidade de coleta de papel em escritórios de maior porte e hotéis.

Impacto Positivo $(\mathrm{G}+)$ : inércia

Existe uma inércia natural das pessoas em depositar o lixo de forma seletiva. A cooperativa não tem como investir em centenas de conjuntos de recipientes, e a coleta seletiva residencial só será possível por meio de convencimento e de uma parceria que disponibilize os recipientes específicos a baixíssimo custo ou mesmo etiquetas, marcações para os recipientes convencionais.

\section{d) Macroambiente demográfico}

O envelhecimento da população traz maior disponibilidade de tempo para que o cidadão pratique a reciclagem, mas também pode ocasionar redução do número de cooperados.

Impacto Positivo $(\mathrm{P}+)$ : aumento do número de aposentados

Pessoas com mais idade possuem maior capacidade de reflexão e, quando se aposentam, têm mais tempo de praticar ações em benefício da comunidade, tipicamente filantropia. Uma ou mais campanhas de sensibilização para a reciclagem direcionadas a esse grupo social podem render mais 
voluntários ou, ao menos, mais pessoas que pratiquem a reciclagem.

Impacto Negativo (M-): redução do número de cooperados

\section{e) Macroambiente político}

No Brasil, a consciência ambiental e de sustentabilidade está implantada com alguma solidez e existe possibilidade de sensibilizar pessoas para a coleta seletiva.

Impacto Positivo $(\mathrm{G}+)$ : política de apoio a iniciativas ecológicas

Gomes, em artigo de 2013, mostra que a consciência ecológica no Brasil já atingiu grande parte da população (praticamente todos os que frequentaram a escola desde os anos de 1980 e os mais velhos que se mantêm informados). Existe, portanto, razão para otimismo sobre uma campanha de reciclagem junto a famílias e pessoas.

Impacto Positivo $(G+)$ : política municipal favorável

Conforme esse segundo impacto positivo, a Prefeitura de Guaratinguetá apoia, principalmente com caminhão e motorista, mas é preciso considerar que existe potencial de a cooperativa efetuar parte da coleta de lixo, à medida que ela seja implantada.

Impacto Negativo (G-): desinteresse de futuros governos

A descontinuidade do apoio da prefeitura (por percepção de conveniência de algum grupo político) é a mais grave ameaça e poderá eventualmente levar a cooperativa à inviabilidade. Ainda que seja mais provável a continuidade do apoio, a cooperativa deve procurar sua independência da prefeitura e elaborar um plano para isso.

\section{f) Macroambiente econômico}

\section{Impacto Positivo $(\mathrm{G}+)$ : novos negócios}

A reciclagem pode ser aperfeiçoada por meio de tecnologias simples e não há problema de mercado para papel, metal e plástico. A Política Nacional de Resíduos Sólidos, em vigor desde 2010 (considera-se que a partir da entrada em vigor, pertence à análise econômica mais que à análise política) amplia o mercado, fazendo surgir soluções pela obrigatoriedade da reciclagem. Espera-se uma implantação efetiva gradual, e a reciclagem tende a se tornar um negócio que não terá necessidade de subsídios além de incentivos fiscais.

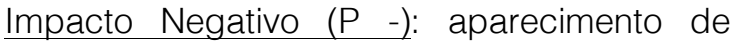
concorrência

O surgimento de um novo negócio de reciclagem na área é improvável, mas mesmo que isso aconteça, não inviabilizará a cooperativa, devido à dimensão do mercado.

\subsection{MATRIZ SWOT}

A matriz SWOT com o estudo da cooperativa Amigos do Lixo, mostrada na Figura 4, apresenta, de forma concisa, o resultado da análise.

Figura 4: Matriz SWOT com o estudo da cooperativa

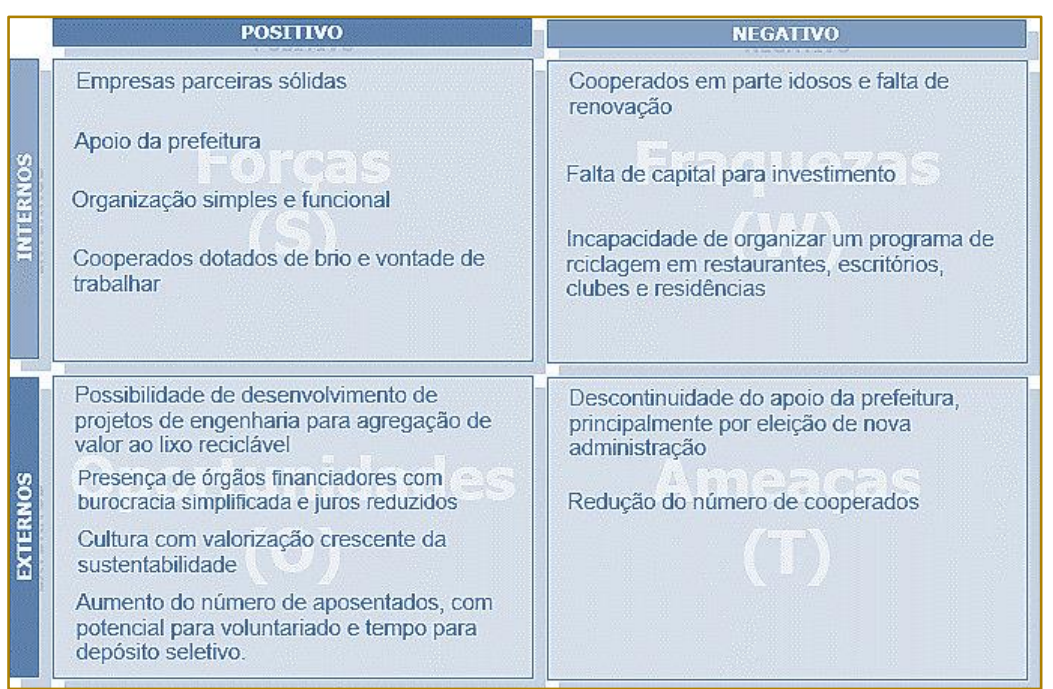




\section{ESTRATÉGIA E METAS}

A análise mostrou que a sobrevivência e o crescimento do negócio da cooperativa dependem de três fatores: a) aumento do número de cooperados ou, no mínimo, sua manutenção;

b) elevação da quantidade de lixo reciclável coletado e c) agregação de valor ao lixo reciclado. Os itens b) e c) estão muito ligados. Por exemplo, existe uma quantidade mínima de material eletrônico que viabiliza a recuperação química do ouro. A sobrevivência será garantida no momento em que a cooperativa não mais depender do auxílio da prefeitura.

\subsection{OBJETIVOS}

Os objetivos aqui colocados são tentativos, uma hipótese de trabalho, porque dependem do resultado de um estudo que gere um business case e promova um refinamento das metas.

Os objetivos, organizados em ordem aproximadamente cronológica, são:

a curto prazo (6 meses), aumentar a quantidade de cooperados em 10\%; aumentar a área coberta em 10\%; conquistar ao menos mais um parceiro significativo (ainda que em outra cidade); iniciar uma campanha de coleta seletiva em ao menos uma área piloto e contratar um estudo para aumento de valor agregado.

a médio prazo (30 meses), adquirir mais um veículo e preparar dois cooperados como motoristas; aumentar a quantidade de cooperados em mais 20\%; aumentar a área coberta em mais 20\%; ampliar a coleta seletiva para 10 pontos e implantar uma unidade fabril de agregação de valor (como moagem seletiva de plásticos).

a longo prazo (60 meses), implantar ao menos mais duas unidades fabris; adquirir mais um veículo; estabelecer 30 pontos de coleta seletiva; estabelecer uma estrutura administrativa empresarial e adquirir independência da prefeitura.

\subsection{AÇÃO}

\subsubsection{O PLANO DE NEGÓCIOS}

O estudo de negócios se divide em duas partes: a primeira é um estudo de engenharia que irá investigar e projetar as possibilidades de agregação de valor, como moagem e extrusão de plásticos, recuperação de ouro de lixo eletrônico, separação e pré-tratamento de metais. A segunda parte trata-se do plano de negócios propriamente dito, que pesquisará custos fixos, custos variáveis, receitas, investimentos, subsídios, financiamento e desenvolverá um fluxo de caixa. Uma das proposições é que tal estudo possa ser feito por meio de convênio com o SEBRAE, universidades e eventualmente outras entidades. Particularmente importantes deverão ser o Departamento de Engenharia da Unesp e os cursos de Gestão e Logística da Fatec.

Além do estudo mencionado, as principais ações são: campanha de reciclagem, com apoio da prefeitura, universidades e planejamento cuidadoso, que pode receber ajuda, por exemplo, do curso de Logística da Fatec. O primeiro objetivo é a criação de um ponto piloto; busca de empresas parceiras, se necessário em municípios vizinhos; campanha de recrutamento de cooperados e reestruturação administrativa, também com a colaboração das universidades mencionadas.

\subsubsection{UMA NOTA SOBRE LIDERANÇA}

Em artigo muito citado de 1993, Nutt e Backoff mostram que liderança estratégica e gerenciamento estratégico são uma necessidade para qualquer entidade ligada, de alguma forma, ao poder público. Os avanços e as ações aqui mencionados não podem prescindir de uma liderança, que poderá vir de segmentos da sociedade interessados, uma vez que o atual gestor, segundo entrevista concedida, pessoa esforçada e com méritos, tende ao ceticismo em relação a mudanças. Cita constantes tentativas que não deram certo e descarta a possibilidade de elas não terem funcionado por falta de planejamento e conhecimento.

Essa liderança pode vir também do SEBRAE, além de indivíduos da Associação Comercial de Guaratinguetá ou das próprias universidades, cabendo ao presidente da cooperativa recrutar essa liderança.

\section{CONCLUSÃO}

A Análise SWOT, pensada para empresas, é perfeitamente adequada como ferramenta para organizações do Terceiro Setor. Não por coincidência, ao menos nesse caso (e 
provavelmente em muitos outros) as soluções encontradas apontam para tratar a ONG estudada mais como empresa e menos como entidade dependente do poder público. Em um contexto mais amplo é possível lembrar Cardoso (1998), que aponta para o imperativo de aumento de eficiência do próprio estado para atendimento às demandas da sociedade.

Cabe notar que a cooperativa, se bemsucedidas as mudanças, continuará uma

\section{REFERÊNCIAS}

[1]. ALMOLA, L. A. L. (2003) Projeto "Amigos do Lixo", Guaratinguetá (SP). In: LOTTA, G. S. et alii (org.) 20 Experiências de Gestão Pública e Cidadania. São Paulo: Programa

[2]. Gestão Pública e Cidadania, pp 3-13.

[3]. BRYSON, $J$ et alii. (2010) The State of Public Strategic Management Research: A Selective Literature Review and Set of Future Directions. The American Review of Public Administration 40 (5) pp 495-521.

[4]. CARDOSO, F. H. (1998) Notas sobre a reforma do estado. Novos Estudos CEBRAP 50, pp. 7 - 11 .

[5]. CHIMENE, Rosilane Gonçalves, Cooperativa Amigos do Lixo - Comunicação Aplicada ao Terceiro Setor: a necessidade de uma visão estratégica. Trabalho de Conclusão de Curso, Fatec - Guaratinguetá, 2008.

[6]. FONSECA, L. O estado, o terceiro setor e o mercado - uma tríade complexa (2000). Disponíve em: http://www.milenio.com.br/siqueira/Trab.025.doc. Recuperado em 10 de maio de 2014.

CAMARGO, M. (org - 2002). Gestão do Terceiro Setor no Brasil - Estratégias de capitação de recursos para organizações sem fins lucrativos. São Paulo: Futura.

[8]. DIMENSTEIN, G. (1998) Aprendiz do futuro: cidadania hoje e amanhã. São Paulo: Ática. FORTES, W. Marketing Social (2007). Disponível em:

http ://inovando.fgvsp/conteúdo/documentos/históri as2002/amigos_do_lixo.pdf. Recuperado em 14 de maio de 2014 entidade do Terceiro Setor. Em outras palavras, utilizará o lucro para proporcionar melhores condições aos cooperados e para investir em melhorias e ampliação. Assim, usar um approach empresarial não significa transformar a cooperativa em empresa, mesmo porque reduzir a poluição de um manancial importante continua a ser um dos objetivos principais.

[9]. FUKUYAMA, F. (1992) The End of History and the Last Man. New York: Free Press.

[10]. KOTLER, P; KELLER, K. (2006) Administração de Marketing. São Paulo: Pearson Prentice Hall.

[11]. GOMES, G. (2013) Ecologia Política: Educação Ambiental e a Formação de uma Determinada Consciência acerca da Questão Ambiental. Revista de Ensino de Geografia, 4 (6) pp. 119-138.

[12]. LIU, T. et alii. (2012) Strategic Orientation and Social Enterprise Performance. Nonprofit and Voluntary Sector Quarterly, in press.

[13]. MELO NETO, F. \& FROES, C. (1999). Responsabilidade social \& cidadania empresarial: a administração do terceiro setor. Rio de Janeiro: Qualitymark.

[14]. NUTT, P. \& BACKOFF, R. (1993). Transforming Public Organizations with Strategic Management and Strategic Leadership. Journal of Management, 19 (2) pp. 299-347

[15]. PANAGIOTOU, G. (2003) Bringing SWOT into Focus. Business Strategy Review, 14 (2) pp. 810

[16]. PIKETTY, T. (2013) Le capital au XXI siècle. Paris: Seuil.

[17]. PRESIDÊNCIA DA REPÚBLICA - CASA CIVIL (2010) - Lei no 12.305 - Política Nacional de Resíduos Sólidos.

[18]. SANTOS, Milton. (2002) Por uma outra globalização: do pensamento único à consciência universal. Rio de Janeiro: Record. 


\section{Capítulo 18}

\section{OS PRINCIIPIOS DO DIREITO VOTADOS PARA A PRESERVAÇÃO AMBIENTAL}

\section{Ana Paula Lima Marques Fernandes}

Amanda Araújo de Souza

Amauri Vítor dos Santos

Carlos Everaldo Silva da Costa

Fábio Augusto Lima Silva

Lidiane Maria dos Santos

Rodrigo Purcell

Resumo: O presente artigo, fruto da disciplina Direito Ambiental, disserta sobre analise da responsabilidade ambiental civil das pessoas jurídicas nas ações ilícitas ambientais, trazendo inicialmente o que se entende por direito ambiental e sua relevância, assim como os principais princípios ambientais. Este estudo foi desenvolvido na reserva Tobogã, situada em Maceió, Alagoas. A metodologia utilizada para atender os objetivos propostos foi de cunho bibliográfico e exploratório. Sendo assim, conclui-se que foi observado que a responsabilidade ambiental civil por danos causados ao meio ambiente é objetiva, tendo apenas a comprovação do nexo de causalidade entre o ato e o dano ambiental causado.

Palavras chave: Direito Ambiental, Princípios Ambientais, Reserva Tobogã, Dano Ambiental. 


\section{INTRODUÇÃO}

O direito ambiental é um ramo autônomo da ciência jurídica do Brasil, onde foram criadas verdadeiras políticas ambientais, com a finalidade de proteção ambiental voltada para todo microssistema. Tem como característica natureza preventiva. Deverá observar os riscos e não somente os danos, em virtude de o prejuízo ambiental ser de difícil identificação e de extensa dimensão.

Ao identificar o bem ambiental, a proteção ao meio ambiente é encontrada no caput do art. 225 quando afirma que "todos tem direito a um meio ambiente ecologicamente equilibrado, bem de uso comum do povo e essencial à sadia qualidade de vida (...)".

Nesse sentido, observa-se que o equilíbrio ecológico é o bem jurídico que constitui o objeto de direito. Também no art. $3^{\circ}$ da Lei $6.938 / 81$ onde o meio ambiente é definido pela interação de diversos fatores bióticos e abióticos, a proteção de cada um desses elementos fundamenta-se na proporção em que serve a preservação desse equilíbrio.

Esta pesquisa foi desenvolvida em um de ensino apresenta durante a trajetória do desenvolvimento da disciplina de Direito Ambiental do curso de Ciências Contábeis da Universidade Federal de Alagoas, campus Maceió. O texto relata a construção do conhecimento através da teoria associada à prática. Descreve desafios e conquistas que todos como seres humanos devemos ter quanto à responsabilidade sócio ambiental.

O exemplo citado pode ser inspirador para a busca do êxito em outras atividades extraclasses.

A metodologia utilizada para atender os objetivos propostos foi de cunho bibliográfico e exploratório. Os dados para construção do caso foram coletados utilizando-se referenciais teóricos, palestras, observação direta em campo através da visita na Reserva Tobogã situada em Fernão Velho, Maceió, Alagoas.

\section{CONSIDERAÇÕES TEÓRICAS}

\subsection{BREVE HISTÓRICO DA EVOLUÇÃO DO DIREITO AMBIENTAL}

De acordo com MACHADO (2013), ao longo da história procurou-se disciplinar no campo do direito comportamento do ser humano relacionado ao meio ambiente no território nacional. Durante esse tempo, o direito ambiental não era ramo autônomo das ciências jurídicas. Embora o seu objeto de tutela esteja relacionado à própria imagem do ser humano, o tratamento no direito ambiental é considerado como uma ciência nova. $\mathrm{Na}$ legislação ambiental a evolução histórica é dividida de acordo com a tabela 2.1.

Tabela 2.1. Evolução das fases histórica

\begin{tabular}{|c|c|c|}
\hline Fases Históricas & $\begin{array}{c}\text { Características } \\
\text { Individualista }\end{array}$ & $\begin{array}{c}\text { Sem preocupação com o meio } \\
\text { ambiente. }\end{array}$ \\
\hline Fragmentária & $\begin{array}{c}\text { Controle de atividades exploratórias } \\
\text { em razão do valor econômico. } \\
\text { Holística }\end{array}$ & De descobrimento até 1950. \\
\hline interdependente. & De 1950 a 1980. \\
\hline
\end{tabular}

A fase individualista também conhecida como exploração desregrada não havia controle sobre as atividades exploradas, tendo como caraterística ausência de preocupação com o meio ambiente, visto que, este não era considerado bem autônomo.

$\mathrm{Na}$ fase fragmentária surgiram legislações (Velho Código Florestal - Lei no 4.771/65; Código de Caça ou Lei de Proteção à Fauna Lei no 5.197/67; Código de Pesca - Decreto-lei no 221/67; Código de Mineração - Decreto-lei no 227/67; Lei de Responsabilidade por Danos Nucleares - Lei no 6.453/77) voltadas ao controle das atividades exploratória tocante aos recursos naturais (água, fauna e flora) destacam TALES et al (2015).

Merece destaque que somente os recursos naturais com valor econômico eram protegidos juridicamente, em virtude de que o 
meio ambiente, nesse período, não era considerado um bem autônomo.

$\mathrm{Na}$ terceira fase, denominada holística é marcada pela compreensão do meio ambiente como um todo integrado sem fragmentação, onde o direito ambiental foi reconhecido, com autonomia científica, afirmação legislativa, jurisprudencial e doutrinária destacam TALES et al (2015).

Com a promulgação da Constituição Federal de 1988, onde contempla um capítulo inteiro ao meio ambiente ocorreu o marco legislativo. Merece destaque que o meio ambiente passou a ser considerado um bem jurídico autônimo, com a Lei ํo 6.938/81. Onde o homem não seria mais o centro das atenções e sim, o meio ambiente em si mesmo considerado, menciona RODRIGUES (2016).

Diante do breve histórico da evolução do direito como instrumento de proteção e defesa ambiental serão destacados os principais princípios do direito ambiental numa visão abrangente.

\subsection{PRINCIPAIS PRINCÍPIOS DO DIREITO AMBIENTAL}

Os princípios do direito ambiental voltados ao desenvolvimento, compreensão, diretrizes básicas, interpretação das normas e proteção ambiental encontram-se na Constituição Federal de 1988, assim como, nos tratados internacionais.

\subsubsection{PRINCÍPIO DO DESENVOLVIMENTO SUSTENTÁVEL}

RODRIGUES (2016) comenta que é inata do ser humano a ideia de desenvolver-se, aumentar-se e expandir-se, seja no aspecto social, econômico, filosófico ou moral.

Sendo assim, de acordo com SIRVINSKAS (2017) o desenvolvimento sustentável tem como pilar as seguintes vertentes: Crescimento econômico, preservação ambiental e equidade social.

Em 1972, em Estocolmo, ocorreu a Conferência Mundial de Meio Ambiente, no qual foi utilizada a expressão eco desenvolvimento e renomeado por desenvolvimento socioeconômico. Segundo a Comissão Mundial sobre o Meio Ambiente e Desenvolvimento (Worl Comissiono n Environment and Development), desenvolvimento sustentável quer dizer: "um desenvolvimento que faz face às necessidades das gerações presentes sem comprometer a capacidade das gerações futuras na satisfação de suas próprias necessidades".

Diante do abordado, observa-se que devem ser asseguradas as gerações futuras 0 acesso aos recursos naturais com 0 crescimento populacional e econômico em paralelo.

LEITE e CANOTILHO (2015) citam que a Constituição de 1988 adota o antropocentrismo protecionista, não se restringindo o ambiente a mera concepção econômica, existindo uma autonomia no texto constitucional.

O equilíbrio entre preservação ambiental, crescimento econômico e equidade social também pode ser observada no artigo 170, caput, da Constituição Federal Brasileira de 1988.

Merece destaque que 0 artigo citado anteriormente enumera os princípios de ordem econômica (parágrafo único), da propriedade privada (inciso II), da função social da propriedade (inciso III) e da redução das desigualdades regionais e sociais (inciso VII).

Desse modo, observa-se que o princípio do desenvolvimento sustentável se fez presente em diversos instrumentos destinados à tutela ambiental.

\subsubsection{PRINCÍPIO DO AMBIENTE ECOLOGICAMENTE EQUILIBRADO}

THOMÉ (2013) destaca que no artigo 225 da Constituição Federal de 1988 que um novo direito fundamental foi assegurado pelo legislador constituinte, disposto em seu caput 225 , onde concebe o direito a um meio ambiente "ecologicamente equilibrado", à pessoa humana, necessária para uma qualidade de vida.

Nesse sentido merece destaque que os direitos fundamentais não são apenas os previstos no artigo $5^{\circ}$ da $\mathrm{CF} / 88$, ou seja, não excluem outros princípios.

O direito fundamental ao meio ambiente equilibrado havia sido reconhecido pela Conferência das Nações Unidas sobre o Ambiente, ocorrido em 1972. Está ligado ao direito fundamental à vida e a proteção da 
dignidade da vida humana, destaca THOMÉ (2013).

\subsubsection{PRINCÍPIO DA PREVENÇÃO E DA PRECAUÇÃO}

Os danos causados ao meio ambiente muitas vezes são irreparáveis e irreversíveis. Nesse sentido é melhor evitar a incidência dos danos ambientais. A prevenção e a precaução foram tratadas de formas diferentes no direito ambiental.

SARLET e FENTERSEIFER (2014) alertam que na prevenção ocorre uma análise prévia dos impactos, medidas preventivas, ou seja, há uma certeza científica desses, onde uma obra possa interferir sendo possível modificar 0 projeto, concretizando sua realização, sem causar danos ao meio ambiente.

É considerado o maior alicerce para o estudo de impactos ambientais, observado no artigo 225, no caput e parágrafo 1을 inciso IV da $\mathrm{CF} / 88$, onde institui não somente a coletividade, como também ao Poder Público o dever de proteger e preservar o equilíbrio ecológico. Observa-se também, o princípio da prevenção na lei 6938 de 1981, Politica Nacional do Meio Ambiente que dispõe no art. $2^{\circ}$, onde reforça a finalidade da preservação, melhoria e recuperação do patrimônio público a ser assegurado, em vista do uso coletivo, protegendo os ecossistemas e as áreas ameaçadas de degradação.

Enquanto que no Princípio da Precaução, SARLET e FENTERSEIFER (2014) citam que não existe conhecimento dos possíveis fatos, onde é necessário proteger para as presentes e futuras gerações. Diante disso, não é necessário licenciar a atividade ou obra, visto que não se ter certeza dos danos irreversíveis ao meio ambiente.

SAMPAIO et al (2003) chamam a atenção a quem consiste em estabelecer se cabe ônus de demonstrar se existe ou não a certeza científica necessária para analisar os possíveis impactos negativos, assim como, se as medidas de prevenção são ou não economicamente viáveis.

Diante do exposto observa-se que quem deve provar que a ausência de rede de esgoto não causa riscos e nem danos ambientais é o proponente.

\subsubsection{PRINCÍPIO DO POLUIDOR PAGADOR E USUÁRIO PAGADOR}

De acordo com SAMPAIO et. al. (2003) o princípio do poluidor pagador pode ser compreendido como mecanismo de alocação da responsabilidade pelos custos ambientais associados à atividade humana.

Atua como uma ferramenta que autoriza aos Estados conduzirem os autores econômicos a assumir os custos dos impactos negativos da produção de bens e serviços mesmo antes que estejas a acontecer.

MUKAY (2016) destaca que o poluidor é obrigado a corrigir ou reparar o ambiente, não Ihe sendo permitido a continuar a ação poluente.

É contemplado no inciso VII do art. 4ำ da Lei $6938 / 81$, que afirma que poluidor e predador tem a obrigação de recuperar e/ou indenizar os danos causados. E tem consequência a responsabilidade objetiva, observada quando cita que o Ministério Público da União e dos Estados terá legitimidade para propor ação de responsabilidade civil e criminal, por danos causados ao meio ambiente, no qual o poluidor será obrigado, independentemente da existência de culpa, de indenizar ou reparar os danos causados ao meio ambiente.

Segundo THOMÉ (2013), a expressão "poluidor pagador" é criticada por alguns doutrinados em virtude de interpretações não condizentes com a realidade, como por exemplo, "quem paga pode poluir". Vale ressaltar que este princípio não autoriza a poluição e nem permite a compra do direito de poluir, entretanto de evitar o dano ambiental.

Diante do exposto, merece destaque a abordagem de:

Se é verdade que os bens ambientais são de uso comum, porque pertence a toda coletividade, é verdade também que aquele que se utiliza dos componentes ambientais de forma incomum deverá pagar a conta pelo uso invulgar, e ainda que devolva o componente ambiental nas mesmas ou em melhores condições do que quando o tomou por empréstimo. (RODRIGUES, 2016, p.351)

Sendo assim, não há bis in idem quando o mesmo agente tiver que responsabilizar-se com os custos, seja pelo uso ou pela poluição causada ao meio ambiente. 


\subsubsection{PRINCÍPIO DA COOPERAÇÃO}

É contemplado no artigo 225 da CF/88 genericamente quando impõe ao Poder Publico e a coletividade a obrigação de defender o meio ambiente e preservá-lo para presentes e futuras gerações.

É destacado na Constituição Federal nas esferas federais, observado no art. $61 \S 2^{\circ}$, onde a iniciativa popular poderá ser exercida pela Câmara dos Deputados, através de projetos de Lei, nas estaduais, artigo $27 \S 4^{\circ}$, e municipais, por Lei Orgânica, contemplado no art. 29, XII (cooperação das associações representativas no planejamento municipal) e XIII (iniciativa popular de projetos de lei).

Merece destaque que a Constituição Estadual de Alagoas contempla o principio da cooperação em seu artigo 14, inciso I, onde entidades representativas da comunidade participam do planejamento municipal. A lei orgânica do Município de Maceió também ampara o princípio da cooperação em ser art 7, IV.

Merecem destaquem as seguintes legislações: Acesso Público à Informação Ambiental (Lei 10650/2003 e 9ㅇ, VII e XI Lei 6938/81) e à Educação Ambiental (art. 225, § $1^{\circ}$, VI, CF/88; Lei 9795/99 e art. $2^{\circ}$, X, Lei $6938 / 81$ ) traduzem desdobramentos do princípio da participação democrática ou da colaboração ou também conhecida como participação comunitária.

Nesse sentido, serão consideradas inconstitucionais leis que venham a ser estabelecidas sem a participação de entidades ambientalistas, visto que se trata de principio fundamental do Direito Ambiental.

\subsubsection{PRINCÍPIO DA VEDAÇÃO AO RETROCESSO}

BARROSO (2009) cita que o princípio da vedação ao retrocesso, decorre do sistema jurídico constitucional, embora não esteja expresso. Ou seja, "se uma lei, ao regulamentar um mandamento constitucional instituir determinado direito, ele se incorpora ao patrimônio jurídico da cidadania e não pode ser absolutamente suprimido".

Este princípio está contido no princípio da dignidade da pessoa humana observada no art. 1ㅜ, inciso III da CF/88.

Sendo assim, os crescentes avanços vinculados aos progressos da ciência fazem com as reformas do direito ambiental absorva novos requisitos tecnológicos com a visão mais protetora do meio ambiente, ou seja, proteção máxima devido as circunstâncias locais.

Nesse sentido, MUKAI (2016), alerta que não tolerar regressões na proporção que seja preservado o essencial que já foi adquirido, sendo considerado como essencial ao desenvolvimento sustentável como segurança dos direitos das futuras gerações.

Merece destaque que o princípio da vedação ao retrocesso evidencia a existência real dos princípios gerais do direito ambiental.

\subsubsection{PRINCÍPIO DA RESPONSABILIDADE AMBIENTAL}

A palavra responsabilidade deriva etimologicamente de responsável que origina do latim responsus, do verbo respondere, que transmite a ideia de recuperar, reparar, compensar ou pagar pelo que fez.

A responsabilidade é fundamental para o equilíbrio do sistema jurídico. Foi analisado anteriormente que a prevenção e a precaução possuem valores fundamentais da proteção ambiental. Já diz o ditado: "Melhor prevenir do que remediar".

Nesse sentido, o desenvolvimento de uma política repressiva tem grande e importante atuação quando ocorre falha na prevenção, onde inicia o princípio da responsabilidade ambiental.

A reparação seja feita o mais rápido possível. Se o que ocorreu é ruim, é certo que as consequências dessa lesão, serão ainda piores. No caso de danos continuativos e muitas vezes ad futurum e eternum, quanto mais tempo se leve para recuperar o meio ambiente, mas se continuará para sua deterioração. A demora na recuperação de um meio lesado poderá ser fatal à sua recuperação. (RODRIGUES, 2016, p. 362)

GUERRA e GUERRA (2014) afirmam que é necessário reparar o prejuízo decorrente a um prejuízo de outro dever jurídico.

O artigo 225, § 3o da CF/88 previu a tríplice penalização do poluidor da pessoa física, como também pessoa jurídica, no qual aquele que causar dano ao meio ambiente deverá responder nas três esferas: civil, administrativa e penal. 
O infrator poderá responder em qualquer uma das esferas ou mesmo nas três, uma vez que não sem comunicam. Observa-se que não há bis in idem quando o elemento é sancionado nas três esferas pela mesma ocorrência.

Entretanto, merecem destaques os artigos 66 e 67 do Código de Processo Penal onde cita que a ação civil poderá ser proposta quando não tiver sido reconhecida a inexistência material do fato, assim como não será impedido a propositura da ação civil quando a sentença decidir que o fato imputado não constituiu crime.

Dessa forma, observa-se que na hipótese de se atestar a inexistência do fato ou da autoria, destacado no artigo 935, na esfera penal, afastará a responsabilidade civil e administrativa.

Entretanto, Rodrigues (2016), cita que quando se trata de tutela ao meio ambiente, há um enfoque que não pode ser oculto: a convergência de finalidades de todas as sanções. Não se pode reprimir, punir, condenar simplesmente como repressão. Precisam acatar as mesmas finalidades, sendo a recuperação imediata do meio ambiente e promoção da educação ambiental.

O artigo 17 da Lei 9605/98 (Lei de Crimes Ambientais) diz que a reparação será feita mediante laudo ambiental. Constata-se que ocorre a preocupação da suspensão condicional da pena privativa de liberdade nos crimes ambientais. Onde, de acordo o artigo 78 do Código Penal, o sujeito condenado ficará em observação e ao cumprimento das condições estabelecidas pelo judiciário.

Nesse sentido, se for reparado o dano, ou as circunstâncias do artigo 59 do CP lhe forem favoráveis, fala Rodrigues (2016), o juiz poderá substituir em prestação de serviços por outras condições.

Diante do abordado, o artigo 17 da Lei de Crimes Ambientais designa duas regras de substituição: a prova de reparação deve ser feita mediante laudo de reparação ambiental e as condições do juiz deverão relacionar-se com a proteção do meio ambiente, reforça RODRIGUES (2016).

\subsubsection{PRINCÍPIO DA OBRIGATORIEDADE DA INTERVENÇÃO DO PODER PÚBLICO}

De acordo com FIORELLO (2016) o legislador no artigo $2^{\circ}$ determinou que a Política Nacional do Meio ambiente tem como objetivo a preservação, melhoria, recuperação da qualidade ambiental, visando assegurar no País, condições ao desenvolvimento sócio econômico, aos interesses da segurança nacional.

Nesse sentido, COSTA e COSTA (2013) afirmam que a Administração não pode silenciar quanto à proteção ao meio ambiente sendo de sua competência, sob pena, de responder civilmente por omissão e criminal por prevaricação.

A educação ambiental, tipificada no art. 225, $\S 1^{\circ}$, VI da CF/88, é considerada uma das formas que o Poder Público pode intervir através dos ensinamentos em todos os níveis educacionais, assim como de conscientização pública com a finalidade da preservação ambiental.

Diante do exposto, afirma-se a relevância dos princípios ambientais, onde registra-se que são verdadeiros pilares, das quais não seria possível alcançar o entendimento de que seja o Direito Ambiental.

\section{ESTUDO DE CASO}

A aula prática ocorreu na Reserva Ecológica Tobogã possui uma área de 1ha, sendo a menor RPPN do Estado. Está localizada no município de Maceió, e está inserida na Área de Proteção Ambiental Estadual do Catolé e Fernão Velho. foi explanada uma palestra titulada A Importância da RPPN e das árvores no meio ambiente.

Em abril de 2014 houve o primeiro rompimento do muro (em construção) de contenção da obra do Cd. Alto da Lagoa de responsabilidade da Habite Construções, com o deslizamento de terra e assoreando os açudes existentes na parte baixa da RPPN Tobogã. O Ima foi acionado e notificou o empreendimento.

Em maio de 2017, já com o empreendimento entregue aos proprietários, houve o desmoronamento do paredão da área de lazer do condomínio, levando ao desmatamento de uma extenção de 200 m² $^{2}$ de mata de encosta (APP) e assoreando nascentes e açudes existentes na RPPN. 
A importância de uma RPPN. Foi criada pela Portaria $n^{\circ}$ 016/2007, com objetivo à preservação integral do meio natural, sendo vedadas todas as interferências sobre este ecossistema e tem como principal bioma a Mata Atlântica. Na área, predomina a vegetação secundária pela ocorrência de várias Imbaúbas, espécie pioneira e importante para o estabelecimento das condições ambientais de regeneração da Mata. Em outros trechos observa-se árvores testemunha a exemplo da Munguba medindo cerca de 20 metros de altura e outras como Sambaquim, Cupiubá, Pau Lacre, Ingá e algumas frutíferas como Jaqueiras, Mangueiras e Cajueiros.

Registra-se a existência de duas nascentes de grande importância ambiental e de uso para abastecimento dos funcionários do sítio. Estas nascentes apresentam boas condições, uma vez que possui vegetação preservada e de grande porte em seu entorno. As nascentes por si só são consideradas como Áreas de Preservação Permanente (APP), através da legislação pertinente à resolução do Conselho Nacional do Meio Ambiente (Conama) n³03/2002.

\section{CONCLUSÃO}

Descrever a importância dos princípios ambientais em uma área protegida, assim como, analisar a responsabilidade ambiental civil das pessoas jurídicas nas ações ilícitas ambientais, trazendo inicialmente o que se entende por meio ambiente, e sua relevância como bem jurídico tutelado, assim como a evolução acerca do tema foi uma experiência bem enriquecedora em ambos os aspectos voltados pra academia e extensão.

Merece destaque as relações com os objetivos da disciplina Direito Ambiental onde no caso, foi possível identificar aspectos que remetem ao desenvolvimento sócio ambiental.

\section{REFERÊNCIAS}

[1]. AMADO, Frederico Augusto Di Trindade. Resumo Direito Ambiental - Esquematizado. 4르. Ed. Elsevier Método. 2016.

[2]. BETIOL, Luciana. Responsabilidade Civil e Proteção ao Meio Ambiente - Coleção Prof. Agostinho Alvim. Saraiva. 2013.

[3]. BRASIL. Constituição (1988). Constituição da República Federativa do Brasil: promulgada em
A disciplina direito ambiental tem como objetivo geral destacar os Princípios de Direito Ambiental, Proteção do meio ambiente na Constituição Federal e a Política Nacional do Meio Ambiente.

Diante do exposto, merece destaque a relevância do estudo do Direito Ambiental com a interdisciplinaridade nas áreas de ciências sociais, bem como expor a legislação, os instrumentos e as competências dos órgãos responsáveis pela proteção do meio ambiente.

Por fim, ao questionar os efeitos da responsabilidade civil referente aos danos ambientais causados no Estado de Alagoas, conclui-se que foi observado que a responsabilidade ambiental civil por danos causados ao meio ambiente é objetiva, tendo apenas a comprovação do nexo de causalidade entre $\mathrm{o}$ ato e $\mathrm{o}$ dano ambiental causado.

Além do mais, verifica-se mais participação do Poder Público. Nesse sentido, merece destaque que as ações aqui elencadas têm como finalidade a reparação e recuperação do dano causado ao meio ambiente.

\section{AGRADECIMENTOS}

- Ao Sr. Eduardo Jorge Purcell pela aula magna disponibilizada na Reserva Ambiental, como também pela disponibilidade ao acesso contribuindo para a elaboração desta pesquisa;

- Ao geógrafo Sr. Marco Antônio Diniz do Nascimento, Fiscal e Assessor Ambiental do IMA/AL pela palestra ministrada contribuindo no conhecimento construído;

- Ao grupo de Pesquisa do CNPq:

Sistemas Integrados a Gestão,

Sustentabilidade e Processos Estatísticos.

5 de outubro de 1988. Organização do texto: Juarez de Oliveira. 4. ed. São Paulo: Saraiva, 1990. 168 p. (Série Legislação Brasileira).

[4]. COSTA JR, P. J, COSTA. Direito Penal Ambiental. 2. ed. Revista dos Tribunais. 2013.

[5]. FARIAS, T, COUTINHO, F. S. N, MELO, G. K. M. Direito Ambiental. 3aㅡ ed. Revista, ampliada e atualizada. Editora JusPodivm. 2015. 
[6]. FIORILLO, Celso Antonio Pacheco. Princípios do Direito Processual Ambiental. 6. Ed. Revisada e ampliada. Saraiva. 2016.

[7]. FIORILLO, Celso Antonio Pacheco. Curso de Direito Ambiental Brasileiro. 17ạ Ed. Saraiva. 2017.

[8]. GALVÃO, F. Responsabilidade Penal da Pessoa Jurídica no Direito Ambiental Brasileiro. 3. Ed. Revisada e ampliada. 2015.

[9]. GUERRA, Sergio, GUERRA, Sidney. Curso de Direito Ambiental. 2ª ${ }^{\mathrm{a}}$ Ed. Atlas. 2014.

[10]. Lei $n^{\circ}$ 6.938/81. Lei de Política Nacional de Meio Ambiente. 31 de agosto de 1981.

[11]. Lei $n^{\circ}$ 9.605/98. Lei das sanções penais e administrativas derivadas de condutas e atividades lesivas ao meio ambiente, e dá outras providências. 12 de fevereiro de 1998.

[12]. MUKAI, Toshio. Direito Ambiental Sistematizado. 10ํed. Editora Forense. 2016.

[13]. MELO, M. E. Restauração Ambiental do dever jurídico às técnicas reparatórias. Livraria do Advogado. 2012.

[14]. RODRIGUES, Marcelo Abelha. Direito Ambiental Esquematizado. 3를. Ed Saraiva. 2016.

[15]. STEIGLEDER, Annelise Monteiro. Responsabilidade Civil Ambiental. $2^{\underline{a}}$ Ed. 2011.

[16]. SIRVINSKAS, Luis Paulo. Manual do Direiro Ambiental. 15aㅡ Ed. Saraiva. 2017. 
ANEXO
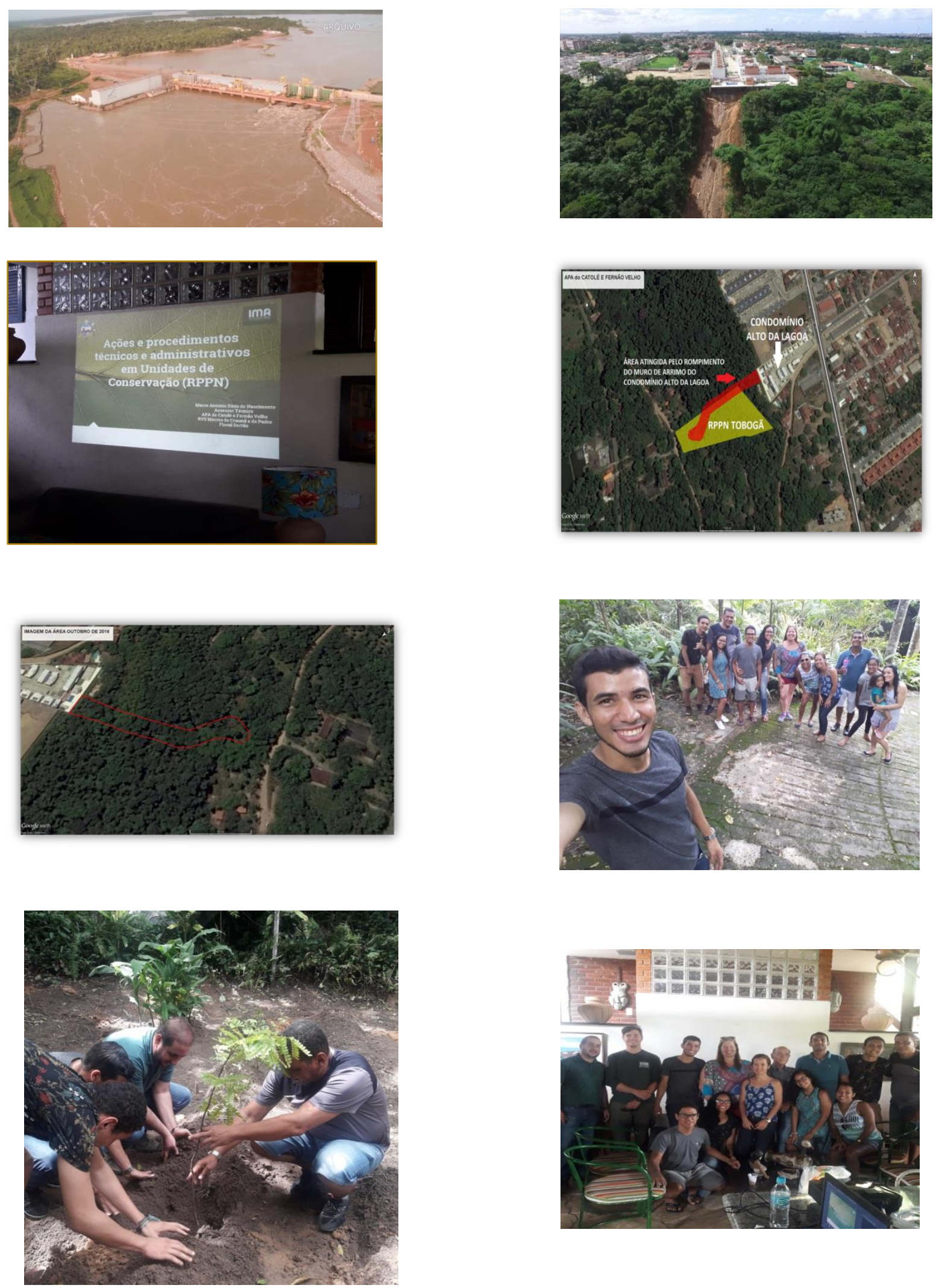


\section{Bapítulo 19}

\section{RESIDDUO HOSPITALAR: UM ESTUDO EM UM MUNICIPIO DE PEQUENO PORTE DO SUDESTE PARAENSE}

\section{Deuzenir Mendes Araújo \\ Wilcker Araújo Sampaio \\ Elizabete Campos Lima \\ Marcilene Feitosa Araújo}

RESUMO: Este estudo teve como objetivo geral analisar o manejo e descarte dos resíduos de serviços de saúde (RSS) e como objetivos específicos, verificar se o hospital público, particulares e clínicas odontológicas estão tratando os resíduos de acordo com as normas regulamentadoras, buscou-se ainda, avaliar se os trabalhadores das unidades executam suas atividades com segurança. Todos os estabelecimentos de saúde devem elaborar o Plano de Gerenciamento de Resíduos de Serviços de Saúde (PGRSS) baseados nas características dos resíduos. Este estudo é de natureza qualitativa e de caráter exploratório. As técnicas de coleta de dados utilizadas foram a análise documental, entrevistas e observação in loco. Os dados foram coletados a partir de roteiros semiestruturados com 72 questões sobre o gerenciamento do resíduo, normas regulamentadoras, equipamentos de proteção individual (EPI) e biossegurança. Como antecipação dos resultados destaca-se que, os resíduos de serviços de saúde por apresentar peculiaridades nocivas ao meio ambiente e a saúde pública necessitam de um tratamento específico, no entanto, observou-se que as unidades de saúde pesquisadas não atendem aos preceitos lei da $n^{\circ}$ 12.305/2010 e as normas RDC $n^{\circ}$ 306/2004 da ANVISA combinada com a CONAMA 끄 358/05.

Palavras - Chave: Resíduos. Resíduos Sólidos de Saúde. PGRSS. Trabalhador de Saúde. 


\section{INTRODUÇÃO}

A Norma Brasileira Regulamentadora NBR 10004/04 da Associação Brasileira de Normas Técnicas (ABNT), define como resíduos, os resíduos sólidos e semissólidos provenientes da indústria, do comércio, das atividades doméstica, agrícolas e hospitalares (ABNT, 2004; CAFURE; PATRIARCHA-GRACIOLLI, 2014).

Os resíduos de serviços de saúde trazem em sua composição, agulhas e seringas contaminadas, resquícios humanos, resíduos laboratoriais, vacinas e antibióticos com prazos de validade vencidos e materiais de curativos contaminados, materiais radioativos e entre outros, que por sua vez, podem trazer sérios danos à saúde do trabalhador e ao meio ambiente, isso por falta de conhecimento e informação dos agentes envolvidos no processo que induz o manejo de forma inadequada (ABNT, 1993; PEREIRA, 2012).

Diante do exposto, a questão que se propõe para esta pesquisa é assim enunciada: Como o hospital público, particulares e clínicas odontológicas de um município no sudeste paraense estão realizando a coleta, o tratamento e o descarte dos resíduos de serviços de saúde?

Dessa forma, o presente estudo teve como objetivo analisar o manejo e descarte dos resíduos de serviços de saúde (RSS) e verificar se o hospital público, particulares e clínicas odontológicas estão tratando os resíduos de acordo com as normas regulamentadoras. $\mathrm{O}$ estudo foi desenvolvido em um município de pequeno porte do sudeste paraense, localizado as margens da BR 222. Para alcançar o objetivo, adotou-se uma metodologia de abordagem qualitativa por meio de um estudo de caso múltiplo. A coleta dos dados foi realizada in loco.

Nesse sentido, este estudo torna-se relevante para conscientização dos trabalhadores e agentes envolvidos quanto à saúde e segurança no manejo do resíduo hospitalar, bem como, os prejuízos que o descarte inadequado desse material provoca no meio ambiente.

\section{REFERENCIAL TEÓRICO}

Gerenciamento dos Resíduos de Serviços de Saúde - RSS

A Norma Brasileira Regulamentadora - NBR 12808/1993 da Associação Brasileira de Normas Técnicas - ABNT, classifica os resíduos de serviços de saúde e derivados, como prejudiciais ao meio ambiente e a saúde pública, como resíduo infectante e resíduo radioativo (ABNT, 1993).

A Resolução CONAMA n 358/2005, segundo - Quadro 1, estabelece uma classificação com cinco grupos de resíduo hospitalar, separando por nível de periculosidade e peculiaridade dos materiais (ELEUTÉRIO; HAMADA; PADIM, 2008).

Quadro 1: Classificação e identificação dos RSS.

\begin{tabular}{|l|l|l|}
\hline \multicolumn{1}{|c|}{ Classificação } & \multicolumn{1}{|c|}{ Características } \\
$\begin{array}{l}\text { Grupo A } \\
\text { Resíduos } \\
\text { Potencialmente } \\
\text { Perigosos }\end{array}$ & $\begin{array}{l}\text { Materiais com possível presença de agentes biológicos, } \\
\text { os quais podem apresentar risco de infecção. São } \\
\text { classificados em 5 subgrupos: A1, A2, A3, A4 e A5. }\end{array}$ & $\begin{array}{l}\text { Placas e lâminas de laboratório, } \\
\text { carcaças, peças anatômicas } \\
\text { (membros), tecidos, bolsas } \\
\text { transfusionais de sangue, etc. }\end{array}$ \\
\hline $\begin{array}{l}\text { Grupo B } \\
\text { Resíduos } \\
\text { Químicos }\end{array}$ & $\begin{array}{l}\text { Contém substâncias químicas que podem apresentar } \\
\text { risco à saúde ou ao meio ambiente, dependendo de suas } \\
\text { características de inflamabilidade, corrosividade, } \\
\text { reatividade e toxicidade. }\end{array}$ & $\begin{array}{l}\text { Produtos hormonais e antimicrobianos, } \\
\text { medicamentos apreendidos, reagentes } \\
\text { de laboratório, resíduos contendo } \\
\text { metais pesados, etc. }\end{array}$ \\
\hline $\begin{array}{l}\text { Grupo C } \\
\text { Rejeitos } \\
\text { Radioativos }\end{array}$ & $\begin{array}{l}\text { Materiais com radionuclídeos em quantidades superiores } \\
\text { aos limites especificados nas normas da Comissão } \\
\text { Nacional de Energia Nuclear (CNEN). }\end{array}$ & $\begin{array}{l}\text { Materiais de serviços de medicina } \\
\text { nuclear e radioterapia. }\end{array}$ \\
\hline $\begin{array}{l}\text { Grupo D } \\
\text { Resíduos } \\
\text { equiparados aos } \\
\text { Resíduos } \\
\text { Domiciliares }\end{array}$ & $\begin{array}{l}\text { Não apresentam risco biológico, químico ou radiológico à } \\
\text { saúde ou ao meio ambiente. }\end{array}$ & $\begin{array}{l}\text { Sobras de alimentos e do preparo de } \\
\text { alimentos, resíduos das áreas } \\
\text { administrativas, etc. }\end{array}$ \\
\hline Grupo E & Materiais perfurocortantes. & $\begin{array}{l}\text { Lâminas de barbear, agulhas, ampolas } \\
\text { de vidro, lâminas e bisturi, lancetas, } \\
\text { espátulas, etc. }\end{array}$ \\
\hline
\end{tabular}

Fonte: Bartholomeu; Branco e Caixeta-Filho (2011, p.45). 
Os resíduos de serviços de saúde por se apresentarem de forma heterogênea exigem cuidados específicos e adequados. Sua classificação tem por finalidade compreender as características dos resíduos, levando em consideração a origem, fator este que facilita a correta manipulação dos resíduos gerados pelos estabelecimentos, de forma econômica e eficiente, assegurando a saúde e bem estar dos trabalhadores, coletividade e meio ambiente (TEIXEIRA, 2004; KOPP; ARAUJO; FIGUEIREDO, 2013). Vale ressaltar que, a classificação dos resíduos de serviços de saúde vem passando por alterações, isso, devido aos novos tipos de resíduos que vêm surgindo nos estabelecimentos de saúde (ANVISA, 2006).

De acordo com a lei no 12.305/2010, é atribuído aos geradores o comprometimento pelo destino dos resíduos de forma obrigatória e indispensável. A obrigatoriedade visa fomenta a construção de um projeto gerencial que seja aplicado na instituição de forma a inibir a prática do manejo inadequado e que por sua vez, pode trazer danos irreversíveis ao meio ambiente e à saúde da população (BRASIL, 2010; RIZZON; NODARI; REIS, 2015).

Os Resíduos de Serviços de Saúde (RSS), abrange todos os resíduos originados de atividades de unidade de prestação de serviço de saúde, referentes a seres humanos e animais. Estes envolvem procedimentos de diagnósticos, investigação, laboratorial, hospitalar, farmacêuticas, embalsamento, veterinários, assim como ações evasivas realizadas em alguns procedimentos estéticos como, por exemplo, piercings, tatuagens e similares (UNESP, 2009; PEREIRA et al, 2013). Além disso, os resíduos oriundos de fontes pequenas e dispersas, incluindo os resíduos gerados decorrente do serviço de saúde realizados em residências resultantes de autoadministração de insulina entre outros (DEBERE et al, 2013; WHO,2014).

A Agencia Nacional de Vigilância Sanitária ANVISA (2004, p. 2), na Resolução da Diretoria Colegiada - RDC № 306/04, combinada com a CONAMA no $358 / 05$ propõe que:

O gerenciamento dos RSS constitui-se em um conjunto de procedimentos de gestão, planejados e implementados a partir de bases científicas e técnicas, normativas e legais, com o objetivo de minimizar a produção de resíduos e proporcionar aos resíduos gerados, um encaminhamento seguro, de forma eficiente, visando à proteção dos trabalhadores, a preservação da saúde pública, dos recursos naturais e do meio ambiente. O gerenciamento deve abranger todas as etapas de planejamento dos recursos físicos, dos recursos materiais e da capacitação dos recursos humanos envolvidos no manejo dos RSS. Todo gerador deve elaborar um Plano de Gerenciamento de Resíduos de Serviços de Saúde - PGRSS, baseado nas características dos resíduos gerados e na classificação constante do Apêndice I, estabelecendo as diretrizes de manejo dos RSS.

O gerenciamento de resíduos de serviços é um processo que visa garantir a higiene e a segurança dos hospitais e dos trabalhadores da área da saúde, envolvendo o planejamento e aquisição de práticas adequadas para assegurar a saúde dos mesmos. O treinamento da equipe, assim como, o uso correto dos equipamentos de proteção individual e métodos de descarte dentro e fora do hospital (ALVES, 2010; ÖRGEV; UTKU, 2016).

A principal razão para integralização do plano de gerenciamento dos resíduos de serviços de saúde nas unidades é a proteção dos trabalhadores, da área de saúde, dos pacientes e público em geral. É por meio do plano que se busca reduzir o risco de exposição dos resíduos através do correto gerenciamento destes (COSTA, 2012; WHO, 2014).

Ainda sobre o plano de gerenciamento, o mesmo tem por objetivo a redução de resíduos gerados na unidade de saúde, reajustamento dos recursos físicos, materiais e da capacitação dos recursos humanos, que aliadas à educação permanente, representam um avanço para os problemas de geração de RSS (PEREIRA et al, 2013).

O Plano de Gerenciamento de Resíduos de Serviços de Saúde (PGRSS) discorre sobre as etapas do manejo dos resíduos desde a unidade geradora até o destino final, passando pela segregação que envolve a fragmentação dos materiais no ambiente de sua formação, dividindo-os de acordo com seus aspectos peculiares (ANVISA, 2004; PAIVA; DIAS, 2013).

Já o acondicionamento envolve a ação de embalar os resíduos segregados em embalagens impermeáveis e resistentes a 
possíveis perfurações, vazamento e violação. As embalagens devem ser devidamente identificadas de forma a facilitar a visualização de acordo com a classificação de risco existente no conteúdo das mesmas, respeitando o limite de peso e não permitindo a reutilização dos sacos (ANVISA, 2004; COSTA, 2012). A classificação do acondicionamento dos RSS é representada em cincos grupos, sendo estes divididos conforme o grau de periculosidade. O Quadro 2, apresenta cada grupo de forma sintetizada.

Quadro 2: Procedimento para acondicionamento e identificação dos RSS.

\begin{tabular}{|l|l|c|}
\hline Classificação & \multicolumn{1}{|c|}{ Acondicionamento } \\
\hline Grupo A & $\begin{array}{l}\text { Devem ser acondicionados em sacos branco leitoso, } \\
\text { resistentes, impermeáveis utilizando-se sacos duplos para os } \\
\text { resíduos pesados e úmidos, devidamente identificados com } \\
\text { rótulos de fundo branco, desenho e contorno preto contendo } \\
\text { símbolo e a inscrição de "Risco Biológico". }\end{array}$ \\
\hline Grupo B & $\begin{array}{l}\text { Devem ser acondicionados em sacos branco leitoso, } \\
\text { resistentes, impermeáveis utilizando-se sacos duplos para os } \\
\text { resíduos pesados e úmidos, devidamente identificado com } \\
\text { rótulos de fundo vermelho, desenho e contornos pretos, } \\
\text { contendo símbolo de substância tóxica e a inscrição de } \\
\text { "Resíduo Toxico". }\end{array}$ \\
\hline Grupo C & $\begin{array}{l}\text { Devem obedecer às normas de uma legislação especifica da } \\
\text { CNEN (Comissão Nacional de Energia Nuclear). }\end{array}$ \\
\hline Grupo D & $\begin{array}{l}\text { Os materiais reutilizáveis e recicláveis devem ser separados e } \\
\text { acondicionados de acordo com as normas dos serviços locais } \\
\text { de limpeza. Os demais são acondicionados em sacos pretos. } \\
\text { Devem ser acondicionados em recipientes resistentes, rígidos, } \\
\text { com tampa e identificados como resíduos perfurocortantes, } \\
\text { sendo proibido o reaproveitamento desses recipientes. O } \\
\text { volume não deve ultrapassar 2/3 da capacidade do recipiente. }\end{array}$ \\
\hline
\end{tabular}

Fonte: Bartholomeu; Branco e Caixeta-Filho (2011, p.55).

O transporte interno dos RSS ocorre num período programado que consiste no momento oposto a distribuição de alimentos e medicamentos, troca de roupas, visitas, respeitando os grupos de riscos e recipientes. O resíduo coletado deverá se destinando a um local de armazenamento temporário, externo a unidade (ANVISA, 2004; MUNIZ,2011; VIEIRA, 2013).

Conforme a Resolução CONAMA n‥ 358/2005, o RSS destinado para o armazenamento temporário deve estar acondicionado na embalagem já identificada de acordo com o grau de risco, estes devem ser destinados a locais de fácil acesso e visualização. O tratamento consiste no processo de modificação deste, isto é, as características são modificadas de forma a minimizar ou excluir os riscos de contaminação ao meio ambiente e possíveis acidentes de trabalho (MUNIZ, 2011; CASTRO et al, 2014).

Ainda a respeito do gerenciamento, destacase o processo de incineração, identificado como sendo um dos mais utilizados no tratamento dos RSS pelas unidades de saúde. Ele consiste na queima em altas temperaturas destes resíduos, dando segmento na redução e eliminação dos microrganismos, resultando em cinzas, resíduos incombustíveis e gases. Geralmente, essas cinzas não apresentam risco inerentes, se operado de modo que respeite as exigências de proteção do meio ambiente (TEIXEIRA,2004).

Apesar de eliminar microrganismos, este procedimento traz consequências, isto é, o processo libera diversas substâncias poluentes que se gerenciadas de forma 
inadequada poderá trazer sérios danos ao meio ambiente e a saúde pública (BARTHOLOMEU; BRANCO; CAIXETA-FILHO, 2011).

No que tange ao armazenamento externo, a lei recomenda que os resíduos sejam guardados em recipientes específicos e fiquem a disposição do processo logístico externo (COSTA; FONSECA, 2009). Este consiste no translado do armazenamento até a disposição final que equivale à acomodação dos resíduos no solo, antecipadamente preparado para recebê-los, respeitando os critérios técnicos e ambientais da Resolução CONAMA no. 237/97 (ANVISA, 2004; CONAMA, 1997).

No que tange à disposição final dos resíduos, a prática mais comum é o descarte nos aterros sanitários, aterros de resíduos perigosos classe I, aterros controlados, lixão e valas sépticas. No que se refere aos municípios da região norte, os "lixões a céu aberto" é uma realidade na maioria dos municípios, sendo o local mais usado para o descarte desse material.

O IBGE (2010) informa que apesar de ser muito usado o descarte deste tipo de resíduo em lixões é irregular, pois a prática resume-se apenas no descarregamento dos resíduos no solo sem prevenção ao meio ambiente. Quanto ao depósito em valas sépticas, prática também comum, esta deve seguir normas específicas da ABNT, devendo ser impermeabilizadas e revertidas, segundo os padrões exigidos (BARTHOLOMEU; BRANCO; CAIXETA-FILHO, 2011; PAIVA; DIAS, 2013).

Conforme o que sugere a lei, a empresa geradora deve seguir as Normas Regulamentadoras, classificando os resíduos conforme cada grupo, realizando o manejo e o descarte correto de forma a não expor o trabalhador e a população em geral aos riscos eminentes à saúde.

\subsection{MANEJO DO RESÍDUO HOSPITALAR, SEGURANÇA E SAÚDE DO TRABALHADOR}

Os Resíduos de Serviços de Saúde constituem ameaças tanto à saúde do trabalhador quanto ao meio ambiente, justamente pelas práticas inadequadas de manuseio dos diversos tipos de resíduos contaminados. Neste sentido, vale destacar que a manipulação correta desse material pode ajudar evitar acidentes e assegurar a saúde do trabalhador (LEMOS, 2012; MOREIRA, 2012).

As medidas de biossegurança visam a precaução e diminuição de acidentes como também o surgimento de doenças ocupacionais. Para a segurança do trabalhador é necessário que este esteja atento quanto à adesão de práticas seguras, evitando riscos de contaminação e disseminação de doenças, bem como, garantindo sua própria segurança e contribuindo para evitar danos ao meio ambiente (ANVISA, 2004; GOMES, et al 2014).

A Agência Nacional de Vigilância Sanitária ANVISA (2010, p. 7), afirma que: "Biossegurança é um conjunto de medidas destinadas a prevenir riscos inerentes às atividades dos laboratórios de assistência, ensino, pesquisa e desenvolvimento tecnológico, que possam comprometer a saúde dos profissionais e o meio ambiente".

Teixeira e Valle (2010, p. 19), afirmam que:

A biossegurança é o conjunto de ações voltadas para a prevenção, minimização ou eliminação de riscos inerentes às atividades de pesquisa, produção, ensino, desenvolvimento tecnológico e prestação de serviços, riscos que podem com prometer a saúde do homem, dos animais, do meio ambiente ou a qualidade dos trabalhos desenvolvidos.

O termo biossegurança, ainda é considerado uma novidade em expansão entre as organizações, o que possibilita uma busca constante por novas descobertas através de investimentos, principalmente em pesquisa científica, pois o objetivo e a proteção e a prevenção dos trabalhadores de saúde contra os riscos de contaminação e proliferação de microrganismos existentes no ambiente de trabalho (GOMES, et al 2014).

Ainda neste sentido, as Normas Regulamentadoras (NR6) estabelecem o uso de Equipamentos de Proteção Individual (EPI's) aos trabalhadores, o objetivo é a proteção destes contra possíveis riscos de acidentes e doenças decorrentes das circunstâncias de trabalho (TEXEIRA; VALLE, 2010; MEIRELES; PINTO, 2016).

As normas destacam ainda que, compete ao empregador institucionalizar o uso do Equipamento de Proteção Individual, também é de sua responsabilidade a aquisição, a 
preparação do colaborador por meio de treinamento referente ao uso, conservação e substituição quando houver necessidade. Nesse sentido, cabe ao trabalhador a responsabilidade de utilizar o equipamento no ambiente de trabalho, guardar, conservar e informar qualquer variação nos mesmos (DOBROVOLSKI; WITKOWSKI; ATAMANCZUK, 2008; MINISTÉRIO DO TRABALHO, 2010).

\subsection{O MUNICÍPIO E A RESPONSABILIDADE QUANTO AOS RSS}

A Constituição Federal, no seu artigo 30, destaca que são de responsabilidade dos municípios a criação das regras de manejo, tratamento e descarte dos resíduos de serviços de saúde. Essa determinação se dá em razão da proximidade do ente com a comunidade. No entanto, nota-se que os municípios, em especial os de pequeno porte, não executam com eficiência o processo, geralmente por falta de recursos para a montagem da estrutura ideal.

O não cumprimento dessa recomendação força a prática incorreta de manejo e descarte, uma vez que, todo o resíduo coletado passa a ser destinado à aterros sanitários e/ou lixões, sem qualquer tratamento (POZZETI; MONTEVERDE, 2017).

De acordo com o Manual de Gerenciamento de Serviços de Saúde da ANVISA (2006, p. 38). "Os estabelecimentos de serviços de saúde são os responsáveis pelo correto gerenciamento de todos os RSS por eles gerados, cabendo aos órgãos públicos, dentro de suas competências, a gestão, regulamentação e fiscalização".

São de responsabilidades dos serviços geradores de RSS a elaboração e execução do Plano de Gerenciamento de Resíduos de Serviços de Saúde, conforme indicam as normas técnicas, bem como, disponibilizar o acesso dos mesmos quando solicitados pelas autoridades de órgãos fiscalizadores e do público em geral. Também é de responsabilidade dos geradores (empresa pública e/ou privada), promover treinamento e capacitação dos trabalhadores de serviços de saúde (ANVISA, 2004; CONAMA, 2005).

A Agência Nacional de Vigilância Sanitária (ANVISA), Ministério do Meio Ambiente por intermédio do SISNAMA - Sistema Nacional de Meio Ambiente sugere o compartilhamento de responsabilidade (poder público e sociedade) pela biossegurança e prevenção de acidentes. No entanto, o que se observa na prática é que esse compartilhamento ocorre de forma negligente por parte dos diversos agentes $\mathrm{o}$ que prejudica $\mathrm{O}$ comprimento do dever de fiscalizar, prejudicando assim, a realização dos procedimentos de tratamento e descarte dos resíduos hospitalares (POZZETI; MONTEVERDE, 2017).

A Lei da Política do Meio Ambiente (Lei 6.938/81), nos seus artigos 3 e 14 e a Lei dos Crimes Ambientais (Lei 9.605/98), artigos 54 e 56, discorre que tanto as pessoas físicas como as jurídicas que provocarem danos ambientais e a saúde humana direta ou indiretamente podem responder, civil, penal ou administrativamente por tais crimes (BAGIO, et al, 2013). O próximo tópico abordará os procedimentos metodológicos adotados no estudo.

\section{METODOLOGIA}

Nesse estudo, utilizou-se uma abordagem qualitativa, porque teve o ambiente como origem principal das informações, interpretando as ocorrências e dando relevância ao estudo, preocupando-se com o processo, analisando e assimilando dados existentes (PRODANOV; FREITAS, 2013).

$\mathrm{Na}$ composição do presente artigo foi realizada uma pesquisa exploratória por meio de entrevista semiestruturada com gestores de unidade de saúde, empresários (clínicas), trabalhadores de serviço de saúde, bem como, observação in $10 c 0$ e análise documental (Planos de Gerenciamento de Resíduos dos Serviços de Saúde - PGRSS).

A observação in loco ocorreu no local em que foram aplicadas as entrevistas (hospitais e clínicas) e teve por objetivo a confirmação das informações prestadas pelos gestores, empresários e funcionários quanto ao manejo e descarte dos resíduos de serviços de saúde produzidos por cada unidade pesquisada no município.

O município é constituído por diversas unidades de serviços de saúde (pública/privada) que prestam os mais variados serviços de saúde à população. Para melhor entendimento dos achados da pesquisa e visando a não identificação e, respeitando o anonimato dos pesquisados e 
de suas unidades, optou por categorizar cada unidade pesquisada Conforme Quadro 4.

Nesse sentido, foram elaboradas entrevistas com os gestores dos hospitais, clínicas odontológicas e trabalhadores da área. Se buscou conhecer como ocorria a aplicação e execução do PGRSS. Buscou-se ainda, entender o papel dos órgãos fiscalizadores e/ou gerenciadores. As entrevistas ocorreram no período de janeiro a fevereiro do ano de 2018 e foram realizadas com os agentes diretamente envolvidos no processo.
Foram elaborados 7 (sete) roteiros de entrevista semiestruturados, um para cada público, isto é, roteiros de entrevista semiestruturado para gestores dos hospitais, gestor da secretária de saúde do município, analista da secretaria de meio ambiente, trabalhadores das unidades de saúde (clínicas e hospitais), agente fiscalizador da vigilância sanitária, totalizando 72 questões sobre gerenciamento e fiscalização dos resíduos de serviços de saúde e a segurança dos trabalhadores de saúde. Conforme demonstrado no Quadro 4, que evidencia a organização da pesquisa.

Quadro 4: Estrutura das entrevistas.

\begin{tabular}{|c|c|c|c|c|}
\hline Instrumento & Agentes & $\begin{array}{c}\text { Unidade } \\
\text { Pesquisadas }\end{array}$ & $\begin{array}{l}\text { Caracterização do } \\
\text { Objeto }\end{array}$ & $\begin{array}{c}\text { Duração das } \\
\text { Entrevistas }\end{array}$ \\
\hline & Gestor & & Clínica 1 & \\
\hline & Gestor & & Clínica 2 & \\
\hline & Gestor & & Clínica 3 & \\
\hline & Gestor & & Clínica 4 & \\
\hline & $\begin{array}{l}\text { Trabalhador de } \\
\text { Saúde }\end{array}$ & Clínicas & $\begin{array}{l}\text { Trabalhado de } \\
\text { Clínica } 1\end{array}$ & \\
\hline & $\begin{array}{l}\text { Trabalhador de } \\
\text { Saúde }\end{array}$ & Odontológicas & $\begin{array}{l}\text { Trabalhado de } \\
\text { Clínica } 2\end{array}$ & \\
\hline & $\begin{array}{l}\text { Trabalhador de } \\
\text { Saúde }\end{array}$ & & $\begin{array}{l}\text { Trabalhado de } \\
\text { Clínica } 3\end{array}$ & \\
\hline & $\begin{array}{c}\text { Trabalhador de } \\
\text { Saúde }\end{array}$ & & $\begin{array}{l}\text { Trabalhado de } \\
\text { Clínica } 4\end{array}$ & \\
\hline Entrevista & Gestor & & Hospital Público & Aproximadamente \\
\hline Semiestruturada & Gestor & & Hospital Privado 1 & 40 minutos \\
\hline & Gestor & & Hospital Privado 2 & \\
\hline & $\begin{array}{l}\text { Trabalhador de } \\
\text { Saúde }\end{array}$ & Hospitais & $\begin{array}{l}\text { Trabalhador de } \\
\text { Hospital Público }\end{array}$ & \\
\hline & $\begin{array}{l}\text { Trabalhador de } \\
\text { Saúde }\end{array}$ & & $\begin{array}{l}\text { Trabalhador de } \\
\text { Hospital Privado } 1\end{array}$ & \\
\hline & $\begin{array}{l}\text { Trabalhador de } \\
\text { Saúde }\end{array}$ & & $\begin{array}{c}\text { Trabalhador de } \\
\text { Hospital Privado } 2\end{array}$ & \\
\hline & Analista & $\begin{array}{l}\text { Secretaria de } \\
\text { Meio Ambiente }\end{array}$ & 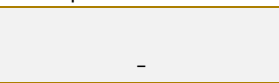 & \\
\hline & Agente Fiscalizador & $\begin{array}{l}\text { Vigilância } \\
\text { Sanitária }\end{array}$ & $\begin{array}{l}- \\
-\end{array}$ & \\
\hline & Gestor & $\begin{array}{l}\text { Secretaria de } \\
\text { Saúde }\end{array}$ & - & \\
\hline $\begin{array}{l}\text { Observação in } \\
\text { loco }\end{array}$ & - & $\begin{array}{l}\text { Hospitais e } \\
\text { clínicas }\end{array}$ & - & $\begin{array}{c}\text { Duração da } \\
\text { pesquisa }\end{array}$ \\
\hline $\begin{array}{c}\text { Análise } \\
\text { documental }\end{array}$ & - & PGRSS & - & $\begin{array}{c}\text { Duração da } \\
\text { pesquisa }\end{array}$ \\
\hline
\end{tabular}

Fonte: Dados da Pesquisa.

Como técnica de análise de dados, usou-se a análise descritiva e a análise de conteúdo de Bardin (2011). Para operacionalizar a fase das análise foram adotadas as categorias (Kerlinger, 1979): CA1: Manejo e descarte dos resíduos CA2: Adequação a norma. A análise das CA's pode permitir que se alcance as repostas referentes às questões de pesquisa e se atenda aos objetivos do estudo, tendo como base o marco teórico revisado e os resultados encontrados. 
CA1: Manejo e descarte dos resíduos: Envolve todas as etapas do gerenciamento desde a segregação até a disposição final, tendo por finalidade reduzir e/ou eliminar os microrganismo existente nos RSS produzidos pelos estabelecimentos de saúde, garantindo a saúde pública e do meio ambiente (ANVISA, 2004).

CA2: Adequação a norma: O cumprimento das normas/leis torna-se relevante para regulamentar o gerenciamento dos RSS produzidos pelas unidades de serviços de saúde, referentes a seres humanos e animais. Cabendo a mesma a elaboração do PGRSS baseados nas características e classificação dos resíduos gerados, devendo contar com todas as etapas do processo desde a capacitação dos recursos humanos materiais, físicos e medida de prevenção emergencial. O objetivo é assegurar a saúde dos trabalhadores, coletividade e meio ambiente, atribuindo aos entes federados mais próximo da unidade o controle e fiscalização do gerenciamento baseados nas normas/leis estabelecidas (ALVES, 2010; LEMOS, 2012; BAGIO, et al, 2013; POZZETI; MONTEVERDE, 2017).

Com a finalidade de responder a questão de pesquisa proposta, analisou-se o grau de conhecimento de cada agente em relação às normas regulamentadoras de biossegurança e uso dos Equipamentos de Proteção Individual - EPl's. Buscou-se ainda, obter informações específicas a respeito da temática abordada.

Em relação aos meios técnicos, foram efetivadas buscas em sites oficiais do governo, os quais se destacam as Resoluções publicadas no Diário Oficial da União - DOU, oriundas do Conselho Nacional de Meio Ambiente - CONAMA, Agencia Nacional de Vigilância Sanitária - ANVISA, Associação Brasileira de Normas Técnicas - ABNT, artigos científicos, livros, dissertações e teses que tratam do assunto.

\section{ANÁLISE E DISCUSSÃO DOS RESULTADOS}

A região sudeste do Pará é composta por 39 municípios em uma área de aproximadamente 297 mil km². Dentre eles destaca-se o município estudado. Este estar situado na BR 222 e conta com aproximadamente 50.925 habitantes (IBGE, 2017).

\subsection{ANÁLISE DAS UNIDADES}

Compreende-se que para os resíduos de serviços de saúde são necessários um tratamento adequado, desde a sua origem até a disposição final, para que possa garantir a segurança dos trabalhadores de saúde, população em geral e prevenir danos ao meio ambiente, conforme sugere Lemos (2012).

As entrevistas realizadas nas clínicas odontológicas, com gestores e trabalhadores de saúde foram caracterizadas como Clinicas 1, 2, 3 e 4; trabalhadores 1, 2, 3 e 4 respectivamente. Ao serem questionados sobre a existência do Plano de Gerenciamento de Resíduos de Serviços de Saúde (CA1) notou-se que as mesmas não possuem o plano. Apesar de ser imposto pela RDC n-306, (CA2), conforme destaca a ANVISA (2004).

Quando questionado sobre o PGRSS nas clínicas odontológicas a Secretaria de Meio Ambiente, por meio de seu representante destacou: "[...] as clínicas odontológicas, elas não têm, porque não são licenciadas pela COEMA 120".

Pelo fato delas não estarem enquadradas na COEMA 120, que é a legislação vigente do estado e, por não disporem de uma resolução específica, não é exigido destas unidades (clínicas odontológicas) o PGRSS de forma obrigatória. Assim, nota-se que por desconhecimento de suas atribuições os estabelecimentos são induzidos a atuarem de forma negligente ao gerenciarem seus resíduos.

Vale salientar que as unidades de serviços de saúde pesquisadas são responsáveis pelos gerenciamentos dos resíduos gerados, conforme sugere a RDC no 306/04 e o manual de gerenciamento de resíduos de serviço de saúde da ANVISA (2006).

De acordo com relato do analista da Secretaria de Meio Ambiente, o mesmo afirma que é de responsabilidade do município: "[...] resíduos domésticos e fragmentos de resíduos florestais da área urbana". Já os "Resíduos de saúde, resíduos industriais, inertes, condomínios e construção civil, é o empreendimento que tem que arcar".

A forma adotada pelas 4 (quatro) clínicas pesquisadas são distintas. Duas (2) delas informou que realizou um acordo extraoficial com o Hospital Público e este passou a receber os resíduos gerados pelas Clinicas 1 
e 2. Vale destacar que a lei responsabiliza pelo tratamento dos RSS e a disposição final desse material o próprio gerador, no caso, a própria clínica.

Em entrevista realizada com o gestor 3 de uma das clínicas, este destacou que: "Nos primeiros anos aqui de trabalho, o depósito do lixo era feito no hospital Público, toda semana nós pegávamos o material chegávamos lá e dávamos para a pessoa responsável e lá fazia a incineração [...] hoje já não recebem mais, cabe a mim fazer essa incineração".

O pesquisado destaca ainda que, por não contar mais com o apoio do hospital público o mesmo passou a efetuar o descarte de forma irregular em sua pequena propriedade rural localizada nas proximidades do município e, segundo ele, sem nenhuma fiscalização.

$\mathrm{Na}$ clínica 4, o gestor informou que por não contar mais com o apoio da unidade púbica que deixou de receber os RSS gerados pela clínica para incineração e, por não possuir nenhuma cobrança dos órgãos fiscalizadores em relação aos mesmos, passou a descartar esse resíduo como lixo doméstico, sem tratamento adequado, colocando em risco a saúde de seus trabalhadores e dos profissionais que trabalham na coleta do lixo urbano, bem como de catadores que atuam no lixão da cidade (CA2).

No entanto, quando questionado a secretaria de saúde do município em relação aos resíduos recebido de outras unidades particulares, o representante respondeu: "Fica livre para receber de quem quiser levar, porém, não existe nada devidamente formalizado. [...] A produção do lixo contaminado no setor privado é de responsabilidade de quem produz. Porém, não recusamos a receber tal demanda para incinerar". Contrapondo os relatos dos entrevistados das Clínicas 3 e 4.

Ainda sobre esse assunto, percebeu-se, apesar da resistência do próprio, também gestor em fornecer informações sobre o gerenciamento dos resíduos da unidade (clínica 4), que na clínica (de caráter familiar), o auxiliar de serviço de saúde não possui treinamento para manipular os RSS. Questão preocupante.

Diante dos relatos, observa-se que esse tipo de prática traz sérios danos ao meio ambiente e à saúde humana, podendo a empresa ser responsabilizada tanto administrativamente, como civil e penal, conforme sugere a Lei da Política do Meio Ambiente (Lei 6.938/81), e a Lei dos Crimes Ambientais (Lei 9.605/98).

De acordo com as entrevistas realizadas com os trabalhadores de saúde das clínicas odontológicas, observou-se que, mais da metade dos entrevistados afirmaram que possuem os cursos técnicos necessários e que receberam treinamentos para o manuseio dos resíduos. Apesar do conhecimento do trabalhador, notou-se, conforme os relatos que, mais da metade dos entrevistados afirmaram já terem sofrido acidentes por descuido ou por usar EPI de forma incorreta, violando a norma NR6 (CA2), conforme sugere Meireles e Pinto (2016).

As entrevistas realizadas nos hospitais, com gestores e trabalhadores de saúde, foram caracterizadas como Hospitais público e privados 1 e 2; trabalhadores de hospitais público e privado 1 e 2 respectivamente. Em entrevistas com os gestores dos hospitais (público e privados), observou-se que, estes não dispõem do PGRSS. No que tange ao cumprimento da norma, todas as unidades pesquisadas informaram que não possuem o PGRSS ou está em andamento (CA2).

Quanto ao tratamento, a observação in loco revelou que nenhuma das unidades de saúde pesquisada atende as normas (CA1). Notouse que o destino mais comum para os resíduos, como por exemplo, peças anatômicas e perfurocortantes são as valas sépticas. Nenhum dos pesquisados souberam nos fornece informações detalhadas quanto à estrutura física das valas sépticas. A falta de informação a esse respeito deixa a dúvida se essa valas atendem os requisitos legais ou se estão irregular, degradando o solo e contaminando o lençol freático, desrespeitando as normas especificadas pela a ABNT (BARTOLOMEU, BRANCO, CAIXETAFILHO, 2017).

Conforme observação in 10co, notou-se que os "incineradores" do Hospital Público e Privado 1, não atendem as normas regulamentadoras (CA2), pois o processo de queima dos resíduos geram substâncias nocivas ao meio ambiente e a saúde pública, uma vez que é realizado de forma incorreta, conforme sugere Bartolomeu, Branco e Caixeta-Filho (2011).

Continuando nesse assunto, quando questionado o gestor do hospital público se o incinerador da unidade era adequado, o 
mesmo afirmou que: [...] "Não 100\% (cem por cento) apropriado, né [...]". O gestor afirma que possui o incinerador, no entanto, este não atende (obedece) todas as regras que a norma exige. A esse respeito, a Secretaria de Meio Ambiente e a Vigilância Sanitária afirmaram que o "incinerador" do Hospital Público, está totalmente irregular, a Vigilância Sanitária ressalta ainda que, o mesmo não pode ser considerado um incinerador, mas sim, um "forno a céu aberto".

$\mathrm{Na}$ observação in 10co, percebeu-se que todos os hospitais, quanto ao sistema de tratamento (CA1), estão irregulares, pois não atendem as normas regulamentadoras. Percebeu-se que o outro "incinerador", pertencente ao Hospital Privado 1, também não segue as normas (CA2) e apresenta-se como uma versão melhorada do incinerador (forno) do Hospital Público.

Ainda sobre o Hospital Público, quando questionado quais RSS eram destinados ao "incinerador" (CA1), foi informado pelo gestor que os resíduos "incinerados" eram resíduos comuns e infectantes resultantes de curativos. No entanto, por meio da a observação in loco percebeu-se nos restos de cinzas provenientes do processo de incineração dos resíduos, a presença de vários materiais hospitalares, dentre eles vidros, tubos de ensaios e seringas. Vale destacar que esse material não se decompõe como o color do "incinerador". Ficou evidente também que a unidade não realiza a segregação, acondicionamento e identificação adequada dos RSS destinados para incineração, conforme é determinado pela norma RDC 306/04.

Uma consequências das ações da unidade foi relatada por um dos funcionários que informou que por pouco não foi atingido por uma explosão de um frasco de aerossol durante a execução do seu trabalho de incineração (CA1). Assim ele destaca: "Quando fui jogar os lixos no "incinerador", como não estava separado, eu não sabia que tinha um frasco de aerossol e quando atirei no fogo houve uma explosão, que voou, quase fui atingido pelo frasco. Ainda bem, que eu tinha me afastado antes!".

Quando questionado sobre o fornecimento dos EPIs para os trabalhadores de saúde (CA2) dos hospitais (público e privados), os mesmos afirmaram fornecerem tais equipamentos parcialmente. Como destaca a entrevista com o gestor do hospital público:
[...] "fornece em partes, né? Depois que eu assumi, a gente vem tentando se adequar da melhor forma possivel, mas ainda não é 100\% (cem por centos) [...]".

Um trabalhador de saúde do hospital público afirmou que: "A luva que uso é essa aqui (mostra a luva), que rasga muito fácil" (luva de látex cano curto). Como demonstrado, as luvas fornecidas para os trabalhadores não são apropriadas para a realização do manejo. O Ministério do Trabalho (2010) na NR6 destaca que o EPI deve ser fornecido de acordo com a peculiaridade da atividade profissional (CA2).

Por não disporem do PGRSS para averiguações (CA2), a observação in loco identificou que os EPIs utilizados para 0 manejo dos RSS não correspondem totalmente as normas de segurança, já em relação ao treinamento dos trabalhadores de saúde a minoria relatou possuir treinamento para o uso do EPI, como sugere o Ministério do Trabalho (2010). Mas nenhum treinamento específico para o manuseio dos resíduos.

Em consequência da ausência de treinamentos específicos e periódicos, um segundo trabalhador de saúde do hospital público pesquisado relatou ter sido vítima de um acidente com perfurocortantes na coleta externa, ocasionado por negligência de outros trabalhadores na segregação e acondicionamento dos resíduos. Lemos (2012) destaca que: o manuseio dos resíduos realizados pelos trabalhadores conciliado com a falta de conhecimento/treinamento traz sérios riscos à saúde dos mesmo, pelo fato dos RSS trazerem microrganismos nocivos à saúde humana.

Segundo o gestor do hospital público, ao tomar conhecimento do ocorrido encaminhou o servidor de saúde ao Centro de Testagem e Aconselhamento - CTA para medidas de prevenção de possíveis contaminações relacionadas ao acidente. O gestor destacou ainda: "[...] esse acidente que ocorreu foi recolhendo o lixo na coleta externa (em outra unidade de saúde) [...] no nosso caso aqui, quando acontece algum tipo de acidente, o funcionário é encaminhado para o CTA e lá é feito todos os exames pertinentes, vacinas e medicações prescritas". Segundo Gomes et al (2014) as medidas de prevenção são necessárias para garantir a biossegurança dos trabalhadores de saúde, coletividade e do meio ambiente. 
Em casos de acidentes semelhantes (CA2), em que o órgão omitir assistência, as pessoas prejudicadas podem entrar com uma ação indenizatória contra o órgão poluidor que causar danos ao meio ambiente ou terceiros, de acordo com o artigo 14, da Lei de Política Ambiental (Lei 6.938/81).

Segundo os relatos dos gestores dos hospitais, compreende-se que, os órgãos fiscalizadores ainda não atuam com o rigor que a lei exige (CA2). As vistorias ocorrem de maneira superficial nas unidades, restringindo-se a quesitos primários (armazenamento e destinação final dos RSS) e no formato de aconselhamento se nenhuma continuidade ou punição a quem descumprir a lei. Observou-se ainda, que não existe uma imposição quanto ao prazo de adequação do gerenciamento dos RSS para as unidades de saúde.

Em entrevista com o gestor do hospital público (CA2), este destaca que: "[...] o setor de vigilância é da gestão (a vigilância sanitária é subordinado a gestão do município), não é um setor à parte do municipio, talvez se fosse, haveria essa cobrança mais frequente, essa expedição de multa, de advertência, no entanto, não há $[\ldots] "$.

Já a Secretaria de Meio Ambiente em resposta a vistoria/fiscalização afirma que (CA2):

[...] os serviços de fiscalização, ele tem sido mais segundo demanda de denúncias, não tem ainda uma programação de fiscalização. Pra fiscalizar esses estabelecimentos seria algo a ser elaborado ainda. No caso dos estabelecimentos licenciáveis eles têm orientações, né? Na medida que acontece as vistorias em prol do licenciamento ambiental, os responsáveis, as pessoas que acompanham são orientadas e, pra que a licença seja emitida também é exigido o plano de gerenciamento de resíduos de saúde, ele tem que contemplar informações sobre qual é o resíduo gerado, de que atividade ele provêm, quais são as medidas mitigadoras, o que é feito na questão do transporte, como é feito o armazenamento e como é feito a destinação final.

Com base na entrevista, percebe-se que há muito a ser feito em relação a questão RSS. Nota-se que não há fiscalização do órgão, que as exigências são apenas para os itens primários do estabelecimento, isto é, o armazenamento e a destinação final dos RSS. No mesmo trecho o entrevistado reafirma que as clínicas odontológicas não são licenciáveis e que apenas os hospitais (público e privados) têm essa licença. Nota-se ainda que, o PGRSS é exigido pelo órgão apenas para liberação do licenciamento conforme sugere a COMANA 237/97. No entanto, na prática, nenhum dos estabelecimentos licenciados (Clínicas e Hospitais) apresentaram o PGRSS.

Ao relatar sobre os hospitais, a secretaria de meio ambiente afirmou que estes precisam se adequar quanto ao gerenciamento dos resíduos (CA2). Apesar de não adequado, o hospital público recebe parte dos resíduos do Hospital Particular 2 e de outros estabelecimentos de serviços de saúde. Já o Hospital Privado 1, de acordo com a observação é o estabelecimento que está mais próximo de atender as exigências recomendadas pela ANVISA, no entanto, no momento ainda não atende.

Conforme o relato do pesquisado na Vigilância Sanitária do município, por um período de tempo, o órgão (vigilância sanitária) realizava a coleta de RSS dos estabelecimentos de saúde, destinando-os para o "lixão" municipal e no mesmo local faziam a "incineração" (CA1). Durante essa prática um dos seus trabalhadores de saúde sofreu um acidente com perfurocortante, a partir do ocorrido deixaram de realizar a coleta e orientaram os estabelecimentos de saúde a levarem os seus RSS para o Hospital Público.

Após um período, o mesmo (hospital público) sobrecarregou-se com o volume recebido e passou a recusar-se a receber esse material de vários estabelecimentos de saúde, (como relatados pelas Clínicas 3 e 4) o que induziu esse estabelecimentos a destinarem seus resíduos ao lixo comum ou realizarem tratamento próprio sem quaisquer fiscalizações (CA2).

Em entrevista com o analista fiscal (Secretaria de Meio Ambiente), quando questionado sobre as limitações do município em fornecer estrutura para as unidades de saúde estudado se adequarem a lei (CA2), o mesmo afirmou que: "Na construção de toda uma estrutura pra atender a destinação final de resíduos sólidos de saúde, ela sairia muito cara, demoraria pra ficar pronta e precisaria de uma disponibilização de valor, que 
acredito que o município não tenha agora" [...].

Com base na observação in loco, percebeuse que até a finalização do estudo, o município não apresentava estruturas físicas e financeiras para se ajusta as normas regulamentadoras vigentes no que tange ao gerenciamento dos resíduos de serviços de saúde (CA2). Conforme relato da Secretaria de Meio Ambiente, uma das limitações do município em adequar-se no que diz respeito aos RSS, é que o mesmo não possui resoluções específicas para controlar e fiscalizar o tratamento dos resíduos. Segundo Pozzeti e Monteverde (2017) os órgãos fiscalizadores negligenciam o controle e a fiscalização do gerenciamento dos RSS produzidos pelos estabelecimentos de saúde.

Por desconhecimento das normas regulamentadoras, criou-se uma cultura nos estabelecimentos de serviços de saúde, atribuindo as responsabilidades somente ao município, isentando-os de suas obrigações, sendo que a adequação é de responsabilidade d próprio gerador (CA2). Tá prática tem se estendido ao longo dos anos, devido ao descaso do poder público, por não haver uma cobrança efetiva voltada pra essa temática com o objetivo de conscientizar e regulamentar e fiscalizar esses estabelecimentos, expondo aos riscos à saúde pública e o meio ambiente, como proposto pela RDC no306/04 da ANVISA. Quando procurada a Secretaria de Saúde para esclarecimentos quanto à disposição final dos RSS, a mesma respondeu que o destino final dos resíduos contaminados produzidos é a incineração no hospital público (CA1). No entanto, a observação in loco evidenciou que os resíduos destinados ao incinerador produz resquícios de materiais que não se decompõem com o processo da queima, e que esses detritos são coletados e destinados a um local não especificado. Em relação as medidas tomadas para regularizar 0 gerenciamento dos RSS (CA2), o gestor (a) afirma que:

O fato de não ter sido melhorado a infraestrutura para tal, devido a regulamentação do uso da cessão de espaço físico da área do Hospital que é uma cessão ao munícipio por parte da FUNASA, porém, não permite alterar a estrutura sem a devida autorização do Órgão Federado mencionado. No momento, o poder executivo pleiteia a concessão definitiva da estrutura ao munícipio.

Vale salientar que a Secretaria de Saúde enviou o relato apresentado acima por escrito aos pesquisadores, e para não ocorrer interpretações distorcidas do relato, este foi exposto na integra. Conforme o relato, entende-se que a adequação do hospital público se limita a autorização da FUNSA a quem pertence o prédio, isto é, nenhuma modificação no sentido de adequar a unidade (parte física) a lei, poderá se realizada sem a permissão do responsável pelo espaço.

Como a secretaria de saúde optou por não receber os pesquisadores e responder o roteiro semiestruturado por escrito e nos enviar, não houve a oportunidade de se argumentar se alguma tentativa junto a FUNASA havia sido realizada, no sentido de obter essa autorização, considerando a necessidade de adequação da unidade de saúde pública a lei. Ainda segundo o relato enviado, considerando a regulamentação do tratamento do resíduo, a secretaria destaca que "o município encara como uma questão ainda a ser resolvida".

\section{CONSIDERAÇÕES FINAIS}

Este estudo teve como objetivo geral analisar o manejo e descarte dos resíduos de serviços de saúde (RSS) e como objetivos específicos, verificar se o hospital público, particulares e clínicas odontológicas estão tratando os resíduos de acordo com as normas regulamentadoras, buscou-se ainda, avaliar se os trabalhadores das unidades executam suas atividades com segurança.

Conforme o resultado observou-se que as informações coletadas pela pesquisa, evidenciou que os estabelecimentos de serviços de saúde atuam de forma imprudente quanto ao gerenciamento dos seus RSS gerados, em geral pelo fato dos mesmos desconhecerem suas obrigações e pelo descaso dos entes federados mais próximos. Percebeu-se ainda que, estes não atuam de forma efetiva para o cumprimento das normas, expondo aos riscos à saúde pública e o meio ambiente.

O resultado do estudo evidenciou ainda, a deficiência no que tange ao tratamento ofertado pelas unidades aos resíduos gerados. Conforme relados dos empresários, alguns são descartados no lixo domestico e 
outros em propriedade rurais de forma irregular e sem fiscalização.

Diante do exposto, entende-se que a falta de fiscalização efetiva dos órgãos responsáveis tem estimulado a cultura de desrespeito ao meio ambiente e a saúde pública, uma vez que, a irregularidade do descarte pode contaminar o ambiente natural e um exemplo são os lenções freáticos, ferir e/ou contaminar os catadores que atuam no lixão do município, sem falar dos trabalhadores que atuam diretamente com o manejo desse material.

Apesar da responsabilidade do descarte, conforme destaca a lei ser do gerador é

\section{REFERÊNCIAS}

[1]. ABNT - ASSOCIAÇÃO BRASILEIRA DE NORMAS TÉCNICAS. ABNT NBR no 12808, de 01 Abril 1993. Resíduos de Serviços de Saúde Classificação. Disponível em: <https://wp.ufpel.edu.br/residuos/files/2014/04/NBR -12808-1993-Resíduos-de-sevirços-de-saúde.pdf>. Acesso em: 9 Nov 2017.

[2]. ABNT NBR no 10004, de 31 maio 2004. Resíduos Sólidos - Definição. Disponível em: <http://www.v3.eco.br/docs/NBR-n-100042004.pdf>. Acesso em: 4 Nov. 2017.

[3]. ALVES. S. B. MANEJO DE RESÍDUOS DE SERVIÇOS DE SAÚDE NA ATENÇÃO BÁSICA. Disponível em: <https://ppgenf.fen.ufg.br/up/127/o/Sergiane_Bisin oto_Alves.pdf>. Acesso em 11 Mar 2018.

[4]. ANVISA. AGÊNCIA NACIONAL DE VIGILÂNCIA SANITÁRIA. Resolução de Diretoria Colegiada - RDC ํㅜ 306, de 7 de dezembro de 2004. Dispõem sobre o regulamento técnico para o gerenciamento de resíduos de serviços de saúde. Disponível em: <http://portal.anvisa.gov.br/documents/33880/2568 070/res0306_07_12_2004.pdf/95eac678-d4414033-a5ab-f0̄276̄d56aaa6>. Acesso em: 03 Dez. 2016.

[5]. AGÊNCIA NACIONAL DE VIGILÂNCIA SANITÁRIA. Gerenciamento dos Resíduos de Serviços de Saúde. Ministério da Saúde, Agência Nacional de Vigilância Sanitária. Disponível em: $<$ http://www.anvisa.gov.br/servicosaude/manuais/m anual_gerenciamento_residuos.pdf >. Acesso em: 08 de Jan. 2018.

[6]. BAGIO et al. O plano de gerenciamento de resíduos de serviço de saúde. Disponível em: <http://www.revistaseletronicas.fmu.br/index.php/r ms/article/viewFile/183/pdf_1 $>$. Acesso em: 18 Mar 2018. necessário que o município por meio dos órgãos fiscalizadores faça cumprir a lei e exija a adequação das unidades e em especial, do próprio hospital público.

As limitações do estudo podem ser descritas em especial, no que tange a resistência dos gestores em fornecer os dados, falta de conhecimento de uma parte dos entrevistados sobre o tema, bem como o tempo limitado para a execução da pesquisa nos estabelecimentos selecionados. Como futuras linhas de pesquisa sugere-se a ampliação deste estudo para outros municípios do estado, bem como a comparação dos achados de pesquisa deste com outras regiões do país.

[7]. BARTHOLOMEU, D. B; BRANCO, J. E. H; CAIXETA-FILHO, J. V. Logística Ambiental de Resíduos Sólidos. São Paulo: Atlas, 2011.

[8]. BRASIL. Lei no 12.305/2010, de 02 de agosto de 2010. Institui a Política Nacional de Resíduos Sólidos. Planalto. Disponível em:<http://www.planalto.gov.br/ccivil_03/_ato20072010/2010/lei/l12305.htm>. Acesso em: 2 Dez. 2017.

[9]. Lei № 6.938/81, de 31 de agosto de 1981. Dispõe sobre a Política Nacional do Meio Ambiente, seus fins e mecanismos de formulação e aplicação, e dá outras providências. Planalto. Disponível em: <http://www. planalto.gov.br/ccivil_03/leis/l6938.htm >. Acesso em: 12 Fev. 2018.

[10]. Lei no 9.605/98, de 12 de fevereiro de 1998. Dispõe sobre as sanções penais e administrativas derivadas de condutas e atividades lesivas ao meio ambiente, e dá outras providências. Planalto. Disponível em:< http://www.planalto.gov.br/CCivil_03/leis/L9605.htm >. Acessado em: 12 Fev. 2018.

[11]. Ministério do Trabalho. Portaria SIT n.. 194, de 07 de dezembro de 2010. NR6 Equipamento De Proteção Individual - EPI. Disponível em: <http://trabalho.gov.br/images/Documentos/SST/N R/NR6.pdf>. Acesso em: 5 Dez. 2017

[12]. CAFURE, V. A. PATRIARCHA-GRACIOLLI, S. R. Os resíduos de serviço de saúde e seus impactos ambientais: uma revisão bibliográfica. Disponível em: <file://D:/artigos\%20lixo\%20hospitalar/cafure\%202 014.pdf>. Acesso em: 28 de Jan. 2018.

[13]. CONAMA. Coselho Nacional do Meio Ambiente. Resoluções do CONAMA. Brasília: Edição Especial, 2012. Disponível em: <http://www.mma.gov.br/port/conama/processos/6 1AA3835/LivroConama.pdf>. Acesso em: 25 Nov. 2017. 
[14]. Coselho Nacional do Meio Ambiente. Resolução CONAMA no 237, de 19 de dezembro de 1997. Dispõe sobre a revisão e complementação dos procedimentos e critérios utilizados no licenciamento ambiental. Publicada no DOU no 247, de 22 de dezembro de 1997, Seção 1, páginas 30841-30843.

[15]. Coselho Nacional do Meio Ambiente. Resolução CONAMA n 358, de 29 de abril de 2005. Dispõe sobre o tratamento e a disposição final dos resíduos dos serviços de saúde e dá outras providências. Publicada no DOU no 84, de 4 de maio de 2005, Seção 1, páginas 6365.

[16]. COSTA. E. C. L. da. Manejo de resíduos de serviço de saúde - Manual básico de procedimentos. Brasília: Edições Câmara; 2012.

[17]. COSTA. W. M. da; FONSECA. M. C. G. da. A importância do gerenciamento dos resíduos hospitalares e seus aspectos positivos para o meio ambiente. Disponível em: $<$ http://www.seer.ufu.br/index.php/hygeia/article/vie wFile/16924/9329>. Acesso em: 2 Mar 2018.

[18]. DEBERE et al. Assessment of the health care waste generation rates and its management system in hospitals of Addis Ababa, Ethiopia, 2011. Disponível em: $<$ https://bmcpublichealth. biomedcentral.com/article s/10.1186/1471-2458-13-28>. Acesso em 7 Mar 2018.

[19]. DOBROVOLSKI. M; WITKOWSKI. V; ATAMANCZUK. M. J. Segurança no trabalho: uso de EPI. Disponível em: <http://www.4eetcg.uepg.br/oral/56_2.pdf>.

Acesso em: 10 Mar 2018

[20]. ELEUTÉRIO. J. P. L; HAMADA. J; PADIM. A. F. Gerenciamento Eficaz No Tratamento Dos Resíduos De Serviços De Saúde - Estudo De Duas Tecnologias Térmicas. Dísponivel em: $<$ http://www.abepro.org.br/biblioteca/enegep2008_ TN_STP_069_490_11445.pdf >. Acesso em: 20 Mar. 2018 .

[21]. GIL, A. C. Como Elaborar um Projeto de Pesquisa. São Paulo: Atlas 2002.

[22]. Métodos e Técnicas para Pesquisa Social. São Paulo: Atlas 2008.

[23]. GOMES, L. C. et al. Biossegurança e resíduos de serviços de saúde no cotidiano acadêmico. Disponível em: <file:///D:/artigos\%20lixo\%20hospitalar/GOMES\%20 ET\%20AL\%202014.pdf>. Acesso em: 2 Dez. 2017.

[24]. KOPP. M. de P; ARAÚJO. C. A. S; FIGUEIREDO. K. F. Gestão dos resíduos sólidos hospitalares: estudo de casos em hospitais do Rio de Janeiro e de São Paulo. Disponível em: <https://seer4.fapa.com.br/index. php/arquivo/articl e/download/209/121 >. Acesso em: 28 Mar 2018.

[25]. LEMOS. M. de C. e. Gerenciamento de Resíduos de um Hospital Público do Rio de
Janeiro: um estudo sobre o saber/fazer da enfermagem no Centro Cirúrgico e Central de Materiais. Disponível em: <http://www2.unirio.br/unirio/ccbs/ppgenf/arquivos/ dissertacoes-arquivo/dissertacoes-

2012/gerenciamento-de-residuos-de-um-hospitalpublico-do-rio-de-janeiro-um-estudo-sobre-osaber-fazer-da-enfermagem-no-centro-cirurgico-ecentral-de-materiais>. Acesso em: 20 de Fev 2018.

[26]. MEIRELES, N. M; PINTO, F. de O. A Conscientização do Trabalhador Quanto à Importância do Uso do Epi $\mathrm{Na}$ Aerosoldas Em Macaé. Revista Científica Interdisciplinar. ISSN: 2358-8411 № 1, v. 3, artigo ํㅡ 4, de Jan/Mar 2016. Disponível

em: <http://revista.srvroot.com/linkscienceplace/index.p $\mathrm{hp} /$ linkscienceplace/article/view/221>. Acesso em 25 Dez 2017.

[27]. MOREIRA, Ana Maria Maniero; GUNTHER, Wanda Maria Risso. Solid waste management in primary healthcare centers: application of a facilitation tool. Rev. Latino-Am. Enfermagem, Ribeirão Preto, v. 24, e2768, 2016. Disponível em http://www.scielo.br/scielo.php?script=sci_arttext\& pid=S0104-

$11692016000100387 \& \operatorname{lng}=e n \& n r m=i s o>$. Acesso em 17 de abril de 2018. Epub 18 de agosto de 2016. 8345.0646 .2768

[28]. MUNIZ. I. C. M. Análise do gerenciamento dos resíduos de serviços de saúde (RSS) dos hospitais das forças armadas de Belém/PA. Disponivel em: <http://www.ufpa.br/ppgec/data/producaocientifica /lvone\%20Cristina.pdf>. Acesso em: 8 Mar 2018.

[29]. NASCIMENTO. E M. M. do. Pragmatismo: Uma filosofia da ação. Revista Redescrições Revista on line do GT de Pragmatismo Ano 3, Número 1, 2011. Disponível em: <http://www.gtpragmatismo.com.br/redescricoes/re descricoes/ano3_01/3_nascimento.pdf $>$. Acesso em: 29 Nov 2017.

[30]. ÖRGEV, C, Çalıca UTKU, A. (2017). Avaliação Microbiológica de Lixeiras de Gerenciamento de Resíduos Médicos em Instituições de Saúde. Revista Sakarya University of Science, 21 (3), 294-301. DOI: 10.16984 / saufenbilder.283805. Disponível em: <http://www.saujs.sakarya.edu.tr/issue/26996/2838 05>. Acesso em: 16 JAN 2018.

[31]. PAIVA. B. R. S; DIAS. L. C. A Experiência de uma estudante do curso técnico em enfermagem sobre separação de resíduos sólidos no grupo hospitalar conceição. Disponível em: $<$ https://coleciona-

sus.bvs.br/lildbi/docsonline/get. php?id=521 >. Acesso em: 15 Mar 2018.

[32]. PEREIRA, Milca Severino et al. Waste management in non-hospital emergency units. Rev. Latino-Am. Enfermagem, Ribeirão Preto , v. 21, n. spe, p. 259-266, Feb. 2013 . Available from 
$<$ http://www.scielo.br/scielo.php?script=sci_arttext \&pid=S0104-

11692013000700032\&lng=en\&nrm=iso $>$. Acesso em 22 Mar. 2018. http://dx.doi.org/10.1590/S010 4-11692013000700032.

[33]. PEREIRA, Suellen Silva. Reflexões sobre o processo de urbanização e a necessidade de gestão ambiental: o caso dos resíduos de serviço de saúde da cidade de campina grande, PB. REVISTA REUNIR, [S.I.], v. 2, n. 1, p. 87-103, dez. 2015. ISSN 2237-3667. Disponível em: $<$ http://revistas.ufcg.edu.br/reunir/index.php/uacc/a rticle/view/48>. Acesso em: 17 abr. 2018. doi:https://doi.org/10.18696/reunir.v2i1.48.

[34]. POZZETI, V. C; MONTEVERDE, J. F.do S. Gerenciamento Ambiental e Descarte do Lixo Hospitalar. Revista Veredas do Direito, Belo Horizonte, v. 14, n. 28, p. 195-220, jan./ Abr. 2017. Disponível em: <http://www.domhelder.edu.br/revista/index.php/ve redas/article/view/939>. Acesso em: 29 Nov. 2017.

[35]. PRONADOV, C. C; FREITAS, E. C. de. Metodologia do Trabalho científico: Métodos e Técnicas da Pesquisa e do Trabalho Acadêmico. Novo Hamburgo: Universidade Feevale $2^{\underline{a}}$ edição, 2013. Disponível em: <http://www.feevale.br/Comum/midias/8807f05a14d0-4d5b-b1ad-1538f3aef538/Ebook\%20Metodologia\%20do\%20Trabalho\%20Cien tifico.pdf>. Acesso em: 03 Dez. 2017.

[36]. R. C. Castro et al., "Gerenciamento dos resíduos de serviços de saúde em um hospital de pequeno porte," Rev Rene, 2014, vol. 15, no. 5, pp. 860-868.

[37]. RIZZON, Fernanda; NODARI, Cristine Hermann; DOS REIS, Zaida Cristiane. Desafio no
Gerenciamento de Resíduos em Serviços Públicos de Saúde. Revista de Gestão em Sistemas de Saúde, [S.I.], v. 4, n. 1, p. 40-54, jun. 2015. ISSN 2316-3712. Disponível em: <http://www.revistargss.org.br/ojs/index.php/rgss/a rticle/view/141>. Acesso em: 17 Apr. 2018.

[38]. TEIXEIRA, P., and VALLE, S., orgs. Biossegurança: uma abordagem multidisciplinar [online]. 2nd ed. rev. and enl. Rio de Janeiro: Editora FIOCRUZ, 2010. 442 p. ISBN: 978-85-7541306-7. Available from SciELO Books .

[39]. TEXEIRA. G. P. A gestão dos resíduos de serviços de saúde no município de juiz de fora mg. Disponível em: $<$ http://www.thecnna.com/pdf/residuo.pdf>. Acesso 15 Mar 2018.

[40]. VIANA. W. C. a metafísica de c. s. peirce: do pragmatismo ao idealismo objetivo. Síntese Rev. de Filosofia v. 41 n. 129 (2014): 55-79, 2014. Disponível

em: <http://faje.edu.br/periodicos/index.php/Sintese/arti cle/view/2753>. Acesso em: 29 Nov 2017.

[41]. VIEIRA, C. S. M. Análise do manejo dos resíduos de serviço de saúde em unidade básica de saúde vinculada a uma instituição de Ensino Superior, Trabalho de Conclusão em Graduação em Engenharia Ambiental e Sanitária, Universidade Federal de Pelotas, Rio Grande do Sul, 2013.

[42]. WHO - WORLD HEALTH ORGANIZATION. Safe management of wastes from health-care activities, 2014. Disponível em: <http://www.searo. who.int/srilanka/documents/safe _management_of_wastes_from_healthcare_activitie s.pdf?ua=1>. Acesso em: 20 Mar. 2018. 


\section{Gapítulo 20}

\section{PROPOSTA DE CERTIFICAÇÃO PARA IMPLANTAÇÃO DE FERROVIAS VERDES NO BRASIL}

\section{Ana Carolina L. de Azevedo}

Fabrício de O. Lavorato

Marcelo de Miranda Reis

Mayssa A. da Silva Sousa

Resumo: Buscando um maior equilíbrio ecológico e preservação ambiental, alguns setores vêm desenvolvendo projetos verdes, ecologicamente corretos, os quais seguem parâmetros determinados buscando reduzir os impactos ambientais possíveis de ocorrência. Para tanto, criou-se o Selo Verde, conquistado por empreendimentos e atividades que tenham seguido os parâmetros referentes ao projeto, construção, manutenção e operação. O presente trabalho propõe a implantação de ferrovias verde, utilizando como referências de estudos desenvolvidos para rodovias verdes, apresentando os impactos ambientais que serão reduzidos, sem prejudicar a segurança e o conforto de quem a utiliza. 


\section{INTRODUÇÃO}

Os recursos naturais disponíveis para a sobrevivência humana têm sido cada vez mais escassos, em vista disso já se tem percebido a busca por soluções alternativas a fim de reduzir/mitigar os impactos causados ao meio ambiente, tais ações têm sido aplicadas em praticamente todas as atividades antrópicas.

As primeiras atividades aplicadas nesse sentido foram realizadas após reuniões para discussão a respeito da redução da emissão de gases do efeito estufa na década de 90, desde então vem sendo instituídas leis, regulamentações e até certificações a fim de incentivar práticas que estimulem o uso racional e a economia dos recursos naturais, o emprego de fontes renováveis de energia, considerando também aspectos relacionados à segurança e sustentabilidade.

Em relação as certificações, é válido ressaltar a Certificação LEED - Leadership in Energy and Environmental Design criada pela Organização Não Governamental (ONG) U.S. Green Building Council (USGBC) que fornece uma certificação para construções sustentáveis (prédios), dentro da verificação ao atendimento de diversos requisitos, considerando pontuações (créditos) adequadas conforme cada categoria, sendo que o empreendimento que conseguir atender a mais de $90 \%$ dos créditos poderão receber o Selo Verde.

As fases de projeto, implantação, operação e manutenção de uma ferrovia causam impactos ao meio ambiente, alguns mais significativos que outros, porém necessitando de um diagnóstico preciso que seguindo a legislação vigente devem ser apresentados e avaliados no Estudo de Impacto Ambiental EIA e em seu relatório (RIMA).

Todavia, o simples atendimento a legislação vigente não implica dizer que um empreendimento pode ser considerado sustentável, ou ser denominado "Ferrovia verde", no caso do estudo em questão. É necessário muito mais que isso, é necessário que o empreendimento esteja "de bem" com o meio ambiente em todos os aspectos e em todas as fases do mesmo.

O Selo Verde, através da certificação LEED, se aplica à construção civil basicamente de prédios. Em relação as rodovias, a Universidade Federal de Santa Catarina UFSC, inspirada na iniciativa do Greenroads na Universidade de Washington-EUA, tem desenvolvido estudos referentes à Rodovias Verdes e, nesse sentido, este artigo busca apresentar uma proposta para institucionalizar no Brasil e no mundo uma certificação Selo Verde Ferroviário que efetue a avaliação e a incorporação de conceitos de sustentabilidade e responsabilidade socioambiental nas fases de projeto, construção, operação e manutenção de ferrovias.

\section{OS EMPREENDIMENTOS FERROVIÁRIOS E O MEIO AMBIENTE}

As fases de projeto, construção, operação e manutenção de empreendimentos ferroviários causam, assim como em outros modais de transporte, vários impactos ambientais que precisam ser identificados e mitigados. Tais impactos ambientais afetam tanto o meio físico, quanto o biótico e o antrópico, conforme citados a seguir:

Meio físico: impactos na qualidade do ar (emissão de poeira/fumaça/gases), geologia/geomorfologia (materiais de construção/encostas e relevo), solos (erosão, uso), recursos hídricos (qualidade da água).

Meio biótico: biodiversidade (desmatamentos, perda de espécies), patrimônio genético (desmatamentos/perda de espécies), fragmentação de habitats (desmatamentos, barreiras entre fragmentos).

Meio Antrópico: dinâmica populacional (fluxo migratório, estrutura ocupacional), qualidade de vida (saúde, lazer/turismo), estrutura produtiva/serviços (produção, emprego), organização social (conflitos sociais, manifestações culturais, populações tradicionais), patrimônio (arqueológico, cultural), desapropriações (seccionamento da propriedade, perda de produção), áreas protegidas (unidades de conservação e áreas indígenas).

Uma segunda visão sobre os impactos causados pelos empreendimentos ferroviários é pelas suas fases e seu potencial de impacto. Um bom exemplo desse mapeamento foi feito pela Oikos Pesquisa Aplicada Ltda para a Ferrovia Norte Sul no Relatório de Impacto Ambiental referente ao trecho de linha férrea na divisa Petrolina de Goiás/Jesúpolis - Ribeirão Sete Voltas (Goianésia) em julho de 2002, conforme quadro 1. 
No quadro 1, observa-se que o impacto ambiental de maior significância é a perda de patrimônio arqueológico, os de significância mediana, a redução da diversidade biológica devido a desmatamentos, alagamentos, erosões e assoreamentos, a fragmentação de habitats, a descaracterização das matas ciliares por alteração em drenagens naturais, poluição hídrica e a poluição provocada por acidentes com cargas perigosas.

Quadro 1: Impactos ambientais causados pelos empreendimentos ferroviários

\begin{tabular}{|c|c|c|c|c|c|c|c|c|c|}
\hline \multirow{2}{*}{$\begin{array}{l}\text { IMPACTOS AMBIENTAIS } \\
\text { SIGNIFICATIVOS - IAS }\end{array}$} & \multirow{2}{*}{ FASE } & \multicolumn{5}{|c|}{ POTENCIAL DE IMPACTO } & \multicolumn{3}{|c|}{ SIGNIFICÂNCIA } \\
\hline & & Adversidade & Ocorrência & Duração & Reversibilidade & Abrangência & Importância & Magnitude & Significadc \\
\hline Desapropriações & Implantação & Negativo & Direto & Permanente & Irreversível & Local & Baixa & Baixa & Baixo \\
\hline $\begin{array}{l}\text { Geração empregos } \\
\text { diretos/indiretos }\end{array}$ & $\begin{array}{c}\text { Implantação/ } \\
\text { Operação }\end{array}$ & Positivo & Direto & Temporário & Reversível & Local & Baixa & Baixa & Baixo \\
\hline $\begin{array}{l}\text { Expectativa de crescimento } \\
\text { regional }\end{array}$ & Operação & Positivo & $\begin{array}{l}\text { Direto/ } \\
\text { Indireto }\end{array}$ & Permanente & Irreversível & Regional & Baixa & Baixa & Baixo \\
\hline Perda de Patrimônio Arqueológico & Implantação & Negativo & Direto & Permanente & Irreversível & Regional & Alta & Alta & Alto \\
\hline $\begin{array}{l}\text { Redução da diversidade biológica } \\
\text { devido a desmatamentos, } \\
\text { alagamentos,erosões e } \\
\text { assoreamentos }\end{array}$ & Implantação & Negativo & Direto & Temporário & Reversível & Regional & Baixa & Média & Médio \\
\hline $\begin{array}{l}\text { Redução da diversidade biológica } \\
\text { provocada por incêndios }\end{array}$ & Implantação & Negativo & $\begin{array}{l}\text { Direto/ } \\
\text { Indireto }\end{array}$ & Temporário & Reversível & Regional & Baixa & Baixa & Baixo \\
\hline $\begin{array}{l}\text { Alterações comportamento da } \\
\text { fauna }\end{array}$ & Operação & Negativo & Direto & Temporário & Reversível & Local & Baixa & Baixa & Baixo \\
\hline Fragmentação de habitats & Operação & Negativo & Direto & Permanente & Irreversível & $\begin{array}{c}\text { Local } \\
\text { /Regional }\end{array}$ & Baixa & Média & Médio \\
\hline Risco de atropelamento de animais & Operação & Negativo & Direto & Temporário & Reversível & Local & Baixa & Baixa & Baixo \\
\hline $\begin{array}{l}\text { Descaracterização das matas } \\
\text { ciliares por alteração em } \\
\text { drenagens naturais }\end{array}$ & Implantação & Negativo & Direto & Temporário & Reversível & Local & Média & Média & Médio \\
\hline Perda de solo & Implantação & Negativo & $\begin{array}{l}\text { Direto/ } \\
\text { Indireto }\end{array}$ & Temporário & Reversível & Local & Baixa & Baixa & Baixo \\
\hline Poluição sonora & Operação & Negativo & Direto & Permanente & Irreversível & Local & Baixa & Baixa & Baixo \\
\hline Poluição atmosférica & Operação & Negativo & Direto & Permanente & Irreversível & Local & Baixa & Baixa & Baixo \\
\hline Poluição hídrica & $\begin{array}{c}\text { Implantação/ } \\
\text { Operação }\end{array}$ & Negativo & Direto & Temporário & Reversível & $\begin{array}{c}\text { Local/ } \\
\text { Regional }\end{array}$ & Baixa & Média & Médio \\
\hline $\begin{array}{l}\text { Poluição provocada por acidentes } \\
\text { com cargas perigosas }\end{array}$ & Operação & Negativo & Direto & Temporário & Reversível & $\begin{array}{l}\text { Local/ } \\
\text { Regional }\end{array}$ & Média & Média & Médio \\
\hline
\end{tabular}

Fonte: OIKOS, 2002.

\section{SUSTENTABILIDADE EM OBRAS DE ENGENHARIA}

Quando se fala em sustentabilidade nas obras de engenharia, o setor de construção civil é o que está mais avançado na incorporação destes conceitos, com o desenvolvimento de mecanismos para certificação das construções e das operações destes empreendimentos.

Um desses mecanismos é o sistema LEED, desenvolvido para orientação e certificação de construções sustentáveis, sendo este sistema a ferramenta mais reconhecida e a que mais cresce no mundo.

Por "construção sustentável" (Green Building) entende-se a edificação ou espaço construído que tem na sua concepção, construção e operação o uso de conceitos e procedimentos reconhecidos de sustentabilidade ambiental, proporcionando benefícios econômicos e na saúde e bem estar das pessoas, com baixo impacto ambiental.

$\mathrm{Na}$ engenharia rodoviária brasileira, a conscientização ambiental foi sendo incorporada aos projetos desde a década de 1970, mas foi a partir da Lei 6.938/1981 de Licenciamento Ambiental, quando se criou a necessidade da realização do Estudo de Impacto Ambiental (EIA) e do Relatório de Impacto Ambiental (RIMA), que os projetos passaram a atender conceitos de preservação do Meio Ambiente.

Foi nesse contexto que começaram a surgir, nas regiões Sul Sudeste, ações buscando reduzir os possíveis impactos ambientais nas 
obras rodoviárias, como reflorestamento, tratamento de água e lixo, uso de revestimentos reciclados ou com agregados alternativos, utilização de borracha de pneus velhos nas misturas, misturas mornas e frias, iluminação sustentável, faunodutos, entre outras atividades que as tornaram conhecidas como rodovias verdes ou eco vias.

Como exemplo, podem ser citados no estado de São Paulo o Sistema Anchieta-Imigrantes, Rodovia dos Bandeirantes, as rodovias SP191, SP-215, SP-225, SP-330, SP-333 e SP352, rodovia Presidente Castello Branco e a rodovia Cândido Portinari. No Espírito Santo, a rodovia do Sol, e no Paraná, as rodovias BR277, BR-376, PR-151 e BR-373. No Rio Grande do Sul, a rodovia BR-290 (Free Way).

Recentemente, um grupo de pesquisadores da Universidade Federal de Santa Catarina (UFSC) desenvolveu uma proposta de certificação sustentável para rodovias, o "Selo
Verde Rodovias", baseada nos estudos desenvolvidos na Universidade de Washington (www.greenroads.us) em 2007, onde as fases de projeto, construção, operação e manutenção devem seguir critérios tais que, se atendidos em determinadas proporções, fornecem ao empreendimento uma classificação indicativa do grau de sustentabilidade, sendo o Selo Verde o grau máximo a ser alcançado.

No setor ferroviário percebe-se que não existe um estudo que incorpore o selo verde verdadeiramente ao modal, no entanto existem projetos avaliados como ecológicos, quando insere ao projeto componentes sustentáveis como:

Vagão ecológico - confeccionado a partir da substituição da caixaria do equipamento, que era de madeira de lei (cedro, Angelim ou canela), e do assoalho em chapa de aço, por plástico reciclado, conforme figura 1 .

Figura 1: Vagão Ecológico

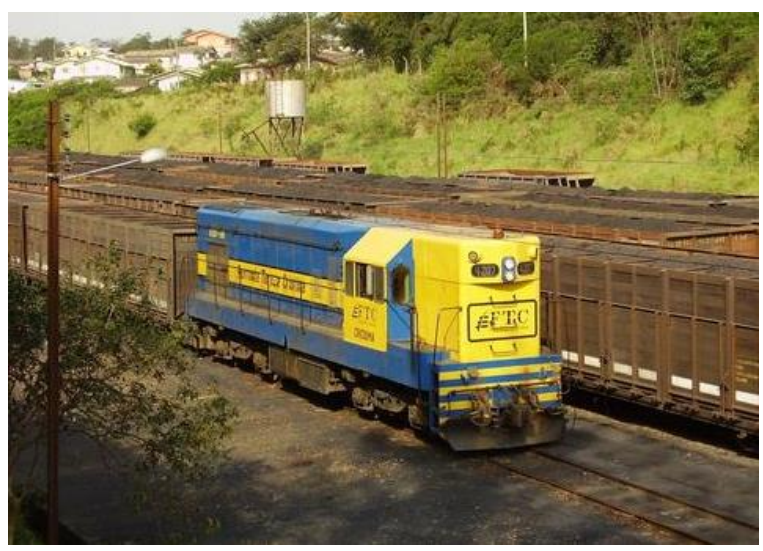

Fonte: http://ferroviaecologica.blogspot.com.br/

Dormentes ecológicos - geometria, materiais e peso o permitem ser usado em qualquer tipo de estrada de ferro: regulares, de alta velocidade, eléctricos e metro linhas tanto de bitola estreita e Convencional conforme figura 2.

Figura 2: Dormente Ecológico

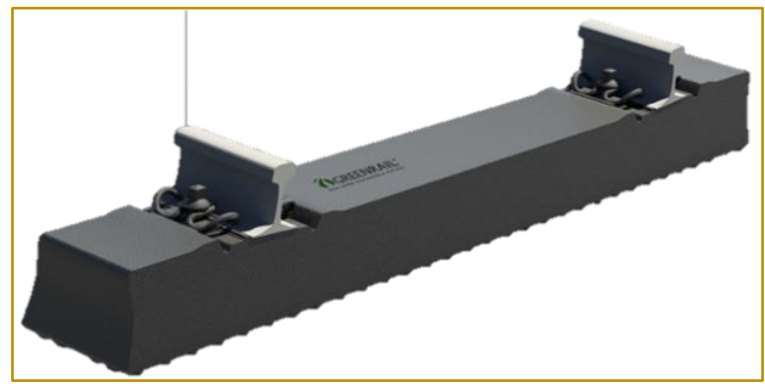

Fonte: http://www.greenrail.it/ 
Mesmo não podendo ser chamadas de verde, algumas ferrovias estão dando o primeiro passo para uma possível implantação, como é o caso da Ferrovia Ecológica Vale do Bom Jesus, a Express Rail Link West Kowloon Terminus, que ligará Hong Kong a Pequim, na China e será inaugurada em 2016, sendo considerada a maior estação ferroviária do mundo e terá telhado verde. Outro ponto importante é o estudo para a utilização de biodiesel como combustível de locomotivas. Segundo a Associação Nacional dos Transportadores Ferroviários (ANTF), o consumo de uma tonelada de biodiesel evita a emissão de 3,5 toneladas de $\mathrm{CO}_{2}$, proveniente do diesel mineral.

Porém, é preciso mais do que somente a substituição de alguns componentes. O estudo realizado pela UFSC apresenta os aspectos necessários para que uma rodovia seja considerada ecológica, ou seja, conquiste o Selo Verde. Da mesma forma o presente artigo propõe a aplicação dessa proposta metodológica no tocante a ferrovias.

Resumidamente, define-se o conjunto de atividades que tendem tornar a ferrovia amigável ao usuário e ao meio ambiente como práticas verdes, como por exemplo: a proteção de mananciais, a construção de faunodutos, capacidade de absorção sonora, a utilização de superestruturas ecológicas, a preservação de sítios arqueológicos, entre outros.

\section{PROPOSTA PARA UMA CERTIFICAÇÃO DO SELO VERDE FERROVIÁRIO NO BRASIL}

A presente proposta, conforme explicado anteriormente, visa a implantação de certificação do Selo Verde Ferroviário, seguindo os mesmos parâmetros do Selo Verde Rodovias proposto pela UFSC, onde as etapas de Projeto, Construção, Operação e Manutenção apresentam uma lista de fatores principais determinantes I) no impacto ambiental provocado pelo projeto, implantação, operação e manutenção de ferrovias, II) na sustentabilidade, responsabilidade sócio-econômica-ambiental do empreendimento, III) na performance de uma ferrovia e IV) na segurança, conforto e economia do usuário.
Devido à similaridade das fases e impactos relacionados à implantação de rodovias e ferrovias, considerou-se os mesmos créditos estabelecidos na proposta Selo Verde Rodovias para cada fator segundo sua importância. Porém, alguns fatores foram adicionados ou removidos de acordo com a aplicação efetiva na área ferroviária, conforme quadros 2, 3 e 4.

Os quadros 2, 3 e 4 apresentam os principais fatores com os respectivos créditos que são avaliados para a emissão da certificação Selo Verde Ferroviário para cada fase de empreendimento.

De acordo com a quantidade de créditos que podem ser obtidos, são fixados 5 níveis de certificação, conforme quadros 5, 6 e 7, quais sejam:

Sem Certificação: quando a soma dos créditos de todos os fatores avaliados atinge um valor menor que $50 \%$ do valor máximo de créditos segundo sua fase (Projeto - 155, Construção - 160 e Operação e Manutenção 161). Neste caso, a ferrovia pode até estar atendendo a legislação vigente, porém, não considera conceitos de sustentabilidade e responsabilidade socioambiental.

Com certificação: quando a soma dos créditos de todos os fatores avaliados estiver entre $50 \%$ e $70 \%$ do valor máximo de créditos;

Certificação Prata: quando a soma dos créditos de todos os fatores avaliados estiver entre $71 \%$ e $80 \%$ do valor máximo de créditos;

Certificação Ouro: quando a soma dos créditos de todos os fatores avaliados estiver entre $81 \%$ e $90 \%$ do valor máximo de créditos; e

Selo Verde: quando a soma dos créditos de todos os fatores avaliados for maior que $90 \%$ do valor máximo de créditos possíveis de serem obtidos. Nesse nível, a ferrovia pode ser considerada amigável ao ambiente e ao usuário, considerando conceitos de Sustentabilidade e Responsabilidade Socioambiental. 
Quadro 2: Certificação de Selo Verde para o Projeto Final de Engenharia Ferroviária

\begin{tabular}{|c|c|c|c|}
\hline Categoria & Descrição & $\begin{array}{l}\text { Créditos } \\
\text { Disponível }\end{array}$ & $\begin{array}{l}\text { Total Disponível } \\
\text { Créditos }\end{array}$ \\
\hline \multirow{2}{*}{ Legislação } & EIA RIMA & 12 & \multirow{2}{*}{15} \\
\hline & Audiência Pública & 3 & \\
\hline \multirow{6}{*}{ Estudos } & $\begin{array}{l}\text { Estudo Geológico, Geotécnico e de } \\
\text { Materiais }\end{array}$ & 4 & \multirow{6}{*}{20} \\
\hline & Compensação Corte e Aterros & 2 & \\
\hline & Patrimônio Cultural, Arqueológico e Povos & 4 & \\
\hline & Geometria da Ferrovia & 4 & \\
\hline & Hidrologia & 4 & \\
\hline & Capacidade e Nível de Serviço & 2 & \\
\hline \multirow{7}{*}{$\begin{array}{l}\text { Materiais e } \\
\text { Inovação }\end{array}$} & Alternativas de Pavimentação & 6 & \multirow{7}{*}{50} \\
\hline & Aproveitamento de Materiais Lindeiros & 3 & \\
\hline & Utilização de Materiais Reciclados & 6 & \\
\hline & Utilização de Sub-produtos da Indústria & 3 & \\
\hline & Tecnologia de Superestrutura Ferroviária & 20 & \\
\hline & Metodologia de Dimensionamento & 3 & \\
\hline & Análise de Custo do Ciclo de Vida & 9 & \\
\hline \multirow{5}{*}{ Fauna e Flora } & Proteção da Fauna/Conectividade Ecológica & 4 & \multirow{5}{*}{18} \\
\hline & Integração com a Paisagem & 1 & \\
\hline & Proteção da Flora & 3 & \\
\hline & Plano de Recuperação de Passivos Ambientais & 5 & \\
\hline & Compensação Ambiental & 5 & \\
\hline \multirow{5}{*}{$\begin{array}{l}\text { Recursos } \\
\text { Hídricos }\end{array}$} & Proteção de Mananciais/Corpos Hídricos & 8 & \multirow{5}{*}{20} \\
\hline & Plano de Controle de Erosão & 3 & \\
\hline & Sistema de Drenagem & 3 & \\
\hline & Plano de Disposição de Resíduos Sólidos & 3 & \\
\hline & $\begin{array}{l}\text { Controle de Emissões de Gases e } \\
\text { Particulados }\end{array}$ & 3 & \\
\hline \multirow{5}{*}{ Segurança } & Acessibilidade e Sinalização & 3 & \multirow{5}{*}{17} \\
\hline & Equipamentos de Segurança & 6 & \\
\hline & Pontos de Descanso e Apoio ao Usuário & 2 & \\
\hline & Desapropriação e Re-assentamento & 3 & \\
\hline & Ordenamento Territorial & 3 & \\
\hline \multirow{3}{*}{ Construção } & Planejamento da Construção & 5 & \multirow{3}{*}{15} \\
\hline & Técnica Construtiva & 5 & \\
\hline & Controle Tecnológico & 5 & \\
\hline \multicolumn{3}{|c|}{ Total de Créditos Disponível } & 155 \\
\hline
\end{tabular}


Quadro 2: Certificação de Selo Verde para o Projeto Final de Engenharia Ferroviária (continuação)

\begin{tabular}{|c|c|c|c|}
\hline Categoria & Descrição & $\begin{array}{l}\text { Créditos } \\
\text { Disponível }\end{array}$ & $\begin{array}{l}\text { Total Disponíve } \\
\text { Créditos }\end{array}$ \\
\hline \multirow{5}{*}{ Legislação } & Licenças & 3 & \multirow{5}{*}{20} \\
\hline & Comunicação e Relacionamento & 2 & \\
\hline & Garantias Contratuais & 8 & \\
\hline & Patrimônio Cultural, Arquiológico e Povos & 4 & \\
\hline & Compensação Ambiental & 3 & \\
\hline \multirow{6}{*}{$\begin{array}{l}\text { Materiais e } \\
\text { Inovação }\end{array}$} & Alternativas de Pavimentação & 6 & \multirow{6}{*}{42} \\
\hline & Aproveitamento de Materiais Lindeiros & 3 & \\
\hline & Utilização de Materiais Reciclados & 6 & \\
\hline & Utilização de Sub-produtos da Indústria & 3 & \\
\hline & Tecnologias de Superestrutura Ferroviário & 20 & \\
\hline & Reutilização de Materiais e Desperdício & 4 & \\
\hline \multirow{4}{*}{ Fauna e Flora } & Proteção da Fauna/Conectividade Ecológica & 4 & \multirow{4}{*}{14} \\
\hline & Integração com a Paisagem & 2 & \\
\hline & Proteção da Flora & 3 & \\
\hline & Recuperação de Passivos Ambientais & 5 & \\
\hline \multirow{6}{*}{$\begin{array}{l}\text { Recursos } \\
\text { Hídricos }\end{array}$} & Proteção de Mananciais/Corpos Hídricos & 8 & \multirow{6}{*}{22} \\
\hline & Plano de Controle de Erosão & 4 & \\
\hline & Tratamento e Recuperação de Efluentes & 3 & \\
\hline & Disposição de Resíduos Sólidos & 3 & \\
\hline & Tratamento de Efluentes Doméstico & 2 & \\
\hline & Redução do Consumo e Reutilização de Água & 2 & \\
\hline \multirow{5}{*}{ Segurança } & Acessibilidade e Sinalização & 3 & \multirow{5}{*}{14} \\
\hline & Equipamentos de Segurança & 3 & \\
\hline & Pontos de Apoio ao Usuário & 2 & \\
\hline & Desapropriação e Re-assentamento & 3 & \\
\hline & Ordenamento Territorial & 3 & \\
\hline \multirow{9}{*}{ Construção } & Estudo Geotécnico e de Materiais & 5 & \multirow{9}{*}{48} \\
\hline & Compensação Corte e Aterros & 3 & \\
\hline & Planejamento da Construção & 5 & \\
\hline & Técnica Construtiva & 7 & \\
\hline & Controle Tecnológico & 12 & \\
\hline & Saúde e Medicina do Trabalhador & 3 & \\
\hline & Consumo de Energia - Eficiência Energética & 3 & \\
\hline & Plano de Controle de Ruídos & 5 & \\
\hline & Controle de Emissões de Gases e Particulados & 5 & \\
\hline \multicolumn{3}{|c|}{ Total de Créditos Disponível } & 160 \\
\hline
\end{tabular}


Quadro 3 - Certificação de Selo Verde para a Manutenção e Operação da Ferrovia

\begin{tabular}{|c|c|c|c|}
\hline Categoria & Descrição & $\begin{array}{l}\text { Créditos } \\
\text { Disponível }\end{array}$ & $\begin{array}{c}\text { Total Disponível } \\
\text { Créditos }\end{array}$ \\
\hline \multirow{4}{*}{$\begin{array}{l}\text { Relação com } \\
\text { Comunidade }\end{array}$} & Licenças & 2 & \multirow{4}{*}{10} \\
\hline & Comunicação e Relacionamento & 2 & \\
\hline & Programas de Educação & 3 & \\
\hline & Patrimônio Cultural, Arquiológico e Povos & 3 & \\
\hline \multirow{11}{*}{ Operação } & Sistema de Gerenciamentode Pavimento & 5 & \multirow{11}{*}{38} \\
\hline & Sistema de Gerenciamentode Pavimento & 5 & \\
\hline & Controle de Ruído & 4 & \\
\hline & Prevenção de Acidentes Naturais & 2 & \\
\hline & Sistema de Informação & 2 & \\
\hline & Gestão de Acidentes & 4 & \\
\hline & Gestão de Área de Domínio & 2 & \\
\hline & Controle de Excesso de Carga e Tráfego & 3 & \\
\hline & Cargas Perigosas & 2 & \\
\hline & Pesquisa e Desenvolvimento & 5 & \\
\hline & Sinalização ferroviária & 4 & \\
\hline \multirow{10}{*}{ Manutenção } & Tecnologias de Manutenção & 5 & \multirow{10}{*}{52} \\
\hline & Utilização de Materiais Reciclados & 5 & \\
\hline & Utilização de Sub-produto da Indústria & 3 & \\
\hline & Tecnologias de Superestruturas - Inovação & 20 & \\
\hline & Sinalização e Vegetação & 4 & \\
\hline & Drenagem e Obras de Arte Corrente & 3 & \\
\hline & Consumo de Energia - Eficiência & 2 & \\
\hline & Controle de Emissões de Gases e Particulados & 2 & \\
\hline & Compensação Ambiental & 3 & \\
\hline & Análise de Custode Ciclo de Vida & 5 & \\
\hline \multirow{2}{*}{$\begin{array}{c}\text { Pontes } \\
\text { Viadutos e } \\
\text { Túneis }\end{array}$} & Gerenciamento de Pontes, Viadutos e Túneis & 8 & \multirow{2}{*}{16} \\
\hline & Manutenção de Pontes, Viadutos e Túneis & 8 & \\
\hline \multirow{4}{*}{ Fauna e Flora } & Proteção da Fauna/Conectividade Ecológica & 4 & \multirow{4}{*}{12} \\
\hline & Integração com a Paisagem & 2 & \\
\hline & Proteção da Flora e Paisagismo & 3 & \\
\hline & Recuperação de Passivos Ambientais & 3 & \\
\hline \multirow{4}{*}{$\begin{array}{l}\text { Recursos } \\
\text { Hídricos }\end{array}$} & Proteção de Mananciais/Corpos Hídricos & 6 & \multirow{4}{*}{16} \\
\hline & Plano de Controle de Erosão & 4 & \\
\hline & Tratamento e Recuperação de Efluentes & 3 & \\
\hline & Plano de Disposição de Resíduos Sólidos & 3 & \\
\hline \multirow{4}{*}{ Segurança } & Acessibilidade & 3 & \multirow{4}{*}{17} \\
\hline & Equipamentos de Segurança & 9 & \\
\hline & Pontos de Apoio ao Usuário & 2 & \\
\hline & Ordenamento Territorial & 3 & \\
\hline \multicolumn{3}{|c|}{ Total de Créditos Disponível } & 161 \\
\hline
\end{tabular}


Quadro 4: Certificação de Selo Verde para a Operação e Manutenção da Ferrovia

\begin{tabular}{|c|c|c|c|}
\hline Categoria & Descrição & $\begin{array}{l}\text { Créditos } \\
\text { Disponível }\end{array}$ & $\begin{array}{c}\text { Total Disponível } \\
\text { Créditos }\end{array}$ \\
\hline \multirow{4}{*}{$\begin{array}{c}\text { Relação } \\
\text { com } \\
\text { Comunidade }\end{array}$} & Licenças & 2 & \multirow{4}{*}{10} \\
\hline & Comunicação e Relacionamento & 2 & \\
\hline & Programas de Educação & 3 & \\
\hline & Patrimônio Cultural, Arquiológico e Povos & 3 & \\
\hline \multirow{11}{*}{ Operação } & Sistema de Gerenciamentode Pavimento & 5 & \multirow{11}{*}{38} \\
\hline & Sistema de Gerenciamentode Pavimento & 5 & \\
\hline & Controle de Ruído & 4 & \\
\hline & Prevenção de Acidentes Naturais & 2 & \\
\hline & Sistema de Informação & 2 & \\
\hline & Gestão de Acidentes & 4 & \\
\hline & Gestão de Área de Domínio & 2 & \\
\hline & Controle de Excesso de Carga e Tráfego & 3 & \\
\hline & Cargas Perigosas & 2 & \\
\hline & Pesquisa e Desenvolvimento & 5 & \\
\hline & Sinalização ferroviária & 4 & \\
\hline \multirow{10}{*}{ Manutenção } & Tecnologias de Manutenção & 5 & \multirow{10}{*}{52} \\
\hline & Utilização de Materiais Reciclados & 5 & \\
\hline & Utilização de Sub-produto da Indústria & 3 & \\
\hline & Tecnologias de Superestruturas - Inovação & 20 & \\
\hline & Sinalização e Vegetação & 4 & \\
\hline & Drenagem e Obras de Arte Corrente & 3 & \\
\hline & Consumo de Energia - Eficiência & 2 & \\
\hline & Controle de Emissões de Gases e Particulados & 2 & \\
\hline & Compensação Ambiental & 3 & \\
\hline & Análise de Custode Ciclo de Vida & 5 & \\
\hline \multirow{2}{*}{$\begin{array}{l}\text { Pontes } \\
\text { Viadutos e } \\
\text { Túneis }\end{array}$} & Gerenciamento de Pontes, Viadutos e Túneis & 8 & \multirow{2}{*}{16} \\
\hline & Manutenção de Pontes, Viadutos e Túneis & 8 & \\
\hline \multirow{4}{*}{$\begin{array}{c}\text { Fauna e } \\
\text { Flora }\end{array}$} & Proteção da Fauna/Conectividade Ecológica & 4 & \multirow{4}{*}{12} \\
\hline & Integração com a Paisagem & 2 & \\
\hline & Proteção da Flora e Paisagismo & 3 & \\
\hline & Recuperação de Passivos Ambientais & 3 & \\
\hline \multirow{4}{*}{$\begin{array}{l}\text { Recursos } \\
\text { Hídricos }\end{array}$} & Proteção de Mananciais/Corpos Hídricos & 6 & \multirow{4}{*}{16} \\
\hline & Plano de Controle de Erosão & 4 & \\
\hline & Tratamento e Recuperação de Efluentes & 3 & \\
\hline & Plano de Disposição de Resíduos Sólidos & 3 & \\
\hline \multirow{4}{*}{ Segurança } & Acessibilidade & 3 & \multirow{4}{*}{17} \\
\hline & Equipamentos de Segurança & 9 & \\
\hline & Pontos de Apoio ao Usuário & 2 & \\
\hline & Ordenamento Territorial & 3 & \\
\hline \multicolumn{3}{|c|}{ Total de Créditos Disponível } & 161 \\
\hline
\end{tabular}


Quadro 5: Níveis de Certificação de Projeto

\begin{tabular}{|c|c|c|}
\multicolumn{3}{|c|}{ Níveis de Certificação de Projeto } \\
\hline Nível de certificação & Créditos mínimos & Máximo de Créditos \\
\hline Nenhum & 36 & 76 \\
\hline Certificado & 77 & 108 \\
\hline Prata & 109 & 124 \\
\hline Ouro & 125 & 139 \\
\hline Selo Verde & 140 & 155 \\
\hline
\end{tabular}

Quadro 6: Níveis de Certificação de Construção

\begin{tabular}{|c|c|c|}
\hline \multicolumn{3}{|c|}{ Níveis de Certificação de Construção } \\
\hline Nível de certificação & Créditos mínimos & Máximo de Créditos \\
\hline Nenhum & 39 & 79 \\
\hline Certificado & 80 & 111 \\
\hline Prata & 112 & 127 \\
\hline Ouro & 128 & 143 \\
\hline Selo Verde & 144 & 160 \\
\hline
\end{tabular}

Quadro 7: Níveis de Certificação da Operação e Manutenção

\begin{tabular}{|c|c|c|}
\hline \multicolumn{3}{|c|}{ Níveis de Certificação da Manutenção e Operação } \\
Nível de certificação & Créditos mínimos & Máximo de Créditos \\
\hline Nenhum & 39 & 79 \\
\hline Certificado & 80 & 111 \\
\hline Prata & 112 & 127 \\
\hline Ouro & 128 & 143 \\
\hline Selo Verde & 144 & 161 \\
\hline
\end{tabular}

Ao verificar as pontuações de cada categoria e seus respectivos itens nos quadros 2, 3 e 4 , é possível fazer as seguintes considerações:

$\mathrm{Na}$ fase de Projeto, os itens com maior quantidade de créditos disponíveis são: na categoria Legislação - o Estudo de Impacto Ambiental (EIA) e o Relatório de Impacto Ambiental (Rima) e na categoria Materiais e Inovação - Tecnologias de Superestrutura Ferroviária.

$\mathrm{Na}$ fase de Construção, os itens com maior quantidade de créditos disponíveis são: a categoria Materiais e Inovação - Tecnologias de Superestrutura Ferroviária e na categoria Construção - Controle Tecnológico.

$\mathrm{Na}$ fase de Manutenção e Operação, o item com maior quantidade de créditos disponíveis é na categoria Manutenção referente a Tecnologias de Superestrutura - Inovação.

É importante ressaltar que uma vez vencida as fases de Projeto e a Construção da Ferrovia, a certificação não muda mais. $E$, nas fases de Operação e Manutenção, o nível de certificação Selo Verde Ferroviário estará em evolução durante todo ciclo de vida útil da ferrovia, podendo ser verificado a qualquer momento. 


\section{CONSIDERAÇÕES FINAIS}

Diante de tudo que foi apresentado, constatou-se que é de suma importância a aplicação de medidas de prevenção, mitigação e controle dos possíveis impactos gerados pela implantação de ferrovias, nos meios físico, biótico e antrópico.

Mesmo com a legislação vigente exigindo várias ações visando a preservação do meio ambiente, com o passar dos anos, percebeuse a necessidade de institucionalizar uma certificação que indicasse o grau de sustentabilidade de um empreendimento, em

\section{REFERÊNCIAS}

[1]. Associação Nacional de Transporte Ferroviário - ANTF. Ferrovias Ecológicas e Baratas. Disponível em: http://www.antf.org.br/index.php/noticias/178ferrovia-ecologica-e-barata Acesso em: 05/05/2015

[2]. Barbosa, Vanessa. (2012) Maior estação ferroviária do mundo terá telhado verde. Disponível em: http://info.abril.com.br/noticias/tecnologiasverdes/maior-estacao-ferroviaria-do-mundotera-telhado-ecologico-24072012-46.shl Acesso em: 06/05/2015

[3]. Capelas Jr., Afonso. Caminhos do Bem. Disponível em: http://planetasustentavel.abril.com.

br/noticia/desenvolvimento/conteudo_405617. shtml?func $=1 \&$ pag $=2 \& \mathrm{fnt}=14 \mathrm{px}$. Acessado em 07/05/2015.

[4]. Fujihara, M.C. Construção Sustentável e Certificação LEED no Brasil. Disponível em: http://iab-sc. org.br/concursofatmafapesc/wpcontent/uploads/2012/08/16.00h- que o setor pioneiro nesta certificação foi o da construção civil.

O setor rodoviário iniciou suas pesquisas também neste sentido buscando instituir o Selo Verde para rodovias e como no setor ferroviário não foi identificado nenhuma iniciativa nesse sentido, o presente trabalho buscou a implementação do Selo Verde também para ferrovias,

Agradecimentos

Os autores agradecem as sugestões recebidas do T.C. Marcelo Reis e dos professores J.C. Amorim e L.A. Silveira Lopes.

Maria_Carolina_Fujihara.pdf. Acesso em 06/05/2015

[5]. Oikos Pesquisa Aplicada Ltda. (2002) Relatório de Impacto Ambiental: Divisa Petrolina de Goiás/Jesúpolis - Ribeirão Sete Voltas (Goianésia). Ministério dos Transportes, VALEC - Engenharia, Construções e Ferrovias S.A. Ferrovia Norte-Sul, Goiás.

[6]. Soares, C. R. Lobão (2013) Sustentabilidade sobre Trilhos. Disponível em: http://ferroviaecologica. blogspot.com.br/ Acesso em: 06/05/2015.

[7]. Trichês, G. Mello, J. V. S de. Vilhena, J. e Knabben, R. N. (2011) Certificação rodovias verdes no Brasil: proposição de metodologia. $7^{\circ}$ Congresso Brasileiro de Rodovias e Concessões BRASVIAS, Foz do Iguaçu.

[8]. Universidade de Santa Catarina UFSC. Rodovias Verdes. Disponível em: http://rodoviasverdes.ufsc.br/ Acesso em: 05/05/2015

[9]. www.greenroads.us 
Alutary 


\section{ADRIANO PEREIRA}

Mestre em Computação pela Universidade Federal de Santa Maria (UFSM), Especialista em Aplicações para a Web pela Universidade Federal do Rio Grande (FURG) e Bacharel em Ciência da Computação pela UFSM. Atualmente é aluno de doutorado em Administração no Programa de Pós-Graduação em Administração da UFSM e atua como Analista de Tecnologia da Informação no Centro de Processamento de Dados (CPD) da UFSM, participando do desenvolvimento de sistemas Web utilizando tecnologia JavaEE

\section{AGOSTINHO AUGUSTO FIGUEIRA}

Mestrado na UNITAU no curso de Engenharia Mecânica, Área de Concentração : Projetos, Formação em Comércio Exterior na Aduaneiras , MBA em Suplly Chain pela Universidade Nove de Julho, Logística Empresarial UNIBAN, atualmente atua como docente de EAD na Anhembi Morumbi, Fmu e Uniritter, docente presencial no Centro Universitário Uniitalo e também na Faculdade Sumaré, atuo na UNIP de Campinas na Pós Graduação, já atuei na Anhanguera, Senac e Unib, Conhecimento avançado do Pacote Office e plataformas de elearning (Moodle, Blackboard learn, etc);. Expertise na carga rodoviária a mais de 20 anos . Atuação em operadores logísticos, com gestão e capacitação para novos negócios, visão para capacitação, motivação, planejamento, liderança e relacionamento interpessoal. Expressiva experiência no gerenciamento de pessoas e planejamento logístico / cadeia de suprimentos, movimentação, armazenagem, implantação de processos, gerenciamento de sistemas, contratos de transportes, gestão de frotas bem como desenvolvimento de novos fornecedores. Amplos conhecimentos no controle de custo operacional, centros de distribuição, transportadoras, configuração de malha logística, elaboração de metas e indicadores de desempenho, gestão de resultados operacionais e financeiros. Forte atuação em Gerenciamento de risco de transportes(GRIS), negociação de apólices de seguro,controle de toda a documentação da frota, atuando na distribuição de produto no mercado obedecendo a normas e requerimentos de nível de serviço, mapeamento de processos, adequação de frota, rotas, carga e descarga, separação, distribuição, transferência, automação, tendo como responsabilidade análise critica para ajuste de custos, desenvolvimento de lideres, treinamentos e readequação de estruturas de terminal e operações in house.

\section{ALINE CRISTINA DE OLIVEIRA SOUZA}

Bacharel em Administração pela Faculdade Metodista Granbery. Participou do Simpósio de Excelência em Gestão e Tecnologia, apresentando o trabalho intitulado " OS DESAFIOS DA GESTÃO DO TERCEIRO SETOR: UM ESTUDO DE CASO DA INSTITUIÇÃO EUNICE WEAVER (EDUCANDÁRIO CARLOS CHAGAS."

\section{AMANDA ARAÚJO DE SOUZA}

Graduanda em Ciências Contábeis, UFAL

\section{AMAURI VÍTOR DOS SANTOS}

Graduando em Ciências Contábeis, UFAL.

\section{ANA CAROLINA LOPES DE AZEVEDO}

Doutoranda em Engenharia de Defesa pelo Instituto Militar de Engenharia, Engenheira Civil pela Faculdade Redentor de Itaperuna (2014), pós graduanda em Engenharia de Segurança do Trabalho pela Faculdade Redentor e Mestre em Engenharia de Transporte pelo Instituto Militar de Engenharia. Sua pesquisa de mestrado estudou a associação de materiais de perfis pultrudados de vibra de vidro com concreto para a utilização como dormentes ferroviários. Sua pesquisa de doutorado estudou vigas híbridas para aplicação como dormente ferroviário. 


\section{ANA CLÁUDIA RIBEIRO PAIVA}

Graduação em Enfermagem e Obstetrícia pela Universidade Federal de Juiz de Fora (1992). Tem experiência na área de Enfermagem, com ênfase em Assistência, atuando principalmente nos seguintes temas: Enfermagem em Nefrologia, Programa de Saúde da Família (PSF), Gestão de Pessoas, Enfermagem, Saúde Coletiva, Hipertensão Arterial , Diabetes Mellitus, Docência em Curso Técnico e em curso de Graduação, orientação de monografias, participação em bancas, além de supervisionar estágio de Administração em Saúde Coletiva e Hospitalar. Possui pós-graduação em Enfermagem em Nefrologia (UFJF), Saúde da Família (Faculdade Redentor), MBA em Gestão Estratégica de Pessoas (UFSJ) e Organização dos Processos de Trabalho na Atenção Primária (NEAD - Canal Minas Saúde).

\section{ANA LÚCIA MAGALHÃES}

Doutora em Língua Portuguesa pela PUC-SP e pós-doutora pela mesma instituição. Professora de Leitura e Produção de Textos, Métodos da Produção do Conhecimento, Comunicação Empresarial e Relações Públicas na Fatec - Faculdade de Tecnologia de Cruzeiro, onde também é Coordenadora do Curso Superior de Tecnologia em Eventos. Membro da ABC - Association for Business Communication (EUA), ISHR - International Society for the History of Rhetoric (Alemanha), SBR - Sociedade Brasileira de Retórica e ERA - Grupo de Estudos Retóricos e Argumentativos da PUC-SP.

\section{ANA PAULA DA SILVA SOUZA COSTA}

Graduanda em Engenharia Civil pela Faculdade de Engenharia de Resende (FER)

\section{ANA PAULA LIMA MARQUES FERNANDES}

Graduada em Engenharia Civil e em Direito. Doutorado em Ciências em Engenharia. Docente da UFAL. Atua nos cursos de Ciências Contábeis e Administração.

\section{ANA VALÉRIA VARGAS PONTES}

Mestre em Sistemas de Gestão pela UFF - Universidade Federal Fluminense, Pós-Graduada em MBA - Organizações e Estratégia pela UFF (2008), graduada em Administração pela Faculdade Metodista Granbery (2005). Diretora de Recursos Humanos da Eduwork Consultoria e Assessoria Educacional Ltda; Coordenadora do curso de Administração da Faculdade Metodista Granbery; Professora da Faculdade Metodista Granbery nos cursos de administração, direito, sistemas de informação; Supervisora de Atividades curriculares Complementares, Visitas Técnicas, Supervisora de Trabalhos de Conclusão de Curso (TCC) e Supervisora de Estagio do curso de Administração da Faculdade Metodista Granbery; Participa do Comitê de desenvolvimento da Revista Acadêmica do Instituto Metodista Granbery; Membro do Núcleo Docente Estruturante dos Cursos de Administração e Sistemas de Informação da Faculdade Metodista Granbery; Membro da Comissão do Prouni - COLAP da Faculdade Metodista Granbery. Já atuou como: Professora no MBA de Gestão de Pessoas da Universidade Federal de Juiz de Fora - MG. Professora de Pós-graduação da Faculdade Metodista Granbery em Responsabilidade Social Ambiental. Professora substituta da UFJF Universidade Federal de Juiz de Fora nos cursos de Administração e Turismo - disciplinas de Recursos Humanos e Administração Geral; Professora Coordenadora da Empresa Júnior do Turismo da UFJF; Professora das Faculdades Integradas Vianna Junior no curso de Administração em parceria com a Fundação Getúlio Vargas; Professora de MBA em Gestão de Pessoas da Universidade Estácio de Sá. Membro do Consu - Conselho Superior da Faculdade Metodista Granbery. Membro do CEPE - Conselho de Ensino, Pesquisa e Extensão da Faculdade Metodista Granbery. Possui experiência profissional na gerência e administração de empresas de varejo. Atuando principalmente na consultoria e treinamento de recursos humanos, proferindo palestras sobre qualidade de vida no trabalho. É pesquisadora sobre Responsabilidade Social Empresarial com trabalhos publicados em anais de congressos. 


\section{ANTÔNIO LISBOA DA SILVA}

Graduado em Administração pela Universidade Federal do Piauí.

\section{BEATRIZ MONICA SCHUCHMANN}

Possui graduação em Administração de Empresas pela FGV- SP (1983), Mestrado em Administração pela UNIP (2011), Pós-graduação em EAD docência FGV- SP (2017). Trabalha na faculdade Sumaré, em consultorias incompany desenvolvendo equipes em inovação. Ministra aulas em diversas área de administração ou gestão, como: Marketing Pesquisa, Planejamento em marketing, Comunicação em marketing de eventos, Projetos de comunicação e audiência, Estratégia Empresarial, Gestão de pessoas, Gestão por competências, Plano de Negócios, Gestão de vendas, Gestão de projetos e de processos , Orientações de TCC entre outras.

\section{BRUNO ANDREONI}

Engenheiro químico com atuação de três décadas em projeto, processo, construção e educação profissional, com ênfase em uso industrial de sistemas informatizados de controle industrial. Trabalhou também por oito anos nessa área nos EUA e Ásia. Atua por meio de consultoria própria em comissionamento de sistemas e treinamento de engenheiros e operadores.

\section{CAMILA DE PAULA CONRADO ROSA}

Bacharel em Administração pelo Centro Universitário Tereza D'Ávila - UNIFATEA de Lorena/SP. Especializando-se em Gestão de Pessoas com ênfase em Liderança pelo Centro Universitário Salesiano de São Paulo - Unisal de Lorena/SP. Atuação profissional voltada para área Administrativa. Atualmente atua no setor de Saúde, na área de gestão de pessoas e otimização de serviços de atendimento.

\section{CAROLINE GERALDINI}

Engenheira Ambiental pela Universidade Veiga de Almeida

\section{CLÉVERSON VASCONCELOS DA NÓBREGA}

Doutor, mestre e graduado em Administração pela Universidade Federal da Paraíba. Atualmente professor lotado no Curso de Administração do campus Senador Helvídio Nunes de Barros (UFPI).

\section{DAIANE SOUZA DO VALE CARNEIRO}

Bacharel em Administração pela Faculdade Metodista Granbery, teve artigo publicado no XII SIMPÓSIO DE EXCELÊNCIA EM GESTÃO E TECNOLOGIA- SEGET, realizado em outubro de 2015, nas dependências da Associação Educacional Dom Bosco, em Resende- RJ.

\section{DANIEL VISENTINI DE BARCELOS}

Possui graduação em Redes de Computadores pela Universidade Federal de Santa Maria(2017) e ensino-medio-segundo-graupelo Colégio Militar de Santa Maria (RS)(2002). Atualmente é Técnico de Tecnologia da Informação da Universidade Federal de Santa Maria.

\section{DANILO MENEZES}

Graduando em Engenharia Ambiental pela Universidade Veiga de Almeida 


\section{DEUZENIR MENDES ARAÚJO}

Graduada em Gestão Empresarial - UNAMA. Pós-graduada em Gestão Hospitalar UNINTER. Graduanda em Administração - UNIFESSPA

\section{DILCILÉRIA DA ROSA DE OLIVEIRA}

Mestra em Ciências Contábeis - FUCAPE ( Business School ) Fundação Instituto Capixaba de Pesquisas em Contabilidade, Economia e Finanças, possui MBA em Controladoria Financeira e Graduação em Ciências Contábeis. Habilidade e competência, adquirida em empresas de grande e médio porte no segmento industrial, comercial e transporte de passageiros, tem experiência profissional de 24 anos na área de Contabilidade, com ênfase em Contabilidade Tributária, Contabilidade Societária e Contabilidade de Custos. Atua como coordenadora do curso de Ciências Contábeis da Fundação Educacional Machado Sobrinho e professora dos cursos de Administração, Ciências Contábeis e Eventos. Também atua como Instrutora de Cursos do CRC-MG. Planejamento Tributário, SPED PIS E COFINS/ ICMS ST / IRPJ. SóciaDiretora da CIC - CENTRO DE INTELIGÊNCIA CONTÁBIL LTDA desde 2009. Perita Contábil na $3^{a}$ e $4^{\text {a }}$ Vara Cível Juiz de Fora-MG e $1^{\text {a }}$ Vara do Trabalho Juiz de Fora - MG, CADASTRO NACIONAL DE PERITOS CONTÁBEIS - CNPC № 2765.

\section{ÉBER JOSÉ DOS SANTOS}

Mestrando em Língua Portuguesa pela PUC-SP. Professor das disciplinas de Projetos Integradores I, II, V e VI, Liderança e Empreeendedorismo e Gestão de Eventos e Agenciamento de Viagens, além de responsável pelos Trabalhos de Gradução do Curso Superior de Tecnologia em Eventos na Faculdade de Tecnologia da cidade de Cruzeiro (FATEC). Técnólogo em Gestão Empresarial pela Fatec de Guaratinguetá, SP. Faz parte do ERA - Grupo de Estudos Retóricos e Argumentativos da PUC-SP.

\section{ELIZABETE CAMPOS LIMA}

Graduanda em Administração - UNIFESSPA

\section{ELVIA FLORENCIO TORRES XIMENES}

Mestre em Engenharia de Produção pela Universidade Federal do Rio Grande do Norte; Graduada em administração pela Universidade Federal do Rio Grande do Norte; atualmente é professora efetiva da Universidade Federal do Piaú, vinculada ao curso de Administração Pública.

\section{EUGENIO DE OLIVEIRA SIMONETTO}

Possui graduação em Análise de Sistemas pela Universidade Católica de Pelotas (1995), mestrado em Ciência da Computação pela Pontifícia Universidade Católica do Rio Grande do Sul (1998), doutorado em Administração (Área: Sistemas de Informação e Apoio à Decisão) pela Universidade Federal do Rio Grande do Sul (2004) e estágio pós-doutoral sênior em Produção e Sistemas na Universidade do Minho (Portugal). Atualmente é professor adjunto no Departamento de Ciências Administrativas da Universidade Federal de Santa Maria (UFSM). Tem experiência na área de modelagem de sistemas de apoio a decisão.

\section{FÁBIO AUGUSTO LIMA SILVA}

Graduando em Ciências Contábeis, UFAL. 


\section{FABRÍCIO DE OLIVEIRA LAVORATO}

Engenheiro Civil formado pela Universidade Federal de Juiz de Fora e Mestre em Engenharia de Transportes pelo Instituto Militar de Engenharia, Fabrício Lavorato tem experiência profissional dentro da Engenharia Civil nas áreas de Infraestrutura de Transportes e de Engenharia Geotécnica, com especial interesse em projetos e obras ligados à Infraestrutura Ferroviária e Rodoviária.

\section{FABRICIO FONTOURA DOS SANTOS}

Engenheiro eletricista, formado pela Universidade Tecnológica Federal do Paraná-UTFPR (2011), tendo se aprofundado nas áreas de projetos elétricos e eficiência Energética. Especialista em Engenharia de Segurança do Trabalho pela Universidade Tecnológica Federal do Paraná (2013) e mestrando na linha de pesquisa em sustentabilidade, com ênfase em energia solar fotovoltaica, pelo Programa de Pós-graduação em Engenharia Civil da UTFPR (início em 2016). Atua como 1ํ Tenente - Engenheiro Eletricista na Comissão Regional de Obras 5 do Exército Brasileiro e foi Professor de Ensino Superior na Faculdade UNISOCIESC Curitiba entre os anos de 2013 e 2016. Tem experiência na área de Engenharia Elétrica, com ênfase em Instalações Elétricas e Industriais (Eletrotécnica), em instalações elétricas, execução e análise de projetos, Licitações e fiscalização de obras. As principais áreas de pesquisa são: Energia Solar Fotovoltaica, Geração Distribuída, Fontes Alternativas de Energia e Eficiência Energética.

\section{GLAUCO OLIVEIRA RODRIGUES}

Possui graduação em Redes de Computadores pela Universidade Federal de Santa Maria (2014). Mestrado em Administração pela Universidade Federal de Santa Maria(2016) e Doutorando pela Universidade Federal de Santa Maria. Tem experiência na área de Ciência da Computação, com ênfase em Redes de Computadores, participante de pesquisa na área de Sistemas de Informação, Pesquisa Operacional e Sustentabilidade Ambiental, atuando principalmente nos seguintes temas: modelagem de sistemas complexos e ambientais.

\section{GUILHERME MUSSI}

Formado em Engenharia Civil pela Universidade Veiga de Almeida, é engenheiro capacitado em avaliações e perícias e atualmente é mestrando, bolsista CAPES, em Geotecnia na Universidade do Estado do Rio de Janeiro (UERJ).

\section{GÜNTHER KALTMAIER JUNIOR}

Arquiteto e Urbanista, mestrando do PPGEC - UTFPR com ênfase nas áreas de sustentabilidade, arquitetura e fotovoltaica. Especialista em Construções Sustentáveis pela UTFPR (2015). Possui graduação em Arquitetura e Urbanismo pela Pontifícia Universidade Católica do Paraná (PUC-PR 2003). Concluiu a formação em nível técnico na área de desenho industrial (CEFET-PR 1996) nas áreas de comunicação visual e projeto de produto. Possui especial interesse na pesquisa de tecnologias aplicadas ao ambiente construído: eficiência energética, arquitetura bioclimática, conforto ambiental e sistemas fotovoltaicos integrados a arquitetura. Atua na área de Arquitetura e Urbanismo, com ênfase em projetos arquitetônicos, planejamento territorial e tecnologias aplicadas ao ambiente construído, tendo apresentando diversas propostas de projeto para participação em concursos de arquitetura nacionais e internacionais. 


\section{HENRIQUE MARTINS GALVÃO}

Possui graduação em Administração de Empresas pelas Faculdades Oswaldo Cruz (SP), pós-graduação em Administração Contábil e Financeira pela Fundação Armando Álvares Penteado - FAAP (SP), Mestrado em Administração pela Pontifícia Universidade Católica de São Paulo - PUCSP e doutorado em Administração pela Faculdade de Economia, Administração e Contabilidade da Universidade de São Paulo - FEA-USP.

\section{INGRID DE OLIVEIRA}

Bacharel em Administração de Empresas pela Faculdade Metodista Granbery, teve Artigo publicado no XII SIMPÓSIO DE EXCELÊNCIA EM GESTÃO E TECNOLOGIA - SEGeT, realizado em outubro de 2015, nas dependências da Associação Educacional Dom Bosco, em Resende - Rio de Janeiro. Tem experiência profissional na área de Departamento de Pessoal, realizou o curso de Desenvolvimento de Analista de Folha de Pagamento Sênior pela Instituição IOB Educação.

\section{JAIR URBANETZ JUNIOR}

Professor Titular na UTFPR. Doutor na área de Sistemas Fotovoltaicos pela UFSC (2010), sob orientação do Prof. PhD. Ricardo Rüther; Mestre em Eletrônica de Potência e Acionamento Elétrico pela UFSC (2002), sob orientação do Prof. PhD. Ivo Barbi; Especialista em Gerência da Engenharia de Manutenção pela UTFPR (1999), sob orientação da Profa. Dra. Andréa Lucia Costa; Graduado em Engenharia Industrial Elétrica pela UTFPR (1995) e Técnico em Eletrônica pela UTFPR (1986). É professor no Departamento de Eletrotécnica da Universidade Tecnológica Federal do Paraná em Curitiba, desde 1996, onde atua nos cursos de Engenharia Elétrica e Engenharia de Controle e Automação. Também é Coordenador do Curso de Pós Graduação a nível de Especialização em Energias Renováveis e Professor no Programa de Pós Graduação em Sistemas de Energia (PPGSE) a nível de Mestrado, e no Programa de Pós Graduação em Engenharia Civil (PPGEC) a nível de Mestrado e Doutorado. É autor do livro ELETRÔNICA APLICADA lançado em 2010 pela Editora BASE, e do ATLAS DE ENERGIA SOLAR DO ESTADO DO PARANÁ, lançado em 2017. Tem experiência na área de Engenharia Elétrica, com ênfase em Eletrônica de Potência e Energia Solar Fotovoltaica. É pesquisador pela UTFPR no Grupo de Pesquisa em Energia Solar e Sistemas Fotovoltaicos, no Grupo de Pesquisa em Eletrônica de Potência e no Grupo de Pesquisa Tecnologia e Meio Ambiente. Pela UFSC é pesquisador no Grupo de Pesquisa Estratégica em Energia Solar. Colabora na coordenação do Laboratório de Energia Solar - LABENS da UTFPR e atua como pesquisador no projeto de pesquisa para determinação do potencial de radiação solar e fotovoltaico no estado do Paraná, parceria entre ITAIPU / PTI / INPE / UTFPR. Revisor dos periódicos Revista SODEBRAS e Revista Brasileira de Energia.

\section{JOÁS LESSA MARTINS}

Engenharia civil (UVA) e com pós graduação em gestão de projetos (USP), trabalha com gerenciamento de projetos voltados para manutenção predial em geral.

\section{JOYCE GONCALVES ALTAF}

Possui graduação em Serviço Social e em Administração de Empresas, pós-graduação em História Econômica, curso de extensão em Marketing e Liderança pelo Marietta College e é mestre em Administração e Desenvolvimento Empresarial. Atua como coordenadora do curso de Administração da Fundação Educacional Machado Sobrinho e professora dos cursos de Administração, Ciências Contábeis e Engenharia de Produção ministrando diversas disciplinas em nível de graduação, elaboração de projetos acadêmicos e publicação de trabalhos científicos na área de Administração, Ciências Contábeis e de Engenharia de Produção. Exerce a função de professora no curso de Pós Graduação em Administração Pública da UAB/UFF. Possui experiência na área de Administração, com ênfase em Estratégia e Marketing, atuando principalmente nos seguintes temas: marketing, 
Comportamento do consumidor, estratégias empresariais, sustentabilidade, grupos estratégicos e redes de relacionamento.

\section{JULIANA D'ANGELA MARIANO}

Doutoranda no Programa de Pós-Graduação em Engenharia Civil na (UTFPR), campus Curitiba, Mestre em Engenharia Civil pela UTFPR (2017), Graduada em Tecnologia em Eletrotécnica pela UTFPR (2010), e Técnica em Eletrotécnica (2007) pela UTFPR. É pesquisadora pela UTFPR no Grupo de Pesquisa em Energia Solar e Sistemas Fotovoltaicos (LABENS) e no Institutos Lactec. Atuou como pesquisadora voluntária no projeto de pesquisa para determinação do potencial de radiação solar e fotovoltaico no estado do Paraná, parceria entre ITAIPU / PTI / INPE / UTFPR. Tem experiência com projetos elétricos prediais, comerciais e industriais e de subestações. As principais áreas de interesse são: Energia Solar Fotovoltaica, Energias Renováveis, Sustentabilidade e Educação Ambiental.

\section{JULIANA GONÇALVES FERNANDES}

Possui graduação em Engenharia Ambiental pela Universidade Federal de Viçosa (2006), Mestrado em Saneamento, Meio Ambiente e Recursos Hídricos pela Universidade Federal de Minas Gerais (2009), Pós-Graduação em Engenharia de Segurança do Trabalho (2013) e cursa o Doutorado em Biotecnologia Industrial pela Universidade de São Paulo. Atualmente é Diretora de Recursos Hídricos da Associação Pró-Gestão das Águas da Bacia Hidrográfica do Rio Paraíba do Sul e professora da Associação Educacional Dom Bosco (AEDB). Tem experiência na área de Engenharia Sanitária e em Planejamento Integrado dos Recursos Hídricos.

\section{JULIANA MAIOLI LAVAL BERNARDO}

Mestre em Sistemas de Gestão pela Universidade Federal Fluminense. Possui pós-graduação em Marketing pela UNESA e MBA em Organização e Estratégia pela Universidade Federal Fluminense. Possui graduação em Administração pela Faculdade Machado Sobrinho. Atualmente é professora dos cursos de Administração, RH e Logística da Faculdade Vianna Júnior. Coordenadora dos Cursos de RH e Logística da Faculdade Vianna Júnior. Tem experiência na área de Administração, com ênfase em Mercadologia, atuando principalmente nos seguintes temas: comportamento do consumidor, satisfação, serviço.

\section{JULIANA VIEIRA BRAZ}

Pós Graduada em Gestão de Pessoas pela Unisal, Bacharel em Administração pela UNIFATEA. Carreira desenvolvida na área de Desenvolvimento de Recursos Humanos, com expertise na área de recrutamento e seleção, entrevistas de desligamentos, dinâmicas de grupo, administração de conflitos, gestão de climas e indicadores, administração de cargos e salários. Acompanhar os Indicadores de $\mathrm{RH}$ e reportá-los a administração propondo alternativas para melhoria contínua. Prestar suporte e auxílio aos gestores, atuando como consultor interno em todas as questões relacionadas à gestão de pessoas.

\section{LIDIANE MARIA DOS SANTOS}

Graduanda em Ciências Contábeis. Ufal.

\section{LILIANE ARAUJO PINTO}

Doutoranda em Administração pela Universidade Federal da Paraíba; Mestre em Administração e Controladoria pela Universidade Federal do Ceará; Graduada em Administração pela Universidade Estadual Vale do Acaraú; Professora Assistente da Universidade Federal do Piauí 


\section{LINCOLN DE LIMA FARIA}

Engenharia Civil pela Universidade Veiga de Almeida, e atualmente é pós-graduando em Engenharia de Segurança do Trabalho pela Universidade Federal do Rio de Janeiro (UFRJ).

\section{LUCAS PEREIRA DE ALMEIDA}

Graduando em Engenharia Civil pela Faculdade de Engenharia de Resende (FER) e estagiário da Diretoria de Recursos Hídricos da Associação Pró-Gestão das Águas da Bacia Hidrográfica do Rio Paraíba do Sul (AGEVAP-Sede). Pesquisador de Iniciação Científica (PICAEDB) na área de Tecnologia dos Materiais com o projeto "Produção e caracterização do concreto têxtil".

\section{LUCIANA NOVAES VIEIRA FERREIRA}

Possui graduação em Ciências Econômicas pela Universidade Federal de Viçosa e mestrado em Extensão Rural pela Universidade Federal de Viçosa. Atualmente é professora da Faculdade Metodista Granbery e professora da Universidade Presidente Antônio Carlos. Atualmente, é professora e coordenadora responsável pela Empresa Júnior Granbery Consultoria da Faculdade Metodista Granbery ; Coordenadora do curso de MBA em Custos e Finanças Empresariais da Faculdade Metodista Granbery; Coordenadora da avaliação institucional da Faculdade Metodista Granbery; Membro do Núcleo Docente Estruturante do Curso de Administração da Faculdade Metodista Granbery; Professora responsável pela visita técnica do curso de administração da Faculdade Metodista Granbery; Membro do Consu - Conselho Superior da Faculdade Metodista Granbery.

\section{LUIS CARLOS DE ANDRADE SILVA}

Graduado em Administração pela Universidade Federal do Piauí.

\section{LUIZA REGINA RAMIRO DE CARVALHO}

Engenheira Ambiental pela Universidade Veiga de Almeida CREA-RJ: 2018113756, Perita Ambiental pela PUC-Rio, Técnica de Segurança do Trabalho pelo SENAI-RJ

\section{LUNARA DE ANDRADE SILVA}

Graduanda em Engenharia Civil pela Faculdade de Engenharia de Resende (FER) e estagiária na Secretaria Municipal de Obras e Serviços Públicos da cidade de Resende.

\section{MARCELLE ROSSO FERREIRA}

Bacharel em Administração de Empresas pela Faculdade Metodista Granbery (2015). Teve artigo publicado no XII SIMPÓSIO DE EXCELÊNCIA EM GESTÃO E TECNOLOGIA - SEGET, realizado em outubro de 2015, nas dependências da Associação Educacional Dom Bosco, em Resende - RJ. Experiência profissional na área de Departamento Financeiro e Tributário.

\section{MARCELO CASSANTA ANTUNES}

Possui graduação em Ciências Contábeis pela Universidade Federal de Santa Maria/RS e em Gestão Pública pelo Centro Universitário Internacional. Também possui MBA em Contabilidade Pública e Responsabilidade Fiscal pelo Centro Universitário Internacional. Atualmente possui cargo de Assistente em Administração na Universidade Federal de Santa Maria/RS. 


\section{MARCELO DE MIRANDA REIS}

Possui graduação em Engenharia de Fortificação e Construção pelo Instituto Militar de Engenharia (1994); mestrado em Mestrado Em Planejamento Energético e Ambiental pelo Instituto Alberto Luiz Coimbra de Pós-Graduação e Pesquisa de Engenharia (2001); doutorado em Recursos Hídricos e Saneamento pelo Instituto Alberto Luiz Coimbra de PósGraduação e Pesquisa de Engenharia (2009) e Pós-Doutorado em Engenharia Civil pela Universidade de Coimbra - Portugal (2011). Tem experiência nas áreas de Engenharia Civil, com ênfase em Transportes, Recursos Hídricos, Saneamento e Meio Ambiente; de Engenharia de Transportes, com ênfase em Meio Ambiente, Portos e Hidrovias; e de Planejamento Energético e Ambiental. Atua principalmente nos seguintes temas: Planejamentos e Gestão Ambiental aplicada aos Transportes; Saneamento Básico; gestão, tratamento e aproveitamento energético de resíduos; Hidrologia e modelos hidrológicos; e Modelagem numérica. Atualmente é Coordenador de Graduação e Professor Adjunto do Instituto Militar de Engenharia. No curso de graduação em Engenharia de Fortificação e Construção ministra as disciplinas de Hidrologia, Hidrologia Aplicada, Hidráulica, Saneamento Básico I, Saneamento Básico II, e Gestão Ambiental, além de orientar trabalhos de tema Dirigido, Iniciação à Pesquisa e Projeto Fim de Curso. No curso de pós-graduação em Engenharia de Transportes ministra as disciplinas de Impactos Ambientais dos Transportes, Obras Hidráulicas e Portuárias, e Sistemas de Transporte Aquaviário. No curso de pós-graduação em Engenharia de Defesa ministra as disciplinas Meio Ambiente e Atividades Militares e Métodos Numéricos.

\section{MARCILENE FEITOSA ARAÚJO}

Docente efetiva da Universidade Federal do Sul e Sudeste do Pará- UNIFESSPA, com Graduação, Mestrado e Doutorado em Administração

\section{MARCOS ROBERTO BURI}

Possui graduação em Administração de Empresas - Faculdades Integradas Campo Salles (1996). Com especialização em Engenharia de Produção (2002) - Universidade São Judas Tadeu e Mestrado em Engenharia de Mecânica - Universidade de Taubaté (2006). Atualmente é professor da Universidade Nove de Julho no curso de Tecnologia de Gestão da Qualidade. Escritor e atua como consultor de produtividade e qualidade em empresas de pequeno e médio porte desenvolvendo projetos de melhoria de processos e cursos de treinamento empresarial. Tem 25 anos experiência na área de Administração de operações atuando principalmente nos seguintes temas: Cadeia de Suprimentos, Manufatura Enxuta, Qualidade, ISO9001:2015 e Planejamento Estratégico

\section{MAYSSA ALVES DA SILVA SOUSA}

Doutoranda em Engenharia Civil, com área de concentração em Geotecnia, pela Universidade Federal de Pernambuco - UFPE. Mestra em Engenharia de Transportes pelo Instituto Militar de Engenharia - IME (Rio de Janeiro, RJ). Bacharela em Engenharia Civil pela Unidade de Ensino Superior Dom Bosco - UNDB (São Luís, MA). Área de Concentração: Infraestrutura de Transportes; Geotecnia. Foi professora e membro do NDE - Núcleo Docente Estruturante dos cursos de Engenharia Civil e de Produção da UNDB. Trabalhou na empresa Ductor Implantação de Projetos Ltda., prestando serviços de análise e fiscalização de projetos ferroviários (Área de concentração em Engenharia Geotécnica e de Pavimentos), sendo principal projeto o de Expansão da Estrada de Ferro Carajás - EEFC da VALE.

\section{MOYSES JAIME ZEITUNE}

Formado em Engenharia Civil pela Universidade Veiga de Almeida, e atualmente é pósgraduando em especialização em estruturas de concreto e fundações pelo Instituto Brasileiro de Educação Continuada (INBEC). 


\section{NORBERTO STORI}

Professor Titular do Programa de Pós Graduação em Educação, Arte e História da Cultura da Universidade Presbiteriana Mackenzie (UPM). Livre Docente em Artes Visuais pelo Instituto de Artes da Universidade Estadual Paulista "Júlio de Mesquita Filho (IA-UNESP)/SP. Doutor e Mestre pela Universidade Presbiteriana Mackenzie (UPM). Licenciado em Desenho e Plástica - Faculdade de Artes Plásticas e Comunicações da Fundação Armando Álvares Penteado (FAAP)/SP.

\section{PALÁDIA DE OLIVEIRA ROMEIRO DA SILVA}

Mestre em Direito e Graduada em Direito pelo UNISAL de Lorena-SP. Doutoranda em Planejamento Urbano e Regional pela UNIVAP, São José dos Campos-SP. Especialista em Direito Ambiental e Gestão Estratégica da Sustentabilidade pela COGEAE PUC-SP. Docente no ensino superior do Centro Universitário Tereza D'Ávila UNIFATEA-SP, da Faculdade de Ciências Humanas de Cruzeiro, FACIC-SP e Faculdade de Roseira, FARO-SP. Advogada.

\section{RANULFO SOARES DA FONSECA JR.}

É Docente Coordenador dos cursos Técnicos do SENAC na área de Administração e Negócios e Professor no Centro Universitário SENAC São Paulo, conduzindo disciplinas de Empreendedorismo, Responsabilidade Social e Sustentabilidade. Professor na Faculdade SUMARÉ atuando na área de Administração e Negócios desde 2014. Consultor Interno Sebrae desde 2015. Mestre em Administração de Empresas pela Universidade de Campo Limpo Paulista, MBA em Finanças e Pós em Gestão de Pessoas pelo Mackenzie, Administrador com ênfase em Comércio Exterior pela Universidade Ítalo Brasileiro. Atuou diretamente no programa de sustentabilidade do banco Bradesco e desenvolve projetos de empreendedorismo, responsabilidade social em programas In-company além da aplicação em empresas ?junior? na forma acadêmica junto a grandes organizações dos mais diversos segmentos, como Natura, Schincariol e ALL Logística. O projeto de dissertação do mestrado focou em Empreendedorismo com Sustentabilidade, onde pode ser criativo e sustentável ao mesmo tempo trabalhando inicialmente com público interno e externo

\section{REGINELLY MEDEIROS}

Engenheira Ambiental pela Universidade Veiga de Almeida

\section{RODRIGO PURCELL}

Graduando em Ciências Contábeis. Ufal.

\section{ROMERO DE ALBUQUERQUE MARANHÃO}

Pós-Doutorando em Educação, Arte e História da Cultura da Universidade Presbiteriana Mackenzie (UPM). Doutor em Administração pela Universidade Nove de Julho (UNINOVE). Mestre em Geografia pela Universidade Federal do Pará (UFPA) e Graduado em Administração Pública pela Universidade Federal Fluminense (UFF).

\section{ROSA MARIA MAIA DE OLIVEIRA}

Mestre em Psicologia pelo Centro Universitário UNIFIEO -2014. Graduação em Psicologia pelo Centro Universitário das Faculdades Metropolitanas Unidas (1983), Graduação em Pedagogia pela Faculdade de Filosofia Ciências e Letras Professor José Augusto Vieira (1995), Graduação em Direito pelo Centro Universitário das Faculdades Metropolitanas Unidas (2002). Professora efetiva na Escola Estadual João Silva, Professora convidada da Pós-Graduação da Faculdade Aldeia de Carapicuíba (FALC). Possui experiência na área de Psicologia Clínica e Educacional, com ênfase em Psicologia do Ensino e da Aprendizagem, 
atuando principalmente nos seguimentos: Formação de professores, ensino aprendizagem, Gestão de pessoas, treinamento e desenvolvimento, liderança e motivação e o profissional e o mercado de trabalho do século XXI. Psicóloga /Professional \&Self Coaching.

\section{ROSILANE CHIMENES}

Professora de Língua Portuguesa e de Leitura e Produção de Texto da Secretaria de Educação do Estado de São Paulo e da Secretaria Municipal de Educação do município de Roseira. Bacharel em Comunicação Social - Jornalismo pela UNESP - Bauru. Licenciada em Língua Portuguesa pela UBM - Universidade de Barra Mansa. Tecnóloga em Automação de Escritórios e Secretariado pela FATEC -GT com ênfase em Marketing. Cursista em Pedagogia pela UNIVESP-SJC.

\section{SANDRA MARA DOS SANTOS}

Graduada em Enfermagem pela Instituição de Ensino superior Presidente Tancredo de Almeida Neves (IPTAN - 2014). Especialização em Gestão de programas saúde da família pela Universidade Cândido Mendes (2016). Atuação profissional Polícia Militar, Subtenente (enfermagem) 38 BPM.

\section{TALES ANTÃO DE ALENCAR CARVALHO}

Mestre em Educação pela Universidade do Pernambuco; Graduado em Administração pela Universidade Federal do Piauí; Professor Efetivo da Universidade Estadual do Piauí; Coordenador e Professor do Curso de Administração do Instituto de Educação Superior Raimundo Sá.

\section{TATIANE DIAS DA CUNHA VIEIRA}

Bacharel em Administração de Empresas pela Faculdade Metodista Granbery, teve Artigo publicado no XII SIMPÓSIO DE EXCELÊNCIA EM GESTÃO E TECNOLOGIA - SEGeT, realizado em outubro de 2015, nas dependências da Associação Educacional Dom Bosco, em Resende - Rio de Janeiro. Tem experiência profissional na área de Departamento de Pessoal,Financeira e Vendas. Atua como Administradora na empresa Ortofarma Laboratório de Controle de Qualidade Ltda.

\section{THAIS EUGÊNIO DE MORAES}

Pós Graduanda em Administração Financeira e Orçamentária pelo Instituto Brasileiro de Formação - IBF. Bacharel em Administração pelas Faculdades Integradas Teresa D'Avila FATEA, com ênfase em Gestão Empresarial Estratégica. Servidora Pública Federal no Hospital Universitário Clementino Fraga Filho da UFRJ. Atualmente atuando na área de orçamento e finanças públicas.

\section{VANESKA RIBEIRO PERFEITO SANTOS}

Mestre em Educação pelo Programa de Pós-graduação em Educação - Processos Socioeducativos e Práticas Escolares da Universidade Federal de São João del-Rei (UFSJ, 2017). Especialização em Formação Pedagógica para Enfermeiros pelo Instituto Federal de Educação, Ciência e Tecnologia do Sudeste de Minas Gerais (IF SUDESTE/MG, 2012) e em Enfermagem do Trabalho pelas Faculdades Integradas de Jacarepaguá (FIJ, 2010). Graduação Bacharel em Enfermagem pela Universidade Presidente Antônio Carlos (UNIPAC, 2008) e em Medicina Veterinária pela Universidade Federal de Minas Gerais (UFMG, 1992). Experiência em docência no ensino superior e tecnológico na área de Enfermagem. Experiência assistencial na área da atenção primária. 


\section{VANESSA LETIÍCIA}

Engenheira Ambiental pela Universidade Veiga de Almeida

\section{WELLINGTON FURTADO SANTOS}

Graduado em Administração de Empresas, Especialista em Economia, Mestre em Economia Empresarial pela Universidade Cândido Mendes do Rio de Janeiro e Doutor em Administração na linha de Pesquisa: Economia e Finanças pela Universidade Federal de Santa Maria - UFSM. Tem realizado Pesquisas nas áreas de Gestão Pública, Economia e Mercado Financeiro. Professor em regime de dedicação exclusiva no curso de Gestão Pública, Administração do Instituto Federal Farroupilha no Campus de São Vicente do Sul.

\section{WILCKER ARAÚJO SAMPAIO}

Graduando em Administração - UNIFESSPA 


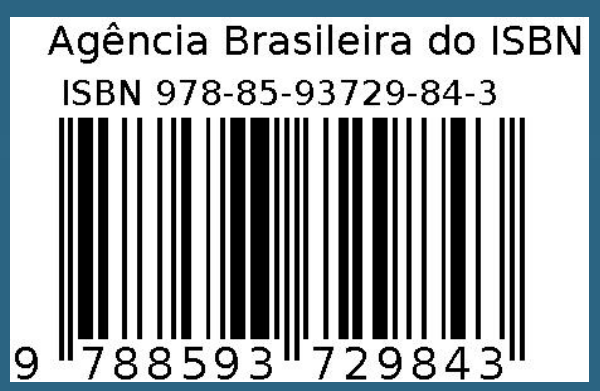

